M. ${ }^{a}$ DEL MAR LLOPIS ORREGO

\title{
BAJO LA MIRADA DE HERACLES: LOS USOS SOCIALES DEL AGUA COMO FUENTE DE SALUD Y PLACER
}




\section{COLECCIÓN VITOR}

272

(C)

Ediciones Universidad de Salamanca

y M. ${ }^{a}$ del Mar Llopis Orrego

$1^{a}$ edición: septiembre, 2010

I.S.B.N.: 978-84-7800-175-0

Depósito legal: S. 1.151-2010

Ediciones Universidad de Salamanca Apartado postal 325

E-37080 Salamanca (España)

Realizado por:

Trafotex Fotocomposición, S. L.

Tel. 923228103

37005 Salamanca (España)

Impreso en España-Printed in Spain

Todos los derechos reservados. Ni la totalidad ni parte de este libro puede reproducirse ni transmitirse sin permiso escrito de Ediciones Universidad de Salamanca 


\section{RESUMEN}

En esta obra se analizan los usos sociales del agua, como fuente de salud y placer; la relación del hombre con el hombre y a su vez con la naturaleza a través del baño. Aguas saladas, dulces y mineromedicinales, una aproximación a la posmodernidad vista desde el placer de la inmersión en tan valorado fluido. El agua en su uso amable, una práctica social, testigo de cambios, normas y conductas son fruto de este estudio.

Este tratado del agua parte de la antigüedad y llega a la actualidad, pero no si antes detenerse en las distintas culturas en las que el baño ha sido parte importante, reflejándose en mitos y ritos, objeto de culto y de creencias, va de lo religioso a lo profano, del placer de la estética, al placer del espíritu, pasando por el placer de los sentidos, experiencias hídricas fruto de un fluido inigualable como el agua que sirve de eje transversal en esta Tesis.

...Una mirada al pasado contempla la higiene como parte de un conjunto de normas de urbanidad y materia de enseñanza en manuales de moral escolar. En la actualidad el discurso higienista pasa del deber, al deseo voluntario de cuidar el cuerpo, tanto para su exhibición social, como para su satisfacción personal.

La recuperación de los usos sociales como fuente de salud y placer tiene mucho que ver con la nueva valoración de la naturaleza y con el deseo irrefrenable de conseguir la belleza y frescura que procura la eterna juventud, carta de presentación que conduce al éxito social tan codiciado por el hombre. El baño hedonista, el baño narcisista, el baño reparador, un acercamiento al agua mediante el baño como vehículo para la consecución de deseos personales e íntimos.

...A través del atuendo y su evolución, nos hemos acercado al baño como fenómeno social, hemos pasado de la sobriedad y el recato, a las marcadas licras por la figura femenina. De la represión a la liberación, de la censura al destape. El traje de baño ha servido de representación para conocer modas y tendencias marcadas por la situación política y social de cada momento. 
...Ocio y negocio se unen en torno a los placeres hídricos, estos, entran en la dinámica del mercado convirtiendo al agua en moneda de cambio. La industria turística bajo la imagen ecologista de la nueva valoración del agua, se disfraza de turismo de salud, un negocio en el que los ingresos se vuelven cada vez más generosos. El deseo lúdico comienza a ser irrefrenable convirtiéndose en fuente de ingresos para empresarios que desean ver en el agua algo más que un recurso limitado. Los viejos balnearios con sus remodelaciones, dejan atrás las marcas de ambiente hospitalario, hoteles y SPA se suman a la oferta saludable y las casas de baños, que antaño se encontraban en las ciudades, regresan como balnearios urbanos, acercando a las urbes la ansiada naturaleza.

El Placer de tonificar el cuerpo, en un ambiente eminentemente social está marcado por los cambios posmodernos, una mirada al recuerdo que sienta las bases de un nueva fórmula de disfrute basada en el individualismo, en reserva de parcelas privadas dentro del espacio público, una nueva forma de acercarse a la naturaleza para recuperar la naturaleza disipada, para nutrirse de sensaciones reparadoras que satisfagan a corto plazo y recompense en el tiempo. Bajo la Mirada de Heracles; testigo pétreo de las termas de Carcalla, el baño convierte al agua en fuente de salud y placer. 


\section{ABSTRACT}

This work examines the social uses of water as a source of health and pleasure, the relationship of man with man and with nature through bath. Saltwater, freshwater and medicinal mineral water, an approach to the postmodernism, viewed from the pleasure of the immersion in such appreciated fluid. Water in its friendly use, social practice, witnessed changes, rules and behaviors are the result of this study.

This study of the water comes from the past and reaches the present, but not without stopping at the various cultures in which the bath has been an important part, reflected in myths and rituals, cult and belief going from religion to the profane, from the aesthetic pleasure, to the pleasure of the spirit, going through the pleasure of the senses, hybrid experiences born of a unique fluid as the water used as cross-cutting theme in this thesis.

.....Looking back, the past provides hygiene as a set of rules of urbanity and a matter of moral education in school textbooks. At present, the hygienist discourse passes from duty, to the voluntary desire to of the body, such as a social exhibition, to our personal satisfaction.

The recovery of the social uses as a source of health and pleasure has a lot to do with the new valoration of the nature and the uncontrollable desire to achieve beauty and freshness that seeks eternal youth, cover letter to success coveted social by man. The hedonistic bath, the narcissistic bath, the repairer bath, an approach to water through bath as a vehicle for achieving personal and intimate desires.

... Through the outfit and its evolution, we have approached the bath as a social phenomenon, we have passed from sobriety and modesty, to the marked lycra by the female figure. From repression to liberation, from the censorship to the nudity. The swimsuit has served as a representative to see trends and tendencies marked by political and social situation of the moment. 
Leisure and business join around the water pleasures, they fall under the dynamics of turning water in change currency. The tourist industry under the green image of the new valuation of water, disguised as health tourism, a business in which revenues are becoming more generous. The ludic desire starts to be irresistible becoming a source of income for entrepreneurs who want to see in the water more than a limited resource. The old spa with their renovations, they leave behind marks hospital environment, hotels and spa adds to healthy supply and the bathhouses, which once were in the cities, returns as urban spas, bringing cities closer to the desired nature.

The Pleasure of tone up the body, in an eminently social environment is marked by changes postmodernist, a look that sets the stages for a new formula of enjoyment based on individualism, private reserve within the public space, a new way to get close to nature to recover the dissipated nature, to feed on remedial sensations that satisfy short-term and rewards over time. Under the Gaze of Heracles; firm witness of the baths of Carcalla the bath becomes water a source of health and pleasure 


\section{INDICE}

• Introducción................................................ 10

• Marco Estructural............................................ 12

• Marco Teórico.................................................... 18

• Justificación................................................. 24

• Objetivos e hipótesis........................................ 25

- Marco Metodológico............................................ 28

- Análisis de Conceptos Utilizados .............................. 33

Parte I: El Agua Aplicada al Baño desde Tiempo Inmemorial...... 38

- Capítulo I: El Baño en la Historia............................... $\quad 50$

- Capítulo II: Varias Formas de Concebir el Baño a Través de la Cultura del Agua................................... 86

Parte II: Magia y Belleza, Pureza y Religión: Una Inmersión en la Esencia del Agua

- Capítulo III: El Placer de la Estética............................ 161

- Capítulo IV: El Placer de los Sentidos....................... 182

- Capítulo V: El Placer del Espíritu............................ 200

Parte III: Recuperación de los Usos Sociales y Terapéuticos del 234 
Agua.

- Capítulo VI: El Baño: Resurgir de un Uso y una Moda..... 240

- Capítulo VII: Función Social del Baño.................... 270

- Capítulo VIII: Ocio y Negocio en torno al Placer del Baño 298

- Capítulo IX: El Agua como Fuente de Salud y Placer..... 332

- Conclusiones Generales................................ 499

Bibliografía......................................... 502

Anexos................................................. 510 


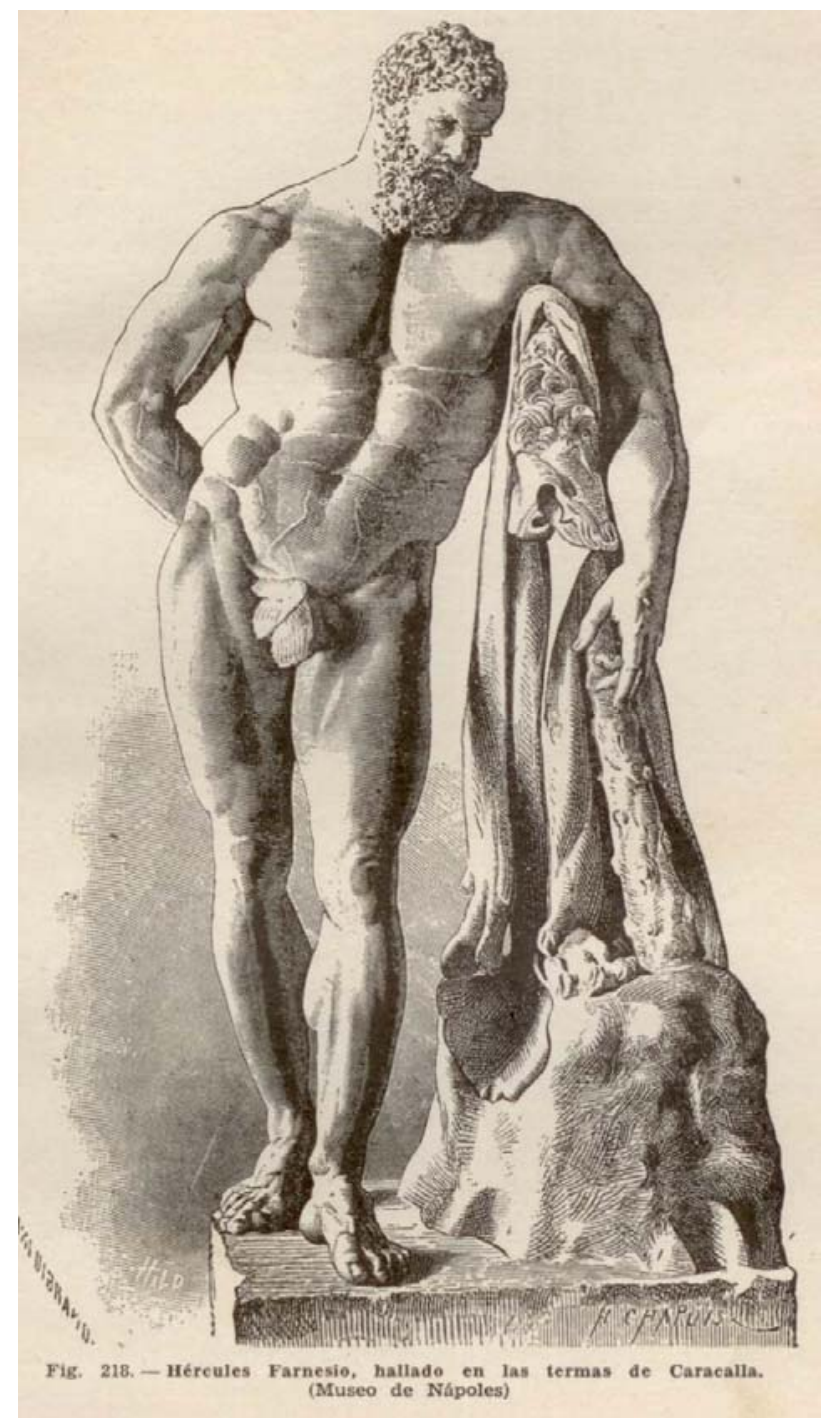

Cuenta la leyenda, que Hércules (Heracles) encontrando próxima la hora de su muerte y sintiendo en su piel el quemazón que le causaba la túnica del centauro Neso, se arrojó al río Traquis (junto a las Termópilas, llamadas así por sus aguas termales) para calmar el quemazón, muriendo ahogado. Las aguas del río conservaron para siempre el calor del héroe. 


\section{INTRODUCCIÓN}

\section{"El ciclo del agua es la corriente sanguínea de la humanidad"}

Que cierto es que la humanidad vive a merced del ciclo del agua, que depende de ella para garantizar la seguridad alimentaria y la salud, que las posibilidades del futuro dependen de la capacidad del ser humano para gestionarla; cierto es también, que el agua es un recurso básico que sufre sobreexplotación, que está repartida de forma desigual por el mundo, que clama una ética humana en su uso y gestión; el agua no puede ser fuente de conflicto social, no puede ser moneda de cambio, el agua es un bien natural y gratuito a compartir y preservar. Habría mucho que decir a este respecto; podríamos hablar de guerras por el agua, realizar reproches a las políticas hídricas, hacer una llamada de atención a las políticas económicas y transnacionales, pero ante todo, tenemos que ser capaces de reconocer que gran parte de la solución a los conflictos surgidos en torno al agua, ha de depender de nuestra capacidad para afrontar y solucionar esos conflictos desde una mirada de atención al medio ambiente social y humano, pero este, no es el motivo de este tratado, aunque en esencia baraja el mismo factor común, la cuestión a plantear es la cara amable del agua, que en forma de legado histórico se vuelve actual en cada momento estudiado de la historia.

Universal y atempóreo, el agua lo fue en el pasado, lo es en el presente, y ha de serlo en el futuro; el agua no es historia pero ha hecho historia, en su esencia no está de moda pero en su uso ha sido y es moda; está presente en la literatura, en los poemas, motivo de musa en el arte, base en los perfumes, tiene gran capacidad como disolvente de todo tipo de sustancias, es parte ineludible del paisaje, compañera de mesa, símbolo religioso, elemento mitológico; el agua se conoce, desde lo que uno por referencia puede decir que el mundo es mundo, y permanece de tal modo, que podría volver a la vida aquel que murió en otro siglo, y no reconocer cosa alguna, sino el agua en su forma natural. $Y$ es que el agua, está presente, su

\footnotetext{
${ }^{1}$ Mailin Falkenmark (2006) “Agua El desafío del siglo XXI” Ed. Vanguardia Dossier n 21 Pág. 7
} 
presencia subyace en todo aquello que forma parte de nuestra vida, y ausente porque pasa de manera desapercibida por su nuevo estado ya sea mezclado o transformado en otro elemento de uso o consumo imprescindible.

El agua, es el elixir de la vida, el motor que la sustenta, valorada por sus usos y prodigada en los mismos, el agua es versátil, directa o indirectamente el fluido indispensable que vierte su caudal en esta tesis para acercarnos al baño, ritual hídrico, renacer espiritual, placer corporal, fuente de salud, remanso de paz, proveedor de belleza, relajante natural, dispensador de bondades alabadas por los siglos de los siglos y avaladas por el reconocimiento humano mediante su apuesta permanente y su continua puesta de largo. 


\section{MARCO ESTRUCTURAL}

Estamos ante una recuperación de los usos sociales terapéuticos del agua, el baño ocupa uno de los principales puestos a la hora de procúranos ocio y deleite lo que a su vez procura una nueva valoración social de este recurso hídrico.

El culto al cuerpo y el bienestar corporal y espiritual son materia primera en una sociedad individualista y egocéntrica en la que lo importante es gustarse a sí mismo pero sobre todo gustar a los demás, ser reconocido y envidiado, centro de atención y poseedor de la clave del éxito.

Ciertas enfermedades sociales, como el estrés, comienzan a hacer estragos en una población carente de tiempo libre, consumido en su mayor parte en medios de transporte fruto de la necesidad de trasladarse de su lugar de origen a su lugar de destino, de casa al trabajo y del trabajo a casa, el resto, una labor frenética en el que la exigencia del cumplimiento de objetivos obliga al consumo de tiempo calculado al minuto.

El tiempo de ocio comienza a ser más valorado que el dinero, aunque es el dinero el único capaz de ofrecer los mejores placeres destinados y orientados al tiempo de ocio, así una oferta que permita recuperarse del estrés a la vez que disfrutar de las delicias que ofrece el baño, siempre es anhelada y bien recibida por una sociedad saturada de obligaciones ineludibles, una sociedad tendente a disfrutar al máximo de su propio yo, de su reencuentro personal consigo mismo y a su vez de su reencuentro con la naturaleza casi olvidada, esto hace que modas y tendencias descubran en el baño el resurgir del gusto por el agua; entre lo tradicional y lo excéntrico se mueve una variada oferta de servicios orientados a ofrecer lo mejor de una práctica rescatada siglo a siglo, capaz de garantizar la exigencias del consumidor de turismo de salud.

El mercado, fiel observador, se hace eco del sentir de un pueblo necesitado de terapias ecológicas, poniendo en marcha la maquinaria de la incitación al consumo; 
los creativos dan rienda suelta a imágenes persuasivas acompañadas de lanzamientos de mensajes, que lejos de lo subliminal, provocan la tentación de quienes necesitados de un equilibrio físico y psíquico, por medios no traumáticos mediante el uso del baño, dan lugar al éxito de un sector que ve aumentar sus posibilidades de negocio amparándose en el turismo de salud.

El baño es un placer al alcance de todos los bolsillos, porque el agua que brota de los manantiales, es regalo de la naturaleza para el ser humano, ríos y playas permanecen expuestos a merced de quien guste sumergirse. El precio por el goce del agua en centros dedicados a su disfrute, dependerá del gusto que el agüista quiera darse, es cuestión de tiempo, terapias y centros, un lujo que aumenta según el poder adquisitivo de quien se lo puede permitir.

Público o privado, el baño se presta al deleite, convirtiéndose en un acto social, un uso compartido para quienes buscan relacionarse y salir de su mundo aislado e impersonal, a su vez, el baño, aún siendo en un lugar público puede convertirse en el más reservado de los placeres, ya que conscientes de la importancia de la privacidad, se crean ambientes y se reservan horarios para dar paso a la intimidad del baño.

El baño, reconforta, laxa, relaja, estimula, atempera, cura, divierte, recrea, deleita, purifica, limpia adelgaza, embellece...........

"El agua es el elemento más favorable para ilustrar los temas de combinación de los poderes. ¡Asimila tantas sustancias! iAtrae tantas esencias! Recibe con igual facilidad materias contrarias, el azúcar y la sal. Se impregna de todos los colores, de todos los sabores, de todos los olores. Se comprende, pues, que el fenómeno de la disolución de los sólidos en el agua sea uno de los principales fenómenos de esta química ingenua que sigue siendo la química del sentido común y que, con que se sueñe un poco, es la química de los poetas."

\footnotetext{
${ }^{2}$ Bachelard, (1942) En: “Termalismo Antiguo” (I Congreso Peninsular. Actas), M J, Peréx. (1997). Ed. UNED-CV. Madrid.
} 
Dar a conocer la estructura organizacional de este trabajo es el objetivo de este apartado.

Aquí comienza el fondear en las profundas aguas del baño a través del tiempo, de culturas y mitos, de sensaciones y magia, de sentimientos y placeres, de salud y belleza en busca de la eterna juventud, aquí comienza un análisis que durante los siguientes nueve capítulos, de los que consta este trabajo sobre el baño, dará cuenta de la realidad social a su paso de la modernidad a la posmodernidad a través de la recuperación de los usos sociales y terapéuticos de agua.

El trabajo lo hemos dividido en tres partes de las que seguidamente daremos cuenta:

\section{PRIMERA PARTE}

\section{EL AGUA APLICADA AL BAÑO DESDE TIEMPO INMEMORIAL}

Esta primera parte de la investigación consta de dos capítulos dedicados a la influencia del baño para la humanidad.

- Capítulo I: EL BAÑO EN LA HISTORIA

El primer capítulo sigue el curso del agua a través del baño a su paso por la historia dando fe de momentos de gloria, esplendor y decadencia en su caso, deteniéndose en aquellas variables que a lo largo de la historia han influido en el devenir del uso social del baño. 
- Capítulo II: VARIAS FORMAS DE CONCEBIR EL BAÑo A TRAVÉS DE LA CULTURA DEL AGUA

El segundo capítulo de esta primera parte, se detiene en la concepción del baño en las diferentes culturas, en las distintas connotaciones y aportaciones a un mismo uso social del agua.

SEGUNDA PARTE

\section{MAGIA Y BELLEZA, PUREZA Y RELIGION: UNA INMERSIÓN EN LA ESENCIA DEL AGUA}

Esta segunda parte de la investigación consta de dos capítulos dedicados a la influencia del baño a nivel corporal, en su parte interna a través de los sentidos y en su parte externa través de la imagen, efectos que se convierten en una constante atemporal del que gusta del contacto con el agua mediante el placer del baño.

- Capítulo III: EL PLACER DE LA ESTÉTICA

El capítulo tercero muestra el resultado del baño a través de la estética, la búsqueda de la belleza y la eterna juventud mediante el contacto corporal con la naturaleza. 
- Capítulo IV: EL PLACER DE LOS SENTIDOS

El capítulo cuarto analiza el mundo de las sensaciones que el individuo experimenta al contacto de su cuerpo con el agua.

- Capitulo V: EL PLACER DEL ESPÍRITU

El capítulo quinto se centra en el placer de espíritu, el agua elemento ritual limpia y purifica el cuerpo logrando la paz interior, el renacimiento a una vida nueva.

\section{TERCERA PARTE}

\section{RECUPERACION DE LOS USOS SOCIALES Y TERAPEUTICOS DEL AGUA}

Cuatro son los capítulos que forman esta tercera y última fase de la investigación, en la que se traen a estudio los nuevos usos sociales del agua que, marcados por modas y tendencias y empujados por intereses económicos y empresariales, invitan en nombre de la salud, el ocio y el descanso a retomar el gusto por el placer del baño.

- Capítulo VI: EL BAÑO RESURGIR DE UN USO Y UNA MODA

El capítulo séptimo, trae a estudio las nuevas tendencias en torno al placer del baño, una nueva valoración del agua que se presenta en forma de turismo de salud, en una sociedad que rinde culto al cuerpo a través de la cultura del agua. 
- Capítulo VII: FUNCIÓN SOCIAL DEL BAÑO

El capítulo quinto se centra en la función social del baño y su evolución, haciendo énfasis en los cambios de percepción social y de comportamiento individual en los centros dedicados al baño.

\section{- Capítulo VIII: OCIO Y NEGOCIO ENTORNO AL PLACER DEL BAÑO}

El capítulo octavo: cruza al otro lado de la barrera de la necesidad del contacto con la naturaleza, del gusto por el agua, de las virtudes del baño, cruza la barrera de lo sensible a lo insensible, de lo espiritual a lo pragmático, para conocer la realidad que esconde el negocio del llamado "Oro azul".

\section{- $\quad$ Capítulo IX: EL AGUA COMO FUENTE DE SALUD Y PLACER}

El capítulo noveno: Se centra en las distintas opciones de baño según sus aguas, analizando de forma empírica al agüista, cuando en relación directa con la naturaleza se sirve de ella como fuente de salud y placer.

A lo largo de estos nueve capítulos que conforman este trabajo nos iremos sumergiendo en la relación del hombre con el hombre y a su vez, de este con la naturaleza, entre los vapores del agua penetraremos en un uso tan antiguo como la propia humanidad. 


\section{MARCOTEÓRICO}

Seguidamente haremos una inmersión en la esencia del agua:

"El agua" es uno de los cuatro elementos de la madre naturaleza, cuna de mitos y sustancia esencial para la vida humana, anhelo de muchos y derrochada por otros, el agua, es una constante y a su vez una olvidada.

Recurso inagotable de placer y salud en sí misma, es un recurso escaso cuyo valor se fija cuando se adolece de ella.

Por el agua se vive y se mata, nacemos envueltos en agua y se hacen guerras por su propiedad, con el agua se comercia, se vende y se compra, un legado gratuitamente heredado que procura poder a las naciones y miseria a algunos pueblos, un legado compartido, un legado indispensable y paradójicamente poco valorado.

El hombre tendente a valorar el fruto del esfuerzo, del ingenio y la conquista, teniendo por banal aquello que de forma natural nos es dado, un patrimonio compartido y en todo instante utilizado, sin el que la propia existencia estaría algo más que amenazada, destruida.

El agua, capaz de convertirse en prisma, nos deja ver una de sus caras más amables, dando como resultado esta tesis que en su modestia, relaja y condensa sus páginas en el vapor del baño, inmersión corporal en esta materia primera en un fascinante reencuentro con la naturaleza perdida.

"Bajo la mirada de Heracles", el agua se torna fuente de placer mediante el baño, fuente de salud por el baño, calidad de vida fruto del baño, por ello, el tema central de este trabajo es el disfrute del agua en su parte más amable "el baño", como uno de los usos sociales del agua que procura el intimar del individuo con la propia naturaleza viva, pero siempre manteniendo el agua como tema trasversal, por ser el elemento de la naturaleza que explica este uso por la humanidad. 
En esta Tesis, "el baño" abandona su parte higiénica en aras de la parte lúdica, estética y salutífera, en aras, al placer de tonificar el cuerpo, en un ambiente eminentemente social marcado por los cambios posmodernos, una mirada al recuerdo que sienta las bases de una nueva forma de disfrute basada en el individualismo.

Herculeas o herculanas ${ }^{3}$, salas frías y calientes de las antiguas casas de baños son testigos de cambios sociales, de una nueva forma de participar de la naturaleza en la sociedad actual mediante una oferta cada vez más variada inmersa en las leyes del marketing y la publicidad, que convierte al agua en un negocio de irresistibles cualidades, que incitan al consumo exacerbado de sensaciones puestas al alcance del individuo deseoso de reencontrarse con la naturaleza, símbolo de salud y proveedora de eterna juventud.

"Qué error haber pregonado precipitadamente el fin de la sociedad de consumo, cuando está claro que el proceso de personalización no cesa de ensanchar sus fronteras. La recesión presente, la crisis energética, la conciencia ecológica, no anuncian el entierro de la era del consumo.. ${ }^{4}$

Estamos ante una recuperación de los usos sociales y terapéuticos del agua, sumergidos en una burbuja de individualismo; el agua a través de los siglos ha sido utilizada en lugares que muchos de ellos aún permanecen tras muchas remodelaciones de sus instalaciones; estos cambios estructurales se han sumado a los cambios sociales en busca del éxito comercial, el paso del tiempo ha sido testigo de cambios en las relaciones sociales que en torno al baño se han ido gestando, ritos

\footnotetext{
${ }^{3}$ Pérez Fernández, M.R. y Novoa Castro, B. (2006) “Historia del Agua como Agente Terapéutico”. En: http://www.doyma.es

${ }^{4}$ Lipovetsky, G. (2008) “La Era del Vacío (ensayos sobre el individualismo contemporáneo)” Ed. Anagrama; Barcelona. Pág. 10
} 
y costumbres aún permanecen pero en esencia, el baño se ha convertido en un nuevo objeto de deseo cuya práctica dista en parte de las hasta ahora utilizadas:

"..Estamos destinados a consumir, aunque sea de manera distinta, cada vez más objetos e informaciones, deportes y viajes, formación y relaciones, música y cuidados médicos. Es la sociedad posmoderna; no el más allá del consumo, sino su apoteosis, su extensión hasta la esfera privada, hasta en la imagen y el devenir del ego llamado a conocer el destino de la obsolescencia acelerada, de la movilidad, de la desestabilización. Consumo de la propia existencia a través de la proliferación de los mass media, del ocio, de las técnicas relacionales, ..."

Salud, placer y calidad de vida, en un uso marcado por la moda y las tendencias, una vuelta a los orígenes, fusión corporal con la naturaleza, con lo rural, un uso del agua que se mezcla con la fe y la magia, con el deseo de la juventud sin límites, un narcisismo enconado que hace que el individuo se mire en el reflejo de las aguas alimentando valores de una cultura posmoderna que representa una nueva realidad social individualista y egocéntrica donde el presente ocupa el límite de todo interés.

"El narcisismo, consecuencia y manifestación miniaturizada del proceso de personalización; símbolo del paso del individualismo $<<$ limitado >> al individualismo <<total >>...... el concepto de narcisismo tiene por objeto hacer eco de esa culminación de la esfera privada"6

\footnotetext{
${ }^{5}$ Lipovetsky, G. Pág 10

${ }^{6}$ Lipovetsky ,G. Pág. 12
} 
Las palabras "público" y "privado" suelen acompañar al concepto "baño", hoy el baño público concibe en sí mismo al baño privado, en un afán individualista de escaso nivel relacional, pequeños jacuzzis en grandes piscinas, saunas de espacios reducidos en grandes ciudades balnearias donde la esfera privada envuelve en aceites y masajes al agüista.

Estamos ante una nueva cultura del agua marcada por el deseo ecologista de su perdurabilidad, por la recuperación de sus usos sociales y terapéuticos y a su vez, por el individualismo fanático de su disfrute.

"Los públicos de las sociedades industriales avanzadas ensalzan cada vez más la calidad de vida y en ocasiones dan más importancia a cosa tales como la protección de medio ambiente que al crecimiento económico."7

Vivimos con sentimientos encontrados, por un lado, tratamos de mantener el medioambiente mediante una utilización racional y responsable del mismo, por otro lado, consumimos y derrochamos elementos naturales por propio placer y de forma incontrolada. Hacemos uso del baño sin pensar en conductas ecológicamente responsables, sin tener en cuenta el consumo o el gasto que supone este acto.

Anthony Giddens en su libro "Modernidad e Identidad del Yo "El Yo y la sociedad en la época contemporánea" dedica un capítulo al narcisismo en el que nos alerta de vivir en una sociedad dominada por las apariencias, un narcisismo alimentado por el capitalismo que incita al consumismo procurando formar gustos mediante la publicidad, una publicidad que vende, atractivo, belleza y popularidad. La belleza es la mejor tarjeta de presentación sostenía Aristóteles y hoy lo sigue siendo, es una carta de presentación a incluir en el curriculum vitae que abre las puertas del éxito personal y profesional en la sociedad actual.

\footnotetext{
${ }^{7}$ Inglehart, R. (2001) “Modernización y Posmodernización” Ed. CIS Madrid. Pág. 106
} 
"El capitalismo consumista, con sus intentos de normalizar el consumo y de formar gustos mediante la publicidad, tiene un papel importante en el fenómeno del narcisismo. La idea de generar un público educado y entendido ha sucumbido hace mucho a la generalización del consumismo, que es una "sociedad dominada por las apariencias". El consumo se dirige a las cualidades alienadas de la vida social moderna y pretende ser su solución: promete las cosas mismas que desea el narcisista- atractivo, belleza y popularidad personal- mediante el consumo de los tipos de bienes y servicios "apropiados". De ahí, en las condiciones sociales modernas, todos nosotros vivamos como si estuviéramos rodeados de espejos donde buscamos la apariencia de un yo sin tacha y socialmente valioso. ${ }^{8}$

La teoría epicúrea del placer se pone en práctica en el acto íntimo del baño, la búsqueda de la paz y la felicidad se convierten en objetivo fundamental, donde hay placer hay ausencia de dolor y aflicción, desparece la tensión y el aburrimiento, el placer que proporciona el baño es un placer moderado. El hedonismo es una teoría moral que propugna el placer como fin último de la vida, una filosofía que subyace en los mensajes publicitarios de balnearios y casas de baño. La racionalidad instrumental pierde importancia en aras de la racionalidad valorativa como anunciaba Inglehart ${ }^{9}$, la felicidad humana prima sobre los medios económicos para alcanzarla, el ser humano necesita tener seguridad económica en cuanto a su subsistencia pero desea poseer la estima y la satisfacción estética.

\footnotetext{
${ }^{8}$ Giddens, A. (1991) “Modernidad e Identidad del Yo”, (El Yo y la Sociedad en la Época Contemporánea) Ed. Península. Barcelona. Pág. 67

${ }^{9}$ Inglehart, R. (2001) Págs.45- 106
} 
"Los posmaterialistas no son materialistas, y menos aún antimaterialistas. El término "posmaterialista" denota un conjunto de metas a las que la gente da importancia después de haber alcanzado esa seguridad material. Así, el colapso de la seguridad podría conducir a un regreso gradual de las prioridades materialistas. El surgimiento del posmaterialismo no refleja una inversión de polaridades, sino un cambio de prioridades: Los posmaterialistas no valoran negativamente la seguridad económica y física, la valoran positivamente, como todo el mundo; pero a diferencia de los materialistas, dan prioridad a la autoexpresión y la calidad de vida.................Cuando la posibilidad de morir de hambre pasó de ser una preocupación fundamental (años, 3540 y 75-80) a una perspectiva insignificante para la mayoría de la gente, los valores dominantes cambiaron gradualmente. La seguridad económica todavía es algo que todo el mundo quiere, pero ya no es sinónimo de felicidad." 


\section{JUSTIFICACIÓN}

Es difícil justificar aquello que se justifica por sí. Sólo, por su esencia misma; es difícil justificar el objeto central de esta investigación, cuyo continente y contenido, sirven de soporte al agua, como eje temático que baña estas páginas empapándolas de cuestiones que no por muy sabidas son menos ignoradas.

El agua es un recurso muy valorado en cuanto a su uso social mediante el baño. El agua ha encontrado su puesto como proveedora de ocio, como proveedora de servicios sociales, pero aún hoy, busca en España, el reconocimiento que merece dentro de las políticas sociales, dentro del sector de la sanidad, un reconocimiento que otros países le han otorgado logrando que el uso social del agua pase a formar parte de sus políticas en materia de seguridad social. El baño proporciona una curación en la que el individuo es parte activa, la farmacopea proporciona una curación que la que el individuo es paciente, el agua mediante el baño cura de forma no traumática y natural permitiendo al enfermo entrar a combatir en su propia guerra.

El baño es patrimonio de la humanidad, el baño es valorado por el ser humano desde los cinco continentes. Culturas y religiones reflejan en el agua años de historia, un uso que pervive y se fomenta un uso que prodiga sus virtudes con la fuerza de sus efectos visibles.

El agua está en la naturaleza misma de las cosas, en nosotros mismos, somos naturaleza viva y somos agua, ella interviene en nosotros pero ¿Cómo intervenimos nosotros en ella?. Herencia en usufructo, legado natural tantas veces valorado y tantas otras derrochado, un patrimonio compartido y en todo instante utilizado, sin el que la propia existencia estaría algo más que amenazada, destruida.

Este trabajo rinde culto al agua merecedora de unas páginas por su aportación constante al ser humano, de salud placer y calidad de vida. 


\section{OBJETIVOS E HIPÓTESIS}

Del culto al agua al culto al cuerpo, hombre y naturaleza componen un binomio inseparable, una relación de dependencia marcada por modas y tendencias que cambian en el tiempo fruto del deseo, el capricho o la necesidad intima del ser humano.

Disfruta, vive el momento "Carpe Diem" no dejes para un mañana incierto la búsqueda de tu propia felicidad, una fórmula que se retoma y vuelve a la actualidad como símbolo de una sociedad posmoderna que busca el placer inmediato y los logros el momento.

Estamos ante una nueva valoración de la naturaleza a través de uno de sus elementos "el agua" y a su vez, a través de uno de sus usos, "el baño". Por motivos distintos de ocio o negocio la época dorada del baño comienza a pasar por uno de sus mejores momentos, se apuesta por un sector cuyo éxito reside en la necesidad creada del deleite, ofreciendo un abanico de posibilidades hídricas para mimar los cuerpos necesitados de la tranquilidad y la calma que el agua mediante el baño puede brindar.

De la naturaleza, el agua, y de esta, su uso como fuente de salud placer y calidad de vida. Los usos sociales del agua en relación al baño están cambiando, se observa una recuperación de los mismos, un regreso a la naturaleza, en la que prima la búsqueda del placer y la felicidad como fin último, consiguiendo a su paso, salud y juventud, la búsqueda en la naturaleza de la frescura y lozanía de aquello que no perece. La belleza conduce a éxito y este al poder y la conquista, el hombre vive para gustarse a sí mismo y a los demás, busca ganarse un puesto en la vida pública, y para ello, busca en la esfera privada el secreto de la eterna juventud, el deseo de intimidad le lleva al baño, que aunque en un ambiente público, consigue reservarse su entorno en el que solo él o sus elegidos participan de placer buscado. Cuerpo y 
mente buscan el equilibrio prefecto en un líquido elemento que solo la madre naturaleza puede proporcionar.

\section{Objetivos Generales:}

Conocer la relación del hombre y la naturaleza a través del agua en uno de sus usos más sociales. Buscar en el pasado, fondear en el presente y prever el futuro a través de la recuperación de este uso social y terapéutico ha sido uno de los objetivos que llevan a la concesión de este trabajo.

Han formado parte de los objetivos de este estudio, el conocer el baño en sus distintas facetas, sus aportaciones culturales y religiosas, la parte lúdica y la espiritual, las experiencias del hombre al contacto con la naturaleza misma, al contacto con el agua.

Analizar el baño desde el punto de vista de sus aguas: mineromedicinales, marinas y dulces, conocer sus virtudes saludables y relajantes, su clientela y el secreto del su éxito.

Acercarnos a las nuevas formas de turismo "Turismo de Salud" que de la mano del baño, surgen como una nueva forma de viajar para conocer zonas que se encontraban deprimidas y que gracias a la recuperación de los centros balnearios han pasado a ser sostenibles, fruto de inversiones que hacen de estos lugares zonas atractivas donde pasar unos días de descanso.

\section{Objetivos específicos:}

Es objetivo de esta investigación, conocer lo que representa para el individuo en la actualidad un uso tan antiguo como el baño; conocer las nuevas formas de acercarnos a la naturaleza y saber lo que esperamos de ella. 
Conocer el perfil de agüista y su motivación para acudir a centros balnearios y su percepción de los mismos. Acercarnos al uso del agua mediante el baño como vehículo para la consecución de deseos personales e íntimos, el baño hedonista, el baño narcisista, el baño reparador, analizar las distintas facetas y sus implicaciones en la vida diaria.

El fin último del baño es objetivo de este trabajo, conocer lo que induce al ser humano a ese contacto con la naturaleza a su valoración por encima de otros placeres, a su necesidad de sumergirse en el agua para romper con la realidad de la vida cotidiana. 


\section{MARCOMETODOLÓGGCO}

Para la consecución de esta tesis sobre el agua como fuente de placer y calidad de vida, ha sido necesaria la consulta de fuentes bibliográficas, y documentales que pudiesen aportar toda la información posible acerca del fenómeno del baño, objetivo principal de esta investigación. Para ello, se ha optado por una metodología que parte de la búsqueda y análisis de la documentación atendiendo a su cronología incluyendo aquellos documentos que contuviesen un contenido informativo valioso a tener en cuenta en la investigación, sumando a esa base documental, toda aportación interdisciplinaria, documentos históricos, legislativos, arquitectónicos, administrativos, médicos o de cualquier otra índole que tuvieran una relación directa o indirecta con el agua y su función social mediante el baño.

Las herramientas electrónicas han jugado un papel importante a la hora de ampliar y actualizar información tanto para España, como para otros países en los que el baño forma parte importante de su cultura o de la religión que profesan.

Han sido bastantes los documentos consultados, estudios de caso, guías turísticas y documentos con fines publicitarios destinados al fomento del turismo de salud y a centros dedicados a la práctica del baño, a través de ellos, hemos podido obtener una visión previa y general y en mayor medida actualizada del fenómeno balneario.

Concluida una primera revisión bibliográfica y definido el objeto de la investigación se profundizó en aquellas fuentes cuyo flujo e información se ajustaba más a los objetivos tanto generales, como específicos de este estudio.

Para la elaboración de la tercera parte de este trabajo bajo el título "Recuperación de los Usos Sociales y Terapéuticos del Agua" se ha llevado a cabo una investigación sociológica sobre el fenómeno del baño en la actualidad; para su consecución se ha utilizado una metodología de triangulación, sumando a la consulta de fuentes bibliográficas y documentales, una metodología cuantitativa centrada en la 
realización de encuestas en distintos centros balnearios de aguas mineromedicinales y una metodología cualitativa mediante la realización de entrevistas personales, a la que se añade una analítica descriptiva basada en la observación participante en la que el investigador pasa a ser usuario del baño público para ofrecer desde la propia experiencia la información necesaria para conocer la realidad social que gira en torno al placer del baño.

Para llevar a cabo la recogida de información, se seleccionaron 42 balnearios repartidos por las distintas Comunidades Autónomas que cuentan con este tipo de centros, con el fin de tener una muestra representativa; sólo 18 aceptaron. El balneario de Puente Viesgo (Cantabria) decidió participar sólo de forma parcial mediante la entrevista, en el balneario del Salugral (Extremadura) y en el de Fuente Amarga (Andalucía), solo se realizaron encuestas ante la dificultad de contactar con el personal responsable.

La recogida de información se estructuró en dos partes, cada una de ellas dirigida a conocer la opinión de un público objetivo utilizando una metodología distinta en cada caso, por un lado, una metodología cuantitativa mediante encuestas, por otro lado, se utilizó una herramienta metodológica cualitativa, a través de la realización de entrevistas.

La recogida de información procedente de directores y responsables de centros balnearios se realizó mediante entrevista (anexo II).

La recogida de información procedente de los bañistas de los distintos centros balnearios se realizó mediante encuesta a través de un cuestionario elaborado al efecto (anexo I), dicho cuestionario se envío por correo a aquellos balnearios que previo contacto telefónico accedieron a participar en esta investigación; en algunos casos en los que por cercanía era posible la realización de encuestas de manera personal, se desplazó al centro un encuestador autorizado que se encargó de realizar las encuestas a los agüistas que se encontraban en el balneario disfrutando de sus aguas, se puede afirmar que la información fue recogida a pie de terma. 
Se ha realizado un análisis observacional de dos balnearios (elegidos ambos por su origen y antigüedad) mediante visita a los mismos con objeto de conocer y presentar en este estudio, la evolución tanto de los centros, como de las terapias como indicadores de la recuperación del uso social del agua mediante el baño.

La recopilación de material fotográfico realizado para esta tesis ha sido otro de los métodos utilizados para reflejar de forma material la situación real y conocer de manera grafica los centros dedicados al baño, así, se muestran a lo largo de toda la investigación un centenar de fotografías (sin incluir aquellas que se han tomado de otros documentos que se encuentran citadas al pie) un material inédito, realizado de forma intencionada, con el fin de informar y enriquecer esta investigación.

"La teoría fotográfica aplicada al análisis de la sociedad está realmente subdesarrollada. Se acepta la Fotografía como arte, como química, a veces incluso como denuncia, como pasatiempo, pero no como Sociología. Sin embargo, la Fotografía contribuye sustantivamente a la construcción de la realidad social." ${ }^{10}$

Una reflexión sobre las investigaciones realizadas desde el ámbito de las distintas disciplinas cuyo tema principal gira en torno al agua y al baño, viene a formar parte del análisis de esta primera parte del estudio en el que se observa un vacío importante de trabajos realizados desde el ámbito de la sociología.

Profuso ha sido el número de trabajos, investigaciones, monografías en torno al agua aplicada al baño, a sí mismo, ha ido en aumento el número de congresos que se han dado cita en torno al tema hídrico. Muchos estudiosos de distintas disciplinas, medicina, historia, arquitectura, geografía, arqueología entre otros, han abordado el tema procurando una aportación de inestimable valor que sin duda se han tenido en cuenta para la consecución de este estudio; sin embargo, se observa un gran vacío

\footnotetext{
${ }^{10}$ De Miguel, J.M. y Ponce de León, O. 1998 “Para una Sociología de la Fotografía” Revista Reis Pág. 86
} 
en cuanto a investigaciones desde el campo de la sociología, siendo ésta la ciencia que estudia las relaciones sociales, la relación ente el hombre y el medio natural en el que habita, el medio ambiente natural y humano. Es del todo necesario acercarse mediante la investigación social, a la realidad de la relación de dependencia del hombre con la naturaleza, a las nuevas formas de acercamiento al medio natural para conocer qué ofrece éste para preservar la naturaleza y qué espera obtener de ella. El hombre y la naturaleza son los verdaderos protagonistas de este estudio que busca conocer a través del baño, las nuevas formas de relación social y de apreciación de lo natural.

La mayor parte de los estudios encontrados son estudios de caso, centrados en un balneario concreto, por el contrario este trabajo pretende ser un tratado general sobre uno de los muchos usos sociales del agua "el baño", desde sus orígenes a la actualidad, analizando las distintas conductas sociales que tienen al hombre como protagonista.

Esta investigación, trata de aportar desde el ámbito de estudio de la sociología, una nueva visión, distinta a las realizadas hasta ahora, que permita explicar el vacío que hay en este campo de investigación, y que sin duda ha de ser complemento importante para tener una visión global sobre el fenómeno del agua, contando en todo momento, con el valioso apoyo y aportación que nos llega de ese importante caudal de investigaciones anteriormente mencionado, sin el que esta investigación no podría llevarse a cabo.

\section{Estudios Previos sobre el sector balneario en España: Aportaciones}

Escaso es el fondo de estudios dedicados al sector balneario en España. Digno de mención es un capítulo dentro del libro "Panorama actual de las Aguas Minerales y Minero-medicinales en España" que centra su análisis en las estrategias competitivas dentro del sector y en las causas que explican la puesta en marcha de nuevos establecimientos balnearios, un estudio en el que se sugieren estrategias 
competitivas para un sector sostenible a largo plazo atendiendo a las particularidades de las distintas empresas que lo componen.

Este estudio nos pone en antecedentes sobre la situación real del sector balneario pero no nos sirve de referente a la hora de comparar la información, en primer lugar, carece de ficha técnica por lo que se desconoce la muestra utilizada y en segundo lugar, se presume que la población objeto de estudio es la población en general mientras que en el estudio que se presenta a continuación la población objeto de estudio son usuarios de centros balnearios que facilitan la información durante su estancia en uno de los centros participantes en el estudio, son individuos que acuden con una motivación y que conocen el producto que consumen.

Apuntes de ponencias y reseñas en estudios de caso son el único referente encontrado, con escasa información y sin el soporte de datos cuantitativos fruto de trabajos de campo dentro del sector objeto de estudio, así mismo, a lo largo de este capítulo se ha realizado una reflexión sobre el sector, basándonos en fuentes secundarias, documentos legislativos, estudios realizados, revistas etc. a través de todos ellos hemos podido conocer, en parte, cual es la situación actual del sector hasta el momento. Con la intención de dar un paso más en la investigación, se plantea la necesidad de investigar con fuentes primarias, mediante la recogida de información en los propios balnearios, a través de encuestas realizadas a los usuarios y entrevistas a personal directivo de los distintos centros. 


\section{ANÁLISISDE CONCEPTOS UTILIZADOS:}

Será objeto de este apartado el análisis de conceptos específicos, en algunos casos confusos, realizando un repaso a las distintas apreciaciones que sobre esos conceptos se consideran oportunos para una mayor comprensión de los mismos a la hora de situarlos en el contexto general de este estudio:

\section{a) Hidrología/Hidrología Médica e Hidroterapia:}

El estudio de las aguas corresponde a la Hidrología y el estudio o aplicación medicinal del agua correspondería a la Hidrología Médica; hecha esta distinción, se hace necesario distinguir también entre Hidrología Médica e Hidroterapia, siendo la primera, la encargada de las características propias del agua orientada al interés terapéutico, utilizando como agente curativo, el agua mineromedicinal, mientras que la Hidroterapia, se centra en la aplicación tópica del agua potable aunque también con fines terapéuticos.

- Hidrología Médica: un término muy utilizado en países mediterráneos y latinoamericanos

b) Crenoterapia: expresión procedente de Francia, procede de "Crenos; fuente o manantial"

c) Balneoterapia: vocablo Germano que alude al estudio de la acción terapéutica del agua mineromedicinal.

\section{Aclaraciones sobre el concepto de balneario.}

Se hace necesario establecer consideraciones generales y precisar ciertos conceptos que están viciados por su utilización errónea, como es el caso del concepto de "balneario" que estudiaremos detenidamente en el capítulo noveno, éste se suele hacer extensivo a centros cuyas características no corresponden a la propia 
definición. Al hablar de balneario o de estaciones termales hablamos de una institución sanitaria, cuyas instalaciones se encuentran ubicadas al pie de un manantial natural, con propiedades físico-químicas y de sales en ella disueltas; Son aguas con propiedades terapéuticas que la hacen favorable para el tratamiento y prevención de enfermedades, así como para el mantenimiento de la salud en general.

Cada manantial termal tiene unas propiedades intrínsecas que los distingue y que los hace favorables a un tratamiento terapéutico concreto: piel, vías respiratorias, articulaciones etc.

Por tanto habría que diferenciar entre:

a) Terma

b) Balneario / Estación termal (ambos son el mismo concepto)

c) Centros de talasoterapia

d) Otros centros.

\section{a) Terma:}

"Aunque el significado de la palabra Terma es conocido por todos los especialistas, para tomar un primer punto de partida es básico establecer su concepto. Tomando como referencia el griego y posteriormente el latín, proviene de la palabra Thermae-thermarum, que equivaldría al lugar de surgencia de las aguas calientes o baños de agua caliente. Otra visión que también se contempla podríamos tenerla a nivel históricoarquitectónico, que la definiría como un establecimiento público de baños". ${ }^{11}$

\footnotetext{
${ }^{11}$ Molina, J.J (1977) “Termalismo Antiguo en los Balnearios del Siglo XIX”. En: Termalismo Antiguo (I Congreso Peninsular. Actas), M. J. Peréx, (1977). Ed. UNED-CV. Madrid.
} 


\section{b) Balneario ó Estación Termal:}

Es aquella instalación que dispone de:

- Aguas Minero-Medicinales, declaradas de Utilidad Pública.

- Servicio Médico.

- Instalaciones adecuadas, según el punto de vista técnicosanitario, para llevar a cabo los tratamientos médicos que se prescriban.

En estos centros se lleva a cabo, lo que se denomina Cura Termal, entendida como el conjunto de técnicas crenoterápicas, hidroterápicas y complementarias llevadas en la práctica a un ritmo, de intensidad, duración y frecuencia, establecidos previamente por el médico y realizadas en un Balneario. Este sector está legislado.

\section{c) Centros de Talasoterapia:}

Son centros o lugares en los que se realizan tratamientos y terapias mediante el uso del agua de mar, así como de algas, sales, fangos o lodos marinos entre otros, que junto con el agua se aplican al cuerpo, en busca de salud y belleza. Talasoterapia: Del griego "Talassa" que significa mar, y terapia (cura y control médico) se trata de la utilización bajo vigilancia médica, con fin preventivo o curativo de los beneficios del medio marino. Tres factores son indispensables para este tipo de tratamiento: agua salina de mar, recogida a una determinada profundidad del fondo marino y calentado a la temperatura del cuerpo humano, y elementos marinos como algas, barro y plancton termal; a todo esto habría que añadir los beneficios del clima marítimo, el aire marino y el sol, que son la combinación perfecta para curar o paliar muchas enfermedades. 
Hay que tener en cuenta que el sector de la Talasoterapia no está legislado. Estos centros de salud se apoyan en la administración de baños de agua corriente y no deben ser confundidos con la balneoterapia o el termalismo ya que no utiliza aguas provenientes de manantiales termales o minerales.

Estos centros deben cumplir los siguientes requisitos:

$>$ Proximidad al mar.

> Utilización para sus terapias de agua natural canalizada desde alta mar.

$>$ Control médico de los agüistas.

> Personal cualificado para la práctica de las distintas terapias (fisioterapeutas, hidroterapeutas etc.)

La Talasoterapia está indicada contra el estrés, los trastornos reumáticos o traumáticos, las alteraciones de la piel, el envejecimiento, los trastornos derivados de la menopausia (osteoporosis), trastornos del apetito, siendo aconsejable como preparación y recuperación del parto.

Estos tratamientos no están aconsejados para aquellas personas que sufren enfermedades cardíacas, cancerígenas, afecciones vasculares o endocrinas, así como infecciones agudas; por estas circunstancias se hace indispensable el reconocimiento médico previo y su autorización para hacer uso de los mismos.

\section{d) Otros centros dedicados al baño:}

Así mismo, Existen otros centros en los que el agua es protagonista, como es el caso de los SPA, que consisten en un espacio en el que se aplican tratamientos por medio del agua para conseguir bienestar, relajación, vitalidad y salud. Estos suelen ser centros específicos o 
centros SPA situados dentro de hoteles que ofrecen este tipo de servicios alternativos con el fin de atraer clientes.

En estos centros, el agua que se utiliza es agua corriente "del grifo" mezclada con sales, aceites, etc. Que proporcionan bienestar y placer por su forma de aplicación, ya sea en forma de chorros, burbujas etc. Este sector no está legislado.

Curhotel: hoteles donde se prestan servicios y atenciones relacionadas con el estado de salud y el bienestar, mediante terapias de anti-estrés, de adelgazamiento, belleza. 


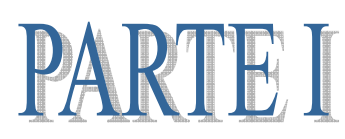

EIAGUAAPLICADA AL BAÑO DESDE TIEMPOINMEMORIAL

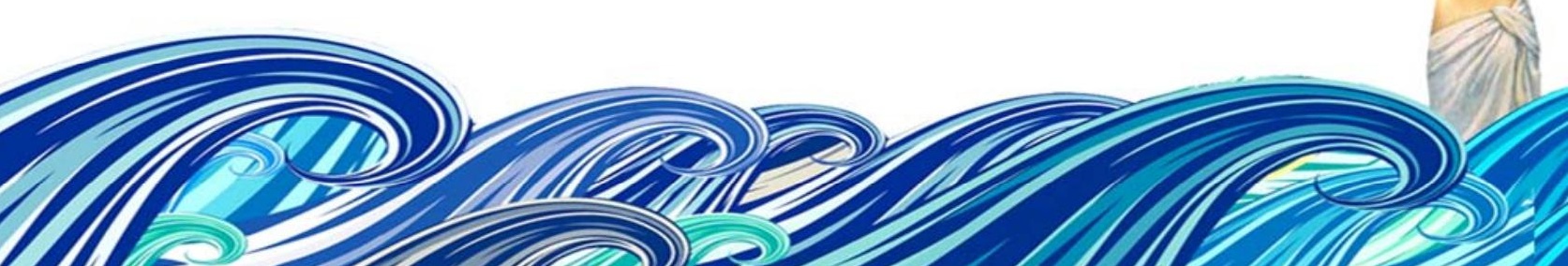




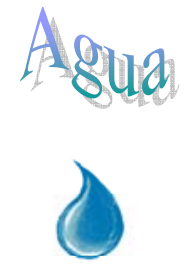

Hablar de agua es hablar de hombre y naturaleza como un binomio inseparable; el cuerpo humano, está en su mayoría formado por agua y para sobrevivir necesita disponer de este elemento natural, no en vano desde la antigüedad, el hombre primitivo, y los primeros asentamientos humanos, buscan la lógica del acercamiento a ríos o lugares donde este líquido elemento es abundante, a fin de tener cubierta una de sus principales necesidades, para su subsistencia.

El agua ha sido un factor condicionante de las actividades humanas; el ser humano siempre ha tenido en cuenta la importancia que tiene el agua para su supervivencia como especie y es por ello que buscaban ríos o lugares donde el agua fuese un recurso copioso, ríos donde extraer el agua para uso propio y a su vez, como vía de comunicación y transporte de mercancías, o de su utilización para el riego en la agricultura. Esta proximidad del hombre a los caudales de agua, no ha sido siempre positiva debido a la fuerza irracional de la misma, en distintas épocas del año, cuando las crecidas de los ríos hacen suyo, todo lo que encuentran a su paso.

El agua está en el origen de la vida, disponer de ella es todo un privilegio del que el hombre no puede prescindir, es esa razón de dependencia, la que ha dado lugar a la construcción de colosales obras arquitectónicas con el fin de modificar el curso natural del agua, acercando de este modo a las ciudades el elemento hídrico para alimentar fuentes y termas, deleite de los sentidos de los ciudadanos urbanitas. Gran cantidad de estas obras tienen como autores a los romanos, que construyeron verdaderas obras de ingeniería, como es el caso de acueductos o puentes que a día de hoy siguen cumpliendo con la finalidad hidráulica para la cual fueron construidos y del mismo modo en la actualidad, con la construcción de nuevas obras de ingeniería, que de la mano de las nuevas tecnologías, se introducen en el paisaje natural con la 
gran repercusión ambiental que conlleva, la absorción por el paisaje de esas obras destinadas al aprovechamiento hidráulico, ejemplo de ello son las grandes centrales hidroeléctricas, o saltos de agua que se encuentran en nuestro entorno natural.

La necesidad del hombre de retener el agua para su uso personal, ha agudizado su ingenio y creatividad modelando desde la antigüedad con sus propias manos, vasijas y vasos de barro, recipientes orientados a contener el agua, que en la actualidad se siguen fabricando de manera más sofisticada no sólo por sus formas, sino por la materia prima utilizada al efecto (plástico, cristal etc.)

"El personal que trabaja en las obras de remodelación de la galería termal del Balneario de Archena ha encontrado restos de vasijas, cerámicas y dos muros de la época romana, que podrían datar de la fecha comprendida entre los siglos I antes y después de Cristo y podrían confirmar su uso por nobles en aquella época."12

A lo largo de este estudio, iremos observando cómo el hombre a través de la historia ha ido haciendo múltiples usos del agua y como sobre este recurso, se erigieron mitos, civilizaciones, religiones y esperanzas de aquellos olvidados por la salud; se podría por ello hacer una extensa tipificación, de la relación del hombre con el agua atendiendo al uso que hace de ella, ya sea por la religión, la curación, la alimentación etc. Pero el objetivo de esta investigación, es la relación del ser humano con el agua a través del baño público, del uso de los balnearios como centros curativos, de descanso y de placer corporal, de cómo el hombre basándose en la necesidad física del contacto con el agua, ha ido creando toda una cultura hídrica, que pasa por la construcción a lo largo de la historia de bellas y emblemáticas termas, hasta la utilización de un sinfín de métodos de aplicación del agua, que al contacto de

\footnotetext{
${ }^{12}$ Servicio de Patrimonio Histórico. Dirección General de Bellas Artes y Bienes Culturales, Consejería de Cultura y Turismo. En: http://www.arqueomurcia.com
} 
ésta con el cuerpo hacen que se produzcan sensaciones inimaginables capaces de trasmitir placeres y conseguir efectos de relax y descanso.

El fenómeno balneario es un fenómeno histórico que va sumándose a los avances de la ciencia, sin perder su esencia primera, es un fenómeno que se ve afectado por los desfases de la economía, y por los problemas sociales o políticos, que afectan a la vida cotidiana, marcas históricas que se pueden percibir en el impulso y ocaso de cada época de esplendor o decadencia del fenómeno balneario y que ha dejado huella en los propios edificios, en cuyas piedras se aprecia con claridad, cómo en momentos de auge los balnearios han sido objeto de remodelaciones y ampliaciones y cómo en los momentos de guerra o de decadencia económica, han sido objeto de profundo abandono por propietarios y usuarios. Esto queda de manifiesto en el siguiente fragmento extraído del estudio de caso que $M^{\mathrm{a}}$ Pepa Lara García hace de los baños públicos en Málaga:

"Este fenómeno pertenece a la historia de la vida cotidiana y discurre paralelo al desarrollo económico, social e higiénico de las sociedades e instituciones, afectando de modo especial a la vida de unas familias, grupos y clases concretas. Usar o no los baños suponía la posesión de una determinada cultura, de unas costumbres muy específicas y de unas evidentes disponibilidades económicas"13

La idea de balneario nace de la mano del descubrimiento de manantiales, de los que fluyen aguas calientes con propiedades curativas, distintas en cada caso, que son descubiertas por el hombre tras la curación de algunos animales, que padecían dolencias principalmente reumáticas, y que al sumergirse en estas aguas de manera fortuita, experimentaban una mejoría palpable de su salud, o como es el caso que se expone a continuación en la siguiente cita, efectos irremediables:

${ }^{13}$ Lara García, Ma P. (1997) “La Cultura del Agua: Los Baños Públicos en Málaga” Ed.: Sarriá. Málaga Pág. 13 
"Más de un siglo ha pasado desde que fue descubierta a finales del siglo XIX de manera casual por tres cazadores (de los cuales uno de ellos era farmacéutico) observaron que las aves, al acercarse a beber al manantial, morían al poco tiempo por asfixia, por el efecto de los gases sulfurosos que de ellas emanan. Un cuadro con los tres cazadores y el manantial, se conservó durante muchos años en el Balneario como prueba histórica de aquel hecho". ${ }^{14}$

Otro ejemplo de descubrimiento de manantiales por medio de la curación de animales, sucede en el balneario de Solán de Cabras, que como su nombre indica debe este reconocimiento a la curación de las cabras de la enfermedad de la sarna. ${ }^{15}$

Los manantiales de aguas medicinales surgen de fallas o fracturas de montañas, lo que hace que los balnearios se encuentren enclavados en plena naturaleza, en paisajes llenos de encanto, situados a la orilla o cerca de un río, ejemplo de ello es el balneario de Puente Viesgo en Cantabria o el de Retortillo en Salamanca; de ahí que los animales se acercasen a los ríos para beber o a bañarse en su aguas de las que desconocían sus propiedades.

A continuación se muestran dos imágenes tomadas en e interior del balneario de Carratraca en la provincia de Málaga, en ellas se puede observar como las instalaciones del balneario se encuentran en el interior de la roca, llegando incluso a formar parte de uno de los pasillos del centro.

\footnotetext{
${ }^{14}$ http://www.balneario.com/cofrentes/

${ }^{15}$ López de Azcona, J. M. Bellot Rodríguez, M. A.. Carrasco de Salazar y Fuentes Catells, A. (1980) "Estudios sobre el balneario de Solán de Cabras” Anales de la Real Academia de Farmacia No 4 Madrid Pág.40
} 

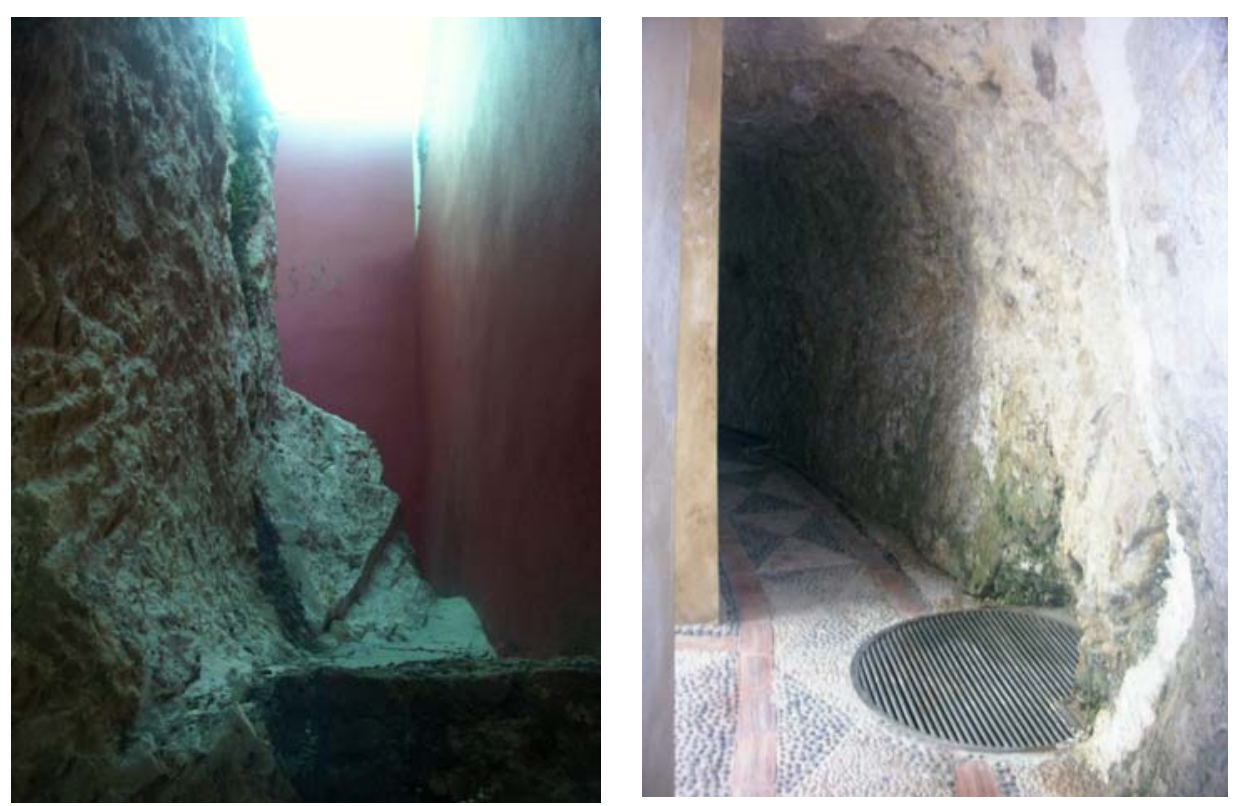

lustración 1 Imágenes del interior del Balneario de Carratraca (Málaga) en el que se observa la roca dentro de las propias instalaciones

"Los balnearios, relacionados directamente con las fallas y fracturas, suelen encontrarse en lugares más o menos montañosos, relativamente próximos a llanuras o depresiones y frecuentemente en las inmediaciones de ríos que transcurren por las hondonadas que originaron las fallas." ${ }^{16}$

\footnotetext{
${ }^{16}$ Bel Ortega , C. y Martínez González, D. (1995) “Balnearios de Andalucía” Ed.: Centro Andaluz del Libro, SA. Sevilla. Pág. 11.
} 


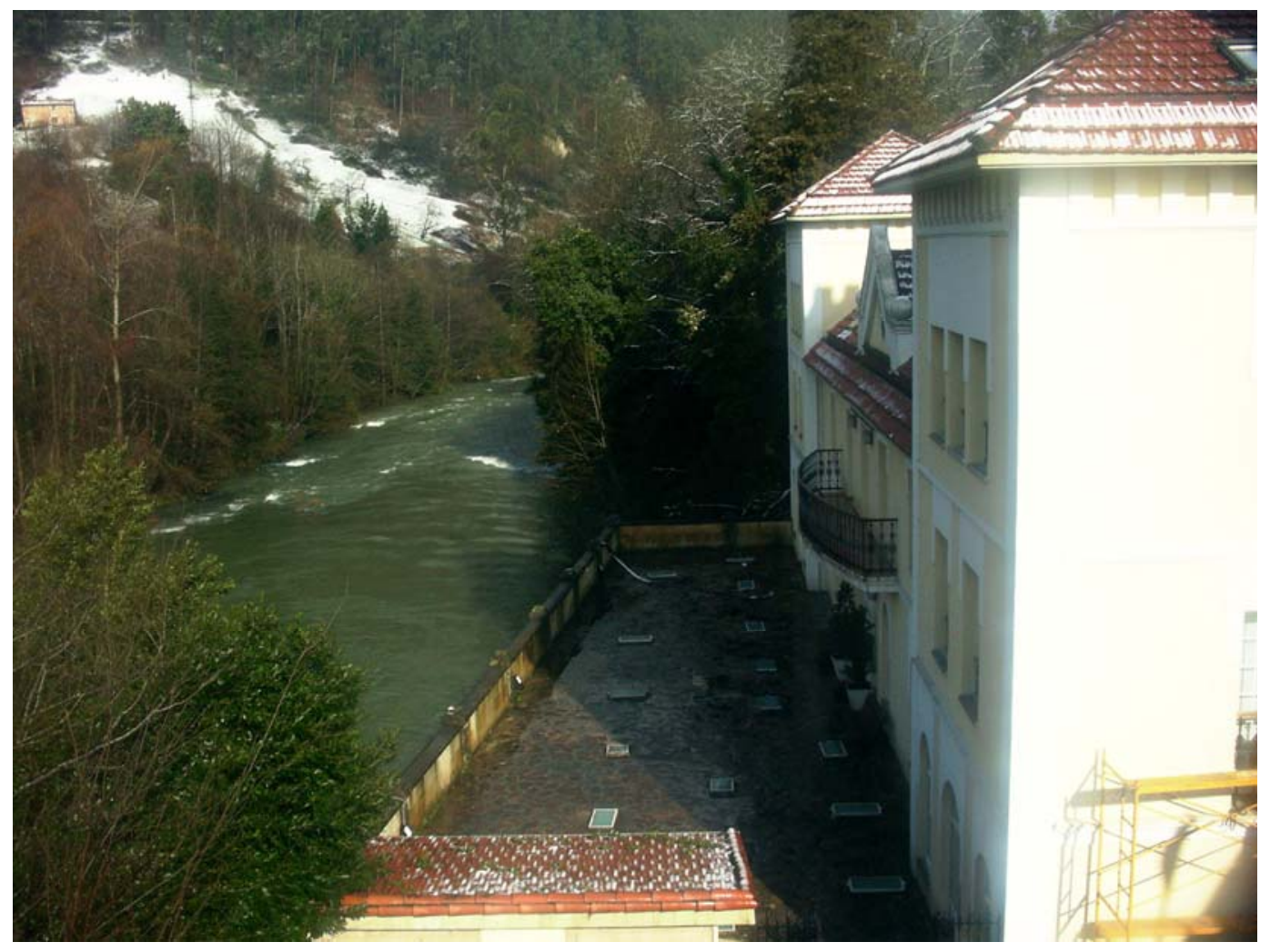

Ilustración 2 Balneario de Puente Viesgo (Cantabria)

El aprovechamiento de estas aguas dotadas de propiedades mineromedicinales, es lo que da lugar a la construcción de edificios sobre estos manantiales, lugares de acceso público donde poder sumergirse en este elemento hídrico de indiscutibles propiedades salutíferas, para ello los romanos hicieron calzadas con el fin de facilitar el transporte y el acceso a las instalaciones de las que aún quedan muestras que dan fe de la importancia del termalismo en la época de la romanización. 
Son griegos y romanos de cuya aportación al fenómeno balneario trataremos detenidamente más adelante en esta investigación, los primeros que comienzan a construir edificios dedicados al baño público en sus pueblos y ciudades, o al menos, es de ellos de quienes aún quedan restos arqueológicos que nos muestran con certeza su ubicación, distribución interior y el uso de los mismos.

Unos balnearios confirman su origen romano a través de la pervivencia de sus topónimos (caldas de Reis en Pontevedra y Caldas de Malavella en Girona). Otros, a través de los restos arqueológicos encontrados en su edificación o en su entorno más inmediato, como es el caso de los balnearios de Lugo, de Montemayor en Cáceres o de Carratraca en Málaga. Y otros a través de su ubicación en el paso de las vías de comunicación romanas llamadas calzadas. Es el caso del balneario de Marmolejo en Jaén. ${ }^{17}$

${ }^{17}$ Bel Ortega, C. y Martínez González, D. (1995).Pág. 12. 


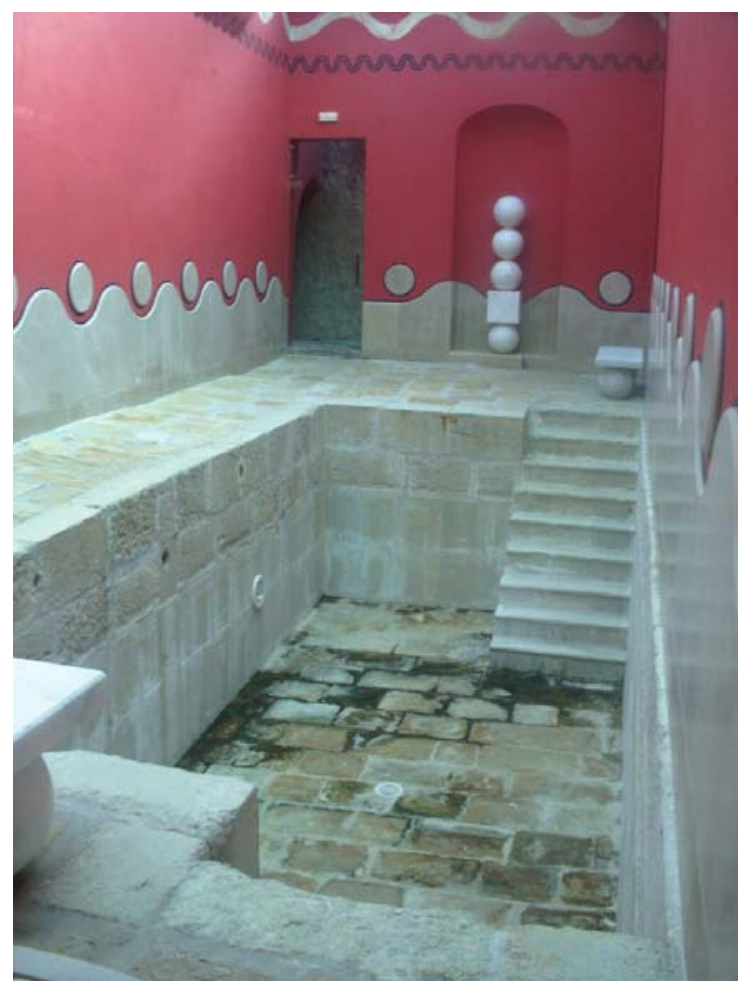

Ilustración 3 Cartel anunciador del Balneario de Carratraca. (Málaga).

El agua, por tanto, es considerada desde muy antiguo objeto de reflexión y pensamiento, es vista desde el poder; se podría decir que hay dos clases de poder en cuanto al agua se refiere: por un lado, el poder de aquel que la posee frente al que carece de ella; por otro lado, el poder intrínseco propio del agua, su fuerza sobre los demás elementos, su valor en sí misma, su capacidad de acción y reacción, su parte positiva, y su parte destructiva, cuando la fuerza de la misma trasciende al control que el hombre pueda hacer de ella dando lugar a inundaciones y catástrofes de grandes proporciones. 
Esta primera parte consta de dos capítulos dedicados a los orígenes del baño, desde una perspectiva histórica y cultural.

Independientemente de la época de que se trate, el baño se ve afectado por los movimientos culturales, costumbres, tradiciones, en definitiva, por la formas de acercarse al agua o de integrarse en la naturaleza. La relación del hombre con el orden natural y la forma de conexión con las fuerzas naturales varían según la cultura, así, cambian los ritos y elementos culturales produciéndose diferentes, aunque en algunos casos muy similares, manifestaciones de lo que podríamos llamar devoción a un elemento tan universal como es el agua y sus efectos en la naturaleza humana.

El uso del agua obedece en cierto modo a las distintas concepciones culturales, llegando a formar en cada comunidad, una cultura específica del agua. Sin agua no hay vida, el agua es un elemento clave para el grupo, todos sus miembros tienen la responsabilidad de transmitir los conocimientos adquiridos sobre ella y el deber ético de conservarla.

Conocer la evolución histórica del baño nos permite analizar los cambios acontecidos y los motivos económicos y sociales que favorecieron esos cambios hasta llegar a la actualidad. Conocer los antecedentes del empleo de agua para fines deleitosos o curativos a lo largo de la historia, es el objetivo principal del primer capítulo del que parte esta investigación.

Remontarnos a los orígenes del baño, conocer su evolución deteniéndonos en las causas y motivos que han dado lugar a momentos de esplendor o decadencia de esta práctica hídrica hasta nuestros días es el ley motiv de estas páginas dedicadas a la historia de un uso que paradójicamente es tan antiguo como actual, un placer que permanece en el tiempo manteniendo su esencia ritual siendo testigo de cambios sociales.

Para la elaboración del capítulo sobre la historia del uso social del agua mediante el baño, se ha realizado una pormenorizada revisión bibliográfica, con el fin de conocer las distintas obras e investigaciones publicadas al respecto. 
Los hitos históricos que se reflejan en el estudio han sido escogidos en base a la información encontrada en la documentación consultada, reiteradamente es coincidente en estos periodos que se presentan, justificándose a sí mismos por su importancia en lo concerniente a épocas de florecimiento o decadencia del uso del baño.

$>$ El baño en la antigüedad

$>$ De la Edad Media al Barroco

$>$ Siglos XV y XVI

$>$ Siglos XVII y XVIII

$>$ Siglo $X X$

$>$ Siglo $X X I$

El agua juega un papel importante en las distintas culturas, estas son modeladas mediante ritos y mitos, dando lugar a las tradiciones de los pueblos. En el segundo capítulo que conforma esta parte primera del trabajo, sondearemos sobre la importancia del agua a través de esos mitos y ritos, a su vez, conoceremos cómo el agua interviene en las distintas culturas mediante el baño, podremos observar como la hidroterapia existe, como reparamos en el capítulo primero, desde tiempos remotos, siendo base de la medicina de muchos pueblos. El gusto por el baño de griegos y romanos, la pasión por el agua mediante el baño de los árabes, el interés por el cuidado del cuerpo demostrado a través de las distintas culturas, de las que presentaremos una pequeña muestra en este capítulo, darán cuenta de la importancia de un hábito que se funde a lo largo de los siglos entre el placer y la pureza, el lujo y la austeridad, la lujuria y el recato, lo público y lo privado. 


\section{Cápitutulo I}

卧 baño en la historia

Durante muchos años han sido precisamente los balnearios, galerías de baños y manantiales los escenarios de una forma de entender la vida, edificios en los que se hace historia $y$ en los que se albergan las esperanzas de curación a través del agua

(Los Balnearios Españoles) 


\section{- Capitulol}

\section{Páginas}

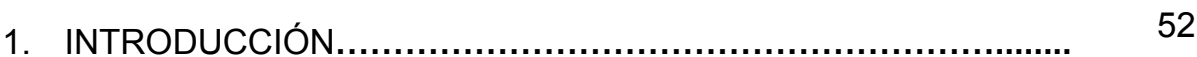

2. EL BAÑO A TRAVES DE SU HISTORIA ................................ 58

2.1. El Baño en la Antigüedad .................................... 58

2.2. De la Edad Media al Barroco ................................. 62

2.3. Siglos XV XVI

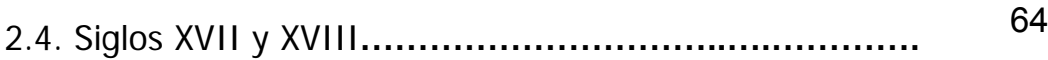

2.4.1. Controversia sobre el Agua (siglo XVIII............. 65

2.4.2. Finales del siglo XVIII................................ $\quad 72$

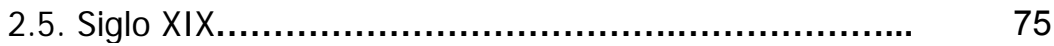

2.6. Siglo XX....................................................

2.7. Siglo XXI ...................................................... 85 


\section{Introdicción}

De igual forma que la historia del agua va ligada a su uso terapéutico en la mayor parte de los textos encontrados, de este uso hay que buscar sus orígenes en las diferentes historias escritas sobre el agua, ya que no hemos podido dar con una historia del baño propiamente dicha, de este modo, el empleo del agua dulce, salada o mineromedicinal, se explica desde su uso social en termas, casas de baño y otros centros dedicados al deleite del baño.

La mayor parte de las obras encontradas, son estudios de caso, que centran su análisis en un balneario concreto; en ellos suele haber referencias históricas de dicho balneario, que en algunos casos incluyen anécdotas de personajes relevantes de la época, reyes como es el caso de Fernando VII en el balneario de Solán de Cabras........ Cadenas y Vicent en su libro titulado "Jornada de Fernando VII y de Amalia de Sajonia en los Reales Baños de Solán de Cabras en busca del deseado Sucesor", nos describe: cómo llevados los monarcas por la fe en las milagrosas aguas del balneario de Solán de Cabras, se acercaron en condición de agüistas en busca del milagro de la sucesión.
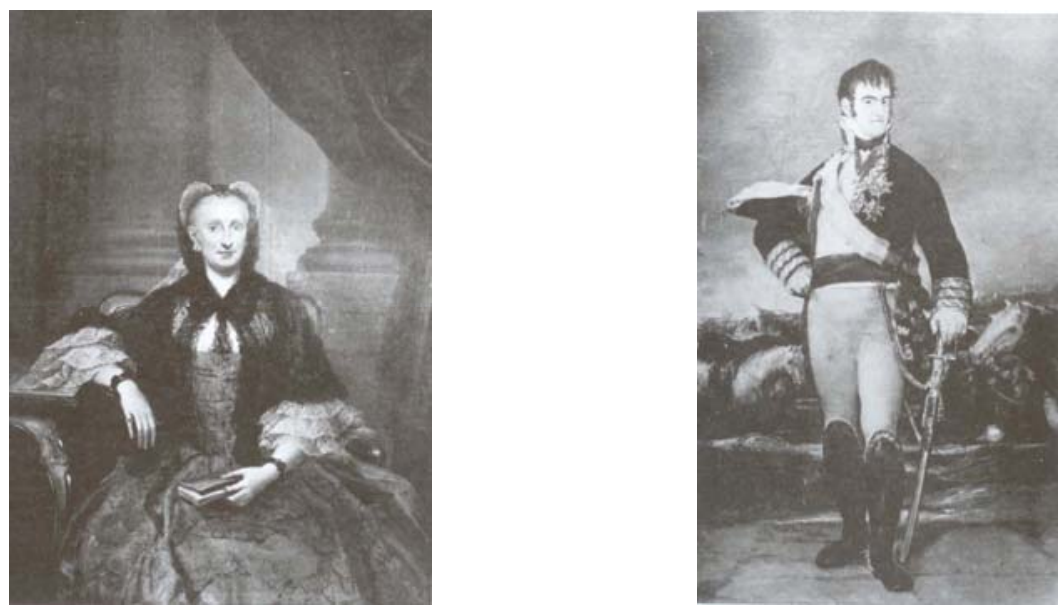

Fotografías de Fernando Séptimo y su esposa Amalia de Sajonia extraídas del libro de Cadenas y Vicent (1984) 
"Enclavado en la serranía de Cuenca, lindante con la meseta castellana, se halla situado en el Valle de Solán de Cabra. Sus accesos naturales eran los que por Aranzueque, Sacedón, Huete y Cuenca Ilevaron a Fernando VII y a su tercera mujer, Amalia de Sajonia, cuando visitaron aquellos parajes, en busca de milagro de sucesión, que tanto deseaban, y que esperaban encontrar tomando aquellas aguas"18

Muchos centros balnearios se han preocupado por editar su propia historia, se escriben pequeños libros que suelen poner a la venta en sus propias instalaciones, estos son en su mayoría adquiridos por los bañistas como recuerdo de su paso por tan insigne lugar, en ocasiones son las guías de viajes las que incluyen en sus páginas parte del enigma que encierran los misteriosos y legendarios lugares de baño; en el interior de sus páginas, se habla de las virtudes de sus aguas, se cuentan anécdotas, recuerdos y pequeñas historias de personajes ilustres que pasaron alguna que otra estancia vacacionando entre sus vapores sulfurosos.

Prácticamente todos los balnearios gozan de este tipo de publicaciones, unas realizadas por encargo del propio centro y otras, fruto del interés de investigadores, podemos citar entre otros:

- Historia del Real Sitio de la Isabela y Baños de Sacedón (2003) escrito por García López A. se trata de un estudio histórico que hace un análisis en profundidad de este centro balneario al que acudía la realeza en busca de salud y diversión, un balneario desaparecido en 1950.

\footnotetext{
${ }^{18}$ De Cadenas y Vicent, V. (1984) “Jornadas de Fernando VII y de Amalia de Sajonia en los Reales Baños de Solán de Cabras en busca del deseado Sucesor” Ed. Hidalguía. Madrid. Pág. 3
} 


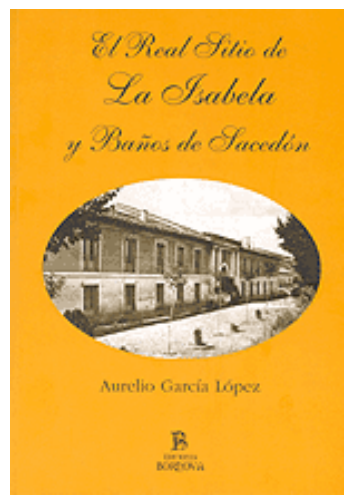

- Historia del balneario de Grávalos (Zaragoza 1993) escrito por Jiménez Pérez P.R. El objetivo de este libro es hablar de los baños naturales, del uso terapéutico el agua, haciendo referencia a la historia del balneario y del pueblo en el que se encuentra situado.

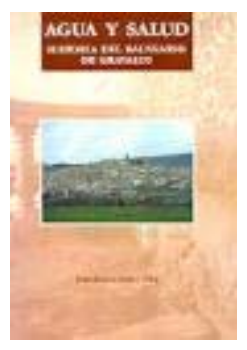

En muchos casos, se trata de ediciones a cargo de instituciones locales o provinciales de poblaciones a las que pertenecen los balnearios objeto de estudio, ejemplo de ello:

- Los Baños de Graena un manantial que sana, escrito por Saavedra Sierra y patrocinado por la Asociación para el desarrollo Rural de la Comarca de Guadix, en la que se encuentra situado este balneario de Graena. 
- Historia de los Baños Termales de Alhama de Granada de Roma a la actualidad: De Salvador Raya Retamero. (Universidad de Granada). licenciado en Filosofía y doctor en Historia, en los últimos años ha investigado sobre Alhama y su comarca a las que ha dedicado su tesis doctoral.

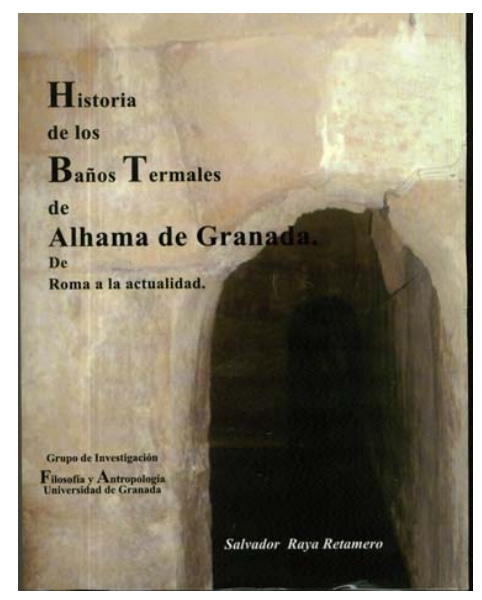

- Aproximación a la Historia de los Baños de Mula del que son coautores González Castaño y González Fernández, una publicación que corría a cargo del Ayuntamiento de Mula.

- Establecimientos balnearios: historia literatura y medicina de Maraver Eyzaguirre F.

Una publicación de la Universidad Complutense de Madrid. En este libro se presentan una gran variedad de artículos de investigadores y estudiosos del baño y aguas termales; ejemplo de ellos presentamos el índice que recoge tanto la temática del mismo como los autores de los distintos artículos: 
INDICE: Presentación. Artículos. El Agua en verso (Notas para una lectura de poemas). Antonio Carvajal Milena.. Juan Antonio Rodríguez Sánchez. Literatura balnearia en España: Azorín y Baroja. José María Urkia Institucionalización de la Hidrología Médica en España Etxabe. La cura climática en "La Montaña Mágica", de Thomas Mann. Luis Montiel Llorente. Uso médico del agua en el mundo hispánico bajo medieval (siglos XII-XV). Fernando Girón Irueste. Figuras galaicas del termalismo. Luis Rodríguez Migues. Balnearios y manantiales del pirineo aragonés a través de los viajeros. Francisco Armijo Castro. La figura del Médico-Director en el Balneario de Lanjarón: siglo XIX. Francisco Maraver Eyzaguirre. El agua como recurso turístico en un entorno rural: el Balneario de Lanjarón. Javier Piñar Samos. Europa vista desde un balneario. Vicente Pedraza Muriel.

Las propias editoriales conocedoras del interés que suscitan las vacaciones en centros balnearios, editan guías de viaje, en las que a demás de publicitar los centros en cuestión, hacen una breve reseña de su ubicación y de su historia.

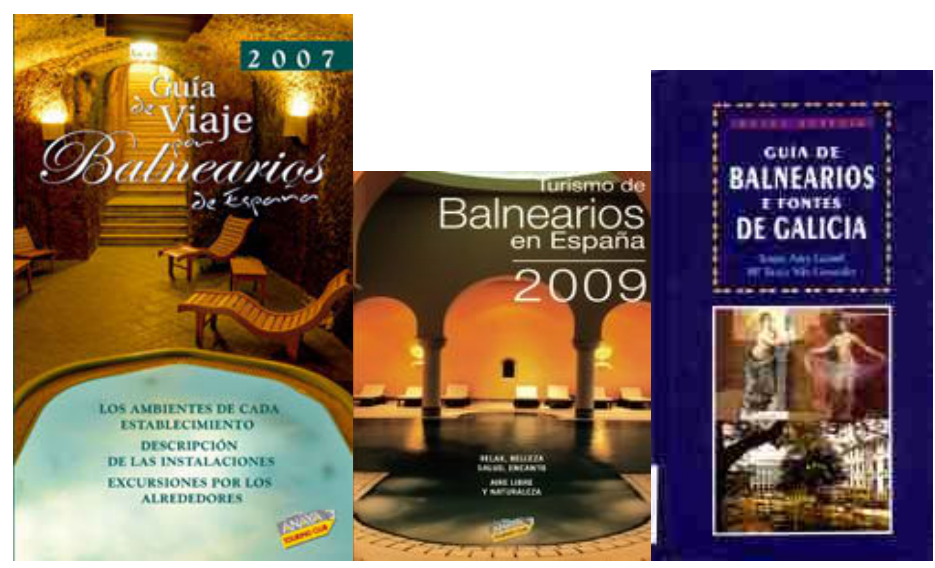


Hay que citar como fuente de información a los Congresos: Generalmente una parte de los congresos consagrados al termalismo reservan alguna ponencia a la historia del baño, estos congresos suelen ser organizados a instancias de alguna Universidad como es el caso del I Congreso Peninsular de Termalismo Antiguo, celebrado en Arnedillo que corría a cargo de la Universidad Nacional de Educación a Distancia. Con el material recopilado podemos formarnos una idea de la importancia del baño para el ser humano a través de los siglos tanto por su valor deleitoso, como higiénico, social o su por aportación arquitectónica.

Del baño se puede decir "que tiene historia" ya que hay que remontarse mucho tiempo atrás para poder conocer sus inicios y aún así, es muy posible que existan datos anteriores a los que nos podamos referir, quizá sea por este motivo que cuando se alude al los orígenes del baño, generalmente, se hace referencia al principio de la humanidad de forma generalizada.

El hombre se ha servido de la naturaleza desde el principio de los tiempos y en ese acto de servidumbre ha usado el agua para su uso personal, trátese de aseo, ingesta o baño entre otras utilidades, así, la historia del baño nace con la historia del hombre que por uno u otro motivo practicó la inmersión en tan agraciado elemento, cogiéndole tal gusto que a día de hoy se sigue deleitando con tan beneficiosa costumbre. 


\section{El baño a través de sul historia}

\subsection{El baño en la antigüedad}

La historia del baño es tan antigua como el propio agua; el uso social del agua en forma de baño de una u otra forma se ha aplicado a lo largo de los tiempos en todas las civilizaciones, desde la época de las cavernas, se trata de un habito o una costumbre que ha ido ligada a la mitología, a la religión, a la medicina; practicada por ricos y plebeyos, por hombres y mujeres, en público o en privado, de forma socialmente ordenada según condición y sexo.

Abad Varela en un capítulo dedicado a la moneda como ofrenda en los manantiales, dentro del libro titulado "Espacio, Tiempo y Forma" reseñado a pie de página, alude a la importancia que desde la antigüedad se ha tenido al culto de las aguas en la península Ibérica.

"Podemos decir que es una realidad que está atestiguada desde la Edad del Bronce, incluso con ofrendas"19.

El uso del agua cómo agente terapéutico proviene desde antiguo, ya en las cavernas, las antiguas tribus que sin ningún tipo de conocimiento, sabían de las propiedades curativas del agua; observaban como los animales enfermos o heridos llegaban hasta los manantiales y tras su inmersión mejoraban; ellos desconocían su poder terapéutico por lo que atribuían esta consecuencia a consideraciones mágicas o sagradas.

El baño a lo largo de la historia ha conocido épocas de auge y apogeo, períodos de decadencia y abandono siempre ligados a los momentos de prosperidad o declive económico. Es en este recorrido por el devenir de los tiempos en el que se centra este capítulo, dejando usos y costumbres, religión y rituales, para capítulos

\footnotetext{
${ }^{19}$ Abad Varela (1992) “Espacio, Tiempo y Forma”, Serie II, Ha Antigua, T. V Pág. 133
} 
siguientes en los que tratar más detenidamente lo que el baño supuso en la vida cotidiana de los diferentes pueblos.

"El uso de los baños en establecimientos públicos era conocido desde tiempo inmemorial, en Oriente (India y China) de donde pasó a Grecia y de aquí a Italia",20

El pueblo asirio-babilónico, el pueblo hebreo, el egipcio, el griego, el romano entre otros, forman parte de la historia del baño, religión y placer se enmarcan en una cultura del agua dejando un legado arquitectónico que en parte aún se conserva y que refleja la importancia de ese uso para el que se levantaron grandes termas y palacios, centros de ocio y negocio, de intercambio social, de superación personal con sus palestras y gimnasios, edificios creados para el deleite la higiene y la belleza corporal.

Griegos y romanos son un referente ineludible en la historia del baño, fueron momentos de gloria para esta práctica, testigo de ello es parte del legado arquitectónico que aún permanece, en unos casos abiertos al público tras varias remodelaciones y otros para su visita, como parte del patrimonio de conservación artística.

La fotografía que se presenta a continuación ha sido tomada para este estudio en el interior del propio baño.

\footnotetext{
${ }^{20}$ De la Rosa, M ${ }^{\mathrm{a}} \mathrm{C}$ y Mosso, M $\mathrm{M}^{\mathrm{a}} \mathrm{A}$; (2004) “Historia de las aguas mineromedicinales en España” Observatorio Medioambiental, $\mathrm{n}^{\circ}$ sumario 7; 117-137; Pág. 2
} 


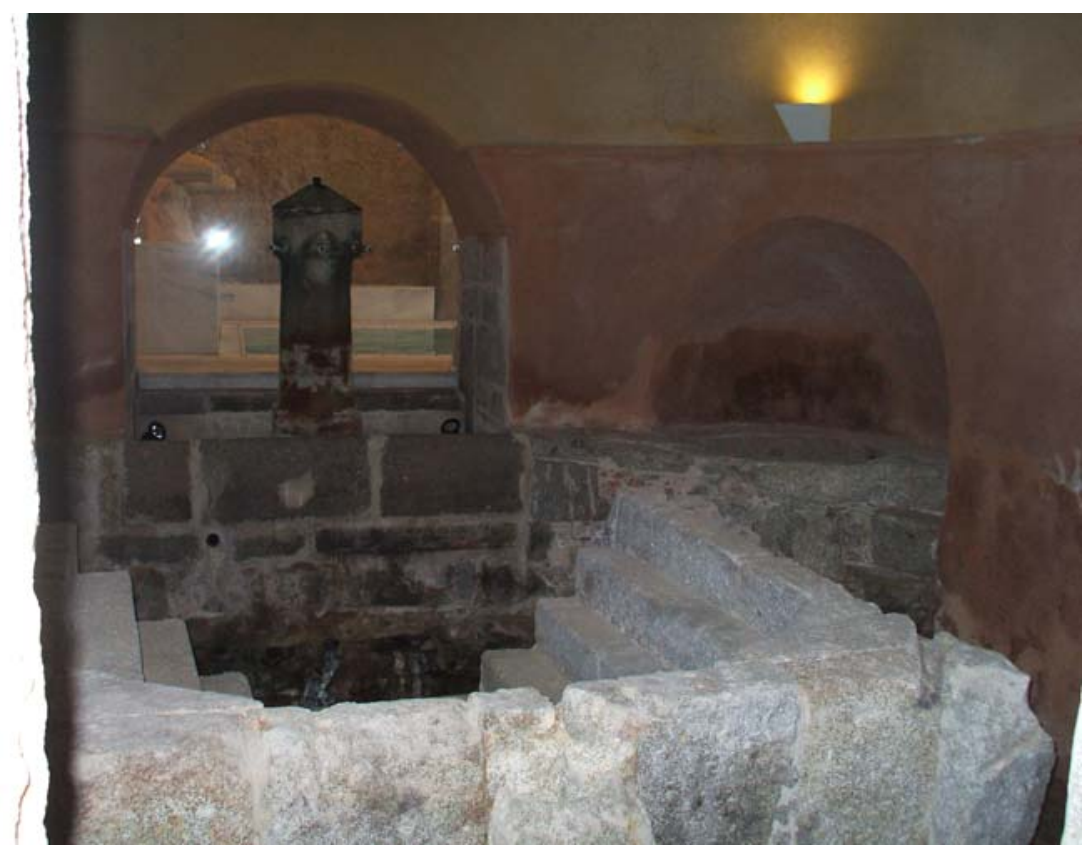

Ilustración 4 Balneario de Baños de Montemayor (Cáceres): Museo de las Termas

“La acción salutífera de los baños arraigó fuertemente en el pueblo romano, refiriendo Plinio que, durante 600 años, las prácticas hidroterápicas con aguas minerales fueron remedio soberano"21

Es en el año 218 a. de C. cuando las legiones romanas llegan por primera vez a la Península Ibérica. La conquista duró doscientos años. Tras la caída del Imperio Romano de Occidente, el uso del baño entra en decadencia, viendo su mayor declive a finales del siglo $X$, fueron las Cruzadas las que provocaron un cierto florecimiento

\footnotetext{
${ }^{21}$ Armijo Valenzuela, M. y San Martin Bacaicoa, J. (2000) “Curas Balnearias y Climáticas Talasoterapia y Helioterapia” Ed. Un Complutense. Pág. 20.
} 
del uso del baño como uso terapéutico, el motivo de este auge era la búsqueda de recuperación de heridos y enfermos contagiados en Oriente.

Con la dominación Romana el uso de los baños se extendió por Europa dejando un gran legado que solo en parte permanece, ya que con la dominación de los pueblos bárbaros gran parte de las termas romanas fueron destruidas.

En la fotografía podemos observar una bañera ya en desuso, estas han sido sustituidas por modelos más modernos y ergonómicos.

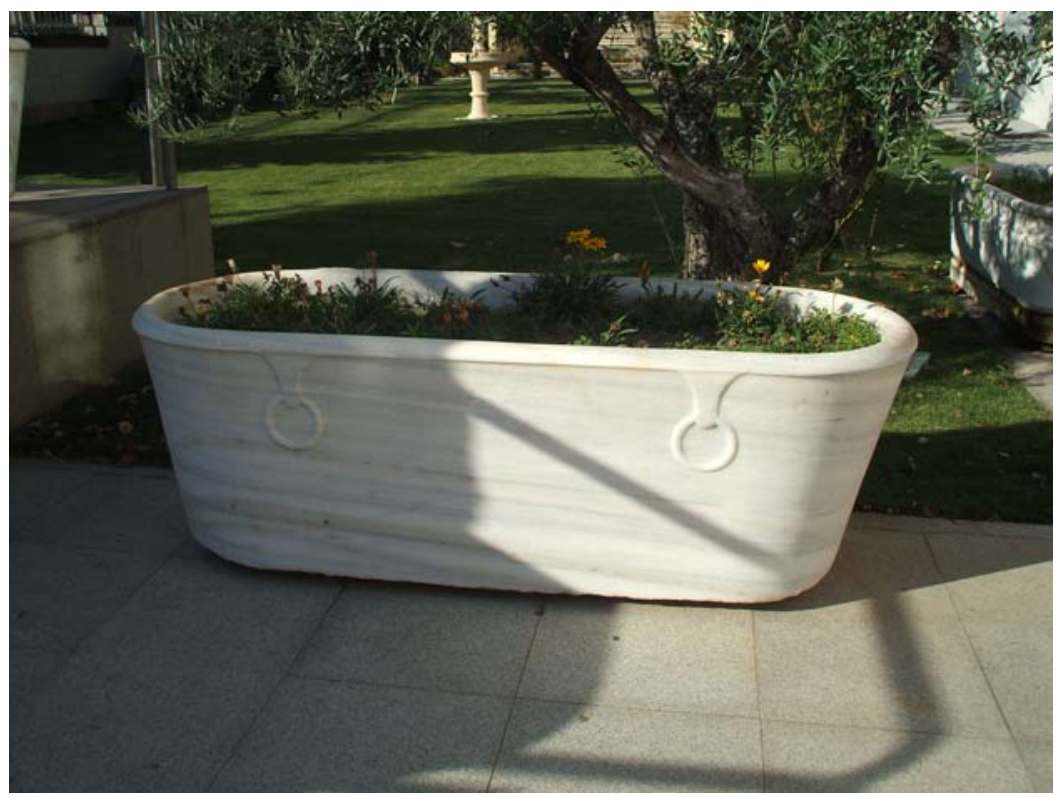

Ilustración 5 Bañera de mármol perteneciente al antiguo balneario de Baños de Montemayor. Se conserva como objeto decorativo en los jardines del propio balneario. Este tipo de bañeras han sido sustituidas por otras más modernas. 


\subsection{De la Edad Media al Barroco}

En los siglos XI y XII en el sur de España y de manos de los árabes, el baño toma un papel relevante como se refleja en este texto:

“La proliferación de baños en al-Ándalus y en la España cristiana es fácilmente constatable en las crónicas, donde habla de cifras elevadas en las capitales (por ejemplo más de trescientos baños en Córdoba en la etapa califal), y al menos había un hammam* público en la mayoría de los pueblos, aunque casi todos han desaparecido tras su abandono a fines del siglo XVI."22

En la Edad Media árabes y bizantinos asimilan la cultura griega y con ella el gusto por el baño, la higiene y el cuidado corporal.

"Se conjuga la tradición termal romana con los usos y costumbres higiénicas musulmanas. Sin olvidar el influjo europeo a través del camino de Santiago que animó el desarrollo urbano en sus servicios públicos."23

Prueba de la gran influencia árabe en España, con respecto al baño, son numerosas las casas de baños y balnearios, muchos de ellos herencia sin duda de griegos y romanos, que se mantienen como señal inequívoca de la valoración y el gusto por el agua de un pueblo que permaneció durante ocho siglos en España.

\footnotetext{
${ }^{22}$ Vílchez Vílchez , C. (2004) “Baños Árabes” Ed.. Diputación de Granada (Guías de Historia y Arte) Granada Pág. 25

*Hamma: así se denomina a los baños naturales (manantial de agua caliente y mineral).

*Hamman: del plural de Amanta (Baño Truco).

${ }^{23}$ Alegría Suescun, D. (Del Val Valdivieso Ma I. coordinadora). (2002) "Baños Urbanos del Patrimonio Real de Navarra”. En: “Usos Sociales del Agua en las Ciudades Hispánicas de la Edad Media” Ed.. Un Valladolid. Pág. 362.
} 
“Las primeras referencias (a los baños públicos) documentales datan del siglo XII y primera mitad del siglo XIII.

A mediados del siglo XIV las casas de baños cayeron en desuso $y$ paulatinamente fueron desapareciendo del paisaje urbano......... La ruina de los baños públicos a los largo del siglo XIV es un fenómeno también generalizado en toda la Península Ibérica"24

Prestigiosos médicos como Ávicena o Albucasis defienden los prodigios terapéuticos del agua, pero este aprecio por los dones de la madre naturaleza no son admitidos de igual manera en todos los lugares; así, en Europa, los baños que a lo largo de la historia han cambiado en muchas ocasiones de dueño, pasaron a ser propiedad de las Órdenes Monásticas, éstas, temerosas del posible peligro moral y físico, por el contagio de enfermedades, impidieron un nuevo momento de gloria para el uso del baño. Comienza un notable abandono por el cuidado de cuerpo y un considerable desinterés por la belleza, quedando la hidroterapia y los conocimientos adquiridos hasta el momento relegados al olvido en los distintos monasterios, lejos de los profanos deseos de lujuria que a ojos de la Europa cristiana, procuraban los baños. Se puede hacer por tanto una distinción entre la Europa Cristiana, que abandona el culto al cuerpo y a la higiene y el mundo árabe, el Islam, que concebía la hidroterapia como un placer maravilloso tanto para embellecer el cuerpo como para sanarlo.

Los baños públicos en el siglo XIV caen en desgracia, llegando prácticamente a desaparecer en toda la Península Ibérica, uno de los motivos principales fue la Peste Negra.

${ }^{24}$ Alegría Suescun, D. (2002). Págs. 330-365. 
"Fase crítica (1347-1363). Se manifiesta en el uso intermitente de los baños por la grave pérdida de clientela, como consecuencia de la oleada de Peste Negra de 1348, cuando ya de por sí la situación era delicada. El miedo a tal contagio provoca el cierre completo de estos edificios. La humedad y calor de los baños fueron un caldo de cultivo perfecto para la propagación de la epidemia., ${ }^{25}$

\subsection{Siglos XV y XVI.}

Será la ciencia y la medicina, a partir del siglo XV, el Renacimiento con su renovación intelectual, el que despertará un nuevo interés por la práctica del baño. La difusión del conocimiento a través de la imprenta hace que grandes obras de la hidrología vean la luz, como es el caso de la obra de Savonarola en 1485 "De Balneis et Thermis" que fue considerada como el primer tratado de balneoterapia. En 1571 otra obra de gran importancia "De Thermis", escrita por Adrea Bacius. Este tipo de publicaciones se hicieron en todo el mundo como es el caso de España en el que ve la luz en 1697, el libro de Limón Montero varias veces citado a lo largo de esta tesis, "Espejo Cristalino de las Aguas Minerales de España". Las publicaciones aumentan a partir del siglo XVIII siendo en el siglo XIX donde alcanzó su mayor auge.

\subsection{Siglos XVII y XVIII:}

Durante el siglo XVII en la Europa barroca se vuelven a poner al uso las prácticas hipocráticas, aconsejándose nuevamente el uso del baño, la medicina irrumpe con fuerza en el plano de la hidrología de la mano de J. Floyer que en el año 1697 advierte de las propiedades del agua como agente preventivo y curativo de algunas dolencias. En 1725, un alemán, Olvelgün, dedica las páginas de una memoria balnearia a la cura termal en combinación con el reposo y la dieta. Frederic Hoffmann, otro alemán, que en 1712 publica una obra de gran interés para la materia titulada "De aqua medicina universali". A finales del siglo XVII y hasta el último tercio del siglo

\footnotetext{
${ }^{25}$ Alegría Suescun, D. (2002) Págs. 365.
} 
XVIII, dos médicos, Sigmun y Johann Hahn, dedicaron sus estudios a la hidroterapia no solo como método preventivo, sino como tratamiento de algunas enfermedades.

\subsubsection{Controversia sobre el agua (siglo XVIII)}

Si en el siglo XVII se vuelven a poner de moda las prácticas hipocráticas, el siglo XVIII es el siglo del hipocratismo por excelencia, la medicina natural ocupa un importantísimo lugar entre los médicos; se traducen los libros de Hipócrates y se practican las teorías expuestas en los "Aforismos", se juzgan las prácticas médicas que se venían utilizando hasta el momento.

León Sanz $\mathrm{P}$ y Barettino Coloma $\mathrm{D}$, escriben un libro que describe la polémica del agua suscitada entre los defensores de la medicina natural y con ello la utilización entre otras de las terapias hídricas y los defensores de la medicina apoyada en la farmacopea del siglo XVIII.

Diego de Torres Villarroel participa en esta polémica con su libro titulado "Uso y provechos de las aguas de Tamames y Baños de Ledesma" un tratado sobre el agua en el que habla de las propiedades curativas de la misma y del cuidado con que hay que tomarlas.

"Torres conoce bien las ideas médicas del momento. El profesor Sánchez Granjel así lo afirma: $<<A$ sus primeras lecturas médicas [...] añadió Torres, más tarde, otras muchas que le convirtieron en un buen conocedor de las doctrinas médicas, antiguas y nuevas, vigentes en su época.

Como buen conocedor de estas doctrinas, y como buen polemista también, entra de lleno en varias polémicas, enfrentándose, por ejemplo, a Martín Martínez. 
El agua era protagonista de una de ellas, que se mantuvo más de la mitad del siglo XVIII, y en la que intervinieron, entre otro, don Juan Vázquez de Cortés, don Manuel Mastrucio, don José Ortiz Barroso y don Vicente Pérez, disputando entre sí acerca de la bondad universal del agua., $^{, 26}$

Según Blanco J. F. Torres Villarroel ataca la codicia de los médicos y, acaso por ello, la terapéutica galénica, defendiendo en cambio la medicina natural con el concurso de los astros. ${ }^{27}$

Esteva de Sagrera J., Catedrático de historia de la farmacia de la Facultad de Farmacia de la Universidad de Barcelona, escribe un artículo en que alude a esta pugna entre la medicina "tradicional" y la medicina natural.

"Durante el siglo XVIII la terapéutica no es única, sino un conjunto de diferentes tendencias muchas veces incompatibles entre sí. Eclecticismo, empirismo, dogmatismo, galenismo, yatroquimismo, farmacia popular, pugnan por imponerse sin conseguirlo. La homeopatía se une a tan abigarrado escenario y proliferan terapéuticas heterodoxas: el agua de alquitrán como panacea, el agua y la música."28

En la terapéutica del siglo XVIII se observa según León y Barettino, una clara racionalización del planteamiento de la terapéutica que tiene entre otras

\footnotetext{
${ }^{26}$ Torres Villarroel, D. Edición preparada por: Blanco, J. F. (1988) “Uso y Provechos de Los Baños de Ledesma” Ed Europa Artes Gráficas. Salamanca. Pág.10

${ }^{27}$ Torres Villarroel D. Edición preparada por: Blanco, J. F. Pág.12

${ }^{28}$ Esteva de Sagrera, J. abril (2007). En: Historia de la Farmacia. "La Farmacia del siglo XVIII una terapéutica barroca" Vol. 26; ${ }^{\circ} 4$.
} 
consecuencias, la comprobación empírica, así la medicina no se alejaba en su aplicación de la experiencia y la observación como lo atestigua el siguiente texto:

"como consecuencia de ello, la terapéutica se orienta hacia una sencillez racional y una peculiar estima de la naturaleza.......En España la primera farmacopea oficial aparece en 1794 ... postulaban una simplificación de la compleja farmacología galénica con la utilización de remedios sencillos obtenidos directamente de la naturaleza. Este naturalismo terapéutico lleva al médico a buscar el posible efecto de las "fuerzas naturales": "la del agua, la del oxígeno, la de los cuerpos electrizados.." 29

Laín Entralgo alude al baño como uso terapéutico y resalta su puesta de largo en la época de la ilustración:

“La historia del uso terapéutico del baño_hablo, como es obvio, de la hidroterapia en sentido estricto, no es la crenoterapia- muestra varias cimas, coincidentes con otras tantas exaltaciones del naturalismo: La Antigüedad clásica, los árabes, el Renacimiento. Una secta médico religiosa del siglo XVI trataba de curar todas las enfermedades mediante ensalmos hídricos. No puede sorprender que en la Europa ilustrada e idólatra de la naturaleza retoñe con vigor el pensamiento hidroterápico". ${ }^{30}$

\footnotetext{
${ }^{29}$ León Sanz, P- y Barettino Coloma, D. “La Polémica del Agua” Pág. 97. En: http://www.cfnavarra.es/Salud/docencia.investigacion/textos/temas_medicina/6_ferrer/polemica_agua.pdf ${ }^{30}$ Laín Entralgo. (1963) “Historia de la Medicina” Pág. 319. En: León Sanz, P y Barettino Coloma, D. “La Polémica del Agua.” Pág. 100
} 
Esta polémica del agua llega a España procedente de Europa, provocando una gran controversia a favor y en contra de de unas u otras prácticas médicas.

“ Una de las polémicas más ruidosas y tenazmente sostenidas, que consistió en considerar el agua natural como panacea en casi todas las enfermedades..... Esta controversia, que dura aproximadamente cincuenta años, comienza hacia 1708-1710, cuando circula por Andalucía y por Madrid un papel titulado Remedio universal del agua natural, en el que se aseguraba que todas las enfermedades se curaban bebiendo grandes cantidades de agua.",31

Según León Sanz P- y Barettino Coloma D la primera reacción a ese panfleto que circulaba en defensa del agua como "remedio universal para todas las dolencias" fue de burla, aunque al parecer este texto no fue el único que se publicó en defensa de esta teoría medico/naturista, llegando a tener gran repercusión y suscitándose con ello una mayor controversia entre seguidores y detractores.

“La respuesta a este movimiento no se hace esperar $y$, en cada ciudad, se producen enfrentamientos en los que intervienen médicos, clérigos y profanos, utilizando generalmente los textos impresos. ${ }^{, 32}$

Entre los clérigos, El benedictino padre Feijoo, defensor del agua como agente curativo:

“El método acuario, por lo que tenía de naturista y de antidroguista, le era a Feijoo particularmente grato. Según Marañón, el monje gallego hubiera sido un nuevo abate Kenipp de haberlo permitido "su época, su talento y su moralidad....Defendía Feijoo en sus escritos la terapéutica

\footnotetext{
${ }^{31}$ León Sanz , P- y Barettino Coloma D, Pág. 100

${ }^{32}$ León Sanz, P- y Barettino Coloma D, Pág. 103
} 
con el agua, lo que originaba -dado su prestigio- un mayor número de seguidores y un rechazo más radical a la farmacopea tradicional. ${ }^{33}$

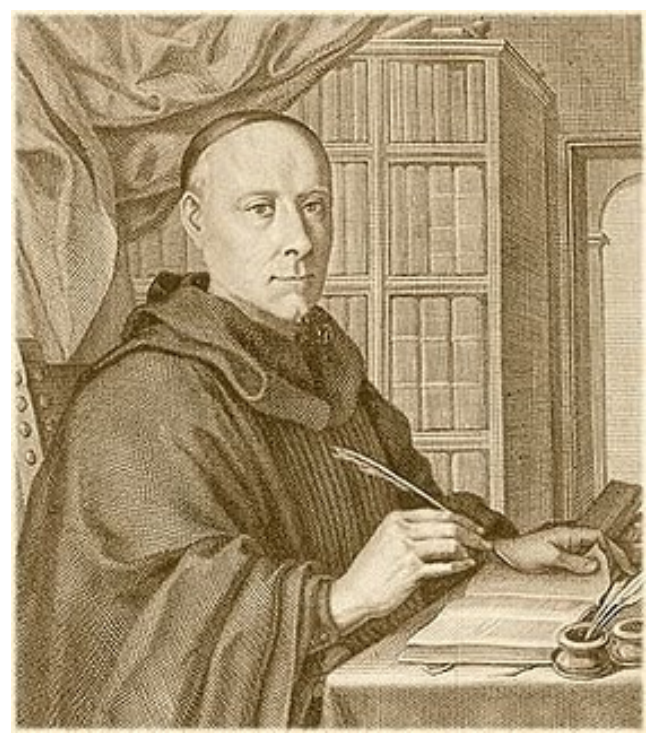

Ilustración 6 Padre Feijoo, 1781. Biblioteca del IFES. XVIII. Universidad de Oviedo. Patrimonio bibliográfico de la Universidad de Navarra $^{34}$.

Manuel Gutiérrez de los Ríos, escribe en 1736 “Juicio, sobre la método controvertida de curar los morbos con el uso del agua y limitación en los purgantes"

"Y de aquí nace la batalla entre los médicos, según el sistema que cada uno sigue. Si el fin de todos fuera descubrir la verdad, y adelantar la practica curativa a favor de los pobres enfermos, tuviéramos menos disgustos, y menos bochornos en las camas de los enfermos. Los discursos metafísicos no sirven en la medicina, debe fundamentarse en la naturaleza, y no en nuestra fantasía. Lástima es ver los impresos de

\footnotetext{
${ }^{33}$ León Sanz, P- y Barettino Coloma, D. Pág. 103

${ }^{34}$ http://4.bp.blogspot.com/
} 
los médicos tan desnudos de enseñanza, y tan llenos de dicterios picantes, que sólo sirvan de divertir estrados.. El agua en la realidad es utilísima y necesaria, así a los que gozan de saludo como a los que están enfermos ... y por consiguiente se debe confesar por Medicina Universal, pues ella sola basta a rendir los morbos. ${ }^{35}$

Estos clérigos, hacían su defensa desde la ciudad de Sevilla, mientras que desde Madrid se abrían nuevos frentes en defensa del agua como remedio curativo universal de la mano de Vicente Pérez y el agustino Vicente Ferrer, hombres de ciencias y letras respectivamente.

Aparece entonces una obra que nace de la pluma de Vicente Ferrer y que tiene como firmante al Doctor Vicente Pérez "vulgó el médico del agua" en su libro cuyo título describe a la perfección su intención para con el libro y sus métodos como médico hidrólogo. "EL PROMOTOR DE LA SALUD DE LOS HOMBRES, SIN DISPENDIO EL MENOR DE SUS CAUDALES: Admirable Método de Curar todo Mal con Brevedad, Seguridad y a Placer" y otra titulada "El secreto a voces. Arcanidades de los polvos de Aix, en la Provenza, descubiertas a los embates del agua. Disección anatómica de las partes de que se componen estos polvos, y razón primordial de sus efectos". En esta obra del Doctor Pérez V, nos detendremos en la tercera parte de esta Tesis, cuando hagamos referencia a las Propiedades curativas del agua mineromedicinal y su justificación científica, ocupándonos en esta primera parte únicamente, por la polémica que dicha obra suscitó en el momento de su publicación.

Según León Sanz P. y Barettino Coloma D. estas dos obras tuvieron mucha repercusión en Madrid donde las opiniones se dividieron aún más, no faltando escritos de repulsa por parte de los detractores, aunque como cabía esperar también salieron en su defensa, entre sus defensores: El padre Feijoo.

\footnotetext{
${ }^{35}$ Gutiérrez de los Ríos, M. (1759), Páginas: 99-100 En León Sanz, P- y Barettino Coloma, D. “La Polémica del Agua” Pág. 106
} 
En 1753 Francisco Rodríguez Corcho publica "Margarita sobre el agua, preciosa perla, que en la divina concha del sagrado texto coge el rocío del cielo, con que evidencia que el agua no es remedio universal" desacreditando al doctor Vicente Pérez y su teoría hídrica. En contraposición, Gómez Arias defiende a Pérez en un nuevo libro titulado "Demostración physico-mechánico-médica del provechosísimo, natural y verdadero del doctor don Vicente Pérez (vulgo) el médico del agua".

En línea con las publicaciones del Doctor V. Pérez, en 1754, aparece una tercera titulada "El médico de sí mismo. Modo practico de curar toda dolencia con el vario, y admirable uso del agua". Dispuesto por el doctor don Joseph Ignacio Carballo de Casto de la Real Academia Matrintense, y médico titular de la antigua villa de Ajofrín, quien lo dedica al Exmo. Señor conde-duque de Luna, duque e Villahermosa" así reza en la portada del libro.

León Sanz P y Barettino Coloma D, llegan a los últimos años de la polémica, haciendo alusión a un documento que el doctor Vicente Pérez envía al Consejo de Castilla, solicitando la investigación oficial de su método (10/10/1757):

“Judicial justificación hela a instancia de don Vicente Pérez (vulgo del agua) de las enfermedades crónicas, habituales y desahuciadas por los medios actuales, curadas con brevedad, seguridad y placer de los enfermos, con el admirable método del agua, aplicada debidamente en cantidad, cualidad, ocasión y modo, sin excusar, cuando la naturaleza lo pide, el uso de la sangría y otros medicamentos simples y nada perjudiciales así interiores como exteriores,

Es en el año 1761 cuando, Carlos III resolvió un pleito a favor de D. Vicente Pérez como se desprende de la siguiente cita con la que damos fin a un pleito generado por la defensa del agua como método curativo, el llamado en su momento

\footnotetext{
${ }^{36}$ Citada en Gutiérrez de los Ríos, M. (1759), Págs.: 99-100. En: León Sanz, P- y Barettino Coloma, D. “La Polémica del Agua” Pág. 143, Citada en Martínez Reguera, L. (1892) Pág. 201
} 
método acuario, que denunciaba el abuso excesivo de la farmacopea y algunas que otras prácticas como las sangrías.

"Carlos III resolvió un pleito a favor de Pérez, en el que ordena que no debe examinase otra vez, puesto que se había examinado en 1721 y manda que se le devuelva su libro, que dicha institución le había requisado." 37

\subsubsection{Finales del siglo XVIII:}

Los Balnearios han sido a lo largo de la historia lugares que albergaban esperanzas de curación; la fe en el poder curativo del agua mediante el baño, hacía de enfermos y acompañantes lugar de peregrinación en busca de la salud perdida.

\footnotetext{
${ }^{37}$ Gutiérrez de los Ríos M. (1759), Págs.: 99-100 En León Sanz P- y Barettino Coloma D. "La Polémica del Agua” Pág. 106
} 


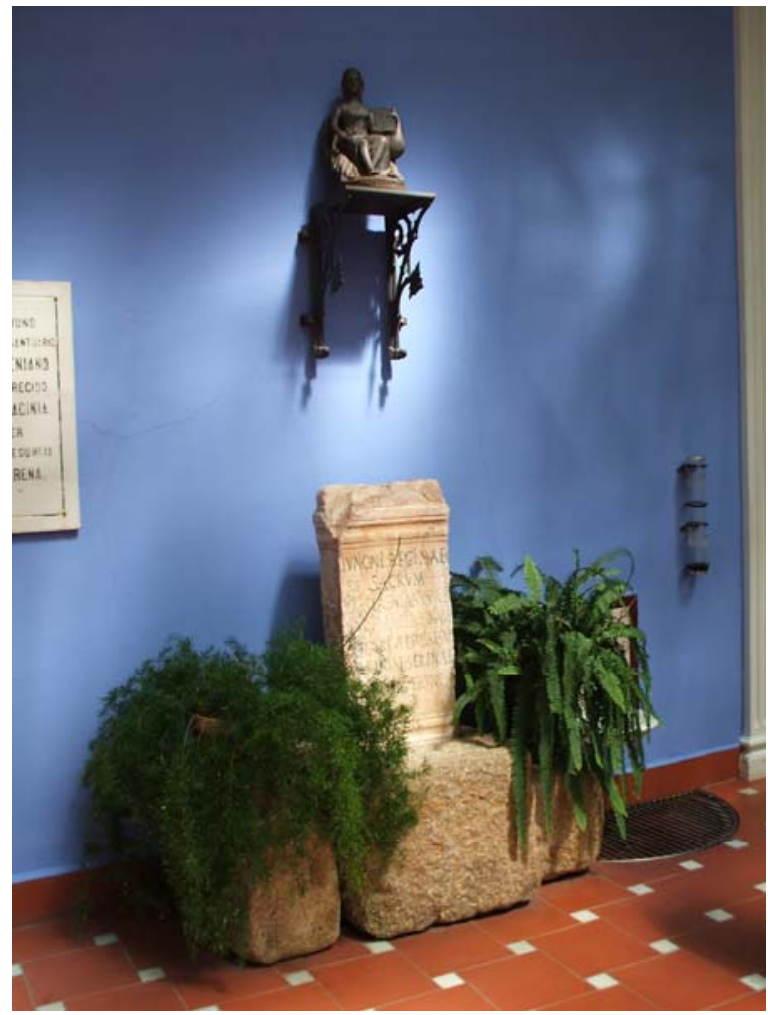

Ilustración 7 Fotografía tomada en el Balneario de Alange (Badajoz). Imagen de la Virgen situada en un patio a la entrada del Balneario.

En la antigüedad esta peregrinación se circunscribía al uso y empleo de aguas y manantiales termales cercanos o pertenecientes al entorno local; todo esto cambia de forma radical con la revolución industrial; la revolución de los transportes y el nacimiento del pensamiento higienista, todos ellos, factores determinantes en la generalización de la práctica balnearia a finales del siglo XVIII.

La raíces del pensamiento higienista se localizan en el impacto que produce el proceso de la revolución industrial y sus consecuencias para la salud y la calidad de vida de la población; de ahí, que en el siglo XVIII se considere como un precepto la influencia decisiva del entorno ambiental y social para la formación de procesos patológicos y para su curación; esta consideración ecológica de la enfermedad al 
ampliar el marco de estudio de la salud más allá del cuerpo humano, continúa la antigua tradición hipocrática que vincula la salud de forma directa con las condiciones físicas, climáticas y sociales de un espacio concreto; en la actualidad, son las condiciones de trabajo por objetivos, bajo presión y las responsabilidades adquiridas dentro de una sociedad cada vez más compleja, las que llevan al padecimiento de nuevas enfermedades sociales como es el caso del estrés, enfermedades que encuentran terapias curativas específicas dentro del campo de la hidrología.

"Para establecer el pronóstico, el médico contaba con los signos externos de la enfermedad, con los órganos y la constitución del enfermo, pero además con las circunstancias ambientales que venían a condicionar el estado de salud del paciente: aguas, vientos, aires $y$ estaciones del año, etc."

Es la vuelta a la naturaleza la que genera el equilibrio corporal necesario para sentirse bien, el regreso al origen del que parte el ser humano para crear toda una forma de vida que le sobrepasa haciéndole regresar a lo natural, para reencontrarse nuevamente; es en este contexto, donde el agua se justifica por sí misma y por sus virtudes, por sus bondades naturales e intrínsecas, que sólo la naturaleza posee en esencia.

"La Desamortización ayudó, sin duda a la nueva actividad balnearia....hará que en pocos años las propiedades de fuentes, manantiales, balnearios, casas de baño (hasta entonces en manos de municipios y órdenes religiosas) pasen a manos particulares. Estos darán impulso a su renovación, iniciándose entonces el interés de las

\footnotetext{
${ }^{38}$ López Pérez, J. A. /introducciones, traducciones y notas/ (2000) “Tratados Hipocráticos” Ed. Gredos. Madrid. Pág. 17
} 
sociedades y empresas del XIX en la construcción de nuevos establecimientos $y$ en la adquisición de los que se desamortiza. Participaron en ello tanto los hombres de negocio del momento y la aristocracia como los médicos y farmacéuticos de prestigio. ${ }^{, 39}$

\subsection{Siglo XIX}

Si pudiésemos hablar de la época dorada de los balnearios, tendríamos que remontarnos a finales del siglo XIX y principios del XX, mejorando la época actual en la que parece estamos asistiendo a un florecimiento de este fenómeno.

En este siglo, la historia del baño sigue irremediablemente unida a la historia de la hidroterapia; Vinzenz Priessnitz, cuyo método consistía en la aplicación de agua fría para curar ciertas dolencias, basándose en que el calor producido como reacción por el cuerpo al agua fría es lo que cura. Sebastián Kneipp, un clérigo que desarrolló una técnica para curar la tuberculosis, enfermedad de la que él mismo estaba afectado, mediante la ingesta y baños de agua fría.

“En España, en 1816, se regula mediante el real decreto de 29 de julio, < que cada uno de los baños más acreditados de todo el reino se establezca un de profesor suficiente conocimiento de las virtudes de las aguas y de la parte médica necesaria para determinar su aplicación y uso". 40

\footnotetext{
${ }^{39}$ Urkia Etxabe, J M y Rodríguez Sánchez, J. A. (1998) “Los Balnearios Españoles” II Reunión de Estudios Históricos sobre Balnearios,” Agua y Terapéutica”. Ed.. Un de Salamanca Pág. 27

${ }^{40}$ Pérez Fernández, M.R. y Novoa Castro, B. (2006) http://www.doyma.es
} 
Ya en el año 1816, durante el reinado de Fernando VII se redactó el primer reglamento sobre aguas termales, creándose en este mismo año, por medio de un Real Decreto, la figura del Médico-Director de Baños.

"Es indudable que para el desarrollo de nuestros establecimientos balnearios, fue un verdadero revulsivo la creación, en 1816, por Fernando VII, de la figura del Médico Director de Baños'41

A este mismo hecho, hace referencia también, Urkia Etxabe y Rodríguez Sánchez, en el libro titulado "Los Balnearios Españoles" en el que hace referencia al primer reglamento de aguas y baños minerales, de él adjuntamos la siguiente cita:

"En 1816 durante el reinado de Fernando VII, se redactó el primer Reglamento de Aguas y Baños Minerales, al que siguieron otros que regularon la intervención de los médicos con competencia y autoridad en los asuntos concernientes a los balnearios." ${ }^{42}$

En este sentido, no sólo hay que hacer referencia a factores sociales y científicos, sino también políticos y económicos derivados de la Revolución Industrial y con ella la Revolución del Transporte, favorecedores de este negocio del agua de gran atractivo para los necesitados de salud y para aquellos que supieron hacer del balneario su centro de descanso y vacaciones.

\footnotetext{
${ }^{41}$ Manzaneque, M. En: Peréx Argorreta (1997) “Termalismo Antiguo” Ed. UNED Madrid. Pág. 43

${ }^{42}$ Urkia Etxabe, J M y Rodríguez Sánchez, J A. (1998). Pág. 24.
} 
“La gran importancia económica de los balnearios, junto con el progresivo perfeccionamiento de los medios de transporte y los conocimientos médico terapéuticos, explican el creciente interés de la gran burguesía del siglo XIX en la construcción y explotación de los balnearios. " ${ }^{43}$

El nuevo resurgir del termalismo de finales del siglo XIX y principios del $X X$ es fruto del nacimiento de una moda termal, que tiene como fundamento el gusto por la higiene y culto al cuerpo, dando lugar a un movimiento basado en el veraneo de salud, envuelto en lujo y diversión, un lugar donde cultivar unas relaciones sociales, compartiendo el gusto común por el disfrute del agua salutífera.

Fue una época floreciente, pero no sólo para los balnearios españoles también para los del resto de Europa, ejemplo de ello, tenemos los balnearios de Baden Baden en Suiza; al sur de la capital se localizan los diversos balnearios de aguas termales, ya conocidos y utilizados por los romanos, pero que llegan a su mayor esplendor en el siglo XIX. El baño también se puso de moda en Francia con baños de reconocido prestigio como el de Vichy, Vittel, Aix les Bains. Los reyes y la nobleza compartían el gusto por los placeres hídricos en Francia durante siglos XIX y XX.

“La Emperatriz Eugenia promocionó con su ejemplo el termalismo. Guy de Maupassant describe de manera realista en "Mont-Oriol" (1887), el nacimiento de una ciudad termal en el campo"A4.

El nuevo gusto por el baño tanto privado como público de países como Francia Hungría e Inglaterra tuvieron su repercusión en España como se desprende de la siguiente cita:

\footnotetext{
${ }^{43}$ Sánchez Ferré, J. 1998 “Arquitectura Balnearia: ¿Un Patrimonio Amenazado?”. En:: “Los Balnearios Españoles” II Reunión de Estudios Históricos sobre Balnearios, “Agua y Terapéutica”. Ed.. Un Salamanca. Pág. 26

${ }^{44}$ http://www.cespte.gob.mx/Hist-agua.htm
} 
"La moda de los baños de mar fue importada de Inglaterra y Francia a mediados del siglo XIX. Esta costumbre trajo a los primeros bañistas a la playa del Sardinero, en Santander. Asmáticos, deprimidos y afectados por problemas circulatorios pueden beneficiarse del mar como una fuente de salud"45

De esta influencia europea por el baño, nacen los llamados Baños de Ola, que aún en la actualidad se recuerdan anualmente en la Playa del Sardinero de Santander, baños que en el siglo XIX ponen de moda el veraneo de salud en las playas del Norte de España. Unos veraneantes cuya opción balnearia no era sólo por enfermedad, sino por el placer de tomar las aguas en un centro turístico de interés y moda, un turismo eminentemente social y generalmente de clase alta, al menos la que se hospedaba en los lujosos hoteles, aunque también hay que citar a los usuarios que alquilaban habitaciones en viviendas cercanas al balneario, estos agüistas, con poder adquisitivo relativamente bajo, tenían como finalidad principal la recuperación de la salud perdida.

\footnotetext{
${ }^{45}$ http://www.castillalamanca.es/clmsalud/contenidos/vida_sana/baños.
} 


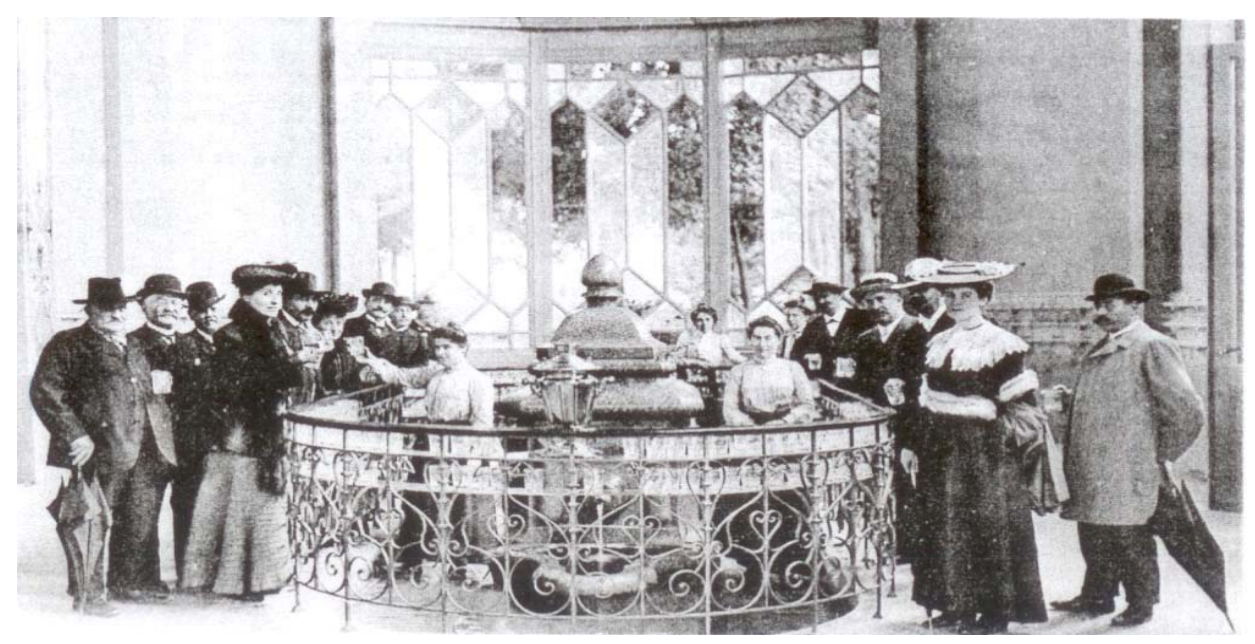

En: Historia de la vida privada (Tomo IV)

El siglo XIX fue un siglo importante para la arquitectura balnearia, por la diversificación surgida del negocio del agua, con la creación de nuevos lujosos hoteles y casinos nacidos al calor del agua termal para divertimento y hospedaje de agüistas y acompañantes.

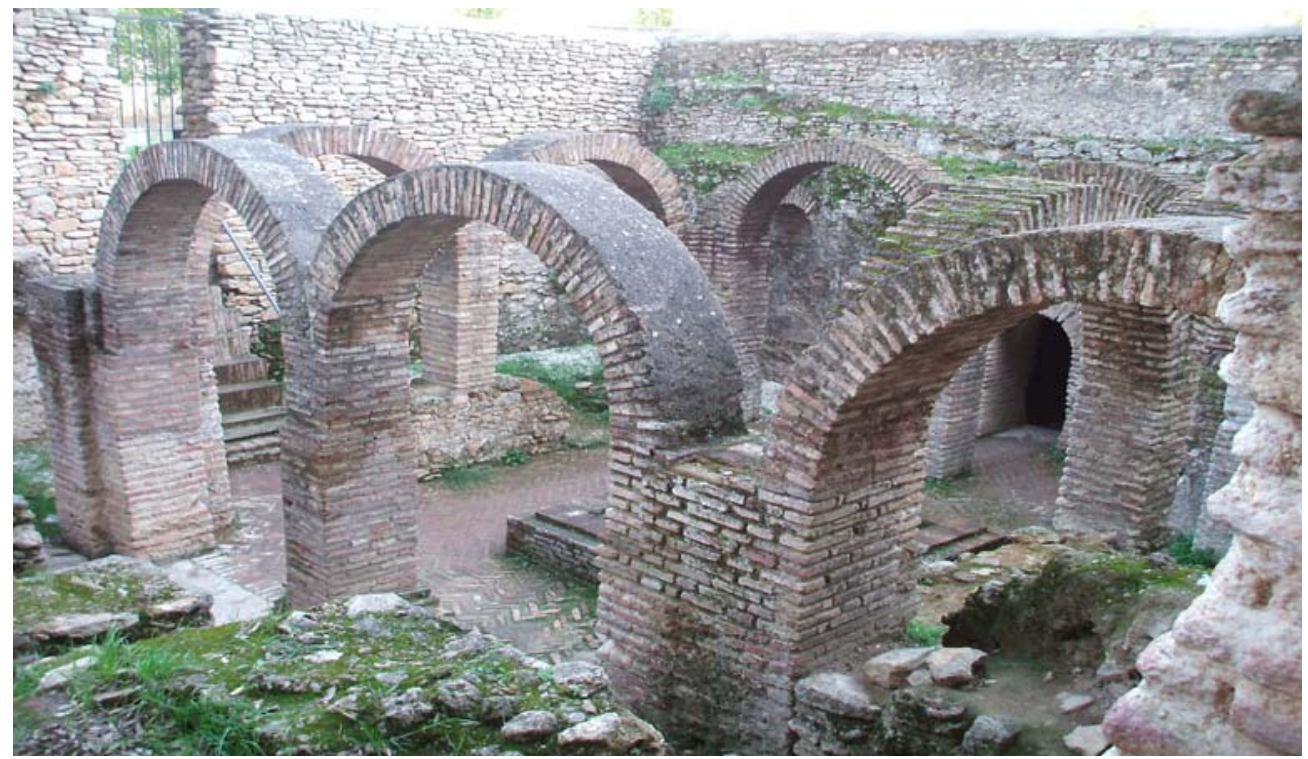

Ilustración 8 Restos arqueológicos de las ruinas del balneario romano de Ronda (Málaga) 
Josep Sánchez Ferré en su capítulo, dentro del libro "Los Balnearios Españoles", referido a La arquitectura balnearia como patrimonio amenazado, nos describe las épocas claves de florecimiento o decadencia de las estaciones termales en España planteando los siguientes puntos de referencia: por un lado, "La Desamortización", como favorecedora de la actividad balnearia; casas de baño, balnearios y manantiales pasan a manos privadas, por otro lado, empresarios que verán en el agua un negocio con posibilidades de beneficio económico, lo que provocaría la renovación y construcción de estaciones termales sobre manantiales mineromedicinales, situación que no dista mucho de la que viven los balnearios en la actualidad.

“La Desamortización ayudó, sin duda, a la nueva actividad balnearia, porque concebida por los ilustrados del siglo XVIII como medio para acceder las clases agrarias a la propiedad de la tierra, adquirió a principios del siglo XIX el carácter de consolidación del poder económico de la burguesía. La toma del poder por los progresistas (1854) acelera la desamortización tanto civil como eclesiástica y hará que en pocos años las propiedades de fuentes, manantiales, balnearios, casas de baños (hasta entonces en manos de municipios y órdenes religiosas) pasen a manos de particulares ${ }^{46,}$

${ }^{46}$ Sánchez Ferré, J. (1998). Pág. 27 


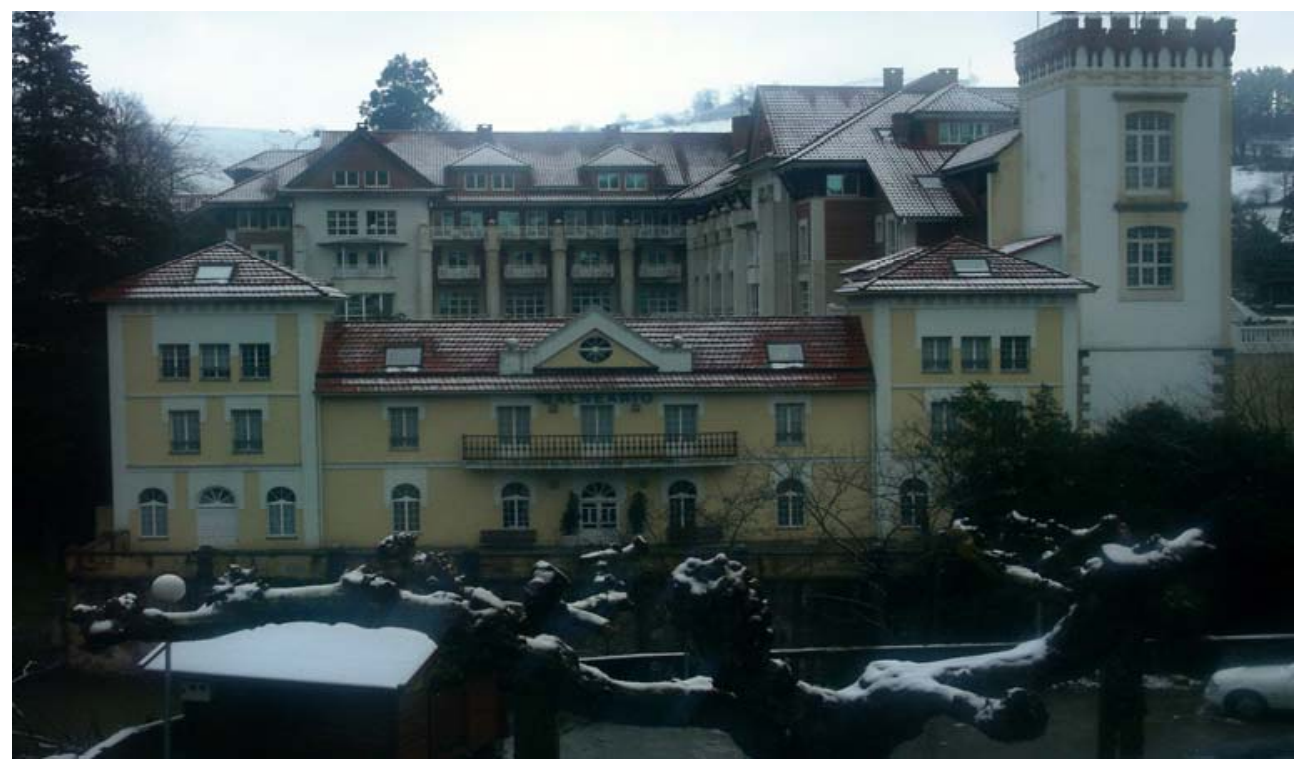

Ilustración 9 Imagen tomada en el antiguo balneario de Puente Viesgo (Cantabria)

El Período de la Restauración será una época de esplendor termal, un negocio floreciente que provoca la construcción de grandes hoteles nacidos al calor de las aguas salutíferas.

Lujosos establecimientos destinados a recibir a una concurrencia de clase acomodada dispuesta a veranear en estos exquisitos lugares de descanso.

"Es durante el periodo de la Restauración (1874-1898) cuando políticamente el sistema se institucionaliza y se estabiliza proponiendo una cierta expansión en las zonas dominadas por la nueva burguesía (Cataluña, Cantabria y el País Vasco). Este impulso dará pie a la construcción de los Grandes Hoteles asociados a los balnearios ya conocidos y concurridos"A7

\footnotetext{
${ }^{47}$ Sánchez Ferré, J. (2000). Pág. 27.
} 
Será el período final de la Restauración (1898/1923) cuando tendrá lugar el primer ocaso balneario de la época, coincidiendo con una coyuntura política de crisis, que provoca recesiones económicas de las que se resienten los agüistas veraneantes en las estaciones termales.

“El período final de la Restauración (1898-1931), determinada por la crisis del sistema político, coincidirá con el primer período de decaimiento de estos establecimientos. Son pocos los balnearios que se construyen o amplían es esta época y los que lo hacen intentan imitar el modelo centro-europeo de las grades estaciones balnearias con vocación para atraer al capital, más que al enfermo oculista, iniciando lo que en otros países se ha llamado capitalismo termal y que en nuestro país son los indicios de las urbanizaciones ligadas al fenómeno balneario." 48

\subsection{Siglo $X X$}

Comienzan momentos difíciles para los burgueses adinerados, promotores de tan importantes empresas, la situación política se agrava y con ella el mantenimiento de unas instalaciones cuyos gastos son difíciles de mantener ante una clientela más preocupada por su futuro, que por su tiempo de ocio presente; por una guerra civil (1936) que torna la situación social y económica de quienes disfrutaban de los favores de la aguas terapéuticas y de lujosos hoteles construidos al efecto, lo que dará lugar al cierre y la desaparición de muchos de estos establecimientos, así como a su utilización con otros fines distintos a aquellos para los que fueron construidos, como podemos ver en la siguiente cita:

\footnotetext{
${ }^{48}$ Sánchez Ferré, J. (2000). Pág, 224.
} 
"El período de la Guerra Civil dará pie a la utilización de estos edificios para nuevos fines. Así, su transformación en Hospitales y Sanatorios es su mutación más inmediata, dado que la mayoría de ellos fueron utilizados, por uno y otro bando, como infraestructura sanitaria. Otros casos curiosos serán los balnearios convertidos en cuarteles (Caldas de Besaya, Caldas de Oviedo) o sedes del ejército (Carabaña, San Juan de Azcoitia), sufriendo muchos de ellos importantes bombardeos debido a su estratégica situación (Montagut, Alceda). ${ }^{49}$

Todos los momentos por los que han pasado los balnearios españoles, ya sean de apogeo o de crisis, han ido aparejados de dificultades sociales, políticas y económicas que han influido de forma determinante para su funcionamiento y evolución.

Durante este siglo, la hidroterapia se somete a la experimentación científica, llega a las universidades como asignatura y avanza a la par que lo hace la medicina. Tras la segunda guerra mundial, la medicina ocupa un lugar primordial entrando la balneoterapia en una época de decadencia; a finales del siglo XX comienza una época restablecimiento fruto de factores sociales, el ritmo de vida acelerado en las ciudades hacen que se muestre una nueva valoración por las cosas naturales y por la naturaleza misma, comienzan a primar las terapias preventivas y para ello la práctica de la balneoterapia es la indicada ya que a la aplicación de las aguas mineromedicinales se unen las circunstancias ambientales de donde surgen los manantiales de estas aguas.

49 Sánchez Ferré, J. (2000). Pág.30. 


\subsection{Siglo XXI}

En la actualidad asistimos a un resurgir del gusto por el agua, los viejos balnearios se visten de nuevas galas recordando glorias pasadas, la ciencia y la técnica se mezclan con las antiguas terapias y el agua, aunque conserva su magia, posee su aval científico. Continúa ese interés por la prevención y los cuidados paliativos.

El turismo de salud se suma a la oferta de ocio, mayores y jóvenes optan por regresar a la naturaleza en busca de descanso placer y calidad de vida.

Sin detenernos en estos hitos históricos de la memoria balnearia, o de la terapéutica del agua, sería difícil comprender el nuevo concepto de termalismo en la actualidad, un uso del agua que basa sus técnicas en las ancestrales utilizando en muchos casos instalaciones originales que gracias a la perdurabilidad de este uso aún se conservan, cuando menos en los nuevos centros se intenta crear el ambiente rancio de lo que supuso la era dorada de los balnearios en España. El termalismo, de la mano del turismo de salud, ha entrado en el mercado lo que provoca el planteamiento de retos y expectativas, fuertes inversiones en nuevas instalaciones, creación de estándares de calidad, búsqueda de nuevos canales de venta del producto, como es el caso de las Agencias de viajes, todo un negocio en torno al ocio que iremos desarrollando en los siguientes capítulos que conforman este Trabajo. 


\section{Capítullo if}

\section{varias formas de comcebir el baño de la culturás del agua}

A partir del triunfo de la razón moderna, las prácticas populares de los usos del agua quedaron relegadas a la eficacia simbólica desterrándolas de la razón práctica.

(González. Y Malpica. El Agua Mitos, Ritos y Realidades.) 


\section{- Capitutioll}

\section{Páginas}

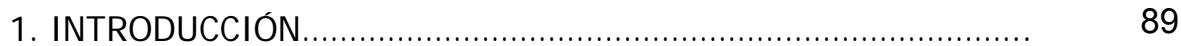

2. MITOS Y RITOS: EI REFLEJO DEL AGUA EN LA MITOLOGÍA........ 91

3. EL REFLEJ O DEL AGUA EN LA FILOSOFIA ................................. 95

4. EL REFLEJ O DEL AGUA EN LAS DISTINTAS CULTURAS ............... 99

4.1. El Baño en la Tradición Greco-Romana................................ 99

4.1.1. Grecia........................................................... 100

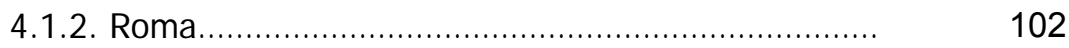

4.1.2.1. Itálica Conjunto Arqueológico: Ejemplo de Esplendor de las termas romanas.

4.1.2.2. Estructura del baño Romano.

4.2. El Baño en la Cultura Arábiga............................................

4.2.1. Estructura del Baño Árabe........................................... 119

4.2.2. Doble Función del Baño Árabe.................................... 123

4.2.3. Breve Recorrido por los Baños Árabes.................... 124

4.2.3.1. Entre los Baños de la Medina de Granada y el Albaicín $\quad 128$ 
4.2.3.2. En la Costa Granadina y cercanos a Granada....

4.2.3.3. Restos Arqueológicos del Baño de Ronda.

4.3. El Baño en el Mundo.

4.3.1. Europa.

4.3.1.1. El Imperio Otomano Rinde Culto al Agua.

4.3.1.2. Finlandia: El Baño Finlandés

4.3.1.3. Hungría "La Perla del Danubio".

4.3.1.4. Francia.

4.3.1.5. Alemania.

4.3.1.6. Portugal.

5.3.1.7. Italia.

5.3.1.8. Mónaco. 


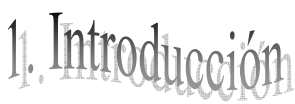

Mito es un término que viene del griego mytos, acontecimientos que no pueden ser explicados por el hombre a través de su experiencia, obras de dioses y seres sobrenaturales. Los mitos forman parte de la vida social y mágico-religiosa de los pueblos, están presentes en la vida cotidiana cumpliendo una función social, son relatos vivos capaces de generar leyes y ordenar la moral. El mito se origina en las civilizaciones primitivas y nacen de la necesidad de explicar el mundo.

La mayor parte de los mitos hacen referencia al origen del universo, explican fenómenos naturales y a través de un paradigma, determinan cultos y conductas humanas, se alejan del pensamiento científico presentando al mundo en una historia sobrenatural, en la que los dioses son los principales protagonistas., los ritos, por su parte, expresan contenidos míticos, se convierten en una puesta en escena del mismo.

Los mitos se alimentan de la tradición oral, se mantienen en el tiempo hasta que por su esencia se convierten en cuento, narraciones sobre hechos que al igual que los personajes que los encarnan son sobrenaturales, héroes, dioses y semidioses, estos protagonizan los mitos formando la base cultural y religiosa de muchas civilizaciones. Entre la realidad y la imaginación, entre el verdadero/falso se mueven estas historias llamadas mitos que explican y justifican los principios de las creencias que construyen la sociedad.

El mito dura y perdura generación tras generación ejerciendo una función simbólica a través del relato cargados de sentido e intencionalidad. La finalidad del mito es muy variada, así se mitifican animales para evitar su caza en aquellos lugares donde pueda existir peligro de extinción; el mito tiene una función que se viste de metáfora para conseguir modelar las conductas humanas. 
El mito cumple una función cultural popular, que ve lo divino en lo extraordinario y que contiene la convicción colectiva de la comunidad popular y cultural de la que surge; se le puede considerar como punto de partida para una filosofía científica.

La mitología precede a la filosofía, esta última responde a la razón y no a la fantasía para dar respuesta a la explicación del mundo. La filosofía se basa en el pensamiento y no en la imaginación buscando el rigor, el orden y alejándose del caos. 


\section{Mitos yj Ritos; El reflejo del agua en la mitología}

El agua, dentro de la mitología ha llegado hasta hoy, aunque ahora, hay quien asegura que el agua está desmitificada y que ha sufrido una pérdida de centralidad; tendemos a considerar como verdaderamente cierto, aquellos objetos y sucesos que percibimos inmediatamente de nuestra conciencia, el resto, entraría a formar parte, en todo caso, de hipótesis que habría que verificar; esta idea es planteada en el libro citado al pie de página y del cual extraemos la cita expuesta seguidamente:

"A partir del triunfo de la razón moderna las prácticas populares de los usos del agua quedaron relegadas a la eficacia simbólica desterrándolas de la razón práctica. Los mitos de fundación de las cosmovisiones podían remitir a un universo imaginario, pero carecerían de sentido práctico y su ritualística era una gesticulación eficaz socialmente pero que se dirigía al vacío instrumental".

Por ello, tenemos que hacer referencia al agua como elemento insustituible en la cosmología de los Incas y fundamento de muchas de sus teorías:

"El agua era el elemento más importante de la cosmología Incaica. Era el principio dinámico que explicaba el movimiento. La circulación y las fuerzas del cambio. Por eso, el agua se veía como la esencia de la vida misma". ${ }^{51}$

\footnotetext{
${ }^{50}$ González Alcantud, J. A y Malpica Cuello, A. (1992). “El Agua. Mitos. Ritos y Realidades”, Ed.. Diputación de Granada. Pág.10

51: González Alcantud, J. A y Malpica Cuello, A. (1992). Pág.87
} 


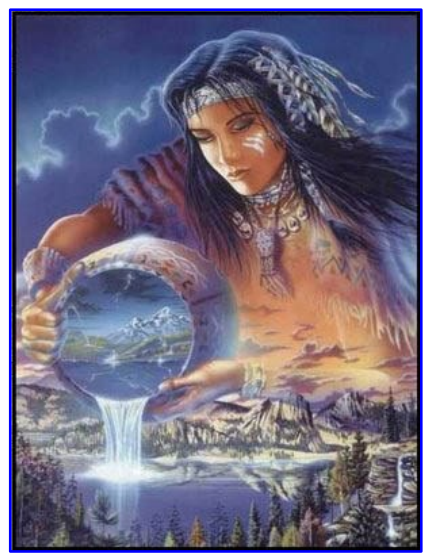

Esta y otras muchas culturas, han respondido a este tipo de preguntas por medio de la mitología, y es que los mitos acerca del surgimiento del mundo y del destino del hombre anticipan actitudes y problemas de la filosofía; los mitos homéricos, hesiódicos y órficos, fueron los primeros que giraron en torno al origen del mundo en la filosofía Griega. En el siglo VI antes de Cristo, el hombre concebía en el mito, al agua como origen del mundo: Para Homero, "la causa del mundo era el agua", el globo terráqueo flotaba sobre el inmenso océano que la consideraba origen de todas las aguas, los astros y los dioses.

"A partir del triunfo de la razón moderna las prácticas populares de los usos del agua quedaron relegadas a la eficacia simbólica desterrándolas de la razón práctica. Los mitos de fundación de las cosmovisiones podían remitir a un universo imaginario, pero carecerían de sentido práctico y su ritualística era una gesticulación eficaz socialmente pero que se dirigía al vacío instrumental". ${ }^{52}$

\footnotetext{
${ }^{52}$ González Alcantud, J. A y Malpica Cuello A. (1992). Pág.10
} 
Homero que vivió en el siglo IX antes de J.C, hablaba por boca de Ulises (Libro.8, Odisea) de los placeres del baño en las termas.

"Los griegos llamaban Tetis (nodriza) a la diosa del mar, esposa de Océano, de la que nacieron los ríos y las fuentes"53

La mayor influencia sobre el poder curativo de las aguas era ejercida por un semidios Heracles para los griegos, Hércules Farnesio para los romanos.

Se veneraban las fuentes y se construían templos en los manantiales de aguas mineromedicinales.

"El tratamiento consistía entre la fe de la acción terapéutica del dios y la aplicación de diferentes técnicas hidroterápicas indicadas por los sacerdotes, que consideraban descendientes de Asclepio, también Ilamado Esculapio, el dios de la medicina., ${ }^{, 54}$

El agua presente en muchos mitos, ha sido un elemento indispensable en el ritual, forma parte de un culto naturalista, como objeto de veneración en sus diversas formas, fuentes, ríos, mares, océanos; la veremos como símbolo de purificación, en la parte III, capítulo $\mathrm{V}$ de esta tesis dedicado al agua como elemento simbólico en la religión.

\footnotetext{
${ }^{53}$ Pérez Fernández, M.R. y Novoa Castro, B. (2006) Pág. 10 http://www.doyma.es

${ }^{54}$ Pérez Fernández, M.R. y Novoa Castro , B. (2006) Pág. 10 http://www.doyma.es
} 


\section{El reflejo dell agua en la fililosofín}

El agua en la filosofía antigua representa un elemento central, de este modo, gran parte de los escritos estaban dedicados a la fuerza del agua y a su superioridad frente al resto de elementos que forman el cosmos, como lo encontramos en este fragmento en el que el autor cita a Plinio en el libro 3, I de su Historia Natural:

"El elemento del agua manda a todos los demás elementos, él se traga la tierra, apaga el fuego, y sobre el aire toma asiento en su superior parte, ocasionando en las nubes preñadas de fuego aquella discordia, que causa terror al universo, en terremotos truenos, y abrasados rayos. Este elemento (dice) es la vida en los campos, pues sin él todos serían estériles, e influenciados, por él viven los árboles, y demás plantas y lo que es más todos los animales. Y aunque para la composición y conservación del universo, todos los cuatro elementos se consideran necesarios. Con todo ello, el agua entre todos los demás reconoce por muchos títulos más ventajosos fueros" ${ }^{55}$

El surgimiento del mundo y su subsistencia eran una cuestión planteada por los primeros filósofos, que encuentra respuesta en la filosofía presocrática mediante un conjunto de relatos centrados en la naturaleza y en el hombre, que buscan respuesta a los interrogantes sobre el origen del mundo, la vida o la muerte, ejemplo de ello es el fragmento del texto de Tales de Mileto con el que comienza la filosofía en Grecia:

\footnotetext{
${ }^{55}$ Limón Montero, A. (1697) “Espejo Cristalino de las Aguas de España” Libro primero Fol. I Introducción. Imp. F. García Fernández. Alcalá.
} 
"La causa primaria y esencia de todo lo que existe es el agua; todas las cosas son agua transformada; toda causalidad no es sino mutación y recambio de agua" ${ }^{\text {"56 }}$

Tales de Mileto, uno de los siete sabios de Grecia, filósofo, científico. Si para Homero, "la causa del mundo es el agua" y el globo terráqueo flotaba sobre el inmenso océano, Tales de Mileto, estaba a favor de un origen oceánico de la tierra firme, tierra que descansa sobre el agua como leño flotante; para este sabio filósofo "Todo es agua", "El agua principio de todas las cosas".

Todo es agua, el agua como elemento originario de la realidad, el principio de todas las cosas ya que todas las cosas estaban formadas por agua.

Esta es la doctrina de Tales de Mileto 624- 546 a. c. que consideraba el agua como "causa de las causas" de este modo lo justifica en la siguiente cita:

"La vemos moviéndose en el mar, cambiándose en millones de olas, que saltan rápidamente. Del mar asciende en forma de vapor y nube; $y$ de formas que son tan diferentes para los ojos y el entendimiento corriente como serlo puedan lo duro y lo blando, lo sólido y lo fluido; y estas formas son, sin embargo, agua, nada más que agua" ${ }^{57}$

El agua es para Aristóteles uno de los cuatro elementos de la naturaleza, agua, aire, fuego y tierra, estos cuatro elementos sobre los que giró gran parte de la filosofía presocrática, persistirán a través de la Edad Media, llegando al Renacimiento para hacer mella en la cultura y el pensamiento posterior.

\footnotetext{
56 Tales de Mileto (1936) “Los Grandes Pensadores”, Tomo I. Revista de Occidente. Pág. 25

57 Tales de Mileto (1936). Págs. 25.
} 
"El culto al agua ha atraído la atención del hombre desde siempre, lo que explica su presencia en todos los planos del pensamiento especulativo, práctico y religioso desde la Antigüedad. En efecto, el agua fue considerada ya por Aristóteles como uno de los cuatro elementos fundamentales; para Tales de Mileto, en cambio, era el único verdadero, del cual se originaban todos los demás cuerpos: "todo procede retorna a las aguas". Por su parte Moisés al relatar la creación de la Tierra sentenciaba que "espíritu de Dios cubría las aguas",58

Estos cuatro elementos, representan para la ciencia, la medicina y la filosofía la clave en torno al origen del cosmos; La idea de génesis, el origen ¿cómo surge el mundo?, y la creación del Cosmos, es recurrente a lo largo del tiempo y en diferentes culturas.

Epicureismo y Estoicismo, dos escuelas basadas en la moral y la ordenación de la conducta humana, orientadas a conseguir una vida y felicidad plena.

Según Epicuro, la felicidad es la consecución del placer que administrado sabiamente consigue apartarse del dolor. La autentica felicidad según el pensamiento estoicista, solo puede consistir en la virtud, fortaleza de ánimo y el autodominio, hacen del hombre una barrera impenetrable a la desgracia y la desdicha.

Ambas doctrinas se fundamentan en el conocimiento de la naturaleza, entendida ésta como naturaleza humana.

En el epicureismo, la ley fundamental de la naturaleza es la búsqueda del placer, una interpretación hedonista de la naturaleza humana. Para los estoicistas, vivir de acuerdo con la naturaleza es vivir en armonía con los dictados de la razón.

${ }^{58}$ Lara García, Mª P. Pág.19 
A Epicuro le interesa el conocimiento de la naturaleza, en la medida en que ésta pueda contribuir a la felicidad del hombre, mientras que para Heráclito todo está determinado y predeterminado y eso es algo que hay que aceptar.

Hipócrates, considerado "Padre de la medicina" desarrollo la llamada "Teoría de los cuatro humores" ${ }^{59}$ estando éstos relacionados con los cuatro elementos de la naturaleza nombrados con anterioridad al referirnos a Aristóteles, agua, aire, fuego y tierra,. Hipócrates comienza a atribuir la enfermedad a causas ambientales y no divinas, llegando a sugerir que el clima, el agua o los vientos son elementos que contribuyen en la salud de los habitantes de una población determinada, es el comienzo de la medicina preventiva. Hipócrates alentaba al uso de las termas ponderando las virtudes de las aguas mineromedicinales.

"El Pensamiento meteorológico (atribución al cosmos de un papel importante en la génesis y en la configuración de las enfermedades) es uno de los rasgos comunes de toda la medicina que hoy solemos llamar hipocrática" porque el médico prestaba atención no sólo al cuerpo del enfermo, sino también a todo el universo cósmico en el que el hombre se halla". 60

\footnotetext{
${ }^{59}$ Hipócrates. En: http://www.portalplanetasedna.com.ar/humores.htm

${ }^{60}$ Laín, P. (1970) “La Medicina Hipocrática” Madrid. Pág. 243. En: López Pérez, J. A. (2000) /introducciones, traducciones y notas/ “Tratados Hipocráticos” Ed. Gredos. Madrid
} 


\section{Reflejo del agua en lass distintas culturass}

El culto al agua ha sido una constante en la historia de los pueblos, esta, ha condicionado su lugar de asentamiento y su forma de vida, entrando a formar parte de sus tradiciones y su cultura, el agua es para el hombre, el hombre en sí, porque su cuerpo, al que también rinde culto mediante el baño, es agua y se nutre de agua en su propia existencia.

\subsection{El baño en la tradición greco-romana:}

Molina J.J en la ponencia presentada dentro del congreso de Termalismo Antiguo celebrado en Arnedillo (La Rioja; 1996) titulada "Termalismo Antiguo en los Balnearios del Siglo XIX", rescata la cultura greco-romana para acercarla a la cultura del balneario actual observando así la evolución de la terma al balneario. Esta aproximación a la antigua cultura termal nos permite conocer, aunque sea de forma indirecta, una información de gran interés para esta parte de la investigación. En este documento, Molina presenta al baño como elemento de unión en la época grecoromana. Purificación física y espiritual se unían a ritos sagrados y a desarrollo de cultos de quienes tomaban las aguas; esto favorecía la fe en la curación o una acción terapéutica sobre un conjunto amplio de enfermedades; según Molina, el culto al cuerpo en la actualidad manifiesta dicha continuidad.

Alude también al hecho social dentro del las termas como elemento unificador de ambas culturas: 
"También en el hecho balneo-termal se han podido observar elementos y factores en común que se conservan de la tradición grecoromana, en el uso del espacio social de la terma, perpetuados y readaptados con el paso del tiempo en los balnearios." ${ }^{11}$

Las termas tenían un carácter público y urbano ya que se encontraban en el interior de las ciudades; la función del agua era higiénica y purificadora.

"La práctica de la medicina romana se integraría dentro del conjunto de servicios que esta institución social ofrecía para el descanso y la utilidad". ${ }^{62}$

\subsubsection{Grecia}

Ya Ulises en la Odisea hablaba de los placeres de los baños termales. Los baños eran denominados "Asclepias", de Asclepio, dios de la medicina, pero la fe no era razón suficiente para Hipócrates que consideró el agua mineromedicinal como un método terapéutico de gran valor, recomendando el agua fría para procesos inflamatorios y para calmar dolores articulares. Él consideraba la enfermedad como disturbio del cuerpo por lo que éste había de llegar a un equilibrio para su restablecimiento y para ello el agua, la dieta sana y la tranquilidad eran receta indispensable; así mismo, recomendaba los baños en agua de mar para las enfermedades de la piel.

\footnotetext{
${ }^{61}$ Molina, J.J. (1997) “Termalismo Antiguo en los Balnearios del Siglo XIX”. En: Termalismo Antiguo (I Congreso Peninsular, Actas) Ed. UNED. Madrid, Pág. 82

${ }^{62}$ Molina, J.J. (1997) Pág. 83
} 
"Entre los griegos este tipo de cura alcanzó enorme difusión y la mayor parte de sus centros médicos disponían de manantiales que facilitaban las prácticas hidroterápicas, tal era el caso de los del Peloponeso, Cos, Pérgamo, Cnido, Rodas etc. La concentración de enfermos en estos lugares favorecía la difusión de los conocimientos médicos y terapéuticos, llegándose a constituir verdaderas corporaciones y escuelas de médicos que, por considerarlas inspiradas por Asclepio (Esculapio), dios griego de la Medicina, se denominaron Asclepiadas. La Medicina griega alcanzó un avance considerable; pero por lo que respecta a la utilización de la cura hidrotermal, siguió prevaleciendo la concatenación del instinto, la casualidad, el tanteo, y la observación, de manera semejante a lo ocurrido en los pueblos primitivos"63

Los griegos se preocuparon por el conocimiento de las aguas desde el punto de vista científico:

"El mundo griego daría un impulso significativo con el estudio de las aguas en su aspecto científico, con los primeros ensayos de análisis de sus propiedades y el aprovechamiento de los recursos desde los baños de mar, en lagos o manantiales, e incluso el aprovechamiento de los rayos solares, en una técnica ritualizada y con un cierto grado de complejidad que conllevará la gradual construcción de edificaciones especializadas, centradas en sus inicios en aspectos higiénicos y terapéuticos del baño" ${ }^{64}$

\footnotetext{
${ }^{63}$ Armijo Valenzuela, M.y San Martín Bacaicoa, J. (2000). Pág. 19.

${ }^{64}$ Molina, J.J. (1997) Pág. 78
} 
Las técnicas utilizadas en los balnearios griegos o romanos de los que nos ocuparemos seguidamente, son las mismas que en la actualidad se aplican en centros de baño, solo difieren en su forma de aplicación con la inclusión de nuevas tecnologías. Con la incorporación de Grecia al mundo romano, llega la asunción por parte de los romanos del culto al agua como aportación griega, algo que influyó de forma determinante en la sociedad romana, que cultivó el gusto por el baño y por la hidroterapia en su concepto de cura médica, esto se puede observar en las cuatro aportaciones que Juan José Molina Villar nos presenta en su trabajo sobre termalismo antiguo del que presentamos una cita a continuación:

"Disponemos, pues de cuatro aportaciones que permitirán definir una actividad con unas características propias, desarrolladas en base a: la actividad social y especializada en un espacio concreto, la adquisición de una práctica, la asimilación y experimentación de dicha actividad y la evolución y consolidación en estructuras permanentes en torno a la terma." ${ }^{, 65}$

\subsubsection{Roma}

La práctica del baño vivió su mayor momento de gloria durante el Imperio Romano, en el que se construyeron enormes villas termales como las de Caracalla situadas en las inmediaciones de la ciudad de Roma, las termas se ubicaban en casi todas las ciudades, las había de carácter público y semipúblico. Durante los doscientos años que duró la conquista, tuvo lugar la adaptación al modo de vida romano por parte de las sociedades conquistadas: es lo que se conoce como romanización; ello supuso un cambio de vida en aspectos tan elementales como la lengua, las costumbres, la religión, el urbanismo, el comercio, la administración etc. Si por algo se caracterizaron los romanos fue por sus magnas obras arquitectónicas, de las que nos interesa

\footnotetext{
${ }^{65}$ Molina Villar, J. J (1997), “Termalismo Antiguo en los Balnearios del Siglo XIX” Ed. UNED. Pag78
} 
destacar por el tema que nos ocupa, las obras hidráulicas. Los romanos construyeron en la península numerosos puentes, acueductos y complejos termales.

La construcción de complejos termales refleja un doble deseo de los gobernantes romanos de embellecer la ciudad por un lado y de pasar a la posteridad como favorecedores del pueblo por otro.

"El desarrollo de las poblaciones con aguas termales fue enorme $y$ algunas de las calzadas romanas que comunicaban amplios territorios pasaban por ellas. A estas poblaciones, lugares de encuentro, no sólo acudían legionarios romanos para curarse de sus heridas, sino también gentes de variada condición al atractivo reclamo del comercio, el descanso y el ocio. Estas termas estaban situadas a pie de manantial, frecuentemente al aire libre, con escasas estructuras arquitectónicas y cuyos restos arqueológicos, compuestos frecuentemente por medallas, exvotos y altares, demuestran la fe y agradecimiento de sus usuarios por sus sanaciones. ${ }^{66}$

Importantes estudiosos de la época como Plinio que escribió una Historia Natural, en la que hacía referencia a manantiales de agua con propiedades mineromedicinales (manantiales ferruginosos), o Vitruvio que se centraba en el calor de las aguas naturales como potenciadoras de sus propiedades minerales y sus virtudes medicinales legitimaban este uso entre el pueblo romano.

En relación a la investigación de las aguas en su aspecto científico, ya practicada por los griegos como hemos mencionado anteriormente, los romanos tomaran el relevo llevando a la máxima expresión su interés por la cultura del agua, tal como se desprende de la siguiente cita de Molina.

\footnotetext{
${ }^{66}$ Bel Ortega, C y Martínez González, D. (1995). Pág. 12.
} 
“La sociedad romana, muy pragmática, recogerá esta tradición griega y la sobredimensionará, debido a la influencia que le llegará con la incorporación de Grecia al mundo Romano. La admiración por dicha cultura $y$, evidentemente, por el pensamiento grifo unirá la técnica romana, dando lugar a un vinoso que alcanzará uno de los mayores esplendores de la antigüedad. La incorporación a determinadas familias romanas de esclavos como sabios, filósofos e incluso médicos griegos, propiciará la introducción de una corriente de influencia de un ideal de vida más lujoso y confortable que repercutirá en muchos aspectos de las sociedad romana, pero es muy destacable en el caso del baño, llegando a elevarlo al rango de cura médica. Este hecho pondrá las premisas a una medicina basada en una metodología más científica, que incorporará nuevos elementos, llegando a la hidroterapia a su máximo esplendor". ${ }^{67}$

Del I Congreso Peninsular celebrado en Arnedillo en 1997, sale a la luz una publicación, editada por la Universidad Nacional de Ecuación a Distancia, que pone de manifiesto la importancia del Termalismo Antiguo. En una de las ponencias presentadas, titulada "Las Termas Romanas de Hispania: Balance Historiográfico y Perspectivas de Investigación" se presenta una línea de investigación centrada en el análisis de los edificios termales dentro de la Península Ibérica en la Hispania Romana.

"Salvo contadas excepciones, los edificios termales han constituido un capítulo al que la investigación peninsular ha prestado escasa atención. Contamos con algunas excavaciones antiguas de complejos termales (Itálica, Carteia, Azila, Arcobriga, Ampurias, Gijón), que ya

\footnotetext{
${ }^{67}$ Molina Villar, J. J (1997), “Termalismo Antiguo en los Balnearios del Siglo XIX”. En: (I Congreso Peninsular .Actas) M.J. Peréx. Ed. UNED. Madrid. Pag78
} 
pusieron de manifiesto la riqueza y antigüedad de algunos de estos monumentos". 68

\subsubsection{Itálica conjunto arqueológico: Ejemplo del esplendor de las termas romanas}

En el municipio sevillano de Santiponce, se encuentra un conjunto arqueológico que pertenece al asentamiento romano más antiguo de la península ibérica.

"Es el asentamiento romano más antiguo de la península. La ciudad de Itálica fue fundada en el año 206 a.e.C. por el general Publio Conerlio Escipion, para establecer en ella a los soldados heridos que habían luchado contra los cartagineses en la batalla de llipa, lugar donde actualmente está ubicado el pueblo de Alcalá del Río, Azati. El asentamiento recibió el nombre de Itálica en memoria de la patria de origen del general Escisión y sus hombres, Italia, y desde un primer momento la ciudad tuvo el rango jurídico de Vicus Civium Romanorum. El lugar elegido por Escisión fue una colina cercana al Guadalquivir, junto a un poblado Tudetano donde se controlaban las comunicaciones con Lusitania y los enlaces fluviales". ${ }^{69}$

Las ciudades romanas solían contar con varias termas, en el caso de Itálica se encuentran excavadas dos tipos de termas las de carácter público y semipúblico, las llamadas Termas Mayores y termas Menores respectivamente.

\footnotetext{
${ }^{68}$ Fernández Ochoa, C. Morillo Cerdán, A. Zarzalejos Prieto, M.y García Entero, V. (1997) “Las Termas Romanas de Hispania: Balance Historiográfico y Perspectivas de Investigación”.En: (I Congreso Peninsular .Actas), M.J. Peréx. Ed Madrid. Pág. 381.

${ }^{69}$ http://www.tarraconensis.com/italica/italica.html
} 
Las termas menores están situadas en la parte más antigua de la ciudad, su construcción data de la época del Emperador Trajano (98-117 d.C.)

En la foto que se presenta a continuación tomada para esta investigación, podemos observar las termas menores de carácter semipúblico pertenecientes a la "Casa de Neptuno", destaca en el área termal los restos del trazado de las salas caliente y templada (Caldarium y tepidarium) desaparecida su solería pero conservando los pilares en que se apoyaba y entre los que circulaba el aire caliente producido por los hornos

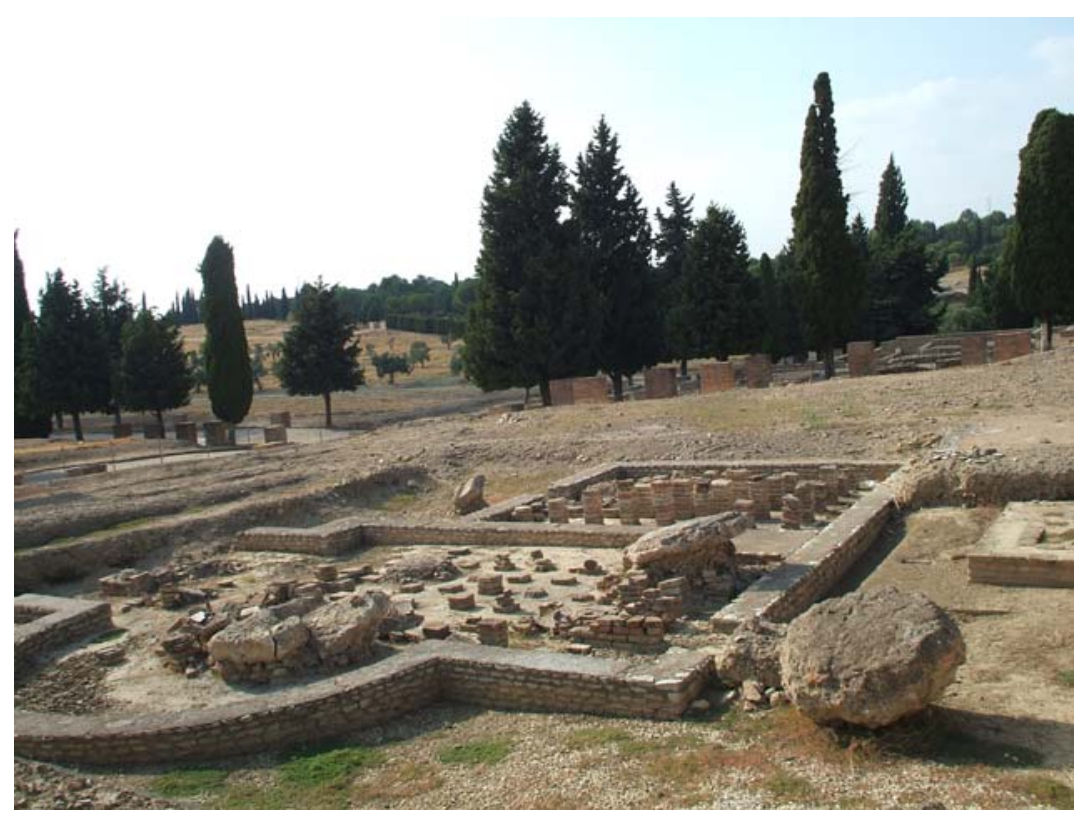

I lustración 10 Termas Menores. Restos arqueológicos de I tálica en Santiponce (Sevilla)

Las termas mayores fueron construidas posteriormente y están conformadas por dos espacios diferenciados; una correspondería al balneario y otra a la palestra. 


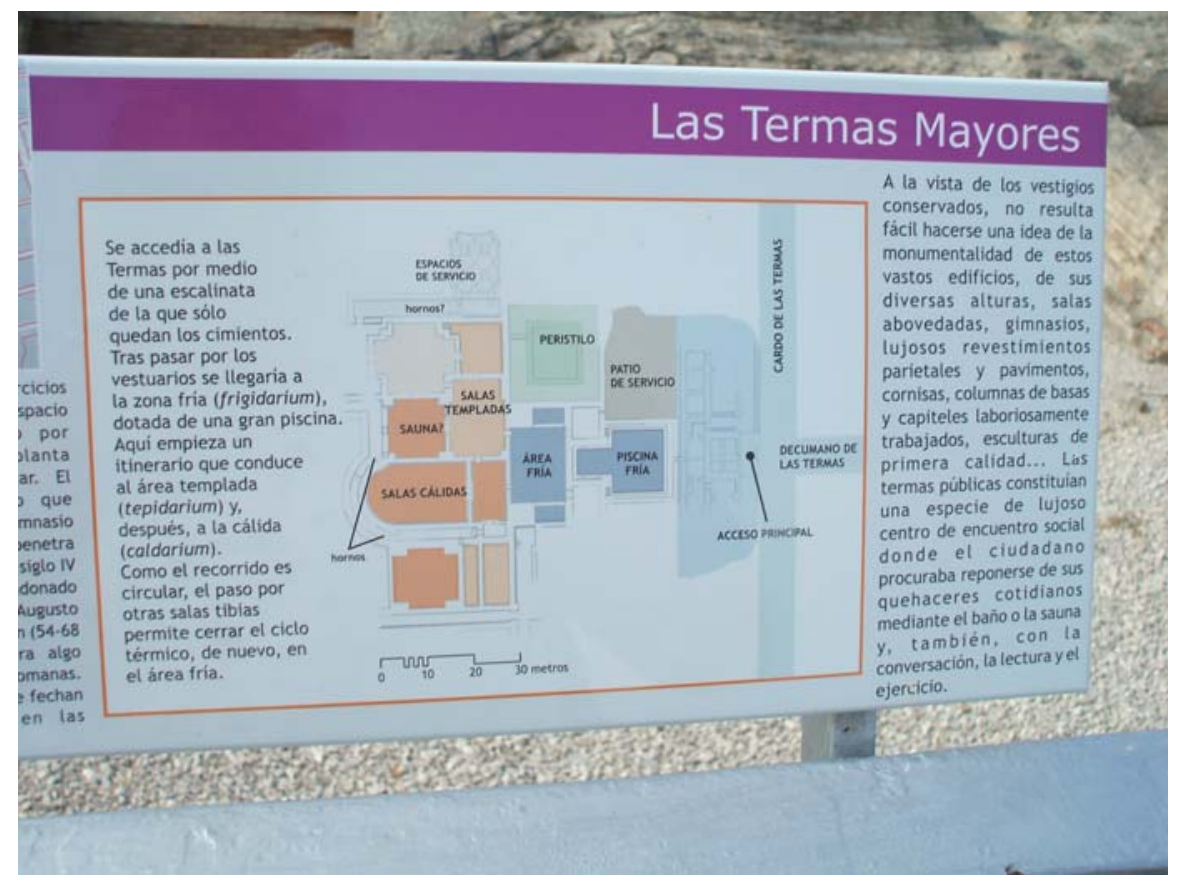

\section{I lustración 11 I magen que rescata la información facilitada al píe de las Termas Mayores en Itálica (Santiponce)}

"desde el último tercio del siglo pasado las termas han sido objeto de cierto interés por parte de eruditos y estudiosos de la antigüedad. Las aportaciones se centraron en yacimientos rurales $y$ en despoblados urbanos, tales como Itálica (De Los Ríos 1861) ${ }^{70}$

\footnotetext{
${ }^{70}$ De los Ríos. En: Fernández Ochoa, C. Morillo Cerdán, A. Zarzalejos Prieto, y M. García Entero, V. (1997) Pág. 382
} 


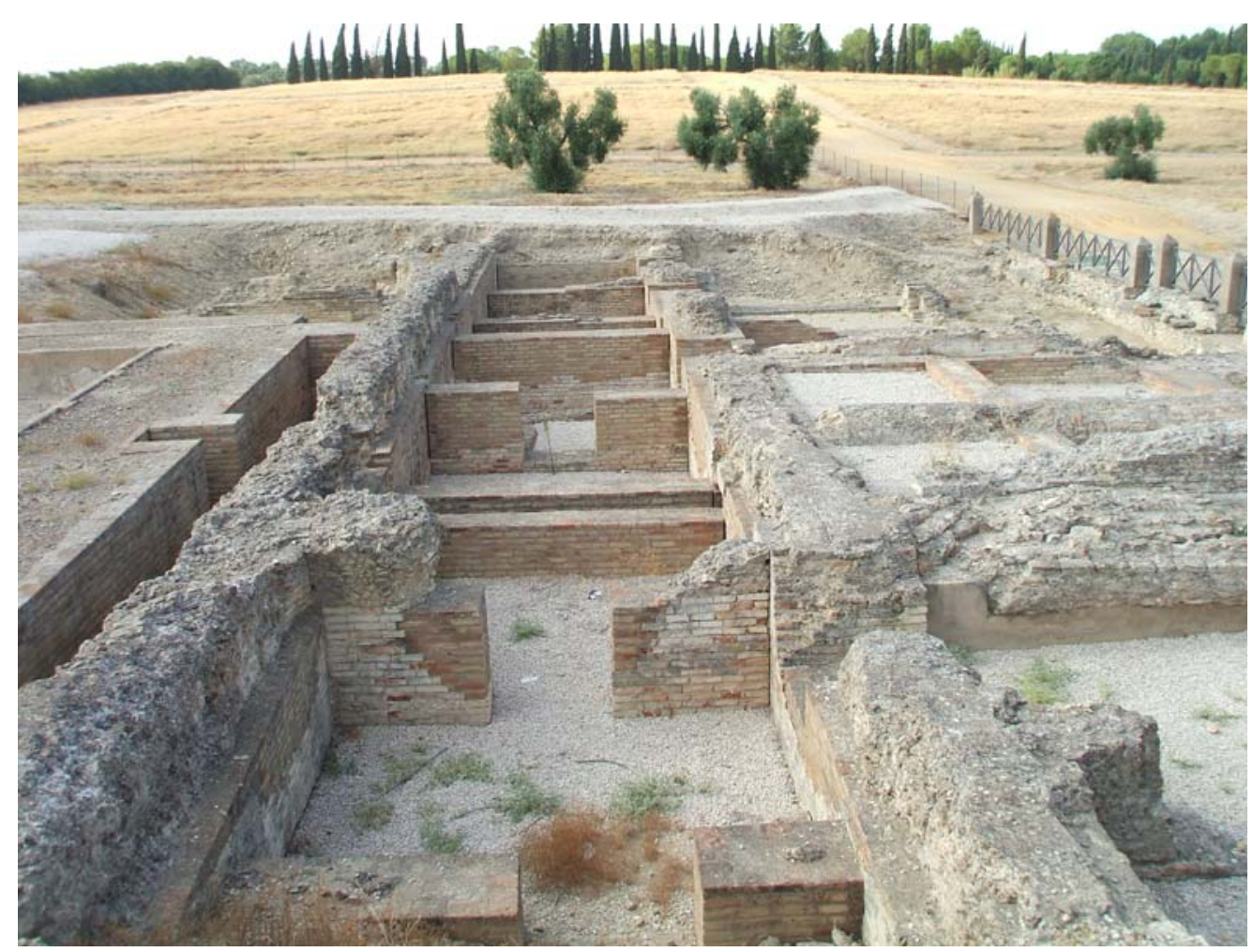

Ilustración 12 Termas Mayores. Restos arqueológicos de Itálica en Santiponce (Sevilla)

Los pavimentos musivos encontrados en las excavaciones arqueológicas de las distintas termas, han sido fuente de información valiosa para el estudio de los conjuntos termales. Los motivos representados en los mosaicos son muy diversos y en algunos casos de gran belleza por su armonía y colorido.

"Como Tantas otras actividades, también los pavimentos musivos reflejan aquellas que tiene relación con los edificios termales y los aspectos científicos del agua". ${ }^{71}$

\footnotetext{
${ }^{71}$ López Monteagudo, G. (1997) “Termas y Tecnología de las Aguas. Testimonios Musivos”. En: Termalismo Antiguo (I Congreso Peninsular .Actas), M.J. Peréx. Ed. UNED-CV Madrid. Pág. 453
} 
A continuación presentamos una muestra de pavimentos musivos en varias fotografías tomadas, para presentar en este trabajo, en las ruinas romanas de Itálica, en ellos se puede observar los motivos y las representaciones o alusiones a la mitología o la fauna en su caso.

El mosaico que se presenta a continuación, tal y como reza al pie de la foto, pertenece a la llamada "Casa de Neptuno" una vivienda que por sus dimensiones (unos 6000 metros cuadrados aproximadamente) y por tener termas propias, se le atribuye a familias patricias de alto rango.

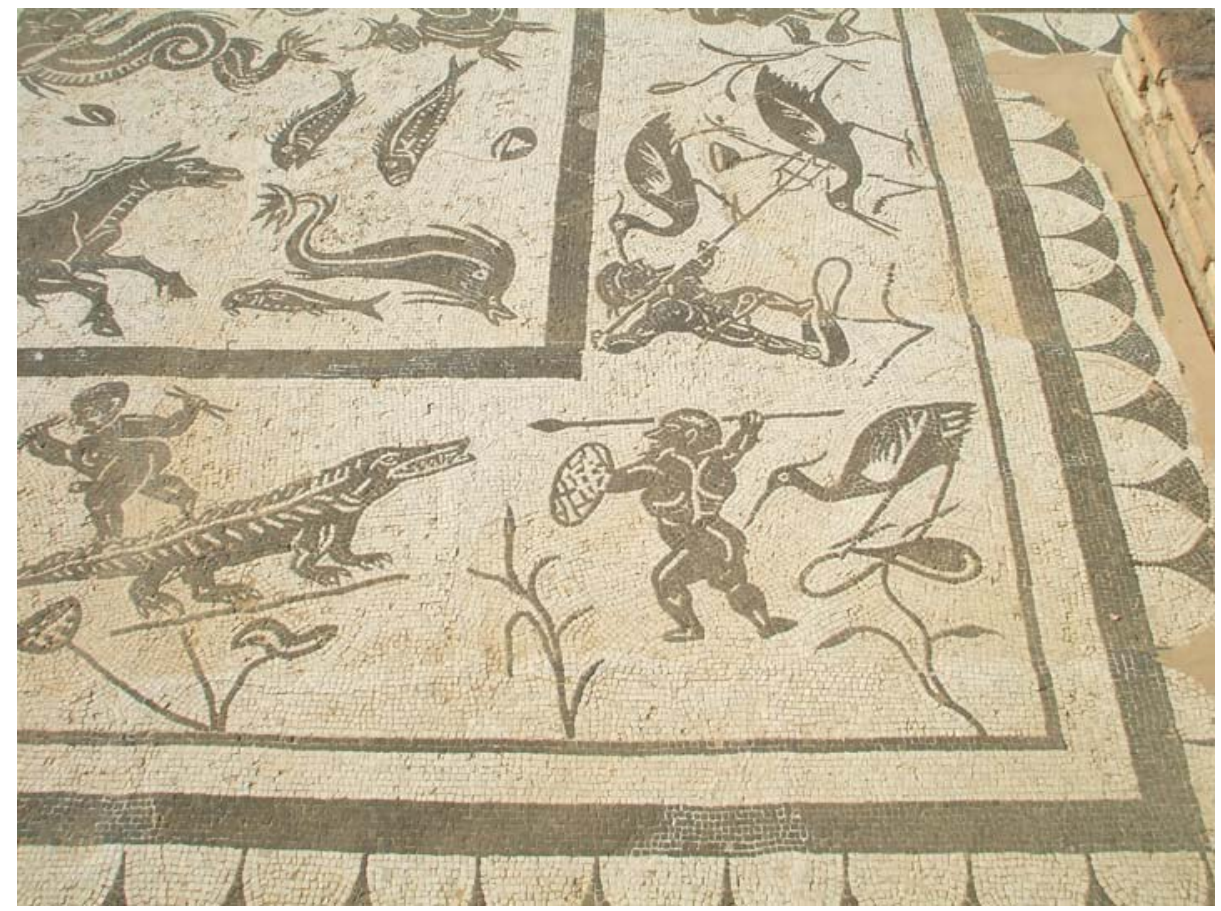

Ilustración 13 Pavimento musivo perteneciente a la Casa de Neptuno. Itálica en Santiponce (Sevilla) 


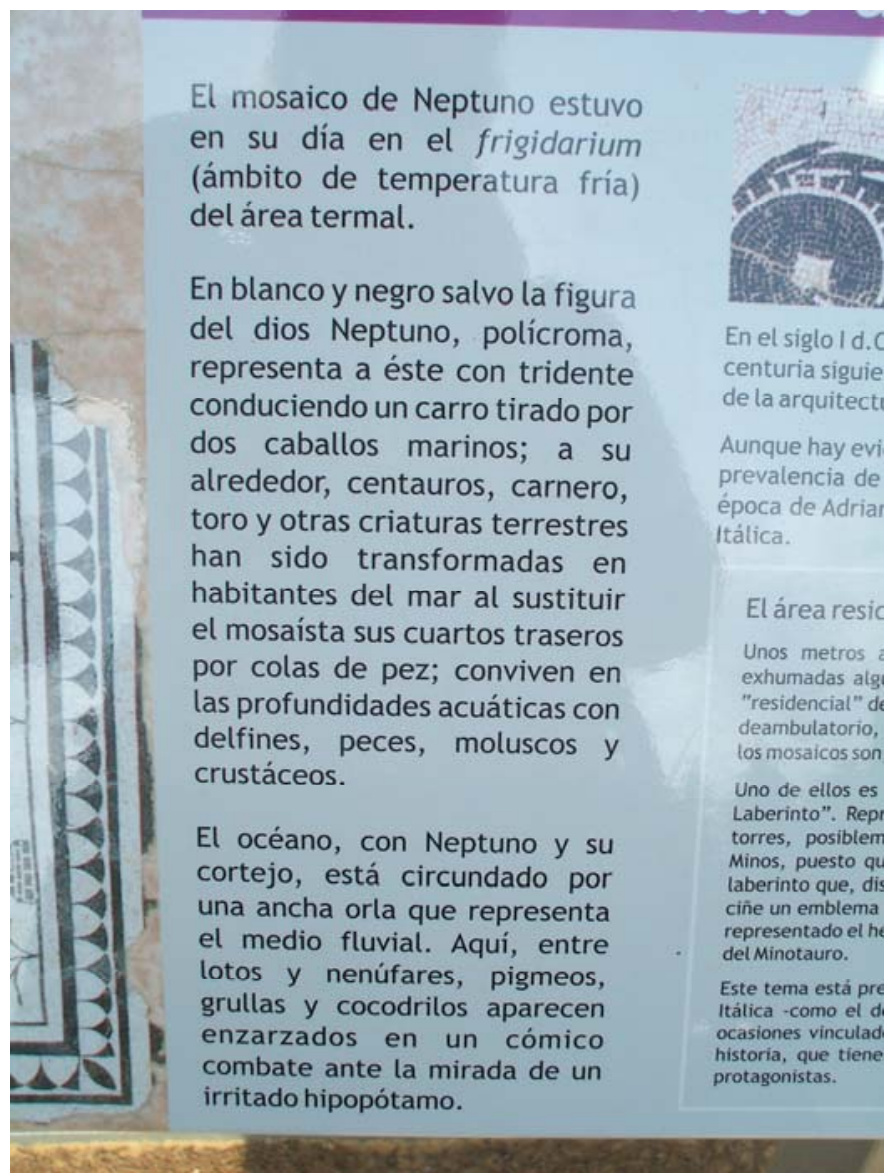

Ilustración 14 Imagen tomada de la explicación que reza al píe del mosaico de la "Casa de Neptuno" en Itálica

Los motivos son diversos y la laboriosidad y el detalle con el que fueron creados estos pavimentos es patente en estas imágenes en las que se observa la calidad del trabajo realizado y su perdurabilidad a los largo de los siglos.

La imagen que se presenta a continuación corresponde a la llamada "Casa del Planetario", ésta toma el nombre del mosaico que podemos observar en la fotografía y corresponde al pavimento de una de las dependencias. 
"Hexágono central con seis perimetrales - uno por lado- En cada uno de ellos aparece la divinidad asociada a cada día de la semana". ${ }^{72}$

Los hexágonos se encuentra en torno a un circulo en cuya parte central se encuentra la figura de Venus que correspondería al viernes, alrededor se encuentra Selene o luna (lunes); Marte (martes); Mercurio (miércoles); Júpiter (jueves); Saturno (sábado) y Helios o sol (domingo).

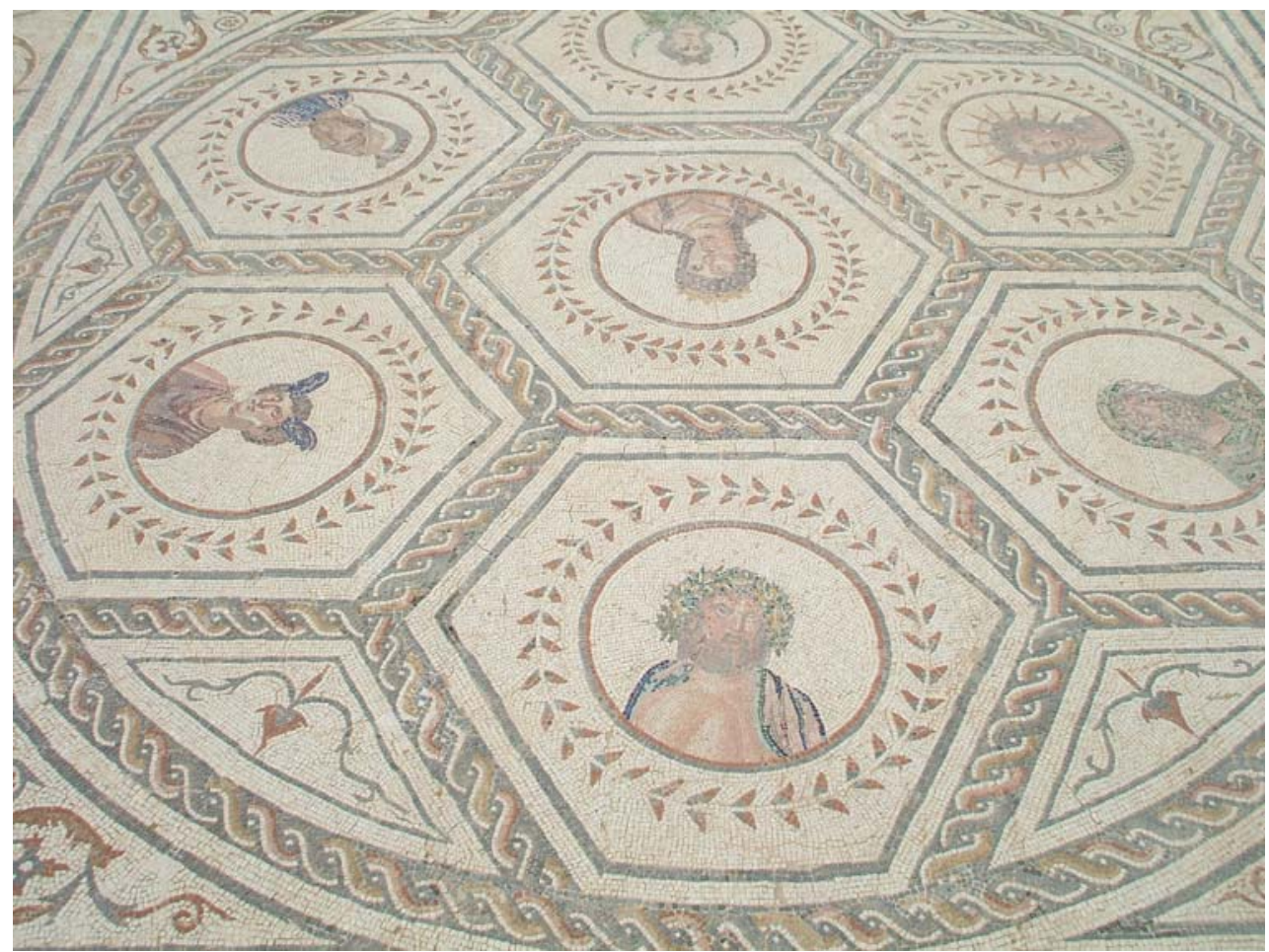

Ilustración 15 Pavimento musivo perteneciente a la "Casa de los Planetas". Itálica en Santiponce (Sevilla)

\footnotetext{
${ }^{72}$ http://www.spanisharts.com
} 
En pavimentos musivos se han encontrado motivos alusivos a, fuentes, ríos, e incluso a motivos naturalistas como es el caso de la casa de los pájaros en Itálica.

"Entre los temas figurados de la musivaria romana se encuentran las fuentes y los ríos, cuya importancia radica no solo por su forma sino también por su contenido alegórico. Son divinidades naturalistas y como tales tenían el don de la fertilidad y prosperidad, además de ser dioses benévolos que curaban a los enfermos y protegían a las flores, los prados y los rebaños. Según Pausanias en Samion, en la ciudad de Elis existía, cerca del río Anigros, una gruta de las ninfas Anigrides que con una sola inmersión en las aguas del río y un sacrificio a las ninfas se curaban las infecciones de la piel $(V, 5,11)$; lo mismo pasa con las aguas termales con propiedades medicinales de Himera o las de las Termopilas, en donde Hércules se bañaba para recuperar sus fuerzas (Herodoto, VII 176; PIND., OI., XII,27)". ${ }^{73}$

\subsubsection{Estructura del Baño Romano}

Hay dos momentos diferenciales en cuanto a los edificios termales: el de la pequeña terma republicana, con sólo tres ambientes y un itinerario lineal, y el de la terma de la época imperial, con dos plantas y un recorrido circular con algunos de los elementos principales que destacamos:

$>$ El Apodyterium, o sala de recepción del estante.

> La Palestra, o sala de ejercicios físicos.

$>$ El Tepidarium, o suelo caliente (agua tibia)

$>$ El Caldarium, para tratamiento de masaje y sudor.

$>$ El Frigidarium, o sala central común con una piscina de agua fría.

> El Laconicum, para conservar el calor.

$>$ El Elaeothaesium, o sala de unciones y masajes.

\footnotetext{
${ }^{73}$ San Nicolás Pedraz, M. P. (1997), “Termas y Tecnología de las Aguas. Testimonios Musivos”. En: Termalismo Antiguo (I Congreso Peninsular .Actas), M.J. Peréx. Ed. UNED-CV Madrid. Pág. 468.
} 
En algunas instalaciones se disponía de Solarium para la toma de rayos solares. ${ }^{174}$

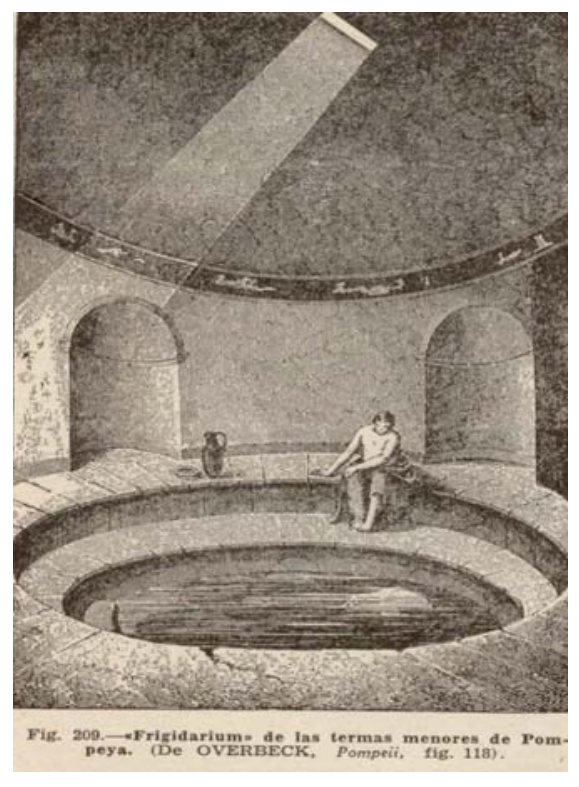

Grabado 1: Extraído de: Jérôme FigCarcopino "La Vida Cotidiana en Roma" Pág. 406

En la cita que se expone a continuación se observa de forma clara como tenían lugar las tres etapas sucesivas, que el bañista realizaba tras practicar el deporte que iba íntimamente unido al baño.

"Ante todo el bañista, cubierto de sudor por el ejercicio realizado, iba a desnudarse, si ya no lo había hecho, a uno de los vestuarios (apodyria) del establecimiento termal. Luego entraba en uno de los sudatoria que flanqueaban el caldariun y activaba su transpiración en esa atmósfera de estufa: era el $\ll$ baño seco»>. A continuación penetraba en el

\footnotetext{
${ }^{74}$ Molina Villar, J. J (1997). Pag79.
} 
caldariun, donde también reinaba una temperatura muy elevada, y en el cual podía además, acercándose al labrum, rociar su piel con agua caliente y frotarla luego con la strigilis. Cuando quedaba limpio y enjuto, volvía sobre sus pasos y se detenía un momento en el tepidarium para que la transición del calor al frío no fuera brusca, y finalmente iba a sumergirse en la piscina frigidarium. Tales son las tres fases del baño higiénico recomendado por Plinio el Antiguo" ${ }^{\text {,75 }}$

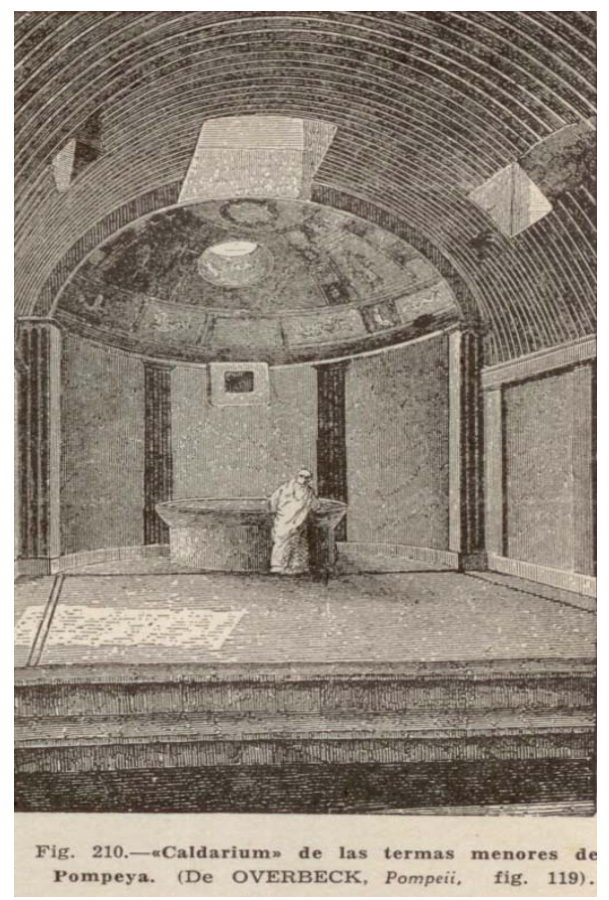

Grabado 3

Extraído de: Jérôme FigCarcopino "La Vida Cotidiana en Roma" Pág. 407

\footnotetext{
${ }^{75}$ Plinio el Antiguo, XXXVIII, 55. En: Carcopino J. (1942) "La Vida Cotidiana en Roma en el Apogeo del Imperio" Ed. Librería Hachete S.A. Buenos Aires. Pág. 418
} 


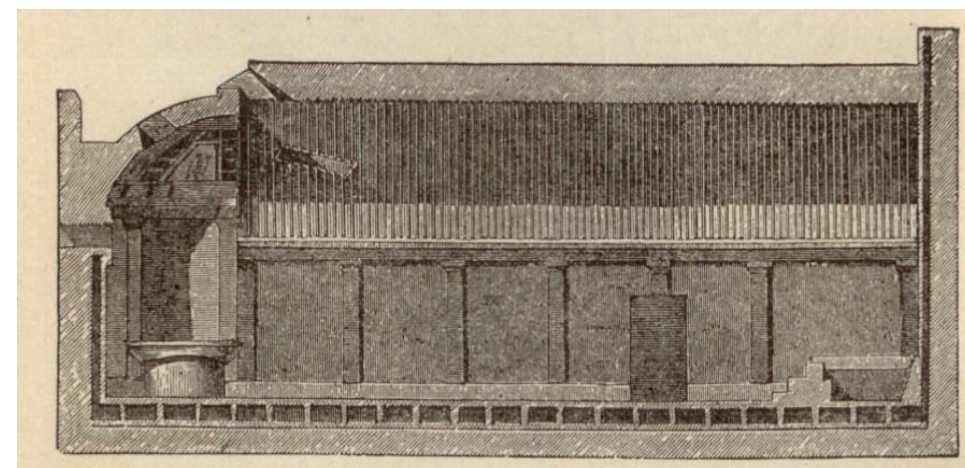

Fig. 211. - Sección longitudinal del «ealdarium» de las termas menores de Pompeya. (De OVERBECK, Pompeii, fig. 122).

Grabado 4

Extraído de: Jérôme FigCarcopino "La Vida Cotidiana en Roma" Pág. 408

"Hay que disponer tres calderas de cobre sobre el horno: una para el agua caliente, otra para el agua tibia, y han de colocarse de forma que la caldera tibia suministre a la caliente tanta cantidad de agua como salga de ésta, y a su vez la caldera de agua fría comunique a la tibia cuánta agua envíe ésta a la caliente. Las cámaras de los baños de asiento se han de calentar con el mismo fuego... Han de colocarse juntas o en lugares próximos a las calderas para los hombres y las mujeres, con ello se conseguirá que el mismo calor entre en el departamento de baños y de la habitación caliente de ambas secciones." ${ }^{176}$

\footnotetext{
${ }^{76}$ Vitruv, 5, 10,1. En: Guillen, J. (1977), “URBS ROMA Vida y costumbres de los romanos” Ed. Sígueme Salamanca Pág. 335
} 


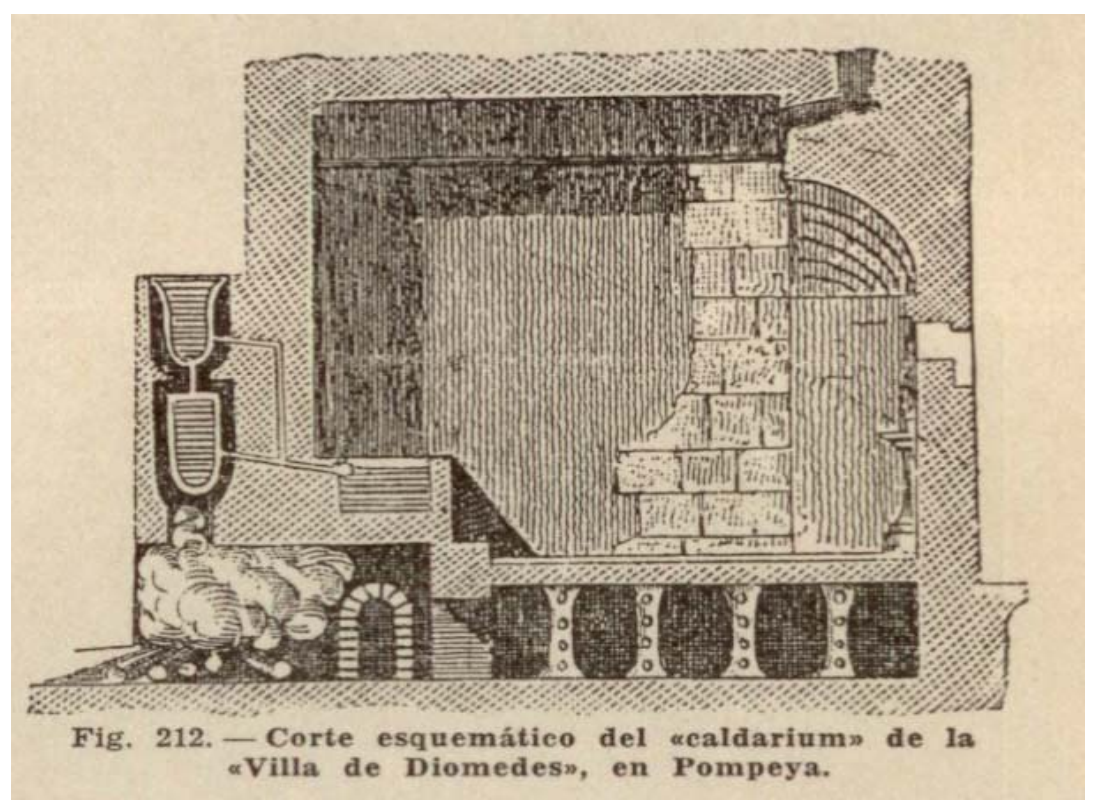

Grabado 5

Extraído de: Jérôme FigCarcopino "La Vida Cotidiana en Roma" Pág. 409

Todos estos servicios se siguen prestando en la actualidad, persiguiendo los mismos efectos reparadores y conservando la esencia de la estructura de la terma romana, aunque con la aplicación de nuevas terapias apoyadas en las nuevas tecnologías y en los nuevos conocimientos y avances de la medicina moderna, pero a su vez, manteniendo otros como la fisioterapia, técnica de los masajes que ya se practicaba en la España de la romanización.

En el presente capítulo hemos tratado las termas romanas desde el punto de vista estructural y arquitectónico, en el capítulo VII dedicado a la "función social del baño", volveremos a la antigua Roma para conocer los usos y costumbres dentro de estos establecimientos termales en los que los romanos invertían gran parte de su tiempo de ocio; el mismo tratamiento que se dará al baño árabe que se presenta a continuación. 


\subsection{El Baño en la Cultura Arábiga}

En los siglos XI y XII en el sur de España y de manos de los árabes, el baño toma un papel relevante.

“La proliferación de baños en al-Ándalus y en la España cristiana es fácilmente constatable en las crónicas, donde habla de cifras elevadas en las capitales (por ejemplo más de trescientos baños en Córdoba en la etapa califal), y al menos había un hammam público en la mayoría de los pueblos, aunque casi todos han desaparecido tras su abandono a fines del siglo XVI." ${ }^{77}$

Para los árabes, la higiene y el cuidado corporal, es además de un placer, un acto de fe, el agua es un don divino que purifica cuerpo y alma, el hammam es una constante en los tres momentos fundamentales para la vida árabe, el nacimiento, la circuncisión y el matrimonio.

Prueba de la gran influencia árabe en España con respecto al baño son las numerosas casas de baños y balnearios, muchos de ellos herencia, sin duda, de griegos y romanos, que perduran como señal inequívoca de la valoración y el gusto por el agua de un pueblo que permaneció durante ocho siglos en España.

Vidal Corella en un diario valenciano, dice que es curioso que una ciudad como Valencia, próxima a la mar, inmediata al río y rodeada de grandes acequias, contara dentro de sus reducidas murallas árabes con tantos establecimientos dedicados al baño en los siglos siguientes a la conquista por el rey don Jaime I.

\footnotetext{
${ }^{77}$ Vílchez Vílchez, C. (2004). Pág. 25
} 
"El libre del Repartiment de la ciudad, donde se consignan los heredamientos de inmuebles que hizo don Jaime entre las personas que con él se hallaron en la conquista de Valencia, cita buen número de establecimientos públicos, muchos de los cuales dieron ocasión a figurar en la nomenclatura de las calles y plazas de la ciudad. Algunas de ellas todavía lleva su antigua denominación alusiva como "carrer del bany dels Pavesos", la calle "del Bany", durante mucho tiempo mal llamada de "Embany", y la calle de los Baños del Almirante, cuyo edificio, con restos árabes, se conserva y forma parte del Tesoro Artístico Nacional." ${ }^{78}$

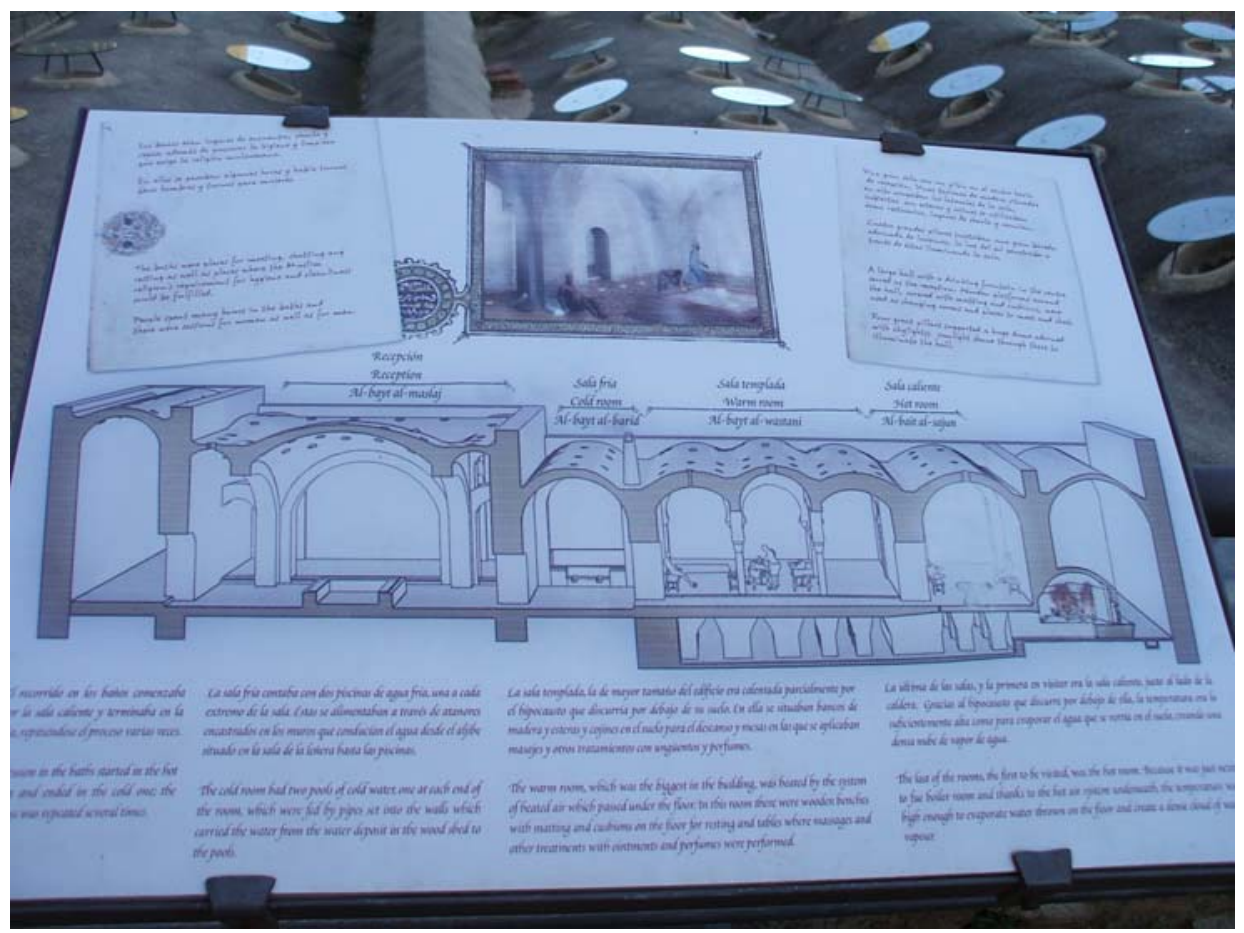

Ilustración 16 Imagen tomada en el balneario de Ronda, en ella se observa una reproducción de la estructura interior del edificio

\footnotetext{
${ }^{78}$ Vidal Corella, V 5/8/ (1994) “La Valencia de otros tiempos: Antiguas Temporadas de Baños” art Periodístico; El Dominical (Provincias) Valencia Pág. 27
} 


\subsubsection{Estructura del Baño Árabe}

Saavedra Sierra, en su libro titulado "Los Baños de Graena un manantial que sana", alude a la existencia de diferencias constructivas entre las termas romanas y los baños árabes:

"La primera es el tamaño. Los baños árabes tienen unas dimensiones menores que los romanos. La solidez de sus muros es mayor para soportar las diferencias térmicas. Los muros son de argamasa, las bóvedas son muy robustas, construidas en ladrillo con claraboyas para que dejen pasa la luz del exterior, El tamaño de las claraboyas es pequeño por lo que la ventilación es escasa." ${ }^{79}$

Vílchez en su obra "Baños Árabes"; el hammam, argumenta que en lo referente a su construcción, posee la misma estructura que la terma romana, contemplándose la desaparición de alguna de las salas, coincidiendo con Saavedra en que sus proporciones son menores.

El Apoditherium romano, sería el Al-bayt al-maslaj, se trata de una sala cuya función era la de guardarropa, en ella se desnudaban y vestían e incluso servía como sala de reuniones.

El Frigidarium romano, sería el Al-bayt al-barid o sala fría.

> El Tepidarium romano, en el baño árabe pasaría a llamarse Al-bayt alwastani, manteniendo el mismo uso de sala templada.

\footnotetext{
${ }^{79}$ Saavedra Sierra, J. (2007) “Los Baños de Graena un Manantial que Sana” Imp. Proyecto Sur Industrias Gráficas, S.L. Pág.35
} 
DEl Caldarium romano, es denominado dentro del baño árabe como el Al-bayt al-sajun o sala caliente.

$>$ El Praefornium que el balneario romano, sería la caldera, pasa a llamarse Al burma.

$>$ El Hypocausis romano, el horno, sería el Al- furn.

> Las Lucernae son los Madawi; lucernas, situadas en las bóvedas que cumplían una doble función y sirviendo por un lado, para proveer de luz a las salas y por otro, como reguladoras del vapor según fuese la posición de apertura en la que se encontrasen en cada momento.

"A las Bóvedas de estas salas se abrían pequeños tragaluces o lucernas llamados en árabe midwa (plural madawi), que eran de piedra o cerámica. Sus formas son geométricas (lobuladas, cuadradas, rectangulares, hexagonales, octogonales o estrelladas), y cumplían una doble misión: en primer lugar daban luz cenital, y en segundo lugar regulaban la cantidad de vapor y calor de las salas según se abrían o cerraban los cristales que las tapaban. Las madawi eran muy llamativas, con cristales de diversos colores, como describe el poeta Ibn Suhayd comparándolas con las estrellas, ${ }^{, 80}$

${ }^{80}$ Vílchez Vílchez, C. (2004) Pág. 15 


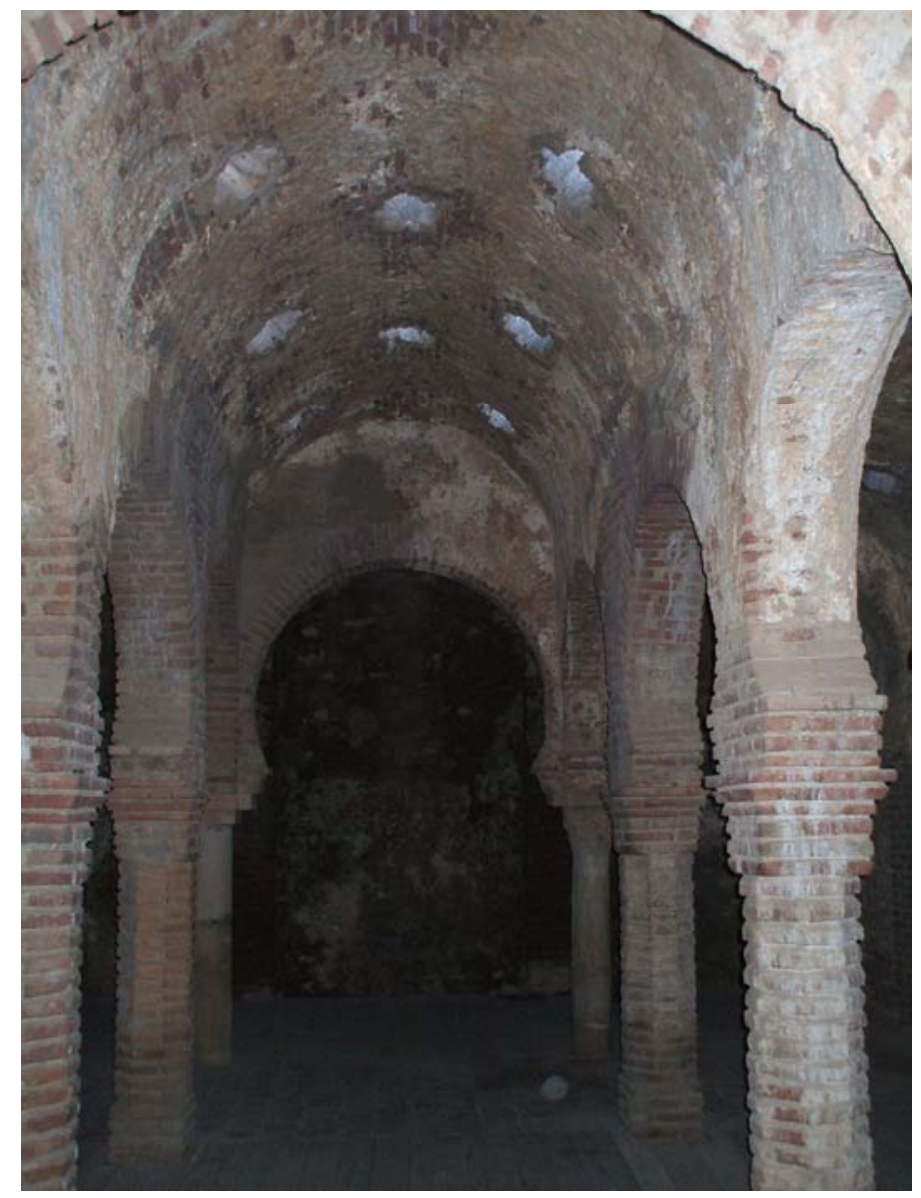

\section{Ilustración 17 Ronda (Málaga) Termas Romanas}

Aunque en esencia la estructura del baño en cuanto a la aplicación del agua era como en otras culturas, la arquitectura por el contrario, era propia y diferenciadora. Los árabes situaban los baños en el centro de las ciudades, como su intención era higiénica, no buscaban solamente las propiedades terapéuticas del agua, sino el acercamiento del establecimiento a la ciudad para facilitar su acceso al mismo; los baños se abastecían de aljibes (al-jubb) y acequias (al-saqiya) así como también de los ríos de los que extraían el agua por medio de norias. 
Eran edificios de gran belleza y cuidada estética que invitaban al baño. En la actualidad, existen recreaciones del ambiente termal arábigo en casas de baño, como es el ejemplo de los baños árabes, situados al pie de la colina de la Alambra de Granada "Baños Árabes de Granada".

"El mundo árabe cuna de ciencia y sabiduría, siempre tuvo una gran tradición en lo que a higiene se refiere. Por este motivo fueron unos auténticos maestros en el arte del baño, así como en sus instalaciones y material empleado. En la Alhambra destacaban los baños reales donde reyes como Abul Hacharch o el mismo Boadil (el chico), se daban magníficos baños reconfortantes para preservar no sólo su salud, sino también su higiene. Las construcciones de éstos eran de lujosa edificación llamada Comaraxia, estando recubiertas de ricos mármoles al tiempo que le flanqueaban esbeltas columnas $y$ arcos policromados". ${ }^{81}$

\footnotetext{
${ }^{81}$ Bravo, A. (1996). “Femenino Singular: La Belleza a través de la Historia” Alianza Ed. Madrid Pág. 255
} 


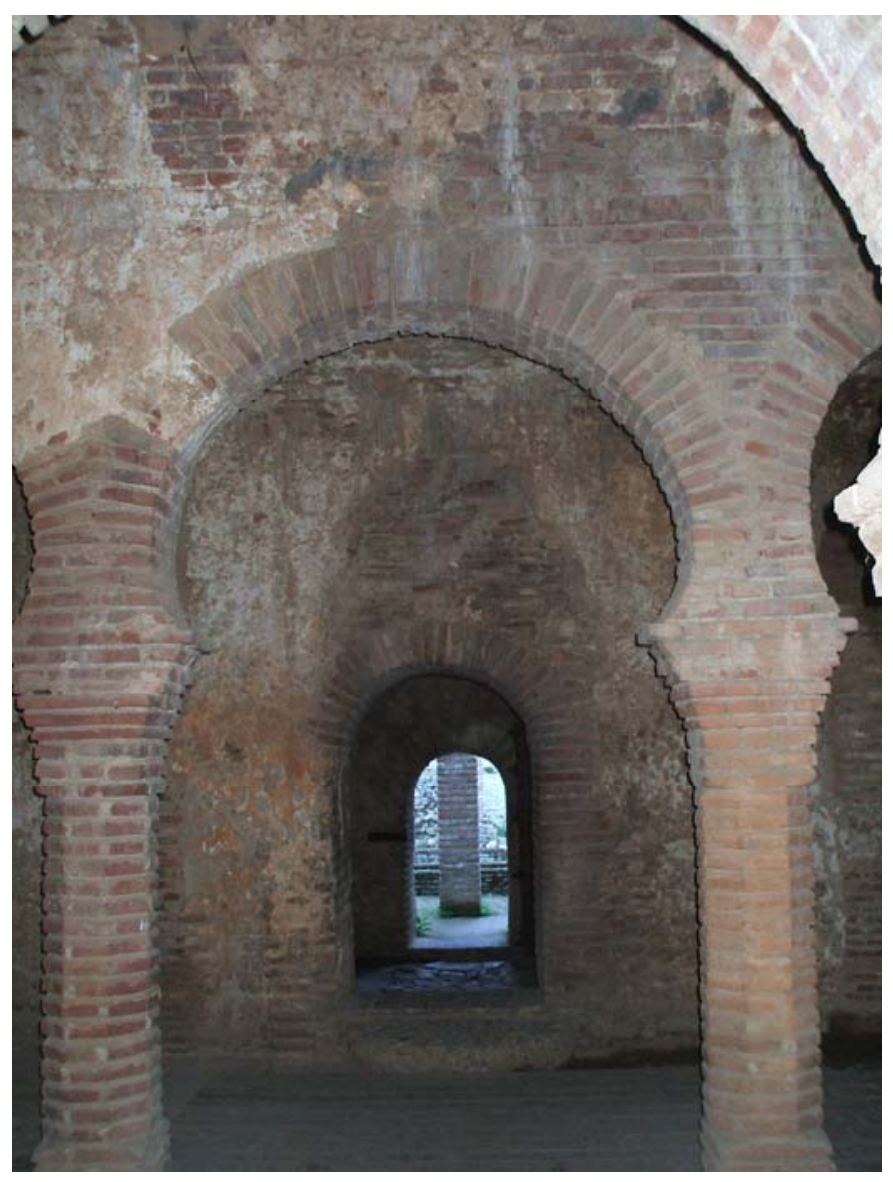

\section{llustración 18 Baños Árabes de Ronda (Málaga)}

\subsubsection{Doble Función del Baño Árabe}

La tradición y el gusto por el baño en la cultura árabe, arranca de la época grecorromana y se inyecta de forma muy profunda en la cultura árabe, que da un papel primordial al agua en todas sus dimensiones, tanto religiosas como estéticas, haciendo del agua uno de sus mayores aliados para conseguir la belleza a través de sus fuentes. 
"El Islam consideraba la hidroterapia como algo prestigioso, Mahoma le daba mucha importancia a la higiene y los cuidados corporales a través del agua. Rhazes y Avicena, considerado el mayor medico de lengua árabe, desarrollaron la hidroterapia como técnica de aplicación en forma de baños, bebidas y aplicaciones locales en quemaduras, viruela y hemorragias. ${ }^{182}$

El baño cumple dentro de la cultura árabe una función religiosa, una obligación a realizar como ritual mediante el que adquirir la pureza necesaria antes de la oración (la tahara $)^{*}$ es por ello que en todas las mezquitas se hacían fuentes o baños, aunque también tenía una función higiénica y de placer como lo fuera para los romanos.

"En la id al-fir o gran fiesta de la ruptura del ayuno al finalizar el Ramadan, los baños eran un hervidero de creyentes que hacían una limpieza completa de su cuerpo". 83

\subsubsection{Breve recorrido por los baños árabes.}

A la hora de estudiar los usos sociales del agua en la cultura árabe, hemos optado por hacer un pequeño recorrido balneario, tomando una muestra de los distintos centros termales situados en Andalucía lugar donde la influencia árabe se manifiesta en lo referente al tema hídrico que nos ocupa.

\footnotetext{
${ }^{82}$ http://www.abalnearios.com/historia/edadmedia/

* Tahara = lo denomina de este modo la teología islámica y se refiere al modo de conseguir la pureza antes de orar.

${ }^{83}$ Vílchez Vílchez, C. (2004) Pág. 16
} 


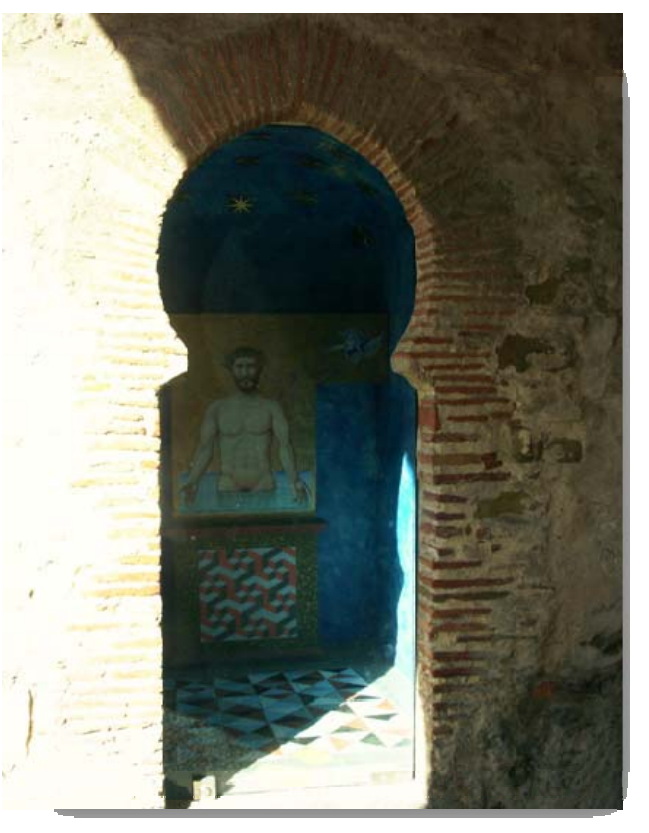

Ilustración 19 Tarifa (Cádiz) Pintura situada en la puerta de entrada a la ciudad

Un ejemplo de baños árabes andalusíes, lo encontramos en Jaén: datan del siglo XI y fueron construidos por el rey Alí, están situados dentro de la ciudad. Estos establecimientos, sufrieron los cambios políticos quedando enterrados bajo un palacio a finales del siglo XVI mandado construir por D. Fernando de Torres y Portugal y recuperados en el siglo XX para su restauración.

Estos baños constaban de varias estancias, con un patio de entrada y sus correspondientes salas en las que se aplicaban los baños fríos, templados y calientes.

"Durante la dominación musulmana se registran en Jaén numerosos baños árabes. Destacan, entre ellos, los de Alí, en la hoy plaza de Santa Luisa de Marillac, bajo el Palacio de Villardompardo, y los del Naranjo, en la plaza de Los Caños, bajo el edificio de las Carnicerías Públicas. Ambos baños forman parte de un grupo de cuatro que cita Al-Himyari, 
alimentados por una fuente de gran caudal que solía identificarse con la de La Magdalena.

Pascual Madoz, en el siglo XIX dice que el mencionado caudal alimentaba a un gran número de fuentes ${ }^{, 84}$

Al norte de la provincia de Granada en un pueblo denominado Baños de Graena, Encontramos enclavados en un paisaje singular por su belleza, un balneario de cuyas aguas salutíferas ya disfrutaban los romanos y que valoraron de forma especial los árabes.

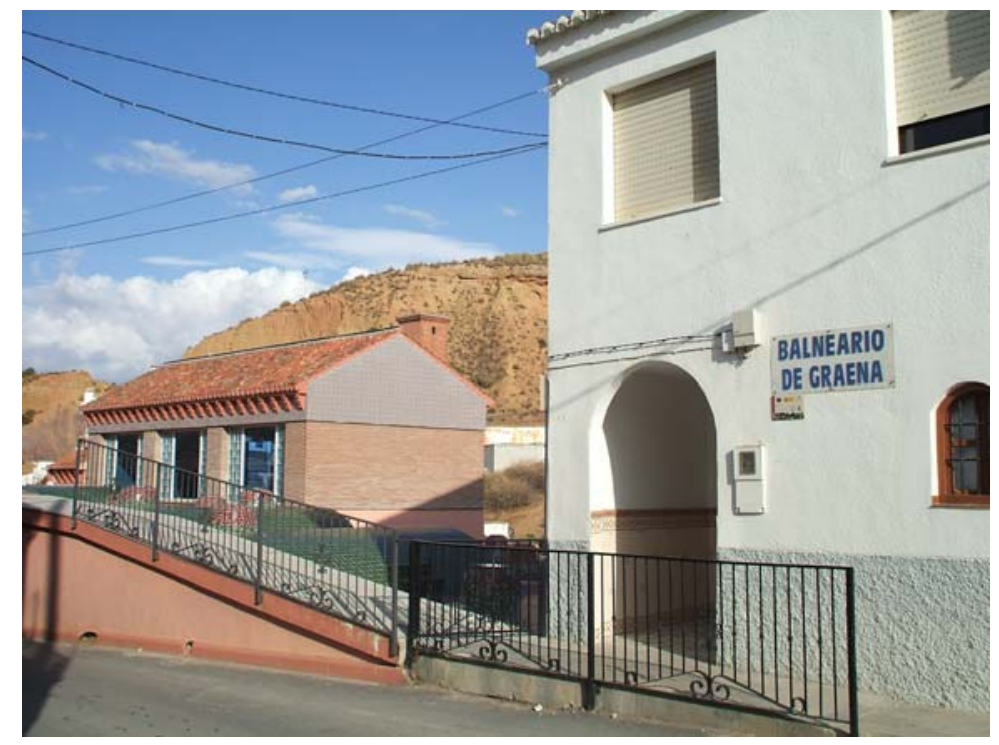

Ilustración 20 Imagen tomada en el Balneario de Granena situado en la comarca de Guadix en Granada; un bello paraje rodeado de cuevas habitadas en la actualidad, muchas de ellas abiertas al turismo.

\footnotetext{
${ }^{84} \mathrm{http} / /$ www.aytojaen.es
} 
Este balneario cuenta con unas aguas cuyas características Físico-Químicas lo hacen especial, entre otras se puede destacar, la temperatura de emergencia que es de $44^{\circ} \mathrm{C}$ siendo por tanto hiper-termal y de caudal muy abundante. Son aguas ferruginosas, cloruradas, sulfatadas, cálcicas, magnésicas, y radiactivas; en cuanto a sus propiedades terapéuticas están especialmente indicadas para tratar afecciones reumáticas, artrosis, neuritis, ciática, bronquitis crónicas asmáticas y alérgicas, faringitis, sinusitis, asma, afecciones dermatológicas, y estrés. Es en la actualidad un balneario que dentro de sus terapias mantiene la esencia de la cultura árabe del agua a través de un circuito termal que contempla la piscina templada (36-37 grados), la piscina caliente (39-40 grados), una Sala de Niebla, Baño Turco, Pasillo de Cantos Rodados, una zona destinada al reposo y solárium.

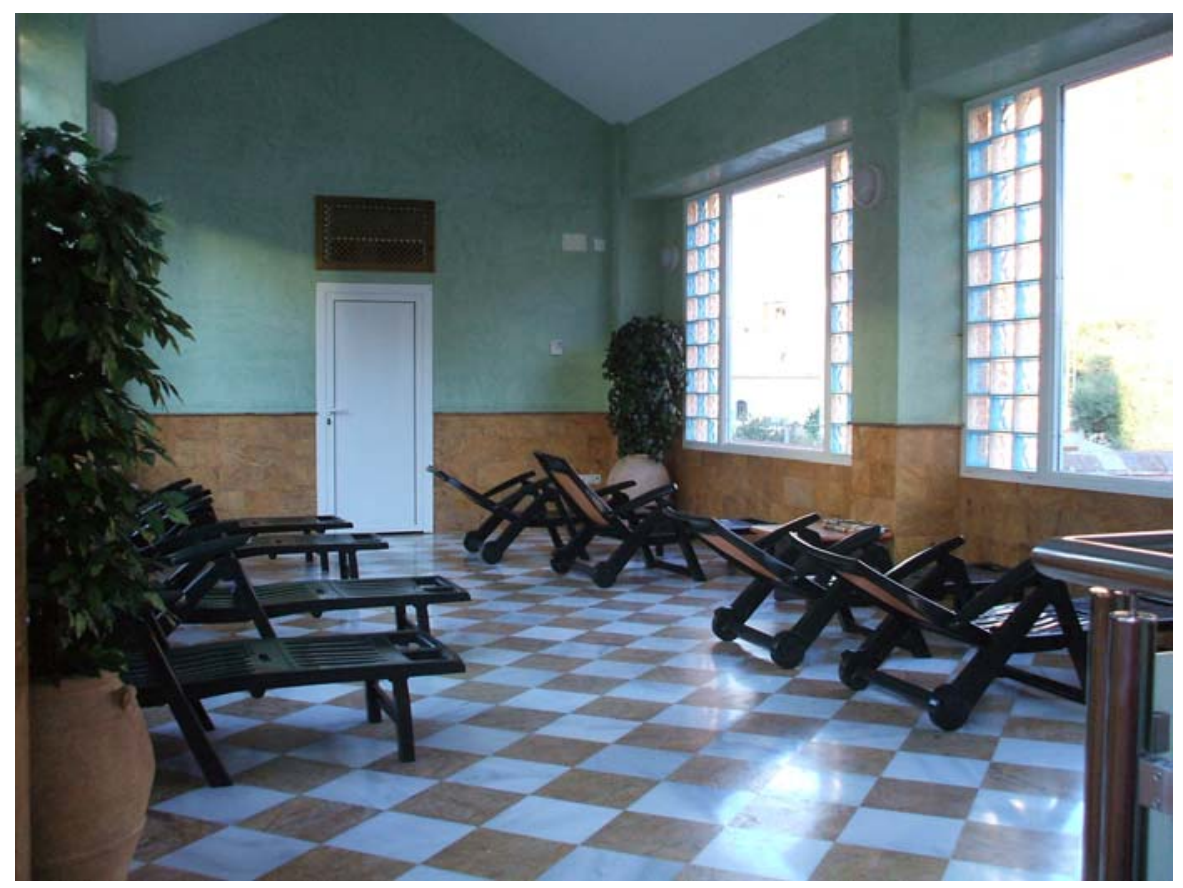

Ilustración 21 Solárium, lugar para el reposo tras el baño. Imagen tomada en el balneario de Graena (Granada) 
En el siguiente articulo extraído del periódico "El Mundo", podemos observar lo atractivo de un balneario con reminiscencias árabes, cuyo paisaje y ambiente evocador, envuelven al agüista y lo transportan en el tiempo a un enigmático mundo que dura lo que dura la estancia en dicho balneario.

"Cae la tarde en el melancólico Paseo de los Tristes, bajo la mirada de la Alhambra iluminada... Un viento helado desciende desde las cumbres de la hermosa Sierra Nevada y un frío terrible se apodera de los desprevenidos huesos. El cuerpo, destemplado, corrige el rumbo y guía a los cansados pies hacia la cercana tierra de las mil y una noches. Abrir la puerta del Hamman es llenarse de vapor aromático, de esencias almizcladas, de suaves melodías árabes que lo inundan todo. Es la réplica de los antiguos baños que aquí una vez, hace cinco siglos, eran el centro de reunión de la sociedad nazarín's5.

Los árabes supieron aprovechar del agua todas su belleza y esplendor, dejando una importante muestra de su apreciación por este líquido elemento, en todas sus formas, a través de las fuentes y de los Hamman, un legado que ha dejado en España ese gusto por lo natural y esa positiva apreciación sobre el agua.

\subsubsection{Entre los Baños de la Medina de Granada y el Albaicín}

Se encuentran entre otros:

$>$ Los Baños del Bañuelo:

\footnotetext{
${ }^{85}$ De Pablo, O. Noviembre de (2003) “Mimar el cuerpo y el alma entre mosaicos y celosías”, número 25 Suplemento del diario El Mundo.
} 
"Este baño era público y ayudaba al mantenimiento como bien de los hábices, de la cercana mezquita de los Conversos (masyid al-Ta 'ibin), en San Juan de los Reyes. Se puede considerar como el ejemplo que seguirán los demás baños hasta el final del al-Ándalus". ${ }^{86}$

Este baño es conocido también como "Baño del Nogal" (Hamman al Yawza) o de los Axares, este último hace alusión al nombre del barrio en el que se encuentra, a la fecha de su construcción, Barrio de los Axares - De la salud y el deleite.

El Bañuelo data del siglo XI, en la época del rey Zirí Badis, y su construcción corrió a cargo del visir judío Samuel Ibn Nagrela, se considera uno de los más antiguos de la ciudad de Granada. Tras la conquista cristiana dejó de utilizarse como baño pasando a construirse en su interior un lavadero público; es durante los años 1928-1932 cuando el arquitecto Leopoldo Torres Balbás lo restaura y recupera. En la actualidad este baño se encuentra abierto al público para su visita, teniendo además un uso cultural ya que en él se ofrecen actos culturales, conciertos, lecturas poéticas etc..

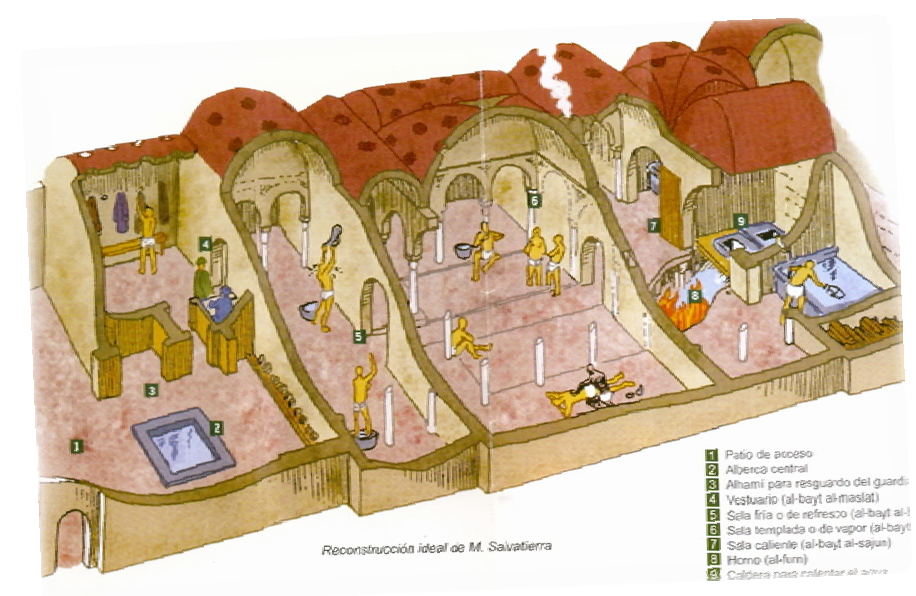

Ilustración 22 Representación Gráfica de los baños del Bañuelo de Granada. (Imagen extraída del catálogo de visitas del baño)

${ }^{86}$ Vílchez Vílchez, C. (2004) Pág. 26 
$>$ La Casa de las Tumbas, ubicado en la calle San Andrés.

"Era un baño público perteneciente a los hábices* de la mezquita sobre la que se construyó la lindera iglesia de San Andrés. Gómez Moreno lo fecha en el siglo XIV, aunque piensa que fue entonces cuando se reformó y remonta su construcción original dos siglos antes, es decir al siglo XII". ${ }^{87}$

> El Baño de las Mercedarias: que data de los siglos XII- XIII situado en la antigua judería granadina.

> Baños de la calle del Agua: situados en la calle que les da nombre.

El agua era un elemento muy apreciado en Al-Ándalus, posiblemente por ser un recurso escaso. Los árabes supieron valorar el agua sacando de ella lo mejor para su propio deleite, así como para su explotación económica. Esto se puede observar a través de los baños de la Alhambra que se presentan a continuación de esta cita que pone de relieve la forma de provisión de agua para estos baños.

"El agua llega a la Alhambra a través del acueducto de la torre del Agua, procedente de una acequia que se toma del río Darro, aguas arriba, y alcanza el Generalife dividida en dos, la acequia Real y la acequia del Tercio, que se vuelven a unir para pasar el acueducto. Según el Manuscrito de Madrid y Copenhague y las referencias del viajero magrebí Ibn Jaldum (siglo XIV), fue el primer sultán de la dinastía nazarí, Muhammad ibn Nasr ibn al Ahmar, el que llevó a la Alambra en $1238<<$ el agua del río, abriendo una acequia con caudal propio>>". 88

\footnotetext{
${ }^{87}$ Vílchez Vílchez, C. (2004) Pág. 31

*Hábices: Bienes pertenecientes a las mezquitas conseguidos por donación pía de los creyentes.

${ }^{88}$ Vílchez Vílchez, C. 2004 Pág. 37
} 
> Baño de la casa principal de la alcazaba: siglo XIII Muahammad I

> Baño de la alcazaba: siglo XIII Muahammad I

> Baño del palacio de Comares: mandado a construir por el sultán Yusuf I en el siglo XIV.

> Baño del palacio del Partal alto: finales del siglo XIII Muhammad II

$>$ Baño del Polinario: siglo XIV Muhammad III.

$>$ Baño de la calle Real sobre el palacio de los Abencerrajes.

> Baño del palacio de los Abencerrajes: finales del siglo XIII Muhammad II

> Baño del palacio del convento de San Francisco: comienzos del siglo XIV Muhammad III.

> Baño del palacio del Generalife: siglo XIV Muhammad III.

$>$ Baño del palacio de Dal al-Arusa: siglo XIV.

\subsubsection{En la costa granadina y cercanos a Granada}

Nos encontramos:

Baños de Alfacar: Los baños árabes de Alfacar han sido recientemente descubiertos. Entre unas viviendas situadas en la plaza del Baño cerca de la Iglesia de la Asunción, en ellos se puede observar a través del croquis la estructura interna de los baños árabes.

Las paredes de este balneario, están construidas con sillares de piedra del la localidad de Alfacar. Ambas salas tienen unas dimensiones aproximadas de cinco metros de largo por tres de ancho. El abastecimiento de estos baños provenía de la "Acequia de Ayanadamar" 


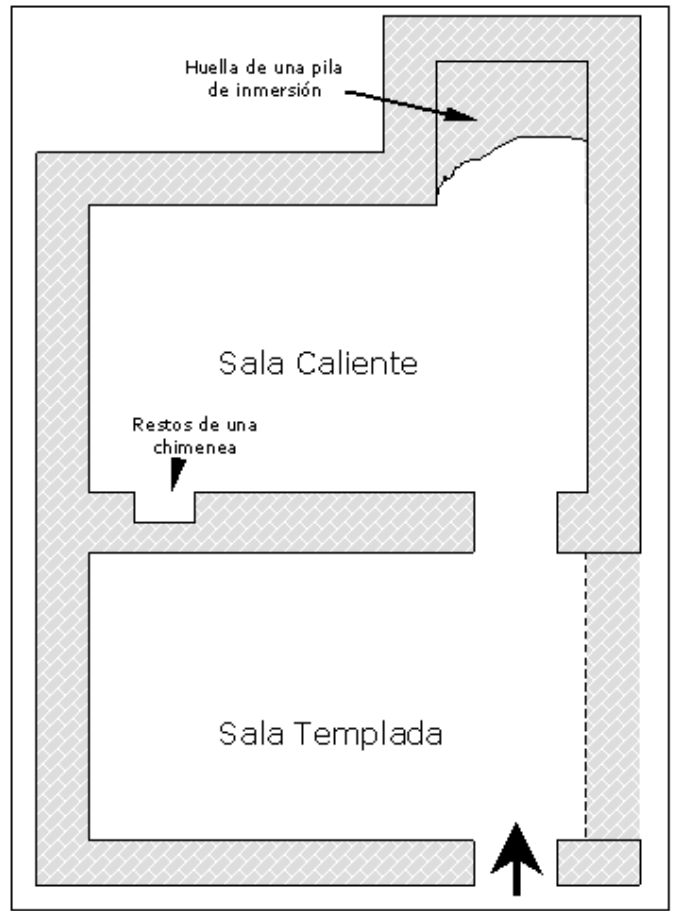

Croquis del baño de Alfacar según C. Vílchez Vílchez

$>$ Baños de Cogollos Vega: siglo XI. Baño público

$>$ Baños de Zubia.

> Baño de Almuñécar: siglo XIII-XV etapa nazarí; se trata de un baño privado ubicado en el castillo de San Miguel.

> Alhama: Final de la etapa almohade y principio de la etapa nazarí.

> Baños de Churriana de la Vega: siglo XI. Baño público

No todo los baños citados están en perfecto estado de conservación, de gran parte sólo nos quedan restos de lo que fue el apogeo del baño en Granada, lo que nos da una idea de la repercusión que tuvo el baño en Al- Ándalus. 


\subsubsection{Restos Arqueológicos del Baño de Ronda}

En el denominado Barrio de San Miguel, en la que en su momento fuera la medina, se encuentra un baño árabe que se remonta a los siglos XIII-XIV d.C., éste es considerado el recinto termal mejor conservado de la Península Ibérica. A continuación presentamos unas imágenes tomadas en estos baños para este estudio:

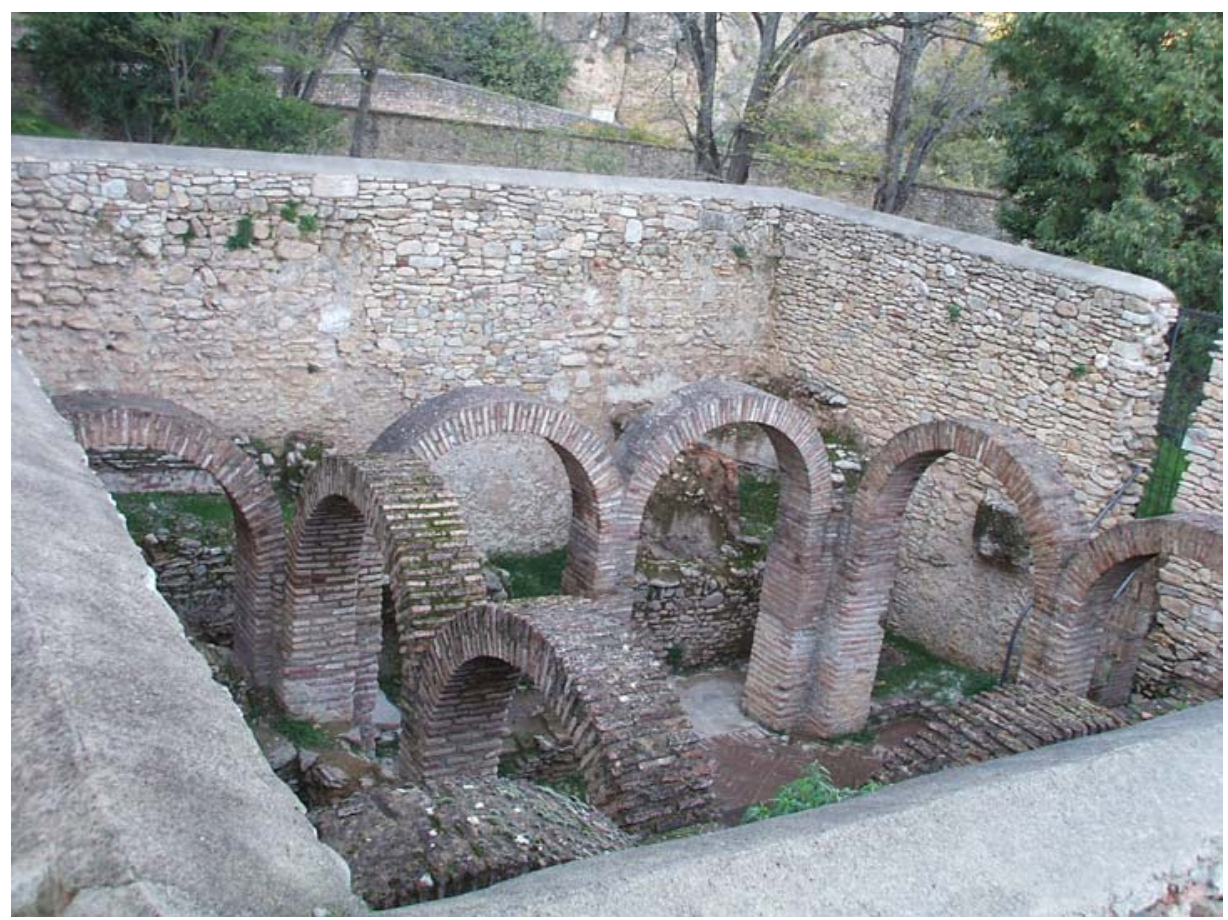

\section{Ilustración 23 Termas de Ronda (Málaga)}

Su estructura sigue el modelo romano, con tres salas (sala de baño frío, caliente y templado) siendo la sala central, la más grande, formada ésta por tres cuerpos que los separan cuatro pares de arcos de herradura sobre unas columnas de piedra y ladrillo que sustentan las bóvedas de cañón (semiesféricas); éstas como puede 
observarse en la fotografía, tienen unos tragaluces en forma de estrella, cubiertos por cristales que embellecen en gran manera la estancia.

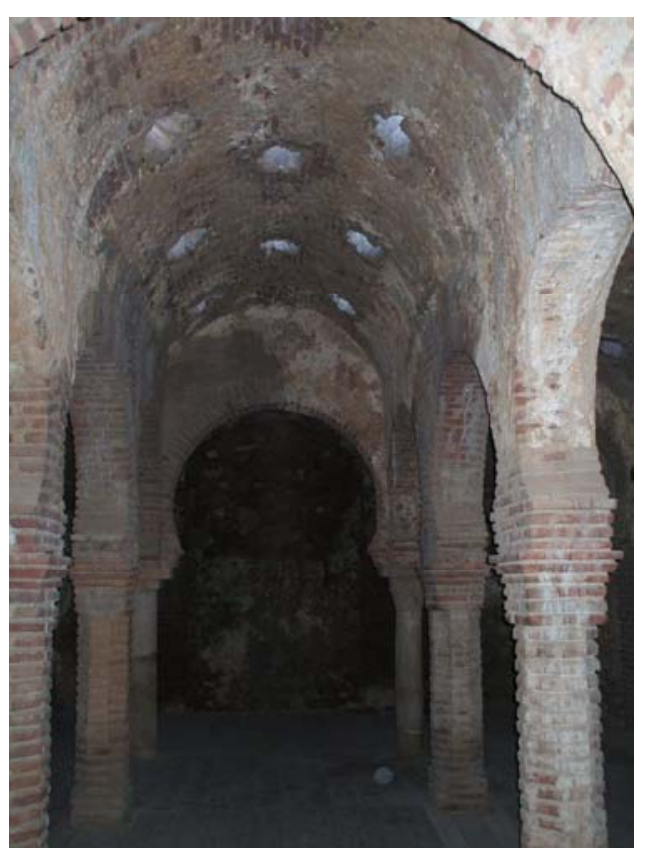

Ilustración 24 Sala caliente Termas de Ronda (Málaga)

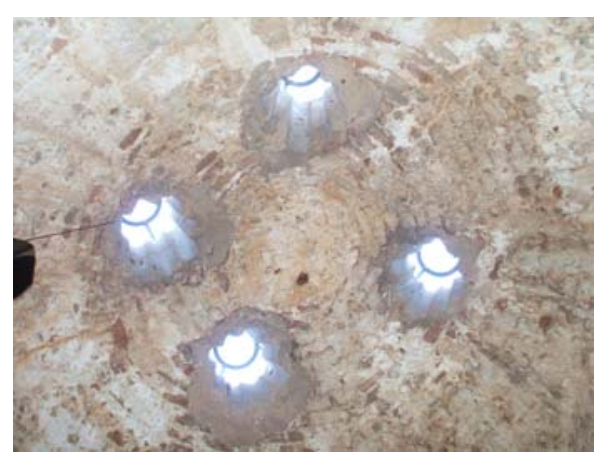

Ilustración 25 Detalle de las lucernas Termas de Ronda (Málaga) 


\subsection{El Baño en el Mundo}

"Desde la antigüedad y hasta nuestros días y de oriente a occidente el agua ha ocupado lugar preeminente en la vida del hombre. Su sacralización y su empleo en rituales, su uso con propósitos medicinales e, incluso, su simple vertiente lúdica han hecho que se considere un elemento vital más allá de su necesidad para la vida de los seres del planeta. Haciendo un recorrido por el mundo es posible encontrar rasgos comunes para una sola tradición: el baño, en Asia y en América, tanto como en Europa o en Arabia, esta costumbre ha traspasado siglos de historia y sin saber muy bien cómo, ha sido transmitida por historiadores, antiguos viajeros o algún que otro aventurero.., ${ }^{, 89}$

El baño es patrimonio universal, podemos observar el baño a través de culturas y tradiciones, de una u otra forma la cultura del agua se encuentra arraigada hasta en los lugares más recónditos.

Este epígrafe dedicado al baño en el mundo servirá como pequeña muestra del valor del agua en relación a su uso mediante el baño en los cinco continentes.

\subsubsection{Europa}

La cultura del agua está fuertemente arraigada en Europa, a continuación haremos un breve repaso de las distintas aportaciones de Europa a la cultura del agua a través del baño.

${ }^{89}$ Basteiro, M. I (2006) “El Baño en las Diferentes Culturas” Revista Thermaespa, № 14 Pág. 65 


\subsubsection{El Imperio Otomano, rinde culto al agua:}

Romanos, Bizantinos, Otomanos forjaron tradiciones, costumbres, rituales hídricos latentes conocidos en la cultura del agua como "Baño Turco".

Vapor de agua y calor se conjugan armoniosamente con los cuerpos en el Baño Turco o Hamman; el agua caliente se evapora, creando en la sala un ambiente íntimo, se posa en la piel humedeciéndola, atemperándola en medio de una neblina que oculta los rostros del baño compartido. El baño frío, el masaje y el chorro de agua con espuma completan este ciclo de contrastes debatiendo a la epidermis entre gustos y rigores hasta que brota de ella la pureza y lozanía perdida o enmascarada.

El metabolismo se acelera, estimulando el sistema nervioso, las vías aéreas se despejan por su efecto expectorante, al tiempo que el vapor de agua dilata los poros del cuerpo expuesto en un proceso purificador, que limpia la piel de impurezas dejándola suave y aterciopelada.

Esta práctica de agua, masaje y sauna ha traspasado las fronteras del Islam para ofrecer al mundo sus virtudes saludables y relajantes, así, el "Baño Turco" es practicado desde Oriente hasta Occidente, sumándolo a su oferta hoteles, gimnasios y baños públicos.

Como su nombre indica, es Turquía lugar inexcusable para referirnos a esta tradición hídrica; para ello, nos acercaremos a Estambul, una ciudad que ha sabido mantener la tradición y el encanto de sus baños que día tras día reciben clientes para ofrecerles sauna y masaje de forma invariable en el tiempo.

Estambul es una ciudad que en cada una de sus esquinas, de sus plazas, de sus calles, rinde culto al agua a través de sus innumerables fuentes historiadas, que con el paso del tiempo luchan por permanecer activas, ofreciendo al transeúnte la posibilidad de acercarse al agua y servirse de ella. 


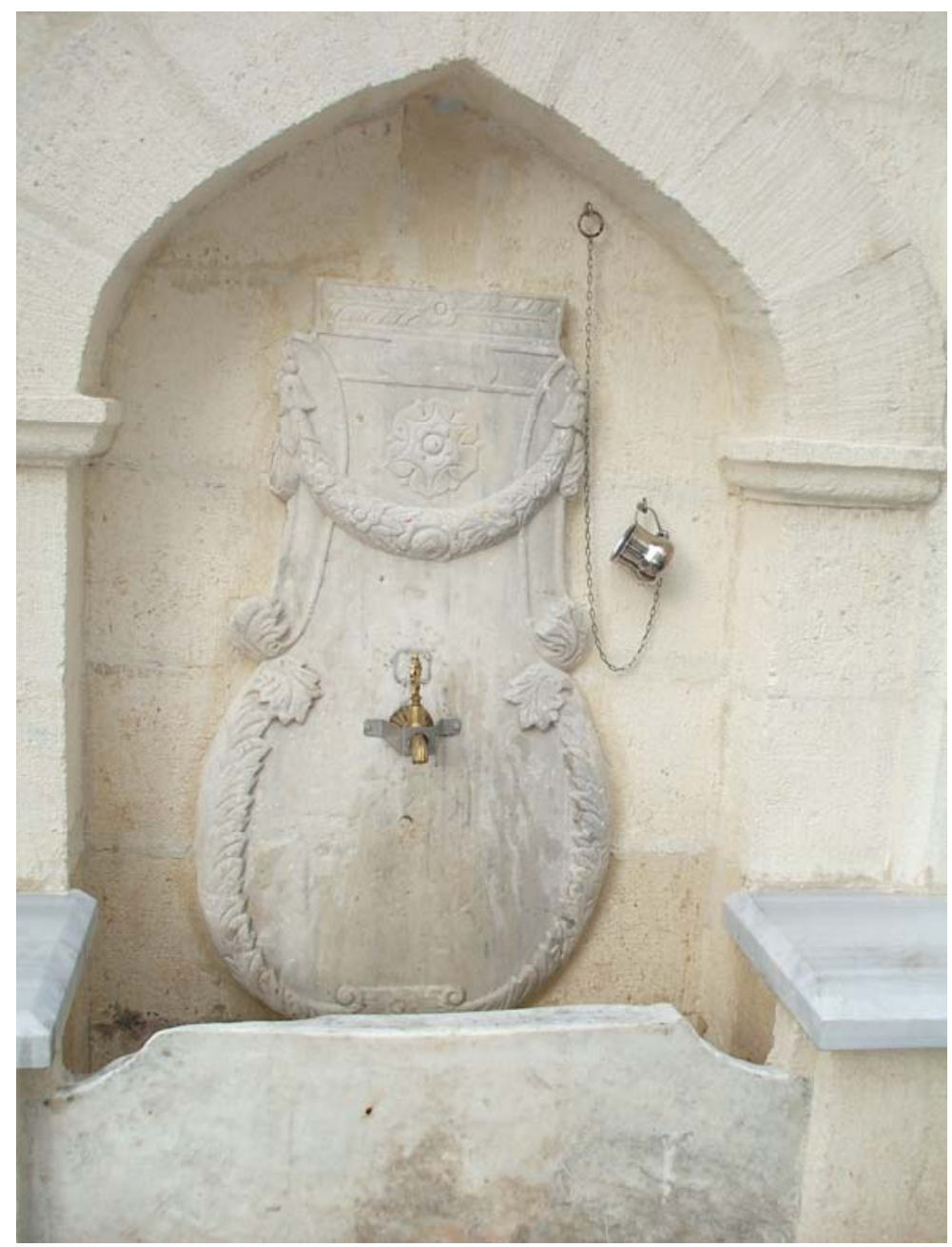

Ilustración 26 Fuente de uso social, situada en una de las calles de Estambul. De la pared pende un vaso de acero inoxidable para beber el agua.

En la época romano/bizantina. En el siglo XVI en 1563, los Otomanos realizaron la construcción de un acueducto que cumplía la misión de acercar agua dulce desde el "Bosque de Belgrado" hasta Estambul, de este modo se abastecían fuentes, 
hammam y pilas de ablución entre otros; gran parte de agua se almacenaba en cisternas.

Ejemplo de ello podemos citar la cisterna de Yerebatan que data del año 532 y aún permanece en la ciudad abierta a la visita del público, para poder admirar esta bella obra de ingeniería subterránea, formada por 336 columnas repartidas en 12 hileras de 28; este inmenso depósito de agua contaba con una capacidad de 80.000 metros cúbicos.

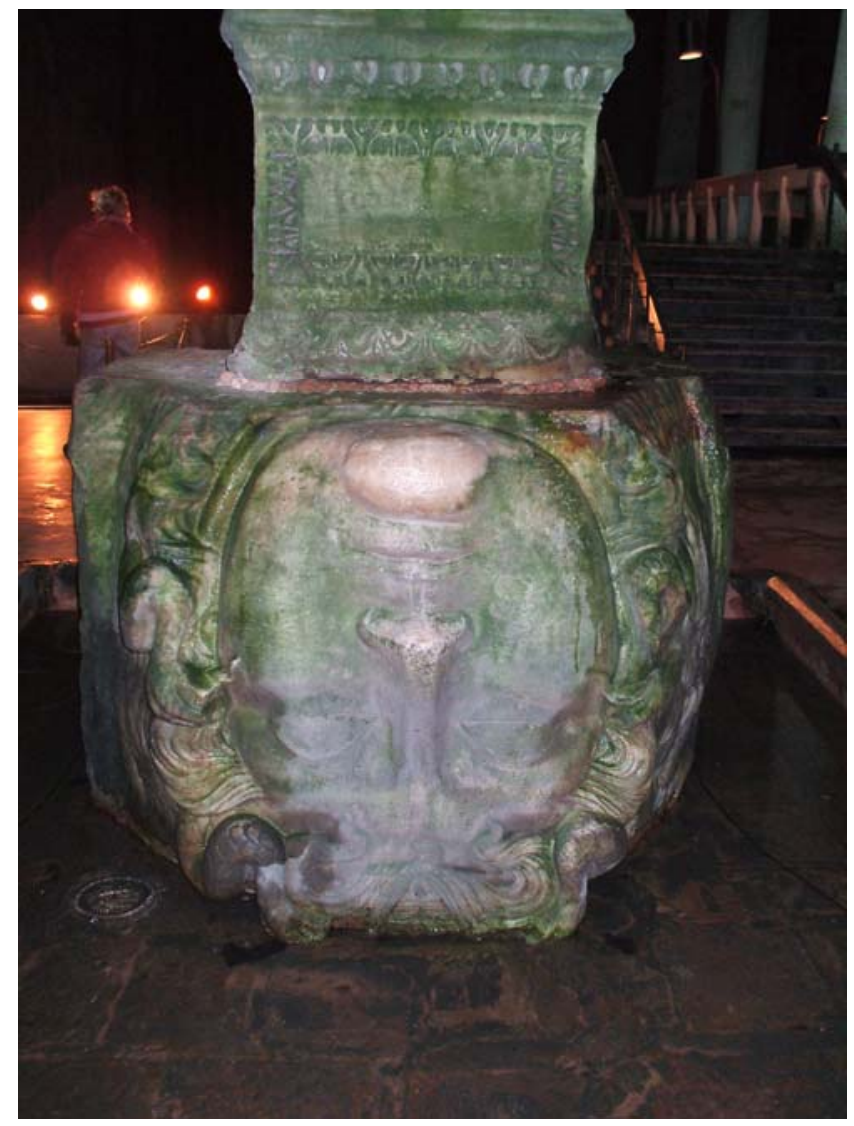

Ilustración 27 Cabeza de medusa. Columna de la Cisterna de Yerebatan en Estambul 
En la actualidad, la cisterna se encuentra abierta al público para su visita cultural y como auditorio de música; en su interior se encuentra una cafetería donde poder relajarse observando el paisaje de columnas que se triplican ante los ojos que fijan su mirada en el reflejo del agua.

Los baños en Estambul son referente ineludible, cuenta con un gran número, unos cincuenta aproximadamente repartidos por toda la ciudad; entre los más famosos se encuentran, el baño de "Galatasaray Hamami", "Suleymaniye Hamami" y el de "Cemberlitas Hamami" entre otros, este último data de 1584, fue un encargo de la madre del Sultan Murat III para recaudar fondos con fines benéficos, se encuentra situado en un lugar estratégico, la calle "Yeniceiler Caddesi" muy cerca de la Mezquita Azul, de Santa Sofía y del Gran Bazar.

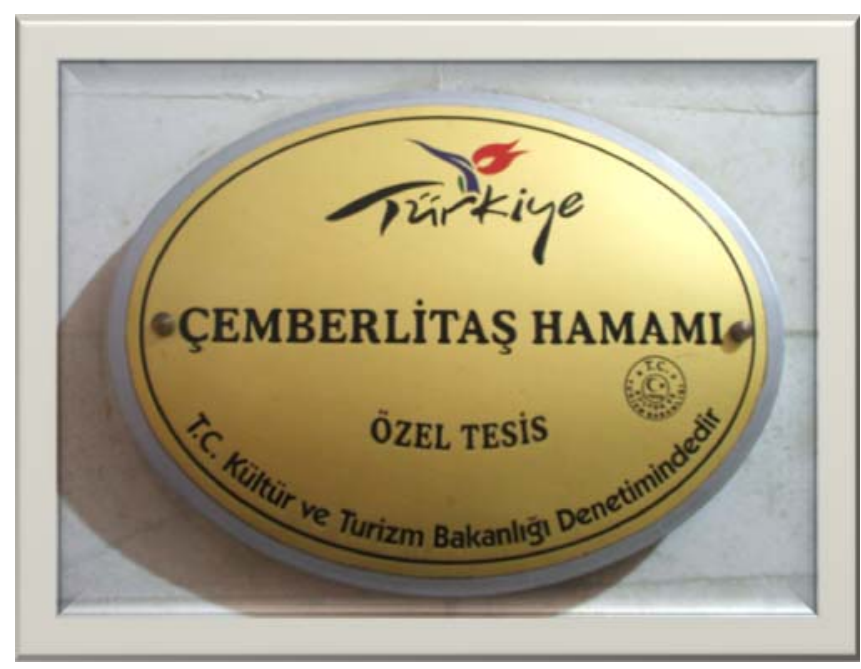

Ilustración 28 fotografía del cartel anunciador situado a la entrada de los baños Turcos 
Con el paso del tiempo este hamam (hamami en turco) ha mantenido la estructura diferenciada en la que se prestan servicios separados por sexo, aunque en la actualidad hombres y mujeres acceden a través de un pequeño vestíbulo en el que realiza el pago, este variará dependiendo del servicio que se contrate. El establecimiento ofrece para el baño (jabón, toallas y zapatillas), una de las cosas facilitadas para acceder al baño es el "Pestemal", a modo de una sábana para envolver el cuerpo desnudo que se prepara para el baño en la primera sala, de nombre "Camekan"; el ritual del baño comienza en una zona de ambiente templado llamada "Sogukluk", se trata de una sala previa con fin atemperante antes de pasar a la sala caliente el "Hararet", donde se encuentra el llamado "Gobek Tasi", a modo de una plataforma elevada forrada de mármol que se encuentra caliente por situarse sobre los hornos o calentadores del Hamam, sobre ella por sus dimensiones tendrían cabida unas tres personas tendidas a la espera de que el cuerpo humedecido por el sudor esté preparado para afrontar el agua con espuma, el calor, y el duro guante "Kese" de la mano de los "Tellak" (en el caso de los hombres) y de las "Natir" (en el caso de las mujeres) se enfrenta con rudeza alternando con la delicadeza del chorro de espuma, a las capas de células muertas descubriendo nuevamente la frescura de la piel tersa y suave. Tras el masaje, el baño que en el caso del baño Turco, no es por inmersión, el agua es aplicada en forma de chorro abundante mediante una palangana llamada "Tas" que en la antigüedad era de bronce y en la actualidad por motivos higiénicos y prácticos se está sustituyendo por material plástico. 


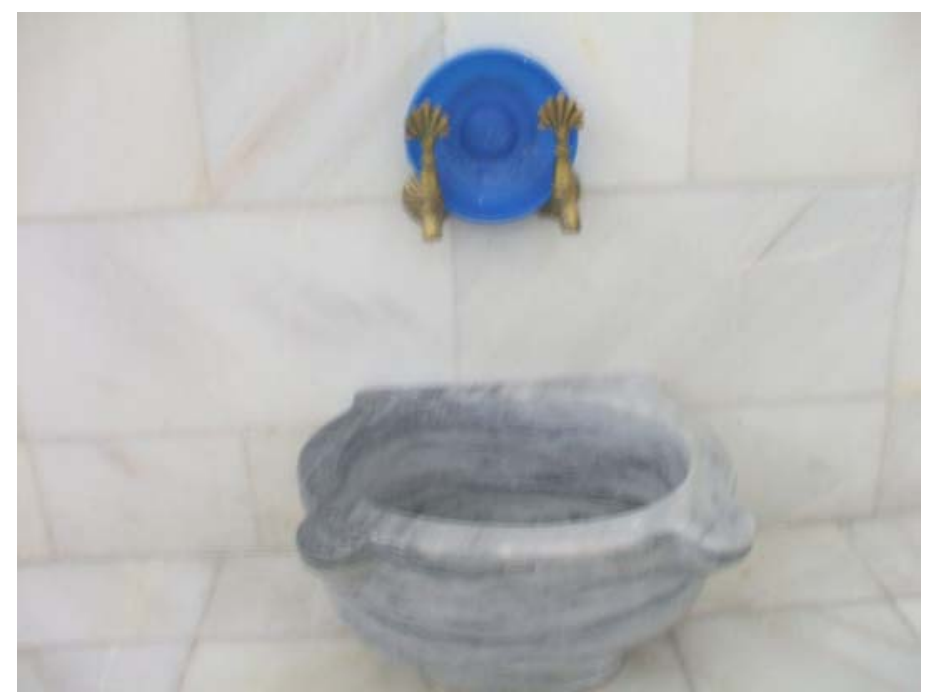

Ilustración 29 Pila para el baño Turco. Imagen tomado en un hammam en la zona de la Capadocia en Turquía

El agüista se sienta en un pequeño pilar de mármol junto a una de las muchas fuentes que rodean la sala circular iluminado por la lucernas de la cúpula, que envuelve la parte superior de las sala, creando un ambiente inimitablemente sugestivo, se aplica de forma continuada el agua para eliminar cualquier resto de jabón y de piel muerta desprendida del cuerpo tras el masaje, este ritual ya se había realizado previo al masaje para preparar la piel haciéndola rendirse en su dureza al contacto insistente con el agua. Tras el baño un tiempo para el recogimiento y el relax y como complemento una bebida de té. 


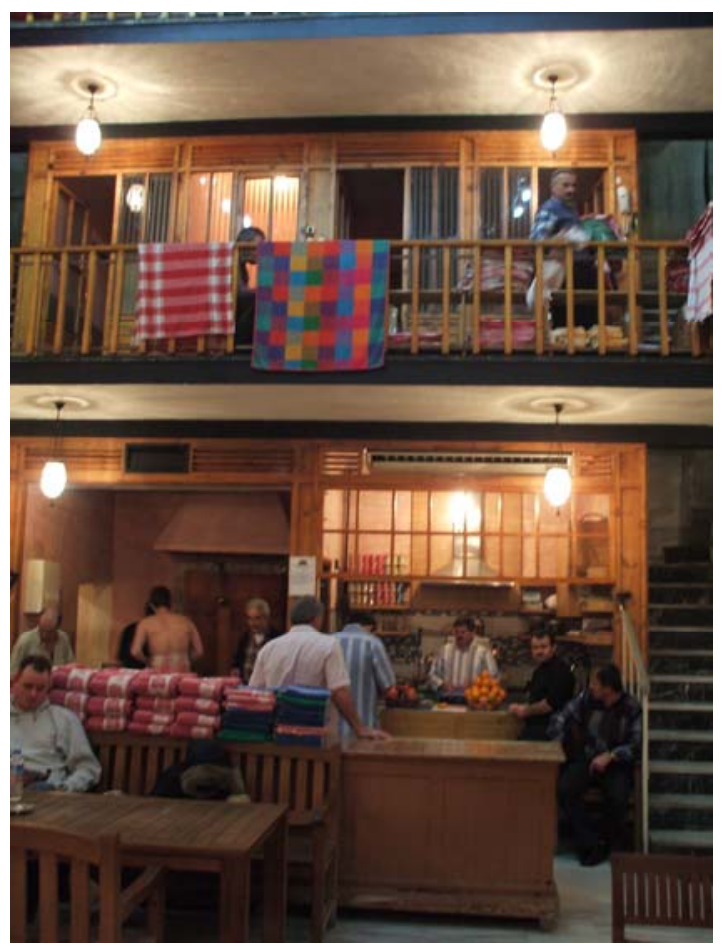

Ilustración 30 Patio central del baño Tuco de Çemberlitas sala reservada para el baño masculino.

Este baño de urbanitas lo fue también de sultanes, estos gustaban en gran manera de los placeres y virtudes que proporcionaba el agua, así, fuentes y estanques abundaban en sus palacios y se reservaban lujosas estancias donde el baño se convertía en el protagonista de sus vidas privadas; 30 de los sultanes de la dinastía otomana vivieron en el palacio de Topkapi en la ciudad de Estambul, este fue residencia de sultanes durante cuatro siglos y su pasión por las delicias del baño quedaron plasmadas en las distintas salas donde el mármol blanco y el oro se conjugan para conformar las ostentosas salas de baño del harén; el lujo de los baños eran un signo de distinción y de poder 


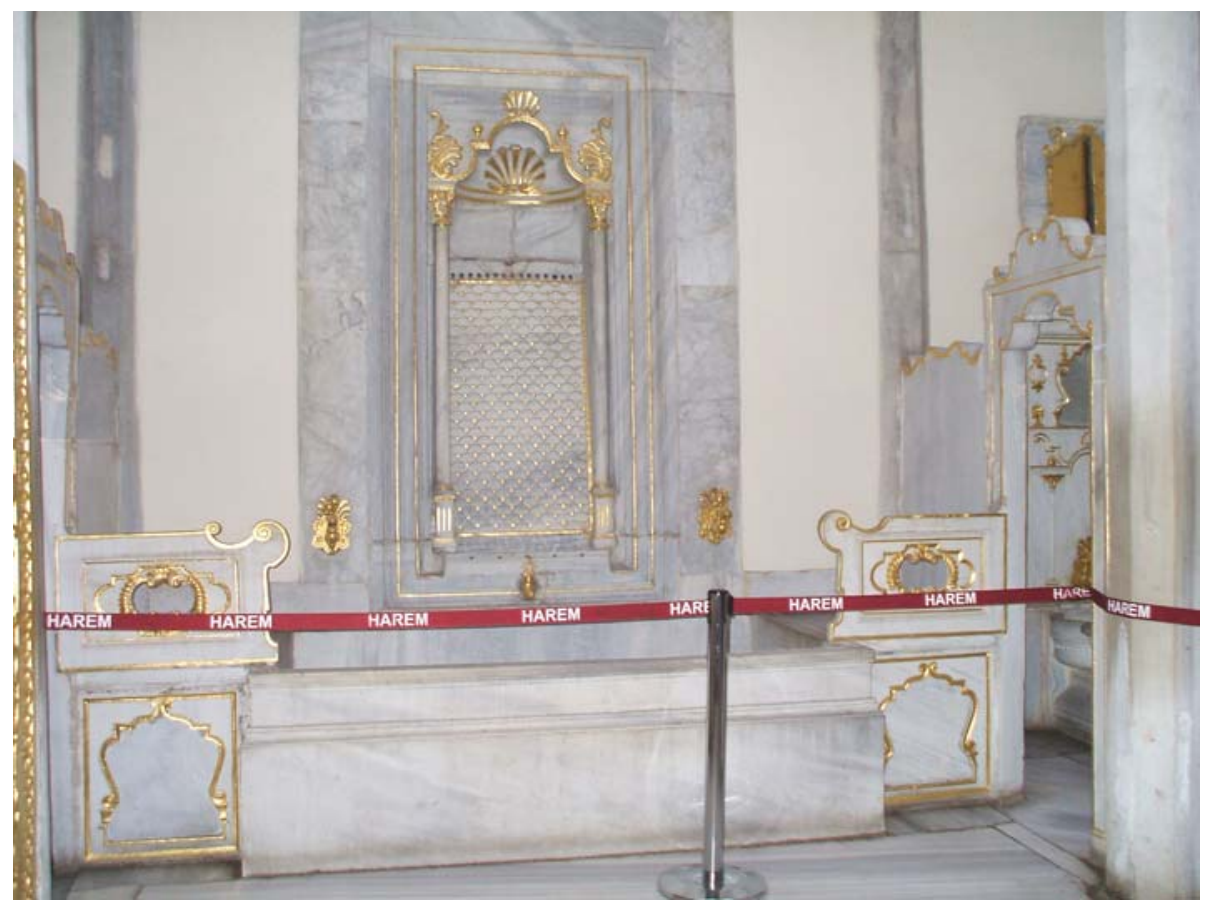

Ilustración 31El Palacio fue construido por orden de Mehmet Fatih y su primer nombre fue Darus-Saadet (casa de la felicidad). 


\subsubsection{Finlandia: el baño finlandés}

El vocablo "Sauna" es una palabra de origen finlandés que alude tanto al tradicional baño como a las propias casas de baños en Finlandia, un país escandinavo que mantiene muy enraizada esta cultura del baño. En su origen la sauna era una edificación sin chimenea, durante el último siglo se introduce este elemento que permite la salida de humos denominándose en la actualidad "Sauna de Humo".

Este tipo de baño se basa en la saturación de vapor de agua a través de su exposición a altas temperaturas, unos $45^{\circ}$; lo que provoca la sudoración corporal depurando el organismo mediante la eliminación de toxinas, limpiando la epidermis con la eliminación de células muertas y aliviando y mejorando las vías respiratorias mediante la inhalación de vapores con esencias de menta, eucaliptos, abedul etc. Es aparentemente muy similar al baño turco aunque su diferencia reside en la temperatura y el grado de humedad relativa que es muy inferior.

"La sauna aparece ligada al poema épico finlandés Kalevla, compilado en 1885, aunque ya en 1678 aparece una mención en una oración cristiana recordada en el noroeste de Finlandia, y hay alguna otra referencia del año 1112, del historiador Néstor de Kiev quien describía la sauna. En cualquier caso su historia está largamente relacionada con la arquitectura vernácula. Para los antiguos finlandeses la sauna era un lugar casi sagrado al que acostumbraban a ir una vez a la semana." 90

\footnotetext{
${ }^{90}$ Basteiro, M. I (2006). En: Revista Thermaespa, Nº 14 Pág. 69
} 
A comienzo del siglo XIX muy pocas familias podían disponer de una sauna propia en su vivienda, pero durante este siglo, fruto de momentos de bonanza económica para el país comenzó la Edad de Oro de las saunas de humo en Finlandia extendiéndose por todo el país.

La sauna se ha convertido en toda una filosofía por la que se ha acrecentado su interés en el tiempo, fruto en parte del incremento del tiempo de ocio, pasando a ser un baño muy popular y muy cotizado como baño de alto standig.

\subsubsection{Hungría "La Perla del Danubio"}

En la historia de Hungría hay un espacio reservado para el baño; salud por medio del agua brota de los abundantes manantiales de agua medicinal con la que esta tierra centroeuropea ha sido agraciada.

Romanos y turcos dejaron su huella y su cultura del agua en un país que ha sabido mantener las tradiciones invitando al mundo a sumergirse en sus aguas, eligiendo Hungría como destino turístico.

Al oeste del Danubio fundaron los romanos Aquincum, ciudad romana, un lugar donde se daba culto al cuerpo a través de las aguas mineromedicinales que se ofrecían en los numerosos baños construidos en la ciudad. Aún hoy quedan vestigios de la majestuosidad de sus baños en un museo en el que se puede ver un impresionante órgano hidráulico y restos de los mosaicos que adornaban las termas; así mismo, se conservan jardines y parte de las Thermae Miores donde tomaban los baños las legiones romanas. 
"Obuda, a la que los romanos llamaron "Aquincum", fue fundada en el año 89 sobre un antiguo asentamiento celta. Durante cuatro siglos fue la capital de la región romana de Pannonia. Aquincum viene de la palabra "aqua" (con agua) en honor a los numerosos manantiales termales que tanta fama ha dado y dan a Budapest. ${ }^{91}$

Budapest es la ciudad del baño por excelencia, una ciudad balnearia sobradamente conocida por el turismo de salud. En el siglo XIX, época dorada de los balnearios, Budapest "La perla del Danubio", una ciudad con más de 2000 años de historia se convirtió en el lugar elegido por las clases altas para disfrutar de sus vacaciones y tiempo de ocio.

. Entre sus balnearios instalados en emblemáticos edificios se encuentran:

- Balneario Király

- Balneario terapéutico Rudas

- Balneario Lukács

- Balneario Széchenyi; uno de los centros termales más grandes de Europa. Data de 1913 y tiene un estilo neogótico. Cuenta con quince piscinas, doce de ellas en recintos interiores y tres al aire libre.

- Balneario Gellért; Data de 1918, su arquitectura art nouveau, un monumento al baño rodeado de vidrieras que ambientan el espacio hídrico dejando pasar la luz externa.

\footnotetext{
${ }^{91}$ http://www.disfrutabudapest.com/historia
} 


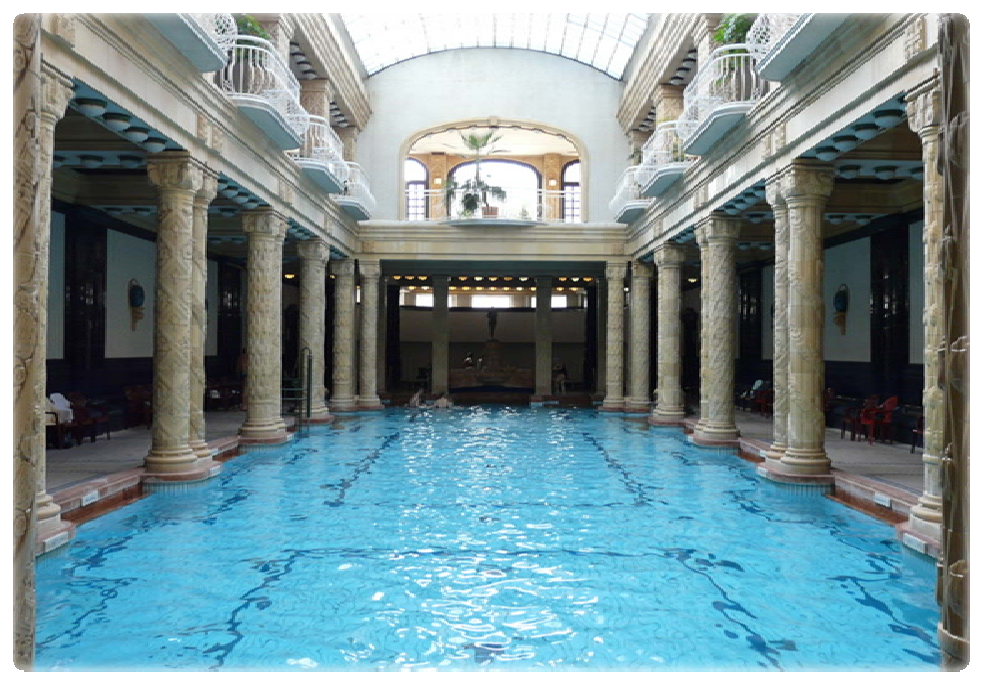

\section{Ilustración 32 Piscina del balneario Gellert (Hungría) ${ }^{92}$}

\subsubsection{Francia}

En Francia existe una larga tradición hídrica, el gusto por el baño ha dado lugar a grandes Villas Balnearias donde el lujo forma parte de su propia expresión.

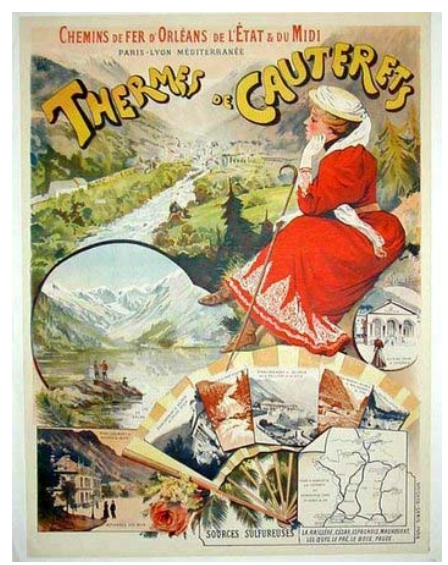

Ilustración 33 Cartel anunciador de las Termas de Cauterets en Francia

\footnotetext{
${ }^{92}$ http://www.disfrutabudapest.com/balneario-gellert
} 
Es famoso por su enclave y sus características terapias:

> Les Sorurces de Caudalie: El balneario está enclavado en Bourdeaux en uno de los viñedos más prestigiosos de Francia, por ello entre sus principales terapias e encuentra la Vinoterapia a la que se añaden aguas minerales que brotan de los manantiales naturales dando lugar a unos tratamientos de los que se obtienen unos excelentes resultados.

\subsubsection{Alemania}

Hacer referencia al baño en Alemania es trasladarnos a Baden-Baden un lugar eminentemente cosmopolita y de elite, que cuenta con unas aguas de gran calidad en lo que se refiere a propiedades curativas, reconocidas y utilizadas desde tiempos romanos.

> Brenner's Spa: es un hotel decimonónico que se encuentra situado frente al río Oos en un parque de carácter privado, en el balneario, se aplican un gran número de terapias influencia en su mayor parte de otras culturas, como es el caso de la sauna finlandesa o el baño de vapor japonés.

\subsubsection{Portugal}

Una gran tradición termal caracteriza a Portugal, en el que brotan una gran cantidad de fuentes de agua mineromedicinal situadas en su mayoría al norte y centro del país.

En Portugal se encuentran una del las Termas más antiguas de Europa, "Caldas da Rainha", datan de 1485.

Thermasa de Sao Pedro do Sul, Curia, Felgueira, de Luso. Las termas de Monfortinho cerca de la zona del Alentejo, donde se encuentran también las termas de Cabeço de Vide y las de Fadagosa de Nisa. 
En la provincia de Lisboa se encuentran las termas do Vimeiro un gran complejo turístico y termal.

\subsubsection{Italia}

Uno de los mejores balnearios de Italia son las "Termas de Saturnia" éstas se encuentran en la Toscana. Sus aguas sulfurosas son de reconocido prestigio en toda Europa.

\subsubsection{Mónaco}

En Mónaco se encuentras les Thermes Marins de Monte-Carlo, un lugar reservado para el baño de élites, un lugar donde disfrutar de los baños de mar y algas en un entorno acotado por el lujo

"El nombre basta para evocar imágenes de glamour $y$ opulencia........ Fue construido por indicación del príncipe Rainiero III" ${ }^{93}$

\subsubsection{Asía}

De Asía rescatamos el baño japonés haciendo referencia a dos tipos de baño, el Onsen y el Furo

\footnotetext{
${ }^{93}$ Taschen, A. Arieff, A. Burkhart, B. (2008) “SPA” Edited by Allison Arieff San Francisco. Pág. 149
} 


\subsubsection{El baño en Japón:}

Uno de los placeres de los japoneses desde tiempo inmemorial es el baño; ricos y pobres, sin distinción, gustan del placer del baño diario.

El baño se tomaba en una tina de madera en la que el agua se encontraba a unos $43^{\circ}$ centígrados, en el agua el cuerpo se sumergía limpio, previamente lavado, el baño no tenía una función higiénica propiamente dicha, tenía una función relajante y placentera. El baño en las casas estaba dispuesto en orden de uso; de este modo, tal como se expone en la cita que se presenta a continuación, el primero en tomarlo es el invitado, continuando en orden de edad y parentesco, el abuelo, el padre, el hijo mayor, y así sucesivamente, siendo el criado el último en hacer uso del mismo.

"El pudor japonés hace que el baño sea usado en solitario. En todas las casas, el uso del baño sigue un orden riguroso: invitado, abuelo, padre, hijo mayor, etc., finalizando con el criado más humilde. Tras el baño, lo habitual es reunirse y relajarse durante largo rato, antes de la comida de la tarde.,94

En pueblos y ciudades están presentes los baños públicos cumpliendo una función social como centros de reunión y encuentro aunque el baño se tomaba en privado y más concretamente en solitario.

Al contrario que en otras culturas que rechazaban el baño por ablandar los cuerpos, el baño de agua fría para el japonés era sinónimo de endurecimiento, por ello se preparaban para los difíciles acontecimientos de la vida, bañándose al amanecer en ríos y cascadas donde el agua se encontraba a una temperatura excesivamente baja.

\footnotetext{
94 “El Placer del Baño:”. En: http://www.artehistoria.jcyl.es/civilizaciones/contextos/8667.htm
} 
- Onsen: son toda una tradición en Japón, éstos vienen a representar los balnearios de occidente, están enclavados en medio de la naturaleza; producto de la orografía de Japón, un país montañoso y volcánico. Son las numerosísimas fuentes de agua termal que brotan de la tierra surtiendo de agua los Onsen unas bañeras en las que introducirse con el fin de relajarse, purificar el cuerpo y el espíritu pasando la función higiénica a un plano muy secundario.

- El Ofuro: En la revista Thermaespa, a la que ya se ha hecho referencia anteriormente, Isabel Basetiro, alude al significado de "Ofuro" como "Baño de vapor"; este tipo de baños se convirtieron en públicos, lugares de ocio y disfrute e incluso según afirma Basteiro en lugares de lascivia y placer, llegando a conocer con el tiempo un nuevo motivo de uso orientado a la recuperación de la salud.

\subsection{3. África}

Al Mar Muerto se le atribuyen numerosas propiedades curativas, su gran concentración de sales minerales hacen que las características de sus aguas sean muy apropiadas para el baño.

> Mövenpik Resort \&Spa del Mar Muerto.

"El balneario combina la arquitectura árabe tradicional con elementos modernos.... Especialmente populares son las termas del balneario, cada una de las cuales dispone de cabina de calor seco, hidromasaje y bañeras para masajes hidroterapéuticos. La Sala de la Tranquilidad del balneario ofrece distas al mar tras los arcos del balneario." 95

$>$ Amanjena Resort \&Spa.

\footnotetext{
${ }^{95}$ Taschen, A. Arieff, A. Burkhart, B. (2008). Pág 13
} 
"Amanjena significa "plácido paraíso", y es un oasis ente las dunas y los secos vientos desérticos......El agua es el elemento unificador de Amanjena, en cuyo centro se abre un enorme depósito, en sus orígenes colector de agua para la irrigación." ${ }^{\prime 96}$

\subsubsection{América}

De América rescatamos para mostrar en este estudio, el Temascal, un baño con una larga tradición que se está recuperando con fines turísticos.

\section{- El Temascal: México se suma al gusto por el baño}

De tradición prehispánica es el baño denominado "Temascal", su nombre se traduce como "casa de vapor", es un baño típico de México y de parte de Guatemala.

Este tipo de baño es una práctica ancestral que comporta todo un rito y una tradición en el que mucho tiene que ver la construcción realizada al efecto; se trata de una estancia redonda y abovedada que según los mejicanos pretende recordar al vientre materno; en ella se introducen un determinado número de personas dispuestas a disfrutar de un baño de vapor producido por el agua al caer sobre unas piedras de origen volcánico con textura porosa, que previamente han sido calentadas a una alta temperatura, este vapor se alimenta mediante un abanicado de plantas recién cogidas de la naturaleza; el agua utilizada es previamente tratada. Los vapores emanados son absorbidos por la piel, aspiradas por las vías respiratorias que se empapan de los beneficios de la naturaleza que alienta el baño. La duración de baño dependerá como en el caso de la sauna, del que el temascal es precursor, del tiempo que cada persona aguante los efectos del vapor.

${ }^{96}$ Taschen, A. Arieff, A. Burkhart, B. (2008) .Pág 17 
"Los indígenas de América del Norte y de Centroamérica tuvieron su forma particular de usar los baños. Ritual de purificación y comunicación con el cosmos fueron los inipi del norte y los temascales de Centroamérica.,97

Tierra, aire, agua y fuego, los cuatro elementos de los que Hipócrates nos hablaba para procurar salud, son los componentes del baño ritual temascal y es que el fin último de este baño es curativo y relajante, ayuda a liberar toxinas y a cuidar la piel exfoliándola. Los efectos permanecen si se utiliza al menos una vez por semana, es a su vez un baño con tinte social ya que se puede tomar en grupo o en familia.

Como ocurre con el resto de los baños, el turismo tiene su parcela reservada para aquellos que visitan el país, ya que hacen de lo tradicional una necesidad turística de la que disfrutar durante su estancia.

> Esperanza (Cabo San Lucas, México) en los acantilados de Punta Ballena, frente al Mar se encuentra el hotel Esperanza, a través de él se accede al balneario atravesando una gruta envuelta en vapor :

"El ritual comienza con una ducha al aire libre y un chapuzón, seguido de un baño de vapor, otro chapuzón bajo la cascada y una copa de zumos tropicales. En el interior, los colores cálidos y la riqueza de las texturas imitan el entrono costero de la Baja California. Verjas antiguas de hierro marcan el camino hacia las siete salas de tratamiento que disponen de jardines propios y de piscinas a la sombra de una pérgola de buganvillas una de las salas dispone de piscina para tratamientos watsu privados). El balneario emplea en sus tratamientos frutas tropicales, minerales del desierto y plantas autóctonas. El pulido corporal

\footnotetext{
${ }^{97}$ Basteiro, M. I (2006). En: Revista Thermaespa, Nº 14 Pág. 65
} 
con papaya y mango emplea una pasta de ambos frutos y rica en enzimas mezclada con harina de maíz para exfoliar la piel." ${ }^{98}$

> Las ventanas al Paraíso: situado en la Baja California se encuentra un hotel que representa la tradición arquitectónica típica de México:

"Los tratamientos oscilan entre las técnicas tepezochuite empleadas por los antiguos mayas y otros rituales y terapias curativas, que van desde la fitoterapia hasta la medicina vegetal., La envoltura curativa tepezochuite es originaria de Chiapas y se usa en casos agudos de insolación y formación de ampollas; el tratamiento Purificación del Desierto en el que se emplea arcilla volcánica para la exfoliación y eliminación de toxinas, se inspira en ceremonias maya y aztecas." ${ }^{99}$

> Hotelito Desconocido: en él se conjugan la armonía, el equilibrio el lujo y la naturaleza en estado puro:

"Llegar al hotelito al anochecer es entrar en un mundo mágico, en el que cientos de velas, antorchas y linternas se conjuran con las estrellas para iluminar los edificios y los senderos que serpentean de camino hacia el $<<$ mundo de la salud $\gg>$, nombre con el que se conoce el balneario." ${ }^{100}$

\subsubsection{Oceanía}

\footnotetext{
98 Taschen, A. Arieff, A. Burkhart, B. (2008). Pág 309

${ }^{99}$ Taschen, A. Arieff, A. Burkhart, B. (2008). Pág 311

${ }^{100}$ Taschen, A. Arieff, A. Burkhart, B. (2008). Pág 317
} 
Nos detenemos en Australia donde se encuentran dos famosos centros de baño:

$>$ Bedarra Island:

"Las cien hectáreas de isla (situada frente a la costa norte de Queensaland, en el famoso Gran Arrecife de Coral) albergan selvas vírgenes, playas recónditas de palmeras mecidas por la brisa, y 16 espectaculares villas ocultas entre los árboles. Los dos pabellones frente a la playa de Wedegerock Bay se caracterizan por sus paredes de vidrio y techos de madera así como por sus piscinas privadas y por unos baños descomunales, que incluyen gigantescas bañeras y una cama flotante especialmente construida." ${ }^{101}$

\section{$>$ Diantre Eco Lodge\&Sp:}

"Precursor del ecoturismo, consta de 15 tranquilas residencias aupadas entre los árboles de sus 12 hectáreas de frondosa selva tropical. La incorporación de la cultura y las tradiciones aborígenes en el concepto mismo el balneario",102

El baño como hemos podido apreciar en esta pequeñísima muestra presentada a lo largo de este epígrafe, es traducido en todos los idiomas, practicado en todos los rincones de los cinco continentes. Las distintas aportaciones culturales que ha ido enriqueciendo el uso del baño se han ido sumando y unos y otros países han hecho suya esa acumulación de riqueza cultural en torno a un uso hídrico universal.

\footnotetext{
${ }^{101}$ Taschen, A. Arieff A. Burkhart, B. (2008) .Pág 291

102 Taschen, A. Arieff A. Burkhart, B. (2008) .Pág 295
} 


\section{PARTE II}

MAGIA Y BELLEZA, PUREZA Y RELIGION:

Una Inmersión en la Esencia del Baño 


\section{Agua}

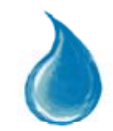

Dos tipos de consideración de suma trascendencia: la consideración científica y la religiosa, ambas bien diferenciadas. Ya Aristóteles hacía una diferenciación entre filósofos y teólogos, siendo los primeros, aquéllos que partiendo de hechos empíricos infieren en la experiencia a través del mito, y los segundos, como aquéllos que recurren a lo divino para dar explicación a las cuestiones del mundo; y es en esta explicación divina del mundo, en la que aparece nuevamente el agua como elemento fundamental. El agua aparece en el principio de la Historia Sagrada, en el libro del Génesis, formando parte del principio de la creación; por otro lado, el rito del nacimiento al cristianismo, es el paso por el agua en el bautismo como símbolo de purificación, que marca el principio de una nueva vida cristiana, es elemento fundamental no sólo en la religión cristiana o en la musulmana con sus abluciones diarias previas al rezo, sino en otras muchas religiones, convirtiéndose en símbolo de pureza de alma y de espíritu.

El agua es un elemento sacralizado, sirve de base y unión entre lo divino y humano convirtiéndose en el elemento vía para obtener la salvación.

El agua, fruto y parte de la naturaleza, se convierte en símbolo de religión, en rito, en elemento cultural.

El agua es un elemento de inigualable belleza en todas sus formas, incolora, inodora e insípida, es portadora de frescura y salud. El agua hidrata y embellece cuando vuelve al cuerpo del que forma parte como miembro de la propia naturaleza, porque el cuerpo es agua en sí mismo, formado por este nutriente necesita de su propio yo para mantenerse fresco y lozano. 
El agua de la vida, el elixir de la eterna juventud, el agua es mágica fluye de las entrañas de la tierra, cae del cielo, el agua cura de forma no traumática, el agua es milagrosa, el agua es inigualable e insustituible, es agua, agua.

El culto al cuerpo toma especial relevancia en la sociedad actual, que convierte la imagen personal en un escaparate visual cuyo atractivo se torna en carta de presentación para alcanzar el éxito, tanto a nivel personal, como laboral o social. En esta búsqueda de la belleza interna y externa es donde el agua se hace protagonista como promotora de cambios positivos en la imagen corporal.

El agua, que como se puede observar a lo largo de este trabajo, es un elemento tan valorado como ignorado en su uso más elemental, parece volver a ponerse de moda en cuanto a su uso social y terapéutico.

Algo parece estar cambiando en la sociedad, que hace que el agua ocupe un lugar privilegiado en la escala de valores del ser humano, que retoma el gusto por la antigua tradición del baño termal, apreciando de forma particular sus propiedades terapéuticas, desde el conocimiento de sus efectos procurado por profesionales especialistas en la hidrología médica.

Este nuevo gusto por el agua puede tener su fundamento en la importancia que la sociedad presta al aspecto físico y la imagen corporal, que se convierte de la mano de empresarios, en "El Oro Azul" capaz de hacer milagros estéticos y salutíferos mediante la inmersión deleitosa en tan preciado elemento.

El agua como balneoterapia es deleitosa y no traumática, no requiere de cirugía ni de fármacos, no es agresiva, es relajante, amable al contacto, tiene tantas virtudes que hacen de ella un elemento mágico aunque su magia sea simplemente ella misma y sus propiedades naturales. Todas esta virtudes atribuidas al agua por su excelencias demostradas durante siglos parecen ser las causantes de una vuelta a tan esencial recurso natural que en moradas balnearias o en centros SPA brindan al agüista lo mejor de sí mismas, a través de un baño reparador, en ese afán por recuperar los usos sociales y terapéuticos del agua, en un ambiente distendido y en 
un entorno natural que hace que el concepto de vacaciones termales vuelva a ser un hecho como ya lo fuera en los siglos XIX y XX.

Tres placeres corporales se traen a análisis en esta segunda parte:

- El placer de la estética.

- El placer de los sentidos.

- El placer del espíritu

Todos ellos serán analizados desde un prisma hídrico, a lo largo de estos tres capítulos, se tratará de ir más allá del propio baño, revisando las sensaciones íntimas experimentadas tras la inmersión corporal en el agua.

- El placer de la estética: A través de este epígrafe conoceremos la otra cara del baño, sus raíces higienistas y su contribución a la belleza corporal.

- El placer de los sentidos: Entraremos en el mundo de las sensaciones íntimas corporales al contacto con el agua, conoceremos el poder de relajación y la capacidad de abstracción mental que proporciona el baño.

- El placer del espíritu: Conoceremos la importancia del agua en la religión, el Re-Nacimiento en la religión Judeo-Cristiana y la Purificación en la religión Musulmana.

Estos tres placeres aunque tratados de forma individual en los siguientes capítulos son en cierta manera complementarios, cuerpo y mente en equilibrio, siendo 
la naturaleza una constante entre ambos, una ecuación que da como resultado la fórmula de la belleza.

La búsqueda del bienestar es uno de los objetivos de quienes se acercan al baño, la influencia del agua en la relajación corporal y los efectos secundarios deleitosos de las bondades del baño, son el eje de este capítulo IV dedicado a las sensaciones placenteras tras la inmersión en la esencia del baño.

Hasta aquí hemos tratado sobre la limpieza de cuerpo, la tranquilidad que procura la inmersión en el agua, el deleite que surge del baño; en el $V$ y último capítulo de esta segunda parte, nos centraremos en el placer del espíritu, la paz interior, la pureza alcanzada por el agua como elemento común en las distintas religiones. 


\section{Capitullo III}

\section{斯 placer de la estética}

Placeres de la metamorfosis en la espiral de la personalización caprichosa, en los juegos barrocos de la súper diferenciación individualista y en el espectáculo artificialista de uno mismo ofrecido a la mirada del Otro.

(Gilles Lipovetsky; El Imperio de lo Efímero) 


\section{- Capitulo III}

Páginas

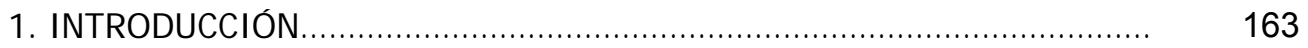

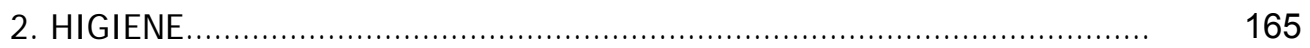

2.1. Del Deber al Deseo............................................................... 168

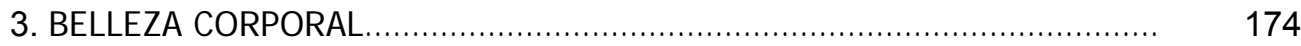

4. LA IMAGEN EXTERNA EN LA SOCIEDAD ACTUAL................................... 178 


\section{Introdidceión}

El concepto de higienismo alude a una corriente de pensamiento que podemos encuadrar dentro de la ciencia médica, en cuya esencia subyace la preocupación por la salud pública y la calidad de vida.

"La persistente atención que los médicos prestaron a estos temas hace de la higiene y el pensamiento médico un punto de encuentro obligado para aquellos que desde las ciencias sociales nos interesamos por la historia del pensamiento medioambiental."103

El concepto de higienismo, está en desuso, es la palabra higiene la que se utiliza hoy en día, no como una corriente de pensamiento, sino como la base de un protocolo personal que garantiza la calidad de vida a la que nos referíamos anteriormente.

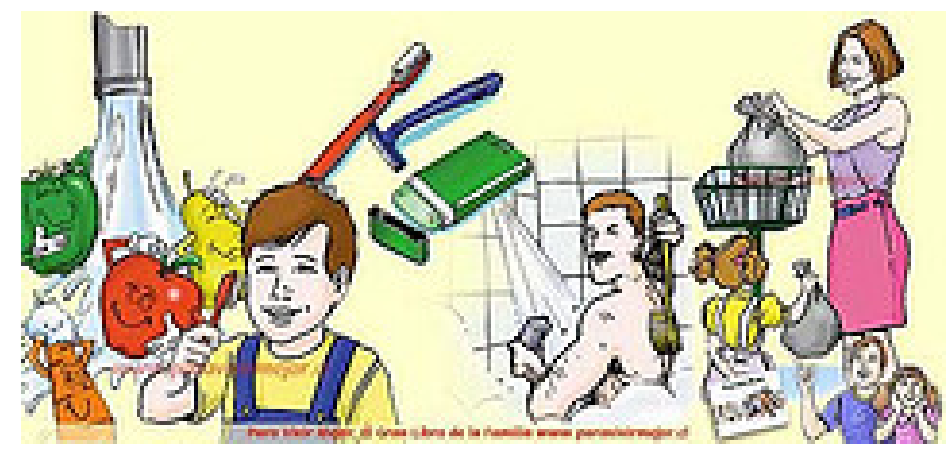

www.paritarios.cl/images/02_higiene.jpg

\footnotetext{
${ }^{103}$ Urteaga, L. “Higienismo y Ambientalismo en la Medicina Decimonónica” http://ddd.uab.cat/pub/dynamis/02119536v5-6p417.pdf.
} 
Con el uso generalizado de los hábitos higiénicos llegó la preocupación por el cuidado personal, no solo desde el punto de vista de la salud, sino de las apariencias, se trataba de combinar el sentirse bien con uno mismo y el hecho de gustar a los demás. Los cuidados corporales pasaban por las buenas prácticas hídricas, que incluía entre otras acciones la del baño. 


\section{Higiene}

No podríamos hablar del baño sin atender a una de sus principales razones de ser: la higiene, uno de los motivos por los que sumergirse en el baño se hace hábito personal. (hýdor) es la palabra griega que significa agua; en los compuestos adopta la forma (hýdro-).Del mismo modo que la denominación griega de salud (higiene) a través de (hyguieinós) correspondería a: "sano, saludable, que concierne a la salud".

En la primera mitad del siglo XIX, con el liberalismo, nace una corriente denominada higienismo que parte de la necesidad de mantener unas condiciones optimas de salubridad para una sociedad que enfermaba producto de unas condiciones de vida y sociales precarias, la revolución industrial, trajo consigo el hacinamiento, la pobreza y la desnutrición a las ciudades, lo que daba lugar a grandes epidemias como el cólera o la fiebre amarilla que afectaban de forma brutal a la población. Esta situación fue fruto de denuncias por los médicos que intentaban luchar contra la enfermedad y que eran conscientes de que se trataba de una enfermedad social fruto de las condiciones higiénicas.

"En 1790, en la Universidad de Pavía, en ocasión de la graduación de médicos ese año, Johann Peter Frank disertó sobre "La miseria del pueblo como madre de las enfermedades."104

\footnotetext{
${ }^{104}$ Rev. Cubana Salud Pública vol.33 no.4 Ciudad de La Habana Oct.-Dec. (2007)
} 

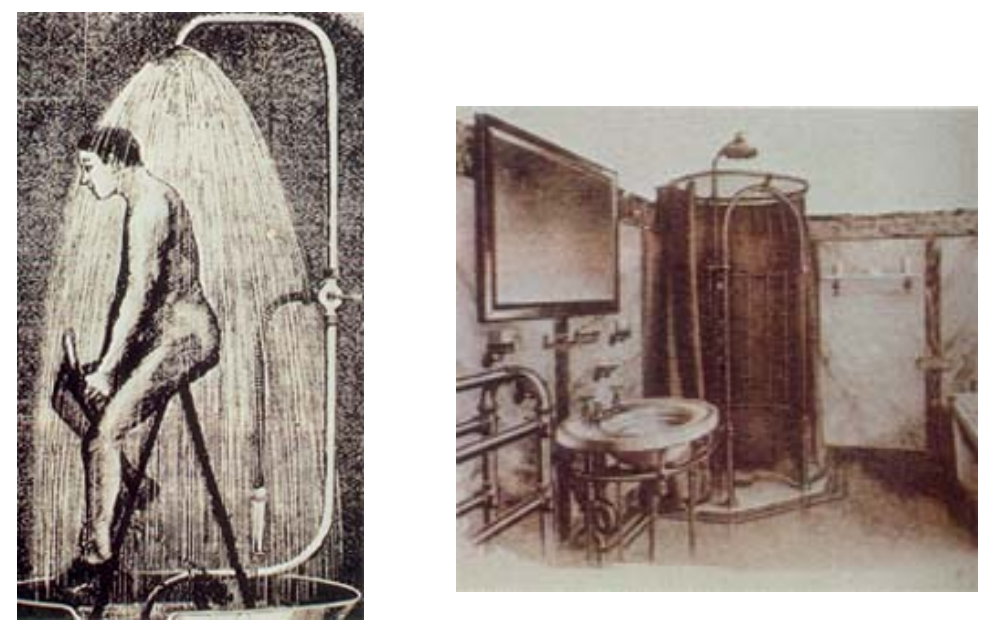

Las ciudades, comienzan a ser objeto de atención por parte de sus gobernantes que empiezan a dotarlas de infraestructuras como agua corriente, cloacas y baños públicos que trayendo consigo un cambio de hábitos, el baño empieza a ser símbolo de refinamiento y de preocupación por la salud. A continuación se muestran unas imágenes que representan esta nueva situación ante la higiene ${ }^{105}$ :

El movimiento higienista transgrede la barrera de lo público y se adentra en lo privado comenzando a instalarse baños privados en las viviendas. Según Justo García Navarro y Eduardo de la Peña Pareja, dos arquitectos que dedican un libro a la evolución histórica de la higiene corporal y del cuarto de aseo "El cuarto de baño en la vivienda urbana", La limpieza, asociada a la higiene, es un concepto de finales del siglo XVIII, cuando comenzaron a aparecer los primeros baños en las viviendas. En un artículo del diario el mundo dedicado al libro de estos dos arquitectos se extrae la siguiente cita:

\footnotetext{
105 “Recorriendo baños por los siglos”. En: http://www.proyectando.com.ar/noticias/not33.htm
} 
"El cuarto de baño asumido como un recinto en la vivienda no surge hasta el comienzo de la Revolución Industrialı, explican los autores.

Hacia 1830, el empresario y médico francés, Monier promovió en Madrid los primeros locales de baños públicos, los cuales también disponían de un servicio de telebaño, consistente en pilas móviles

De este modelo al triunfo de las doctrinas higienistas hubo pocos pasos. El arquitecto Le Corbusier recomendaba en 1921 a los usuarios que el cuarto de baño fuera una de las habitaciones más grandes de la casa, y que tuviera «bañera, lavabos, duchas y aparatos de gimnasia”. ${ }^{106}$

Según Emilio Quevedo., Director del Centro de Historia de la Medicina, de la Universidad Nacional de Colombia, en una revista publicada por esta Universidad, la higiene personal/higiene privada es una responsabilidad de carácter individual en aras de la propia salud del individuo, ésta nace en la Grecia Clásica, fundamentada en la teoría "Humoral Hipocrática", y se transforma en la Edad Media por influencia de la teoría miasmática. La higiene pública, tiene como responsables a las autoridades públicas, que han de asegurar la salud de la población, ésta como tal, nace en la Edad Media como resultado de la pandemia llamada "Muerte Negra". Estas dos formas de concebir la higiene, según Quevedo, sufrirán cambios importantes durante los siglos XVII y XIX hasta que en el siglo XX se transformen en lo que hoy llamamos "salud pública".

\footnotetext{
${ }^{106}$ http://www.elmundo.es/1998/11/22/madrid/22N0077.html
} 


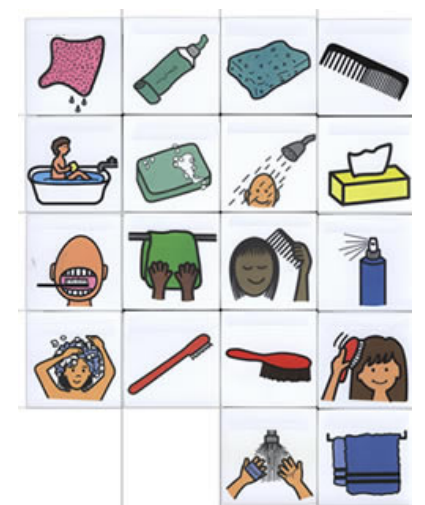

hypatia.morelos.gob.mx/.../Personal_Higiene.jpeg

En la actualidad en los países desarrollados, no se concibe una vivienda sin al menos algún lugar destinado para el baño y el aseo personal; el baño se ha convertido en una necesidad y en un ritual de uso diario bien sea por inmersión o mediante la ducha. No está bien vista la falta de higiene siendo objeto de rechazo social.

\subsection{Del deber al deseo}

La higiene corporal ha pasado del deber al deseo, así, lo que a mediados del siglo pasado era una norma de urbanidad basada en el respeto a uno mismo y hacia los demás, hoy se torna en placer y culto al cuerpo.

"Hasta mediados de nuestro siglo, la limpieza y la higiene fueron prescritas como otros tantos deberes respecto de uno mismo, los manuales de moral escolar, la literatura filantrópica, los tratados de higiene popular fijaron con precisión y solemnidad los imperativos de limpieza corporal." ${ }^{107}$

\footnotetext{
${ }^{107}$ Lipovestky, G. (1994) “El Crepúsculo del Deber. La ética indolora de los nuevos tiempos democráticos” Ed. Anagrama. Barcelona; Págs. 99/100
} 
Se editaban una especie de cartillas de obligado cumplimiento que marcaban pautas y normas de buena educación, cortesía y saber estar.

Todo este tipo de publicaciones doctrinarias y feministas, tenían una estructura común, presentada a modo de catecismo compuesto por preguntas y respuestas cortas para facilitar su aprendizaje y memorización, lo que llevaba a la interiorización de una serie de normas, que con la práctica debían de convertirse en habito; estas se resumían en los siguientes puntos fundamentales:

$>$ De la Urbanidad en general: en este punto se definiría la urbanidad como signo de buena educación.

- “¿Qué es la Urbanidad? El conjunto de reglas a que debemos ajustar nuestras acciones para hacer amable el trato en la sociedad.

- ¿Qué se dice generalmente de las personas que carecen de urbanidad?

- Que están mal educadas”108

$>$ Deberes de urbanidad de inferior a superior.

$>$ Deberes de urbanidad relativos al culto.

$>$ Deberes para con los padres

$>$ La niña en la escuela

$>$ Respeto a las personas de dignidad

$>$ De la limpieza

$>$ Deberes para con los iguales

$>$ De las visitas

$>$ De la correspondencia

$>$ Deberes de superior a inferior

\footnotetext{
${ }^{108}$ Pascual de San Juan, P. (1991) “Breve Tratado de Urbanidad para las Niñas” Ed. Hijos de Paluzie. Barcelona Págs. 3/4
} 
Entre todas estas normas se observa en todos estos manuales, un capítulo dedicado a la limpieza.

“¿Es precisa la limpieza para tener urbanidad? Tan precisa, que una persona sucia, despeinada y con el vestido roto o manchado no puede presentarse en sociedad.

¿Qué debe hacer, pues, una niña? Lavarse cara y manos todas las mañanas y entre el día, siempre que de ello tenga necesidad; peinarse, así mismo, diariamente; cortarse las uñas, limpiarse la dentadura y lavarse de cuando en cuando su cuerpo, en particular los pies. ${ }^{109}$

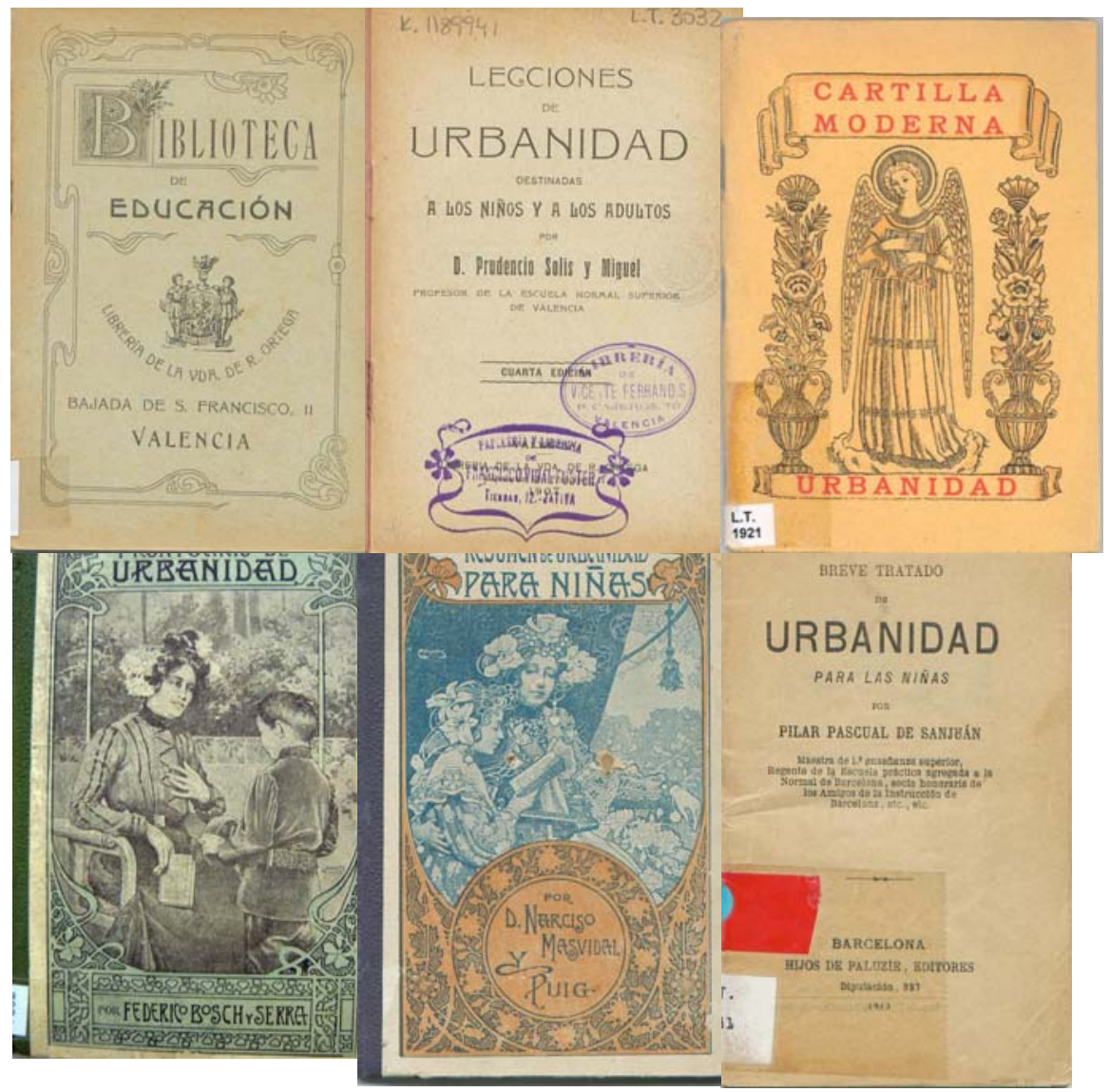

${ }^{109}$ Pascual de San Juan, P. (1991). Página 14 
Martínez Aguiló en su cartilla de "Urbanidad y Deberes Religiosos y Sociales" dentro del capítulo dedicado a las normas de higiene diaria, hace unas recomendaciones en relación al baño. Nos habla de deberes físicos entendidos como la obligación de cuidar al cuerpo para preservar la salud:

"Deberes físicos: ¿A qué se llaman deberes físicos? Llámense físicos á las obligaciones que tenemos de cuidar nuestro cuerpo, conservar la salud y evitar todo cuanto pueda perjudicarla",110

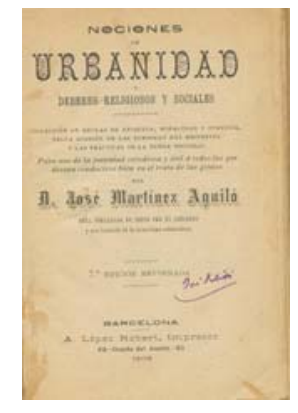

Aguiló cita a Monlau argumentando que la higiene es el arte de conservar la salud y a Tales de Mileto con la siguiente frase: "la felicidad del cuerpo consiste en la salud, la de la inteligencia, en el saber".

\section{¿Cómo conservaremos la salud? - Con el aseo constante, el trabajo moderado, la templanza y beber y la observancia de las reglas higiénicas.}

Nuevamente cita a Monlau "La higiene dice el sabio previene las enfermedades y alarga la vida tendiendo á que el hombre muera de vejez o muerte senil...

\footnotetext{
${ }^{110}$ Martínez Aguiló, J. (1906). “Nociones de Urbanidad y deberes Religiosos y Sociales”. Imp. A. López Robert. Págs. 21/22
} 
“¿Son convenientes los baños llamados de aseo? - Sí, Señor; porque además de contribuir á la limpieza general son muy beneficiosos para la salud. Deben ser con agua tibia, y usarlos de cuando en cuando y con más frecuencia en el estío."111

En la época moderna, dice Lipovestsky: "El esfuerzo higienista y los proyecto de saneamiento social y moral van unidos... La limpieza del cuerpo no hace más que anunciar la de las costumbres". ${ }^{112}$.

El discurso higienista ha pasado del deber y la obligación al deseo del individuo de cuidar su cuerpo.

"En nuestras sociedades, la invitación a las voluptuosidades del cuerpo ha reemplazado las exhortaciones culpabilizadotas $y$ solemnes a la limpieza, ya no se trata de marcar con el sello de la infamia los olores pútridos y obligar a gestos austeros y voluntaristas de limpieza de la piel, sino de gustar los placeres de los buenos aromas, emulsiones y sales perfumadas. Las prácticas de higiene ya no revelan deberes hacia uno mismo sino que se celebran en el registro de los placeres íntimos: la retórica sensualista, estética, intimista ha puesto fin a los sermones dirigidos contra la suciedad y los olores....Predomina en todas partes una poética de la seducción, del amor a uno mismo, del bienestar narcisista. En otra época, el jabón estaba asociado a la energía, a la salud, a la disciplina moral, en la actualidad los productos de higiene insisten en la suavidad, en el encanto de las apariencias". ${ }^{113}$

Lipovestsky anuncia que ha terminado la temática de la obligación hacia uno mismo y hacia los demás porque los cuidados del cuerpo se orientan a la seducción y

\footnotetext{
${ }^{111}$ Martínez Aguiló, J. (1906). Pág. 24

${ }^{112}$ Lipovestky, G. (1994). Pág. 100

${ }^{113}$ Lipovestky, G. (1994). Pág. 100
} 
autoseducción., la higiene por obligación se ha terminado y comienza la preocupación por uno mismo, la obsesión por cuidar el cuerpo, por conservar la línea, entrando en la dinámica del culto al cuerpo a través del deporte y los productos light. El cuerpo afirma Lipovestsky jamás fue objeto de tanta atención.

"El utilitarismo individualista de la seducción de los productos de cuidados y de higiene tienen socialmente más éxito que el idealismo abstracto de los deberes. Ya no se machaca con las obligaciones de respeto hacia uno mismo, se exaltan en technicolor los modelos del cuerpo joven y seductor: la devaluación de la actitud rigorista significa menos presiones autoritarias pero simultáneamente más control social a través de las normas <<técnicas〉> del cuerpo sano y logrado, menos culpabilización pero más ansiedad narcisista, menos directrices ideales pero más directricidad funcional mediante la información, la moda, los profesionales de la dietética, de la higiene y de la estética del cuerpo."114

${ }^{114}$ Lipovestky, G. (1994). Pág. 102 


\section{Bellezacorporal}

¿Qué es la belleza? según la definición extraída del diccionario Anaya de la lengua:

"Belleza: Conjunto de cualidades de las cosas o de las personas, cuya manifestación sensible produce placer, deleite o admiración; la belleza de una puesta de sol; el agua aporta una gran belleza a nuestros paisajes; en este poema se exalta la belleza de la mujer; admiro la belleza de esta obra de arte"115

En esta definición de belleza se aplica el concepto en su mayor parte a la naturaleza, al sol, al agua, al ser humano e incluso al arte poniéndola en relación con sentimientos siempre positivos producidos por la observación de la belleza; el concepto de ideal de belleza, es un concepto dinámico, que ha ido cambiando a lo largo de la historia en las distintas culturas.

Referencia ineludible cuando se trata el tema de "la belleza" es el escritor Umberto Eco, él, ha dedicado gran parte de su carrera al estudio de la estética y la belleza, prueba de ello es su tesis doctoral (1956) centrada en el estudio del problema estético en Santo Tomás de Aquino. Uno de los libros más importantes de su obra lo dedicó al análisis de la belleza en la historia, siendo el título de su libro "Historia de la belleza"; es asimismo, autor de otras obras como "Arte y belleza en la estética medieval".

\footnotetext{
${ }^{115}$ Polanco Martínez, F.y Renal Araque I. Redactores (2002) “Diccionario Anaya de la Lengua” Ed.. Anaya. Madrid
} 


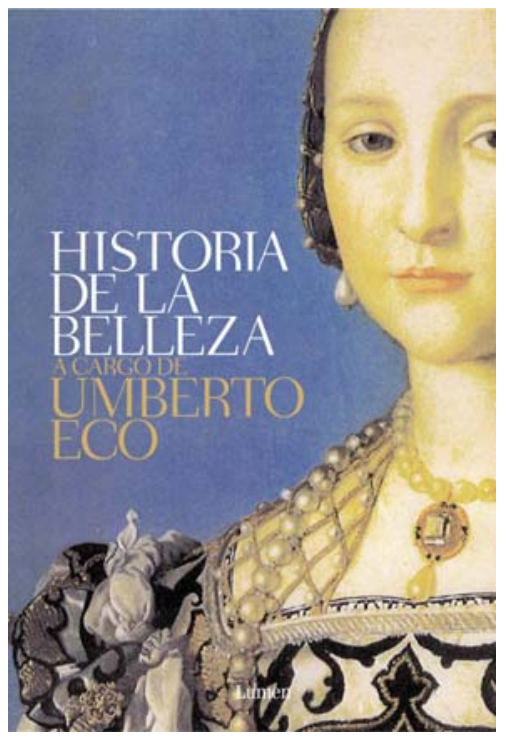

www.libros.universia.es/.../9788426414687.jpg

La belleza ha sido anhelada por la humanidad a lo largo de la historia, la belleza es la mejor carta de presentación, Aristóteles hace referencia al orden y la magnitud como requisito indispensable para lograr la belleza en el arte, añadiendo el concepto de armonía, el canon de belleza tenía sus bases en la proporción. En el año 1970 sale a la luz una obra de Adorno titulada "Teoría Estética", una reflexión filosófica sobre el arte moderno y obras de vanguardia, en este documento defiende que el placer estético no es constitutivo del arte, él lo considera como algo accesorio que debe ser eliminado. Para Kant "el arte bello" ${ }^{116}$ es el que tiene la capacidad de generar un sentimiento de placer en aquel que lo observa, pero aún en la actualidad, determinar lo bello de lo que no lo es, supone una dificultad añadida si se tiene en cuenta que la belleza puede ser un factor subjetivo, contaminado por las modas o influido por las culturas, aunque algo que parece ser una constante, es el resultado obtenido mediante la observación de la belleza "el sentimiento de placer".

\footnotetext{
${ }^{116}$ Montecinos,H. y Fernández Vega, J. (19/03/2008). “La belleza ya no es o que era”. Revista Ñ, del diario Clarín. Buenos Aires. En: http://hernanmontecinos.com/2008/03/19/la-belleza-ya-no-es-lo-que-era/
} 
"Belleza $<<$ radiante>> es la unión armoniosa de nuestra imagen externa con nuestra percepción del yo interno. Es el arte de ser, es todo lo que es vida y estilo; gracia y encanto."117

Belleza y naturaleza son dos conceptos que van relacionados, esto es muy evidente en manifestaciones artísticas, pintura, escultura etc. son fiel reflejo de esta relación. Una de las razones por las que naturaleza y belleza hilan juntas es por el encanto de lo saludable; la naturaleza caudal de salud y belleza.

El agua, naturaleza viva, es promotora de salud, placer y calidad de vida y en consecuencia, de equilibrio corporal traducido en una imagen en la que se reflejan los beneficios naturales aplicados mediante inmersión en el agua.

En este contexto de búsqueda de la belleza por el placer de la estética, el agua aplicada mediante el baño cobra una gran popularidad sobre todo entre jóvenes y talludos, en ese intento de conseguir perpetuar, o al menos, retener la belleza, embellecerse para conseguir la recompensa social y personal de la estética.

El estímulo de la belleza es atemporal, no tiene edad, es un comportamiento legítimo que aunque se sabe cuando comienza y termina, el ser humano lucha por mantener y acrecentar, ser bello, estar bello, sentirse bello, es el éxito como fin; la búsqueda del éxito es una constante en todas las facetas de vida social del hombre y si el medio para conseguir ese fin no es traumático, sino placentero, la combinación se vuelve perfecta.

\footnotetext{
${ }^{117}$ Beth janssen, M. (2003) “Belleza Radiante” Guía de salud y cosmética natural para el bienestar de todo el cuerpo. Ed.: Océano. Barcelona. Pág. 3
} 
La belleza pertenece a lo que Lipovetsky denomina "El Imperio de lo Efímero" el ideal supremo es parecer joven, la imagen corporal se convierte objeto de marketing social, ser bello está de moda en una sociedad en la que prima lo frívolo.

"La moda abierta de esta segunda etapa está dominada por el lookexquisito, artificio por el que lo rebuscado debe parecer espontáneo lo que nos habilita para disfrutar sin inhibiciones el éxtasis de exhibir el espectáculo de nuestra renovada imagen a la carta para la admiración de otro",118

Ser bello, sentirse bello eleva la autoestima del individuo creando en él mismo, una actitud positiva ante la vida, requisito indispensable para la consecución del éxito y del logro personal, uno de los objetivos del hombre es seducir, gustar y que mejor que comenzar por uno mismo cuidando su imagen externa.

\footnotetext{
${ }^{118}$ Lipovetsky, G. (2004) “El Imperio de lo Efímero, la moda y su destino en las sociedades modernas” Ed. Anagrama. Pág. 143
} 


\section{La imagen externa en la sociedad actual}

La imagen corporal es la tarjeta de presentación del ser humano, es el currículo personal en el que se reflejan los hábitos individuales saludables. La belleza abre puertas en el mundo laboral, en el ámbito social; la belleza es un valor añadido a la inteligencia, es incluso, un valor añadido cuando se carece de inteligencia; la belleza es un pasaporte hacia la consecución de objetivos personales.

"La Belleza posee la peregrina virtud de enajenar, de conmover y arrastrar la inteligencia y el corazón de los hombres"

Como decíamos anteriormente, el ideal de belleza es un concepto dinámico que aplicado al ser humano se ve influido en el tiempo por patrones de comportamiento, por hábitos de consumo, en definitiva, por el cuidado del cuerpo. Sentirse bello implica recompensas positivas, tanto externas como internas, externas, de cara a la consecución de objetivos sociales, e internas, mediante la satisfacción personal la percepción positiva de sí mismo.

La imagen externa del individuo depende en gran manera, de su autoconocimiento, de su autoestima, de él dependerá su auto-confianza, su seguridad en sí mismo. De igual modo que una enfermedad se refleja en el rostro; cuando se encuentra el equilibrio y el bienestar, cuando uno se siente sano, se refleja externamente.

${ }^{119}$ Cano, R. (1895) “Las Leyes de la Belleza” Ed. Imprenta Calatrava. Salamanca. Pág. 53 
El cuidado de la imagen hasta hace muy pocos años parecía ser privativo del sexo femenino; en la actualidad, por invitación de las casas de cosmética y la publicidad televisiva, la figura del hombre participa de forma activa en este sentido, así, la clientela de balnearios urbanos en los que no se busca la curación sino belleza y relajación, han visto incrementar su público objetivo.

"El neonarcisismo masculino configura el cuerpo principalmente como una realidad indiferenciada, una imagen globo que hay que mantener con salud y en forma; muestra poco interés por el detalle, y raras son las regiones parciales del cuerpo que despiertan la preocupación estética, a excepción de esos inevitables puntos críticos: Las arrugas de la cara, la <<barriga >> y la calvicie. Ante todo es la gestalt de un cuerpo joven, esbelto y dinámico la que se trata de conservar a través del deporte o los regímenes dietéticos; el narcisismo masculino es más sintético que analítico.

Por contra, en la mujer el propio culto se halla estructuralmente fragmentado, y la imagen que tiene de su cuerpo es muy pocas veces global: La mirada analítica prevalece sobre la sintética. Tanto la mujer joven como la <<madura >> se ven en <<proporciones $>>$.........Todas las regiones del cuerpo femenino son investigadas, el narcisismo analítico detalla el rostro y el cuerpo en elementos distintos, dotados uno por uno de un valor más o menos positivo: nariz, ojos, labios, piel, hombros, senos, caderas, nalgas, piernas son objeto de una autoapreciación y de una autovigilancia que conlleva unas <<prácticas propias >> específicas, destinadas a poner de relieve o corregir tal o cual 
parte del físico. Narcisismo analítico que se debe esencialmente a la fuerza preponderante del código de la belleza femenina. "120

Estos centros de culto al cuerpo combinan las terapias hídricas con los masajes corporales e incluso con el ejercicio físico mediante una zona de gimnasio, complementos al agua para conseguir un cuerpo diez que te encamine hacia la consecución del éxito social y laboral, el cuerpo perfecto está de moda, es signo de distinción para ambos sexos, unos brazos musculados, una cintura de avispa y para ambos, una piel perfectamente depilada y cuidada. Una piel un tanto morena por el sol, implica estatus, capacidad para permitirse ciertos lujos como el tiempo de ocio en una playa; un cuerpo escultural, tiempo de ocio en un gimnasio, una piel natural y fresca es fruto de tiempo dedicado al baño, a los masajes de aceites y cremas corporales, y todo ello en común significa poder adquisitivo.

"La persistencia de la disyunción entre sexos se refleja incluso en la nueva figura dominante de la individualidad contemporánea compartida hoy por ambos sexos: el narcisismo mental y corporal. Con el neonarcisismo, se produce una mezcla de los papeles e identidades anteriores de los sexos a favor de una inmensa ola <<unisex>> de autonomía privada y de atención hacia uno mismo, de obsesión por el cuerpo, la salud y los problemas de relación. ${ }^{121}$

Hombres y mujeres luchan en el mundo de las apariencias para lograr el éxito y la aprobación en una sociedad competitiva, una sociedad de vencedores en todos los ámbitos sociales, en los negocios, en las relaciones personales e

\footnotetext{
${ }^{120}$ Lipovetsky, G. (2004).Pág. 153/154

${ }^{121}$ Lipovetsky, G. (2004). Pág. 287
} 
interpersonales, en el trabajo, en todas aquellas esferas en las que la imagen juega un importante papel para la consecución del éxito.

"Los nuevos aires del tiempo no hacen sino continuar el esfuerzo de la emancipación de los individuos ante las referencias colectivas del éxito social y de la aprobación del Otro........sino más como autopublicidad, goce narcisista de aparecer en la pantalla, ser visto por el mayor número de personas, deseo de ser amado y agradar, más que de ser respetado y estimado por sus obras: Narciso prefiere seducir que ser admirado, quiere que se hable de él, que se interesen por él y que se le escoja."122

Con la nueva valoración de la imagen personal, aparece la figura del "asesor de imagen", una persona que estudia al cliente, gustos, estilos y necesidades y le aplica los cambios perceptivos y conductuales que considera necesarios para conseguir los objetivos planteados; este tipo de profesionales son contratados principalmente por políticos, cineastas y mundo de la farándula en general, personas en contacto con la opinión pública y con los medios de comunicación. Los medios de comunicación visuales, el cine o la televisión, e incluso los gráficos, como es el caso de algunas revistas, se convierten en espejo de una parte de la sociedad que intenta competir con la imagen que consideran ideal de belleza. Los gimnasios están cada vez más solicitados y los balnearios urbanos y los Spa son cada vez más populares entre los que su objetivo personal se centra en el culto al cuerpo.

${ }^{122}$ Lipovetsky, G. (2004). Pág. 287 


\section{Capítullo IV/}

卧 placer de los sentidos

Cientos de burbujas envuelven cuerpos semidesnudos, fuentes de agua golpean impetuosas firmes espaldas, lánguidos chorros fríos y calientes buscan el relax del abandono corporal.... es la bendición del agua.

(Suplemento El Mundo no 30 Abril 2004) 


\section{- Capitulo N}

Cas

.

Páginas

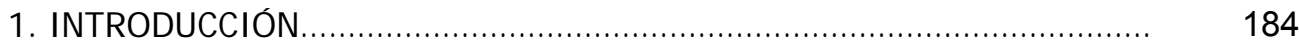

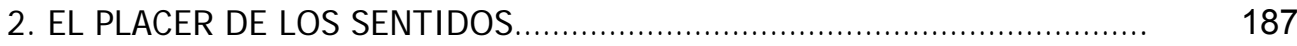

2.1. Búsqueda de la Relajación........................................... 189

2.2. Recetas de los Baños Mágicos ..................................... 192

2.3 La Torre de Marfil ................................................... 197 


\section{Introdilución}

Parte de la magia del baño no es otra que su capacidad de relajar el cuerpo hasta conseguir que alcance su equilibrio natural y ahí radica "el hechizo del agua".

El agua fría estimula, el agua caliente relaja, el baño de contrastes provoca en el cuerpo respuestas estimulantes que relajan el cuerpo y descansan la mente.

El placer de los sentidos es objetivo de empresas dedicadas a la terapia hídrica. Empresarios que dirigen casas de baños, balnearios urbanos, spa entre otros, son conocedores de la necesidad de relajarse y alejarse de los problemas y las tensiones promocionando sus negocios con anuncios como estos:

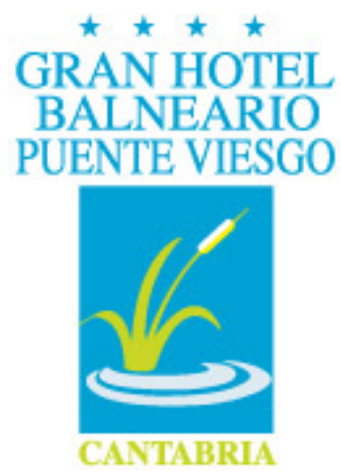

\section{"Cuidamos tu bienestar Relajación y descanso en plena naturaleza de Cantabria"}

Business Traveller Cinco Días/Siete Noches ( $\left.n^{\circ 10}\right)$ Titula su revista: 


\section{SPA URBANOS EN ESPAÑA 13 TEMPLOS DEL RELAX}

En el interior de esta revista se alude y publicita, trece centros de baño con titulares tan sugerentes como estos:

"SPA, Chorros de Bienestar: Relajación de los músculos, descanso mental, reactivación de la circulación, limpieza de la pie o una mejoría del aspecto físico son los tratamientos de agua que se hacen en los Spa. Y todo en poco más de una hora".

"El descanso de los Emperadores: Un exclusivo centro de salud integral ubicado en el corazón de Zaragoza".

"Un Respiro en el Cielo Barcelonés: y, de bajada a la tierra, una excursión por la técnicas tailandesas de masaje."

"Manjar de Sensaciones: La chocolaterapia es uno de los tratamientos más apetecibles de este spa valenciano. “

"Pensado para Complacer: En medio de la Castellana, entre el caos del tráfico y las oficinas, hay un lugar del que uno nunca querría salir."

"Santuario del Silencio: Sumergirse en la intimidad de estos baños árabes es una experiencia absolutamente relajante."

"Un Sosiego que entra por la vista: Pese a ser un club de fitness.... Es un espacio en el que los clientes más exigentes pueden satisfacer sus necesidades de bienestar por dentro y por fuera."

“Una Vida, Vívela bien: Un fenomenal gimnasio en el que se puede moldear y relajar el cuerpo gracias a la acción del agua." 
Imágenes como ésta, nos introducen en el placer de los sentidos a través del baño:

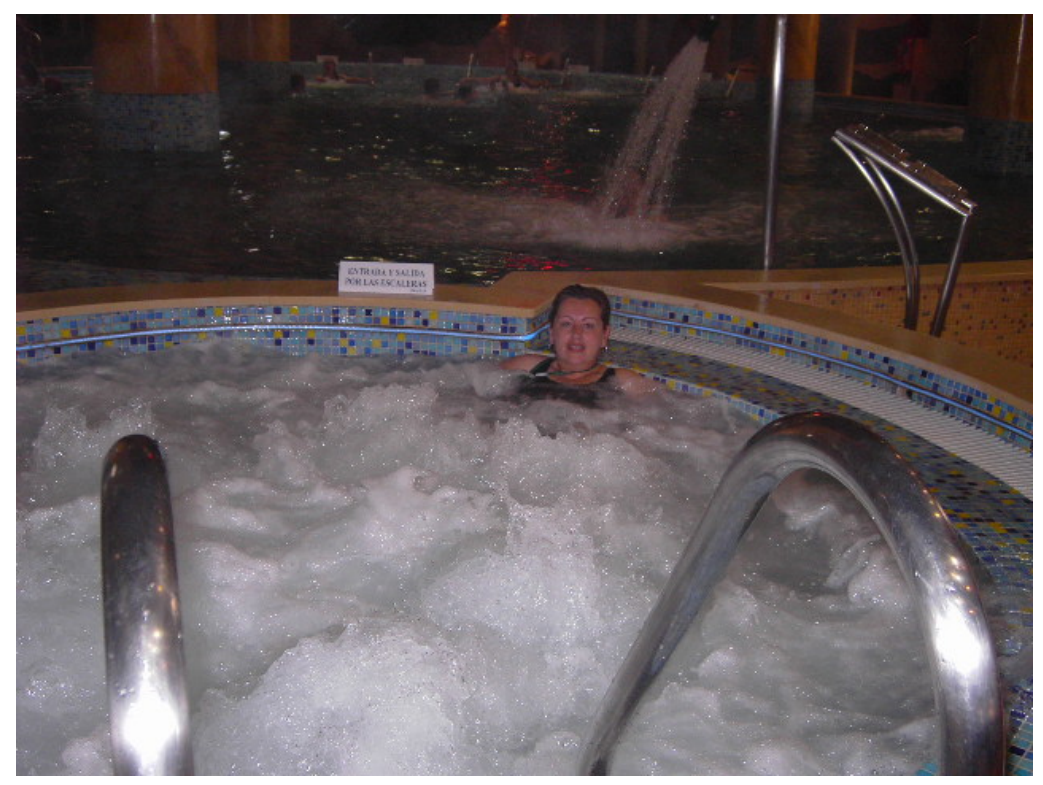

Ilustración 34 Piscina Jacuzzi Marina D`Or, en Oropesa del Mar (Castellón) 


\section{El Placer del los sentidos}

"El más célebre poeta épico griego, Homero, que, según Herodoto, vivió en el siglo XI antes de J.C. hablaba, en boca de Ulises (Lib. (, Odisea), de los placeres de su tiempo, citando entre ellos los baños termales"123

Sentir y sentirse bien, es una de las consecuencias del contacto corporal con el agua, sentirse bien es uno de los objetivos de aquellos que se acercan a las casas de baño.

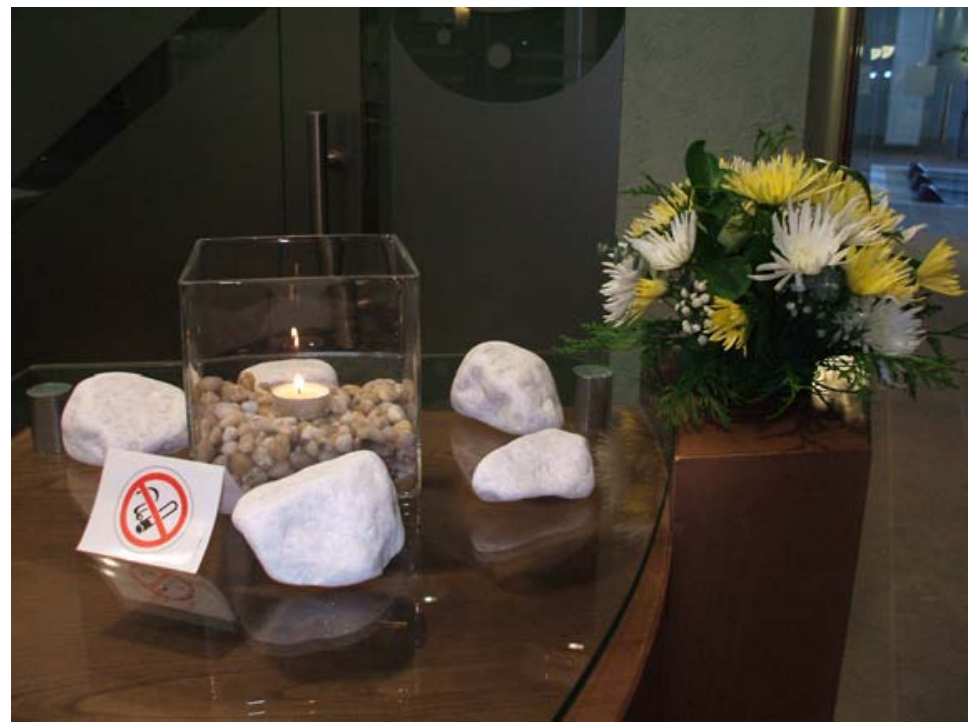

Ilustración 35 SPA del hotel el Rompido (Huelva)

\footnotetext{
${ }^{123}$ Pérez Fernández, M.R y Novoa Castro, B. (2002) “Historia del Agua como Agente Terapéutico” Art. En: http://.doyma.es
} 
El baño provoca una cadena de sensaciones placenteras. El baño invita a disfrutar del recogimiento, del encuentro con el propio "yo", de unos momentos de comunión con uno mismo, acompañado simplemente del vapor del agua o del rumor de su fluir; una sensación aún más placentera si se acompaña con perfumes y aromas. Sólo es necesario sumergirse y dejarse llevar en busca de un equilibrio corporal alejándose de la rutina diaria para entrar en un estado de satisfacción íntima y reconfortante, el contacto con el agua, cuna posnatal, nos da la posibilidad de aislarnos del mundo exterior y con ello de problemas y tensiones del devenir diario.

Algunos balnearios urbanos conocedores de estas virtudes del agua, han orientado sus centros con un enfoque holístico dedicados al cuidado personal en un ambiente natural, en el que se despierta el placer de los sentidos.

Los pétalos de flores flotando en la superficie, la luz de las velas, el rumor del agua, el vapor de los aceites perfumados, convierten el baño en un lugar exótico donde poder aislarse en un ambiente de paz y tranquilidad donde solo queda espacio para la felicidad, donde solo el deleite puede hacerse patente en estos momentos de disfrute hídrico; se trata de crear ambientes pensados para el descanso y la interiorización, lugares donde uno se siente el protagonista de su propio momento, donde lo importante es el cuidado de uno mismo lejos de toda contaminación externa.

No es extraño que los balnearios urbanos se conviertan cada vez más en válvulas de escape en escasos momentos de ocio, son lugares diseñados para conseguir en tan solo cincuenta minutos desconectar de la tensión generada por la responsabilidad adquirida en sociedad, ya sea por una condición laboral o familiar.

"Durante siglos se ha dado un enfoque holístico al cuidado personal, pero a mediados de la década de 1990 asistimos a un resurgir de este, cuando la cultura de los balnearios se popularizó. La gente quería utilizar productos biológicos y naturales en casa, igual que hacían en los balnearios". ${ }^{124}$

${ }^{124}$ Beth janssen, M. (2003). Pág. 5 
El contraste del agua a diferentes temperaturas, la aplicación del agua a distintas presiones, un baño de espuma o sumergirse en un baño caliente, tonifica el cuerpo y relaja la mente, una terapia amable que invita al recogimiento, a la búsqueda de la torre de marfil, en un ejercicio de liberación y de recuperación de paz interior. El disfrute en el agua se convierte en el disfrute del propio cuerpo mediante el baño que concluye en un envoltorio placentero de felpa mollar.

En el hamman, en medio de una trémula oscuridad del ambiente, el vapor que todo lo envuelve en una neblina íntima, da paso, tras el baño, al suave masaje corporal con aceites naturales, perfumados de rosas, violetas y jazmines, brillan en los cuerpos femeninos que tras el baño experimenta el frescor de la piel renovada, un cúmulo de sensaciones placenteras que afectan al cuerpo y al espíritu.

\subsection{Búsqueda de la relajación}

Agua, relax, son antídotos contra el estrés; sumergirse en el agua, procurando cerrar los ojos, dejándose llevar por la tranquilidad y el bienestar del cálido ambiente del baño, hace que de manera natural el cuerpo se relaje. El resultado de la sal en el agua, permite la flotación que a su vez incrementa la capacidad de relajación; algunos centros balnearios imitando a la naturaleza, se sirven de esta técnica o terapia (del agua saturada de sales) ofreciéndosela a los clientes como un valor añadido; se trata de imitar los efectos de la propia naturaleza que tiene su ejemplo en las aguas del "Mar Muerto", un lugar en el que permanecer suspendido sobre la superficie no supone esfuerzo alguno permitiendo unos resultados relajantes muy efectivos.

En este epígrafe dedicado al placer de los sentidos es necesario hacer referencia a algunas de las distintas terapias cuya filosofía es liberar cuerpo, mente y espíritu como es el caso del la terapia Wastsu, ésta, relativamente joven, nace en el año 1980 de la mano de un filósofo y físico norteamericano, Harold Dull, su obra ha recibido varios reconocimientos. 
El Watsu es una terapia corporal que se aplica en el agua, ésta usa los dedos pulgares y la palma de las manos para aplicar el masaje, se trata de apoyar, alargar y masajear los distintos puntos de tensión muscular, dentro de una piscina a una temperatura de $35^{\circ} \mathrm{C}$, lo que provoca el aumento de sensibilidad de los tejidos a la vez que favorece el sistema circulatorio. Dull ha sido terapeuta durante veinte años en las fuentes termales de Harbin, en California.

"La alternación del masaje, prolongación y flotación simple, lleva al paciente a un estado consciente de integración físico, mental y espiritual, ${ }^{125}$

Se trata de una terapia en la que flotando en el agua, sin sentir el peso del propio cuerpo se recibe un masaje cuyo fin es el de relajar y energizar al mismo tiempo, un masaje muy peculiar ya que utiliza el agua como medio para conseguir su objetivo. El agua permite libertad de movimientos por lo que hace que el masaje sea extremadamente relajante.

En el baño, se pierde la noción del espacio/tiempo, entrando en un estado regido por el ritual de la búsqueda de la armonía y la purificación del cuerpo; el estímulo de la belleza brota del interior fruto del bienestar y el equilibrio alcanzado por el cuerpo, la mente al contacto con el agua descarga sobre ella la mochila del cansancio y la pesadumbre acumulada por el simple hecho de vivir. En el baño las energías negativas se disipan cargando el cuerpo, de energías positivas que generan bienestar y salud.

El ambiente creado para el baño, forma parte del ritual al que nos referimos, así, las luces procedentes de las lucernas o las velas, tan utilizadas en los baños, provocan en el bañista una sensación de paz que mezclada con lo enigmático produciendo una

${ }^{125}$ http://www.elguaitador.com/medicina/watsu.htm 
sensación placentera de privacidad, de tiempo para uno mismo, de primacía para el cuerpo, de concentración en el acto puro del baño corporal.

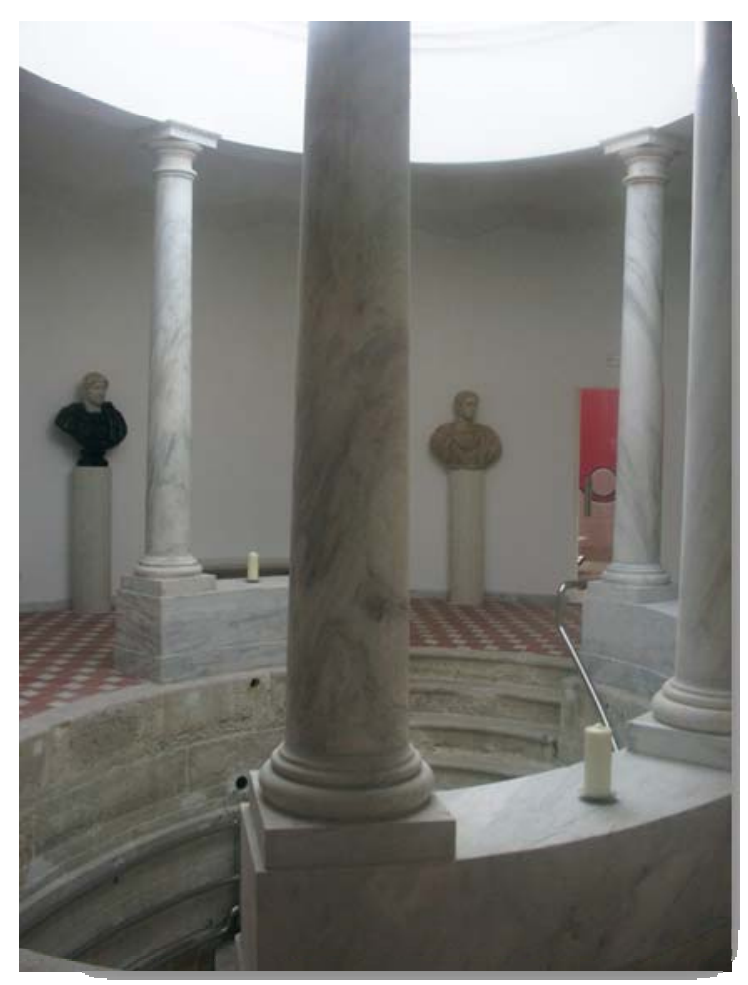

Ilustración 36 Baño romano. Balneario de Carratraca (Málaga)

Que el baño es una terapia relajante es algo sabido, por lo que se aplica con frecuencia a los bebés antes de acostarlos con el fin de que su sueño aparezca pronto y sea duradero y placentero. El baño es a su vez un ritual divertido, distendido, que procura el olvido de responsabilidades, es como un espacio neutral, un tiempo muerto donde no caben las prisas y todo puede esperar. 
Los complementos al baño son fruto del estudio de quienes saben de las propiedades relajantes del baño, así, chorros, burbujas, contrastes y esencias, productos naturales que sumados al agua del baño procuran intensificar los resultados deseados, de ahí las recetas de los baños mágicos.

\subsection{Recetas de los baños mágicos}

Cual receta de cocina, se mezclan ingredientes para conseguir efectos deseados. Trucos y recetas para crédulos y desesperados:

"Recetas y baños para conseguir trabajo: Esencia de Pompeya, abre caminos, albahaca macerada, polvo de almizcle y agua bendita. Mezcle los ingredientes en un frasco pequeño que sea fácil de llevar consigo. Úselo como esencia diaria en las articulaciones superiores y en el cuello. Salga radiante a buscar empleo y regrese con él."126

\footnotetext{
${ }^{126}$ http://elrincondelabruja.mforos.com
} 


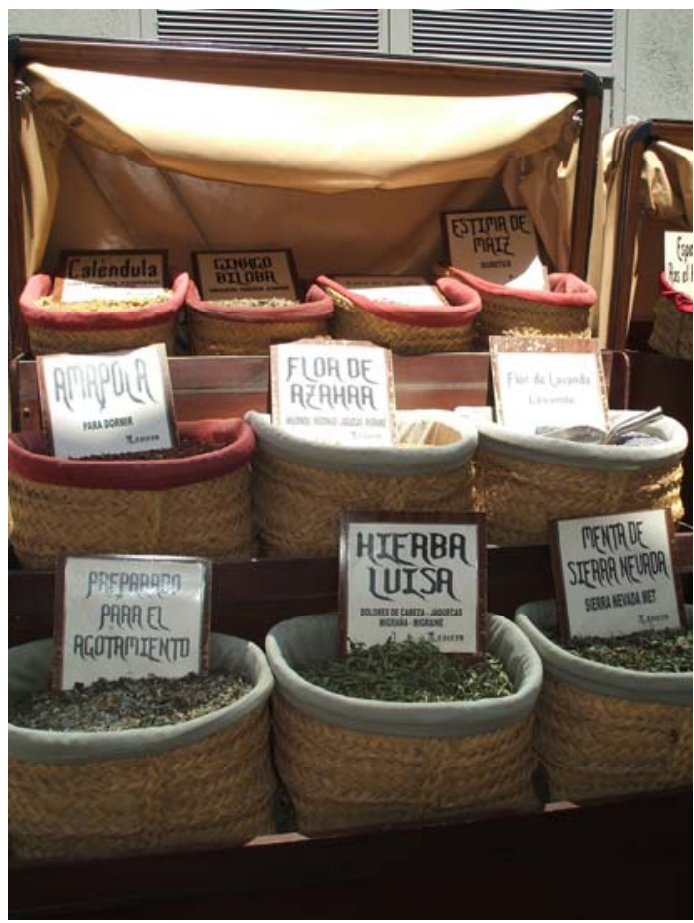

Ilustración 37 Mercado de hierbas medicinales y aromáticas (Granada)

Recetas para encontrar la belleza, recetas para relajarse, recetas para conseguir un baño de placer; una mezcla de elementos de la naturaleza se maceran en el agua desprendiendo en ella su esencia más intima, impregnando los cuerpos al tiempo que entre vapores empañan la estancia que alberga la bañera.

\section{Baño suavizante con manzanilla}

Ingredientes:

4 tazas de leche en polvo.

1 taza de agua.

5 bolsitas de manzanilla. 


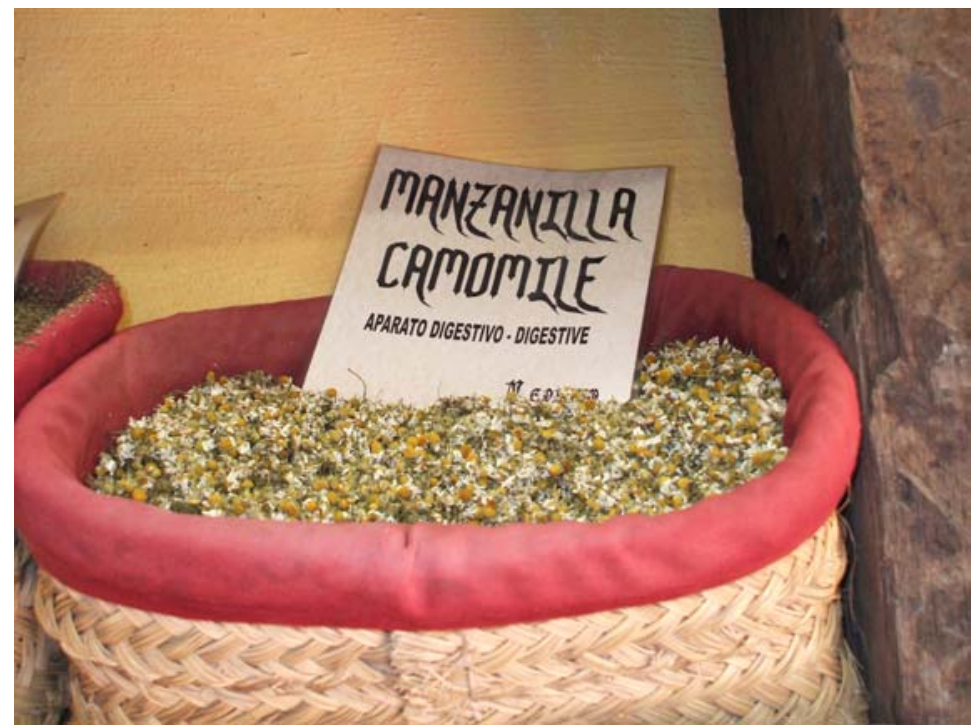

Ilustración 38 Flor de la manzanilla (mercado de Granada)

Preparación:

Poner a hervir el agua en un cazo. Cuando esté hirviendo, retirarlo del fuego, e introducir las bolsitas de manzanilla, dejando que infusionen durante 20 minutos. Mezclar la infusión con la leche. Echar la mezcla a la bañera.

\section{Baño de burbujas de cerezas}

Ingredientes:

1/2 taza de champú sin perfume.

3/4 taza de agua.

$1 / 2$ cucharadita de sal de mesa.

12 gotas de aceite esencial de cereza.

2 gotas de colorante alimentario rojo. 


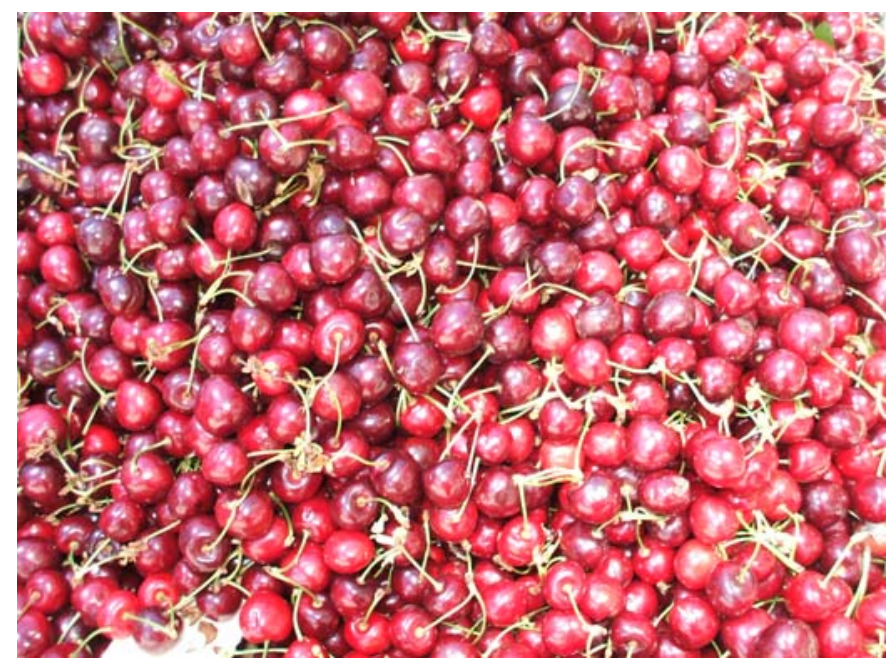

Ilustración 39 Mercado de la fruta (Granada)

\section{Preparación}

Mezclar el champú y el agua. Cuando estén bien mezclados, añadir la sal y remover hasta que la mezcla se espese, Añadir el aceite esencial de cereza y el colorante alimentario, y volver a remover. Guardar en un frasco hasta que se vaya a usar.

\section{Gelatina para baño a la lavanda}

Ingredientes:

$>1 / 2$ taza de agua.

$>1$ sobre de gelatina sin sabor.

$>1 / 2$ taza de jabón líquido.

$>6$ gotas de aceite esencial de lavanda.

$>2$ gotas de colorante alimentario rojo.

$>2$ gotas de colorante alimentario azul. 


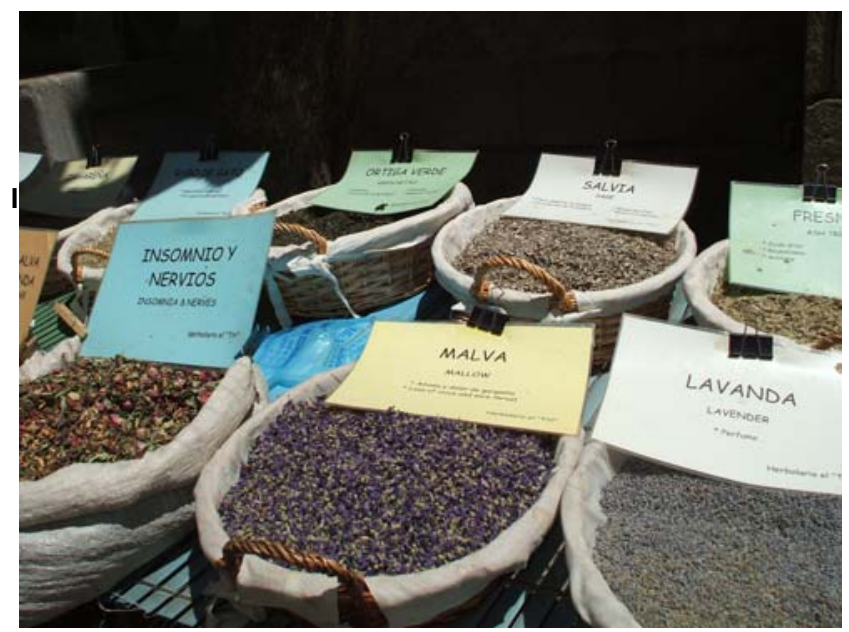

lustración 40 Mercado de hierbas medicinales y aromáticas (Granada)

Preparación:

En una cazuela calentar el agua hasta que hierva. Echar la gelatina y disolverla. Quitar la cazuela del fuego. Añadir el jabón líquido y las gotas de aceite y colorantes, removiendo. Vaciar el contenido de la cazuela en un frasco de conservas. Meter en el frigorífico para que se solidifique.

Cuando se quiera usar, colocar una pequeña cantidad de la gelatina debajo del grifo, cuando llenamos la bañera

> Cómo Hacer Un Baño Relajante de Cebada

> Cómo Hacer Un Baño Salado Relajante

> Cómo Hacer un Baño De Heno Relajante

> Cómo Hacer Un Baño de Popea Rejuvenecedor

> Cómo Hacer Un Baño Estimulante de Abrómato

> Cómo Hacer Un Baño Astringentes de Corteza de Encina

> Cómo Hacer Preparado Nutritivo de Siemprevivas 
> Cómo Hacer Un Baño Verde Adelgazante

$>$ Cómo Hacer Baño De La Abuela Antiarrugas.

> Cómo Hacer Un Baño Estimulante de Pino"127

\subsection{La Torre de Marfil}

Como piedra faceteada se presenta la noción de baño en el individuo, un acto cuyas posibilidades se adapta al momento, a la necesidad personal, a la necesidad física o psíquica.

El baño como acto social está presente en todas las culturas; disfrutar de un baño placentero en la playa, acompañado de familiares y amigos, al tiempo que se comparten las aguas con otros bañistas que acuden a la costa en busca de descanso y disfrute, es algo muy usual. Piscinas, balnearios, ríos, son lugares de encuentro social con un común denominador "el agua", se trata de un bien compartido que crea entorno, que por sus virtudes aglutina a individuos y grupos de individuos que practican el baño y se relacionan en el ambiente creado.

Tras este comportamiento en masa, el baño presenta otra de sus facetas, el baño "íntimamente compartido", para esta ocasión sirven los mismos escenarios y el mismo denominador común "el agua", sólo la situación de aislamiento social es la que cambia. Una playa desierta, una cala, un arenal en el recodo de la orilla de un río, una reserva en un Spa, situaciones que hacen del baño un lugar de encuentro fuera de miradas y convencionalismos sociales.

"El baño individual", el baño con uno mismo, en el que se busca por placer (no por higiene) el encuentro con la naturaleza, el recuerdo celular del seno materno, de la paz de aún no nato. El escenario suele ser el cuarto de baño, un lugar reservado y pensado para la intimidad personal, un lugar para el disfrute del agua. El baño individual es un acto de personalización en un espacio donde lejos de miradas y obligaciones sociales el individuo entra en unión con el agua, se sumerge, se

${ }^{127}$ http://cosmeticanatural.jaimaalkauzar.es 
desinhibe y en un acto de casi pérdida de conciencia entra en contacto con su propio Yo, desnudo de cuerpo y desnudo de mente busca su torre de marfil, su paz interior, en trance con la propia naturaleza descarga sus tensiones cargándose de energía positiva, son momentos en los que nada cuenta, en los que todo el bagaje personal quedó junto a la ropa que vestía al cuerpo antes del baño, un bagaje que tras el baño se retoma como ropa limpia con otra visión más positiva, en definitiva otra forma de ver las cosas.

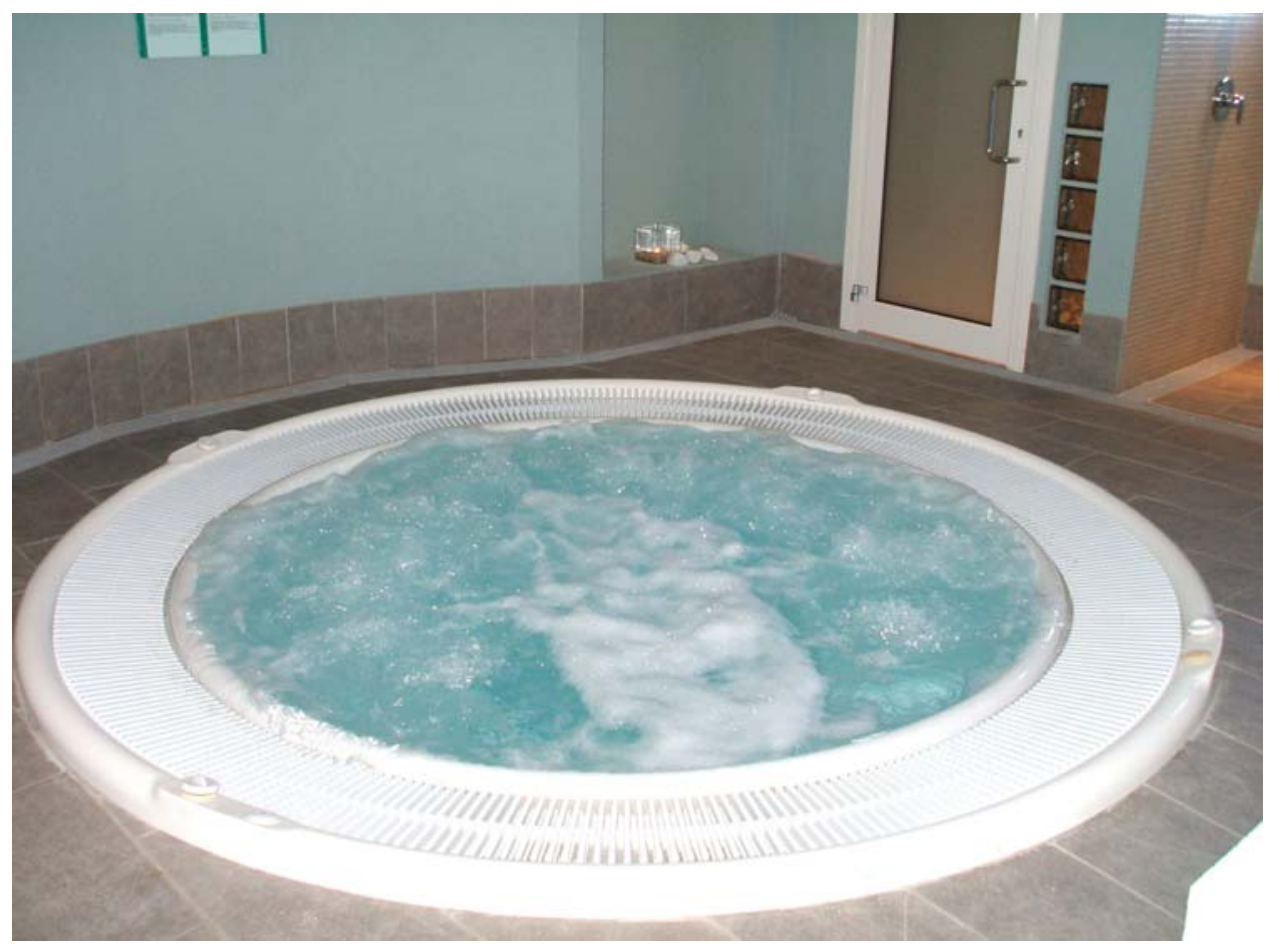

Ilustración 41 Jacuzzi (hotel el Rompido en Huelva) 
En una gran parte de los hogares del mundo, aunque no en todos, no olvidemos que muchos no disponen ni de agua corriente, existe un lugar reservado para el baño; los fabricantes de bañeras se han esforzado por ofrecer al usuario las últimas tendencias al respecto, así, encontramos bañeras clásicas con sus patas metálicas, bañeras con chorros, jacuzzis etc., el placer trasladado al domicilio, toda una oferta que recorre el abanico de los más modestos a los más exigentes a la hora de sumergirse en el baño. 


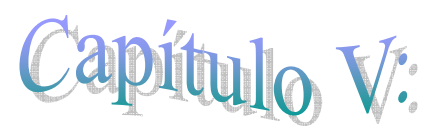

卧 placer dell espinitut

"Sacramento de la Naturaleza, puede con razón llamarse el agua, pues hace en lo natural este elemento purísimo, lo que en lo espiritual los sacramentos"

(Vicente Pérez 1752) 


\section{- Capitulo V}

1. INTRODUCCIÓN

202

2. EL PLACER DEL ESPÍRITU

203

3. AGUA, BAÑO Y RELIGIÓN 207

3.1. Budismo. 207

3.2 Hinduismo 208

3.3. Sintoísmo 209

3.4 Zoroastrismo 209

4. AGUA Y PUREZA EN LA RELIGIÓN MUSULMANA

211

4.1. El I slam

5. AGUA Y PUREZA EN LA RELIGIÓN JUDEOCRISTIANA 220

5.1 J udaísmo 220

5.2. Cristianismo 224

5.3 Agua milagrosa. 229 


\section{Introdilucción}

El agua como elemento simbólico se convierte en un universal cargado de significados distintos según la cultura y la sociedad.

Limpieza, purificación, renacimiento, el agua cumple una función distinta en cada una de las religiones constituyendo un elemento fundamental en ritos y ceremonias religiosas, por inmersión o mediante abluciones, el agua es líquido elemento capaz de calmar la sed de espíritu.

El agua bendita procura el renacimiento a una nueva vida, aunque el agua está íntimamente relacionada con la muerte, o visto de otro modo prepara para una nueva vida, la vida detrás de la muerte, la vida del más allá

El agua ocupa un lugar preferente en los libros e historias sagradas de las religiones, así, en la Biblia desde el Génesis al Apocalipsis, el agua está presente como elemento sagrado. En la religión musulmana, en el Corán, el agua tiene también un lugar reservado.

Ríos sagrados en la India como el Ganges, el Yamuna, el Saranwati, Godavari, Narmada, Sindhu (Indo) y el Kaveru (Cauvery), Saryu, Gomti, Gandaki, Sabarmati, Tamsa, Chandarbhaga, Shipra y Kratmala. Aguas benditas y milagrosas, que hacen de enfermos peregrinos.

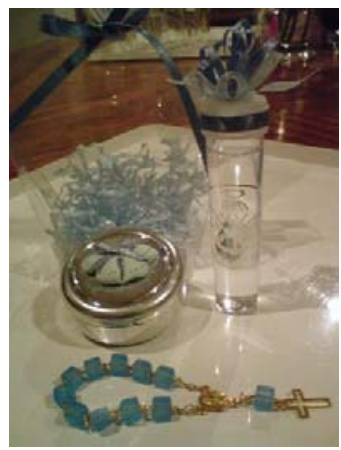

http:// www.actiweb.es/eltallerdelosangeles/imag 


\section{El placer del espíritu}

"En la antigua Grecia era frecuente la relación entre salud, agua y religión y muchos de los grandes santuarios, como Epidauro, y Delfos, estaban ubicados en manantiales con propiedades curativas, ${ }^{, 128} \mathrm{El}$ agua aparece como símbolo, ejerciendo un papel inexcusable en muchas religiones pasando a formar parte de ceremonias religiosas como elemento purificador y en algunas creencias como un elemento sagrado.

"En el caso de las aguas sagradas contamos con un añadido fundamental de orden simbólico. La inmersión se convierte en una suerte de bautismo, el agua en un líquido en el que mora la divinidad, el paraje natural en el lugar en el que se manifiesta el poder favorable de las fuerzas sobrenaturales". ${ }^{129}$

El agua como fuente de vida nace de la necesidad vital de este elemento, sin ella todo se convertiría en un desierto que no conduce a otro lado que el de la muerte, todo ser humano, animal o vegetal tiene necesidad de este fruto de la naturaleza que nutre, refresca y alimenta con su mágico don.

Felipe Cencerrado Alcañiz, en su libro titulado "Antropología del simbolismo religioso" y haciendo referencia a otras publicaciones, nos transporta a la esencia del agua en el origen de las religiones:

\footnotetext{
${ }^{128}$ De la Rosa, M C y Mosso Ma A; (2004). Pág. 2

${ }^{129}$ Diez de Velasco, F.. (1997) “Termalismo y Religión: Consideraciones Generales en el apartado dedicado a la Arqueología Termal”. En: Termalismo Antiguo (I Congreso Peninsular, Actas). Ed. UNED. Madrid. Pág. 100
} 
"La cosmogénesis de todas las religiones hacen emerger de las aguas la tierra firme la vida (82), y es común a todos los pueblos la tradición purificadora del diluvio. Los filósofos griegos la consideraban como uno de los cuatro elementos de que constan todos los seres. Los pueblos hindúes veneran las aguas del río sagrado, al cual peregrinan días y días para poder purificarse en sí. Abntofáil describe el nacimiento del hombre saliendo de una burbuja formada en las aguas marinas, acariciadas por el sol. Los poemas indios cantan a Narayana <<porque ha tenido las aguas por refugio >>. Hay tribus en el Orinoco que unen la fecundidad de sus parejas a ritos mágicos en el seno de las aguas, dotadas -según ellos- de virtud purificadora y vigorizante........ Y es que el hombre ve en las aguas el símbolo de la maternidad, y en las fuentes la corriente de la vida(83)

La inmersión en las aguas es interpretada por el hombre como la muerte, y la emersión de ellas como la regeneración a una nueva vida. Las aguas tempestuosas borran el pasado y lo destruyen; pero una vez que han remitido, hacen retoñar la vida y le prestan vigor y lozanía (84).,130

Este mismo autor, nos habla del simbolismo de los baños purificadores adoptados por los pueblos orientales y helénicos, (El río Nilo, el Éufrates y el Ganges eran considerados ríos sagrados en la antigüedad)

\footnotetext{
${ }^{130}$ Cencerrado Alcañiz, F. (1981) “Antropología del Simbolismo Religioso” Ed. Ingrasa. Cádiz. Págs. 37/38. En: (82): cf. Gen. 1.2 ; (83): cf. BACHELARD, G.: L'eau et les réves.- París, (1963), 20; (84): cf. ELIADE: Imágenes y símbolos,- Madrid, 1955, cap V.
} 
“También la religión mosaica prescribía numerosas abluciones para purificar a los que habían contraído impureza legar (46). El baño de agua y la aspersión de sangre de los animales sacrificados en la fiesta de la Expiación eran conocidos y practicados por el pueblo de Israel Ciertamente no producían una transformación moral de los impuros, sino que eran prescripciones rituales entroncadas en la Ley, $y$, a veces, ocasión magnífica para la compunción interior." 131

Diez de Velasco, alude al "Culto al Manantial atendiendo a ritos y objetos", así, manifiesta que la potencia sagrada del agua termal se concentraba en el propio manantial lugar donde se realizaban los rituales de acción de gracias. A continuación presentamos un ara votiva; una piedra de mármol tallada con el siguiente motivo:

"Fue dedicada a Juno Regina por Licinius Serenianus Clarissimus y su mujer en agradecimiento por la salud de su hija Varinia Serena $y$ demuestra la efectividad del tratamiento hidroterápico. Estuvo situada en la fachada principal de la Ermita de San Bartolomé (también conocida como Ermita del Cristo de los Baños), desde comienzos del siglo XVII."132

${ }^{31}$ Cencerrado Alcañiz, F. Págs. 109-110-111

${ }^{132}$ Gallego Real, A.L Dpto de Griego del IES Vegas Bajas. En:

http://aliso.pntic.mec.es/agalle17/latin/exrom/Termas\%20de\%20Alange.pdf 


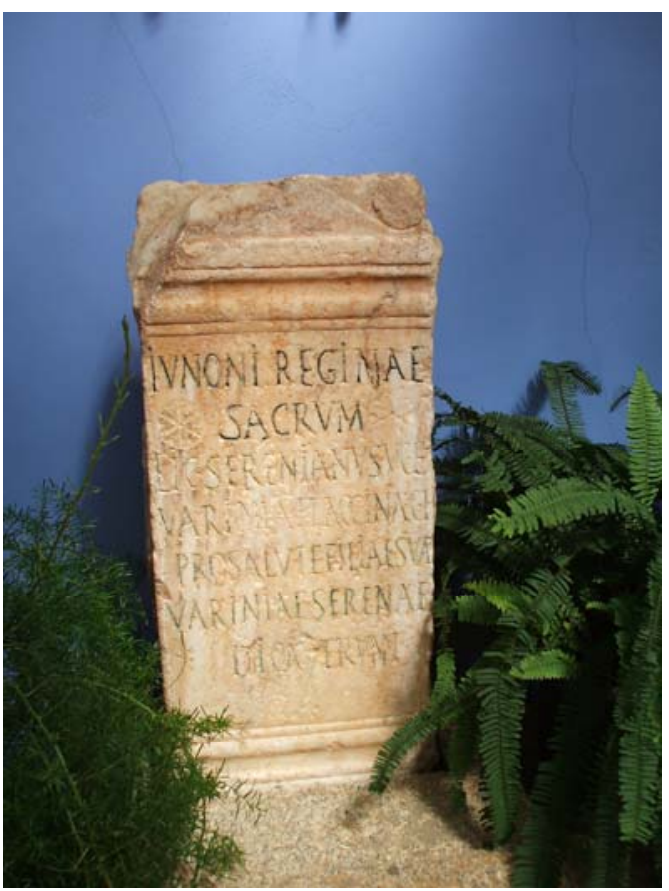

Ilustración 42 Ara Votiva en mármol que data del Siglo III. Se encuentra a la entrada de los Baños de Alange bajo la imagen del la Virgen.

Según Gallego Real, este Ara Votiva que se presenta en la imagen se encontró en las minas del antiguo establecimiento balneario.

"El mecanismo habitual frente a la enfermedad es prometer a la divinidad la realización del epígrafe si la curación se cumple. El pacto imaginario con la fuerza sobre natural tiene dos fases: la primera la satisface la divinidad por medio de la sanación,........la segunda es la liberación del voto por parte del ahora dedicante al adquirir y erigir la piedra (por la acción del votum solvere)". ${ }^{133}$

\footnotetext{
${ }^{133}$ Diez de Velasco, F. (1997) "Termalismo y Religión: Consideraciones Generales en el apartado dedicado al Culto al Manantial: Rito y Objetos”. En: Termalismo Antiguo (I Congreso Peninsular, Actas) Ed. UNED. Madrid, Pág. 100
} 


\section{Agua, baño y religión}

Si realizamos un breve repaso por algunas de las religiones, podremos observar lo que representa agua y su inmersión en ella, una gran cantidad de símbolos y significados que la hacen parte fundamental en ritos y tradiciones, siendo una constante en todas ellas el agua como símbolo purificador; a continuación se presenta una pequeña muestra del significado del agua en las distintas religiones:

\subsection{Budismo}

Es una religión que nace durante el siglo $\mathrm{VI}$ antes de nuestra era y que propugna las enseñanzas de Siddârtha Gautama Buda; una religión basada en la búsqueda del despertar espiritual mediante la meditación, la sabiduría y la renuncia a los placeres para poder liberarse de ataduras materiales que provocan sufrimiento. El agua en el Budismo es también utilizada en el fin de la vida, convirtiéndose en un elemento ritual en los funerales, como podemos observar en la cita que se presenta a continuación:

"El agua se utiliza sin embargo en el marco de los funerales budistas: ésta se vierte hasta desbordar en un recipiente situado ante los monjes y el cuerpo del difunto". ${ }^{134}$

En la era Heian, (años 784 a 1191) el baño de vapor,"Ofuro*, se realizaba con la intención de recibir las bendiciones de Buda

"Baños de horno o Kamado furo, y baños de piedra o isi furo, que eran criptas de la región de Yase o de las cuevas pedregosas de algunas zonas de Japón. Su evolución llevó al furo a ser una especie de

\footnotetext{
134،“Año Internacional del Agua Dulce” (2003), UNESCO. En: http://agualab21.com/fuente/hechos/a_religion.html
} 
baños de vapor done el agua hervía en un caldero y el vapor se extendía hasta los jardines como en los templos budistas...El furo es muy importante no solo como forma de aseo corporal sino como medio de purificación. $^{135}$

\subsection{Hinduismo.}

Nace en la India aproximadamente a partir del siglo XV a C; es otra de las religiones relacionadas con el agua, ésta se considera con poderes de purificación espiritual.

"Cerca de cada templo se encuentra una fuente de agua y los adeptos deben bañarse en ella antes de entrar en el templo. A menudo los lugares de peregrinación se sitúan en la orilla de los ríos; sobre todo se veneran los sitios donde convergen dos o incluso tres ríos. Siete ríos son sagrados: el Ganges y los ríos de Godavari, Kaveris, Narmadas, Sarasvatis, Sindhus y Yamuna. Según las creencias hindúes, las personas que se bañan en el Ganges o que depositan parte de su cuerpo (pelo, huesos del difunto) en la ribera izquierda del río alcanzarán el Svarga, el paraíso de Indra, dios de la tormenta. Los ritos fúnebres siempre tienen lugar cerca de los ríos; el hijo del difunto debe verter agua en la hoguera funeraria para impedir que el alma se escape y vuelva a la tierra en forma de fantasma. Cuando el fuego alcanza el cráneo del difunto, los padres se bañan y vuelven a su casa. Tres días después de la cremación, se reúnen las cenizas que, algunos días más tarde, se verterán sobre un río sagrado." ${ }^{\text {"136 }}$

\footnotetext{
${ }^{135}$ Basteiro, M. I. (2006); Revista Thermaespa, Nº 14 Pág. 65

* Furo u Oruro: Baño tradicional Japonés

${ }^{136}$ Idem
} 


\subsection{Sintoísmo}

Es la religión nacional de Japón, una mezcla de creencias y ritos atávicos que se centran en la adoración de fuerzas sobrenaturales llamadas "Kami"

"El culto de los Kamis empieza siempre por un acto de purificación con agua. La purificación permite restablecer el orden y el equilibrio entre la naturaleza, los humanos y las deidades"137

\subsection{Zoroastrismo}

Se trata de una religión ancestral, de la religión de la antigua Persia (actual Irán). Fundada como su nombre indica, por Zoroastro /Zaratustra, entre el 628 y el 522 a.C, se trata de una religión monoteísta que comparte rasgos con la religión judía.

"Esta religión dualista, fundada por Zoroastro (Zaratustra), opone el dios del bien al del mal. En el momento de la creación del mundo, el espíritu del mal atacó la tierra y transformó una parte del agua pura en agua salada. La pureza y la polución están en el centro de las creencias de los zoroastristas, que consideran la polución como el mal y el agua pura como sagrada. Escupir, orinar o lavarse las manos en un río está prohibido para no quitarle el carácter sagrado al agua. Para conservar la pureza de agua, del fuego y de la tierra, los difuntos no pueden ser sumergidos, inhumados enterrados."

\footnotetext{
${ }^{137}$ http://www.wateryear2003.org (Página dedicada al año 2003 como Año Internacional del Agua Dulce)

138 http://www.thewaterpage.com/religion.htm
} 


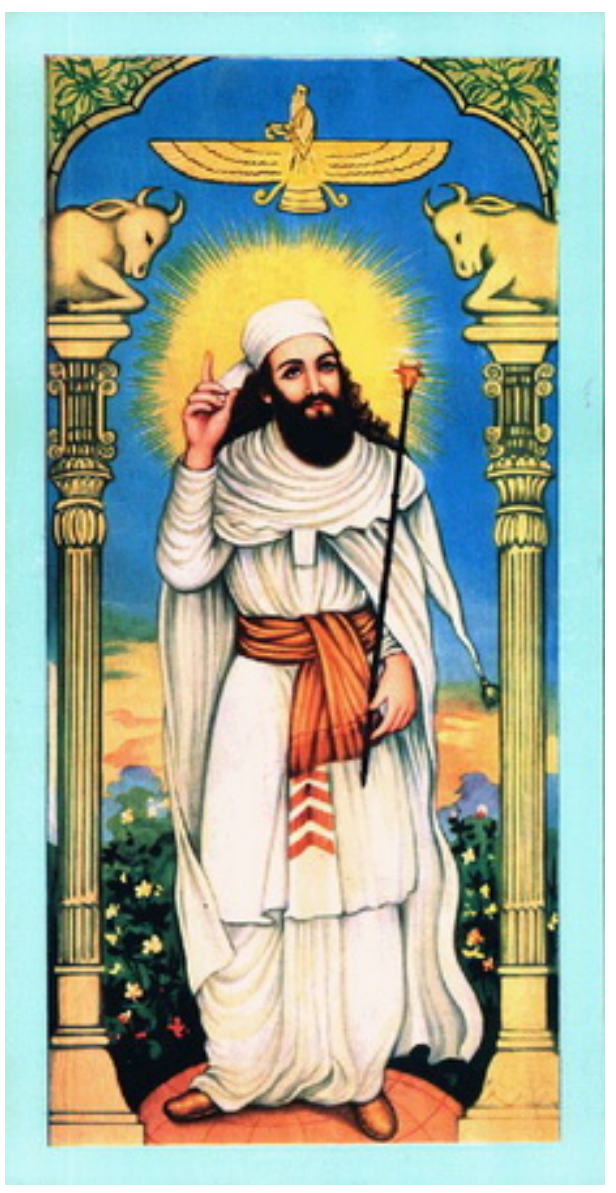

http://www.vopus.org/es/images/articles/Diccionario/zoroa ster.jpg 


\section{Agua y pureza en la religión musulmana}

\subsection{EI Islam}

Una doctrina religiosa expuesta por el Profeta Mahoma en el siglo $\mathrm{VI}$ antes de C; para los musulmanes (practicantes de esta religión), el agua tiene una función purificadora mediante el ritual de la ablución.

La ablución más importante concierne al cuerpo entero; obligatorio después del ato del amor, se recomienda antes de la oración del viernes y antes de tocar el Coran.

- Todos los días, el musulmán debe enjuagarse la cabeza, lavarse las manos, los antebrazos y los pies antes de las cinco oraciones diarias. Las mezquitas siempre tienen puntos de agua, a menudo fuentes, para estas abluciones.

En la fotografía que se presenta a continuación, en la que se puede observar una pila de ablución, se aprecia el desgaste de la piedra de mármol por el uso constante de la misma.

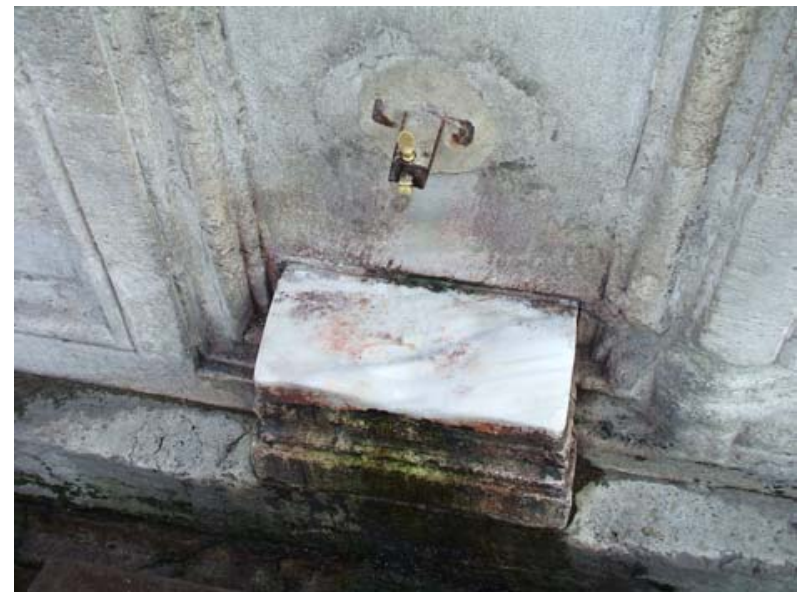

Ilustración 43 Pila de abluciones (Detalle tomado a la entrada de una mezauita en la ciudad de Estambul) 
-Cuando falta agua, las personas de confesión islámica utilizan arena; se trata del tercer tipo de ablución. Para que pueda llevarse a cabo el rito de la ablución, todas las mezquitas cuentan con una o varias fuentes a la entrada de la misma, generalmente situadas en el patio central, que da paso a la puerta principal.

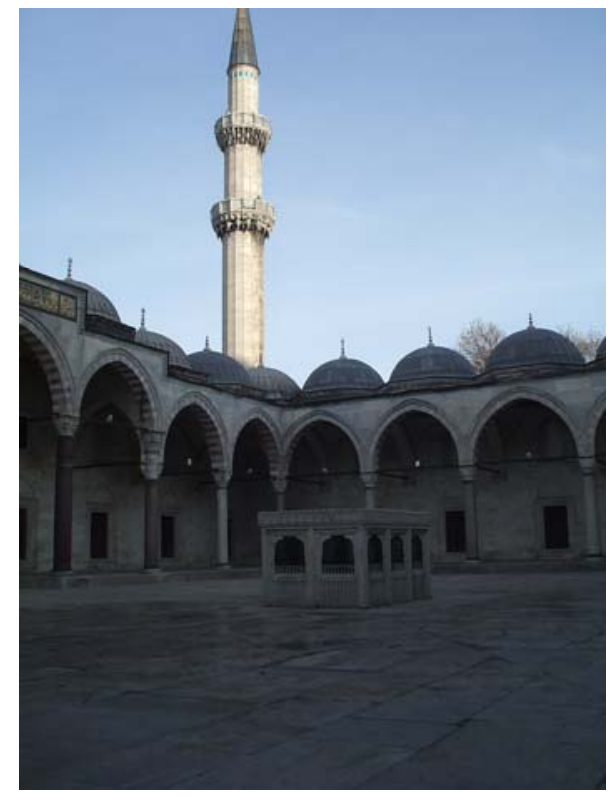

Ilustración 44 Patio central de la Mezquita Azul en Estambul (Detalle fuente central)

El wudu es un ritual de purificación con agua que se hace previo a la salâ (segundo pilar del Islam). Su propósito es limpiar el cuerpo y los sentidos, tanto en el plano físico como en el espiritual, para así, llegar a la oración libre de impurezas. La intención (niya) es un requisito imprescindible para su validez, ya que implica presencia y conciencia de lo que se está haciendo.

Los Jardines de los Justos (Ryyad As Sálihin) es un manual de comportamiento que ha de servir como referente en todos los órdenes de la vida del musulmán, su práctica conducirá al éxito en la vida presente y en la futura: 
"Dijo el Mensajero de Allah (s.a.s): "La purificación es la mitad del imán."

"Si alguien hiciera su ablución en toda regla y con todo detalle, todas sus faltas saldrían de su cuerpo, hasta las de debajo de sus uñas."

"Ciertamente, mi pueblo será llamado el Día del Juicio y llevarán iluminados como luceros los miembros de sus cuerpos, como señal que les ha dejado el agua de la ablución."

"Cuando hace el wudu el siervo musulmán, al lavar su cara, salen con el agua o con la última gota de agua, las faltas que cometió con sus ojos; $y$ al lavar sus manos sale con el agua o con la última gota de agua, cada falta cometida con ellas; $y$ al lavar sus pies salen con el agua o con la última gota de agua, sus faltas cometidas con ellos, hasta que queda puro y limpio de ellas."

"A cualquiera de vosotros que completara o perfeccionara su ablución y después dijera: 'Ashhadu an La ilaha illa Allah wahdahu la sharíka lahu, wa ashhadu anna muhammadan abduhu wa rasúluh'. (Atestiguo que no hay más dios que Allah, sólo y sin asociado, y atestiguo que Muhammad es su siervo y mensajero).

Se le abrirían las ocho puertas del Jardín, entrando por la que quisiera." mutatahhirina."

Y añadió: "Allahumma iyalní min at tawabina wa iyalní min al (' $i$ Oh Allah, hazme de los que se arrepienten y hazme de los que se purifican!') $)^{139}$.

\footnotetext{
${ }^{139}$ IMAM AN-NAWAWI /Traducido por: Zakaría Maza Vielva. (1999) “Los Jardines de los Justos”: Del beneficio de la ablución. Ed..: Junta Islámica centro de documentación y publicaciones. Almodóvar del Río Córdoba Capítulo 185. Pág. 457
} 


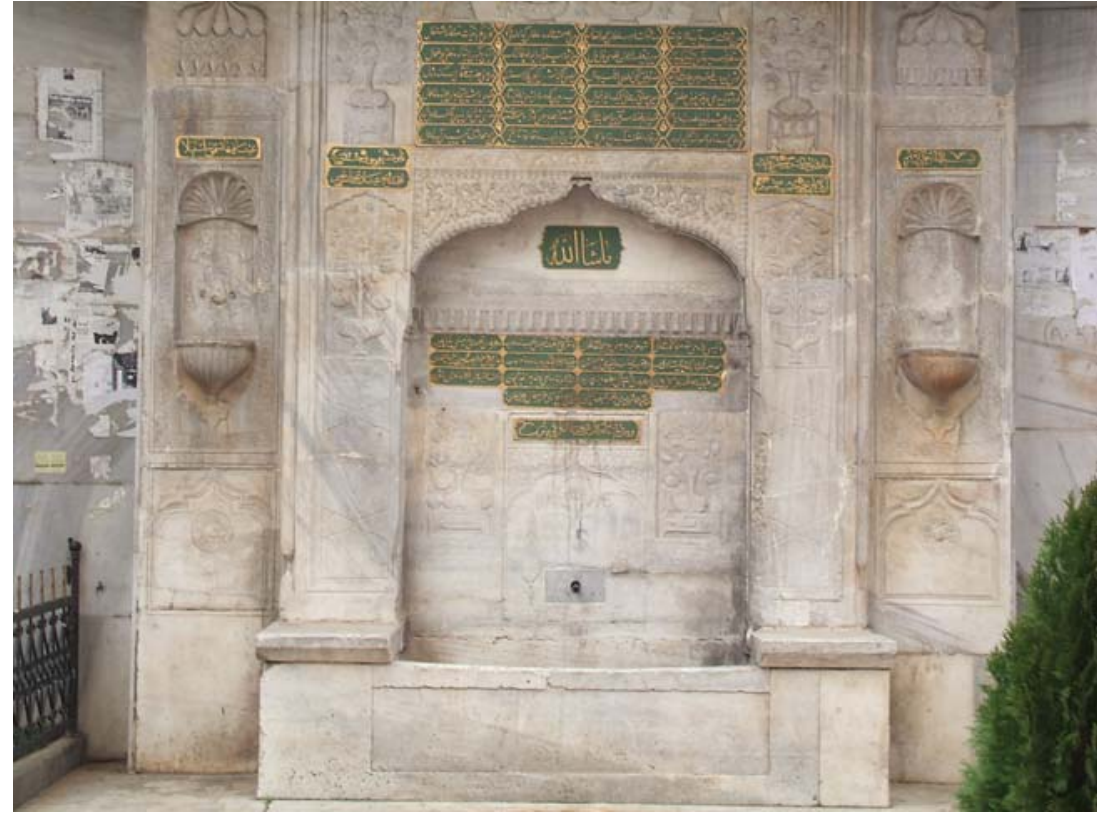

Ilustración 47 Fuente de uso social, se encuentra en una de las calles del centro histórico de Estambul.

“El Ghusl o Ablución Mayor es la forma por la cual se asegura la limpieza del creyente cuando ha incurrido en la Impureza Mayor (Hadath Akbar o Yanabah). Cuando se ha configurado tales impurezas, es indispensable llevar a cabo el ghusl a fin de poder con cada oración (e inclusive para la recitación del Sagrado Corán).

El Ghusl consiste en un baño total del cuerpo (a diferencia del wudhu, que implica una limpieza corporal parcial), aunque no se trata de un simple baño pues conlleva la realización de ciertos actos específicos, de acuerdo con el Islam." 140

\footnotetext{
${ }^{140}$ www.musulmanesperuanos.com/ghusl.htm
} 
El musulmán antes de comenzar su oración tiene que purificarse haciendo sus abluciones (wudo) siguiendo el orden que citamos a continuación:
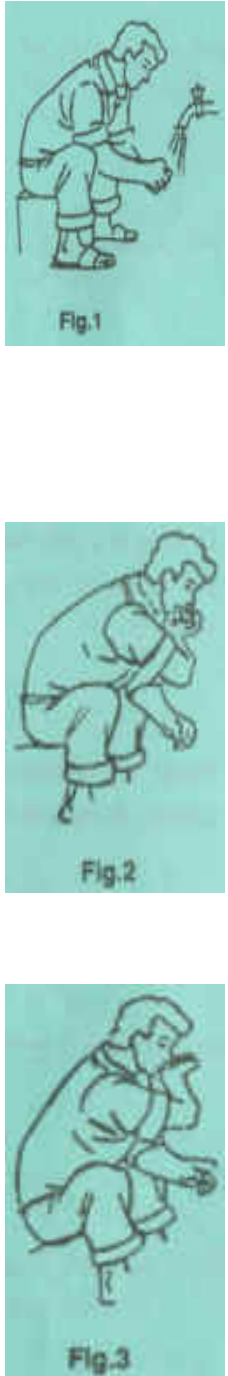

- Tener presente la intención:

- Recitar ante todo: Bismil-Láh (en el nombre de Dios).

- Lavarse las manos hasta la muñeca tres veces, procurando limpiar entre los dedos (Fig. 1)

- Enjuagarse la boca tres veces y limpiar los dientes con un cepillo o con el dedo: (Fig. 2)

- $\quad$ Aspirar tres veces por la nariz un poco de agua de la mano derecha y sonarse. (Fig. 3) 


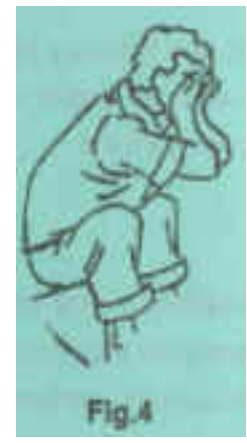

- Lavarse la cara tres veces desde la frente (implantación del pelo) hasta debajo del mentón, peinando la barba con los dedos en caso de tenerla. (Fig. 4)

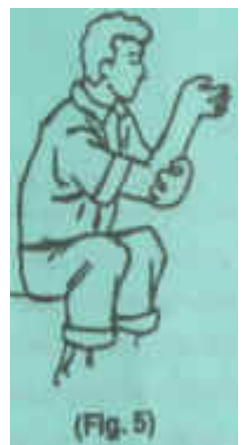

- Lavarse de antebrazo y mano derecha hasta el codo, (incluyendo el mismo) tres veces: (Fig. 5)

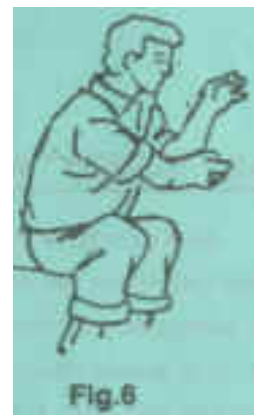

- Lavarse el antebrazo y mano izquierda, hasta el codo, (inclusive) tres veces: (Fig. 6) 


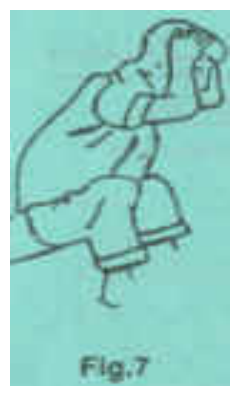

- Pasar las manos mojadas por el cabello, de delante hacia atrás. (Fig. 7)

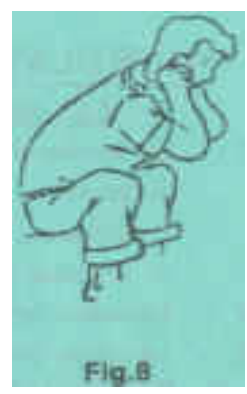

- Con los índices y pulgares mojados, limpiar las orejas tanto por dentro como por fuera. (Fig. 8)
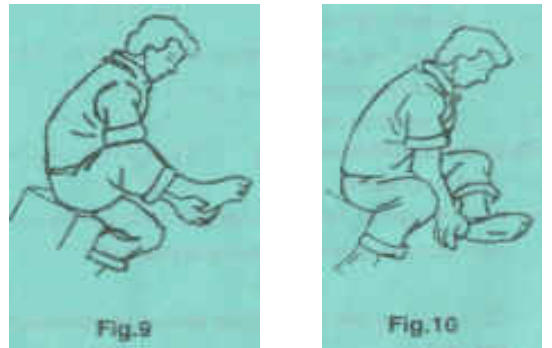

- Finalmente lavar los dos pies empezando por el derecho y acabando por el izquierdo, comprendiendo los tobillos, tres veces. (Fig. 9 y 10) 
Esta permitido pasar las, manos mojadas por el dorso de los zapatos o calcetines, en vez de lavarlos en la Ablución, pero tiene que haberlos puesto la primera vez, teniendo Ablución (wudú). En caso de estar de viaje, puede pasar las manos mojadas las veces que quiera, pero sin exceder tres días; si no está de viaje, solo durante un día (24 horas)." 141.

Los baños están esencialmente ligados a la religión musulmana, adosados a la mezquita nace de la exigencia islámica de acudir a la misma limpios e impolutos. Hacer referencia al agua en la religión musulmana es hacer referencia al Hamman como testigo de gran parte de los ritos de iniciación de un musulmán, de la circuncisión y del matrimonio.

Las bodas en la religión musulmana, están precedidas por un ritual que tiene como escenario principal el baño árabe o Hamman. La novia ha de pasar por un ritual de purificación mediante el agua, tras el que comienza el ritual de transformación estética con la intención de que la futura esposa se entregue en matrimonio, renovada tanto en su interior como en su aspecto externo; el cuerpo y el alma se exponen a los vapores del baño en un ritual que acaba con los malos espíritus y se clausura con el olor a hierba buena del té servido tras el mismo.

"un hadith del Profeta dice así "La higiene es una manifestación de la fe", para el mundo islámico el agua es un don divino (quizás por la escasez en los desiertos donde vivían) El agua, también significa Sabiduría profunda y pureza, para ellos es la bebida por excelencia..." que apaga la sed del alma", por estas razones y otras muchas para los islámicos el Hammam

\footnotetext{
${ }^{141}$ http://www.nurelislam.galeon.com/purificacion.htm
} 
es paso obligado en los grandes acontecimientos de su vida, nacimiento, circuncisión y matrimonio."142

Los significados y rituales del agua no son privativos de la religión musulmana, como hemos podido ver anteriormente, de igual manera, en la religión Judeo-cristiana el agua juega un papel importante en cuanto a significados.

142 http://www.granada-in.com/hammam_granada-in/informacion_banos_arabes.html 


\section{Agua y pureza en la religión judeocristiana}

\subsection{Judaísmo}

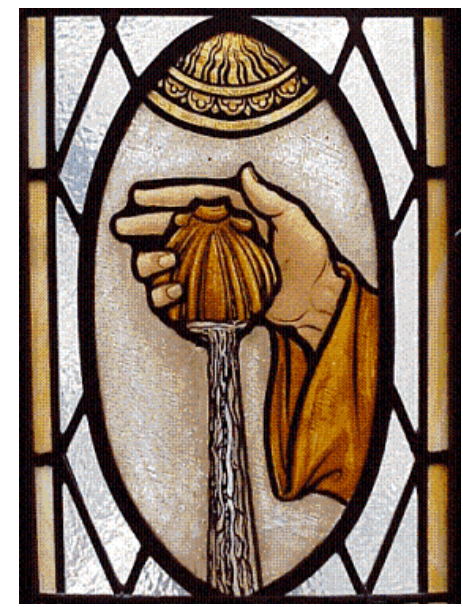

El Judaísmo cuna del cristianismo y del Islam, en su historia, el agua es símbolo de la Torá (thora, libro de la ley de los judíos) Pentateuco para los cristianos, jugando un papel importante como elemento purificador y rejuvenecedor.

"En el antiguo servicio del Templo de Jerusalén se utilizaba para el aseo de aquellos que participaban en el culto religioso. El paradigma de las facultades cuasi místicas del agua se expresa en la práctica de la inmersión en la mikve, el baño ritual de purificación tanto para hombres como para mujeres. Diversas ceremonias religiosas además han enfatizado el uso del agua. En Sucot, la fiesta de las cabañas, durante la época del Templo se acostumbraba realizar un alegre festival en honor de quien distribuía el agua y en Rosh Hashaná, el año nuevo judío, hasta la fecha se practica el ritual de Tashlikh, a través del cual simbólicamente se arrojan los pecados humanos a una fuente de agua. 
El lavado de manos antes y después de tomar los alimentos es también parte del ritual judío.

El agua constituye la fuerza vital que impulsa al ser humano hacia su Creador y que permea la vida judía en todas sus dimensiones. Con el paso del tiempo diversos cuerpos de agua específicos adquirieron especial significado para el pueblo judío gracias a sus asociaciones con la historia, el folklore y los personajes bíblicos. Sin embargo, de acuerdo a la tradición religiosa, "las aguas reales que alimentan, mantienen, reviven y definen, sólo son aquellas simbolizadas por la Torá". ${ }^{143}$

Como ya se anunciaba en la introducción, a lo largo de la historia de la religión judía se alude al agua, grandes ríos toman fama entre salmos; El Éufrates, El Nilo donde fue abandonado Moisés para protegerlo de la matanza de niños en Egipto, El Jordán, El Mar rojo, El Mar Muerto.

“Para los judíos, la limpieza ritual del agua permite restaurar o conservar un estado de pureza. Es obligatorio lavarse las manos antes y después de las comidas.

El baño ritual, o Mikveh, era sumamente importante para las comunidades judías en otro tiempo; si bien se practica menos hoy en día, sigue siendo obligatorio para los convertidos.

\footnotetext{
${ }^{143}$ http://jinuj.net/articulos_ver.php?id=60
} 
. Los hombres van al Mikveh los viernes y antes de las grandes fiestas; las mujeres, antes de su matrimonio, después de los partos y al final de sus menstruaciones" 144

En el Génesis se narra historia del Diluvio Universal cuyo motivo no fue solo el de castigar a un pueblo rebelde y desobediente, sino la purificación de un pueblo inmoral inmerso en el pecado; siendo el agua el elemento elegido por Dios para el renacimiento de un pueblo limpio y libre de pecado.

"La historia del gran diluvio aparece en el Génesis, el primer libro de la Biblia que narra la Creación. Con el fin de castigar a la humanidad por su desobediencia, Dios envía una lluvia torrencial sobre el mundo entero, solamente Noé, su familia y una pareja de cada raza de animales, escapan de este castigo, protegidos por un arca. El diluvio destruye todos los pecados del mundo para que pueda renacer de nuevo libre de impurezas." 145

Muchos son los pasajes de la Biblia que hacen referencia al agua como símbolo purificador, así en del libro del Éxodo extraemos dos pasajes que muestran claramente el significado del agua en esta religión:

\footnotetext{
144 http://jinuj.net/articulos_ver.php?id=60

145 http://jinuj.net/articulos_ver.php?id=60
} 


\section{Purificación, vestidura y unción}

“Mandaras que Aarón y sus hijos se acerquen a la entrada de la Tienda el Encuentro, donde los bañarás con agua. Tomarás las vestiduras y vestirás a Arón con la túnica, el manto de efod, el efod y el pectoral, que ceñirás con la cinta del efod. Pondrás la tiara sobre su cabeza, y sobre la tiara colocarás la diadema sagrada. Entonces tomarás el óleo de la unción lo derramarás sobre su cabeza y así lo ungirás. $^{146}$

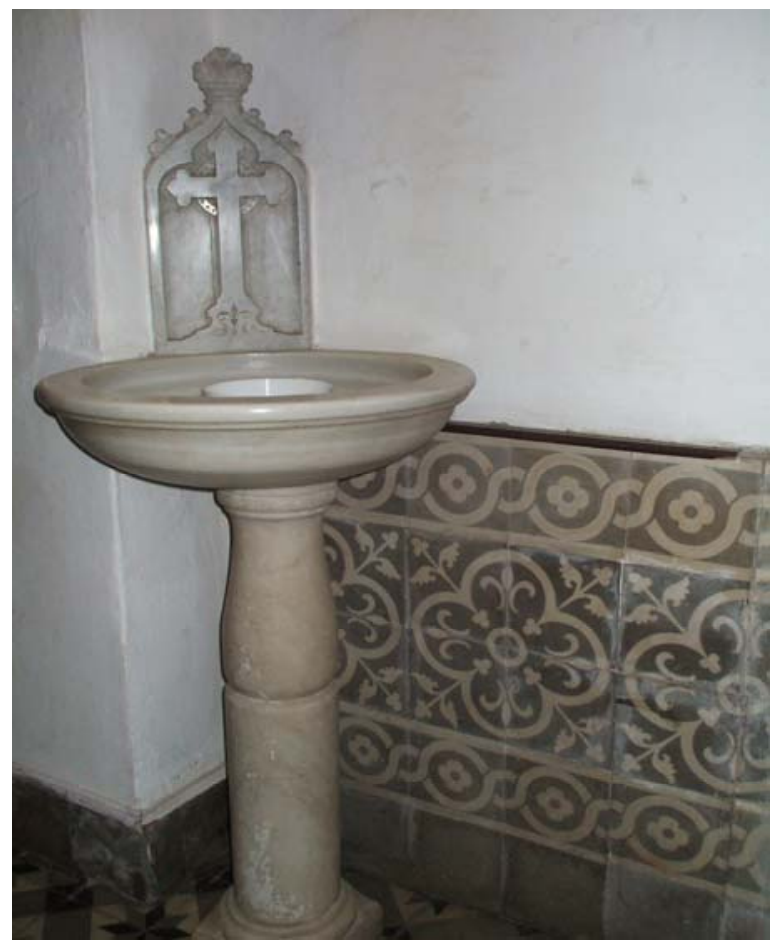

Ilustración 45 Pila bautismal (situada a la entrada de la iglesia para que el cristiano realice la señal de la cruz con agua bendita cuando haga su entada y salida del templo.

${ }^{146}$ Éxodo 29- 17 


\section{La pila de bronce}

"Yahavé habló así a moisés: Haz una pila de bronce, con su base de bronce, para las abluciones. Colócala entre la Tienda del Encuentro y el altar y echa agua fría en ella, para que Aarón y sus hijos se laven las manos y los pies con agua. Antes de entrar en la Tienda del Encuentro se han de lavar con agua para que no mueran; también antes de acercarse al altar para el ministerio de quemar los manjares que se abrasaran en honor de Yahvé. Se lavarán las manos y los pies, y no morirán. Éste será decreto perpetuo para ellos, para Aarón y su posteridad, de generación en generación."147

\subsection{Cristianismo}

El agua en la religión cristiana cumple un papel purificador, regenerador y a su vez es símbolo de muerte y renacimiento.

"Las aguas simbolizan la suma universal de las virtualidades. Son fons et origo, depósito de todas las posibilidades de existencia; preceden a toda forma y sostienen toda creación. La imagen ejemplar de toda creación es la Isla que se <<manifiesta〉> repentinamente en medio de las ondas. En revancha, la inmersión en el agua significa la regresión a lo preformal, la reintegración al mundo indiferenciado de la preexistencia. La emersión repite el gesto cosmogónico de la manifestación formal; La inmersión equivale a una disolución de las formas. Por esto, el

${ }^{147}$ Éxodo 30- 21 
simbolismo de las Aguas implica tanto la Muerte como el Renacimiento. El contacto con el agua lleva siempre en sí mismo una regeneración: por una parte, porque la disolución va seguida de un <<nuevo nacimiento >>; por otro que la inmersión fertiliza y multiplica el potencial de vida." ${ }^{148}$

El agua es una constante en la historia de la salvación, multitud de parábolas se ciernen en torno al agua, curación, purificación; el agua limpia de todo pecado e incluso del pecado original mediante el sacramento del bautismo.

"La voz agua aparece 582 veces en el Antiguo Testamento y cerca de 80 veces en el Nuevo. Pero no se agota allí el vocabulario referente al agua. Tenemos en la Biblia toda una constelación de términos en torno a este tema. La palabra mar es de las más frecuentes (395 veces) en hebreo y 92 veces en griego. Estas y otras palabras expresan de una manera muy directa la experiencia humana y religiosa del agua. La riqueza del uso del vocabulario referente al agua es muy rica en el texto sagrado, y recoge todos los aspectos que tienen que ver con ella. Hay una terminología que se refiere a los fenómenos meteorológicos: lluvia (de otoño, de invierno, de primavera), rocío, escarcha, nieve, granizo, huracán; una terminología geográfica: océano, abismo, mar, fuente, (agua viva), río, torrente, (inundación, crecida); otra que se refiere al aprovisionamiento: pozo, canal, cisterna, aljibe; y también los términos que indican su uso: abrevar, beber, saciar la sed, sumergir (bautizar), lavar, purificar, derramar. Una forma gráfica de representarnos la importancia del agua en la Biblia es pensar que en el Antiguo Testamento este tema se encuentra en 1.500 versículos y en $430 \mathrm{del}$ Nuevo Testamento. Y no se trata sólo de la cantidad numérica de textos, sino sobre todo del rico simbolismo que ese elemento encierra, y como

\footnotetext{
${ }^{148}$ Mircea Eliade (1999) “Imágenes y Símbolos”: En Cáp. V “Historia y Simbolismo, Bautismo, Diluvio y Simbolismo Acuático” Ed. Taurus.; Madrid. Pág. 165.
} 
símbolo nos ayuda a captar de una manera intuitiva realidades profundas que no podemos percibir y experimentar sino de una manera indirecta. ${ }^{149}$

La existencia de todo cristiano se fundamenta en el bautismo, así, en el evangelio de San Marcos "El que crea y sea bautizado se salvará; el que no crea, se condenará" (Mc 16, 16.), de igual forma el apóstol San Mateo transmitiendo las palabras de Jesús, dijo: "Id, pues, y haced discípulos a todas las gentes bautizándolas en el nombre del Padre, del Hijo y del Espíritu Santo". (Mt 28,19.).

"En el bautismo en el Jordán, Jesús no solo anuncia el compromiso del sufrimiento redentor, sino que también obtiene una efusión del Espíritu, que desciende en forma de paloma, es decir, como Espíritu de la reconciliación y de la benevolencia divina. Este descenso es preludio del don del Espíritu Santo que se comunicará en el bautismo de los cristianos............. El bautismo cristiano, precisamente porque sumerge en el misterio pascual de Cristo, tiene un valor muy superior a los ritos bautismales judíos y paganos, que eran abluciones destinadas a significar la purificación, pero incapaces de borrar los pecados. Confiere, además, un don mucho mayor: la vid a nueva de Cristo resucitado, que transforma radicalmente al pecador"150

\footnotetext{
${ }^{149}$ Girlanda, A. (1990), "Agua”, En: Nuevo Diccionario de Teología Bíblica. Ed. Paulinas, Madrid. Pág. 33-44

150 Juan Pablo II “Creo en la Vida Eterna: Catequesis sobre el Credo (VI)”Ed. Palabra; Madrid .Pág. 48-49
} 


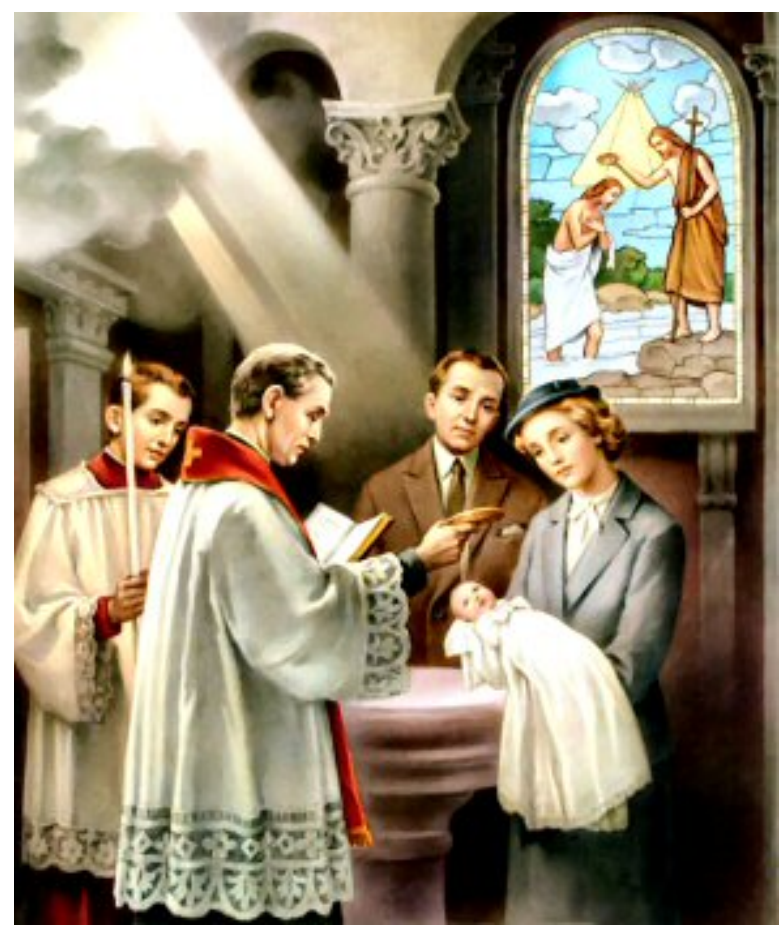

Ilustración 46 Sacramento del Bautismo.

Renacimiento a la vida del cristiano

Godoy Fernández en el capítulo dedicado al "Simbolismo del Agua en el Sacramento de la Iniciación Cristiana" describe brevemente el sacramento de la iniciación, en los primeros años del cristianismo.

"De todos es conocido el protagonismo especial que el agua tiene en la religión cristiana, sobre todo a partir del sacramento del bautismo, dentro del ritual de la iniciación. Resultaría estéril pretender aislar, sin embargo, no ya el mismo agua, sino el propio bautismo ya que, en época antigua, forman parte del sacramento de la iniciación que incluye la instrucción, el bautismo y la participación en los misterios, la primera comunión. 
Brevemente podemos describir el sacramento de la iniciación, en los primeros años del cristianísimo, con una compleja ceremonia, celebrada en la festividad de la vigilia solemne de pascua - o en la Epifanía en las tradiciones orientales-, que representaba la culminación de un período más o menos largo de instrucción, denominado catecumenado. La ceremonia incluía tanto el bautismo propiamente dicho como la primera comunión, puesto que los neófitos, una vez admitidos en la comunidad, podían asistir a la celebración de los misterios de la eucaristía. Por lo que se refiere al bautismo, los candidatos eran conducidos al baptisterio, donde proferían la renuncia a Satanás contra Occidente $y$, una vez desnudos, se introducían en la piscina, en dirección a Oriente. Dentro de la piscina, los candidatos, increpados por el oficiante, formulaban su profesión de fe y eran inmerso una o tres veces dentro del agua, del que emergían como hombres libres de todo pecado. Una vez que habían ascendido de la piscina, eran investidos de la túnica alba, color de la candidez y de la pureza. Algunas tradiciones incluían la unción con aceite bendito - el chrisma-, o incluso el lavatorio de pies, como en Milán. Tras este baño purificador, los neófitos se dirigían en procesión hasta la iglesia, donde eran presentados como nuevos miembros ante el resto de la comunidad." ${ }^{151}$

Los motivos de agua y baño, se encuentran en elementos de ornamentación dentro de las iglesias, pequeños detalles que aluden a la limpieza del alma y cuerpo, como es el caso de la fotografía que se expone a continuación que representa una imagen de un detalle de la Sillería Baja realizada por Rodrigo Alemán, perteneciente a la Santa Iglesia Catedral Primada de Toledo. (Fotografía extraída del Catálogo 2005 Exposición "ISABEL LA REINA CATÓLICA)

\footnotetext{
${ }^{151}$ Godoy Fernández, C. (1997) “Algunas Aportaciones al Simbolismo del Agua en el Sacramento de la Iniciación Cristiana”. En: Termalismo Antiguo (I Congreso Peninsular, Actas) Ed. UNED. Madrid, Pág. 187
} 


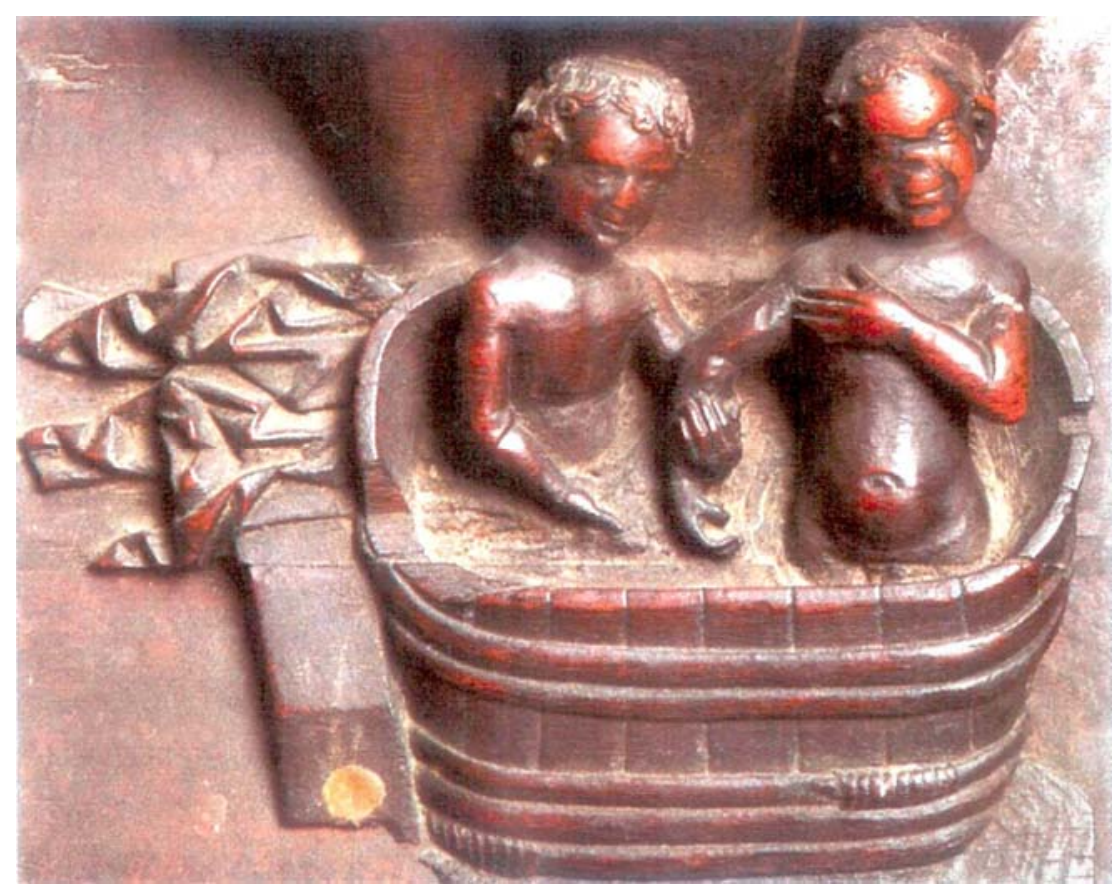

Ilustración 47 Detalle de la Sillería Baja de Rodrigo Alemán, perteneciente a la Santa Iglesia Catedral Primada de Toledo (imagen extraída del catálogo 2005, exposición “Isabel la Reina Católica”.

\subsection{Agua Milagrosa.}

Al agua se le atribuyen milagros, curaciones de personas desahuciadas por la ciencia y la medicina, que guiadas por la fe, acuden en peregrinación a santuarios y ermitas donde brotan fuentes de agua milagrosa.

En la mayoría de los casos en este tipo de fuentes se venera a alguna santa o virgen, se trata de manantiales que tienen que ver con apariciones marianas en las que el agua surge como símbolo de purificación y como agua de vida. Ejemplo de ello, podemos citar el santuario de la Virgen de Lourdes a la que se le atribuyen varios casos de milagros por medio del agua. 
"Era el mes de julio de 1963, cuando contaba yo solamente siete meses. De repente se me presentaron los terribles síntomas de una enfermedad que parecía desconocida. Luego se diagnosticaría como leucemia. ¡Dios mío, leucemia a mis siete meses! Entre tanto la medicación nada conseguía en mi pequeño y débil cuerpo. El mal avanzaba. Cada vez estaba peor. Finalmente al comprobar que los tratamientos médicos nada conseguían para detener el avance del mal, el Dr. Pedrerol, muy buen médico pediatra de Vilafranca, que llevaba mi caso, les dijo a mis padres que hicieran el esfuerzo de llevarme a Barcelona, para que las eminencias del Hospital Clínico de aquella ciudad tal vez encontraran una solución a mi enfermedad y recobrara la salud............... Hoy han pasado 36 años de aquel terrible día en el que mis padres escucharon en el Hospital Clínico de Barcelona, que tenía leucemia y que no había curación para mí en la ciencia médica. Vivo en la actualidad feliz con mi esposa Dolores, con mi hija Jesica y con mis padres. A todos los amo de todo corazón. Amo la revista AVE MARIA que me habla de la Virgen. Sigo siendo lo que mi familia ha sido. Un trabajador de bien y honrado. Pero hay algo grande en mi vida. La Virgen me ha curado. A Ella le debo mi vida. Quiero que mi vida y la de los míos sean para Ella también." ${ }^{152}$

\footnotetext{
152 Junqué Tort, E. Tomado de la Revista Ave María. En: http://www.lamparaencendida.net
} 


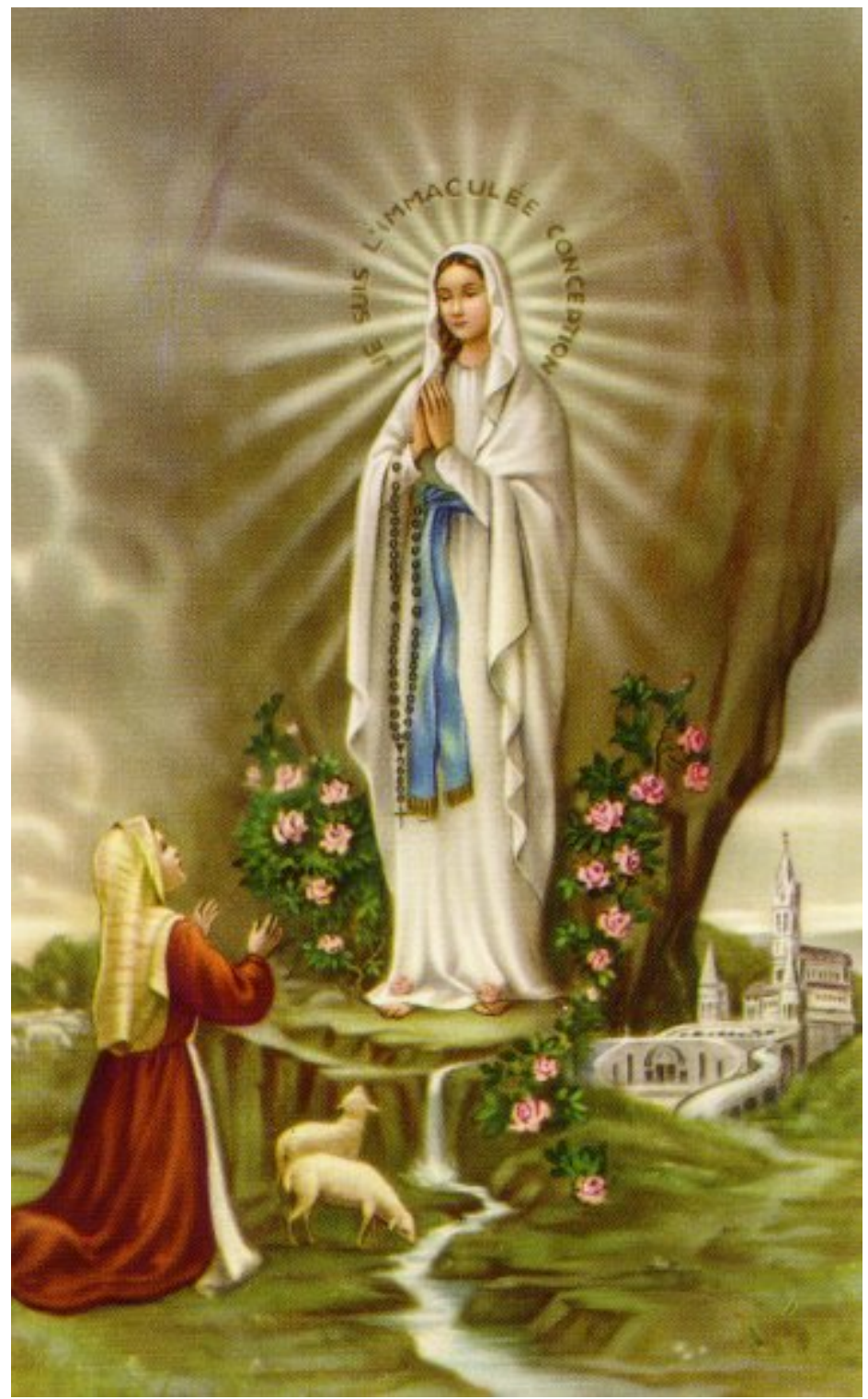

Virgen de Lourdes en:http://www.lamparaencendida.net

En una gruta del pueblo de Lourdes, se apareció la Virgen ante la mirada de una niña que se encontraba recogiendo leña, por intercesión de la Virgen, surgió una fuente de agua milagrosa; desde entonces, a la gruta donde se edificó un 
santuario, acuden multitud de peregrinos en busca de un milagro que cambie sus vidas.

El agua aparece una vez más como elemento sagrado y bendecido, el agua sana por mediación del milagro, el agua, un elemento material, natural, procedente de la naturaleza, se vuelve por intercesión divina en un elemento mágico que mediante la fe es capaz de salvar el cuerpo y el alma.

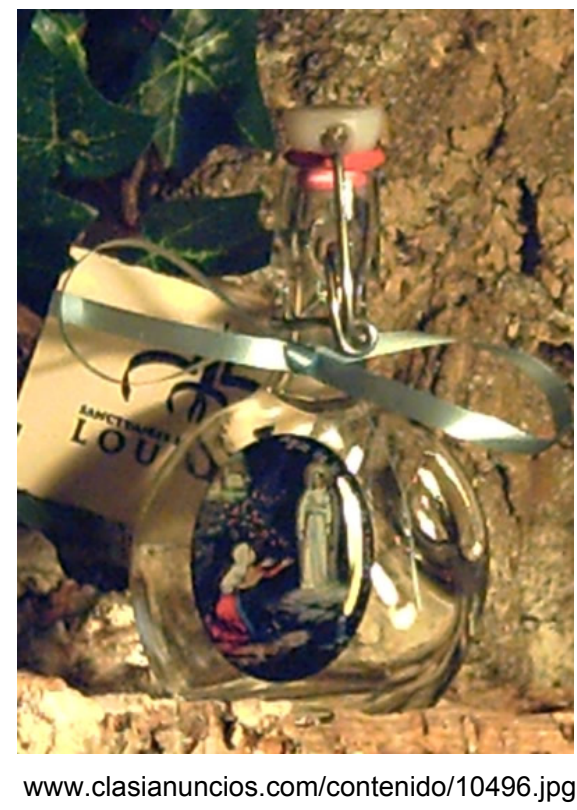

El agua es la parte tangible entre la divinidad y el creyente, el agua se convierte en un signo de fe.

Esta experiencia mariana en la que el milagro y el agua se encuentran en comunión es vivida desde la fe en muchos pueblos de España y en muchos países del mundo, así, podemos citar la veneración a la Virgen del Rosario de Agua Santa de Baños en Ecuador, a la Virgen de las Aguas que se encuentra en la iglesia del Salvador en Sevilla, a la Virgen del Agua en Castellote en Teruel donde a lo largo del año acuden sus devotos en romería con rogativas pidiendo lluvia. 
Existen leyendas que giran en torno al agua, milagros por medio de la Virgen, así en la ciudad de Toledo, se dice que durante la reconquista de la ciudad por Alfonso VI se encontró en el pozo de un claustro, a la imagen de la Virgen del Sagrario, lugar donde al parecer fue escondida para protegerla de la invasión musulmana; el agua del pozo se convirtió en fuente de milagros para el que con fe se acerca.

Agua y milagro van unidos en la fe cristiana por la intercesión de la virgen y por mediación en el bautismo del Espíritu Santo.

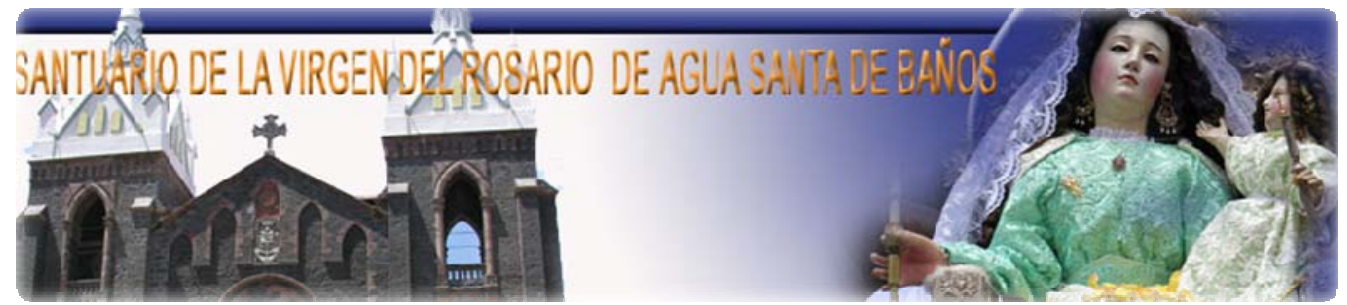

http://www.periodicoenlace.com/PUBLICIDAD/santuario/santuario.htm 


\title{
PARTE III
}

\section{RECUPERACION DE LOS USOS}

\section{SOCIALES Y TERAPEUTICOS}

\author{
DELAGUA
}

MEDIANTE EL BAÑO

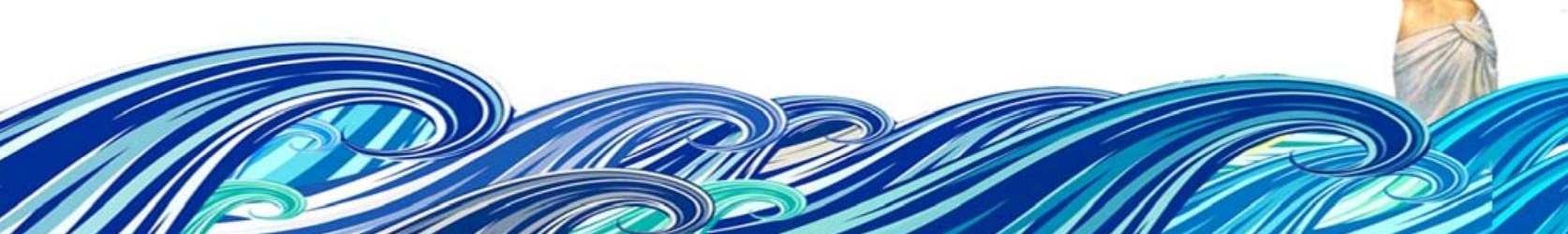




\section{Agua}

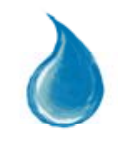

Hoy toma relevancia lo natural, todo lo que llega de la naturaleza parece ser un buen argumento publicitario para sacar al mercado cualquier producto $\circ$ ungüento. Extraer lo mejor de la naturaleza para uno mismo, se convierte en eslogan publicitario para atraer nuevos clientes; quizá sea éste también un buen argumento para concienciar a la sociedad, de que lo natural es limitado si el uso que hacemos de ello no es el adecuado; puede que basarse en la necesidad de lo natural como lo mejor para uno mismo pueda servir para algo más que un motivo para incitar al consumo, para conservar aquello que nos ha dado la madre naturaleza para uso y no abuso por lo escaso de los recursos.

El agua forma parte de una gran paradoja humana, se considera un bien altamente valorado, considerado fundamental en todos los ámbitos de nuestra existencia, del que no podemos prescindir y del que nos jactamos de consumir, el agua es símbolo de riqueza y placer, de belleza y bienestar pero, ja qué precioi ¿Qué cuesta en términos ecológicos llenar una bañera? ¿Y llenar una piscina? Y ¿Cuál es el coste ecológico en consumo de agua de los grandes complejos hídricos dedicados al placer del baño, dos, tres....más piscinas? ¿Cada cuánto se vacía una bañera; ¿se recicla el agua? ¿Se valora verdaderamente el agua?, el agua se derrocha en grandes cantidades en aras de dar gusto al cuerpo, en aras del egoísmo personal, del deseo de poseer parte de la naturaleza en beneficio propio. 


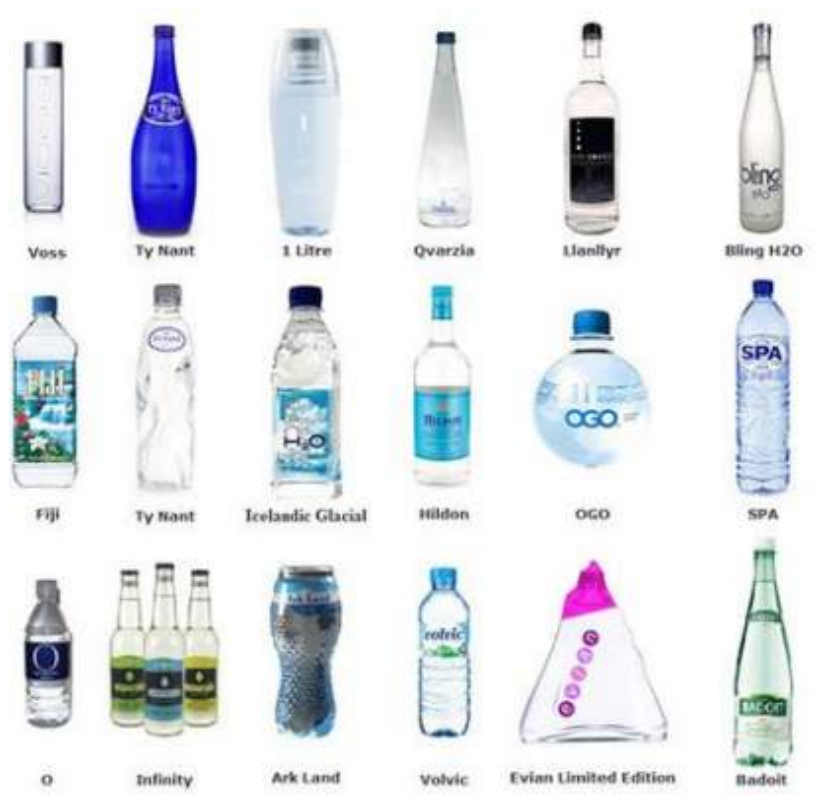

www.juliaardon.com/.../s1600/2808.pic.jpg

El agua es la bebida universal, embotellada, se ha convertido en un negocio próspero por su consumo masivo, a su vez, ha sabido ocupar su lugar entre las élites pasando a formar parte de las cartas de los más lujosos hoteles y compartiendo mesa y mantel con los más deliciosos menús.

El consumo de agua embotellada en el planeta va en aumento, se consume aún cuando la posibilidad de poder beber agua del grifo sea factible, esto supone un aumento indiscriminado de residuos plásticos con el consiguiente desgaste ecológico.

El agua se ha convertido en símbolo de poder, llegando a costar en algunos casos más que el petróleo, los manantiales se venden y se compran, el agua es objeto de manipulación económica, se trata de una garantía que se encuentra condicionada por la especulación. 
El agua es un negocio y al parecer de los más rentables, es una de las sustancias legales que más dinero mueve en el mundo.

Sequía y la escasez, hacen del agua un producto altamente codiciado, a mayor escasez mayor poder para quien la posee, suben los precios de un elemento sin el que el ser humano no pervive.

La situación hídrica a nivel mundial comienza a ser insostenible, según el Dr. Osvaldo Canziani, integrante del Panel Intergubernamental de Cambio Climático (IPCC)

"El recurso hídrico es fundamental para alcanzar los llamados Objetivos del Milenio, especialmente la erradicación de la pobreza y la reducción de la mortalidad infantil".

Celebrar el agua por su fruto placentero no ha de cegar la existencia del consumo irresponsable.

A lo largo de este capítulo analizaremos el resurgir del gusto por baño a través de la moda, su nacimiento y evolución marcada por la moral y el pensamiento del momento.

En contraste, nos detendremos en el baño como musa de pintores, se observará como este tema entra a formar parte de los lienzos más prestigiosos, que lejos de tabúes conjugan el baño con la desnudez.

La literatura se hace eco de la moda del baño y refleja en sus páginas historias de amor, de lujo, soledad, historias que fluyen al vapor de las aguas termales, publicaciones recientes y no tan recientes que tienen como testigo algún centro balneario. 
Público y privado, dos formas muy distintas de entender el baño desde las relaciones sociales. En el capítulo VII, trataremos el baño desde las dos perspectivas, atendiendo a su vez a los cambios sufridos por este uso a lo largo del tiempo.

A fin de aclarar ciertos conceptos que podría llevarnos a error, realizaremos una distinción entre los distintos centros dedicados al baño, profundizando en cada uno de ellos, en las características que los distinguen y en los beneficios que aportan como fuente de salud y/o placer en cada caso, teniendo en cuenta al agua y su composición como principal elemento diferenciador.

Un preámbulo para definir la pureza del agua y su capacidad de mezclarse con otras sustancias esenciales, y tres partes fundamentales en las que se analiza de forma minuciosa el baño como fuente de salud, placer y calidad de vida, a través de los tres tipos de centros: balnearios, Talaso y Spa, resaltando las diferencias entre ellos tanto por las características de sus aguas, como por su clientela o por los servicios que prestan. Se trata de acercarnos al fenómeno del baño para observarlo desde tres ópticas diferentes que suponen tres opciones distintas motivadoras del baño social con un punto común a todas ellas, "el agua", y con un punto que las diferencia, "el agua", en tres lugares dedicados al baño cuyo fundamento no es otro que "el agua".

Primera parte: está dedicada al agua mineromedicinal y su influencia en la salud mediante el baño. A lo largo de este punto se da a conocer por un lado las propiedades del agua mineromedicinal y por otro los centros balnearios, establecimientos que nacen junto a este tipo de fuentes con virtudes curativas.

Para enriquecer y reflejar la realidad social actual del sector balneario en España, se ha realizado un estudio en distintos balnearios distribuidos por la geografía española que amablemente se prestaron a colaborar, administrando entre sus usuarios un cuestionario realizado para llevar a cabo esta investigación; los resultados y conclusiones de las encuestas se muestran al final de este epígrafe. Así mismo, se realizaron entrevistas a los directores de los centros balnearios que quisieron colaborar; el resultado de las mismas se incluye en el apartado de "El sector balneario en la actualidad".. 
Segunda parte: está dedicada a "El Agua Salada": El mar y sus propiedades terapéuticas. En este punto se expone lo que ha supuesto para la sociedad y para la ciencia la investigación del agua marina. Los centros de Talasoterapia son los protagonistas como lugares dedicados a la aplicación de terapias mediante agua de mar.

Tercera parte: esta parte se detiene en los balnearios urbanos y los centro SPA como centros terapéuticos y de relajación mediante la aplicación de agua de la red urbana, una forma de negocio con demanda creciente en la actualidad. 


\section{Capítullo VI}

\section{卧 baiñ: \\ Resurgirir de un uso y una moda}

Tenemos indicios y pruebas más que evidentes que nos hacen pensar que la evolución positiva del mercado spa no es fruto de una moda pasajera, sino que se trata de un sector que ha entrado de lleno en los hábitos de consumo de los españoles.

("La industria termal en España" Quality Spa) 


\section{- Capitulo VI}

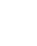




\section{1.. Introdilución}

El baño ha conocido momentos de gloria y esplendor, ha sido testigo del paso de modas y tendencias en centros dedicados al baño y en playas; lugares donde se exhibe el cuerpo en un ambiente eminentemente social. "La moda ilustra el ethos de fasto y dispendio aristocrático"153 la moda penetra en el juego de las apariencias y de la seducción.

El traje de baño evoluciona en la medida que la moral de la época lo ha ido permitiendo, asimilando poco a poco que el atuendo del baño ha de ser una prenda diseñada para tal actividad.

Hacer un seguimiento de su memoria supone un análisis paralelo de la situación histórica y del pensamiento religioso en cada una de sus etapas.

La representación del baño en el arte, da fe de la importancia de ese uso a lo largo de la historia representando la imagen corporal en su más extrema desnudez, ajena a indumentarias presenta su cara más femenina, el placer del baño parece tener en la pintura, salvo excepciones, nombre de mujer.

Pero el arte no es el único que se hace eco de modas y tendencias, la literatura refleja a través de la novela el acontecer de historias de baños, en ellas se determinan los atuendos, se describen las desnudeces del cuerpo y el alma y los placeres de los que son objeto los personajes en los centros balnearios.

El baño de placer es una constante en la historia de la humanidad, presente en todos los ámbitos sociales y culturales, forma parte de un gusto compartido, que surge y resurge como moda, pero que en ningún momento desaparece. Desde el sector turístico se ha querido recuperar un negocio que promete ser bastante exitoso "El turismo de salud", las administraciones públicas en aras a la sostenibilidad de

153 Lipovetsky, G. (2004). Página 35 
zonas consideradas deprimidas, como es el caso de algunas zonas rurales en las que brotan manantiales de agua mineromedicinal, apuesta por este tipo de turismo cada vez más demandado. Hoy hablar de turismo de salud es hablar de turismo de calidad en todos los aspectos, tanto en relación a sus aguas, en lo referente a profesionales y tratamientos a aplicar, como en los lugares destinados al efecto; edificios que cuidan hasta el más mínimo detalle; algunos de ellos conservando en la actualidad sus características iniciales, que los hacen inimitables, otros ambientados en la "bélle époque", en los años dorados del termalismo, otros por el contrario, vuelcan su imagen en lo sugestivo de la cultura árabe y su legado de belleza arquitectónica, y como no, las reproducciones de mosaicos y piscinas romanas que transportan al agüista durante su estancia a los orígenes del baño griego y romano y todos ellos unidos por la misma filosofía del uso social del agua con uno u otro fin. 


\section{El baño de moda y la moda de baño}

La popularidad del baño hace que las gentes, principalmente las élites, se concentren en los balnearios convirtiéndose el baño en un acto social para el que hay que estar a la altura, sobre todo si tenemos en cuenta que las apariencias son indicativo de posición social; para ello se lucen las mejores galas a diferentes horas del día, el paseo, el baile y como no podía ser menos "el baño".

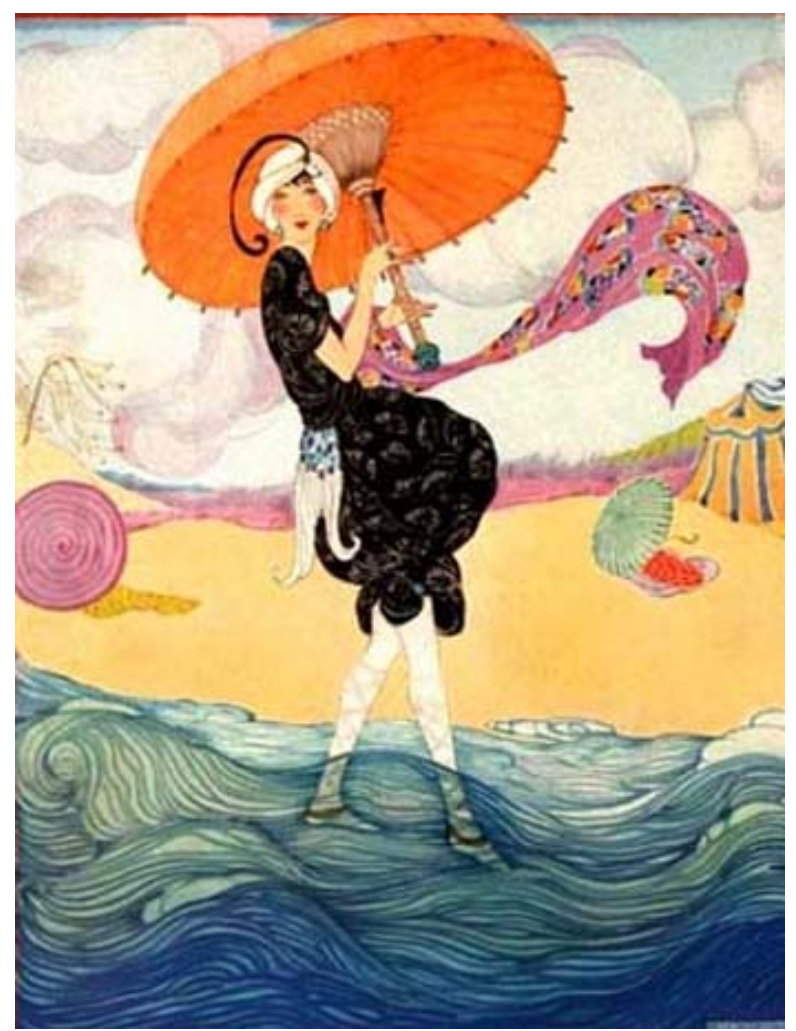

Según nos cuenta Sintes Pros en su libro, las guerras de religión del siglo XVI dan al traste con la obediencia de las gentes, y el baño vuelve con fuerza en la época estival. 
"En Pleno Paris, la gente se echaba al Sena completamente desnudos. El gran poeta francés Pierre de Ronsard se enamoró de una de aquellas ninfas, a las que inmortalizó en el nombre de Genèvre".

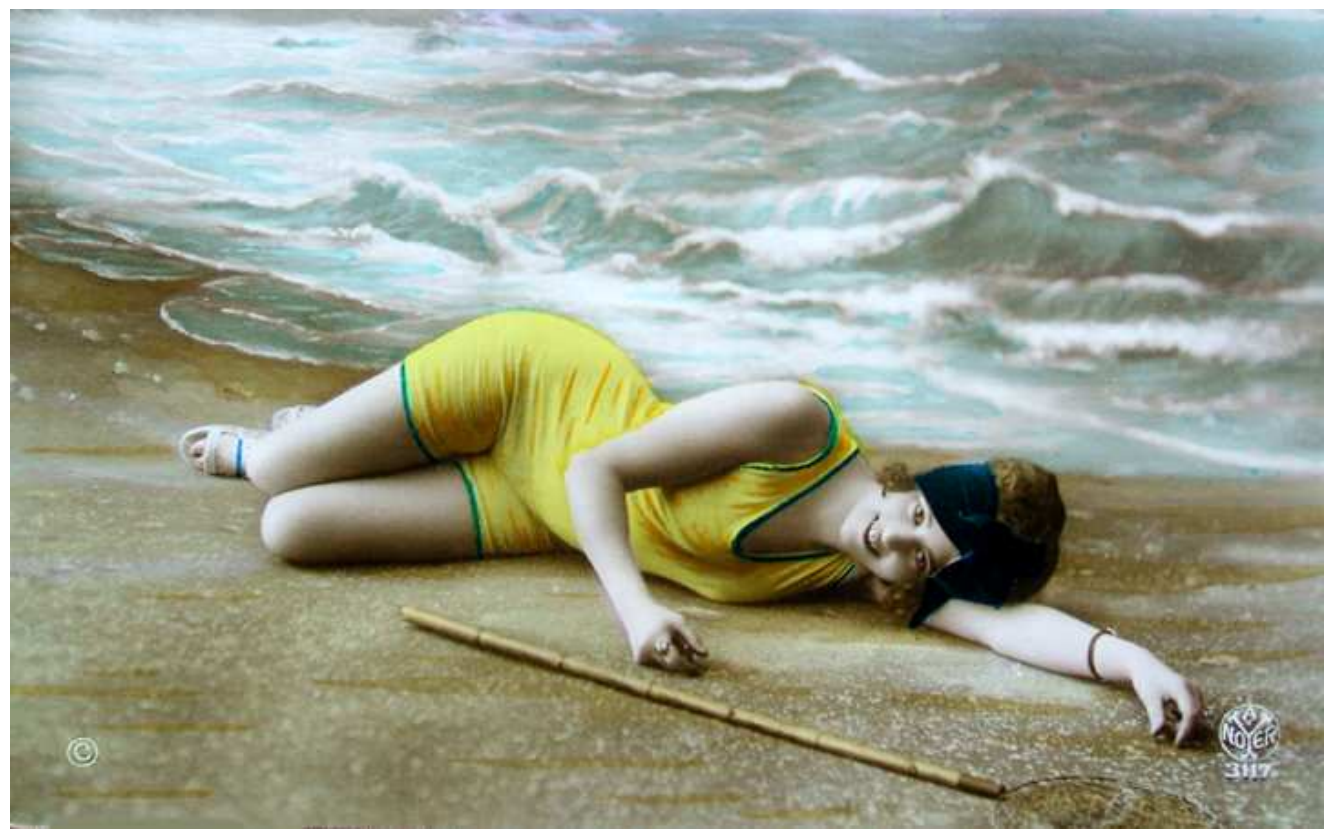

www.almirante23.net/.../banistas/banistas.htm

Las autoridades parisinas intentaron abortar este tipo de prácticas con medidas disuasorias sin obtener mucho éxito.

Es el en el siglo XVIII cuando a orillas del Sena se abren al público varios establecimientos dedicados al baño en los que se podían alquilar prendas de baño. 
"De mediados del siglo XIV a mediados XIX, se trata de la fase inaugural de la moda, aquella en la que el ritmo precipitado de las frivolidades y el reino de las fantasías se manifiestan de manera sistemática y duradera. La moda revela ya sus rasgos sociales y estéticos más característicos"154

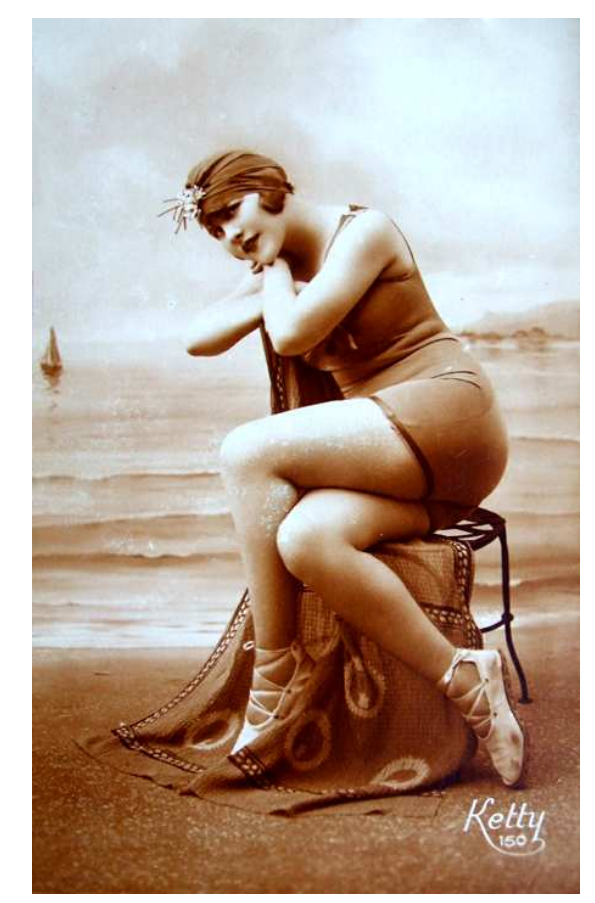

www.almirante23.net/.../bañistas/banistas.htm

El nuevo resurgir del termalismo de finales del siglo XIX y principios del XX es fruto del nacimiento de una moda termal, que tiene como fundamento el gusto por la higiene y culto al cuerpo, que da lugar a un movimiento basado en el veraneo de salud, envuelto en lujo y diversión, un lugar donde cultivar unas relaciones sociales que compartían el gusto común por el disfrute del agua salutífera. El uso del baño se pone de moda y con él nace la moda de baño.

\footnotetext{
${ }^{154}$ Lipovetsky, G. (2004). Pág. 26
} 


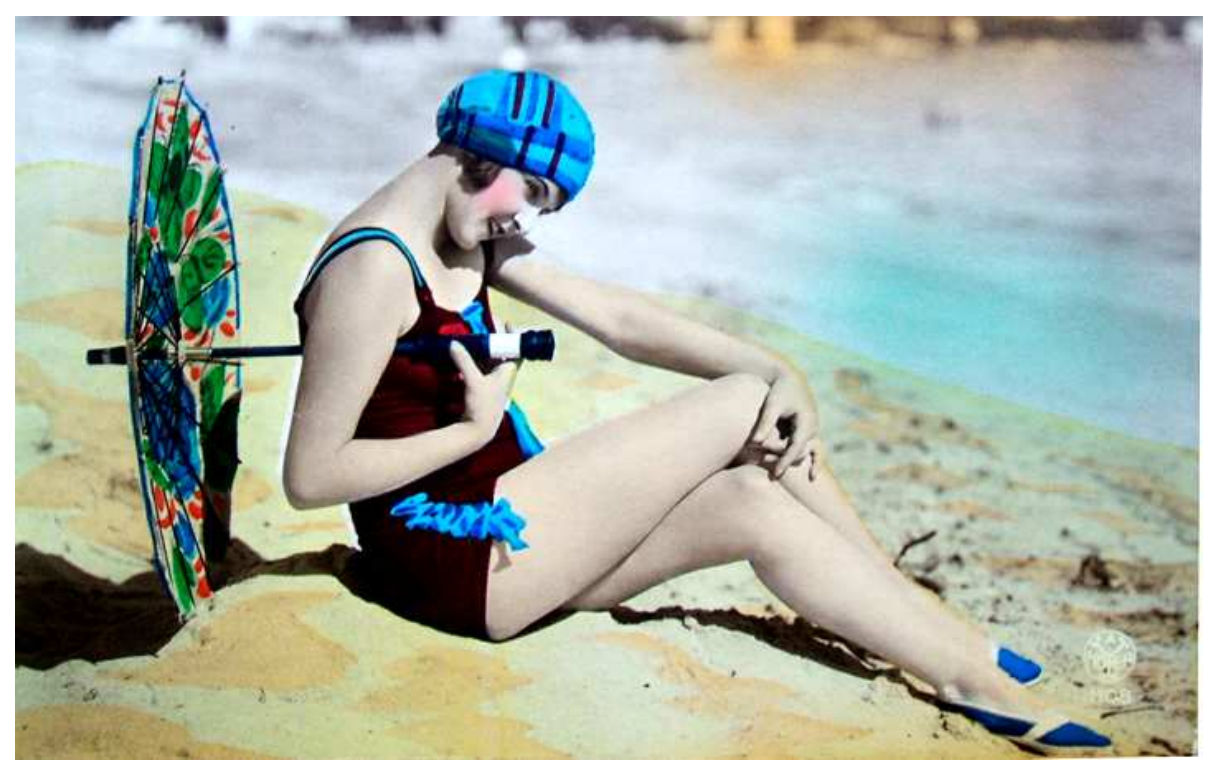

www.almirante23.net/.../bañistas/banistas.htm

El ambiente social creado en torno al uso de las aguas provoca la preocupación por las apariencias, se intenta cuidar la imagen como seña de identidad o de pertenencia a una clase determinada.

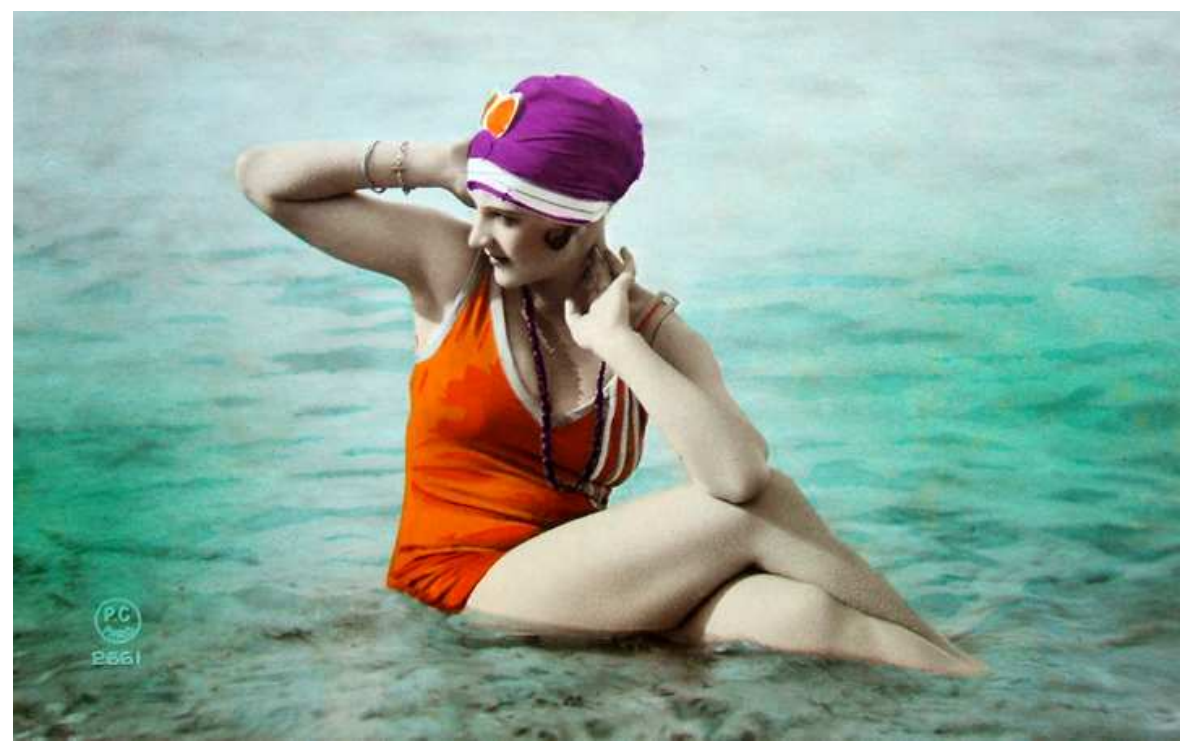

www.almirante23.net/.../bañistas/banistas.htm 
El traje de baño evoluciona: a lo largo de su historia se ve afectado por los cambios sociales y religiosos del momento, épocas en las que la moral se encontraba más relajada y otras en las que la represión pasó la censura por esta vestimenta.

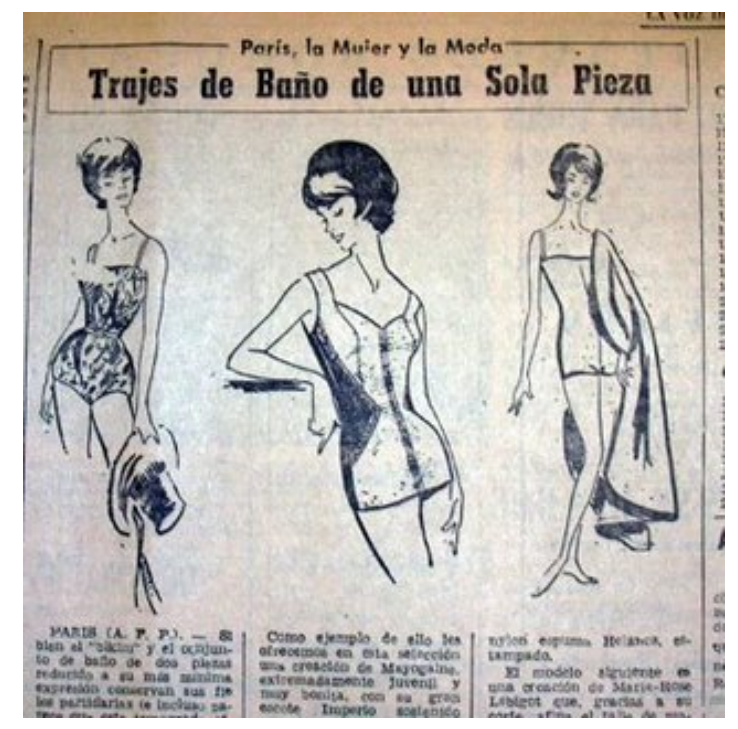

http://merceybea.blogspot.com/

"El Papa Clemente II declara que $<$ la limpieza del cuerpo es hermana de la voluptuosidad >>; los obispos exhortan a sus fieles a no expongan su desnudez en las playas. A partir de entonces, para tomar baños se hace con una larga camisa que llega a los pies.. pero los baños van cayendo en desuso",155

Son los ingleses los que vuelven a poner de moda los baños:

"En Brington, pequeño pueblo de pescadores del Canal de la Mancha, se instalaron sobre los guijarros de la playa, elegantes cabinas donde divertirse y tomar baños de agua de mar, previamente calentada.

\footnotetext{
${ }^{155}$ Sintes Pros, J. (1980) “El Poder Curativo del Mar (Talasoterapia)” Ed. Síntesis. Barcelona. Pág. 9
} 
Para quienes guardaban su turno se instalan parasoles que los protegen tanto del viento frío como de los ardores del sol."156

Según Sintes Pros, los baños de mar se practicaban en grupo y las mujeres con los ojos previamente vendados para no asustarse de las olas, eran conducidas por los maestros bañistas.

La moda de baño consistía en vestidos largos y anchos acompañados de amplios sombreros para proteger la tez del sol.

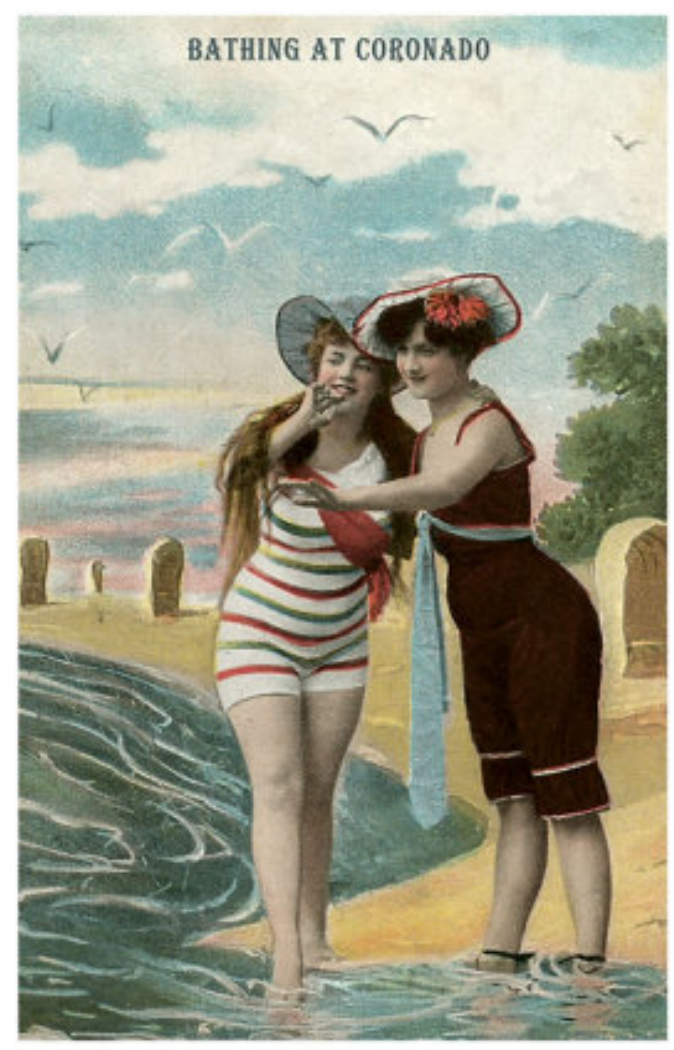

foro.forosmexico.com/showthread.php? $p=248680$

\footnotetext{
${ }^{156}$ Sintes Pros, J. (1980). Pág. 10
} 
"El 31 de julio de 1824, la duquesa de Berry fue por primera vez a Dieppe. Desde entonces y hasta 1832, en que fue encarcelada por actividades subversivas, era la que abría la temporada oficial de baños. Esta se iniciaba con un disparo de cañón en el momento en que Su Alteza Real entraba en el mar, lo que hacía acompañada del médico inspector, doctor Mourgué, vestido de etiqueta y con guantes blancos, cogiendo con la mano derecha a la princesa, como para un baile. Cuando el agua les llegaba a la cintura, un bañista, vestido con pantalón y blusa de color azul marino oscuro y con un sombrero de cuero en el que se podía leer << baigner juré>> (bañista jurado), tomaba a la princesa de la mano del médico y la sumergía varias veces la cabeza en el agua. Con esto quedaba terminado el baño.,157

Sintes Pros hace un repaso a la vestimenta utilizada para el baño, según información recabada procedente de los cronistas de la época. El traje consistía en un pantalón y una especie de blusa ancha abierta por detrás, tejido en lana negra, con ausencia de adornos; como calzado, unas gruesas zapatillas y como complemento al atuendo, un gorro de tafetán encerrado que cubría los cabellos en su totalidad.

"Al salir del baño con sus ropas pegadas al cuerpo, las mujeres más bonitas resultaban monstruosas. Sin embargo, como se bañaban frente al paseo, desde lo alto de la terraza, los caballeros, armados de gemelos de teatro, asistían al ir y venir de las bañistas, a veces bastante largo, de la playa al mar y del mar a la playa, donde se quitaban $y$ volvían a poner los trajes de calle." ${ }^{\text {158 }}$

\footnotetext{
${ }^{157}$ Sintes Pros, J. (1980) Pág. 10

${ }^{158}$ Sintes Pros, J. (1980) Pág. 11.
} 


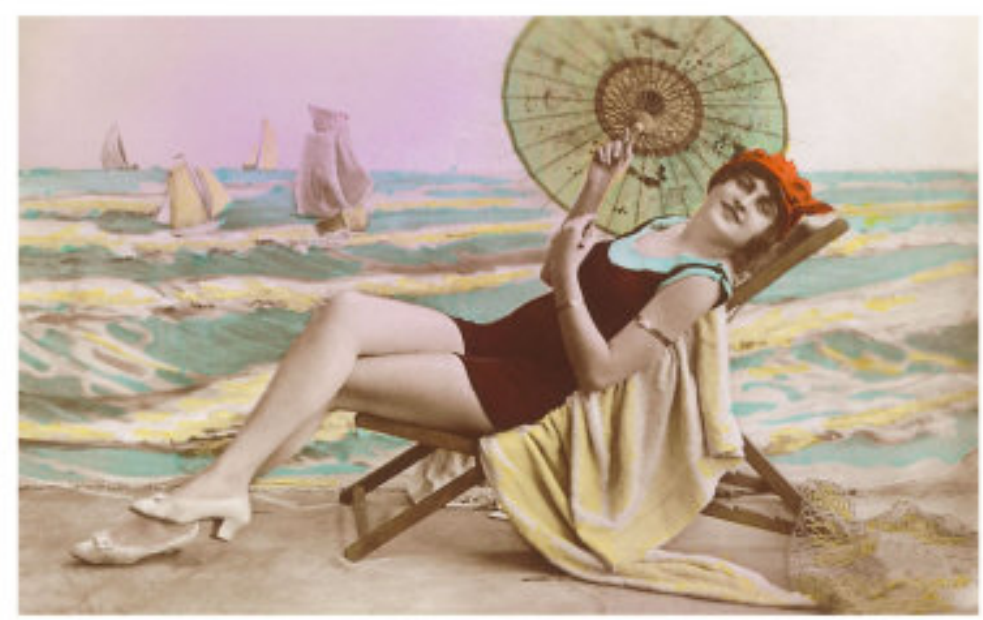

quieroeso.blogspot.com/2008_12_01_archive.html

En el grabado que se presenta a continuación, se pueden observar otros modelos de traje de baño femenino del siglo XIX, compuesto por una parte de arriba ajustada como el cuerpo de un vestido, con cuello y mangas que llegaban hasta el codo, a esto, se sumaba una falda que llegaba hasta las rodillas bajo la que se portaba un pantalón. 


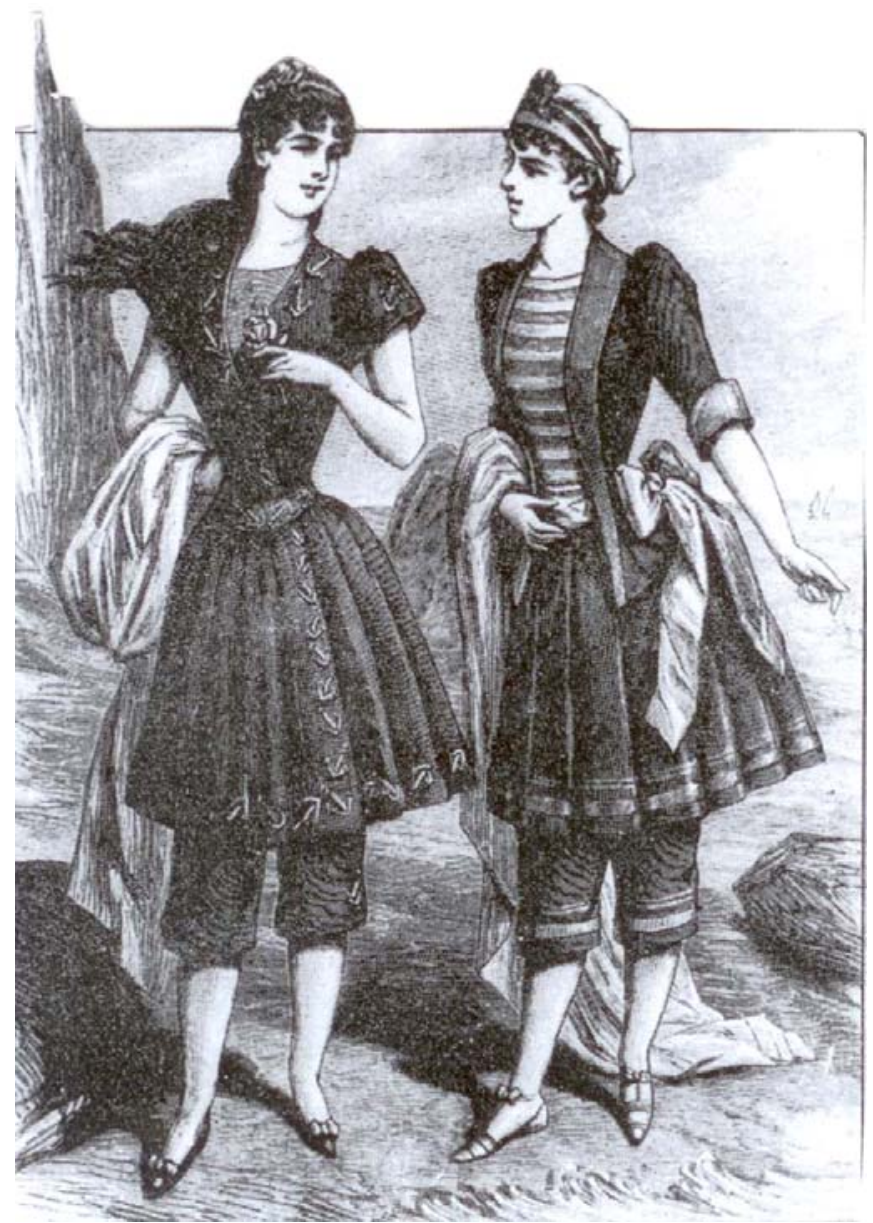

Ilustración 48 Grabado. La moda y el baño en: Vidal Corella V. 05/08/1984 "Antiguas temporadas de baño: La Valencia de otros tiempos" Artículo publicado en: El Dominical Pág. 27

Los trajes de baño, estaban confeccionados con telas de iguales características que los vestidos que usaban normalmente por lo que al contacto con el agua, el traje de baño se volvía pesado e incluso peligroso a la hora de flotar en el agua ya que no existía mucha diferencia entre bañarse con este atuendo diseñado para el baño o con uno de los vestidos que utilizaban para la vida diaria. 
"La alta sociedad fue arrebatada por la fiebre de las novedades, se inflamó con los últimos hallazgos, imitó cada vez más las modas en vigor en Italia, en España, en Francia, y manifestó un verdadero esnobismo por todo lo que era diferente y extranjero. Con la moda aparece una de las primeras manifestaciones de una relación social que encarna un nuevo tiempo legítimo y una pasión propia de Occidente, la de los $<<$ moderno>>. La excelencia social: hay que seguir $<<$ lo que rehace $<<y$ es nuevo, y adoptar los últimos cambios del momento. El presente se impone como eje temporal que rige un aspecto superficial pero prestigioso de la vida de las elites." ${ }^{159}$

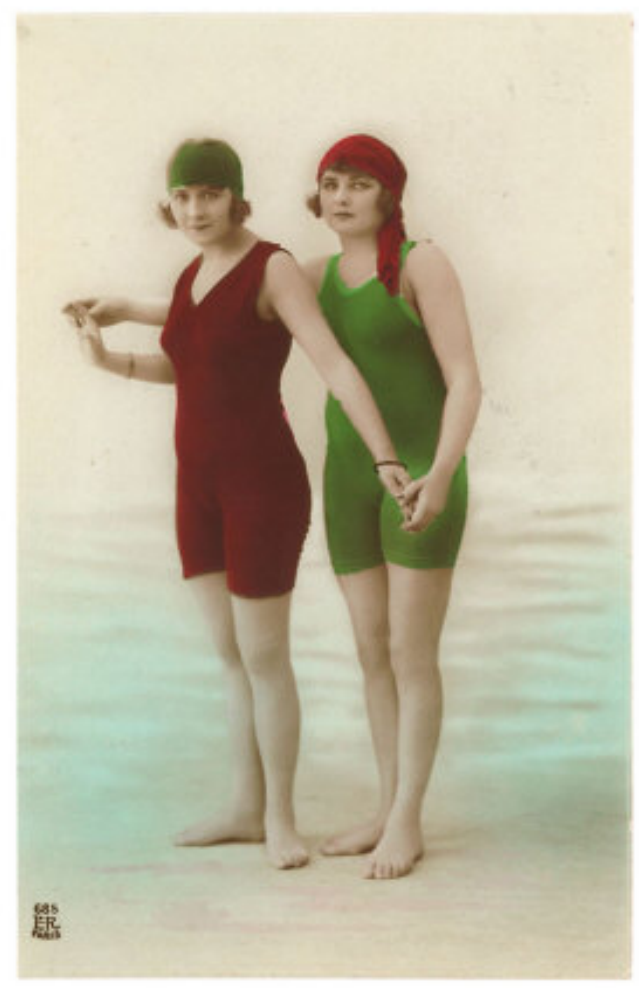

http://img.allposters.com/6/LRG/10/1002/HW2W000Z.jpg

\footnotetext{
${ }^{159}$ Lipovetsky, G. . (2004) .Pág. 35
} 
En 1920 nace el traje de baño de una sola pieza elaborada con un tejido pensado para la inmersión en el agua. Se trataba de un traje ceñido que mantenía la falda y las mangas. ${ }^{160}$

En 1930 aparece el primer traje de baño compuesto por dos piezas que incorpora los tirantes anchos como elemento innovador.

En España durante la dictadura del General Franco, la moda regresa al recato:

El Padre Laburu, intentó poner, con la colaboración de la <<Sección Femenina >>... un recatado modelo de traje de baño que el público, socarronamente bautizó con el nombre de $<<$ traje Padre Laburu>>.

En 1946 nace el "Bikini" una atrevida prenda que fue objeto de críticas por lo escandaloso del modelo que pasaba a mostrar gran parte del cuerpo femenino en playas y casas de baño. ${ }^{161}$

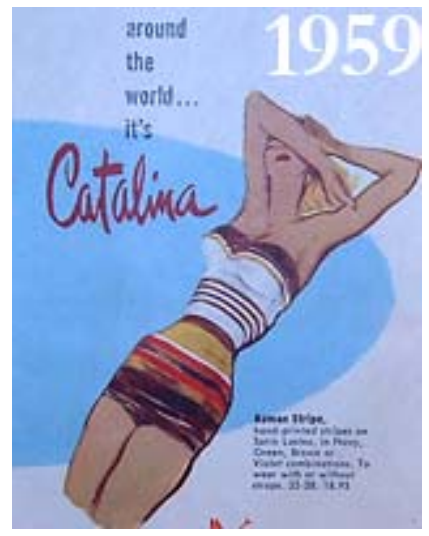

http://chileancharm.com/1952/SWIMSUITS.htm

"Los bañadores se tornaron más reveladores en los años 1930. Desde la adopción de los modelos sin espalda o con delgados tirantes,

\footnotetext{
${ }^{160}$ http://www.familia.cl/cultura/historia_trajedeba\%F1o/historia.htm

${ }^{161} \mathrm{http} / / /$ www.cienciapopular.com/n/Historia_y_Arqueologia/Bikini/Bikini.php
} 
el atuendo de las mujeres progresó rápidamente hasta las dos piezas con cuello y pantalón corto. El bikini fue el paso siguiente y, a través de su nombre, la moda ha quedado unida para siempre con el comienzo de la era nuclear.

El 1 de julio de 1946, los Estados Unidos iniciaron las pruebas nucleares en tiempo de paz dejando caer una bomba atómica en el archipiélago de las Marshall, en el océano Pacífico, exactamente en el atolón de Bikini. Esta bomba, similar a las que un año antes habían devastado Hiroshima y Nagasaki, llamó la atención de todos los medios de comunicación mundiales.

"En París, el diseñador de modas Louis Réard se disponía a presentar un osado bañador de dos piezas que aún carecía de nombre. Los periódicos multiplicaban los detalles acerca de la explosión de la bomba y Réard, deseando que su bañador fuera objeto de interés para los medios de comunicación, y convencido de que su modelo era en sí explosivo, seleccionó aquel nombre entonces tan repetido."162

El bañador se convierte en prenda de desfile en los certámenes de belleza.

"En la primera década del Miss Universo, las postulantes llevaron mallas de baño de colores caramelo, en las gama de rosas, celestes, amarillos, lilas y turquesas. Junto con el modelo, se crearon unas chaquetas livianas o "salidas de baño" de media manga y ajustadas en la cintura, que fueron usadas en algunas presentaciones oficiales. Primera década del Miss Universo, las postulantes llevaron mallas de baño de colores caramelo, en las gama de rosas, celestes, amarillos, lilas y turquesas. Junto con el modelo, se crearon unas chaquetas

\footnotetext{
${ }^{162}$ http://www.tinet.cat/ vne/indumentaria_12.htm
} 
livianas o "salidas de baño" de media manga y ajustadas en la cintura, que fueron usadas en algunas presentaciones oficiales ${ }^{163}$

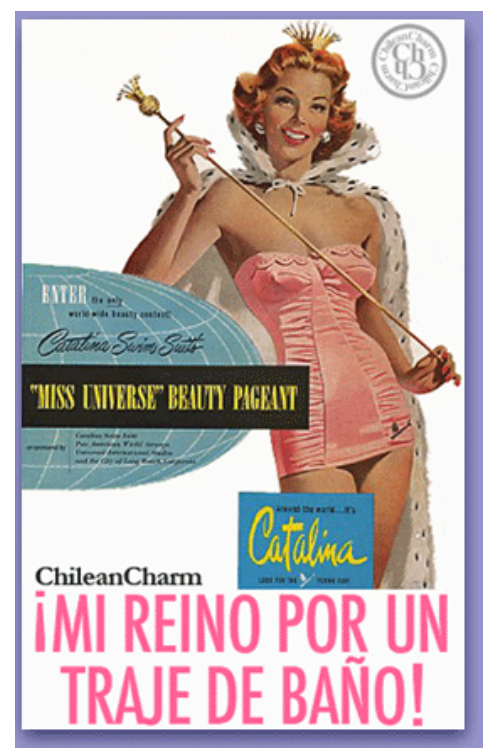

http://chileancharm.com/1952/SWIMSUITS.htm

En 1961 la invención de un nuevo tejido revoluciona la moda de baño, nace la Lycra, una fibra textil caracterizada por su elasticidad, secado rápido y adaptación al cuerpo.

En el contexto actual continúan los gustos hídricos latentes, se puede afirmar que el gusto por el baño está de moda, ha pasado a lo largo de la historia, de ser una necesidad higiénica a convertirse en un delicioso placer al que siempre que uno se lo pueda permitir en términos económicos es difícil resistirse. La oferta lúdica y salutífera que se ofrece en los centros dedicados al baño recorre todo el arco de las

\footnotetext{
${ }^{163}$ http://chileancharm.com/1952/SWIMSUITS.htm
} 
necesidades gustos y caprichos que el individuo quiera aplicar a su propio cuerpo. Se podría decir que estamos en el nuevo Siglo de Oro de los centros de baño, que hoy nos muestran su cara más renovada y nos ofrecen el mejor servicio de la mano de la tecnología más innovadora, nacen nuevos espacios dedicados a la búsqueda del placer por el agua y en algunos casos como es de los centros hoteleros habilitan nuevas instalaciones para dar paso a una moda que promete en términos económico.

Estamos ante una nueva cultura del agua que es valorada por sus usos y virtudes; en la actualidad todos los lugares dedicados al baño están utilizando un lenguaje hídrico, "en la cresta de la ola" y representan una buena opción para pasar unas horas, unos días o unas vacaciones, rural o urbano, todo depende de la prisa o del tiempo de ocio del que se pueda disponer, el agua hace el resto.

Hoteles con spa, balnearios de agua mineromedicinal, balnearios urbanos, curhoteles, centros de Talasoterapia, clubs termales son en definitiva centros lúdicos pertenecientes a un sector en alza y orientados a una clientela en aumento cada vez más exigente y cada vez más fidelizada.

Las nuevas formas de disfrutar el tiempo de ocio junto con las nuevas formas de turismo marcan las nuevas tendencias vacacionales, que buscan alternativas entre los nuevos destinos turísticos en su mayor parte lugares con encanto en plena naturaleza.

El gusto por el baño público, tal y como se ha ido viendo a lo largo de esta investigación, no es algo nuevo, las nuevas tendencias beben de la fuente de las antiguas tradiciones, la historia es testigo de modas y tendencias que hicieron vestir con las mejores galas a los centros de baño de la época; así, el traje de baño se ha convertido en una pieza indispensable que ocupa fondo de armario y de maleta, pendiente de la variada oferta hídrica que se pueda encontrar en la mayor parte de los hoteles a la hora de viajar.

Objeto de pasarelas y diseñado por grandes firmas, el traje de baño se ha ido convirtiendo en una pieza sofisticada donde el tejido y el color juegan con las formas para dar paso a la comodidad y la elegancia. 
Atrás quedaron las mangas largas, y los pantalones largos con sobrefalda, para dar paso a unas prendas exiguas que se limitan a cubrir en definitiva las partes más intimas.

La imagen que se presenta a continuación sirve de ejemplo de moda de baño actual, una prenda diseñada para favorecer la libertad de movimiento en el agua. El paisaje en las playas y casas de baño cambia con la imagen de estos trajes y se adapta a los nuevos tiempos enfrentándose de modo distinto a un mismo uso del agua en el baño.

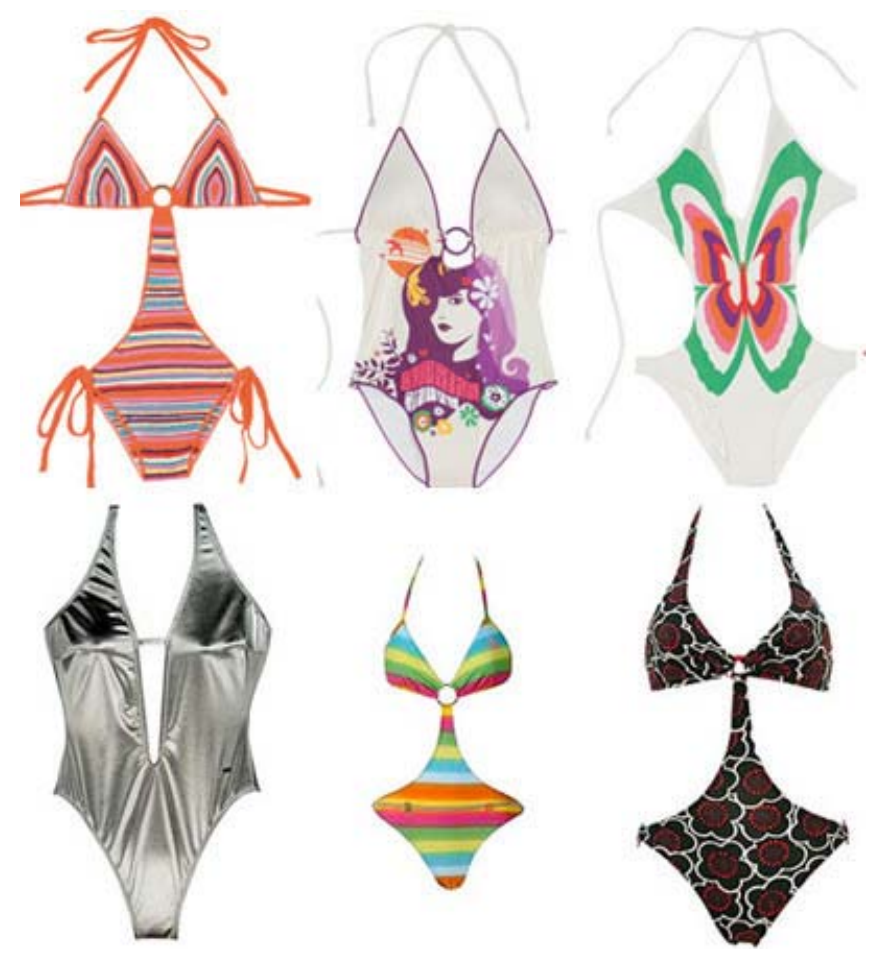

http://img.trendencias.com/2008/07/triquini1.jpg 


\section{3) Ellbañoenellate}

El baño en el arte supone una paradoja tras la lectura del epígrafe anterior. La desnudez prima sobre el vestido, persiste una moda a lo largo de las épocas pictóricas "El baño" una moda que no entiende de atuendos.

\section{Sorolla:}

(Valencia, 1836- Cercedilla 1923) Joaquín Sorolla, influido por el mar mediterráneo de su tierra natal, supo reflejar en el lienzo el baño de una forma espectacular, sus imágenes impresionistas, están llenas de la luz y el color de la naturaleza viva.

Sorolla reflejaba la realidad del baño de mar, representado la imagen social, el tiempo de ocio y disfrute en compañía, sus cuadros reflejan el baño compartido.

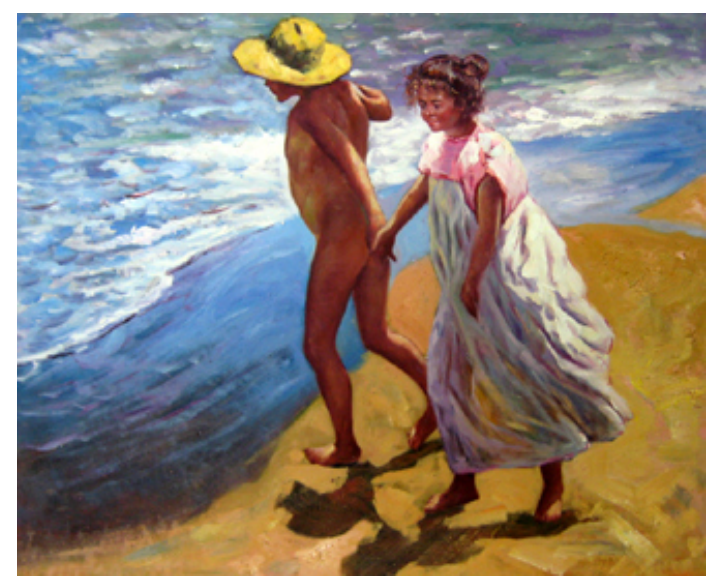

Ilustración 49 El Agua 


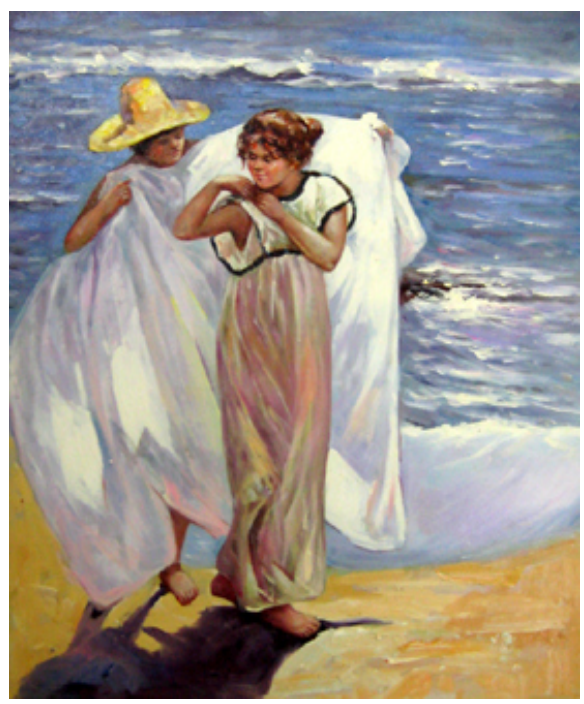

Ilustración 52 Al salir del baño

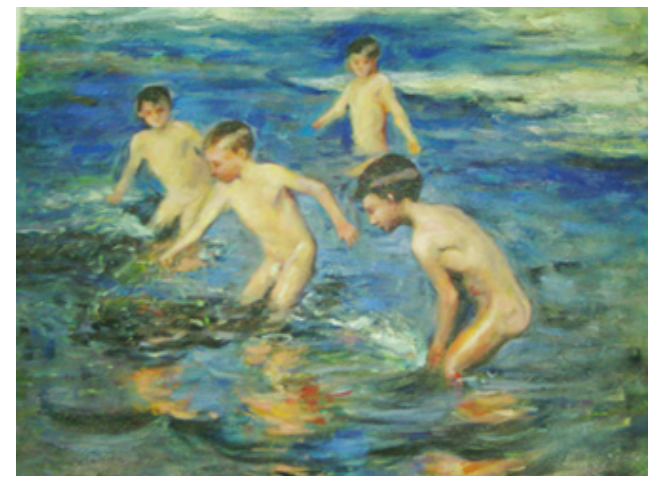

Ilustración 51 El Baño

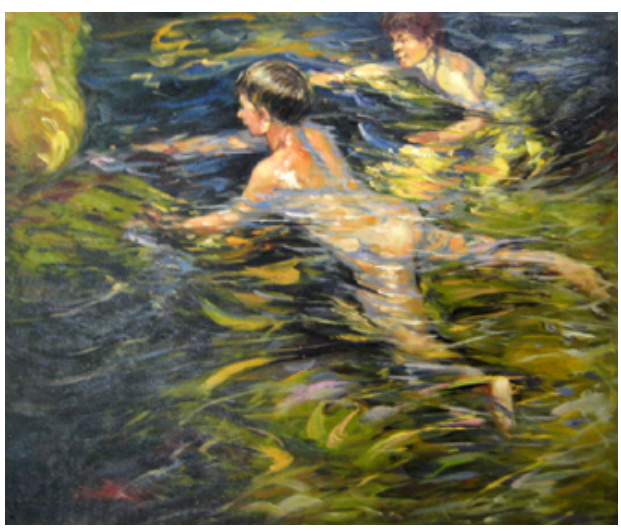

Ilustración 50 Nadadores 


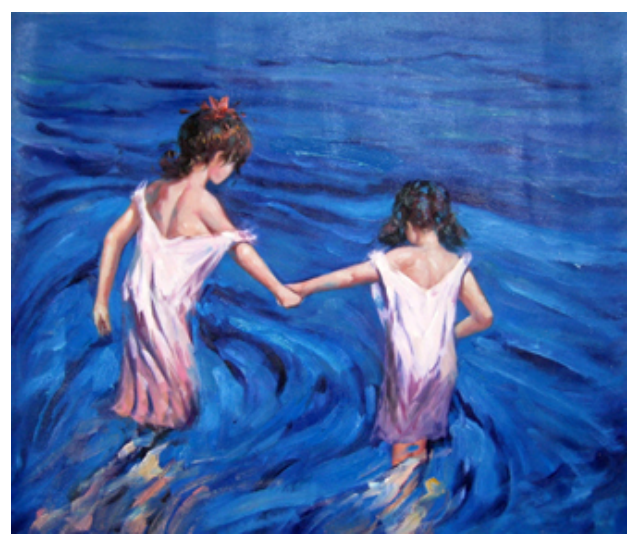

Ilustración 53 Niñas en el Mar

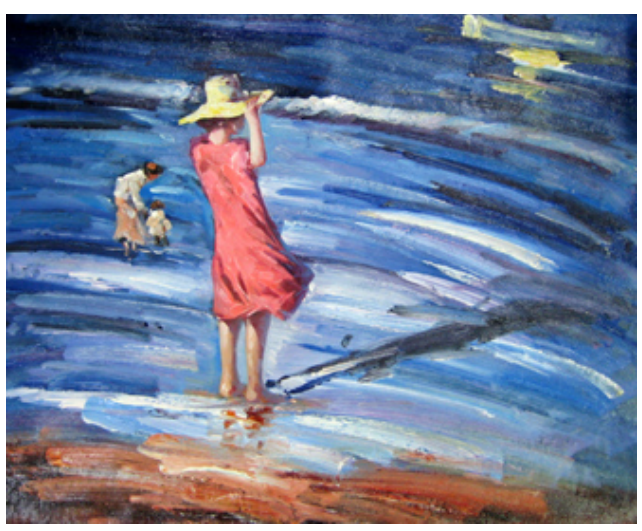

Ilustración 54 Niños en la Playa

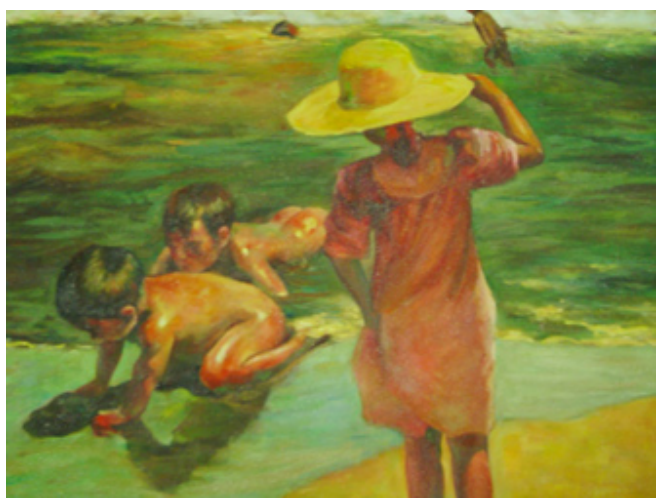

Ilustración 55 Niños a la Orilla del Mar 


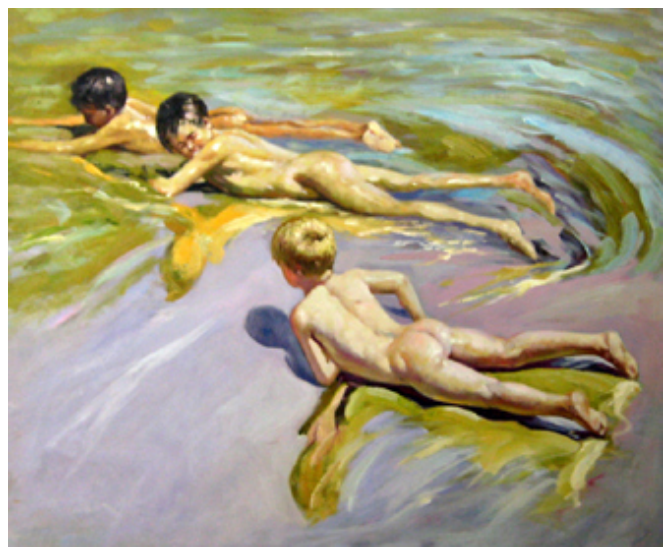

Ilustración 56 Niños Desnudos en la Playa

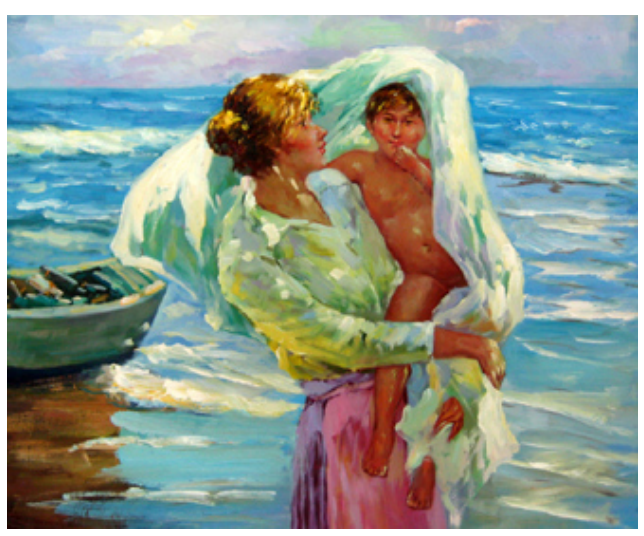

Ilustración 57 Saliendo del Baño

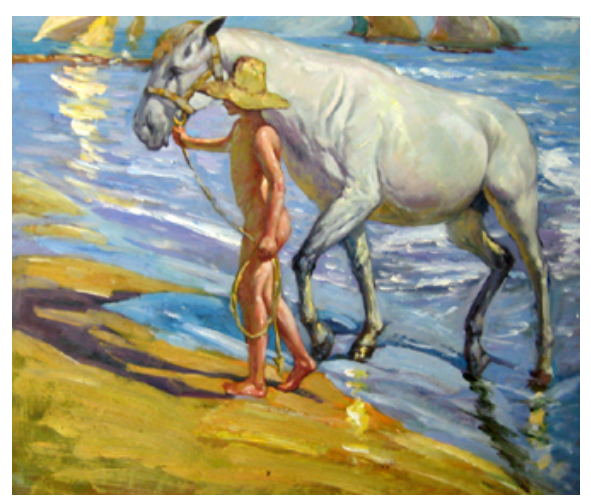

Ilustración 58 El baño del Caballo 
Otros muchos pintores se han inspirado en el baño para expresar su arte, ambientes de interior lejos del mar y la luz de Sorolla. A continuación se presenta una muestra de la representación clásica del baño. Representación del baño en la pintura clásica:

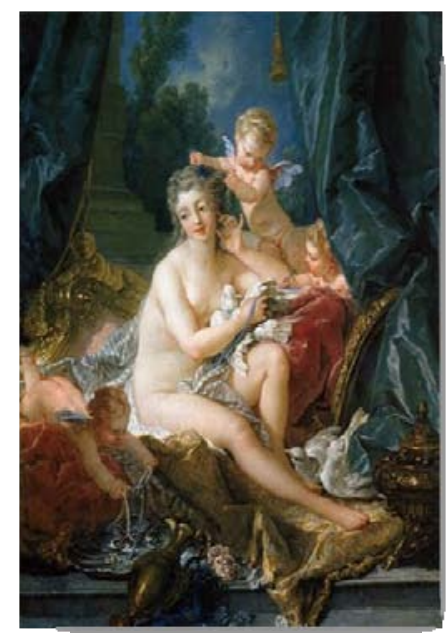

Ilustración 59 El Baño de Venus. De François Boucher (1751)

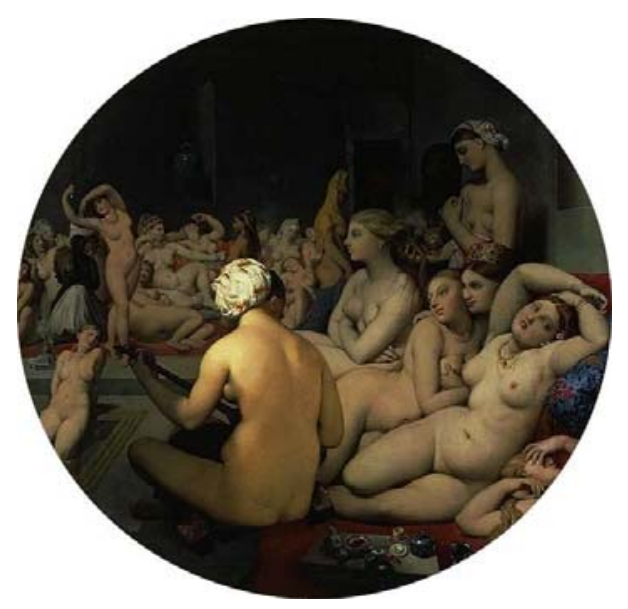

Ilustración 60 EL BAÑO TURCO, DE: Ingres (acusado de pornográfico en su época 
Botero también se inspiró en el baño para representar parte de su obra
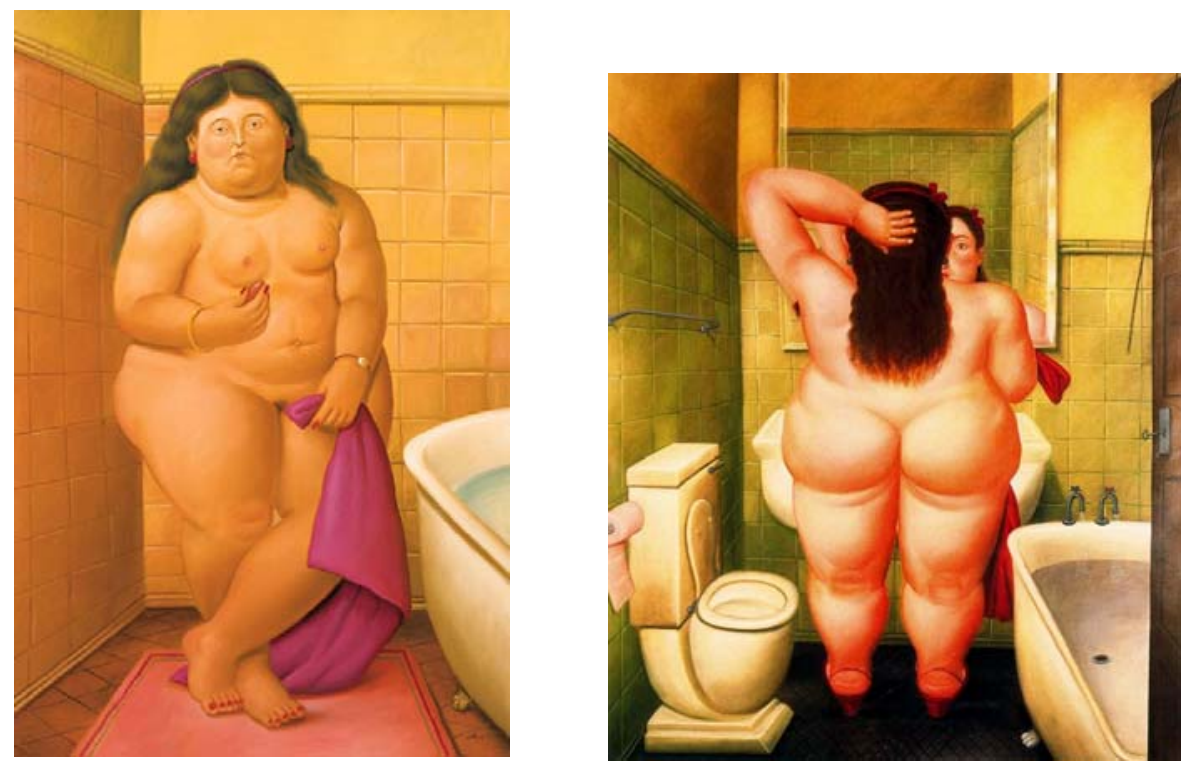

La mayor parte de las representaciones del baño de interior tanto de la época clásica como de la actual tienen como imagen humana a la mujer; Botero contempla también la imagen masculina del baño.

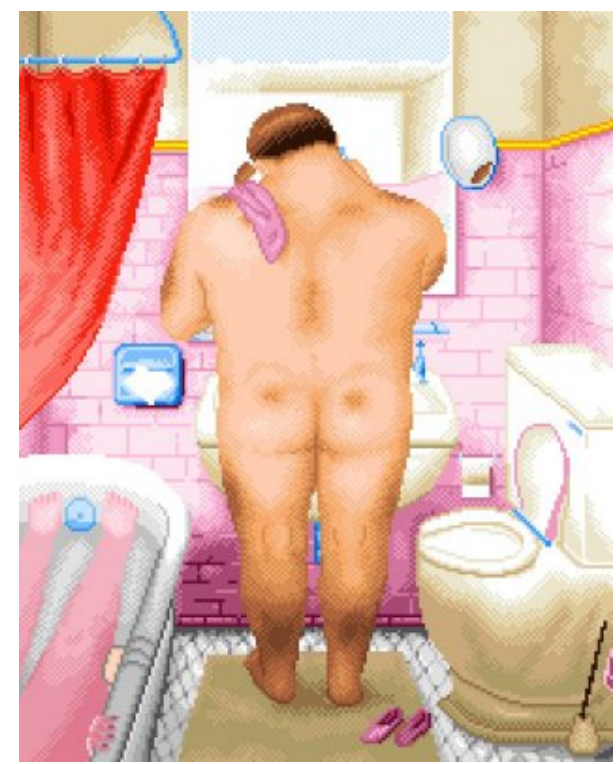




\subsection{Pintura y Filatelia homenajean al baño.}

A continuación se presenta una imagen tomada para este estudio; corresponde a una recopilación de sellos pertenecientes a una colección privada, cuyo tema es el baño en el arte.

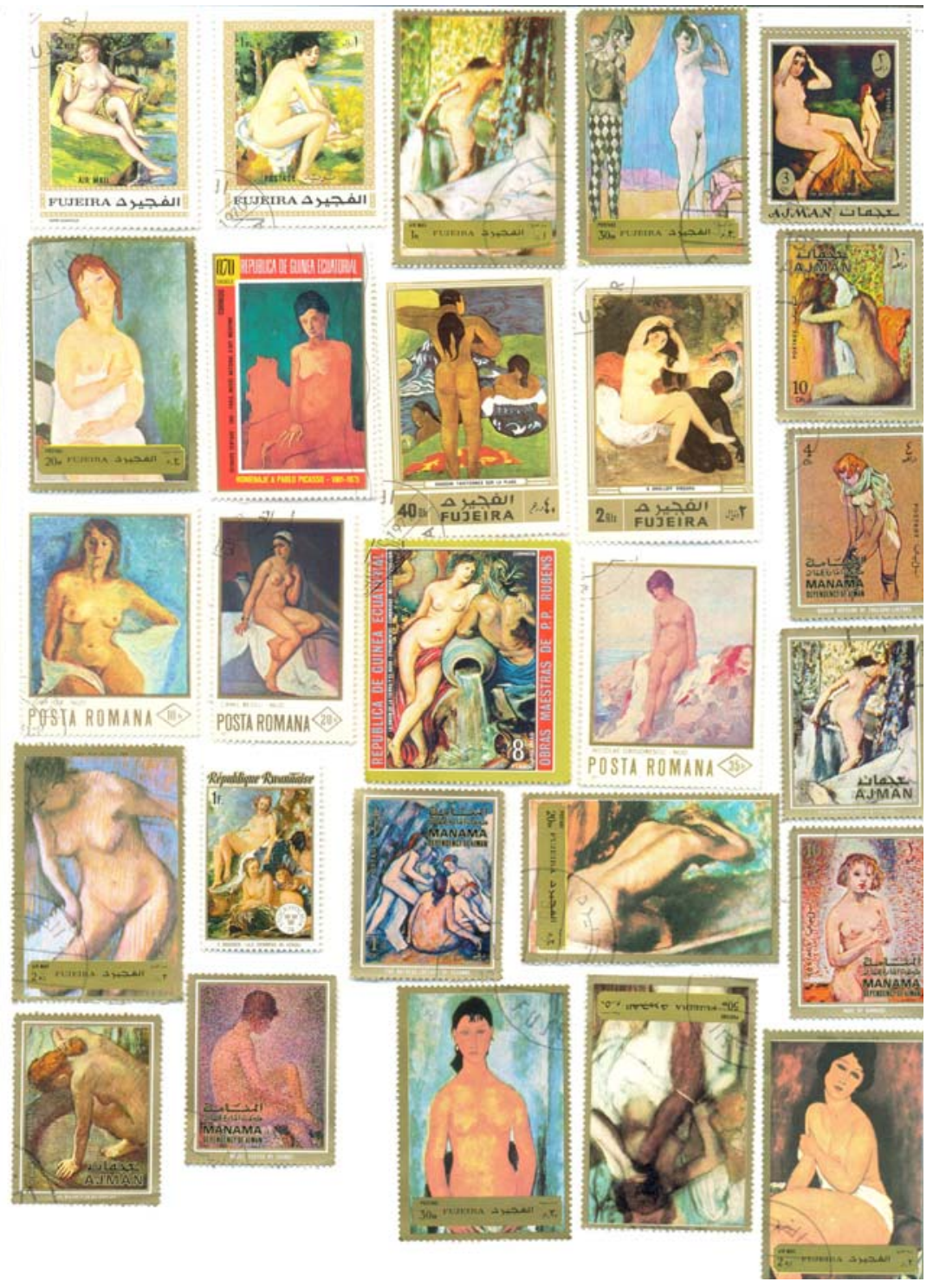




\section{Ellbañoen lgiliteraturiag}

El tema del baño ha sido recurrente en la literatura, los balnearios antiguos están dotados de cierto ambiente enigmático que sirve de escenario perfecto para la ambientación de novelas, en ellos caben historias que pudieron tener lugar entre sus paredes y al rumor de sus aguas.

Esta cita que se presenta a continuación, ha sido extraída del libro titulado "El Balneario" (figura...), escrito por Carmen Martín Gaite en el año 1954 y que forma parte de una recopilación que incluye otros 16 relatos.

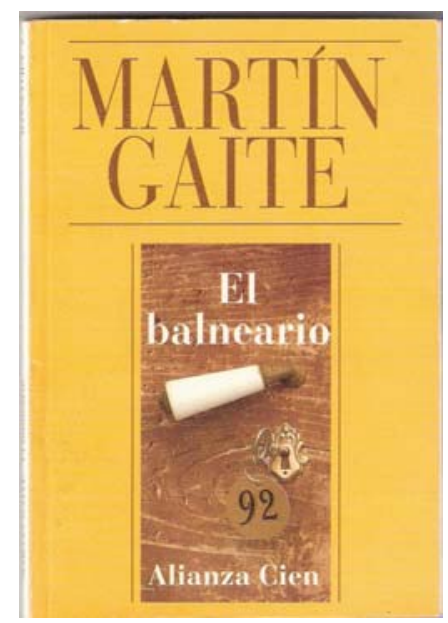

"Al balneario se entraba por un paseo de castaños de indias, bordeado de hortensias y boj, paralelo al río, que quedaba a la izquierda"164

\footnotetext{
${ }^{164}$ Martín Gaite, C. (1993) “El Balneario” Alianza Ed. S. A. Madrid Pág. 17
} 
El balneario" se titula también la obra de Manuel Vázquez Montalbán

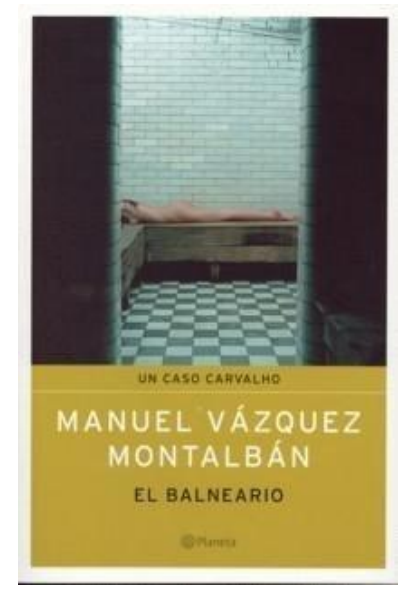

"Sólo he venido a purificarme durante algunos días. Dos semanas de purificación me permitirán otros diez años de pecado"165

Herman Hesse ya en su madurez escribió en el año 1953, una obra titulada "En el Balneario" esta obra se inspira en el balneario de Baden.

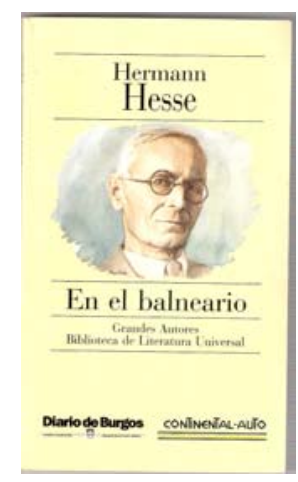

${ }^{165}$ Vázquez Montalbán, M. (1986) “El Balneario” Ed. Planeta. Madrid. Pág.9 
Hesse en el prólogo de su libro dice que son los achaques de la edad, la gota, el reumatismo y la ciática, las dolencias que le conducen al balneario de Baden.

"El día en el balneario de Baden tiene para mí una ventaja sobre los días de la vida ordinaria: durante el tratamiento, todos los días empiezan con un deber importante y primordial, y este deber es fácil e incluso agradable de cumplir. Me refiero al baño". ${ }^{166}$

En el año 1957, es Marínina Alexandra, la autora de otra obra enmarcada en el entorno Balneario, la obra se titula "Los Crímenes del Balneario".

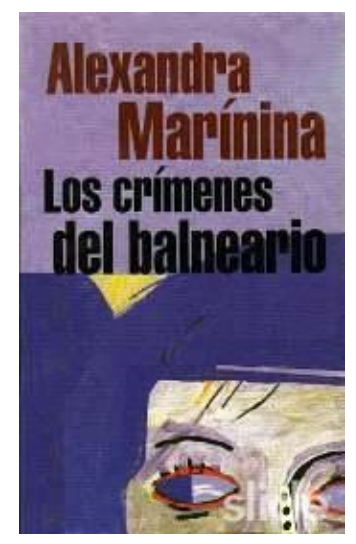

Aunque no coronando la obra formando parte del título, el balneario ha estado presente en escenas y capítulos en los que los protagonistas disfrutaban del deleite de sus aguas, ejemplo de este tipo de obras en las que se dedica una páginas al baño termal, está el libro titulado "El Mozárabe" escrito por Jesús Sánchez Adalid.

\footnotetext{
${ }^{166}$ Hesse, H. (1993) “En el Balneario” Ed.. Diario de Burgos, S.A.
} 
La periodista Teresa Viejo, escribe "La memoria del Agua", una novela de corte histórica ambientada en el balneario "La Isabela" una historia en la que se pasa de la época dorada de los balnearios a las miserias de la Guerra Civil española, del lujo y esplendor de los balnearios del siglo XIX a la decadencia del termalismo en 1936.

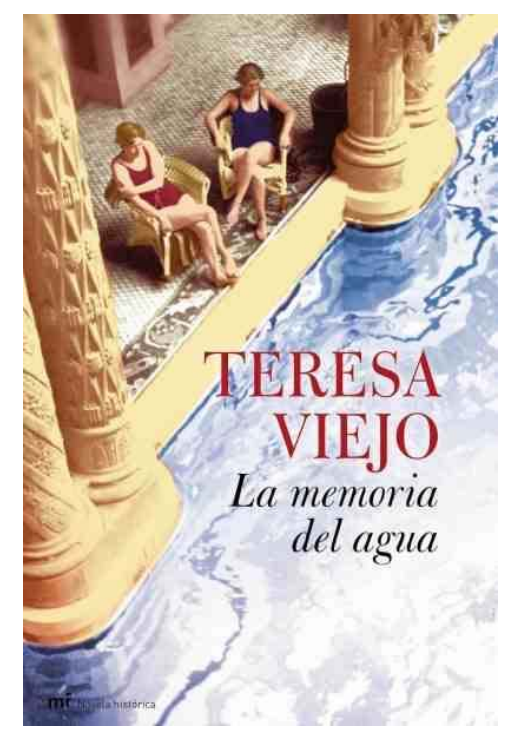




\section{Cápitululo VII}

\section{Función social del baño}

El agüista y el usuario del balneario son individuos profundamente sociales que necesitan ocupar el día y la noche, alimentarse, vestirse, trasladarse y divertirse....Balnearios, hoteles, paseos parques, quioscos, galerías de baños, manantiales...han sido durante muchos años los escenarios de una forma de entender la vida.

(Sánchez Ferré J. 2000) 


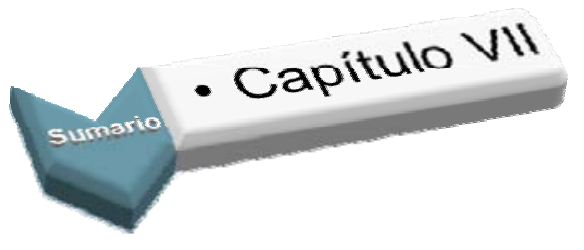

\section{Páginas}

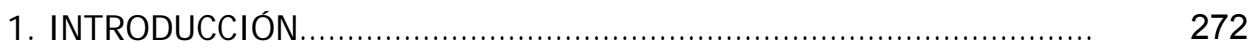

2. FUNCIÓN SOCIAL DEL BAÑO _........................................................ 273

2.1. El baño entiende de clases sociales..................................... 274

3. BAÑO PÚBLICO Y BAÑO PRIVADO EN LA ÉPOCA ROMANA................. 276

3.1. El baño como centro de la vida social .............................. 277

3.2. El baño y la lujuria en las termas ................................... 285

4. BAÑO PÚBLICO Y BAÑO PRIVADO EN EL HAMMAM ........................... 288

4.1. El Baño y la lujuria en el hammam.................................... 290

5. RELACIONES SOCIALES A TRAVÉS DEL BAÑO: De la antigüedad

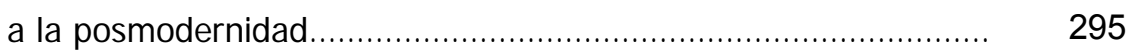




\section{1.: Introdicción}

El baño ejerce una función social y a su vez el baño es testigo de un ambiente en el que las relaciones sociales se dan por la necesidad de compartir espacios creados y diseñados para el uso común.

La estancia en un centro de baño lleva consigo espacios de tiempo donde el baño no es el protagonista, aunque sea el motivo de asistencia, estos espacios temporales están dedicados al descanso, la alimentación y el disfrute, muchos de ellos llevados a cabo en espacios físicos compartidos con el resto de usuarios asistentes al balneario; esto da lugar a que en algunos casos las relaciones interpersonales fluyan.

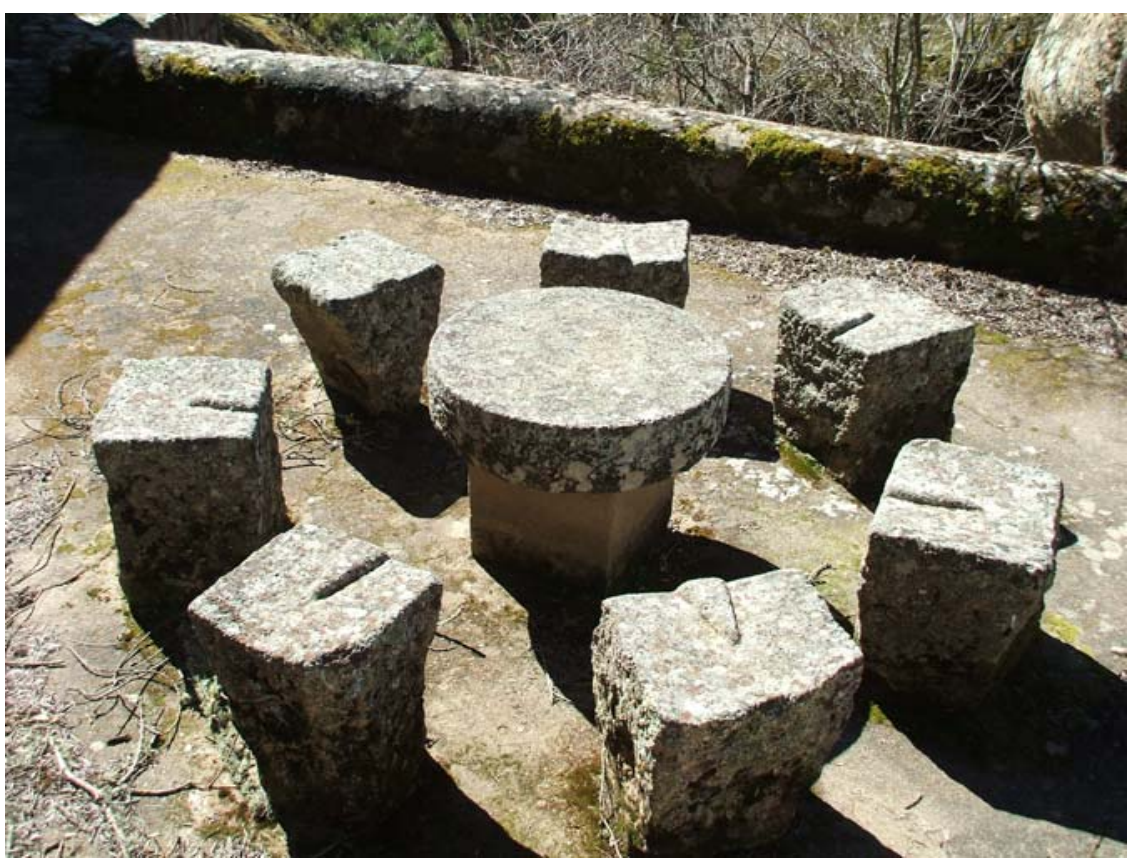

Ilustración 61 Jardines del Balneario de Retortillo (Salamanca) 


\section{Función sacial del baño}

El baño público cumple una función eminentemente social. Hay que tener presente a Aristóteles cuando afirmaba:"El hombre es un animal social" 167 esto se manifiesta claramente en el uso del baño.

El bañista que acude a un centro balneario al que traslada su residencia durante su estancia, el baño es el lugar en el que descansa, duerme, come, se baña, pasea y se relaciona de una u otra forma, como ya iremos viendo a lo largo de este capítulo.

La arquitectura balnearia siempre ha tenido en cuenta esta condición social del hombre, orientando sus infraestructuras al ocio y al disfrute, creando amplias zonas de descanso, cafeterías, jardines, gimnasios, salones de baile, zonas de juego etc., instalaciones que no distan mucho en esencia de las que utilizaban griegos y romanos en la época clásica, por el contrario, la forma de relacionarse en los centros de baño sí ha sido distinta según la época y según el país en el que se den, los hábitos, las costumbres y las formas de comportamiento y de relación difieren de una cultura a otra como podremos ir observando en este capítulo.

Una variable importante a la hora de hablar de relaciones sociales en el baño, es la edad del agüista, y la compañía con la que acuda al balneario.

Los viajes a baños termales son para la tercera edad, además de un placer saludable, una oportunidad para ampliar las relaciones interpersonales.

El Imserso pone en marcha una iniciativa "juntos en navidad" para que los mayores pasen las fechas señaladas de la navidad acompañados.

"La típica estampa navideña con la familia reunida alrededor de una mesa puede resultar idílica, pero en muchas ocasiones, no es real, muchas personas tienen que pasar las navidades solas y esta situación se acentúa según se van cumpliendo años.

${ }^{167}$ http://www.webdianoia.com/aristoteles/aristoteles_polis.htm 
En España, alrededor de un millón y medio, de los que ya han sobrepasado los 65 años, viven solos y desde las asociaciones se solicitan actuaciones que mitiguen el sentimiento de soledad; por eso, el Imserso ha puesto en marcha 'Juntos en Navidad', un proyecto ligado al programa de 'Vacaciones y Balnearios', que todos los años oferta la administración.

Desde el Imserso se señala que con 'Juntos en Navidad' se pretende que las personas mayores «pasen las fiestas navideñas en compañía de otras, en el entorno de un viaje turístico a lugares cálidos de la costa o de estancia en establecimientos termales, combinando el atractivo del propio viaje con el desarrollo de un programa de actividades de interrelación personal con el objetivo de crear vínculos de relación y evitar la situación de soledad». Además de las personas que vivan solas, los matrimonios que no tengan compañía en casa también pueden acceder a este programa." $^{168}$.

\subsection{El Baño Entiende de Clases Sociales}

El baño entendido desde el disfrute en centros balnearios o casas de baños, ha tenido a lo largo de la historia de este uso desde que comienza a ser una actividad con fines no exclusivamente terapéuticos sino de veraneo, una preferencia por las clases acomodadas, así, durante el siglo XIX, la clientela que acude a los balnearios no tiene como único objetivo la cura, sí en cambio el disfrute de unas vacaciones en unos espacios creados para el ocio de grupos sociales acomodados.

$M^{a}$ Azucena San Pedro en su libro titulado "Balneario de Puente Viesgo 1796/1936" nos describe los cambios de reorientación al ámbito turístico, sufrido por los balnearios, lo que llevaba implícita una selección casi natural de la clientela. 
"La moda balnearia que llega de Europa renovará los lugares tradicionales de cura termal, convirtiéndolos en centros de veraneo y relación social para las clases más acomodadas de la sociedad mientras que las clases populares, asiduos clientes hasta entonces, ven disminuir hasta desaparecer en muchos casos, los espacios a los que se reduce."

Esta clientela, por ser más acaudalada podía permitirse viajar, las distancias no suponían un obstáculo para el objeto de su deseo, así mismo, su poder adquisitivo les permitía gastar alquilando las lujosas habitaciones de hoteles o grandes villas y chalets de la zona aledaña al centro termal. El fenómeno de las vacaciones se pone de moda en las clases influyentes convirtiéndose los balnearios en centro de vacaciones para las élites de la época. 


\section{Baño público y baño privado en la época romana}

"Urbs Roma; Vida y costumbre de los romanos", se titula el libro de José Guillen; en él dedica un capítulo a la vida privada; dentro de este capítulo dedica el punto cuarto a los baños.

"Los Romanos eran muy limpios en el aseo de sus personas. Se lavaban todos los días la cara, los brazos y las piernas, y tomaban un baño completo cada nueve días." ${ }^{169}$

Este autor distingue en su obra entre distintos tipos de baño; por un lado, los baños domésticos o privados situados en la casas (Balneum*), por otro lado, los baños públicos construidos por empresas particulares (balnea meritoria*) y un tercer tipo, los construidos por ciudadanos poderosos y Emperadores (Termas*).

"En las casas había su baño doméstico o privado, que, según Varrón:<<Por ello cada cual tenía en su casa una pieza donde lavarse que llamaron balneum; a pesar de que los antiguos no la llamaban balneum sino lauatrinam>> "Además de éstos, había baños públicos, abiertos para todos, unos contraídos por empresas particulares para explotarlos (balnea meritoria) y otros construidos para el pueblo por ciudadanos ricos y poderosos, y luego por los Emperadores, estos se llamaban termas". ${ }^{170}$

\footnotetext{
${ }^{169}$ Seneca Benef., 27, 6. En Guillen, J. (1977) “URBS ROMA Vida y costumbres de los romanos”. Ed. Sígueme. Salamanca. Pág. 329.

${ }^{170}$ Guillen, J. (1977) Pág. 329/331
} 


\subsection{El baño como centro de la vida social}

Con los magníficos recintos de los baños, la higiene llegó al pueblo incorporándose a la vida cotidiana. Se acudía a las termas para tomar los baños, pero también para ungirse con aceites perfumados, recibir masajes, hacer ejercicio y tomar algún refrigerio, al tiempo que se fomentaban las relaciones sociales.

Serra Ráfols en su libro titulado "La vida en España en la Época Romana" y dentro del capítulo "La distribución del día" encontramos un epígrafe dedicado al "Empleo de la Tarde". En él se describen las actividades a las que los romanos dedicaban estas horas del día, deteniéndose en el baño y las termas. Ráfols sostiene, que en Roma hubo una intensa vida social, que eran frecuentes las comidas multitudinarias, las reuniones en casas de campo, pero el centro de la vida social más que en las casas particulares, en los palacios o en los edificios dedicados a espectáculos y en el foro, estaba en las termas.

"Las termas, en la vida social ocuparon un lugar semejante al de nuestros casinos, clubes y sociedades recreativas y aun a los cafés en las ciudades del mediodía. La gente, a las termas iba tanto o más que para bañarse, para conversar, discutir, censurar, comadrear, y para todas las del día para muchas personas que no necesitan de aquel para subvenir a sus necesidades. Y cuando más romanizada era una ciudad mayor importancia tomaron estos edificios." ${ }^{171}$

\footnotetext{
*Balneun: baños domésticos situados en casas particulares.

* Balnea meritoria : Baños públicos construidos por empresas particulares

*Termas: las construidas por los Emperadores

${ }^{171}$ Serra Ráfols, J de C. (1944) “La Vida en España en la Época Romana” Ed. Alberto Martín. Barcelona. Pág. 139

* SPA: Salus per Aquam” (Salud por medio del agua) Un Spa dispone de un espacio de bienestar donde se aplican los tratamientos que se realizan con agua. El Spa busca en mayor grado conseguir relax, vitalidad y salud.
} 
Una de las grandes pasiones de los romanos, era el disfrute de la vida en todas sus facetas, y entre las formas de llevar a cabo esa máxima, se encontraban los placeres corporales derivados del baño, un culto al cuerpo basado en una cultura del agua que aglutinaba en torno a ella otros placeres lúdicos y sociales que se plasmaban en la construcción de numerosas termas, cuyos vestigios son testimonio de esa pasión romana, que sirven de modelo en la actualidad para la ambientación de muchos baños, fundamentalmente baños públicos urbanos o SPA*, que reproducen la idea de los baños romanos, con sus mosaicos y pilas de mármol recreando una época de esplendor termal y pretendiendo transportar en el tiempo al agüista.

El uso del agua en las termas, era un uso social compartido, basado en el baño como tónico relajante corporal y en las relaciones sociales, que encontraban en los "balnea" el lugar idóneo para llevarse a cabo.

Es importante reseñar la distinción que Ráfols hace, entre Termas destinadas al baño por placer y termas salutíferas. Con referencia a estas últimas, dice:

"Muy diferente es el caso de las termas salutíferas, que, extendidas por todos los rincones del Imperio, aprovecharon las aguas termales $y$ minerales que manaban en puntos tan numerosos del antiguo mundo romano. Puede decirse que no existe manantial en el que no hayan sido descubiertos restos de utilización en tiempo de los romanos. En muchos casos ésta debía ser incluso más antigua, aunque su aprovechamiento debía hacerse de una manera primitiva. Los romanos elevaron en estos lugares edificios más o menos suntuosos, pero siempre suficientes". ${ }^{172}$

${ }^{172}$ Serra Ráfols, Pág. 143 
Otra de las grandes preocupaciones de la cultura romana, era el cultivo del cuerpo y de la mente, la necesidad de preparación física y mental, gustarse a sí mismo y gustar al público estando en perfectas condiciones físicas y siendo un buen orador, por lo que las termas eran el lugar perfecto para la preparación total del cuerpo, ya que por un lado conseguían el beneficio del relax y el descanso que procuraban la serenidad necesaria para enfrentarse a la vida cotidiana, tras la preparación física que con anterioridad habían tenido la posibilidad de adquirir en los gimnasios, que formaban parte de la dotación termal; por otro lado, tras el baño comunitario se fomentaban las relaciones sociales, la posibilidad de disfrutar del resto de servicios ofrecidos a los agüistas como eran las bibliotecas, las salas de oratoria, auditorios musicales etc., que formaban parte de tan completos complejos de descanso, en un primer momento para clases sociales altas, (anexo I) llegando más tarde a las clases populares. Se trataba de inmensas construcciones dedicadas al descanso y al disfrute de actividades lúdicas de todo tipo como se puede desprender del Trabajo del Ma Pepa Lara García en su estudio sobre los baños públicos en Málaga, del que se extrae el siguiente fragmento:

“las inmensas construcciones balnearias de Agrípa, continuadas por varios emperadores y conocidas con el nombre de Termas eran enormes y comprendían además de baños un gran número de salas, pórticos y patios espaciosos para los ejercicios gimnásticos, los juegos, la tertulia, la lectura y hasta para comer"173

${ }^{173}$ Lara García, Mª P. Pág. 21 


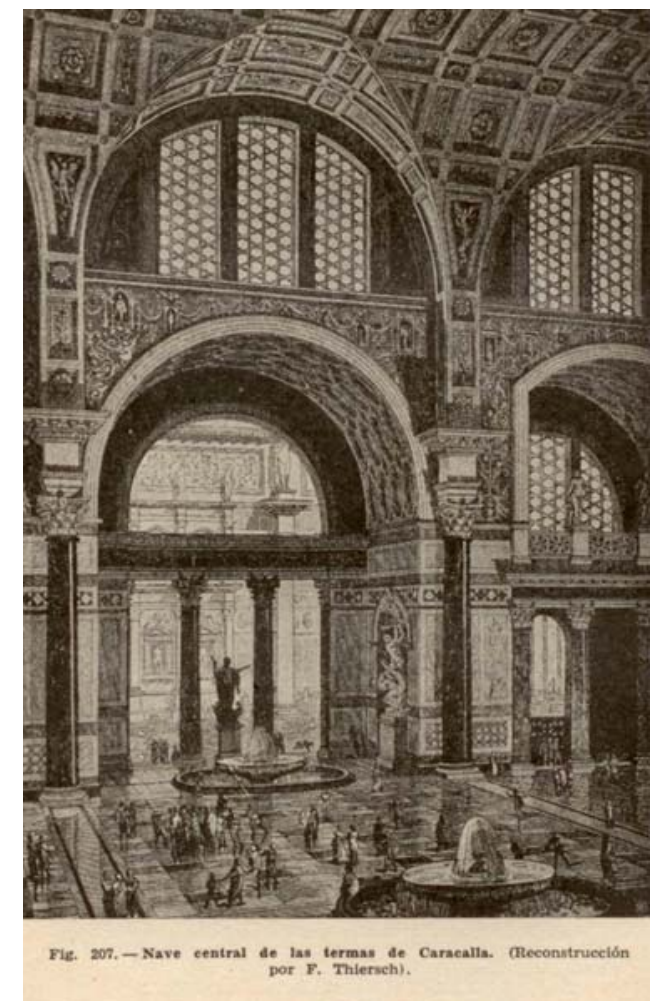

Ilustración 62Grabado 6 Extraído de: Jérôme FigCarcopino

“La Vida Cotidiana en Roma” Pág. 404

Era contemplada por los romanos la parte terapéutica, que en un primer momento atribuía ese beneficio del baño a enfermedades propias de la piel y que tras los primeros estudios científicos efectuados por Galeno, Vitrubio, Plinio y otros tantos estudiosos de la salud en la época, extendieron los distintos tratamientos para la curación de otra tipología de dolencias.

La hidroterapia ocupó un lugar privilegiado entre griegos y romanos, que ya utilizaban las aguas con fines terapéuticos es decir la "crenoterapia"*. En la época romana la finalidad del baño era terapéutica e higiénica aunque ya comenzaba a tomar fuerza la idea del baño como elemento reparador de descanso y placer, como un lugar donde entablar conversación y hacer relaciones sociales, donde abstraerse de la rutina diaria y donde disfrutar de los masajes, lociones y perfumes tras el baño; 
muchos de estos datos se desprenden de los restos arqueológicos que permanecen a pesar de los años y que se convierten hoy en un legado testimonial de lo que los baños representaron en su ámbito social.

"Sabemos que las termas eran establecimientos de función primordial higiénica y médica, aunque posteriormente se convirtieran en centros de reunión e incluso en lugares de diversión y esparcimiento". ${ }^{174}$

Jérôme Carcopino, en su libro "La Vida Cotidiana en Roma en el Apogeo del Imperio" publicado en el año 1942 dedica un capítulo a "El Paseo, El Baño y La Cena”; como introducción a este capítulo cuenta cómo el romano se recreaba con el paseo, el juego, el ejercicio y el baño en las termas, distrayendo así sus horas de ocio cuando no había espectáculos para entretener las horas de la tarde antes de la cena, comida que cerraba su jornada antes del sueño.

Una parte de este capítulo, la dedica Carcopino a las Termas; el vocablo Termas dice, que es de origen griego, pero que representa una realidad puramente romana. Las Termas son según este autor una de las más nobles y hermosas creaciones del régimen imperial.

"Construyendo termas, los Césares introdujeron la higiene en el programa de la Ciudad y la pusieron al alcance de las masas; además, con la maravillosa decoración con que dotaron esos edificios, hicieron de los ejercicios físicos y de los cuidados corporales un placer gustado por todos, un esparcimiento accesible aún a los más humildes”175

\footnotetext{
174 Zaragoza Rubira, J R. (1971) “Medicina y Sociedad en la España Romana” Ed. Pulso. Barcelona Pág. 162.

${ }^{175}$ Carcopino, J. Pág. 402.
} 


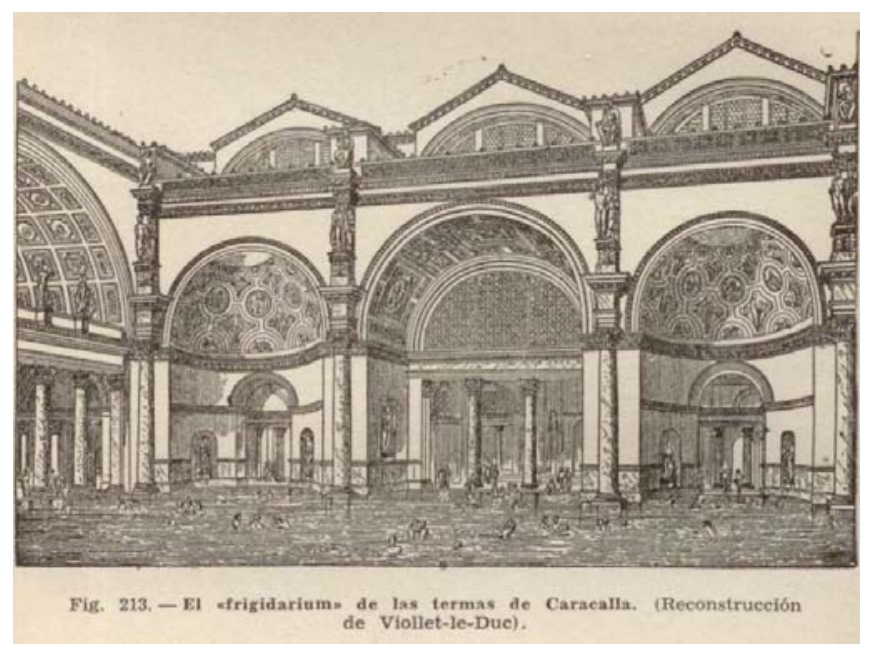

Extraído de: Jérôme FigCarcopino

“La Vida Cotidiana en Roma” Pág. 410

El precio de la entrada a los baños según escribe Carcopino en su capítulo dedicado a las Temas, era muy pequeño y los niños estaban exentos de pago. Agripa en el 33 a. C., por ser edil, era el encargado del cuidado y mantenimiento de los baños públicos o Balneae; éste durante su mandato ordenó que la entrada a los baños fuese gratuita. "Agripa fundó las Thermae que llevan su nombre y cuyo acceso libre debía ser perpetuo. Ese fue el principio de una revolución, que unida al concepto tutelar que el Imperio habíase forjado de su misión hacia las masas, se cumplió a la vez en la historia de la arquitectura y en la historia de las costumbres" ${ }^{\text {"176. }}$.

* Crenoterapia es la utilización del agua con fines terapéuticos. (Crenos=Fuente o manantial)

${ }^{176}$ Carcopino, J. Pág. 403 
Las termas romanas no eran solamente un lugar donde tomar el baño en sus diversas formas, eran también centros de ocio y disfrute como lo son en la actualidad, lugares donde relajarse entablar relaciones sociales, pasear o hacer deporte.

"Esas termas no eran solamente edificios en los que se hallaban reunidas las más diversas formas de baño: seco y húmedo, frío y caliente, piscinas colectivas y bañeras individuales; sino que además encerraban - dentro del enorme cuadrilátero bordeado exteriormente de pórticos con innumerables tiendas de todo género - jardines y paseos, estadios y salas de reposo, gimnasios y salas de masaje, y hasta bibliotecas y verdaderos museos. Las Termas ofrecían a los romanos un muestrario de las cosas que hacen la vida hermosa y feliz."177

Estos momentos de ocio los refleja también José Guillen en su Libro "Urbs Roma, Vida y costumbres de los romanos". El dice que es imposible plasmar en unas líneas toda la ostentación de la vida regocijada de miles de personas en unas horas de termas, como se puede extraer de esta cita perteneciente al capítulo dedicado a los baños:

"El refinamiento de la vida en tiempos del Imperio estableció una serie de cuidados extremosos del cuerpo antes y después del baño. Claro que todo dependía de la edad, de la salud y de la condición de cada cual, pero había épocas, unas veces por el agobio estivo, otras por enfrío exterior y otras por el contraste del frío exterior y la tibia y perfumada atmósfera de las termas, había romanos y romanas que permanecían allí desde que se abría hasta que se cerraban. Hablaban, paseaban, corrían, jugaban, descansaban, se tostaban al sol, o se sumergía en la lectura

${ }^{177}$ Carcopino, J. Pág. 407 
de sus obras preferidas en la biblioteca. Los filósofos buscaban su auditorio entre los grupos más serios; los poetas leían sus elegías o sus epigramas ante los bañistas más ligeros, las bellas siseaban a sus admiradores, y la admiración y la bulla domina por doquier". ${ }^{178}$

Los juegos y el deporte tenían su espacio en las termas, una forma distendida de pasar el tiempo de ocio.

"El tiempo de ocio alcanzaba uno de sus máximos desarrollos en el escenario de las termas. Mas que un paréntesis o descanso en la vida cotidiana era algo casi programado dentro de la actividad humana, altamente estimado para el cuerpo y para la mente: < Mens sana in corpore sano>>......Un tal Ursus que vivió durante el reinado de Adriano, fue famoso por practicar un juego con una pelota de vidrio. Sus actuaciones atraían a un gran gentío en cuatro de las termas de Roma (Thermae e Trajano, Agripa, Tito y Neron) Ursus compuso su propio epitafio esperando preservar la memoria de su fama e inusual habilitada para la posteridad (YEGÜL, 1992: 39). Por otro lado en los <<juegos de mesa>> se utilizaban peones o fichas realizadas de distintos materiales, entre ellos vidrio. Procedentes de las termas de Los Bañales (Uncastillo) y de las de Bilbilis hay fichas de juego en vidrio". ${ }^{179}$

Carcopino termina su capítulo dedicado a las termas romanas con grandes elogios y reconocimiento, al beneficio que éstas habían procurado al pueblo y a la cultura.

\footnotetext{
${ }^{178}$ Guillen, J. 1977 Pág. 337

${ }^{179}$ Ortiz Palomar, M.P. y Paz Peralta, J.A. (1997) “El Vidrio en los Baños Romanos”. En: (I Congreso Peninsular .Actas) Ed. UNED. Madrid. Pág.435.
} 
"En su importante majestad marmórea, ellas no fueron sólo el esplendido <<Palacio del Agua Romana>> Fueron sobre todo, el Palacio del Pueblo, con el cual sueñan hoy nuestras democracias. Antaño los romanos adquirieron en las termas la afición a la higiene del cuerpo, a los deportes útiles y a la cultura desinteresada, demorar su decadencia mediante el retorno al viejo ideal que había inspirado su pasada grandeza, y que en el siglo segundo preconizaba Juvenal: <<Un espíritu sano en un cuerpo sano (orandum est ut sit mens sana in corpore sano) $>>^{180}$

\subsection{El baño y la lujuria en las Termas.}

El culto al agua en la sociedad romana hizo del baño una necesidad de primer orden, y esto se refleja en la gran cantidad de construcciones de baños públicos, privados o aquéllos asentados sobre manantiales de aguas minero-medicinales. Aunque algunas salas eran destinadas exclusivamente al baño femenino; Los baños estaban destinados a ambos sexos, lo que suscitó alguna suspicacia entre los gobernantes ante los escándalos acaecidos al amparo del rumor del agua termal, lo que provocó ciertos cambios para evitar la promiscuidad dentro de los centros termales.

"Excepto contados casos, (las termas) eran públicas y las dependencias comunes para ambos sexos, aunque las mujeres podían asistir a baños especiales para ellas. Fueron tantos los escándalos que esta convivencia originó que Adriano ordenó se establecieran distintas horas de baño para hombres y para mujeres" ${ }^{181}$

\footnotetext{
${ }^{180}$ Juvenal, X 356. En: Carcopino, J. Pág. 422

${ }^{181}$ Zaragoza Rubira, J R. Pág. 162
} 
Esto nos da una idea de la dimensión social del baño en la España romana, en la que el baño pasa de lo exclusivamente privado aunque éste se mantenga, a lo público con la construcción de la terma, convirtiéndose en centro de relaciones sociales y de reunión, tanto para hombres como para mujeres, en unos establecimientos cuyas instalaciones permitían además del disfrute del baño y el masaje, el disfrute de jardines y de otras instalaciones nacidas al auspicio del propio baño, que servían de complemento al mismo.

Serra Ráfols en su libro "La vida en España y en la Época Romana", ${ }^{182}$ nos habla de la censura a la que se vieron sometidos los baños a causa de los episodios lujuriosos acaecidos dentro de las instalaciones termales. Según este autor, la hora en la que se abrían los baños era sobre las diez y media de la mañana (hora quinta) y se cerraban cuando anochecía.

Según Carcopino, Los baños construidos en Roma, eran distintos para hombres y mujeres, los baños públicos se denominaban "Balneae"* y los baños privados "Balnea". Hasta Trajano, no existió prohibición alguna de la utilización de las termas por hombres y mujeres al mismo tiempo, si bien las mujeres podían ir a las termas especiales para ellas Balnea. Según este autor, esta mezcla de sexos dio lugar a escándalos frecuentes, ordenando el emperador Adriano una diferencia de horarios para hombres y mujeres en aquellos lugares destinados al baño, quedando excluidos de esta normativa, los lugares añadidos a las temas, como eran los gimnasios, jardines, tiendas, palestras etc.

“En el año 33 antes de Jesucristo, Agripa ordenó un censo de las Balneae: eran ciento setenta, y su número creció en lo por venir. Plinio el Antiguo renuncia a contar las de su época, y más tarde, se aproximaron a mil",183

\footnotetext{
182 Serra Ráfols,. Pág. 142

*Balnea: se refiere a baños privados

*Balneae: se refiere a baños públicos.

${ }^{183}$ Datos de los Regionarios: 858 balneae en el Curiosum, 927 en la versión de Zacarías, 956 Notitia. En Carcopino, J. (1942) Pág. 403.
} 
La promiscuidad era una constante; de cualquier forma, existía la posibilidad para aquellas mujeres que no aprobasen verse inmersas en este tipo de conductas, de asistir a los balnea*.

"En el reglamento que los procuradores imperiales imponen al adjudicatario de los baños, se dice que las mujeres los utilizarán desde el comienzo de la hora prima, o sea desde el amanecer, hasta el final de la hora séptima, o sea poco más o menos de una a una y cuarto; mientras los hombres concurrirán a ellas desde el comienzo de la hora octava, o sea de una a dos y media, hasta el final de la hora segunda de la noche, cosa concebible en un edificio termal pequeño, pero no en las enormes termas de Roma, en las que se habría carecido de luz artificial suficientemente potente". 


\section{Baño público y baño privado en ell Hammam}

El baño público fue en un primer momento privado y con una intención higiénica, más tarde como lugar de reunión y centro de discusión en el que se conciliaba, política y cultura en torno al agua y al descanso; había baños Públicos en las ciudades y en algunos pueblos, por lo general pertenecían a las mezquitas y el dinero que generaban contribuían al mantenimiento de éstas.

"Eran construidos por los emires y grandes personajes, que los donaban a las mezquitas para su mantenimiento gracias al sistema de fundación piadosa de los hábices (ahibis). Un arrendador era el encargado y lo ayudaban los mozos del baño o tayyab, y los masajistas o hakkak, que limpiaban el baño atendían la caldera y la regulación de las lucernas" ${ }^{184}$.

Los baños privados solían estar situados en casas de personas adineradas que los construían para su goce particular y en palacios donde no podía faltar un lugar destinado al recreo y el baño.

${ }^{184}$ Vílchez Vílchez, C. 2004. Pág. 17 


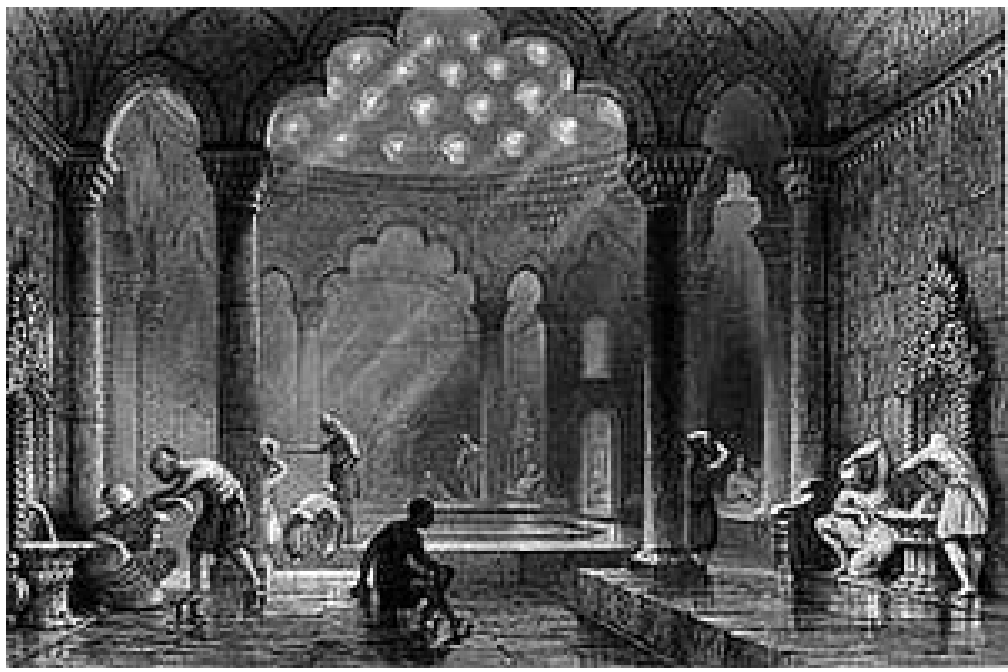

www.amarruecos.com/articulos/tag/banos-arabes/

El historiador Carlos Vílchez, en su libro “Baños Árabes” establece una distinción entre los baños naturales llamados hamma* y los baños clásicos hammam*, Los primeros son baños procedentes de manantiales de agua mineral, caliente, el hammam es lo que hoy reconocemos como baño turco.

"Los hamma o manantiales de agua caliente y mineral abundaban en tierra granadina (Sierra Elvira, La mala, Alicún de Ortega, Baños de Granena, Alhama, etc.), pero no en todos se construyó un edificio que los albargara. De hamma precisamente deriva el topónimo Alhama, del que tenemos ejemplos en Zaragoza (Alhama de Aragón), en Murcia, en Almería y en Granada"185

\footnotetext{
${ }^{185}$ Vílchez Vílchez C. 2004. Pág. 12

*hamma: así se denomina a los baños naturales (manantial de agua caliente y mineral).

*hammam: del plural hammamat (Baño turco).
} 


\subsection{El baño y la lujuria en el Hammam.}

El hammam a demás de limpieza, procura ocasiones para relajarse, divertirse y disfrutar.

"Todos lo utilizan: ricos y pobres, hombres y mujeres. En efecto, el mismo baño acoge a las clientelas por la tarde, mientras que por la mañana y por la noche está reservado exclusivamente a los hombres. En su interior pasan varias horas. Los masajistas ofrecen sus servicios. Las mujeres se hacen depilar, peinar, componer el tocado, perfumar y ungir con ungüentos" ${ }^{\prime 186}$

Dufourcq en su libro "La Vida Cotidiana de Los Árabes en la Europa Medieval" alude a El Calendario de Córdoba, en el que dice que "hay que abstenerse de ir al hammam en diciembre" ${ }^{187}$ dejando la cuestión en una incógnita ¿Por el frío? ¿o, tal vez, porque, en este mismo párrafo, el tratado aconseja $<<$ practicar el coito $>>$ en dicho mes?

\footnotetext{
${ }^{186}$ Lévi Provençal,: V, 278-279 en ; Dufourcq, C.E. (1994 )“La Vida Cotidiana de los Árabes en la Europa Medieval” Ed. Temas de Hoy (colección bolsiTEMAS 22) Madrid. Pág. 132.

${ }^{187}$ Pellat: 174. En: Dufourcq, C.E. (1994) Pág. 132
} 


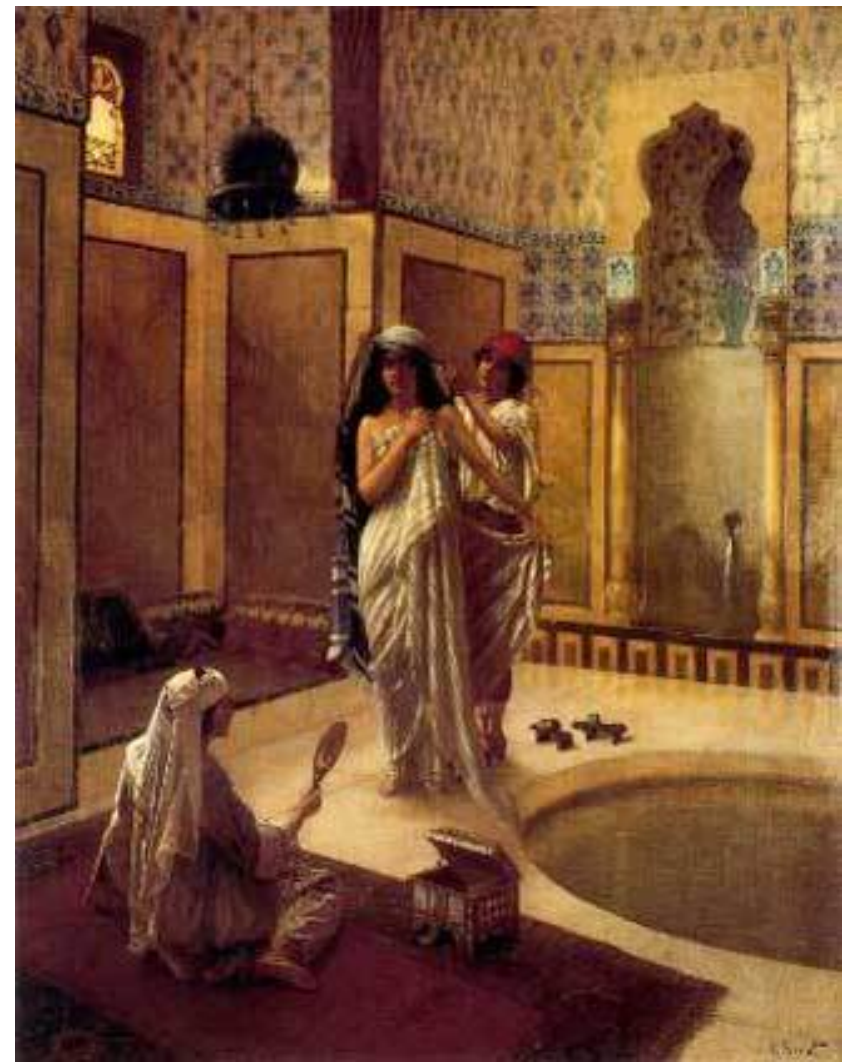

http//www.elbuenpretexto.com

El tema de la lujuria, es también tenido en cuenta por Vílchez, en su libro "Baños Árabes" en el que sostiene que el funcionamiento de los baños públicos estaba perfectamente regulado existiendo prohibición expresa de coincidencia de hombres y mujeres a la hora del baño; por las mañanas acudían los hombres y por la tarde las mujeres.

"Según Ibn `Adun $<$ el arrendador del baño no debe sentarse en el vestíbulo cuando éste se abre para las mujeres, por ser ocasión de libertinaje o fornicación>>". ${ }^{188}$

${ }^{188}$ Vílchez Vílchez, C. (2004). Pág. 16 
Vidal Corella en un artículo periodístico dedicado a la "Antiguas Temporadas de baños" en un apartado dedicado a "Los baños Moros" habla de las prácticas lujuriosas en los baños públicos.

"De antiguo se cita que estos establecimientos públicos en alguna ocasión traspasaron los límites de su misión higiénica, degenerando en centros de libertinaje que recordaban las orgías de las termas paganas. El gran satírico Valenciano Jaume Roig, poeta del siglo XV, en su famosa obra "Libe de les dones", describe las escenas no muy edificantes que tenían lugar en los establecimientos de baños, que eran verdaderos lugares de placer donde los escándalos y riñas eran frecuentes, como se cita en los antiguos libros de demandas ante la Justicia en lo criminal"189.

Según Vidal Corella, los fueros valencianos dictaron disposiciones para que los domingos y días de Viernes Santo estuviesen cerrados con el fin de no profanar la santidad del día. Anteriormente citábamos el libro "Los Baños de Graena un manantial que sana", en él Saavedra Sierra alude a la promiscuidad en los baños, haciendo distinción entre los presupuestos morales y prácticos de la comunidad musulmana y la cristiana, citando para ello a, Asejo Sedano C. en un documento d 1994; En el Sínodo de la diócesis de Guadix y Baza.

"La sociedad musulmana era más proclive a la promiscuidad que la cristiana. Esta promiscuidad sigue latente en los cristianos nuevos. La concepción sexual de ambas comunidades es muy distinta. Los presupuestos morales y prácticos de estas comunidades son

\footnotetext{
${ }^{189}$ Vidal Corella, V. 5/8/ (1994). Pág. 27
} 
diametralmente opuestos. La concepción de los cristianos nuevos es más sensual y sexual que la de los cristianos viejos. El morisco pasa de una cultura poligámica a una monogámica, de una libertad sexual a una sexualidad reducida a una sola mujer. Se pasa del placer de la carne al placer del espíritu." 190

Saavedra hace referencia a una documentación aportada por el doctor Ayuda J.D. "Examen de las aguas medicinales que hay en las Andalucias"; de ella se extrae el párrafo que se presenta a continuación y que viene a confirmar los actos lujuriosos al vapor del baño:

“ Otro sí: que el dicho arrendador tenga puerta con llave, e tenga cargo, e gran diligencia de guardar, que a el tiempo, que se entraren a bañar algunas mujeres cristianas, o moras, no puedan entrar, ni entren ningún hombre a se bañar, ni las mirar por la puerta ni por encima de la bóveda."191

\footnotetext{
${ }^{190}$ Saavedra Sierra, J. (2007) Pág.34

191 Saavedra Sierra, J. (2007) Pág.34 En Ayuda J D. Baeza (1793). “Examen de las agua medicinales que hay en las Andalucias”.
} 


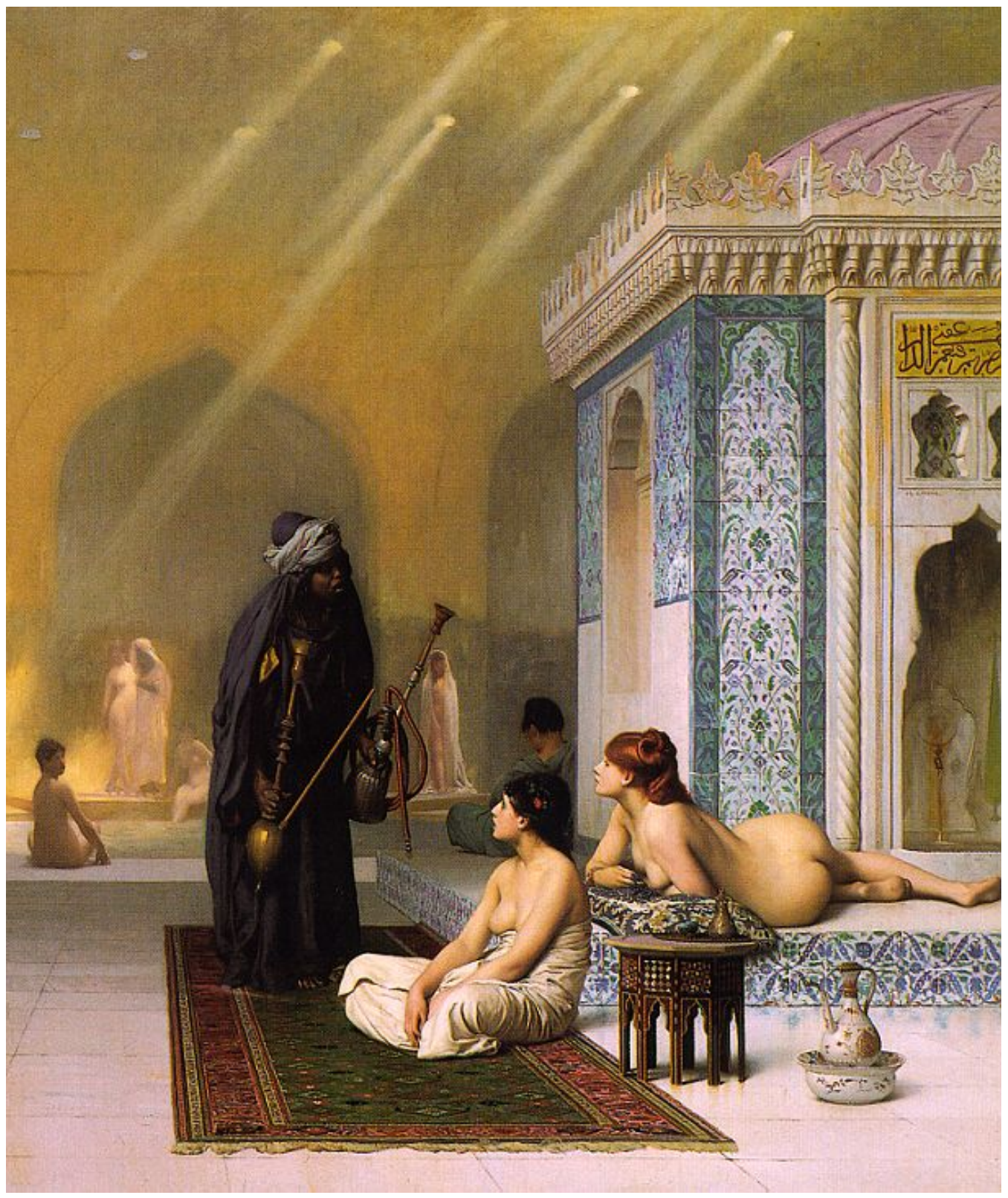

www.amarruecos.com/articulos/tag/banos-arabes/ 


\section{Relaciones sociales a traves del baño De la antiguedad a la posmodernidad}

El baño público ha tenido siempre un trasfondo social, en muchos casos, el acto del baño ha sido un simple pretexto para el encuentro social, en otros, ha sido causa de nuevas relaciones sociales nacidas al rumor de las aguas, es por su carácter social por el que su resurgimiento se debe a tendencias; en la actualidad nos encontramos en una sociedad tendente a primar lo natural, se trata de una valoración posmaterialista; la vuelta a la naturaleza fuente de placer y calidad de vida, la única capaz de alejarnos del paso del tiempo tanto en esencia (tiempo presente), como en imagen, (marca del tiempo). Resignarse a las marcas que el paso del tiempo va dejando en la piel, "resignarse con gallardía a las cosas de la edad" es una opción difícil de contemplar por ambos sexos, que buscan en lo natural la frescura de lo nuevo, la tersura de lo atemporal. Los signos de cuidado corporal son por otro lado, señal de pertenecer a una clase que se cuida que mira por sí misma y que tiene muy encuentra su posición en el resto de la sociedad, se trata de una apuesta por regresar a la naturaleza perdida en todas sus formas, prima una alimentación natural una cosmética natural e incluso la medicina natural pero a lo natural se le ha puesto precio, un precio bastante alto, el sinónimo de "natural" es "bueno", y lo bueno cuesta muy caro, así los frutos de agricultura ecológica o los productos naturales orientados a la mejora corporal son exclusivos de unos pocos, aquellos cuyo poder adquisitivo les permite preocuparse más de su conservación y apariencia social que se su cuenta bancaria llegue a fin de mes. El agua por su carácter natural tiene un precio en algunos casos, tratándose del baño, más accesibles que en otros o podríamos decir, más subvencionados que otros que son centros privativos para quien no dispone de unos ingresos generosos. El baño como esencia y el agua como medio, determinan relaciones sociales que ponen en discreta armonía, tradición y modernidad, fruto de intereses distintos.

La sociedad se mueve por tendencias, por modas, y está de moda la búsqueda individual de satisfacción personal a su vez compartida con el círculo social elegido 
para disfrutar del tiempo de ocio. Prima el individualismo sobre el grupo y el grupo elegido de forma individual sobre el resto del grupo que forma el entorno social.

"El agüista y el usuario del balneario son individuos profundamente sociales que necesitan ocupar el día y la noche, alimentarse, vestirse, trasladarse y divertirse." 192

Varias son las formas de disfrute del baño en cuanto a su elección del entorno social:

El usuario de centros dedicados al baño se acerca de forma individual con la clara intención de alejarse del grupo social no elegido, surgido en su mayor parte de su entorno laboral, suele ser un grupo social en el que se generan tensiones fruto de tomas de decisión o del tiempo de exposición al trato, este alejamiento en su tiempo de ocio le permite disfrutar de un tiempo de descanso y relajación, de desconexión con la rutina diaria.

La pareja es otra forma de acompañamiento recurrente en la asistencia a este tipo de centros, que en un ambiente eminentemente social fomentan el individualismo mediante la creación de ambientes pensados para la relajación y el descanso.

La asistencia en solitario no es la más usual, aunque se da la circunstancia de considerar el ambiente social del balneario como un lugar idóneo para iniciar nuevas relaciones en un entorno distendido y falto de tensiones donde el tiempo no supone un obstáculo para restringir el trato social.

De los posibles beneficios de la toma de decisiones y acuerdos en un ambiente relajado y distendido, saben las empresas que reservan estancias en los centros balnearios para sus empleados, (generalmente ejecutivos) que alternan el disfrute hídrico con el proceso decisorio de cuestiones de responsabilidad, siempre mejor meditadas al píe de una sauna o de una piscina de chorros. 
Las élites del deporte apuestan con fuerza por los retiros en centros balnearios en busca de bienestar, testigo ejemplo de estos encuentros es el balneario de puente Viesgo en Cantabria o el club termal del balneario de La Toja.

Siempre hay acontecimientos que sirven de pretexto para asistir a disfrutar de un buen balneario o spa, así, se celebran despedidas de soltería o se regalan bonos de baño y de masajes por onomásticas o cumpleaños, se trata de regalos con alta valoración por parte de la sociedad agraciada.

En algunos países de Europa como es el caso de Finlandia, el uso de la sauna ha tenido una evolución importante en cuanto a usos sociales se refiere, así, el uso de la sauna en la antigüedad era muy diferente del que tiene en la actualidad para los finlandeses; el baño estaba presente en la vida cotidiana, en ellas se descardaba el lino, se trataba de un lugar donde el ritual se hacía presente, una esfera temida y respetada, en la se purificaba el cuerpo, la mente y el espíritu; la navidad no podía dar comienzo sin que todos los miembros de la familia hubiesen tomado una sauna; era un lugar donde se embellecían los cuerpos y se preparaban para la vida ya que algunas mujeres optaban por dar a luz en este lugar y para la muerte, ya que en él se disponían los cuerpos para ser enterrados, un ritual que se ha mantenido hasta la Segunda Guerra Mundial, hoy el uso de la sauna, no difiere mucho de su mismo uso tan practicado en el resto de Europa donde se dan esas relaciones que se acaban de describir como ejemplo tipo de las relaciones sociales en torno al baño en la actualidad. 


\section{Cápitulu VIIII}

\section{Oción y megecio \\ en torno al placer del baño}

No existen contrapesos que limiten el consumo. Antes lo fueron la religión, las ideologías y la cultura tradicional, que consideraba que la vida era dura y que había que ser moderado. Todo eso ha perdido peso. ¿'Y qué queda? El hedonismo. El ideal es vivir mejor, ahora. La gente no quiere postergar el paraíso.

(Guilles LipovetskY 20/03/2009) 


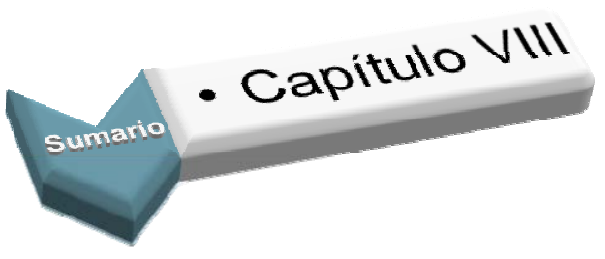

\section{Páginas}

1. INTRODUCCIÓN............................................................................. 300

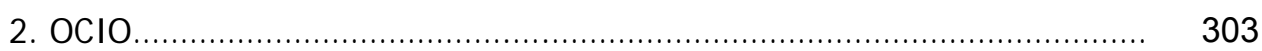

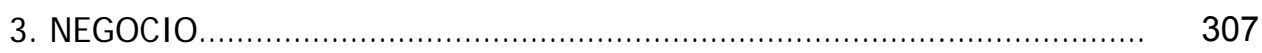

4. TURISMO DE SALUD: PREVENIR O CURAR ......................................... 313

4.1. Turismo de Salud en Europa.................................................... 318

4.1.1.Alemania............................................................. 318

4.1.2.Italia .................................................................... 318

4.1.3.España: El fenómeno balneario como turismo ecológico/Turis-

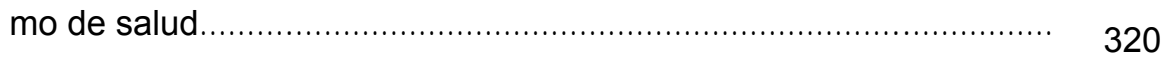




\section{Introducción:}

El tiempo de ocio, va ligado al tiempo libre, sin embargo, si nos atenemos al significado de ambos términos, encontraríamos diferencias entre ellos, así, el tiempo libre sería el tiempo libre de obligaciones, dejado al arbitrio del individuo, el tiempo de ocio es el tiempo en el que uno no tiene nada que hacer; por lo que, el ocio necesita del marco del tiempo libre para configurar el propio tiempo de ocio individual.

El ocio se ha convertido en una necesidad individual, con una dimensión que va de lo cultural a lo social pasando por la práctica del consumismo. El tiempo libre/ tiempo de ocio va unido a nuevas necesidades generadas por el mercado actual.

Juarez Gallego en su artículo "La cultura del ocio y su función de cambio social hacia el final del siglo XXI"193 analiza las distintas teorías planteadas por los estudiosos de la sociología del ocio, G. Friedmann, J. Dumazedier y A. Touraine, se entiende por ocio lo siguiente:

Para el sociólogo francés A. Touraine, autor de "Un Nuevo Paradigma: Para Comprender el Mundo de Hoy" o "La Mirada Social" ${ }^{194}$ " "ocio es la actividad que se realiza al margen del trabajo", Touraine hace una diferenciación entre actividades laborales y no laborales pero obligatorias y otras actividades no productivas.

J. Dumazedier según plantea Gallego, entiende que el "ocio es un tiempo liberado por el trabajo productivo, bajo la acción conjugada del progreso técnico y las fuerzas sociales, en beneficio de una actividad improductiva del hombre, durante o después del período de producción". La división entre productivo y no productivo, vuelve a escena en esta definición. Dumazedier entiende que el conjunto de obligaciones y necesidades diarias de la vida a las que se contrapone el ocio son:

\footnotetext{
${ }^{193}$ http://revistas.ucm.es/edu/11302496/articulos/RCED9393120029A.PDF

194 Touraine, A. (1971)” La Sociedad Postindustrial”. Ed. Ariel, Barcelona. En: Juárez Gallego M. “La cultura del ocio y su función de cambio social hacia el final del siglo XX.” En: http://revistas.ucm.es/edu/11302496/articulos/RCED9393120029A.PDF
} 
$>$ El trabajo derivado de la profesión

$>$ El trabajo extraordinario

$>$ El trabajo doméstico

$>$ Las actividades propias del mantenimiento (comer, dormir, asearse)

$>$ Ceremonias o rituales que procedes de obligaciones familiares, sociales, o espirituales.

$>$ Actividades propias de la dedicación al estudio (cursos, exámenes)

L. González Seara (1971), considera que "ocio es toda actividad no obligatoria a la que uno se dedica después de haber cumplido sus deberes laborales, familiares y sociales".

Jacques Motisseau, según Gallego Juárez, dice que "las actividades de ocio ya no son consideradas como períodos de reposo, sino como períodos de recreación en el sentido etimológico noble del término... Y en una apariencia de indolencia y ociosidad, el individuo se recupera y remodela destacando los aspectos creativos de ociosidad o tendencia al no trabajo, así como recuperación de funciones más importantes del ocio en la sociedad industrial: procurar una creatividad que no facilita (en general) el trabajo y las actividades obligatorias, y recuperar individualmente las energías físicas y psíquicas gastadas durante el tiempo de trabajo e incluso parte del tiempo libre".

El ocio en este capítulo se entiende como una forma de emplear con sentido el tiempo libre, pierde la esencia de estar ocioso para retomar la idea de tiempo para el disfrute personal, la realización de tareas nacidas de las libertades personales y ajenas a obligaciones y tensiones.

El tiempo de ocio ha sido una preocupación de los gobiernos, así en el año 1930 se diseñaron programas con la intención de racionalizar el tiempo libre/ tiempo de ocio, el objetivo era conseguir que la masa desocupada estuviese entretenida mientras no estaba trabajando, un tiempo muerto en el que podían darse conductas reprochables.

Nace la figura del animador sociocultural, encargado de entretener y ocupar el tiempo libre de una forma organizada, en la que mucho tenían que ver los grupos eclesiásticos y las propuestas políticas de bienestar social entre otras. 
En el año 1980 el ocio organizado da un giro para dar paso a un nuevo usuario: "el consumidor de tiempo libre", el ocio se torna negocio ante el consumo voraz de quienes de forma individual y lejos de organizaciones gubernamentales comienza a reivindicar su tiempo de descanso para fabricarse en su tiempo libre un itinerario a la carta en el que prima la libertad de elección y el gusto personal. Los mass media, Internet entre otros, brindan una oferta atrayente de productos objeto del deseo de cualquier consumidor de tiempo libre; este comienza a valorarse tanto o más que el dinero, aunque para conseguir formar parte de la demanda de este tipo de consumo es necesario que el poder adquisitivo esté en línea con los precios marcados por la oferta que sale al mercado. 


\section{Ocio}

Los estilos de vida han ido cambiando fruto del rumbo que la sociedad ha ido tomando a lo largo de la historia; evolucionando así los gustos, las necesidades y las preferencias con respecto al empleo del tiempo libre y el tiempo de ocio.

Las nuevas formas de familia y su economía, las prisas, el estrés, etc. forman parte, y en cierto modo promueven, el cambio de tendencias con respecto a la moda hasta ahora imperante de las vacaciones mensuales o quincenales. Hoy el tiempo de ocio se programa a corto plazo; puentes, fines de semana e incluso excursiones de un día permiten la práctica del turismo de una forma más frecuente y asequible. Se puede decir que el turismo adquiere cada día mayor complejidad y lo que en principio eran movimientos de turistas interesados en sol y playa son en la actualidad movimientos especializados en busca de otros tipo de sensaciones, cada vez más exigente y sin un tinte estacional.

En todos estos cambios de percepción social del turismo han influido de una manera importante los transportes, turismos rápidos, cómodos, y una oferta sugerente de transportes públicos como es el caso de vuelos a bajo precio y ofertas de viajes en trenes de alta velocidad. También se ha visto favorecido por el crecimiento de la industria hotelera, el incremento de las rentas y la disponibilidad de tiempo libre.

Se trata de un consumo de turismo rápido o turismo de excursión independientemente de la motivación: deportiva, de salud, cultural, de aventura etc.

"La vida actual no se entiende sin ocio" "El ocio ha cobrado tal importancia en nuestras vidas que actualmente es considerado un derecho fundamental de las personas." Así opina Manuel Cuenca Cabeza director de programas de postgrado de estudios de ocio de la Universidad de Deusto, humanista e investigador en esta materia.

De una entrevista realizada por la revista Consumer, se extraen las citas precedentes en las que se analiza el ocio en la sociedad actual. 
"La vida no se entiende sin ocio. Es decir, sin televisión, sin música, sin salir de paseo o hacer un viaje; o sin deportes que practicar o que ver. $Y$ es así porque en el actual mundo de valores se ha producido un cambio, y el ocio se ha situado en los primeros puestos."195

El tiempo de libre/tiempo de ocio empieza a ser valorado de forma primordial, hacer aquello que verdaderamente se desea es lo que da sentido a su vida; no siempre el trabajo conseguido coincide con el ideal de tarea vocacional en la que habíamos pensado, por lo que en muchos casos el trabajo empieza a estar en un segundo plano, se convierte en una vía para la consecución de medios para invertir en ocio.

"Como valor vital. Es una cualidad que mueve a las personas y las capacita para vivir experiencias satisfactorias, más enriquecedoras o menos, pero sin duda trascendentales en cuanto que ofrecen un sentido a su existencia. Al preguntar a la gente qué es importante o muy importante en su vida, el ocio ocupa el cuarto puesto. Es más, la juventud, en la búsqueda de sí misma y del sentido de su vida, ha desplazado al trabajo como prioridad y lo ha puesto en su lugar.

El ocio no es patrimonio de la Juventud. Los jóvenes disfrutan de tiempo libre, en vacaciones, fines de semana, festivos o puentes, por el contrario las personas mayores que han llegado a la etapa de la jubilación, son objetivo principal como posibles consumidores de ocio; ellos tienen el tiempo libre a jornada completa, sin horarios laborales, ni responsabilidades, son susceptibles de ofertas orientadas a su entretenimiento. Las políticas sociales se plantean nuevas fórmulas de ocio y de ocupación del tiempo libre para estos mayores, así el Imserso, cada año saca la

\footnotetext{
${ }^{195}$ http://revista.consumer.es/ página 10
} 
nueva oferta de Termalismo Social, de la que se tratará más detenidamente en el capítulo siguiente.

"Antes no había jubilados. La esperanza de vida era menor, y además, el trabajador seguía trabajando para seguir viviendo. En los años 70 comienza a aparecer una nueva clase social. Personas que no tienen que trabajar, que tienen dinero, que tienen salud y que tienen ganas de seguir descubriendo cosas. Pero, ¿qué sucede? Que no saben qué hacer fuera del trabajo. Su identificación había sido a través de él, su presencia social era por el trabajo. Cuando dejan de desempeñar su puesto, si no han sido preparados, si no son creativos, o personas dinámicas, tardan 3 años en enfermar. Por eso, ahora, la sociedad se ha dado cuenta de que es importante preparar a las personas para que disfruten y vivan su jubilación. Es una cuestión económica: las personas que tienen una autonomía cuando dejan de trabajar, enferman menos y generan menos gasto social. Es una cuestión social: a su alrededor crearán un ambiente positivo para toda la familia, y eso, sin duda, es beneficioso."196

En la entrevista realizada a Manuel Cuenca Cabeza, de la que hemos extraído las citas precedentes, se le formula la siguiente pregunta: ¿hasta qué punto el ocio no es sinónimo de consumo? Una cuestión que plantea la cuestión del negocio del ocio.

"La clave de disfrutar del ocio no es el dinero, sino una serie de valores basados en el respeto de la persona humana y sus potencialidades, por eso, la educación del ocio trata de que la persona

\footnotetext{
${ }^{196}$ http://revista.consumer.es/ página 10
} 
descubra cuanto antes esas cualidades. Cierto que en la sociedad actual se ha hecho del ocio un sinónimo de consumo, pues lo intangible lo ha convertido en producto. Sentir la libertad se puede, o eso dicen, comprar. Pero al final, el ocio es hacer aquello con lo que te sientes bien, es una experiencia gratificante que haces porque quieres, y nadie, ni nada te obliga. No es necesario gastar dinero en ello. Sin embargo, y esto es una ventaja, detrás del ocio hay una industria que cada vez va a ser más potente, y esto se puede traducir en términos positivos. Para alguien que le gusta la música clásica, por un módico precio tiene a su disposición un buen equipo y a los mejores directores del mundo. $Y$ eso, hace 50 años era impensable. Se han democratizado las posibilidades de disfrutar. Antes, las familias compartían el trabajo, ahora se encuentran en los momentos de ocio, con la ventaja de que lo positivo une mucho más que las tragedias o la obligación. Por lo tanto, compartir el ocio en familia es transmitir un mundo de sensaciones y sentimientos que no están ligadas a la razón. Lo mismo pasa con los sistemas de gestión en las empresas. Cada vez tienden a tener más en cuenta el ocio, pues si no es así, todo el elemento emocional falla, y éste es fundamental para la motivación., ${ }^{197}$

Detrás del ocio hay una industria, dispuesta a brindar a la demanda de este bien tan valorado toda una oferta de productos orientados al disfrute, difícil de rechazar, así el ocio se convierte en negocio para quienes saben de la necesidad imperante en la sociedad actual de este tipo de productos que salen al mercado. Existen verdaderas industrias de ocio, solo hay que reflexionar en la importancia económica de una de ellas: "La Industria del Turismo" ha crecido de forma acelerada en las dos últimas décadas. El ocio goza de una nueva valoración tanto a nivel individual como social por lo que quizá estemos llegando, como afirmaba Dumazedier, "Hacia una civilización del Ocio".

${ }^{197}$ http://revista.consumer.es/ página 11 


\section{3;. Negocio}

En la sociedad actual el tiempo libre ha entrado en el mercado, el ocio se ha convertido como hemos visto anteriormente en un elemento de consumo de masas, el ocio se compra y se consume por lo que se convierte en posibilidades de futuro empresarial para aquellos que saben ver en este mercado un negocio.

El ocio no se entiende en la sociedad actual si no es de la mano del consumo.

"Equitación, excursiones, pesca y senderismo, e incluso los más variados deportes de aventura, figuran entre las principales actividades de dispersión que ofrecen las termas portuguesas." ${ }^{198}$

Como no podría ser de otra forma, en este capítulo, nos centraremos en el negocio que se genera en torno al placer del agua, ese tiempo de ocio dedicado a los cuidados corporales mediante el baño que forman parte de una gran oferta que intenta dar salida a una demanda cada vez mayor.

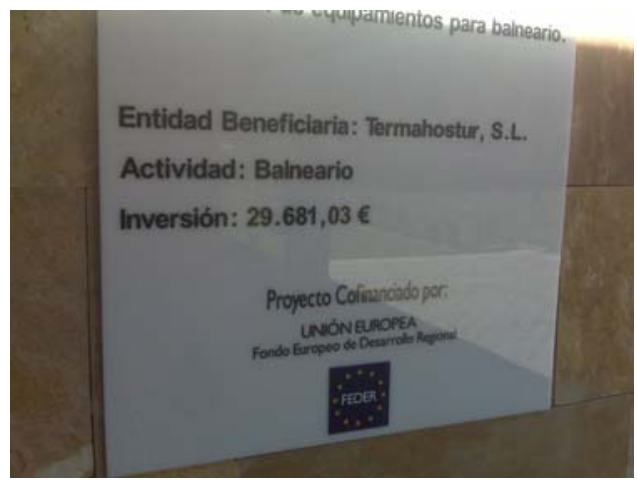

Ilustración 63 Imagen tomada en el Balneario del Salugral en Cáceres.

${ }^{198}$ García, I. “La Riqueza Termal de Portugal” Revista Thermaespa № 14. Página 74 
Las políticas ven en el turismo de salud una fórmula para la reactivación de la economía de algunas zonas rurales en las que nacen fuentes termales de aguas mineromedicinales tan codiciadas por la sociedad actual, así, orientan subvenciones con el fin de modernizar los antiguos balnearios y crear nuevos puestos de trabajo, a la vez que se fomenta el turismo y se crean negocios alternativos que viven al vapor de las aguas termales.

A la hora de hablar del negocio termal es necesario hacer referencia a "Termatalia", se trata de un punto de encuentro empresarial para profesionales del sector balneario en el que se llevan a cabo acciones de negocio, se trata de una feria en la que se pretende fomentar este negocio no sólo en España, sino de forma internacional, ya que a ella acuden representantes de los principales mercados termales. Termatalia se convierte en centro de negocios turístico y empresarial; turístico mediante las distintas bolsas de contratación creadas entre turoperadores, spa, centros termales o talaso, y empresarial con la presencia de proveedores, fabricantes, importadores de bienes de equipo etc. El mundo que gira en torno al negocio del ocio que se da cita en esta convención multicultural en la que el baño ocupa una parte importante desde el sector turístico.

Termatalia nos da una idea de lo que supone a nivel internacional el negocio termal y sobre todo nos ofrece datos de la situación de resurgimiento de este sector en España, concretamente Galicia, donde el negocio del agua supone una fuente de ingresos y riqueza.

Otras comunidades autónomas fomentan a través de ferias el turismo de interior cuyo mayor exponente es el turismo de salud, como es el caso de Castilla y León. 


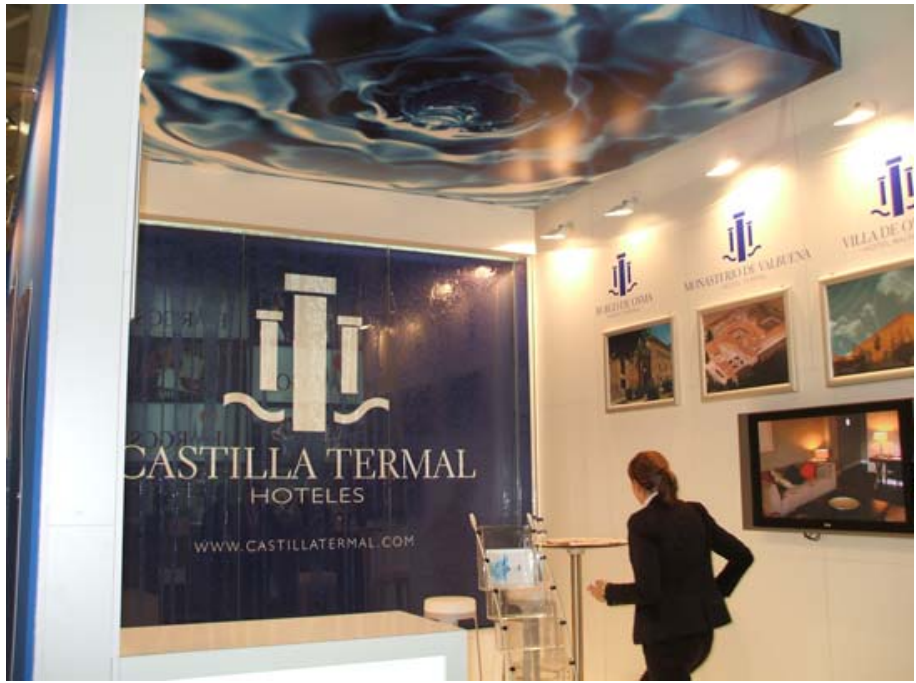

Ilustración 64 INTUR 2007 Feria del Turismo de Interior en Castilla y León

"Intur", una cita en la que se presentan los centros balnearios con su aspecto renovado envueltos en el brillo del marketing y la publicidad más sugerente, capaz de atraer las miradas y el deseo del visitante

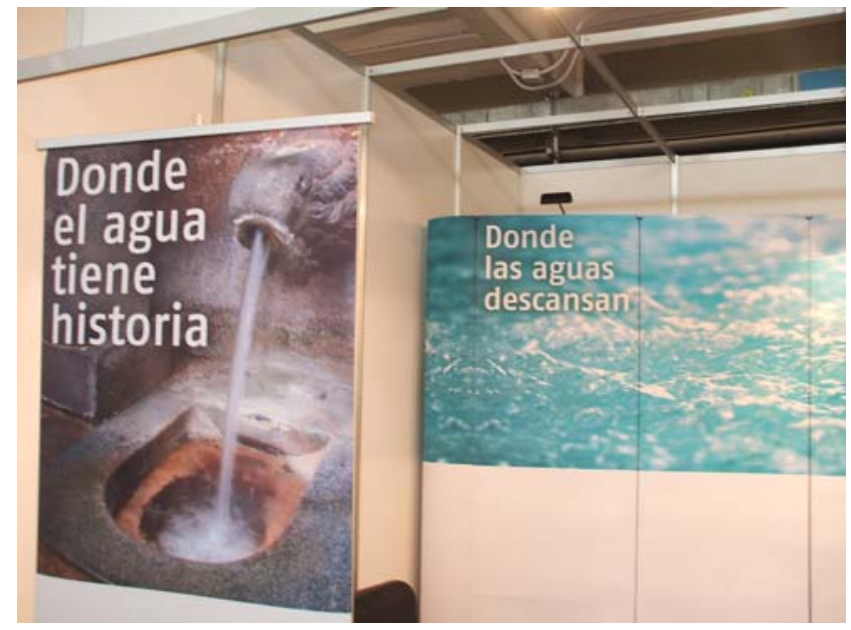

Ilustración 65 INTUR 2007 Feria del Turismo de Interior en Castilla y León 
En este tipo de ferias los centros balnearios derrochan panfletos publicitarios cargados de imágenes atrayentes que evocan destinos que, de no ser por los centros balnearios, estarían prácticamente olvidados o cuando menos, lejos de ser objeto de deseo para pasar unas vacaciones.

El mensaje es claro, reservar una estancia en un balneario, es garantizar unas vacaciones saludables.

\section{RESERVE SALUD}

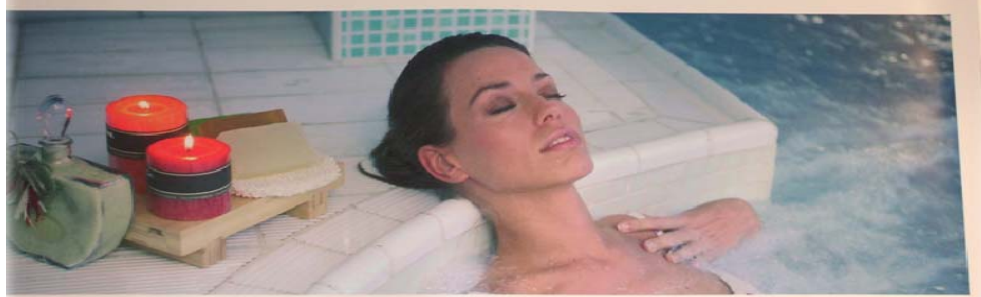

Balnearios • Thalasso • Spa $\cdot 2007$

Nicasio Pérez Menzel como presidente de la Asociación Nacional de Estaciones Termales (ANET), en uno de los capítulos del libro recopilatorio: "Panorama actual de las Aguas Minerales y Minero-medicinales en España" titulado PRESENTE $Y$ FUTURO DEL TERMALISMO ESPAÑOL Y EUROPEO, analiza hacia donde conducen algunos conceptos en expansión relativos al sector balneario, haciéndose eco a su vez del usuario que acude al balneario por ocio o negocio; entendido el negocio en este caso, como la persona que se acerca al balneario por motivos laborales, reuniones de trabajo, congresos, cuestiones relacionadas con su negocio personal. 

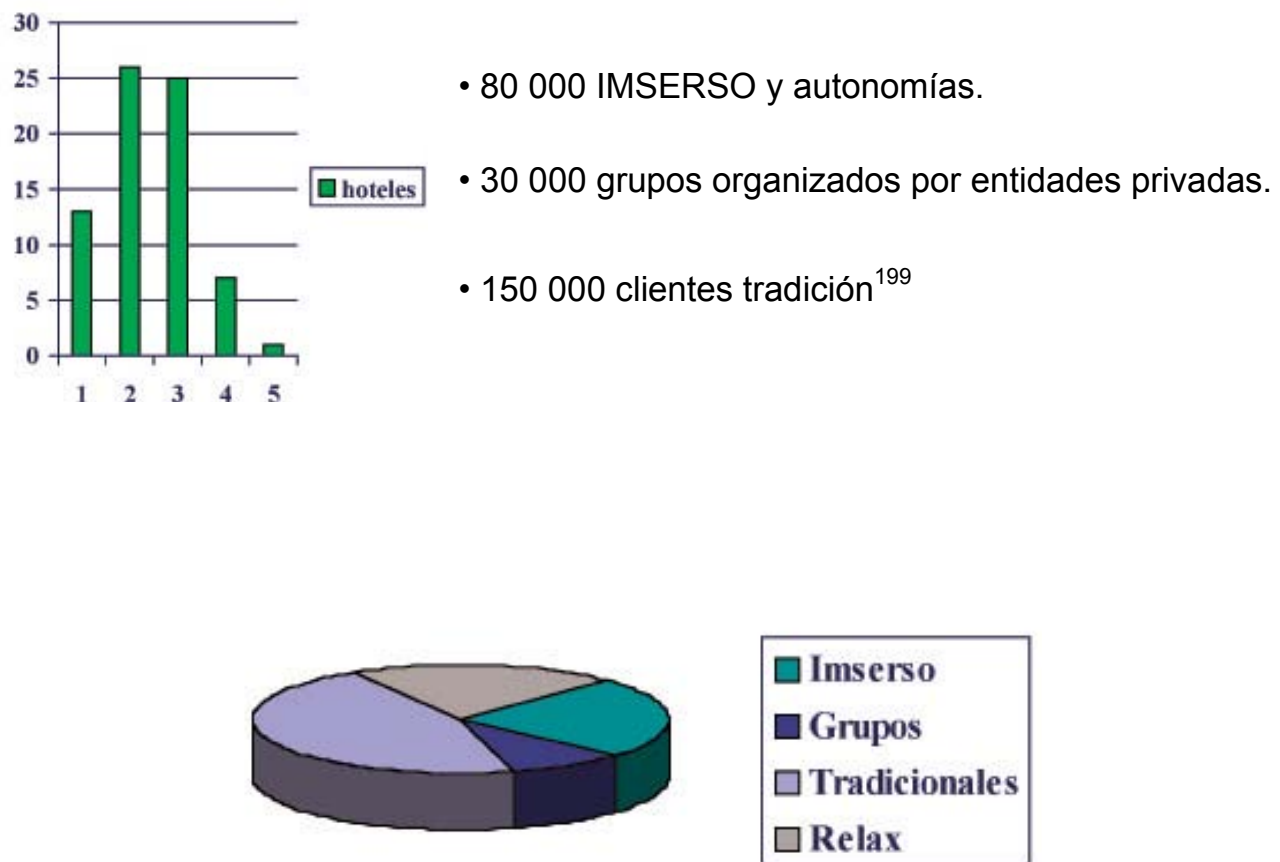

En Alemania: El turismo de salud supone el $50 \%$ de los ingresos turísticos (M. Bywater, 1990).

Todo tipo de negocio que gira en torno al baño está de moda, la industria turística es consciente de esta realidad y apuesta fuerte por abrirse camino en este ámbito en el que cada vez más empresas entran a formar parte de esta oferta, en la que el demandante está dispuesto a invertir en aras de su disfrute personal y en el que los ingresos se vuelven cada vez más generosos.

"Volumen de negocio de los balnearios 2004: 20.000.000€ (incremento 6,3\% respecto del año anterior). ${ }^{, 200}$

\footnotetext{
${ }^{199}$ Pérez Menzel, N. año (2000) "Presente y Futuro del Termalismo Español y Europeo” En: Panorama de las Aguas Minerales y Minero-Medicinales en España.” Ed. Instituto Tecnológico Geominero de España. Página 69.
} 
En lo referente al sector balneario, mencionar que la mayor parte del volumen económico que mueve está relacionado con las instalaciones hoteleras que lleva asociadas.

En cuanto a los datos económicos propiamente dichos se puede mencionar que los balnearios gallegos ofrecen actualmente más de 2.300 plazas, en comparación con las apenas 1.300 de las que se disponía a comienzo de esta década, lo que es un buen botón de muestra de la revitalización que el sector ha sufrido en los últimos años. Esta revitalización está directamente relacionada con las considerables inversiones que en los últimos años se realizaron en este tipo de instalaciones para su ampliación y mejora, las cuales superaron los 2.000 millones de pesetas. Esto ha llevado a alcanzar los 6.000 millones de pesetas en facturación. ${ }^{201}$

TERMATALIA 2009 tratará de familiarizar a los profesionales de las Agencias de Viajes con el producto "Turismo de Salud" con dos fines primordiales:

- Formar a los comercializadores que están en contacto con el cliente final con las distintas ofertas del producto (termalismo, talasoterapia y spa) de forma que trasladen una información cualificada a los usuarios.

- Fomentar las ventas del "Producto Turismo de Salud" de Galicia y de las distintas regiones expositoras en feria, reforzando el proceso en el

\footnotetext{
${ }^{200}$ García, I. “La Riqueza Termal de Portugal” Revista Thermaespa № 14. Página 75, información obtenida En: Asociación das Termas de Portugal (con estadísticas de ESPA y FEDETERME) y la direcÇao Geral de Geología e Energía.

${ }^{201}$ Del Moral Crespo, J. año (2000) “Panorama actual de las Aguas Minerales y Minero-medicinales en España”. En: “Contribución Socio -Económica de la Aguas Minerales en la Comunidad Autónoma de Galicia” Página 261.
} 


\section{Turismo de Salud Prevenitro curar}

La medicina ha caído en cierta forma en la lógica de la personalización, la parafarmacia y la medicina natural comienzan a ganar protagonismo ante el proceso de personalización que se vive en la sociedad actual, que describíamos anteriormente, en la que el enfermo no es un sujeto pasivo, el enfermo conoce su cuerpo, siente su cuerpo y por tanto es protagonista y responsable en su propio proceso de curación.

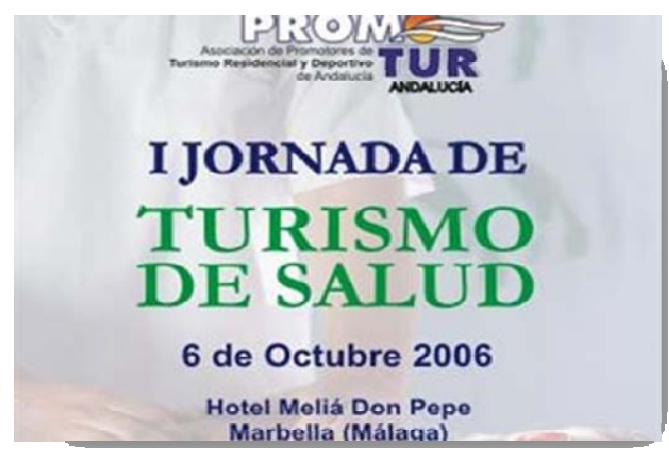

"La medicina sufre una evolución paralela: acupuntura, visualización del interior del cuerpo, tratamiento natural por hierbas, biofeedback, homeopatía, las terapias <<suaves>> ganan terreno enfatizando la subjetivación de la enfermedad, la asunción <<holística>> de la salud por el propio sujeto, la exploración mental del cuerpo, en ruptura con el dirigismo hospitalario; el enfermo no debe sufrir su estado de manera pasiva, él es el responsable de su salud, de sus sistemas de defensa gracias a las potencialidades de la autonomía psíquica."202

${ }^{202}$ Lipovetsky; G. (2008). Página 21. 
Estamos ante una sociedad posmoderna que comienza su apuesta por hábitos de consumo más respetuosos con el medio natural y a su vez más respetuosos con su propia salud; refrán o tópico, "Vale más prevenir que curar" resulta ser en muchos casos el motivo de tomar como una opción de vacaciones el "Turismo de Salud" y no es de extrañar, ya que la salud es uno de los valores posmaterialistas más deseados y preservados del ser humano, incluso cuando se trata de valores materialistas prima la salud, es muy común oír frases como: "Lo importante es la salud" "La salud es lo primero" "que haya salud y lo demás vendrá por añadidura", salud, dinero y amor como dice la canción, salud por encima de todo para poder disfrutar del resto de cosas que ofrece la vida.

El cuidado del cuerpo y de la mente comienza a asociarse con ocio y descanso. Turismo de salud comienza a representar en muchos casos una primera opción, se buscan destinos saludables, como son el entorno rural en el que se enclavan los centros balnearios, lugares elegidos por la naturaleza de forma caprichosa para que broten sus manantiales de agua termal.

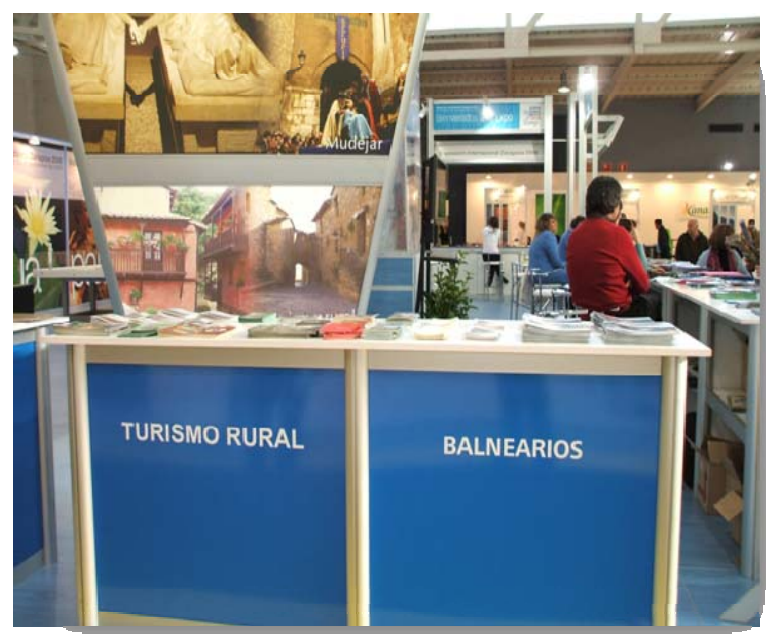

Ilustración 66 INTUR 2007 Feria del turismo de interior en Castilla y León 
El turismo de salud se trata de un turismo emergente que hasta ahora era demandado por personas de una cierta edad y que se ha convertido hoy en día en una apuesta cada vez mayor, por parte de los jóvenes que optan por unas vacaciones dedicadas al bienestar personal.

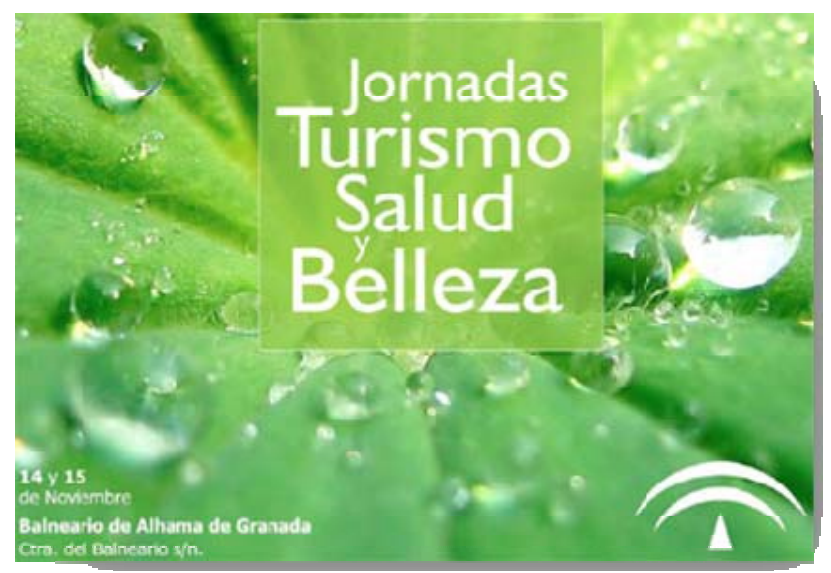

De esta nueva concepción del tiempo libre, tiempo de ocio, de la necesidad de acercamiento a la naturaleza, propias de la sociedad posmoderna, saben las empresas dedicadas al turismo que ven un nuevo filón de negocio nacido al rumor de las aguas.

"Esa es la sociedad posmoderna, caracterizada por una tendencia global a reducir las relaciones autoritarias $y$ dirigistas $y$, simultáneamente, a ofrecer fórmulas de <<programas independientes >>, como en los deportes, las tecnologías psi, el turismo, la moda informal, las relaciones humanas y sexuales" ${ }^{\text {"203 }}$

${ }^{203}$ Lipovetsky; G. (2008). Pág. 19 
El placer de viajar conjugado con el placer del agua la dosis de salud, conforman una mezcla difícil de rechazar..

"La vida Kit modulada en función de la motivaciones individuales, la vida flexible en la era de las combinaciones, de las opciones, de las fórmulas independientes que una oferta infinita hace posibles, así opera la seducción. Seducción en el sentido de que el proceso de personalización reduce los marcos rígidos coercitivos, funciona sibilinamente jugando a la carta de la persona individual, de su bienestar de su libertad, de su interés propio."204

El Turismo de salud es un producto que se vende bien a la sociedad actual, un producto al que se juntan otra serie de empresas auxiliares de servicios, que buscan completar ese Kit que nos planteaba Lipovetsky, un turismo de salud al que se suma un turismo de belleza, de relax y de ocio.

El sector turístico apuesta por el Turismo de Salud como una nueva forma de turismo sostenible. El hecho de que sea el entorno rural, el enclave de muchas fuentes de agua salutífera hace de zonas geográficamente deprimidas un centro de atracción turística.

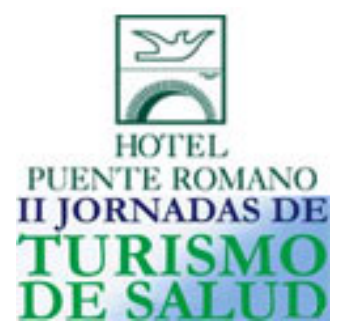

${ }^{204}$ Lipovetsky; G (2008). Pág. 19 
Son numerosas las jornadas que se organizan en torno a este tema, en las que expertos en turismo de salud y profesionales del turismo tratan de dar las claves sobre estrategias de desarrollo y comercialización de este sector; estas jornadas suelen tener como escenario los centros balnearios e incluso los propios hoteles que cuentan con este tipo de servicio, se trata de dar a conocer un sector en alza que busca abrirse paso entre el turismo de sol y playa.

El turismo de salud no es necesariamente un turismo de largas temporadas o dilatadas estancias en un centro hotelero, se puede ver como un turismo de fin de semana en contacto íntimo con la naturaleza.

Existe un refrán popular que dice "más vale prevenir que curar", hoy por hoy es uno de los leif motiv de turista de salud.

El turismo de salud, como ya hemos mencionado con anterioridad, vive una época de esplendor a finales del siglo XIX y principios del XX, fruto de grandes cambios sociales y tecnológicos, fundamentalmente en el sector de los transportes; ir de vacaciones se pone de moda y aparece el llamado fenómeno del "veraneo" al que se suman sanos y enfermos para prevenir, curar o simplemente disfrutar, en un entorno deliciosamente saludable; con este fenómeno del veraneo aparece el turismo de salud que no se denominará de este modo hasta finales de siglo XX, principios del XXI, aunque en esencia es el mismo que desde época inmemorial se encuentra ligado al uso de fuentes termales.

"Al balneario acuden personas con distintas afecciones e incluso sin padecimiento alguno y por puro recreo, siendo las pioneras de lo que actualmente se denomina $<<$ Turismo de Salud $>>$.,205

\footnotetext{
${ }^{205}$ De la Rosa, M C y Mosso, A. (2004).Pág., 101-104.
} 


\subsection{Turismo de salud en Europa.}

Alemania, Italia, Francia y Hungría son países con un gran peso específico dentro del sector, éstos cuentan con un alto porcentaje de turistas y suponen un alto porcentaje de los ingresos procedentes del turismo; si la demanda es grande, la oferta de paquetes turísticos también es muy amplia, adaptándose a las necesidades del cliente.

A continuación se presenta una información pormenorizada de tres países en los que el turismo de salud es un referente, extraída del capítulo "Presente y Futuro del Termalismo Español y Europeo" perteneciente al libro titulado "Panorama actual de las Aguas Minerales y Minero-medicinales en España." Así mismo, nos acercaremos a este fenómeno en España y Portugal.

\subsubsection{Alemania}

- El turismo de salud supone el 50\% de los ingresos turísticos (M.Bywater, 1990)

- Las Compañías aseguradoras que subvencionan los tratamientos termales han desarrollado un papel esencial en el sector.

- En los últimos años se han reducido las subvenciones pasándose de 4 a 3 semanas de cura y solo permitiéndose una nueva cura cada 4 años.

- 266 balnearios: resort, complejos turísticos de salud, centros de hidroterapia etc..

- 137 centros ofrecen tratamientos médicos cuya base es el agua minero medicinal.

\subsubsection{Italia}

- El sector reviste una gran importancia. Un $22 \%$ se había alojado alguna vez en un balneario, de estos un $46 \%$ lo hizo para recibir un tratamiento y el 54\% restante fue de vacaciones, acompañando a alguien o asistiendo a una convención. 
- [............ 450 instalaciones en 210 villas termales. La estancia media es de 11 días.

- El 25\% de las pernoctaciones se deben al turismo extranjero.

- Sector ligado a la profesión médica. Tienen gran dependencia de los subsidios estatales. Los balnearios franceses solo son los que tienen aguas mineromedicinales. Actualmente son 104 estaciones termales.

- La oferta de puesta en forma y relax ha sido recogida por los centros de talasoterapia.

- La seguridad social reembolsa el coste total del tratamiento y una contribución del viaje alojamiento.

- La calidad de los balnearios es supervisada por el Ministerio de Salud. ${ }^{206}$

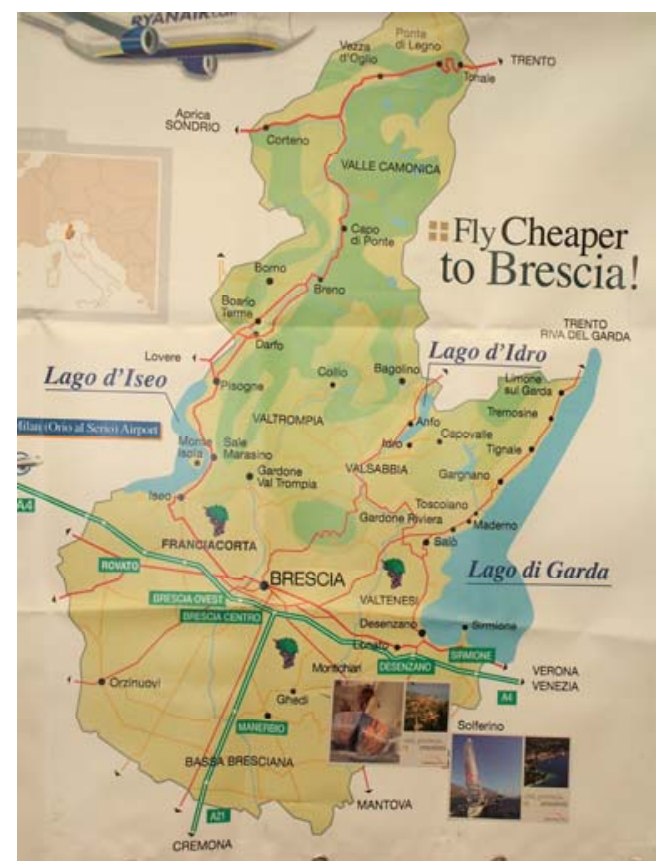

Ilustración 67 Imagen publicitaria de balnearios en Berscia (Imagen tomada en INTUR 2007)

\footnotetext{
${ }^{206}$ Pérez Menzel, N. 2000 “Presente y Futuro del Termalismo Español y Europeo”. En “ Panorama actual de las Aguas Minero-Medicinales en España” .Página 69
} 


\subsubsection{España: El fenómeno balneario como turismo ecológico/turismo de salud}

Veranear en un balneario o en una estación termal, es una de las alternativas al turismo convencional, un turismo de calidad producto de una demanda en alza, exigente a la hora de recibir servicios especializados y en busca de nuevas sensaciones, que por su situación geográfica hacen de las estaciones termales el sitio ideal para encontrar el descanso reparador deseado. Se trata de un turismo ecológico, "turismo verde". Los balnearios de aguas termales se asientan en plena naturaleza, generalmente junto a un río, tenemos como ejemplo el balneario de Puente Viesgo, en Cantabria en la margen derecha del río Pas, o el de Retortillo en Salamanca, en un entorno rural, lo que hace de estos centros lugares apropiados para el descanso en contacto directo con la naturaleza.

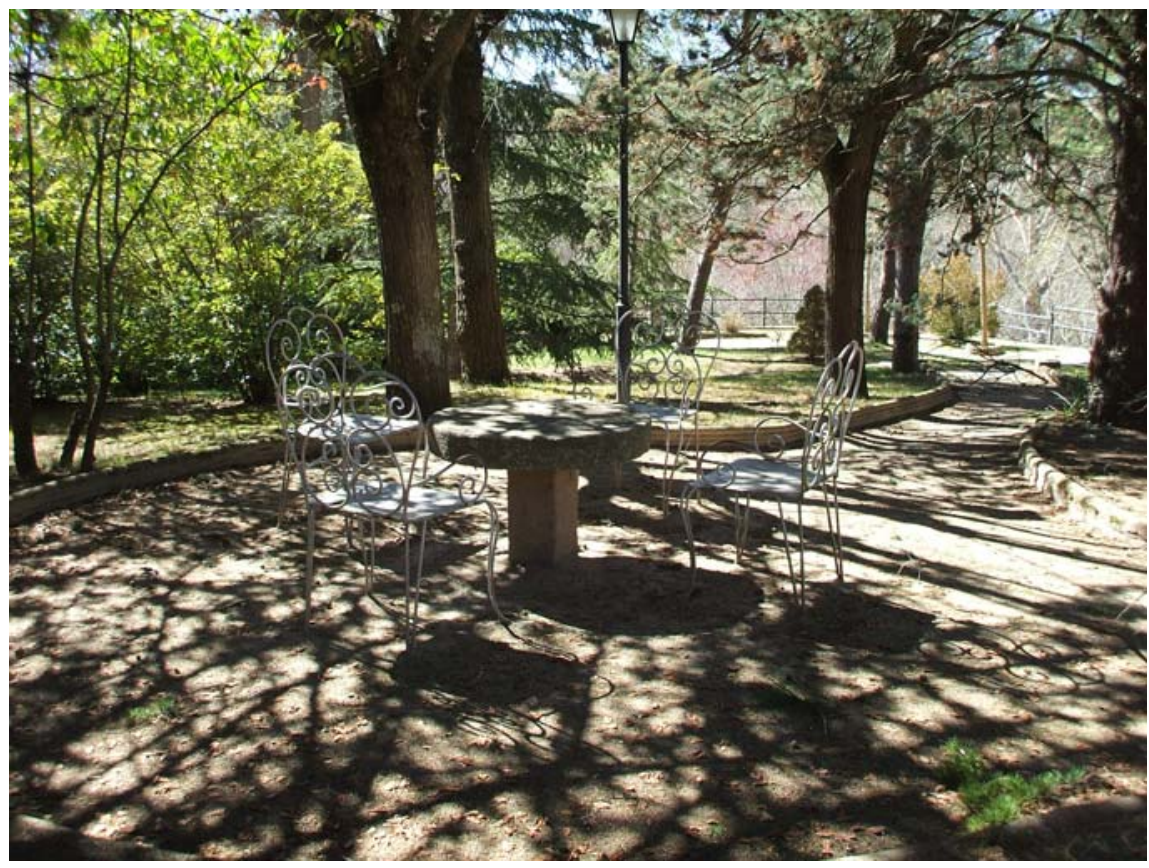

Ilustración 68 Jardines del Balneario de Retortillo (Salamanca) 
Quienes deseen unas vacaciones tranquilas y no por ello aburridas, deben incluir en su agenda a las Estaciones Termales. Hoteles con todos los servicios, maravillosos paisajes, paseos y lugares para el descanso, animadores del ocio, actividades culturales, son sus credenciales. ${ }^{207}$

Esta búsqueda de descanso y salud en balnearios, complementados con visitas turísticas por la zona en la que éste se encuentra enclavado, se denomina "Turismo de Salud"; un nuevo concepto que nace como una forma de combinar salud con viajes, descanso y reposo, un turismo con segundas intenciones que hace que no sean las zonas marítimas las únicas ofertas atractivas para el turista, sino que, también contempla las zonas rurales y de interior como destino ideal para renovarse disfrutando en un entorno natural en el que poder disfrutar, entre otros, de conciertos de música clásica organizados al efecto que hacen las delicias del turista.

El Turismo de salud es cada vez más practicado por la gente joven, que busca nuevas formas de descanso y diversión, lejos de la rutina de las vacaciones tradicionales, o como complemento a las mismas, ya que son una buena alternativa de fin de semana.

"Son las Estaciones Termales fuente de salud, que pueden prestar importantes servicios a la sociedad, atención a la tercera edad, prevención de enfermedades infantiles, enfermedades reumáticas o de tipo respiratorio, remedio contra el estrés de ejecutivos, artistas y políticos, preparación del deportista, etc.

Se trata de lugares ideales, tanto para personas afectadas por alguna dolencia como para personas sanas, porque son aconsejables

\footnotetext{
${ }^{207}$ López Yuste L. Wellness > Artículos técnicos (2006) ANET miércoles 01/02/06 En: http://www.cosmobelleza.com/es/wellness/informacion/tecnicos
} 
como preventivos $y$, de hecho, así lo demuestra el cada día más elevado número de personas que recurren a este método curativo." ${ }^{208}$

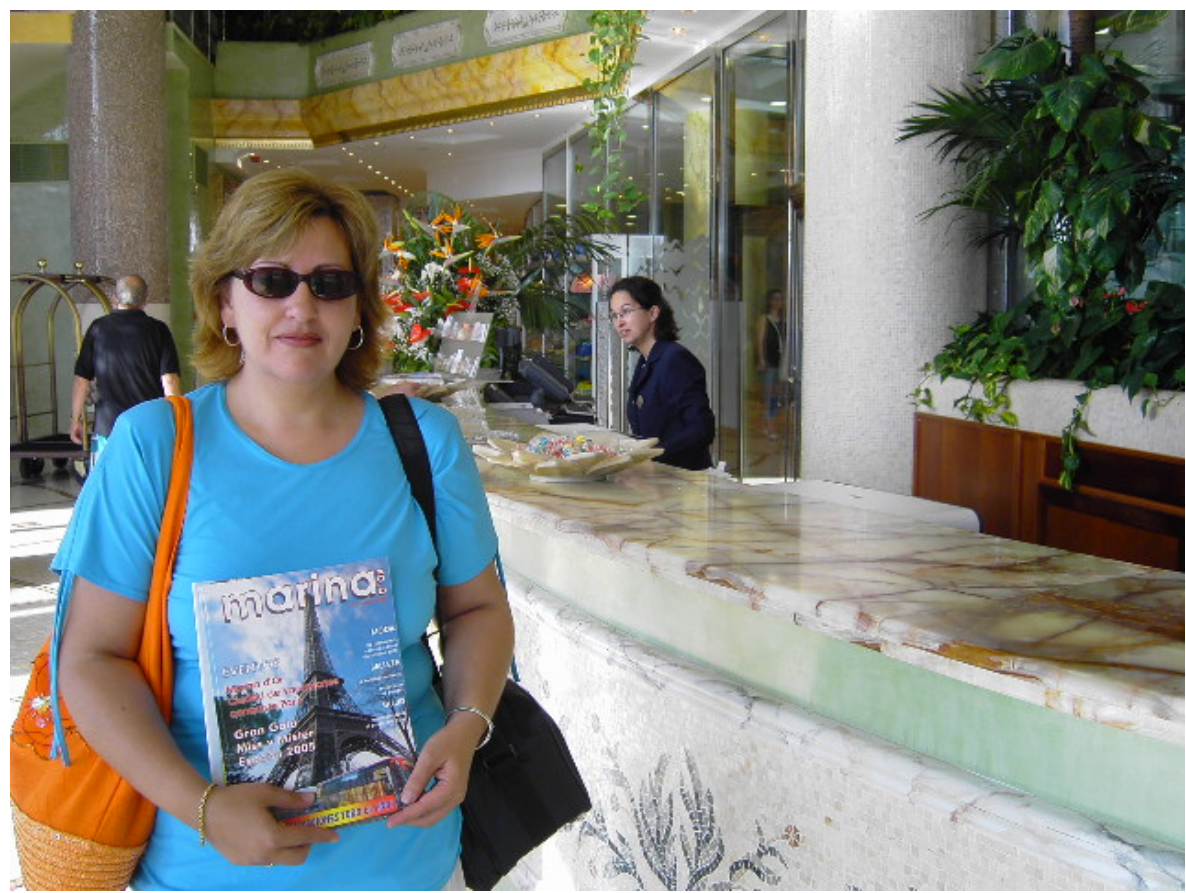

Ilustración 69 Balneario de Marina D’ or en Oropesa del Mar (Castellón)

La realización de estas prácticas hídricas tiene lugar en tiempo de ocio, tanto para el agüista como para el acompañante; turistas ambos, que requieren de una oferta alternativa de "Turismo ecológico", rutas a caballo, senderismo, rafting, piragüismo, todo esto dependiendo del enclave geográfico del balneario elegido para disfrutar las vacaciones, por otro lado y para aquellos agüistas y acompañantes que lo deseen, se crea la necesidad de construcción o recuperación en algunos casos, de hoteles, salones de juego, cafeterías, salones sociales, billares, donde distraerse en las horas alternativas al baño, así como también, la organización de visitas turísticas por la zona que sirvan de distracción y de conocimiento del entorno balneario. Todo este conjunto de hoteles, lugares de ocio y diversión, nacidos al aliento cálido de las aguas

\footnotetext{
${ }^{208}$ López Yuste L. Wellness > Artículos técnicos 2006 ANET miércoles 01/02/06 En: http://www.cosmobelleza.com/es/wellness/informacion/tecnicos
} 
termales, es lo que dará lugar a la llamada "Ciudad Balnearia", "Ciudad de las Aguas" y a los grandes "Complejos Sanitarios Recreativos", lugares donde la terapia no es solo la aplicación de las aguas, sino también, el aire puro del campo y la tranquilidad de la que se puede disfrutar durante la estancia del agüista o acompañante dentro del balneario, sirven como tratamiento.

Los balnearios se han ido adaptando a los tiempos y a las nuevas demandas sociales, renovando sus instalaciones y ampliando sus servicios y tratamientos, pero sin perder su esencia de centro de salud y reposo dentro de un entorno natural, algo tan demandado hoy en día.

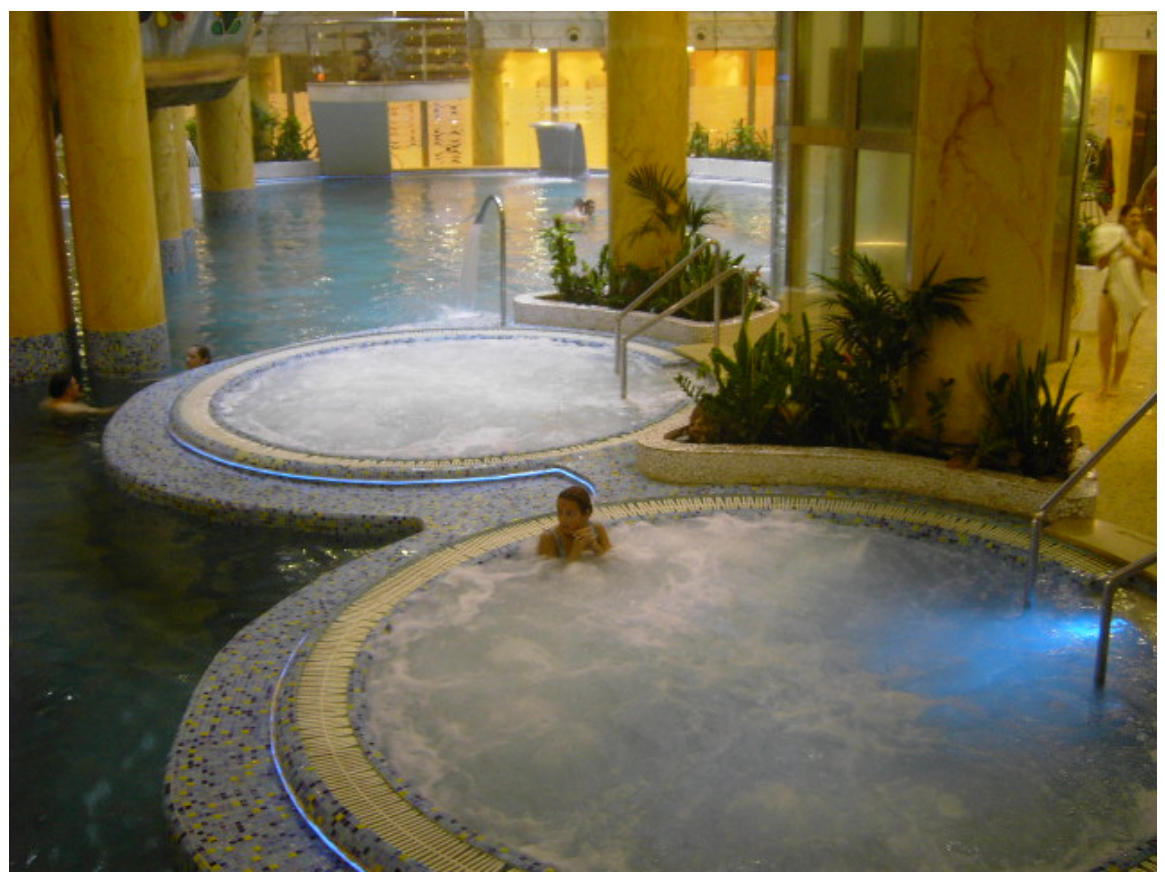

Ilustración 70 Jacuzzi. Balneario de Marina D’ or en Oropesa del Mar (Castellón)

Las estaciones Termales son un lugar ideal para descansar, y de esta demanda nace la idea de las ciudades balnearias de vacaciones, suelen ser balnearios de agua marina, verdaderos complejos turísticos con circuitos termales e incluso con servicios 
de tratamiento estético dotado de las más sofisticadas técnicas de aplicación corporal del agua, cuyo objetivo es conjugar los antiguos conocimientos naturales, sol, agua marina, barro y algas entre otros, e implementarlos con técnicas de laboratorio y farmacopea actual, entre otros tratamientos hidrotermales como son: baños de algas, baño con ducha subacuática, fango-terapia localizada, barro auto-calentador.

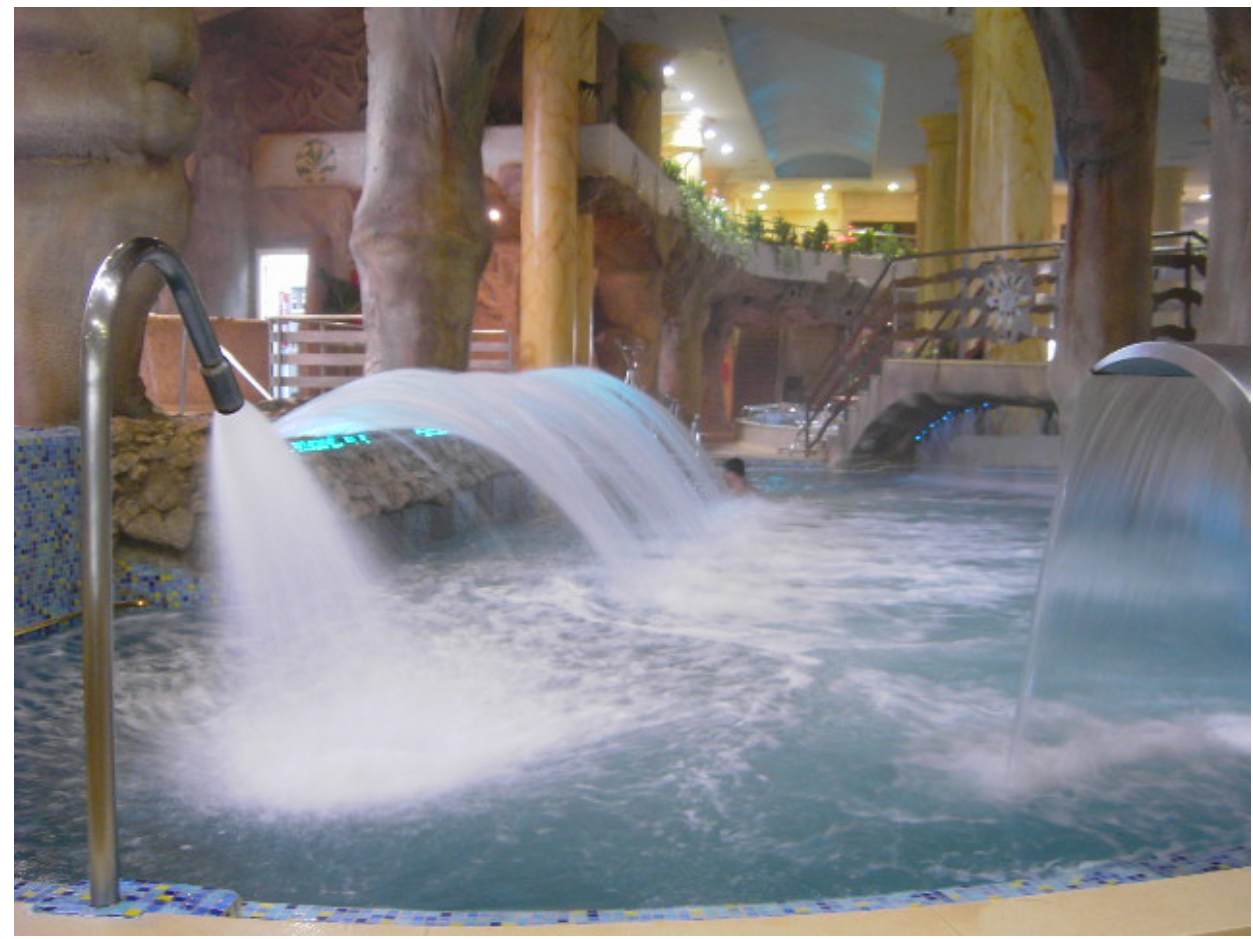

Ilustración 71 Balneario de Marina D’ or en Oropesa del Mar (Castellón)

Las agencias de viaje ante la creciente demanda de servicios termales y de turismo rural y ecológico, sacan ofertas tentadoras a través de sugestivas publicaciones en las que se observan fotografías en las que el agua es el principal protagonista, imágenes que incitan al baño en entornos naturales, acompañadas de ilustraciones sobre la gastronomía, el folklore y la artesanía popular de la zona donde está enclavado el balneario, todo un compendio que hace que el turismo de salud sea 
un turismo atractivo por su tinte ecológico y por las posibilidades que ofrece de acercarse a lugares desconocidos por el agüista, a través de la cultura del agua.

El turismo de salud se está convirtiendo, en una alternativa al turismo convencional debido a la creciente demanda de usuarios, atraídos por una publicidad irresistible ante el deseo de unas vacaciones relajantes; ejemplo de ello es la información sobre turismo ecológico y de salud que lanzan a través de Internet, las diferentes comunidades autónomas con la intención de atraer y fomentar el turismo de su región como es el caso de Castilla y León:

"Castilla y León es una Comunidad que ha sabido aprovechar las aguas de sus manantiales para hacer de ellas auténticos puntos de acogida para los visitantes. El turista podrá disfrutar del agua de estas 'ciudades del agua' en los llamados balnearios. Las aguas salinas y primaverales de la campiña vallisoletana, los baños salmantinos, conocidos ya en tiempos de los romanos, los abulenses, los de la provincia de León o Burgos permiten al turista que quiere descansar y reponer fuerzas, hacerlo en enclaves paisajísticos y culturales de primer orden, muy bien comunicados con puntos urbanos. La oferta se completa con las mejores instalaciones y tratamientos medicinales, a los que se suman complejos..hoteleros..de..primera..categoría.

La oferta del turismo de salud se amplía a varios alojamientos donde la práctica del turismo rural se conjuga con la del turismo de salud. Los balnearios o estaciones termales han dejado de ser una alternativa turística para personas mayores. Cada vez es más el número de jóvenes que optan por sumergirse en este tipo de turismo con el objetivo de escapar del estrés, las prisas y encontrar la calma. Ejecutivos, familias completas y grupos de amigos disfrutan de este destino turístico que conjuga ocio, descanso y salud"209.

${ }^{209}$ Www.turismocastillayleon.com 


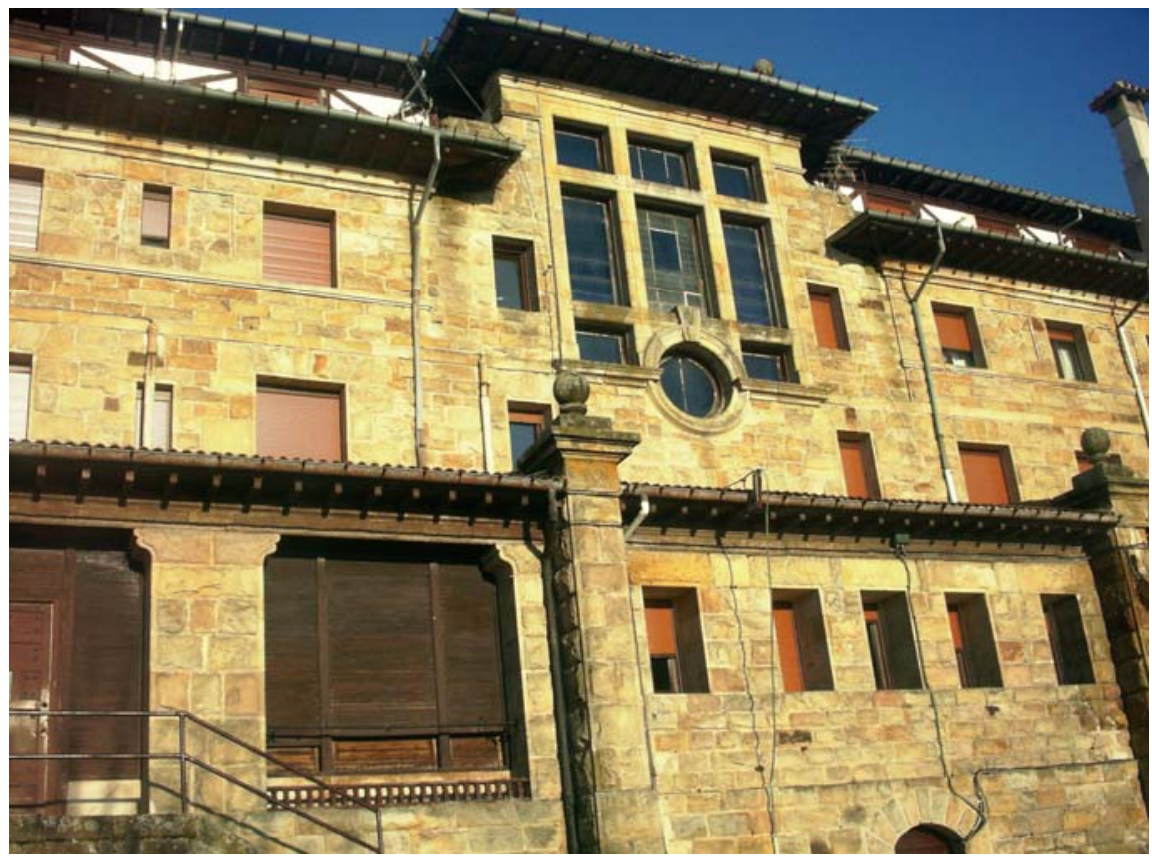

Ilustración 72 Balneario de Corconte (Burgos)

El que fuera presidente de la Asociación provincial de Hoteles en Cádiz y director en la actualidad del hotel Duque de Nájera, propone los centros de Talasoterapia como una alternativa contra la estacionalidad en Cádiz y provincia.

"La alternativa a la estacionalidad podría ser que se crearan muchos centros de talasoterapia (balnearios con agua de mar), que no cierran en invierno. La materia prima (mar) ya la tenemos. La Costa de la Luz tiene que pasar a llamarse Costa de la Salud"210

Y es que lo cierto es que el concepto de uso de los balnearios está cambiando; han ido perdiendo la connotación de centros-hospital donde asistir única y exclusivamente para terminar con la enfermedad, para pasar a ser lugares de reposo y descanso, e incluso centros de ocio y disfrute, donde tomar la energía suficiente para enfrentarse a la vida laboral o a la tensión que imprime la sociedad actual

\footnotetext{
${ }^{210}$ Morión, F. 18/01/2006 Diario de Cádiz. Pág. 23
} 
basada en la prisa y generadora de estrés para el que la cura balnearia es la terapia idónea. Por otro lado, los balnearios han dejado de ser lugares para mayores; hoy los jóvenes también contemplan la opción de veranear en un centro de reposo, en contacto con la naturaleza, donde poder practicar deportes, hacer senderismo, etc.

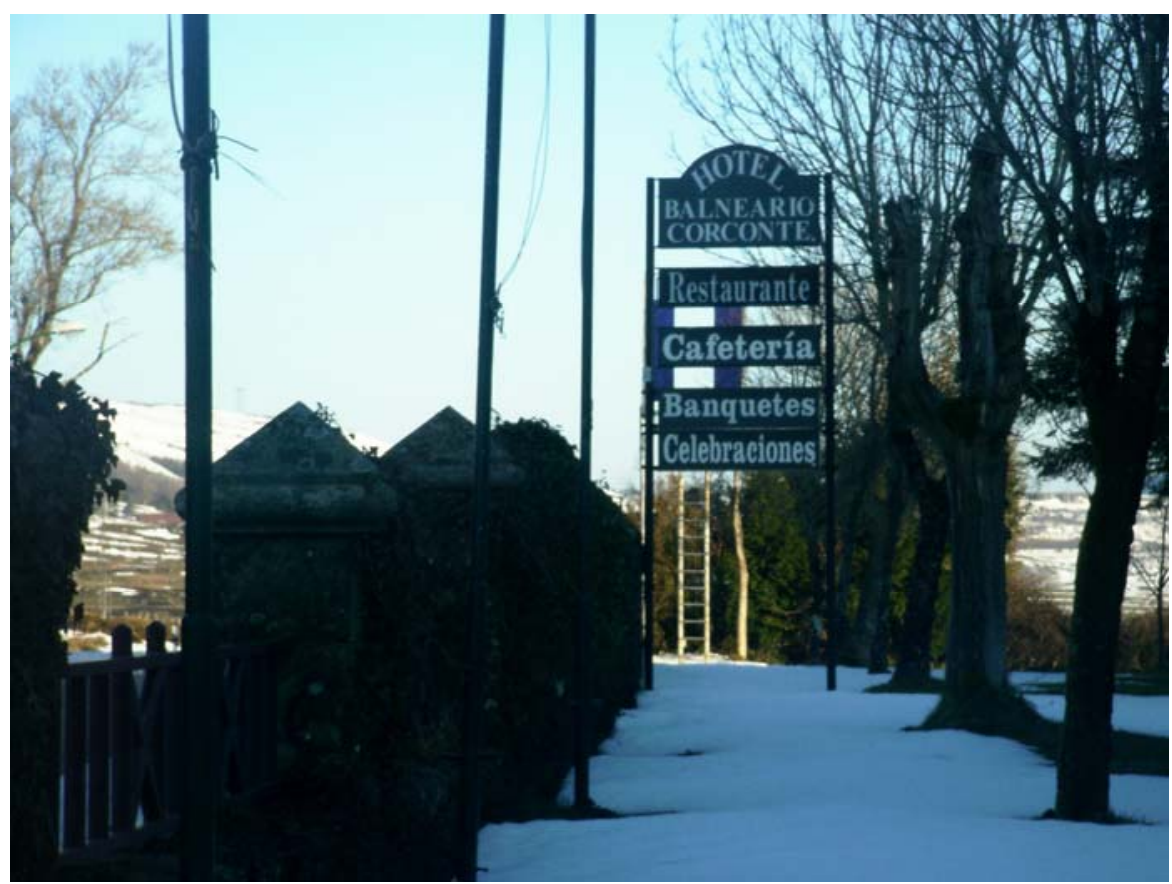

Ilustración 73 Balneario de Corconte (Burgos)

El turismo ecológico, el turismo de salud, tiene cada día más aceptación a edades más tempranas, no solo por sus servicios terapéuticos, sino también por su diversificada oferta de ocio, son lugares para disfrutar sólo o en compañía, en familia o en grupos.

El turismo de salud se está convirtiendo en un negocio al alza, el mercado del "oro azul" parece ser un negocio rentable a juzgar por su gran aceptación entre la población, producto de una nueva forma de entender el concepto de Turismo Termal como Turismo de Salud. Esto ha dado lugar a la recuperación de viejos balnearios, su ampliación y remodelación creciendo en calidad en cuanto a sus instalaciones, 
equipamientos y servicios. Podemos poner como ejemplo las numerosas remodelaciones sufridas en positivo en el balneario de Puente Viesgo en Cantabria, o la reconstrucción del balneario de Solares, que sin perder su enclave geográfico y manteniendo su entorno se está llevando a cabo en la provincia de Santander, con la construcción de un hotel balneario, que contará con ciento trece habitaciones, salones de banquetes y reuniones, parque y jardín privado, Balneario Termal, Termas Romanas, SPA y Fitness, así como también de un Balneario Infantil, unas modernas instalaciones en las que se procuraran tratamientos funcionales, relajantes y estéticos, lo que indica que los balnearios son un valor en alza por el que se sigue apostando después de los años.

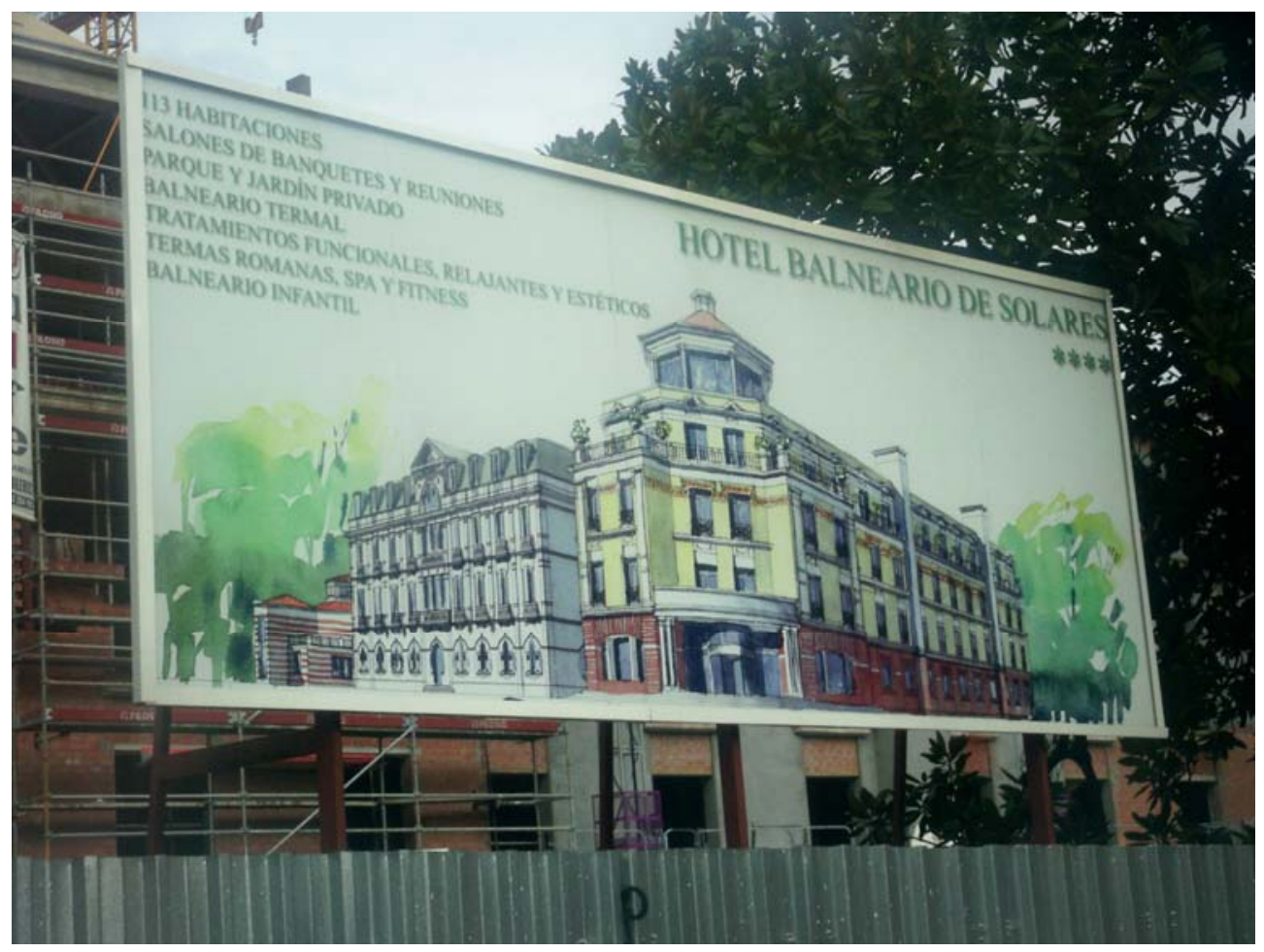

Ilustración 74 Imágenes de la reconstrucción del Hotel Balneario de Solares. En Cantabria.

Las remodelaciones de antiguos balnearios, son sin duda signo de florecimiento de un sector que vuelve a estar de moda en el siglo XXI. 


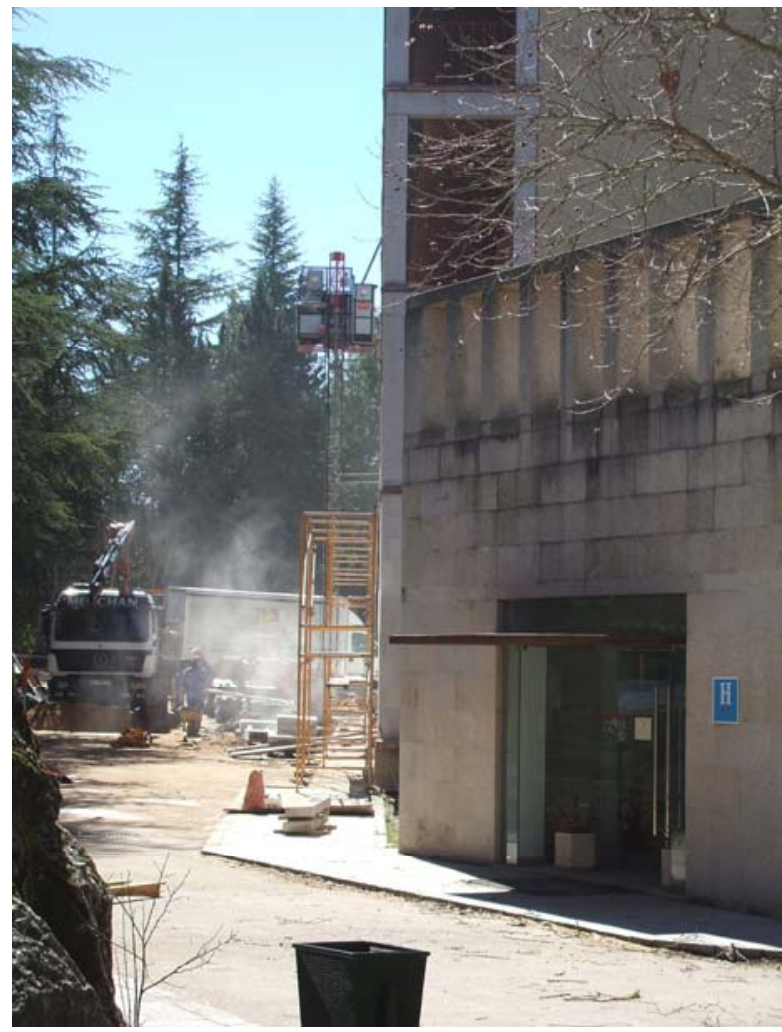

Ilustración 75 Imágenes de las obras de remodelación del Balneario de Retortillo (Salamanca)

\subsection{Portugal}

El turismo de salud se ha convertido para Portugal en una alternativa al turismo tradicional, no podía ser de otra manera si tenemos en cuenta la riqueza que en aguas termales atesora este país. 


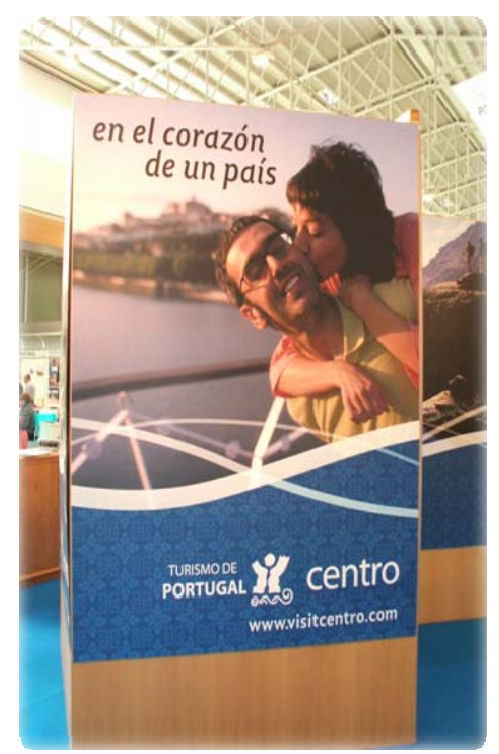

Ilustración 76 Imagen publicitaria del Turismo de Salud de Portugal ( Imagen tomada en INTUR 2007)

"El principal reto del termalismo portugués es promover el interés turístico de este sector, incentivando la regeneración de balnearios actualmente inactivos y promocionando los nuevos y recientemente remodelados. De este modo, también se logrará un equilibrio entre diferentes tipos de turismo, perfectamente compatibles con la práctica del golf y el disfrute del sol y de las playas de sus principales zonas turísticas." $^{211}$

\footnotetext{
${ }^{211}$ García, I. “La Riqueza Termal de Portugal” Revista Thermaespa; n 14, Página 75.75 procedentes de Asociación das Termas de Portugal (con estadísticas de ESPA Y FEDETERME) y la DirecÇao Gral de Geología e Energía.
} 
A continuación se presenta un cuadro en el que se presentan datos sobre el termalismo en Portugal, en él se refleja la evolución de este sector que lleva implícito el turismo de salud. ${ }^{212}$

\section{Datos del termalismo en Portugal}

$\mathrm{N}^{\circ}$ de frecuentadores o termalistas en 2005: 98.039 (frente a los 93.596 de 2003)

Comparativa Europea: $n^{\circ}$ de frecuentadores en 2004:

Eslovenia $\quad 27,5 \%$ de la población

España $\quad 2,1 \%$ de la población

Portugal $\quad 0,9$ de la población

Termas más antiguas: Caldas da Rainha (1.485)

Tipo de aguas mayoritarias: sulfúreas (segundas de las hiposalinas y las gasocarbónicas)

Época Termal: en su mayoria de mayo a octubre

${ }^{212} 1$ García, I Revista Thermaespa; n 14, Página 75 


\section{Capítulo IX}

\section{Aguta como fuente de salud y placer}

"El promotor de la salud de los hombres, sin dispendio el menor de sus caudales: Admirable método de curar todo mal con brevedad, seguridad y a placer...El agua es remedio universal"

(D. Vicente Pérez; año 1752) 
2. A MODO DE PREAMBULO: Diferencia de las aguas y su efecto en el baño

3. EL AGUA MINEROMEDICINAL Y SU INFLUENCIA EN LA SALUD MEDIANTE EL BAÑO

3.1. Propiedades curativas del agua mineromedicinal y su justificación científica.

3.2. Balnearios y estaciones termales. 355

3.3. Concepto social del balneario

3.4. Legislación balnearia 363

3.5. Termalismo Social 372

3.5.1. Termalismo Social en Europa. 373

3.5.2. Termalismo Social en España. 377

3.6. El Sector balneario en España. 380

3.6.1. Estudio sobre el sector balneario en España. 385

3.6.1.1. Análisis de resultados de la encuesta. 386 
3.6.1.2. Análisis de resultados de las entrevistas. 409

3.6.1.3. Análisis observacional en el balneario de Ledesma.. 443

3.6.1.4. Análisis observacional en el balneario de Alange.... 453

4. EL AGUA SALADA: El mar y sus propiedades terapéuticas. 462

4.1. El baño de mar

466

4.1.1. Virtudes saludables del baño en el medio marino. 467

4.1.2. Contraindicaciones de los baños de mar 469

4.1.3. El agua de mar: Prevenir o curar 470

4.1.4. Talasoterapia 471

4.1.4.1. Orígenes de la talasoterapia 472

4.1.4.2. El sector de la talasoterapia.

475

4.1.4.3. La técnica de la talasoterapia.

476

4.1.4.4. Centros de Talasoterapia

477

4.1.4.4.1. Requisitos a cumplir por un centro de talasoterapia 481

4.1.4.4.2. Dolencias a tratar en un centro de talasoterapia 482

4.1.4.4.3. Belleza y placer en un centro talaso 483

4.1.4.5. Túnez, un país referente en talasoterapia. 483

4.1.4.6. España y Francia, dos ejemplos de talasoterapia en Europa.

5. AGUAS DULCES SIMPLES; Salud y /o placer 
5.1. De las facultades de aguas simples............................................ 488

5.2. Del agua simple: SPA y Baños urbanos......................................... 490

5.3. Público objetivo de los centros SPA y Baños urbanos ....................... 491

5.4. Concepto social de SPA.......................................................... 493

5.5. Espacios hídricos, lugares pensados para el placer del baño........... 494 


\section{Introdicción}

Estamos ante un proceso de personalización, consistente en plantear una oferta muy diversificada de productos dedicados al placer y la calidad de vida, una oferta en que lo que cuenta es ofrecer al individuo un número cada vez mayor de bienes y servicios para poder elegir, estamos ante el baño a la carta donde el consumo sigue siendo el factor prioritario.

Varios son los motivos que inducen al cliente a acercarse a un centro de baño; por un lado, la prescripción médica o el deseo de mejorar la salud, por otro, la búsqueda de descanso y placer que proporcionan las aguas y terapias de estos centros; estos motivos no son excluyentes sino que en algunos casos se complementan. A la hora de elegir el lugar donde recibir estas terapias o donde disfrutar de unos días de descaso, la elección dependerá de los motivos y las posibilidades que en origen tenga el cliente para elegir el centro más adecuado.

El agua, que como hemos podido observar a lo largo de este trabajo, es un elemento tan valorado como ignorado en su uso más elemental, parece volver a ponerse de moda en cuanto a su uso social y terapéutico, aunque algo parece estar cambiando en la sociedad, que hace que el agua ocupe un lugar privilegiado en la escala de valores del ser humano, que retoma el gusto por la antigua tradición del baño termal, apreciando de forma particular sus propiedades terapéuticas, desde el conocimiento de sus efectos procurado por profesionales especialistas en la hidrología médica. Este nuevo gusto por el agua puede tener su fundamento en la importancia que la sociedad presta al aspecto físico y la imagen corporal, que se convierte de la mano de empresarios, en "El Oro Azul" capaz de hacer milagros estéticos y salutíferos mediante la inmersión deleitosa en tan preciado elemento.

El culto al cuerpo toma especial relevancia en la sociedad actual, convirtiendo la imagen personal en un escaparate visual cuyo atractivo se torna como carta de 
presentación para alcanzar el éxito tanto a nivel personal como laboral o social. En esta búsqueda de la belleza interna y externa es donde el agua se hace protagonista, como promotora de cambios positivos en la imagen corporal.

Hoy toma relevancia lo natural, todo lo que llega de la naturaleza parece ser un buen argumento publicitario para sacar al mercado cualquier producto $o$ ungüento. Extraer lo mejor de la naturaleza para uno mismo, se convierte en eslogan publicitario para atraer nuevos clientes; quizá sea este también un buen argumento para concienciar a la sociedad, de que lo natural es limitado si el uso que hacemos de ello no es el adecuado; puede, que basarse en la necesidad de lo natural como lo mejor para uno mismo, pueda servir para algo más que un motivo para incitar al consumo, para conservar aquello que como decíamos en un principio, nos ha dado la madre naturaleza para uso y no abuso por lo escaso de los recursos

El agua como balneoterapia es deleitosa y no traumática, no requiere de cirugía ni de fármacos, no es agresiva, es relajante, amable al contacto, tiene tantas virtudes que hacen de ella un elemento mágico, aunque su magia sea simplemente ella misma y sus propiedades naturales. Todas estas virtudes atribuidas al agua por sus excelencias demostradas durante siglos parecen ser las causantes de una vuelta a tan esencial recurso natural, que en moradas balnearias o en centros SPA brindan al agüista lo mejor de sí mismas, a través de un baño reparador, en ese afán por recuperar los usos sociales y terapéuticos del agua, en un ambiente distendido y en un entorno natural que hace que el concepto de vacaciones termales vuelva a ser un hecho, como ya lo fuera en los siglos XIX y XX.

El ser humano vive en continua dependencia hídrica, que toma intensidad con las necesidades creadas por él mismo en busca de su satisfacción personal y en función de su estado de salud.

La idea de los balnearios como lugar indicado para las personas mayores con dolencias propias de la edad, es una imagen obsoleta; hoy estos centros continúan siendo centros terapéuticos y de salud, pero también de atención turística para las personas de la tercera edad, de igual modo que de jóvenes, a los que les gusta cuidar de su cuerpo o ejecutivos presa del estrés, que encuentran en estos lugares no sólo 
salud sino un buen ambiente de distracción y diversión; un lugar perfecto para salir de la rutina diaria sacando un beneficio personal, que puede constituir una alternativa al periodo vacacional tradicional o simplemente remitirse a tiempo de ocio del fin de semana.

Finalmente, la recuperación del los usos sociales y terapéuticos del agua son una realidad que se suma a las nuevas tendencias y técnicas de aplicación de agua y prueba de ello son los balnearios históricos, que no solo permanecen sino que se han remodelado e incluso reconstruido y de otros centros de talasoterapia e hidroterapia de nueva creación, sin olvidar los SPA que componen un gran abanico de opciones y posibilidades para acercarse algo tan natural como el agua. 


\section{A modo de Preambullo:}

\section{Diferencias de las aguas y su efecto en el baño.}

El agua por su naturaleza es un elemento puro hallándose diferencias por su mezcla con otras sustancias, provenientes de la naturaleza misma o fruto de la intencionalidad humana.

"Aunque el agua considerada según su naturaleza sea un elemento puro, que no admite diferencias. Conociendo por la primera y más universal división del agua, en pura, ó elemental, y mixta, o mejor decir no pura.

Aquella es el elemento del agua considerado según su sustancia y naturaleza sin mezcla alguna de otra cosa.

El agua mixta, o no pura es la que vemos, y tocamos y sirve para los usos del universo.

El agua común la dividimos en potable y universal. Potable llamamos a aquella que no tiene cualidad especial, comunicada de los minerales de la tierra, y mineral aquella que recibió de dichos minerales alguna virtud extraña. De la primera señalan los autores comúnmente 6 diferencias, las cuales son: Llovida, de fuente, de río, de pozo, de estanque o de laguna, y finalmente; el agua que procede de nieve o granizo. De la mineral, no es fácil señalar número determinado; comúnmente se señalan 7 diferencias: que son para los autores de las 
aguas minerales: Azufrada Salitrosa, aluminosa, salada ferruginea, betunosa, obituminosa y aquella que pasa por minas de cobre."213

Tras esta distinción pormenorizada que nos ofrece el doctor Limón Montero, sólo resta adentrarse en las placenteras consecuencias del baño tras la mezcla caprichosa del agua pura con las distintas sustancias naturales.

${ }^{213}$ Limón Montero. (1697) “. Página 13 


\section{Ellaguamineromedicinal ysu influencia en las salud mediante ell baño}

Hablar de agua mineromedicinal, es remitirnos directamente al balneario, un lugar donde el baño es fuente de esperanza curativa, donde empaparse de la magia del agua, absorbiendo como esponjas sus bondades con el cuerpo.

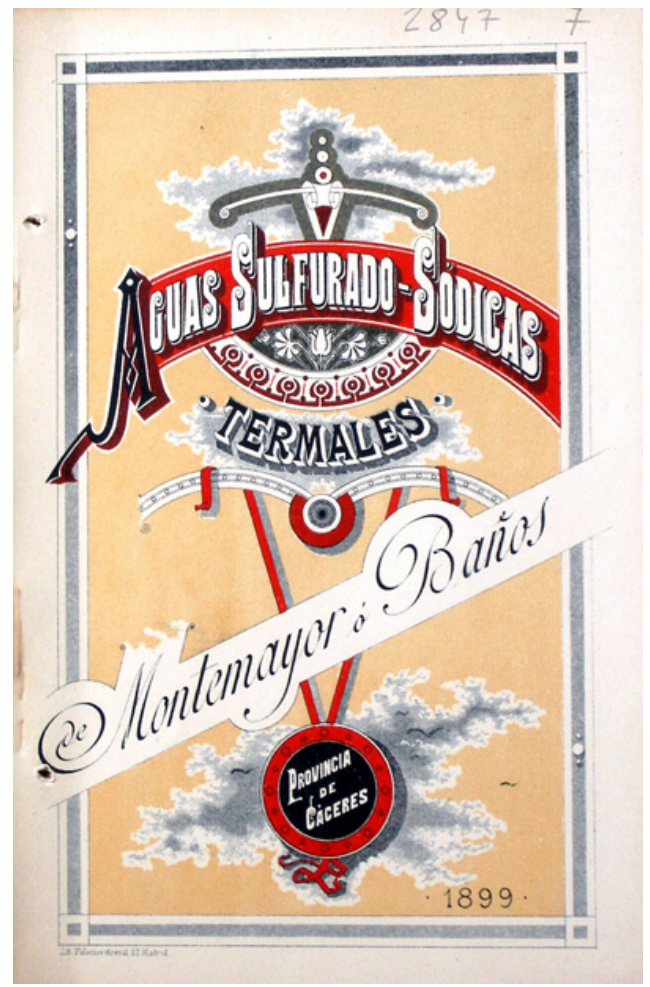

Cubierta de color: "Aguas sulfurado-sódicas termales. Montemayor ó Baños..." 214

\footnotetext{
214 correspondiente al folleto impreso "Breve reseña de las aguas sulfurado-sódicas termales de Montemayor ó Baños...", impreso en Madrid, Est. Tip. de J. Palacios, (1899) . En: http://www.ucm.es/BUCM/media/images/catalogos/fotocat4582.jpg
} 
Existen varias formas de aplicación y administración de las aguas mineromedicinales, como indica el título de esta Tesis, son las relativas al baño las que analizaremos en este estudio; nos centraremos en baños de inmersión, de vapor, duchas y chorros, cuya definición se acompaña en la siguiente cita extraída del Vademécum Maraver, a excepción de los baños de asiento

"Balneación. Los baños, es decir, la inmersión del cuerpo o parte de él en el agua mineromedicinal, pueden ser generales o parciales.

Los generales, pueden ser: en piscina; individuales; en forma de aerobaños, con insuflación de aire o gas termal; con chorros subácuaticos incorporados o tipo jacuzzi, es decir, un hidro-aero-baño a alta presión.

Los locales o regionales, pueden ser: de brazos, maniluvios; de pies, pediluvios o de asiento, para la región abdominal, baja o perineal.

Aplicaciones con presión: son las diferentes Duchas o Chorros, como también se les denominan, que difieren entre sí una de otras por la forma, presión y temperatura con la que se administran las aguas. Fundamentalmente pueden ser: generales, locales o especiales". ${ }^{215}$

Dentro de este apartado dedicado al agua mineromedicinal, conoceremos sus orígenes acercándonos al manantial de donde brota, a su historia que aún perdura, a las leyes que regulan su uso y extracción; se revelarán las bondades de su esencia para con el cuerpo humano, estudiaremos y analizaremos la realidad social actual de un fenómeno que resurge con fuerza y de un sector que lucha por abrirse camino ante los nuevos centros dedicados al placer hídrico.

\footnotetext{
${ }^{215}$ Maraver Eyzaguirre, F. y Armijo Castro, F. “Vademécum II de aguas mineromedicinales españolas” Ed. Un Complutense. Madrid
} 


\subsection{Propiedades curativas del agua mineromedicinal y su justificación científica:}

El agua termal es considerada por el hombre desde tiempos remotos por sus cualidades higiénicas y valorada por sus propiedades curativas, por su método amable y caliente de curar, por su mágico don de devolver al cuerpo la salud perdida mediante un baño placentero, en un ambiente eminentemente social, donde lo público y lo privado se funden entre los vapores del agua emergente.

El afloramiento de manantiales de los que fluyen aguas calientes con propiedades curativas, distintas en cada caso, son descubiertas en la antigüedad por el hombre, en su mayor parte, pastores o cazadores, hombres de campo en definitiva, que observan la curación de algunos de sus animales que padecían dolencias principalmente reumáticas; ellos comprueban como éstos, al sumergirse fortuitamente en estas aguas, experimentaban de forma palpable una mejoría de su salud, como es el caso que se expone a continuación en la siguiente cita:

"Más de un siglo ha pasado desde que fue descubierta a finales del siglo XIX de manera casual por tres cazadores (de los cuales uno de ellos era farmacéutico) observaron que las aves, al acercarse a beber al manantial, morían al poco tiempo por asfixia, por el efecto de los gases sulfurosos que de ellas emanan. Un cuadro con los tres cazadores y el manantial, se conservó durante muchos años en el Balneario como prueba histórica de aquel hecho". ${ }^{216}$

\footnotetext{
${ }^{216}$ http://www.balneario.com/cofrentes/
} 
Otro ejemplo de descubrimiento de manantiales por medio de la curación de animales, es el caso del balneario de "Solán de Cabras", como su nombre indica, debe este reconocimiento a la curación de las cabras de la enfermedad de la sarna. ${ }^{217}$

En la época romana, el agua termal se valoraba tanto por sus aplicaciones higiénicas como curativas, así se desprende del estudio de Diez Velasco sobre las Aquae y la practica balnear en la Península Ibérica en época romana:

"Ios médicos racionalistas romanos llegaron de un modo empírico a discernir las propiedades curativas del agua termal dependiendo de sus componentes principales reconocidos por medio del análisis organoléptico (las distinciones de las diversas propiedades terapéuticas del agua sulfurata, aluminada, bituminata, ferrata o nitrata),218

Diez Velasco comenta en su artículo publicado en la revista Contrastes, que "no hay que olvidar que la práctica del baño termal higiénico es posterior a la utilización de las aguas termales naturales con fines terapéuticos"

Limón Montero en el año 1697, publicaba un libro que ya es un referente ineludible en todos los estudios o líneas de investigación relacionadas con el termalismo, "El Espejo Cristalino de las aguas de España", sin duda una de las obras maestras más importantes de la antigüedad, que de una forma exquisita dedica sus páginas al estudio del agua, como fuente de riqueza natural al servicio del ser humano; en él, realizaba una clasificación atendiendo a la temperatura de las aguas y a sus componentes minerales como promotores curativos de ciertas dolencias:

\footnotetext{
${ }^{217}$ López de Azcona, J. M. Bellot Rodríguez, M. A. Carrasco de Salazar y Fuentes Catells, A. (1980) "Estudios sobre el balneario de Solán de Cabras” Anales de la Real Academia de Farmacia No 4 Madrid Pág.40

${ }^{218}$ Díez de Velasco, F “Las Aquae y la práctica balnear en la Península Ibérica en la época romana” Un de la Laguna. Revista Contrastes en Plinio N.H. XXXI, 32: “Est autem utilis sulphurata neruis, aluminada praralyticis aut simili modo solutis, bituminata aut nitrosa”.
} 
"Ninguna debe ser de mayor estimación y aprecio para los naturales que la habitamos, que la multitud de aguas que produce en común beneficio de todos. Son tantas esta agua en España, que sería tarea imposible tratar de todas ellas, ni siquiera de todas aquellas que por ser de gran provecho para la cura de las mayores, y más rebeldes enfermedades, que afligen al hombre, de las cuales hay en estos Reynos grande abundancia, así de las que nacen calientes, y por esta causa se llaman termales; como de las que nacen frías, que por la participación de algunas cosas extrañas metálicas, y minerales son acomodadas para curar dichos males"219

En Toledo, en el año 1752 escribía el doctor Vicente Pérez, Socio de la Real Academia de Solidistas (del que hablamos en la primera parte de esta Tesis Doctoral), al referirnos a la polémica suscitada en torno al agua como método curativo, método "acuario" por lo que en su momento fue denominada disertación Histórico-Critica- Medico Práctica, en la que se establecía el agua como "Remedio Universal de las Dolencias". El título de la obra podría calificarse de extenso para ser título, pero expresa con una enorme capacidad de síntesis lo que significa el agua mineromedicinal:

"El promotor de la salud de los hombres, sin dispendio el menor de sus caudales: Admirable método de curar todo mal con brevedad, seguridad y a placer,220

Vicente Pérez en este libro expone las propiedades curativas del agua y sus valores intrínsecos, aunque reconoce no saber a qué acusarlo, el agua con sus

\footnotetext{
${ }^{219}$ Limón Montero, A.(1697). Libro primero Fol I Introducción.

${ }^{220}$ Pérez V. (1752) “El promotor de la salud de los hombres, sin dispendio el menor de sus caudales: Admirable método de curar todo mal con brevedad, seguridad y a place”. Toledo. Pág. 26
} 
propiedades se legitima a sí misma mediante actos curativos, por lo que no considera necesario otro tipo de justificaciones ya que a su juicio tampoco se le exigen a otras medicinas cuyo fin es el mismo; curar dolencias:

"No me costará mucho rubor el confesar, que curo, sin saber por qué, pues a mí el agua no me ha revelado sus secretos; ni sé, que otras medicinas hayan revelado los suyos. ¿Sabe algún profesor de medicina porqué sea la Quina febrífuga? Sabe, porqué el agua milagrosa de Mr. Durand cura las heridas con tanta prontitud. Sabe: pero para que me canso, que sabe de botica ningún médico? Pues lo mismo se yo del agua: se por 14 años de práctica, que cura todos los males; pero ignoro, como ejecuta estos primores- yo sólo sé que el agua, que el humedecer es su efecto característico y esencial, considerando en el agua sólo aquello que tiene por su eficiencia."221

Lo importante para él, no es el secreto medicinal del agua, lo importante es su efecto curativo mediante su aplicación al cuerpo humano; el agua se justifica científicamente por sí misma, por sus bondades y primores, de los que él mismo es testigo durante los catorce años, que hasta ese momento llevaba de profesional de la medicina aplicando el agua como terapia curativa.

El Doctor Vicente Pérez reconoce las virtudes del agua y de su aplicación como medicina curativa. El agua es valorada por sí misma y por sus efectos beneficiosos para la salud.

"El agua aplicada al cuerpo humano en bebida, en cristeles, en apósitos, con este, o la otra preparación accidental, es tan varia como su modo de obrar, que tiene tantas virtudes ella sola, cuantas se conocen

\footnotetext{
${ }^{221}$ Pérez, V. (1752) .Pág. 26.
} 
en todas las medicinas pues ella es purgante, temperante, diluyente, dulcificante, nutriente, estomática, eretica, sudorífica, diurética ${ }_{\text {COCrdial }}{ }_{i}$ ella comprime, ella laxa, ella nutre, ella recrea."222

Ese tanteo y la experimentación realizada mediante la práctica de la utilización del agua como medio curativo, es la que, según nos indica la doctora Josefina San Martín Bacaicoa, catedrática de hidrología de la Universidad Complutense de Madrid, ha conducido a los hallazgos de la Ciencia.

"La utilización del agua como remedio terapéutico es pues muy antigua, basada en el empirismo, primer eslabón de la Ciencia y que junto con la observación de los hechos, la casualidad, el tanteo y la experimentación han conducido a los hallazgos de la Ciencia". ${ }^{223}$

Hoy día, según la doctora Bacaicoa, la ciencia de la medicina no puede basarse en el conocimiento que se origina desde la experiencia, es necesaria una justificación científica basada en la investigación que sirva de soporte legitimador de la terapéutica hidrotermal:

"La situación actual de la ciencia médica no admite empirismos y aun el uso repetido a lo largo de los años, o siglos, no se admite como prueba de eficacia suficiente. En nuestros días, todo agente curativo debe estar respaldado por la justificación científica de su actividad y para ello, en el caso de la terapéutica hidrotermal, no hay otro camino que la

\footnotetext{
${ }^{222}$ Pérez, V. (1752) .Pág. 35

${ }^{223}$ San Martín Bacaicoa, J. (2000) “Técnicas actuales de tratamiento balneario. Balneocinesiterapia”. En: Panorama actual de las Aguas Minerales y Mineromedicinales en España”. Ministerio de Medio ambiente. ITGE Madrid, Pág. 106.
} 
investigación científica suficiente y bien dirigida que proporcione argumentos sólidos e irrebatibles". 224

La justificación científica se basa en la investigación crenoterápica* ${ }^{225}$ que ha buscado a través de un análisis minucioso y estricto conocer las propiedades del agua a pie de manantial evitando de este modo que intervengan agentes externos que puedan sesgar el resultado de la investigación, este campo de investigación realizado desde la Hidrología Médica ha conseguido que el tratamiento termal se reconozca hoy como medio terapéutico, económico y social.

"Por tanto, en la actualidad, la utilización de las aguas mineromedicinales se justifica en parte por el empirismo remoto y el pragmatismo de su repetido empleo, pero fundamentalmente, por sus bases científicas y experimentales que permiten incluirla, con pleno derecho, entre los agentes terapéuticos, obedeciendo las prescripciones hidrológicas a las mismas reglas que cualquier otra terapéutica, en las que se establecen meticulosamente: dosificación, técnica, duración, etc. ${ }^{, 226}$

El Dr. Armijo Valenzuela en su compendio de hidrología define de forma sencilla el agua mineromedicinal como "Aquellas aguas de origen natural, utilizadas en terapéutica, y con propiedades terapéuticas conocidas y probadas"

En el cuadro que se acompaña a continuación se presenta una clasificación de las aguas minerales extraída de la ley de $8 / 1990$, de diciembre, perteneciente a Castilla-La Mancha.

\footnotetext{
${ }^{224}$ San Martín Bacaicoa, J. (2000) Pág. 106.

$225 *$ Crenoterapia, etimológicamente la palabra procede del griego Krenos que significa fuente o manantial. La crenoterapia es una técnica cuyo fin es el tratamiento para la cura de ciertas enfermedades por medio del agua.

${ }^{226}$ San Martín Bacaicoa, J. (2000) Pág. 106
} 


\begin{tabular}{|c|c|}
\hline $\begin{array}{l}\text { Aguas } \\
\text { minero- } \\
\text { medicinales: }\end{array}$ & $\begin{array}{l}\text { Son aguas superficiales o subterráneas alumbradas natural o artificialmente, que por su composición y, en } \\
\text { su caso, por su temperatura poseen propiedades terapéuticas susceptibles de ser utilizadas en } \\
\text { establecimientos balnearios emplazados en el área de emergencia o como aguas de bebida envasadas. }\end{array}$ \\
\hline $\begin{array}{l}\text { Aguas } \\
\text { minerales } \\
\text { naturales }\end{array}$ & $\begin{array}{l}\text { Son aguas subterráneas alumbradas natural o artificialmente, cuyo contenido en minerales, oligoelementos y } \\
\text { otros componentes, así como su pureza bacteriológica, producen en el organismo efectos favorables } \\
\text { complementarios de las funciones fisiológicas, sin poseer necesariamente propiedades terapéuticas. }\end{array}$ \\
\hline $\begin{array}{l}\text { Aguas de } \\
\text { manantial }\end{array}$ & $\begin{array}{l}\text { Son aguas subterráneas alumbradas natural o artificialmente, cuyo contenido en minerales, oligoelementos y } \\
\text { otros componentes cumplen las normas de potabilidad vigentes y que, por su pureza bacteriológica natural, } \\
\text { son susceptibles de utilización como aguas de bebida envasadas. }\end{array}$ \\
\hline $\begin{array}{l}\text { Aguas } \\
\text { minero- } \\
\text { industriales }\end{array}$ & $\begin{array}{l}\text { Son aguas superficiales o subterráneas alumbradas natural o artificialmente, cuyo elevado contenido en } \\
\text { determinados elementos o sustancias minerales permite un aprovechamiento industrial para obtención de } \\
\text { los mismos. }\end{array}$ \\
\hline $\begin{array}{l}\text { Aguas } \\
\text { termales }\end{array}$ & $\begin{array}{l}\text { Son aguas subterráneas alumbradas natural o artificialmente, cuya temperatura de surgencia es superior en } \\
4 \text { o-C en la media anual del lugar de emergencia, susceptible de aprovechamiento energético, siempre que la } \\
\text { producción calorífica máxima sea inferior a } 500 \text { termias por hora; Ley } 8 / 1990 \text {, de } 28 \text { de diciembre, de Aguas } \\
\text { Minerales y Termales de Castilla-La Mancha "Título Primero: De la clasificación de las aguas minerales y } \\
\text { termales y de su aprovechamiento, en: Capítulo Primero: clasificación de las Aguas Minerales y Termales }\end{array}$ \\
\hline
\end{tabular}

Agustín Francisco Gibert, miembro titular de la Cámara Argentina de Termalismo y Turismo de salud y delegado para la región N.E.A, realiza una clasificación de las aguas atendiendo a su origen geológico en el que distingue entre magmáticas y telúricas; por su conformación física, y por los residuos secos que contiene, la clasificación es la siguiente:

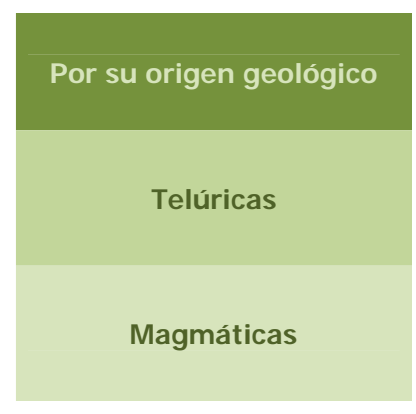


Las aguas magmáticas son primitivas. Surgen de una cierta relación con filones metálicos o eruptivos. Sus temperaturas son elevadas, siempre superiores a $50^{\circ} \mathrm{C}$. Tienen un caudal periódico, rítmico y constante, siendo así mismo constantes, su temperatura y su composición.

En este tipo de aguas, son comunes los elementos característicos de emanaciones metálicas, como boro, fósforo, arsénico, bromo, cobre, nitrógeno... Por su parte, las aguas telúricas, denominadas también aguas de "infiltración", pueden surgir de cualquier terreno. Su caudal es variable, según los regímenes de lluvia y estaciones del año.

Las temperaturas rara vez llegan a los $50^{\circ} \mathrm{C}$. El grado de mineralización es de mediano a bajo y la concentración de minerales está en inversa proporción con su caudal. En las aguas "Telúricas" existen sales de cal y de magnesio, cloruros, bicarbonatos, etc. ${ }^{227}$

Por su conformación física

menos de 20ㅇ C

de 21ㅇ a 35ㅇ C

${ }^{227}$ Gubert A. F. (Miembro Titular de la Cámara Argentina de Termalismo

y Turismo de Salud - Delegado para la región N.E.A.) Fuente: www.termasalud.com 


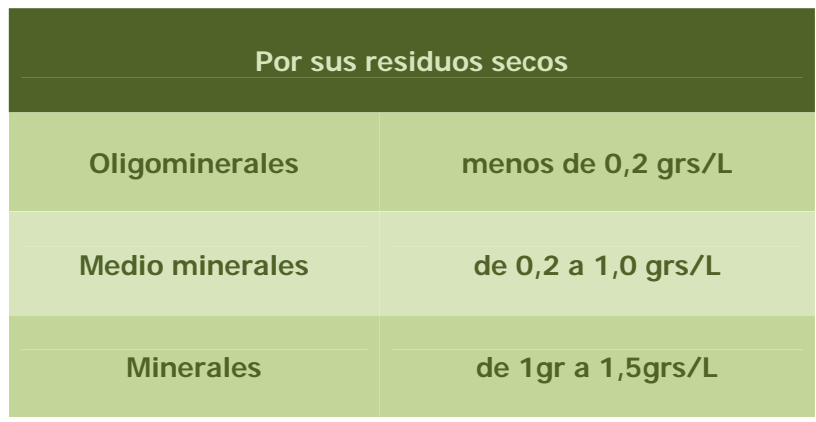

Se suele denominar como agua termal o mineromedicinal, de forma indistinta, al agua con propiedades curativas; pero a este respecto conviene hacer una distinción, ya que aunque las aguas termales son a su vez mineromedicinales, no todas las aguas mineromedicinales son termales, por tanto:

Se denomina "Agua Termal" a la que brota del manantial con una temperatura $5^{\circ} \mathrm{C}$ superior a la temperatura media anual del lugar de donde emana.

Se denomina "Agua Minero-medicinal" al agua que en su composición contiene minerales con características terapéuticas.

No es banal la elección de un centro balneario; ésta, ha de ir relacionada con el tipo de agua que ofrece al bañista y la dolencia que desea tratar, las características o propiedades del agua, el tiempo de baño y las terapias variarán en cada caso, y deberán ir reguladas e indicadas por un médico de baños. El Cuerpo de "Médico de Baños" se crea en el año 1816, durante el reinado de Fernando VII; es entonces, cuando se redacta el primer reglamento sobre aguas termales, creándose en este mismo año por medio de un Real Decreto la figura del Médico-Director de Baños. 
"Es indudable que para el desarrollo de nuestros establecimientos balnearios, fue un verdadero revulsivo la creación, en 1816, por Fernando VII, de la figura del Médico Director de Baños"228

Esta figura se mantiene vigente en la actualidad, su función consiste en aplicar sus conocimientos como médico trabajando junto a un equipo de profesionales preparados y cualificados del sector de la hidrología, como es el caso de fisioterapeutas, hidroterapéutas, bañeros etc.

Las indicaciones terapéuticas de las aguas minero-medicinales, son distintas en cada caso y corresponde al médico del balneario la prescripción de las distintas terapias, según las dolencias de las que se aqueja el bañista que acude al centro balneario en busca de mejora.

Según las propiedades de las aguas, éstas pueden tener distintas indicaciones terapéuticas, como se desprende de la siguiente tabla extraída de la ponencia presentada por Jiménez Espinosa en un congreso celebrado en Jaén, bajo el título "Presente y Futuro de las aguas subterráneas en la provincia de Jaén". De la tabla original se ha eliminado aquella información sobre aguas cuya aplicación terapéutica no se realiza mediante el baño, por no ser objeto de este estudio.

\footnotetext{
${ }^{228}$ Manzaneque, M., En Peréx Argorreta (1997). Pág. 43
} 
"I ndicaciones y Técnicas Crenoterápicas de las aguas Minero-Medicinales".

\section{tuberculosis}

quirúrgicas, afecciones

traumáticas, afecciones

reumáticas, secuelas

posthemiplégicas, afecciones,

ginecológicas, rinitis y laringitis

crónicas, dispepsias,

hipoclorhidria y estreñimiento,

alteraciones hepato-biliares,

afecciones de la piel, gota

baños,

duchas,

\section{Cloruradas}

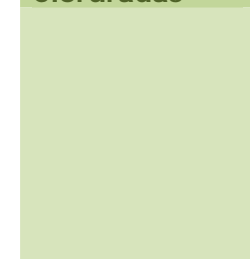

Carbogaseosas

dipsias hipoclorhídricas,

litiasis úrica, afecciones cardio-

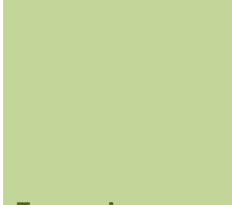

Ferruginosas

$\begin{array}{ll}\text { Ferruginosas } & \text { diabetes } \\ & \text { afecciones del aparato } \\ \text { digestivo, afecciones }\end{array}$

hepáticas, litiasis, afecciones

del riñón y vías urinarias,

litiasis afecciones reumáticas,

gota, afecciones ginecológicas

secuelas de traumatismos,

afecciones alérgicas

inhalaciones y

Anemias, dispepsias con

hiposecreción, afecciones,

cutáneas, afecciones

Radioactivas bebida

baños y

bebida

baños,

duchas y

bebida

Sulfatadas

Sulfuradas

baños,

duchas,

inhalaciones $y$

bebida colecistopatías y litiasis biliar,

afecciones de la piel, rehabilitación,

afecciones reumáticas, dispepsias,

enteritis, y estreñimiento, gota y

diatesis úrica, oxalurias y fosfaturias

obesidad

afecciones de las vías respiratorias,

afecciones de la piel, reumatismo,

rehabilitación, afecciones hepáticas

enteritis, afecciones ginecológicas,

secuelas postraumáticas

alteraciones metabólicas

enteritis, afecciones ginecológicas,

secuelas postraumáticas

alteraciones metabólicas

afecciones circulatorias, afecciones

respiratorias gastritis hiperesténicas,

enterocolitis, a fecciones vías urinarias,

litiasis procesos ginecológicos, baños,

afecciones de la piel, procesos duchas,

alérgicos, afecciones reumáticas, gota, inhalaciones

distonías vegetativas

Oligominerales

Tabla 1. Indicaciones terapéuticas de las principales aguas mineromedicinales (R. J iménez Espinosa) 
En algunos países de Europa, como es el caso de Francia, se está asistiendo a un importante avance en el sector de la hidrología médica debido en gran parte a que la crenoterapia se considera como medio terapéutico sin distinción alguna; Francia ha sido un país pionero a la hora de dotar de una legislación específica para aquellos servicios que se prestan en el sector.

"La Academia de Medicina Francesa ha dado a las aguas mineromedicinales el carácter de medicamento $y$, como tal debe ser prescrito,.vigilado y controlado por el médico. Además, la Organización Mundial de la Salud dio en 1962 la Normativa internacional para Investigación Biomédica y en ella especifica textualmente:<< La evaluación clínica de la terapéutica hidrotermal debe ser conforme a los principios internacionales admitidos para la evaluación de los medicamentos $>$ Todas estas consideraciones de las aguas mineromedicinales como medicamento hace que su uso y aplicación, en sus distintas acepciones, requiera de profesionales adecuados y una labor interdisciplinar entre los distintos especialistas, desde el hidrogeólogo al médico, pasando por el químico."229

Como hemos podido observar, se ha pasado en cierta manera de la magia a la ciencia, del milagro a la comprobación científica, del efecto placebo al efecto terapéutico, pero en cualquier caso, sin perder la esencia de las propiedades benéficas de un elemento incoloro, inodoro e insípido, que administrado con prudencia y conocimientos produce salud y placer.

\footnotetext{
${ }^{229}$ Jiménez Espinosa, R. (2002) “Indicaciones y Técnicas Crenoterápicas de las aguas Minero-Medicinales” Ponencia presentada en las Jornadas de Aguas Mineromedicinales en España: "Presente y Futuro del las Aguas Subterráneas en la Provincia de Jaén” CIGME. MADRID 2002. ISBN. 84-7840-472-4
} 


\subsection{Balnearios y Estaciones Termales.}

Atendiendo a su origen geológico: los baños termales tienen como origen un manantial de agua mineromedicinal, el aprovechamiento de estas aguas dotadas de propiedades mineromedicinales, da lugar a la construcción de edificios sobre estos manantiales, los denominados balnearios; lugares de acceso público donde poder sumergirse en este elemento hídrico de indiscutibles propiedades salutíferas, que por su composición, los distingue del resto de centros que se estudian a lo largo de este capítulo; centros de Talasoterapia y SPA, en los que las características de sus aguas, que estudiaremos detenidamente, difieren de ellas; lo que determina que estos balnearios por sus aguas mineromedicinales, poseen propiedades curativas distintas a las del agua de mar de los Talaso, y propiedades que no procuran los SPA, que utilizan para sus terapias agua corriente o de grifo como se denomina de forma vulgar.

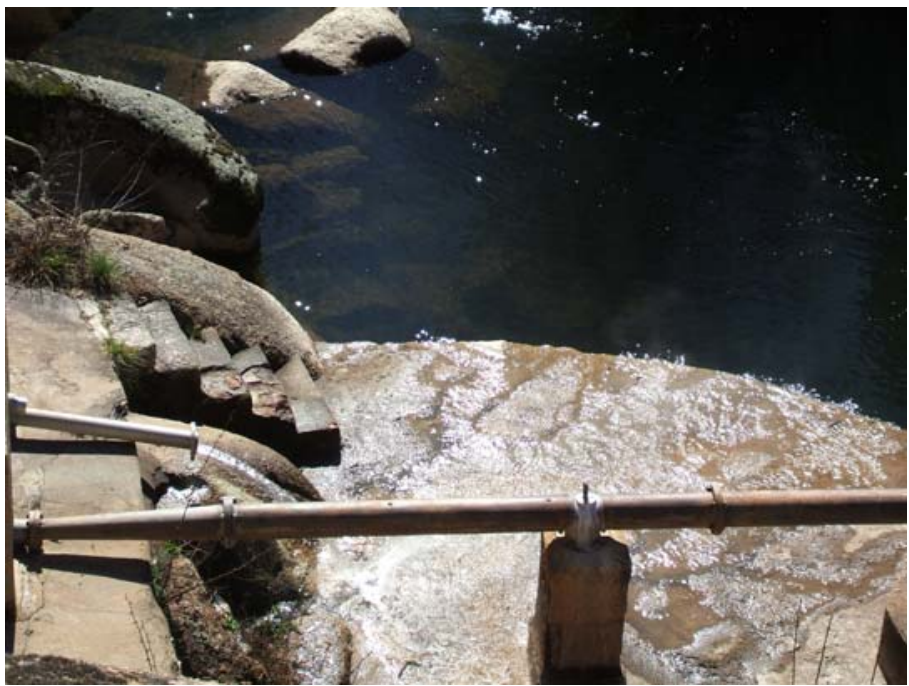

Ilustración 77 Salida de agua mineromedicinal. Balneario de Retortillo (Salamanca) 
El agua mineromedicinal por su origen geológico se encuentra regulada por la ley de Minas (Ley 22/1973, de 21 de julio) de la que se trata más ampliamente dentro de este estudio en el apartado de legislación balnearia.

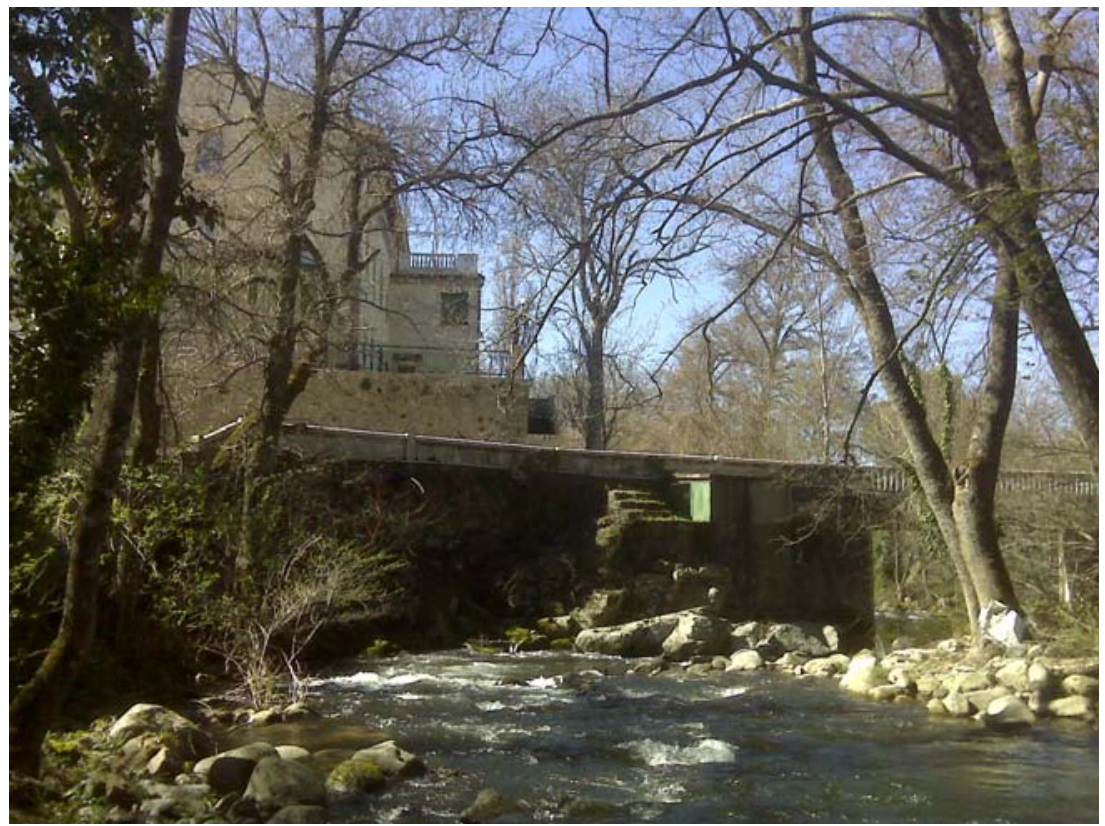

Ilustración 78 Balneario del Salugral (Cáceres) do a la orilla del río Ambroz.

La condición de proximidad al manantial de donde surge su esencia, hace del centro balneario una estancia eminentemente rural, entornos naturales donde se instala el hombre para servirse de los beneficios que graciosamente le brinda la naturaleza, una naturaleza caprichosa que pone las bases del establecimiento balneario.

Son lugares con encanto que permiten al hombre un reencuentro con la naturaleza lejos del ambiente eminentemente urbano. 
"Se considerará establecimientos balnearios aquellos que, estando dotados de los medios adecuados, utilizan las aguas minero-medicinales y/o termales con fines terapéuticos ${ }^{, 230}$

Esta es una de las muchas definiciones utilizadas para denominar el concepto de balneario, y todas ellas coinciden en esencia con respecto a la utilización de aguas minero-medicinales.

"Hoy en día el agua minero-medicinal es, por tanto, considerada como agente medicamentoso; aplicada en todas sus formas, oral, inhalatoria y tópica, constituye un "factor de bienestar y salud", es el factor básico del tratamiento balneario y el responsable de la existencia del balneario"231

El concepto de "balneario" quedó determinado al inicio de este estudio, pero antes de profundizar en la realidad de los balnearios, retomaremos a modo de recordatorio, algunas cuestiones que den claridad al mismo.

"Según la Asociación Nacional de Balnearios y Estaciones termales, Los balnearios son los únicos herederos de la tradición de la cura termal que griegos, romanos y árabes practicaron en España". 232

\footnotetext{
${ }^{230}$ Extremadura; Ley de 24 de Noviembre de (1994), NUM 6/1994 Asamblea de Extremadura “Balnearios- Aguas Minero. Medicinales. Regulación”; en: DO Extremadura, 22 Diciembre de 1994, núm. 144

${ }^{231}$ San Martín Bacaicoa J.(2000). Pág. 107

${ }^{232}$ Pérez Fernández, Mª R. (2005) “Principios de Hidroterapia y Balneoterapia”. Ed.. McGraw- Hill. Interamericana. Pág. 36.
} 
Un Balneario es una instalación adecuada en la que se llevan a cabo curas termales por medio del agua minero-medicinal, aguas declaradas de utilidad pública; es decir, utilizan las aguas minero-medicinales y termales con fines terapéuticos. Son instalaciones adecuadas desde el punto de vista técnico sanitario que cuentan con el servicio de un Médico; este carácter de centro sanitario le obliga a las prestaciones hidroterapéuticas y balneoterapicas y por consiguiente a una legislación específica.

"El balneario debe desarrollar aquello que tiene de especifico y de original aprovechando las propiedades específicas de sus aguas, de ese medicamento termal reconocido, estudiado y utilizado en su complejidad y en su diversidad; medio frágil, inestable en algunos casos, en los que las propiedades físicas, físico-químicas se pueden alterar (cambio de temperatura, contacto con el aire, etc.) y modificar también las acciones terapéuticas. $^{, 233}$

Estas características son las que diferencian los balnearios del resto de centros dedicados al baño que serán también objeto de estudio, como es el caso de los centros de Talasoterapia, o los modernos Spa.

"La razón fundamental de la propia existencia de un balneario o estación termal es la presencia y disponibilidad de una determinada agua minero-medicinal. Tanto es así, que por lo menos en su cabal acepción tradicional puede afirmarse que si no hay agua minero-medicinal, no hay balneario o estación termal".

\footnotetext{
233 San Martín Bacaicoa J Pág. 107

${ }^{234}$ En (Panorama actual de las Aguas Minerales y Minero-medicinales en España) Benito Oliver-Rodés Clapés Director del Laboratorio de Análisis Dr. Oliver Rodés, S.A. - Barcelona

http://www.castillalamancha.es/turismo/sp/contenidos/turismo\%20saludable/enlaces/PonenciaAguas.pdf
} 
En los balnearios se utiliza el agua minero medicinal declarada de utilidad pública, para la recuperación, la rehabilitación, la prevención, el alivio de dolencias y el cuidado de la salud en general, tanto física, como psíquica.

Son los balnearios, manantiales de agua saludable y a su vez centros sociales donde acudir solo o en compañía; disfrutar de una estancia en un balneario incluye en cierto modo, pasar a formar parte de un lugar donde se comparte no sólo el gusto por el baño; en el balneario se vive, se pasea, se disfruta, un marco en el que las relaciones personales, como ya apuntábamos anteriormente, fluyen a pie de manantial, son centros donde el ocio y el disfrute entran a formar parte de la terapia. 


\subsection{Concepto social de balneario}

En la actualidad algunos centros balnearios, luchan por terminar con el concepto de centro/hospital, y con la etiqueta de un lugar "sanatorio", condición que vivieron en algún momento de la historia por necesidades coyunturales y que producía rechazo a una parte de la población que pretende el uso del balneario como un centro de descanso y placer, donde asistir a recuperar fuerzas o a curar pequeñas dolencias, un lugar en el que no sentirse como un enfermo más, un espacio placebo donde recurrir en caso de aislamiento en busca de un contacto intimo con la naturaleza; esto es algo que al parecer los centros balnearios van poco a poco consiguiendo, aunque en algunos balnearios aún se percibe como rezuman ese ambiente hospitalario de centro de salud, quizá por esa condición indispensable que ha de reunir y que los distingue de centros como es el caso de los SPA, es decir, el requisito de ser unas instalaciones adecuadas desde el punto de vista técnico sanitario que cuentan con el servicio de un Médico.

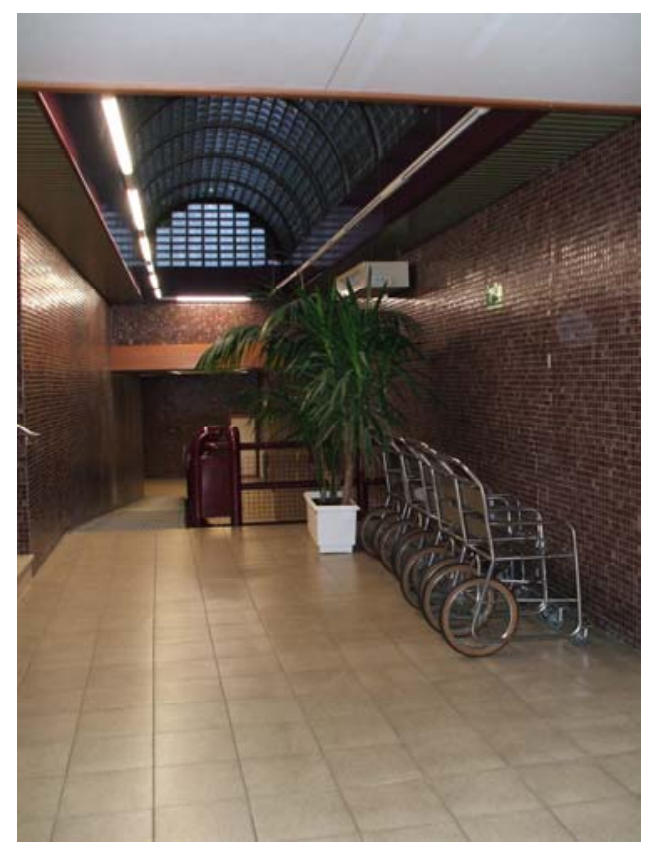

Ilustración 79 Instalaciones del Balneario de Ledesma (Salamanca) 
Todo esto intenta contrarrestarse no por considerarse negativo, sino por tener acceso a una nueva clientela, que apuesta por acudir a los balnearios en busca de otro tipo de beneficios, relajarse, descansar, recuperarse, al tiempo que disfruta de unas buena vacaciones en un entorno natural; para ello, el centro balneario se reforma, moderniza y embellece sus instalaciones con salones de lujo, renueva sus hoteles y la oferta de ocio que pretende desdibujar esa sensación de centro hospitalario; en base a esto, los balnearios disponen de varios tipos de clientes, por un lado, las personas pertenecientes a la tercera edad: este tipo de clientela es mayoritaria, en gran parte, aunque no en exclusiva, pertenecen a los programas de Termalismo Social del "IMSERSO" un programa que permite poner al alcance de muchas personas mayores la posibilidad de acudir a un centro balneario de vacaciones, un lugar donde se recuperan de pequeñas dolencias y donde cogen fuerza para enfrentar el futuro inmediato.

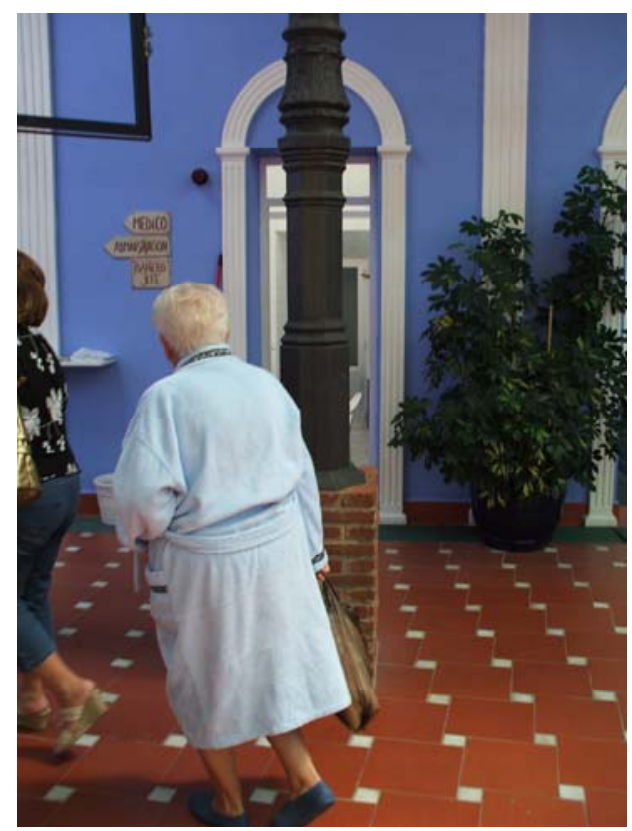

Ilustración 80 Imagen tomada en el Balneario de Alange 
Los programas de Termalismo, son cada vez más solicitados y aseguran una clientela que supone un importante activo para el sector balneario y en muchos casos la supervivencia de los mismos; por otro lado, una clientela más joven, mencionada anteriormente, que busca en el balneario, prevención, descanso, belleza, ocio, turismo etc. Se trata de una savia nueva que supone un valor en alza para aquellos centros etiquetados y estereotipados por la enfermedad que a sabiendas toman conciencia de su situación; son centros que se modernizan para ofrecer una imagen renovada, actual y en relación con los tiempos que corren. No se puede decir que todos los centros hayan entrado en esta dinámica, pero son cada vez más los balnearios que se suman a esta idea de renovarse o morir pensando en cambiar su imagen a los ojos de un cliente joven y de futuro.

Los centros balnearios en la actualidad, intentan ofrecer las terapias modernas para atraer a esa clientela que se inclina por los nuevos centros dedicados a placer en el agua, como es el caso de los SPA, ofreciendo a un tiempo algo que los SPA no pueden ofrecer. "Agua mineromedicinal" un valor en alza, para un sector que empieza a ser regentado en su mayor parte, por jóvenes directivos influidos por las nuevas tendencias y por las estrategias de Marketing más actuales, como motor impulsor de un sector que se encontraba en decadencia ante una sociedad cada vez más demandante de este tipo de servicios hídricos y lúdicos.

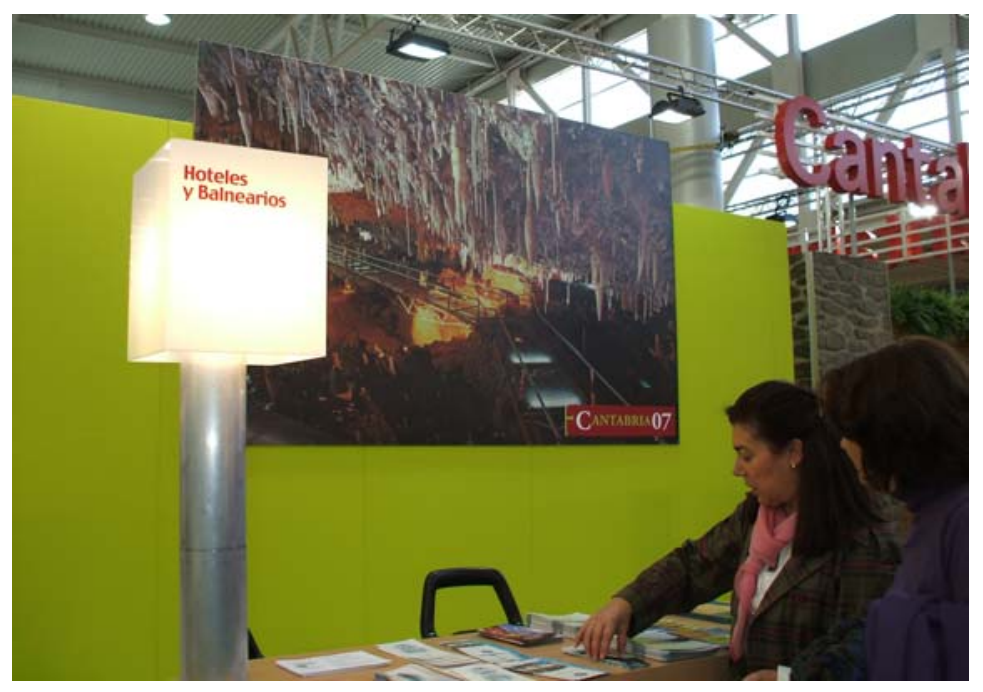




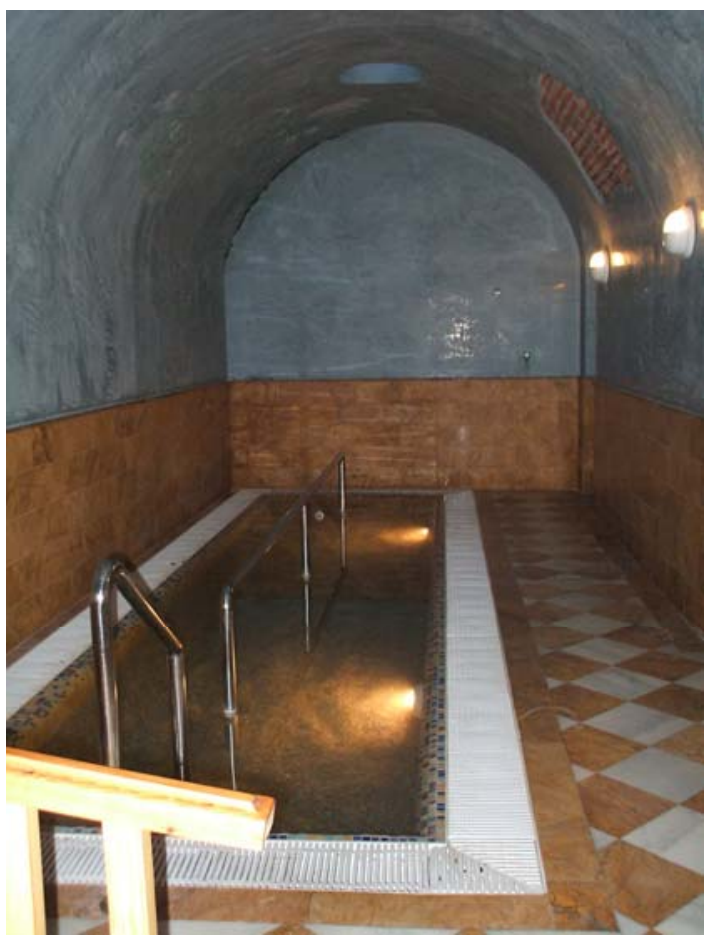

Ilustración 81 Imagen tomada en el Balneario de Granea en la comarca de Guadix (Granada)

\subsection{Legislación balnearia}

El agua mineral se caracteriza por su contenido en minerales y por su pureza, propiedades que adquieren por su condición de aguas subterráneas y que pueden alterarse por la intervención humana en la naturaleza, lo que hace necesaria la adopción de medidas legislativas que velen por la protección de las aguas minerales, por su composición y por la conservación de los manantiales evitando su deterioro. Al referirnos a la intervención humana aludimos a:

- Alteración de caudales.

- Agotamiento de manantiales por sobreexplotación.

- Variación de temperatura del agua por conexión con otros acuíferos. 
Por todo ello, el sector balneario está legislado, y es por este motivo por el que no se puede obviar en este estudio el marco legislativo que lo regula.

En este epígrafe no se pretende profundizar en el ámbito legislativo, pero sí conocer de forma sucinta, las distintas legislaciones que contemplan la ordenación.

Dos profesionales en la materia, Juana Baeza Rodríguez-Caro y José Antonio Fernández Sánchez dentro del capítulo "Ordenamiento Legal de Las Aguas Minerales" - en el libro titulado "Panorama Actual de las Aguas Minerales y Mineromedicinales en España" presentan una clasificación - que se expone a continuaciónestructurada en cinco bloques, sobre la normativa española en materia de aguas minerales, que resume de forma esquemática todo lo contemplado dentro del marco de la ley en este ámbito:

Regulación de las aguas mineromedicinales:

"Primer bloque: Legislación sobre aguas minerales de uso terapéutico. Arranca con el Reglamento de Baños y Aguas Mineromedicinales de 28 de marzo de 1817, primera normativa española de aguas minerales, modificado por los Reglamentos de 1834, 1874 y, finalmente, el Real Decreto Ley de 25 de abril de 1928 que aprobó el Estatuto sobre la Explotación de Manantiales de Aguas Mineromedicinales. El Estatuto fue la principal norma reguladora de la declaración de utilidad pública, régimen de propiedad, aprovechamiento y protección de las aguas minerales hasta 1973, año en que fue derogado -excepto en los aspectos meramente médico-sanitarios por la Ley de Minas".

Segundo bloque: Legislación de minas. En un principio las Leyes de Minas, desde la primera de 1849, pasando por las de 1859, 1868, 1938 y 1939, no contemplaban las aguas minerales por considerarlas de 
régimen estrictamente privado. La Ley de 1944 se limitó a incluirlas en la clasificación de los recursos, como sustancias de la Sección B (Minerales). Finalmente, la Ley 22/1973, de 21 de julio, desarrollada por el Reglamento General para el Régimen de la Minería de 1978, pasó a ser la norma fundamental en materia de aguas minerales, sustituyendo al Estatuto de 1928 en la regulación de la declaración, explotación y protección de estos recursos. Esta normativa permanece vigente en las Comunidades Autónomas que no han promulgado legislación propia, y subsidiariamente en las restantes.

Tercer bloque: Regulación de las aguas minerales envasadas, utilizadas como bebida. Este uso de las aguas minerales tiene normativa propia, a nivel de Decreto, que se inicia en 1967 con el Código Alimentario y prosigue con las Reglamentaciones Técnico-Sanitarias de 1981 y 1991. Aunque, como indica su nombre, dichas normas son de carácter básicamente sanitario, la última -aprobada por R.D. 1164/1991 de 22 de julio, y modificada por R.D. 781/1998 de 30 de abril - tiene especial interés desde el punto de vista hidrogeológico, ya que, al transponer la Directiva 80/777/CEE sobre explotación y comercialización de aguas minerales naturales, introduce en la legislación española una exigencia expresa de estudios geológicos e hidrológicos para el reconocimiento de la condición de agua mineral y el establecimiento de medidas para su protección.

Cuarto bloque: La legislación de aguas. Las Leyes de Aguas de 1866 y 1879 no mencionan las aguas minerales. La Ley 29/1985 de 2 de agosto, aunque remite la regulación de estos recursos a su legislación específica, afecta de modo indirecto -pero importante-a su régimen legal, ya que declara de dominio público las aguas subterráneas integrantes del ciclo hidrológico, entre las que se encuentran -según el criterio más generalizado- las aguas minerales. 
Quinto bloque: Las legislaciones autonómicas. La Constitución y los Estatutos de Autonomía reconocen la competencia -incluso legislativade las Comunidades Autónomas en materia de aguas minerales. En desarrollo de dicha competencia, cuatro Comunidades han establecido legislación propia: la Ley 2/1988 de 26 de octubre, de Fomento, Ordenación y Aprovechamiento de los Balnearios y de las Aguas Mineromedicinales y/o Termales de Cantabria, con Reglamento aprobado por Decreto 28/1990 de 30 de mayo; la Ley 8/1990 de 28 de diciembre, de Aguas Minerales y Termales de Castilla-La Mancha, con Reglamento aprobado por Decreto 4/1995 de 31 de enero; la Ley 6/1994 de 24 de noviembre, de Balnearios y de Aguas Mineromedicinales de Extremadura; la Ley 5/1995 de 7 de junio, de Regulación de las Aguas Minerales, Termales, de Manantial y de los Establecimientos Balnearios de Galicia, con Reglamento aprobado por Decreto 402/1996 de 31 de octubre. En términos generales, estas normativas autonómicas no introducen grandes modificaciones respecto a las estatales anteriormente vigentes, aunque cabe señalar que las Leyes de CastillaLa Mancha, Extremadura y Galicia fijan un régimen de concesión para el aprovechamiento de las aguas minerales -lo que supone reconocimiento expreso de su pertenencia al dominio público, y que la legislación gallega regula con especial detalle los perímetros de protección. ${ }^{235}$

Durante todo el recorrido realizado por el marco jurídico que regula y ordena las aguas minero-medicinales se puede observar el vacío legal en Europa a este respecto, encontrando como documentos los expuestos continuación relativos a tres directivas europeas relativas a las aguas en general o las aguas envasadas, en ningún caso al tema que nos ocupa en este estudio, la regulación de las agua dedicadas al baño. 235 Baeza Rodríguez-Caro, J. y Fernández Sánchez, J. A (2000)“Aspectos Legales y Técnicos en la Protección de Las
Aguas Minerales “. En: “Panorama Actual de las Aguas Minerales y Minero-Medicinales en España” Págs. 250/251 
DIRECTIVA 2003/40/CE (AGUAS MINERALES NATURALES) DIRECTIVA 2003/40/CE DE LA COMISIÓN de 16 de mayo de 2003: Por la que se fija la lista, los límites de concentración y las indicaciones de etiquetado para los componentes de las aguas minerales naturales, así como las condiciones de utilización del aire enriquecido con ozono para el tratamiento de las aguas minerales naturales y de las aguas de manantial.

DIRECTIVA 2000/60/CE (DIRECTIVA MARCO DEL AGUA) DEL PARLAMENTO EUROPEO Y DEL CONSEJO de 23 de octubre de 2000: Por la que se establece un marco comunitario de actuación en el ámbito de la política de aguas.

\section{DIRECTIVA 2000/60/CE (ANÁLISIS DE TRANSPOSICIÓN Y PROCEDIMIENTOS} DE DESARROLLO): Documento, elaborado por el Ministerio de Medio Ambiente, recoge el texto íntegro de la Directiva 2000/60/CE, de 23 de octubre de 2000, conocida como Directiva Marco de Aguas, incorporando a este texto diferentes observaciones, análisis y comentarios pertinentes desde el punto de vista de su trasposición jurídica y aplicación práctica en nuestro país. ${ }^{236}$

Con el siguiente titular citado a continuación, arrancaba una entrevista en profundidad realizada por la revista Thermaespa, revista de termalismo, tendencias y cultura del agua, a Ennio Gori Presidente de la Organización Mundial de Termalismo OMHT. En esta entrevista aboga por la creación de una legislación Europea.

"Uno de los objetivos de la Organización Mundial de Termalismo es la creación de una legislación Única para Europa”237

\footnotetext{
${ }^{236}$ http://www.villastermales.com/legislacion.htm

${ }^{237}$ Revista Thermaespa; nº13 pág. 54 año (2006).
} 
A lo largo de la entrevista se le pregunta:

- ¿Cómo crearán una legislación unificada a partir de muchas legislaciones se tomará alguna como modelo o una parte de cada país para crear ese gran modelo europeo y mundial?

- "Hemos hecho una comparación de legislaciones. Pero le confirmo, el núcleo del problema en Bruselas es que un estado miembro de la Comunidad Europea debe exponer el problema. El problema- déjeme señalar- es que la construcción comunitaria es lenta. Las ideas son muchas pero el problema es iniciar el proceso.

"El proyecto debe estar en el contexto del sistema sanitario, por su rigor científico. Si entra en el sistema sanitario debe estar abierto a la generalidad de los ciudadanos. Toda la labor de elaboración técnica ha sido presentada en Bruselas. Este es un objetivo posible. No es sólo aspiración. Existe esta concreción. Como ven no es poca la batalla que tenemos por delante"

Este extracto de la extensa entrevista nos da una idea de la situación prenatal en la que aún se encuentra el panorama legislativo europeo.

El cuadro que se presenta a continuación es una pequeña sinopsis sobre las leyes más significativas que componen el marco legislativo del sector balneario en la actualidad, tanto a nivel nacional como autonómico, lo que nos acerca al motivo de la ley, así como a la fecha y forma de su publicación.

Tres son por tanto las leyes de ineludible alusión con respecto a las aguas mineromedicinales por ser de ámbito general:

1- Real Decreto-Ley de 25 de Abril de 1928- Estatuto sobre la explotación de Manantiales de Aguas Minero-Medicinales.

2 - Ley 22/1973, de 21 de Julio, de Minas. BOE de 24 de Julio 1973. 
3 -Real Decreto 2857/1978, de 25 de Agosto, por el que se aprueba el Reglamento General para el Régimen de la Minería.

No nos detendremos en el Real Decreto, de ella hay que decir, que se trata de una ley actual y vigente aunque su nacimiento fuese en 1928 época de singular apogeo termal en España; por el contrario nos detendremos en la Ley 22/1973, de 21 de julio, de Minas ya que esta nos acerca a la esencia y espíritu del agua mineromedicinal para su preservación desde las entrañas la tierra misma.

b) Ley 22/1973, de 21 de julio, de Minas (BOE núm. 189, de 24-07-1973).

El agua es un recurso natural disponible al servicio del hombre y se hace necesario añadir que es un recurso natural escaso, por lo que al igual que el resto de los recursos naturales disponibles, se encuentra dentro de un plan de ordenación que regula el uso y control de los mismos.

En el Título primero referente al ámbito de aplicación de la Ley y clasificación de los recursos y dentro del artículo primero de dicha ley se establece el régimen jurídico de la investigación y aprovechamiento de los yacimientos minerales, así como de los demás recursos geológicos independientemente de su origen y estado físico.

"En el título I de la presente Ley se reafirma la naturaleza jurídica de los yacimientos minerales de origen natural y demás recursos geológicos como bienes de dominio público y se mantiene la concesión administrativa como institución tradicional al principio básico de nuestro ordenamiento minero"............ Se han creado así tres secciones, en la primera de las cuales se incluyen la mayor la de las que se denominaban «rocas»; en la segunda, las aguas minerales y las termales, las estructuras subterráneas y los yacimientos formados como consecuencia de las operaciones reguladas por esta Ley, y en la tercera, cuantos yacimientos minerales y recursos geológicos no están incluidos en las anteriores. "238.

${ }^{238}$ (BOE núm. 189, de 24-07-1973). Ley 22/1973, de 21 de julio, de Minas 
El Título IV de esta Ley, regula el aprovechamiento de los recursos y define las aguas minerales y termales, manteniendo la distinción entre las minero-medicinales y las minero-industriales, clasificando las aguas termales destinadas al uso terapéutico o industrial en su caso pero considerándose ambas aguas minerales a todos los efectos de la ley.

"1. Los yacimientos minerales y demás recursos geológicos se clasifican, a los efectos de esta Ley, en las siguientes secciones:

A) Pertenecen a la misma los de escaso valor económico y comercialización geográficamente restringida, así como aquellos cuyo aprovechamiento único sea el de obtener fragmentos de tamaño y forma apropiados para su utilización directa en obras de infraestructura, construcción y otros usos que no exigen más operaciones que las de arranque, quebrantado y calibrado.

B) Incluye, con arreglo a las definiciones que establece el capítulo primero del título IV, las aguas minerales, las termales, las estructuras subterráneas y los yacimientos formados como consecuencia de operaciones reguladas por esta Ley.

C) Comprende esta sección cuantos yacimientos minerales y recursos geológicos no estén incluidos en las anteriores y sean objeto de aprovechamiento conforme a esta Ley." 239

El Título IV de esta Ley, trata de la regulación de los aprovechamientos de los recursos; en su artículo 23 y dentro de su Capítulo Primero realiza una clasificación de las aguas minerales diferenciándolas de las aguas industriales, definiendo a su vez de forma concisa las aguas Minero-medicinales por un lado y las aguas Termales por otro, algo de lo que ya se trató con anterioridad "El agua mineromedicinal y su

${ }^{239}$ (BOE núm. 189, de 24-07-1973). Art. 3 “ Ley 22/1973, de 21 de julio, de Minas” 
influencia en la salud mediante el baño" dentro del epígrafe dedicado a "Las propiedades curativas del agua mineromedicinal y su justificación científica" y que ahora está ley viene a corroborar:

"1. A efectos de la presente Ley, las aguas minerales se clasifican en:

a) Minero-medicinales, las alumbradas natural o artificialmente que por sus características y cualidades sean declaradas de utilidad pública.

b) Minero-industriales, las que permitan el aprovechamiento racional de las sustancias que contengan.

2. Son aguas termales aquellas cuya temperatura de surgencia sea superior en cuatro grados C. a la media anual del lugar donde alumbren." 240

La Ley de Minas en su Capítulo II, Sección 1a "Aguas minerales y termales" artículo 24; determina que será requisito previo La declaración de la condición de mineral de unas aguas determinadas, para la autorización de su aprovechamiento como tales, siendo la declaración efectuada mediante resolución del Ministerio de Industria a propuesta de la Dirección General de Minas, mediante informe previo facilitados por el Instituto Geológico y Minero de España y del Consejo Superior de dicho Departamento. Así mismo; para la clasificación y el aprovechamiento de las aguas Minero-medicinales, la Dirección General de Sanidad, deberá emitir un informe con carácter vinculante. Será mediante resolución ministerial la notificación de La declaración de la condición de mineral de dichas aguas, esta resolución se publica en el Boletín Oficial del Estado y en de las correspondientes provincias.

El artículo 25 de esta Ley se centra en la concesión de aprovechamiento de las aguas, esta, es concedida por el Estado al que en el momento de la declaración de su

\footnotetext{
${ }^{240}$ (BOE núm. 189, de 24-07-1973). Título IV Cáp.II (Autorizaciones de aprovechamiento de recursos de la sección B) Art. 36 “Ley 22/1973, de 21 de julio, de Minas”
} 
condición de mineral a quien fuere propietario de las mismas, pudiendo ceder este derecho a terceras personas. En caso de que los manantiales se encuentren en terrenos de dominio público, le corresponderá a la persona que solicitó el expediente para la obtención de la declaración de la condición de mineral de las aguas. Antes de concluir este epígrafe es necesario hacer alusión a los tres organismos que intervienen en la coordinación de la actividad balnearia.

1) Organismo competente en materia de aguas termales y mineromedicinales

2) Organismo competente en materia sanitaria.

3) Organismo competente en materia turística.

\subsection{Termalismo Social:}

Las políticas sociales en materia de termalismo que nombrábamos anteriormente, se están imponiendo en España y en el resto de Europa como una necesidad de favorecer a las clases sociales con menos poder adquisitivo, centrándose fundamentalmente en el sector de la tercera edad, un público que dispone de unas pensiones reducidas y que por sus condiciones de edad y salud encuentran en los balnearios el lugar idóneo para disfrutar de unas pequeñas vacaciones anuales subvencionadas y adaptadas a sus necesidades. 


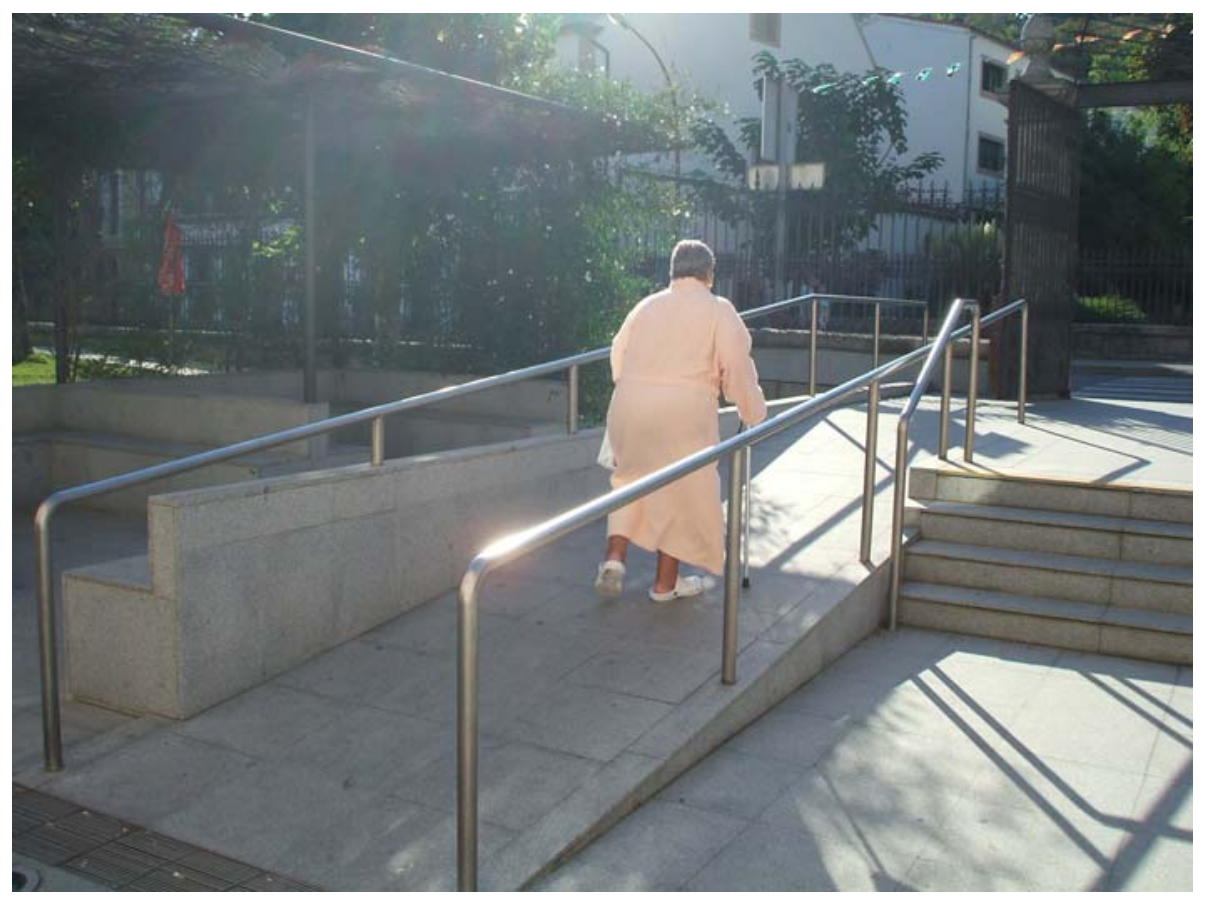

Ilustración 82 Agüista dirigiéndose a tomar el baño. (Balneario de Baños de Montemayor en Cáceres)

\subsubsection{Termalismo Social en Europa}

Al referirnos al termalismo social en Europa la primera referencia ineludible ha de ser Hungría, por ser el primer país en alcanzar para sus ciudadanos mayor cobertura sanitaria en lo que a tratamientos termales se refiere teniendo en cuenta en esta cobertura desde las clases menos favorecidas (atendiendo a su poder adquisitivo), hasta las capas más altas de la sociedad húngara.

Es a partir del año 1986 cuando la cura en centros balnearios pasa a pertenecer integramente a la Seguridad Social. 
"En el 2001, la Seguridad Social de Hungría pagó los gastos generados por los 8.800. 221 tratamientos terapéuticos. Importe que se elevó a unos 3.808.450.776 florines húngaros (forint), aprox. unos 15.6 millones de euros. En el 2002, las personas que se beneficiaron de estas prestaciones asistenciales en baños termales, ascendieron a 9. 272.440, Siendo el volumen de inversión a cargo de la Seguridad Social de unos 4.020.091.030 florines húngaros, .aprox. 16,5 millones de euros". ${ }^{241}$

En la actualidad la Seguridad social húngara financia hasta el $85 \%$ de los tratamientos en centros balnearios y hasta el $100 \%$ en casos específicos.

La Seguridad Social en Francia ofrece una cobertura por tratamientos termales de un $65 \%$. En Francia de igual modo que en Alemania existen convenios de colaboración entre los seguros médicos privados y los centros balnearios.

Francia es uno de los países pioneros en promoción de termalismo infantil, ya que cuenta con Estaciones Termales cuya especialidad son las terapias pediátricas, así podemos citar las de Allevard, Luchon, Lons -Le Saulnier y Bourboule; concretamente en esta última la cura termal es bastante considerable a tenor del número de curas practicadas:

"La cura termal pediátrica beneficia anualmente a unos 35.000 niños que reciben tratamiento médico de patologías respiratorias y de la piel,242

\footnotetext{
${ }^{241}$ Dra Suárez Santos, M. http://www.termasworld.com 242 http://www.termasworld.com/
} 


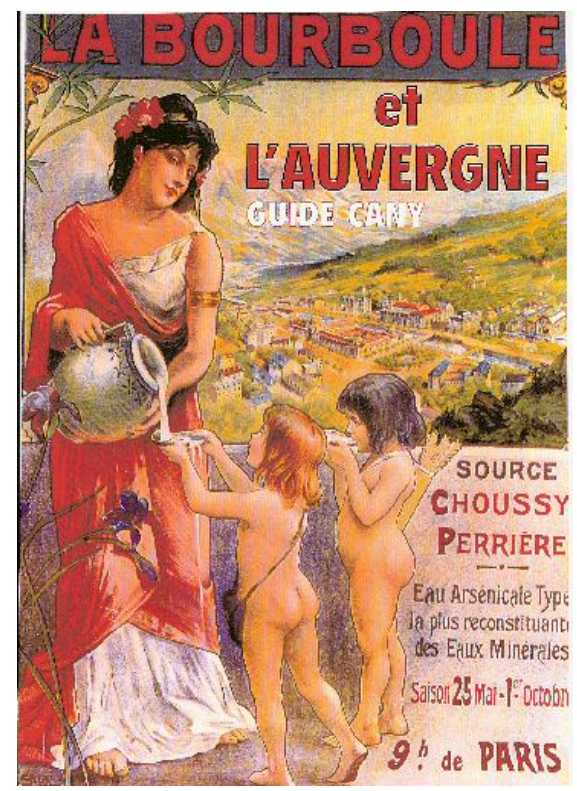

www.editionsrevoir.com/F_grp_14-1.html

En una encuesta realizada por IPSOS-CNETEH, en el año 2004 a una muestra representativa de 1022 personas, se extrajeron los siguientes resultados que han sido publicados en la página de las propias termas y que se presentan aquí traducidos al castellano.

* $94 \%$ dicen que palian eficazmente el dolor.

* $87 \%$ de los franceses estiman que una cura termal es una alternativa a un tratamiento de afecciones como las alergias, el asma y los problemas dermatológicos. * $83 \%$ piensan que el termalismo permite reducir el consumo de medicamentos.

* $82 \%$ de los franceses consideran la medicina termal eficaz.

Otro centro de relevancia internacional es "Roche- Posay", éste se encuentra situado en la conjunción de tres provincias, del Berry, de Poitou y de la Touraine, junto al río Loire y las montañas del Macizo Central; se trata de un centro europeo de dermatología termal considerado como una de las más importantes estaciones 
pediátricas francesas, por ella pasan cada año unos 10.000 curista, de los cuales unos 3000 son niños.

A continuación se presenta un cuadro que recoge información sobre el número de termalistas en Europa; ${ }^{243}$

\begin{tabular}{|lrl|}
\hline \multicolumn{3}{|c|}{ TERMALISMO EN EUROPA } \\
\hline Alemania & 9.400 .000 & Termalistas \\
\hline Italia & 1.040 .000 & Termalistas \\
\hline Francia & 600.000 & Termalistas \\
Finlandia & 500.000 & Termalistas \\
Suiza & 472.000 & Termalistas \\
España & 320.000 & Termalistas \\
Bélgica & 5.000 & Termalistas \\
\hline
\end{tabular}

\subsubsection{Termalismo Social en España:}

En el año 1989, mediante una orden procedente del Ministerio de Trabajo y Asuntos Sociales, nace en España el "Programa de Termalismo Social"; se trata de un servicio complementario a las prestaciones de la Seguridad Social, cuyo objeto es el de facilitar la asistencia a centros balnearios de personas pertenecientes a la tercera edad que, por prescripción facultativa, así lo precisen. Los solicitantes de

\footnotetext{
${ }^{243}$ Esta información se extrae de un artículo titulado “Presente y Futuro del Termalismo Español y Europeo” su autor es Nicasio Pérez Menzel, Presidente, en tiempo de esta publicación, de la Asociación Nacional de Estaciones termales (ANET), este artículo forma parte del libro titulado "Panorama actual de las Aguas Minerales y Mineromedicinales en España”. (Entendemos que los datos que se presentan corresponden al año 2002 fecha de la publicación de este documento ya que en ningún momento se alude a la fecha de toma de datos).
} 
asistencia al programa, podrán ir acompañados de su cónyuge; a éstos no se les exige como condición para asistir (en condición de acompañante) los requisitos de pensión y edad.

De forma anual se publica en el Boletín Oficial del Estado, la convocatoria para la concesión de plazas para aquellos pensionistas que estén interesados en participar de programa de Termalismo Social: para ello han de rellenar una solicitud con sus datos acompañada de un informe médico para los cuales se facilita un impreso oficial.

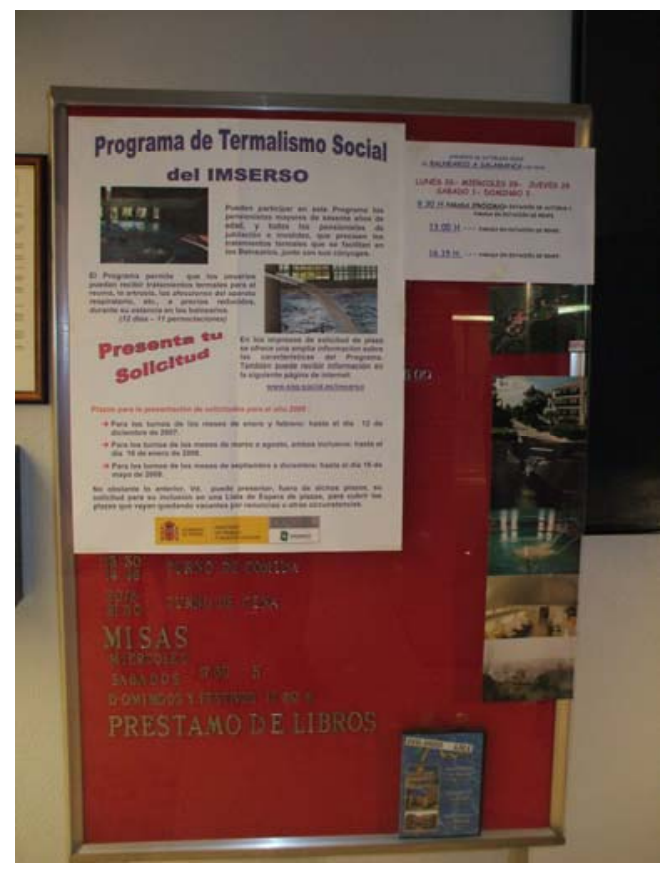

Ilustración 83 Cartel informativo del Programa de Termalismo Social. Imagen tomada en el Balneario de Ledesma (Salamanca) 
Las plazas se adjudican atendiendo a una serie de criterios:

- Grado de necesidad de recibir por parte del solicitante, los tratamientos termales.

- Situación económica.

- Edad de los solicitantes.

- $\quad$ Situación familiar (ser miembros de una familia numerosa)

- Haber participado en anteriores programas de termalismo (2 últimos años).

En este programa de Termalismo social que tiene una duración de 12 días (11 noches) pueden participar aquellos que pertenezcan al Sistema de Seguridad Social, por los siguientes conceptos:

Jubilación.

- Invalidez

- Viudedad

- Otras pensiones (habiendo cumplido los sesenta años de edad )

Para poder participar en el Programa del Ministerio de Trabajo han de cumplir ciertos requisitos que se exponen a continuación:

- Han de valerse por sí mismos.

- No deben de padecer alteraciones de comportamiento que impidan la convivencia.

- No han de padecer enfermedad infecto-contagiosa.

\section{El programa de Termalismo social ofrece servicios de:}

Alojamiento en régimen de pensión completa, en habitaciones dobles a fin de poder compartirla con la persona acompañante.

- Durante el programa de Termalismo, los asistentes disfrutaran de tratamientos termales básicos, previo reconocimiento del médico 
hidrólogo que será el encargado de prescribir las sesiones de baño y el seguimiento del tratamiento durante su estancia en el centro balneario.

- Se llevaran a cabo durante su estancia en el balneario, actividades de animación que servirán para divertir y distraer el tiempo de ocio tiempo dedicado para el encuentro social.

Las plazas no estás subvencionadas en su totalidad por lo que el pensionista ha de cubrir una parte proporcional de estos servicios que incluye también una póliza de seguro turística.

“Desde 1989 y hasta 2005, más de un millón de pensionistas, han asistido a un centro termal.

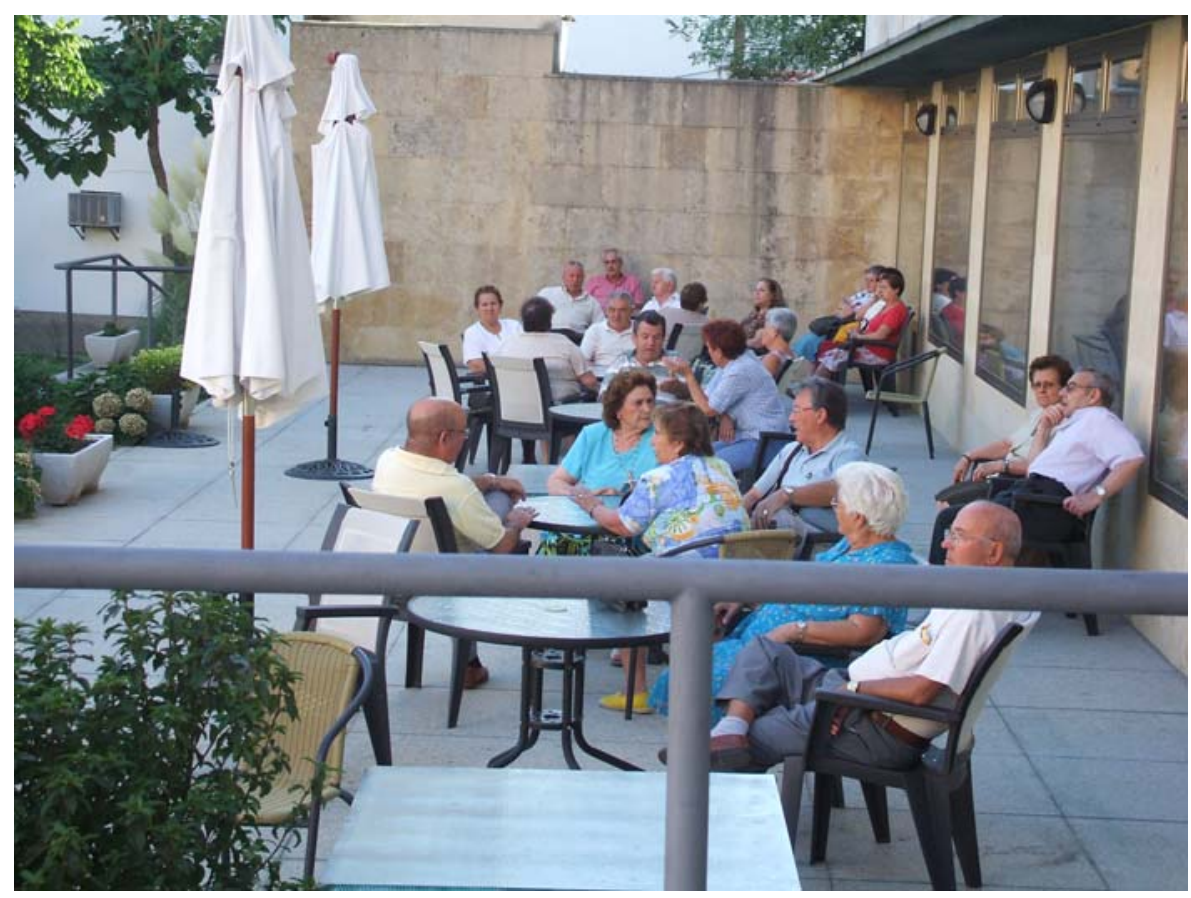

Ilustración 84 Bañistas en su tiempo de ocio. (Balneario de Baños de Montemayor en Cáceres) 
"El programa ha ido incrementando año tras año su cuantía económica y el número de establecimientos que se adhieren a él ante la demanda, cada vez más intensa, de los pensionistas. Desde la Administración se espera que en 2008 la cifra de plazas ofertadas pueda ampliarse a $225.000 " .244$

En España aún no está incluida la cura balnearia en el Sistema de Seguridad Social, a diferencia de otros países de Europa que si contemplan esta situación, lo que facilita la asistencia a los centros balnearios a un mayor número de personas con independencia de su edad.

\subsection{El sector balneario en España}

Los balnearios se distribuyen de forma irregular por toda la geografía española, los edificios se levantan en plena naturaleza, allá donde brotan las fuentes de forma caprichosa.

Pascual Madoz (1846-1850) escribió un diccionario geográfico-estadístico-histórico de España y sus posesiones de ultramar, en él describía de forma concisa las fuentes minero-medicinales en todas las poblaciones, informando de la situación del manantial y de las características mineromedicinales de cada una de ellas, un documento de indudable valor para la catalogación y ubicación de los manantiales repartidos por toda la geografía española. A continuación, se presenta una cita extraída de este diccionario que da cuenta de la descripción hecha por Madoz de la fuente mineromedicinal de una población de Granada "Alicún de las Torres" donde se encuentra el balneario de su mismo nombre.

\footnotetext{
${ }^{244}$ Guía de la Tercera Edad 20.Diciembre, Enero y Febrero, (2006/2007) Muface
} 
"ALICÚN......Tiene multitud de huertos en su rededor, y en un extremo una gran balsa ó alberca cuadrilonga de 1800 varas cuadradas $y$ tres de profundidad, en cuyo fondo nacen infinidad de veneros, unos que llevan el agua muy caliente y otros muy fría, que producen saludables efectos para los dolores reumáticos ${ }^{\text {"245 }}$

Existen en España aproximadamente unos 2.000 manantiales declarados de utilidad pública que contienen aguas catalogadas como minero-medicinales. El número de Estaciones Termales activas en España es de 130 de ellas 125 disponen de servicio de hotel.

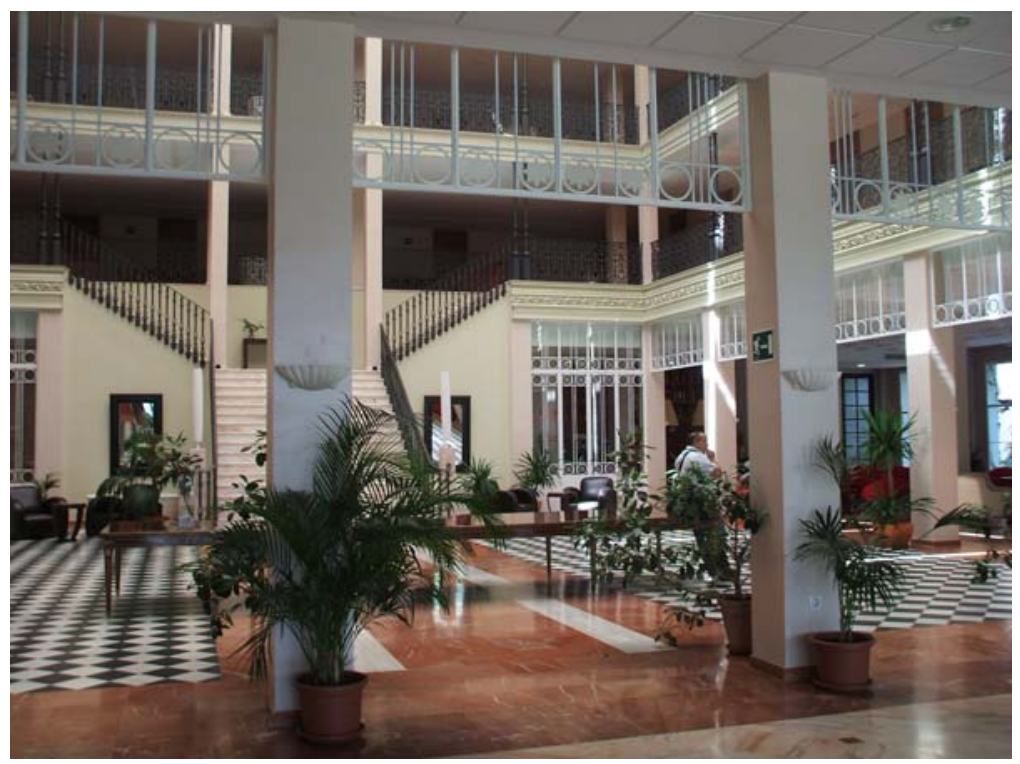

Ilustración 85 Hotel Balneario de Alange (Badajoz)

245 Madoz, P. (1846-1850) “Diccionario geográfico-estadístico-histórico de España y sus posesiones de ultramar” Imp. Establecimiento tipográfico de P. Madoz y L. Sagasti. Madrid. Página 7 
Los balnearios están repartidos por toda la geografía española, siendo las Comunidades Autónomas de Galicia, Cataluña, Aragón y Andalucía respectivamente, las que mayor número de centros balnearios activos poseen en la actualidad. Así la Comunidad de Galicia dispone de un total de quince centros, a ésta, le iguala Cataluña en la misma proporción con quince, seguida de la Comunidad Andaluza con doce, Castilla la Mancha con siete, Extremadura seis, al igual que Castilla y León, la Comunidad Valenciana con cinco, Cantabria cuatro, Asturias y Canarias dos, Baleares, Navarra, La Rioja y País Vasco con uno respectivamente, como se puede observar en el gráfico que se presenta a continuación:

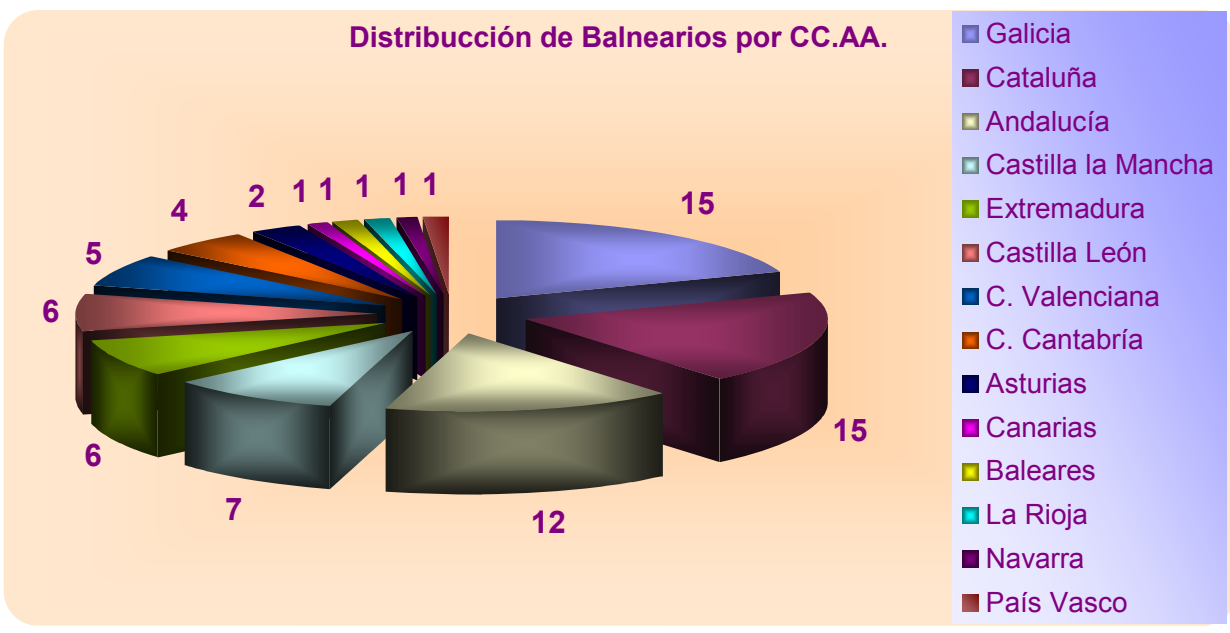

En la actualidad estamos asistiendo a una recuperación de los usos sociales y terapéuticos del agua, un retorno a la naturaleza que ve en el agua su máximo exponente.

"El sector de los balnearios en España, aun siendo una industria que se ha desarrollado desde fechas muy remotas, vive hoy una nueva fase de crecimiento; de renacimiento podría incluso calificarse. Son muchos los establecimientos que han surgido en los últimos años y que siguen 
surgiendo habiendo aumentado de forma importante las inversiones en curso y las previstas"246

Varios son los condicionantes que hacen que los centros balnearios resurjan del olvido una vez más; por un lado y en primer lugar, la sociedad en sí misma es portadora de enfermedades endógenas, las prisas, la competencia, la competitividad, la lucha por la superación, la obligación creada de ser el mejor en cada empresa; la sociedad es como una olla a presión en la que el ser humano sufre de estrés, padece sentimiento de agobio y angustia, lo que provoca un cambio en la escala de valores, el ocio y el descanso pasan a ser uno de sus objetivos prioritarios, en algunos casos, anteponiendo las retribuciones en forma de descanso frente al dinero, buscan ofertas de vacaciones de salud que les permitan conocer nuevos lugares, fundamentalmente lejos de la gran ciudad, en hermosos parajes rurales donde el contacto con la naturaleza les permita reencontrar nuevamente el equilibrio espiritual y corporal. Por otro lado, y en segundo lugar, podemos situar a las administraciones públicas que conscientes de la situación ambiental y de la necesidad de fomentar políticas de sostenibilidad, ven en los antiguos centros balnearios un revulsivo para aquellas zonas rurales en las que se encuentran enclavados, y a su vez, los ven como generadores de sinergias y progreso, así, los balnearios atraen a un sector de la sociedad que tiene como objetivo vacacional un turismo de salud, que práctica el baño y visita el entorno generando riqueza; este esfuerzo impulsor no es extrapolable en intensidad a todas las Comunidades Autónomas, así, es obligado poner como ejemplo de apuesta por el sector balneario, a la Comunidad Autónoma de Galicia, que ha visto en el termalismo una de sus mayores fuentes de riqueza turística, otras en cambio, tienen mucho camino por recorrer como es el caso de la Comunidad Autónoma de Andalucía, una Comunidad que dispone de magnificas fuentes termales, pero que aún necesitan del impulso fuerte de la administración pública. En tercer y último lugar se encuentran el sector económico y empresarial que ven en los centros balnearios una oportunidad de negocio, el valor en alza que suponen estos

\footnotetext{
${ }^{246}$ Vázquez-Illa, J (1997) “Estudio Producto Termal”. Anet-Futures. En: “Panorama Actual de las Aguas Minerales y Minero-Medicinales En España”; Madrid (2000).
} 
centros para la sociedad actual, concentrando todos los recursos posibles en sacar el máximo partido a un negocio que unido al ocio reporta grandes beneficios obtenidos, por un lado, de las nuevas generaciones victimas del estrés social y por otro, de la viejas generaciones, que de la mano de los Programas Sociales del IMSERSO completan el calendario intervacacional suponiendo un valor seguro y un seguro de sostenibilidad en temporada baja. Este desarrollo de la industria balnearia produce una sinergia en otros ámbitos afines y complementarios, se trata de servicios auxiliares que ven cómo el progreso del sector redunda en su propio progreso, de igual modo, existen nuevas iniciativas que surgen al calor del sector; a continuación se expone una pequeña muestra de este tipo de empresas o servicios:

El sector de la ingeniería ve en el sector balneario un espacio en el que desarrollar su actividad, tanto en el de rehabilitación de antiguas instalaciones, como en el de creación de instalaciones modernas y centros de ocio e implantación de nuevas tecnologías.

En el ámbito de la hidrogeología surgen empresas especializadas en fuentes de aguas mineromedicinales/termales, su labor se centra en la puesta en marcha de procedimientos de captación, protección y funcionamiento de acuíferos y manantiales

Un nuevo nicho de mercado encuentran los operadores turísticos en el sector del turismo de salud, un turismo alternativo que complementa el turismo tradicional. Se trata de un turismo creciente por su alta demanda durante todo el año, así, se ponen a la venta en el mercado guías de viajes por balnearios y catálogos en los que se refleja toda la oferta del sector.

Hay que atender también a los nichos de empleo que se generan con los centros balnearios, Jóvenes muy preparados que cuentan con estudios de Formación Profesional, estudios de Postgrado, Master etc. especialistas en tratamiento termal, como es el caso de profesionales fisioterapeutas, bañeros, médicos hidrólogos, dietistas, biólogos etc. 
El agua mineromedicinal es un recurso "inagotable" en sí mismo y esto los profesionales del sector lo saben y no dudan en explotar todas las posibilidades de negocio que el agua les brinda lanzando al mercado productos altamente demandados por la sociedad, así, muchos centros sacan al mercado agua embotellada, esto en el caso de algunos balnearios no es algo nuevo sino que se viene comercializando desde hace muchos años, ejemplo de ello tenemos el agua de "Solan de Cabras", "Lanjaron" "Vichy Catalán" etc; por otro lado, está la venta de productos elaborados a partir del agua mineromedicinal, como es el caso de jabones, lociones, cremas corporales etc. cuya comercialización se realiza tanto en los centros balnearios como en farmacias; son productos que por su procedencia, nacen con sello o marca de fama reconocida, un prestigio que sirve de aval para aumentar sus ventas.

En la actualidad muchos centros balnearios comienzan a modernizarse en sus instalaciones y terapias, en gran medida, el éxito de la modernidad se refleja en la demanda fruto de una labor exhaustiva de marketing que hace que la opinión pública comience a ver los antiguos balnearios como una opción fresca y renovada, los empresarios son conscientes de la importancia de estas técnicas para ser competitivos frente a centros talassos, balnearios urbanos o SPAS, e invierten cada vez más en este tipo de cambio de imagen corporativa y publicitaria, con el fin de atraer a una clientela cada vez más numerosa y si es posible cada vez más selecta.

\subsubsection{Estudio sobre el sector balneario en España}

A lo largo de éste capítulo se ha realizado una reflexión sobre el sector basándonos en fuentes secundarias, documentos legislativos, estudios realizados con anterioridad, revistas etc. A través de todos ellos hemos podido conocer, en parte, cual es la situación actual del sector hasta el momento.

Con la intención de dar un paso más en el estudio, se plantea la necesidad de investigar con fuentes primarias mediante la recogida de información en los propios balnearios, a través de encuestas realizadas a usuarios y entrevistas a personal 
directivo de los distintos centros; así mismo, hemos realizado una visita a dos centros balnearios con el objeto de analizar de forma presencial la situación actual de estos centros en la actualidad con el fin de comprobar si la recuperación de los usos sociales del agua es un hecho.

A continuación se presenta la ficha técnica y los resultados obtenidos tras la recogida de información y su posterior análisis.

\section{Ficha Técnica:}

Nivel del confianza del 95\% 20, error de $\pm 5 \%$

Muestra: 394 encuestados

Universo poblacional. Usuarios de centros balnearios en España

Fecha de realización años 2008/2009

\subsubsection{Análisis de resultados de la encuesta:}

A continuación se presenta un cuadro en el que se observa la relación de balnearios que han participado en esta parte del estudio, junto con el número de encuestas aplicadas en cada uno de ellos.

En total se recogieron trescientas noventa y cuatro encuestas entre todos los centros colaboradores, concretamente dieciocho balnearios de aguas mineromedicinales. 


\section{Relación de centros donde se realiza el trabajo de campo (puntos de muestreo):}

\begin{tabular}{|l|r|r|r|}
\hline & \multicolumn{2}{c|}{$\begin{array}{l}\text { Lugar donde se realiza la encuesta } \\
\text { Encuestas }\end{array}$} & 48 \\
\hline Balneario El Raposo & 15 & Balneario de Graena \\
\hline Balneario Arnoia & 15 & Balneario de Ledesma \\
\hline Balneario Cervantes & 15 & Balneario Lobios & 41 \\
\hline Balneario de Alange & 32 & Balneario Sicilia (Estación Termal de Jaraba & 7 \\
Balneario de Alhama de Granada & 38 & Balneario Vilas del Turbón & 14 \\
Balneario de Alicún de las Torres & 14 & Baños de Montemayor & 13 \\
Balneario de Archena & 15 & El Paraíso (Balneario de Manzanera) \\
Balneario de Fortuna & 14 & Termas de Laias & 40 \\
Balneario de Fuente Amarga & 30 & El Salugral & 15 \\
\hline Total & & & 15 \\
\hline
\end{tabular}

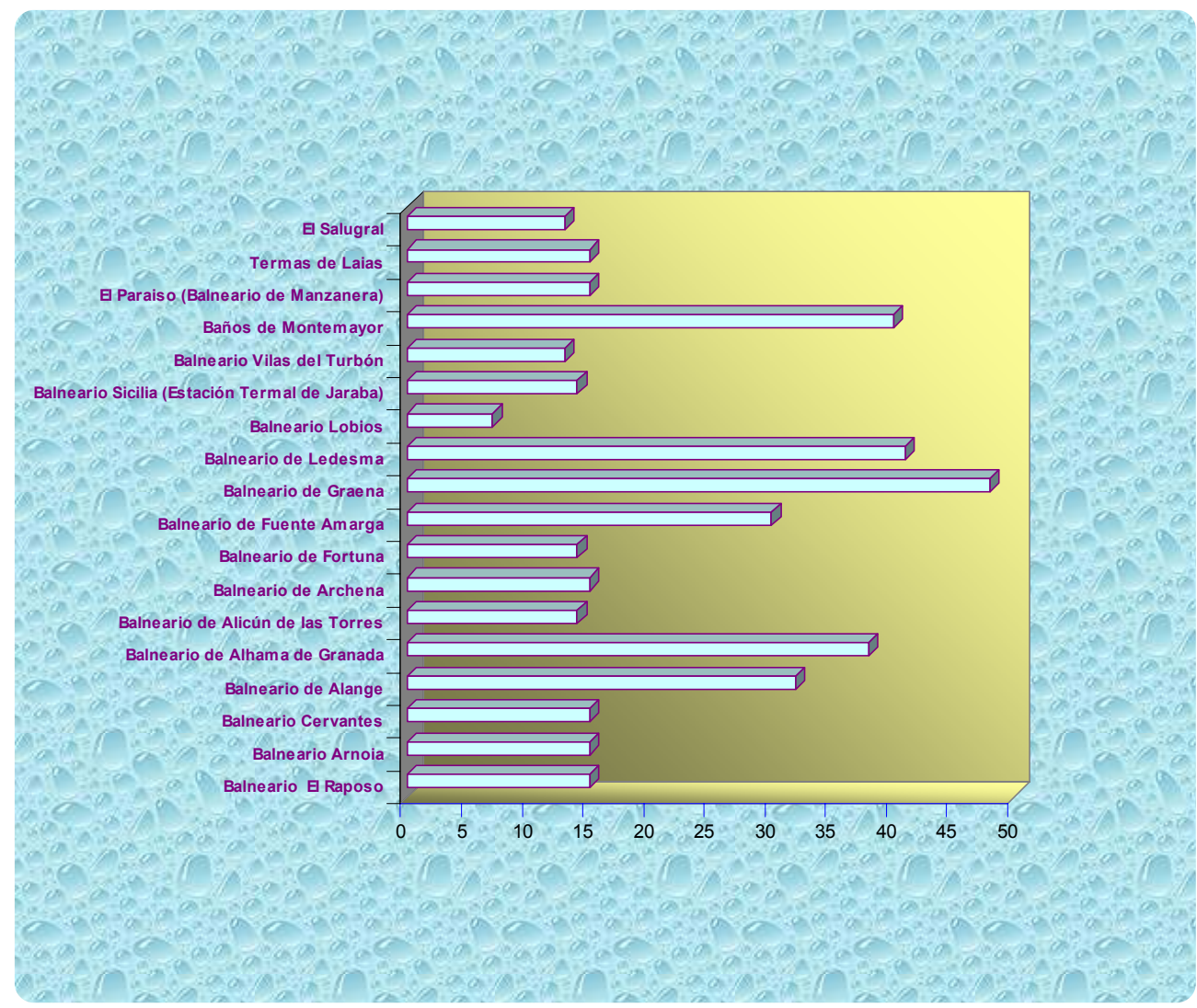




\section{Distribución de los encuestados por sexo:}

A continuación se presenta un cuadro acompañado de un gráfico en el que se puede observar la distribución de los encuestados por sexo.

\begin{tabular}{lrr}
\multicolumn{2}{c}{$\begin{array}{l}\text { Sexo de los encuestados } \\
\text { Frecuencia }\end{array}$} & Porcentaje \\
\hline Hombre & 137 & $34,80 \%$ \\
Mujer & 219 & $55,60 \%$ \\
NS/NC & 38 & $9,60 \%$ \\
\hline Total & 394 & $100 \%$ \\
& &
\end{tabular}

\section{Sexo de los encuestados}

38

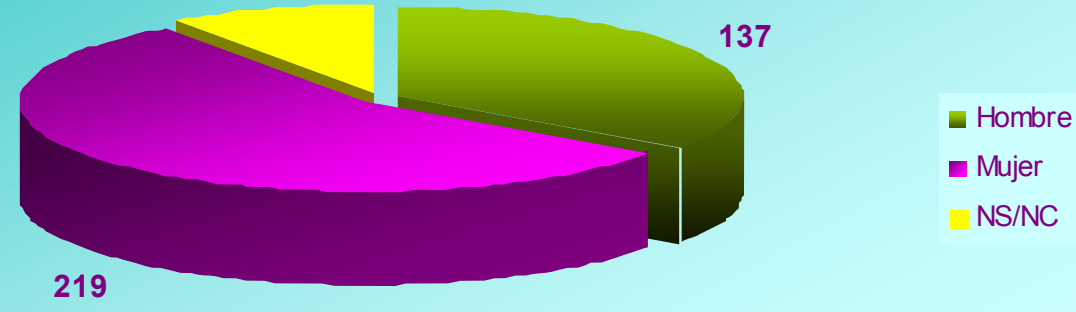

El número de mujeres encuestadas en los centros balnearios, supera al de hombres en un $20,81 \%$. La recogida de información fue totalmente aleatoria, sin tener en cuenta criterio de sexo o edad, por lo que la causa de esta diferencia de proporción hay que buscarla en la esperanza de vida de hombres y mujeres ya que el 
$40,40 \%$ de los encuestados, como veremos más adelante afirmaron tener 64 años o más.

A continuación presentamos datos oficiales para el año 2008 (año en el que se realiza la encuesta) sobre la población por edad y sexo para ese rango de edades. Esta toma de datos oficiales la rescatamos para esta investigación, con el fin de observar si el desfase de representación encontrado entre los usuarios de balnearios con respecto al sexo, a la hora de realizar la encuesta, tiene reflejo en la sociedad en el momento de realizar el trabajo de campo. Como se desprende de los datos que se presentan a continuación tomados del INE, el número de mujeres supera al de hombres para todas las edades:

Revisión del Padrón municipal 2008. Datos a nivel nacional.

00.- Nacional

Población por edad (año a año) y sexo

Unidades:Personas

\begin{tabular}{|l|r|r|}
\hline & Varones & Mujeres \\
\hline 64 & 220717 & 237376 \\
\hline 65 & 190782 & 206181 \\
\hline 66 & 175244 & 190045 \\
\hline 67 & 212960 & 235231 \\
\hline 68 & 139822 & 160114 \\
\hline 69 & 157991 & 180510 \\
\hline 70 & 174055 & 201738 \\
\hline 71 & 186689 & 224464 \\
\hline 72 & 179104 & 214143 \\
\hline 73 & 173809 & 212134 \\
\hline 74 & 174134 & 216672 \\
\hline 75 & 166940 & 212153 \\
\hline 76 & 154113 & 199131 \\
\hline 77 & 147818 & 200111 \\
\hline 78 & 133498 & 184753 \\
\hline 79 & 124982 & 179819 \\
\hline 80 & 110737 & 163626 \\
\hline 81 & 103087 & 158800 \\
\hline 82 & 90198 & 145970 \\
\hline 83 & 81032 & 136388 \\
\hline 84 & 71968 & 123939 \\
\hline 85 y más & 289338 & 648702 \\
\hline & & \\
\hline
\end{tabular}

Fuente: Instituto Nacional de Estadística

Copyright INE 2010 
Así mismo en la siguiente tabla, elaborada a partir de los datos del INE, se muestra el cálculo diferencial en porcentajes año a año y se observa que la diferencia porcentual entre el número de mujeres y hombres es bastante significativa para las distintas edades, esto puede ser reflejo de la diferencia observada con respecto a los encuestados por sexo en los centros balnearios:

\begin{tabular}{|c|c|c|c|c|c|}
\hline \multicolumn{6}{|c|}{ Porcentajes de Población por edad (año a año) y sexo } \\
\hline & Varones & Porcentaje & Mujeres & Porcentaje & Diferencia porcentual \\
\hline 64 & 220717,00 & $7,82 \%$ & 237376,00 & $6,94 \%$ & $0,87 \%$ \\
\hline 65 & 190782,00 & $6,76 \%$ & 206181,00 & $6,03 \%$ & $0,73 \%$ \\
\hline 66 & 175244,00 & $6,21 \%$ & 190045,00 & $5,56 \%$ & $0,65 \%$ \\
\hline 67 & 212960,00 & $7,54 \%$ & 235231,00 & $6,88 \%$ & $0,66 \%$ \\
\hline 68 & 139822,00 & $4,95 \%$ & 160114,00 & $4,68 \%$ & $0,27 \%$ \\
\hline 69 & 157991,00 & $5,60 \%$ & 180510,00 & $5,28 \%$ & $0,31 \%$ \\
\hline 70 & 174055,00 & $6,16 \%$ & 201738,00 & $5,90 \%$ & $0,26 \%$ \\
\hline 71 & 186689,00 & $6,61 \%$ & 224464,00 & $6,57 \%$ & $0,05 \%$ \\
\hline 72 & 179104,00 & $6,34 \%$ & 214143,00 & $6,26 \%$ & $0,08 \%$ \\
\hline 73 & 173809,00 & $6,16 \%$ & 212134,00 & $6,21 \%$ & $-0,05 \%$ \\
\hline 74 & 174134,00 & $6,17 \%$ & 216672,00 & $6,34 \%$ & $-0,17 \%$ \\
\hline 75 & 166940,00 & $5,91 \%$ & 212153,00 & $6,21 \%$ & $-0,29 \%$ \\
\hline 76 & 154113,00 & $5,46 \%$ & 199131,00 & $5,83 \%$ & $-0,37 \%$ \\
\hline 77 & 147818,00 & $5,24 \%$ & 200111,00 & $5,85 \%$ & $-0,62 \%$ \\
\hline 78 & 133498,00 & $4,73 \%$ & 184753,00 & $5,40 \%$ & $-0,68 \%$ \\
\hline 79 & 124982,00 & $4,43 \%$ & 179819,00 & $5,26 \%$ & $-0,83 \%$ \\
\hline 80 & 110737,00 & $3,92 \%$ & 163626,00 & $4,79 \%$ & $-0,86 \%$ \\
\hline Total & 2823395,00 & $100,00 \%$ & 3418201,00 & $100,00 \%$ & $0,00 \%$ \\
\hline
\end{tabular}




\section{Distribución por edades de los encuestados:}

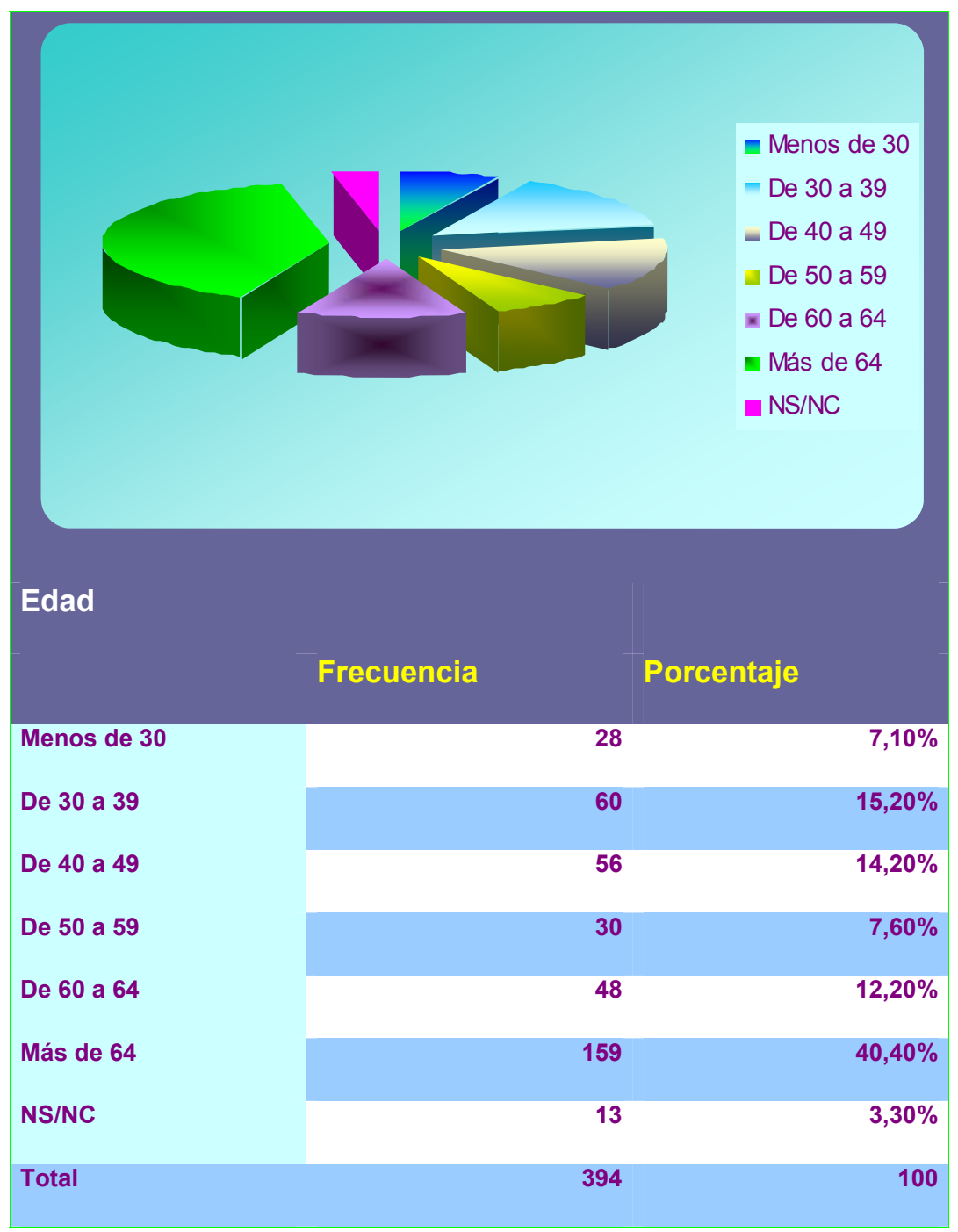

Un dato importante a la hora de analizar el perfil de los asistentes a centros balnearios de aguas minero-medicinales es la edad de los mismos; se observa, por los datos obtenidos, que el porcentaje mayor, más del $40 \%$, lo representan mayores 
de 64 años, es decir, aquellas personas que por edad, en su mayoría, podrían pertenecer a los programas de "Termalismo Social" que organiza el IMSERSO para la tercera edad, por otro lado, es de resaltar el alto porcentaje de encuestados con edades comprendidas entre treinta y treinta nueve años, siendo también significativo el de cuarenta y cuarenta y nueve años.

Estos datos vienen a reforzar lo expuesto anteriormente con respecto a los dos tipos de clientela que acude al balneario, por un lado, los pertenecientes a lo los programas que organiza el gobierno mediante el Ministerio de Asuntos Sociales y por otro aquellos que acuden a tomar las aguas sin el auspicio de los programas estatales.

\section{Solo, o en compañía:}

Según se desprende de los datos que se presentan a continuación, la manera más usual de acudir al balneario es en pareja, más de un $84 \%$ de los encuestados afirmaron ir en compañía de su esposo/a o su pareja en su caso.

Consideramos importante estos datos para conocer las posibles relaciones sociales que se mantienen en los centros balnearios.

\begin{tabular}{|l|r|r|}
\hline \multicolumn{3}{|c|}{ Acude al balneario: } \\
\hline \multicolumn{1}{|c|}{} & \multicolumn{1}{|c|}{ Frecuencia } & Porcentaje \\
\hline Solo & 44 & $11,20 \%$ \\
Con mi pareja & 332 & $84,30 \%$ \\
Con la familia (Padres, hijos, hermanos) & 8 & $2,00 \%$ \\
Con amigos/as & 8 & $2,00 \%$ \\
Otra situación & 2 & $0,50 \%$ \\
\hline Total & 394 & 100 \\
\hline
\end{tabular}




\section{Acude al balneario:}

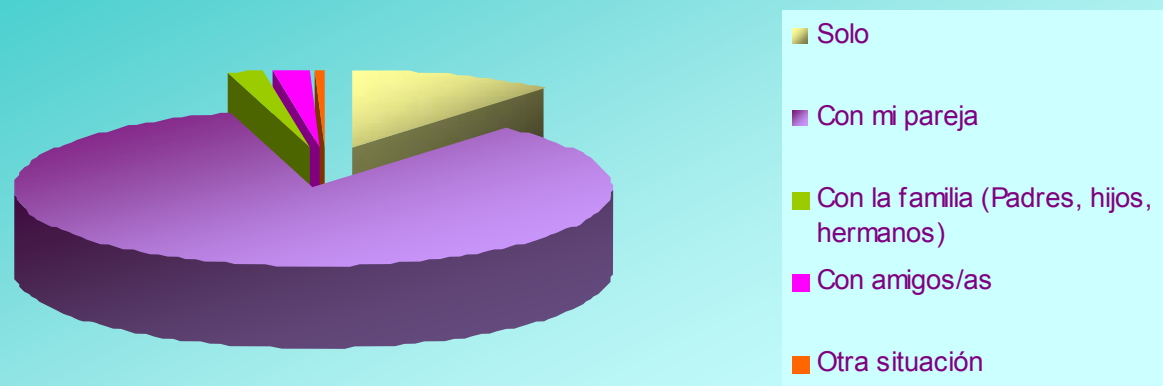

Un 11,20\% acude sólo al balneario; también hay quien acude al balneario con otra compañía como es el caso de padres, amigos, hermanos e hijos, estos en todos los casos observados, siempre menores de edad.

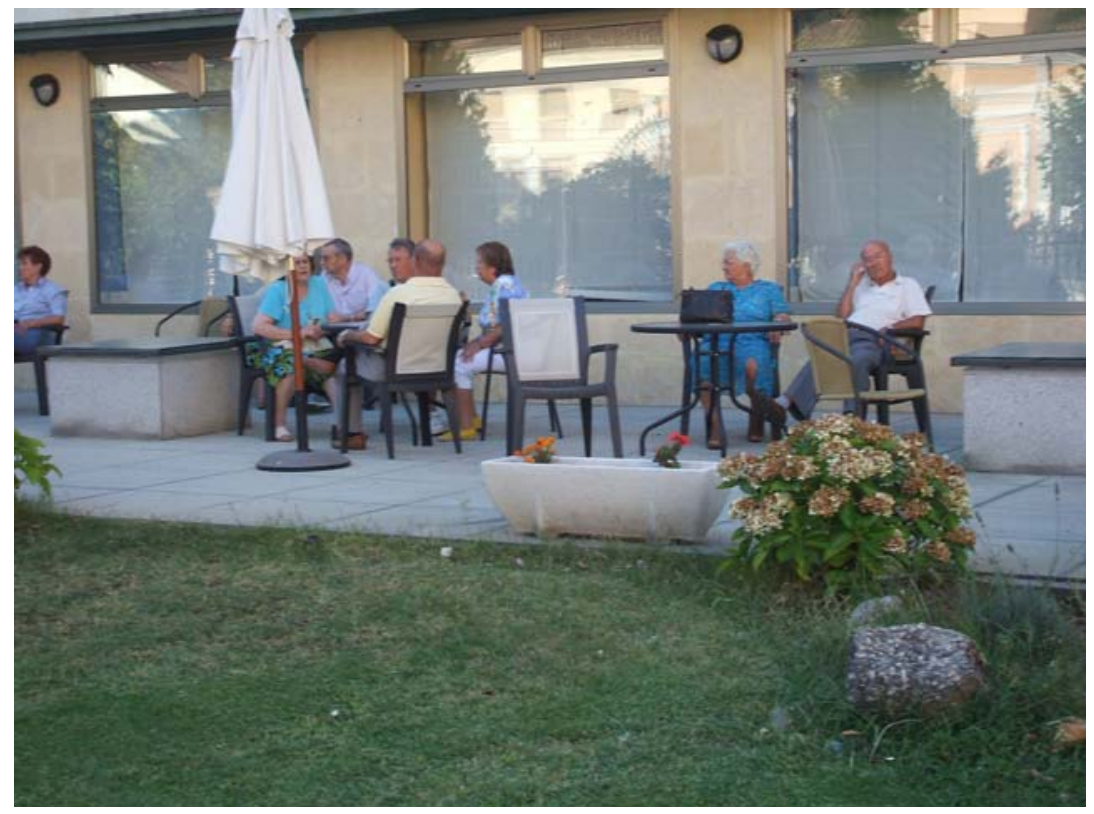

Ilustración 86 Zona de descanso Balneario de Baños de Montemayor (Cáceres) 


\section{Datos socioeconómicos:}

Mediante los ingresos mensuales por unidad familiar y la actividad a la que se dedica el encuestado, podemos conocer el nivel socioeconómico y cultural de los encuestados en los distintos balnearios en los que se realizaron las encuestas.

\begin{tabular}{|lcc|}
\hline Ingresos familiares mensuales & & \\
& Frecuencia & Porcentaje \\
\hline Hasta $600 €$ & 72 & $18,30 \%$ \\
\hline De 600 a $1.200 €$ & 115 & $29,20 \%$ \\
\hline De 1.201 a $2.100 €$ & 97 & $24,60 \%$ \\
\hline De 2.101 a $3.000 €$ & 52 & $13,20 \%$ \\
\hline De 3.001 a $4.500 €$ & 16 & $4,10 \%$ \\
\hline De 4.501 a $6.000 €$ & 8 & $2,00 \%$ \\
\hline Más de $6.000 €$ & 2 & $0,50 \%$ \\
\hline NS/NC & 32 & $8,10 \%$ \\
\hline Total & 394 & $100 \%$ \\
\hline
\end{tabular}

Se puede observar como el porcentaje mayor de encuestados tiene unos ingresos mensuales por familia que se encuentran entre 600 y $1.200 €$, éstos corresponden en su mayor parte a pensionistas; muy cerca de ellos se encuentran aquéllos que tienen como ingresos mensuales de 1.201 a 2.100 . 


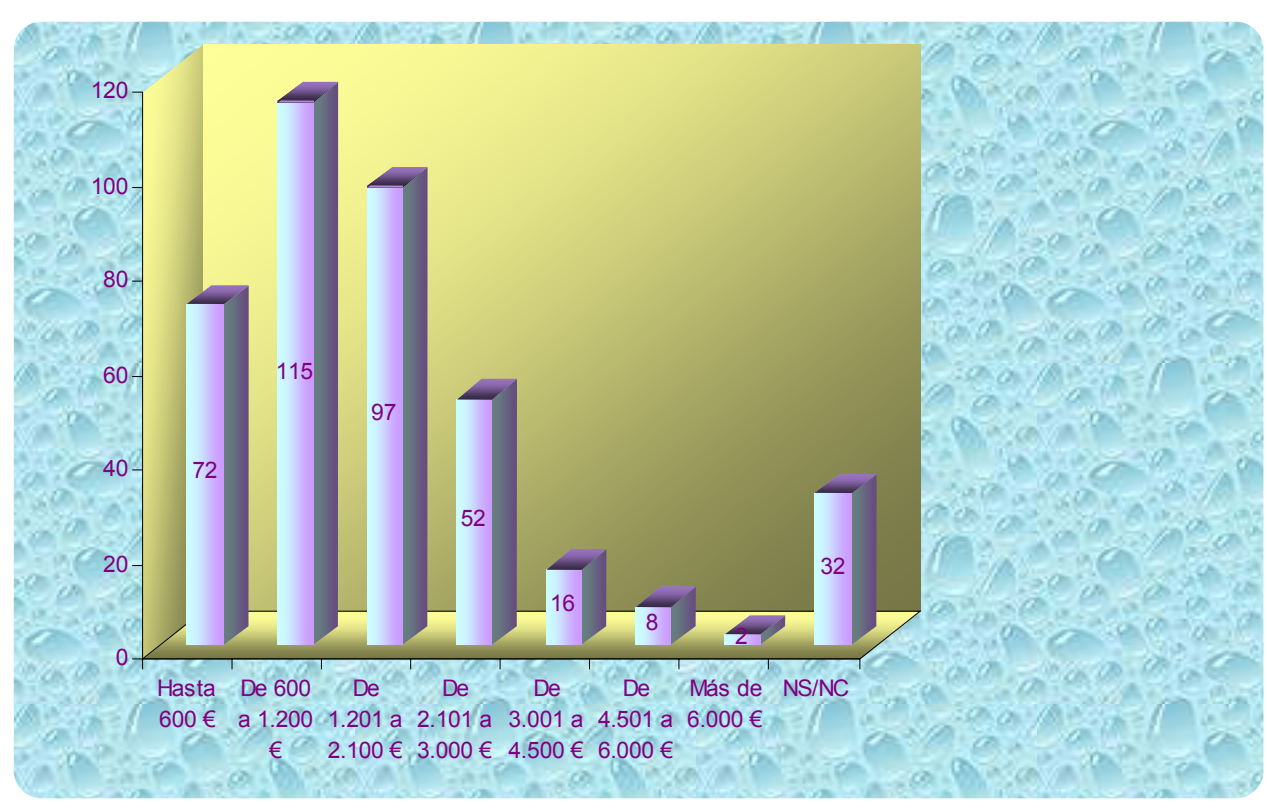

Si tenemos en cuenta que se trata de ingresos familiares mensuales, se puede decir que las personas encuestadas tienen un poder adquisitivo medio e incluso bajo, como es el caso de aquellos pensionistas cuyos ingresos familiares no superan los $600 €$, por otro lado, esto no indica que la asistencia a los centros balnearios sea muy asequible, ya que como citábamos con anterioridad, estos agüistas disponen del colchón económico aportado mediante los programas de termalismo social para asistir una vez al año a un balneario.

El precio de los balnearios es más bien alto, por lo que la variación de costes en cada caso, se encuentra en los días de disfrute y el número o tipo de terapias que deseé aplicarse cada individuo. 
A continuación se presenta una tabla en la que se recoge la actividad laboral de los empleados.

\begin{tabular}{|c|c|c|}
\hline \multicolumn{3}{|c|}{ Actividad } \\
\hline & Frecuencia & Porcentaje \\
\hline Trabajo & 155 & $39,30 \%$ \\
\hline Estudiante & 2 & $0,50 \%$ \\
\hline Ama de Casa & 61 & $15,50 \%$ \\
\hline Desempleado & 3 & $0,8 \%$ \\
\hline Jubilado/Pensionista & 168 & $42,60 \%$ \\
\hline NS/NC & 5 & $1,30 \%$ \\
\hline Total & 394 & $100 \%$ \\
\hline
\end{tabular}

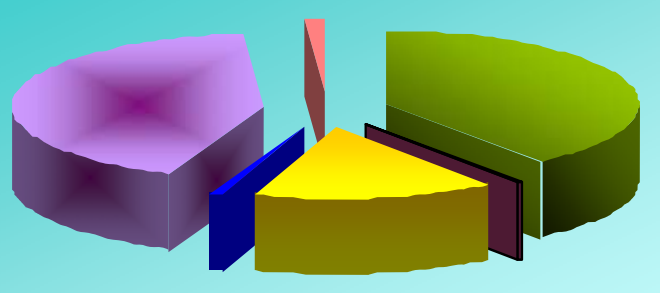

- Trabajo

口 Estudiante

Ama de Casa

- Desempleado

× Jubilado/Pensionista

$\sim N S / N C$

En líneas generales podemos observar, en el siguiente cuadro como, la actividad los encuestados, recorren todo el arco profesional, desde operarios, funcionarios, 
técnicos etc. hasta jubilados. Esto indica que en muchas ocasiones, son las circunstancias personales de salud las que obligan a la visita al balneario, independientemente de la circunstancia económica; en estos casos se trata de invertir en salud, no en ocio, algo que no se produce en otros centros cuya materia prima no es agua mineromedicinal.

\begin{tabular}{|c|c|c|c|c|c|}
\hline Actividad del Encuestado: & Frecuencia & Porcentaje & Actividad del Encuestado: & Frecuencia & Porcentaje \\
\hline Abogado & & $0,80 \%$ & Guardia Civil & 1 & $0,30 \%$ \\
\hline Actriz & 1 & $0,30 \%$ & Hostelería & 6 & $1,50 \%$ \\
\hline Administrativa/o & 18 & $4,58 \%$ & Industrial & 6 & $1,50 \%$ \\
\hline Agente de viajes & 1 & $0,30 \%$ & Informático/a & 2 & $0,51 \%$ \\
\hline Agricultor & 4 & $1,00 \%$ & Ingeniería medioambienta & 1 & $0,30 \%$ \\
\hline Albañil & 1 & $0,30 \%$ & Jubilado / Pensionista & 167 & $42,40 \%$ \\
\hline Ama de casa & 60 & $15,20 \%$ & Limpieza & 2 & $0,51 \%$ \\
\hline Aparejador & 3 & $0,80 \%$ & Maestra & 2 & $0,51 \%$ \\
\hline Arquitecto & 1 & $0,30 \%$ & Mantenimiento & 1 & $0,30 \%$ \\
\hline Automoción & 1 & $0,30 \%$ & Matricero & 1 & $0,30 \%$ \\
\hline Autónomo/a & 7 & $1,80 \%$ & Mecánico & 1 & $0,30 \%$ \\
\hline Auxiliar de ayuda a domicilis & 1 & $0,30 \%$ & Médico/a & 2 & $0,51 \%$ \\
\hline Banca & 1 & $0,30 \%$ & Mercader & 1 & $0,30 \%$ \\
\hline Bibliotecario/a & 1 & $0,30 \%$ & Músico & 1 & $0,30 \%$ \\
\hline Camarero/a & 2 & $0,51 \%$ & Peluquera & 2 & $0,51 \%$ \\
\hline Camionero & & $0,30 \%$ & Periodista & 1 & $0,30 \%$ \\
\hline Cantero & 1 & $0,30 \%$ & Perito de seguros & 1 & $0,30 \%$ \\
\hline Carpintero metálico & 1 & $0,30 \%$ & Policía & 2 & $0,51 \%$ \\
\hline Cocinera & 1 & $0,30 \%$ & Profesor de autoescuela & 1 & $0,25 \%$ \\
\hline Comercial & 4 & $1,02 \%$ & Profesor/a & 11 & $2,80 \%$ \\
\hline Construcción & 4 & $1,02 \%$ & Protésica dental & 1 & $0,30 \%$ \\
\hline Dependiente & 3 & $0,80 \%$ & Psicóloga & 1 & $0,35 \%$ \\
\hline Economista & 2 & $0,51 \%$ & Publicista & 1 & $0,30 \%$ \\
\hline Electromecánico & 2 & $0,51 \%$ & Química & 1 & $0,30 \%$ \\
\hline Empleado/a & 3 & $0,80 \%$ & Sanitario/a & 4 & $1,02 \%$ \\
\hline Empresario/a & 3 & $0,80 \%$ & Tatuador & 1 & $0,30 \%$ \\
\hline Esteticista & 1 & $0,30 \%$ & técnico en telecomunicacic & 1 & $0,30 \%$ \\
\hline Farmacéutico/a & 3 & $0,80 \%$ & Tele-marketing & 1 & $0,30 \%$ \\
\hline Funcionario/a & 9 & $2,28 \%$ & Terapeuta ocupacional & 1 & $0,30 \%$ \\
\hline Gerente & 1 & $0,30 \%$ & Traductora & 1 & $0,30 \%$ \\
\hline NS/NC & & & & 20 & $5,08 \%$ \\
\hline Total & & & & 394 & $100 \%$ \\
\hline
\end{tabular}


Se trata de actividades en las que prima el sector servicios, no correspondientes a una elevada clase social.

\section{Concepto balneario:}

Este concepto ha sido tratado al inicio de este capítulo y como apuntábamos anteriormente parece que existe cierta confusión con respecto al mismo, motivo por el que en el cuestionario aplicado para este estudio se planteara esta cuestión mediante opciones, con la posibilidad de contestar de forma abierta a la pregunta:

\section{¿Qué le sugiere la palabra balneario?}

Se ha realizado el análisis basándonos en la incidencia en la respuesta, siendo el resultado obtenido de forma agrupada, el que se presenta en la tabla siguiente:

\begin{tabular}{|lcr|}
\multicolumn{2}{c}{ ¿Qué le sugiere la palabra balneario? } \\
& Frecuencia & Porcentaje \\
\hline Descanso & 158 & $25,60 \%$ \\
Salud & 198 & $32,10 \%$ \\
Turismo & 15 & $2,40 \%$ \\
Belleza Corporal & 20 & $3,20 \%$ \\
Hospital & 1 & $0,20 \%$ \\
Tranquilidad & 92 & $14,90 \%$ \\
Curación & 28 & $4,50 \%$ \\
Placer & 32 & $5,20 \%$ \\
Ocio & 14 & $2,30 \%$ \\
Otra razón & 58 & $9,40 \%$ \\
\hline Total & 616 & $100 \%$ \\
\hline & & \\
\hline
\end{tabular}


Salud y descanso siguen siendo una máxima cuando se alude a la palabra "balneario", el resto de cuestiones planteadas tienen un porcentaje de incidencia más bajo. "Descanso" y "salud" fueron las opciones de respuesta más recurrentes, seguidas de "tranquilidad".

Otra de las lecturas que se hace necesaria a tenor de los resultados obtenidos, son los distintos conceptos aportados (en la opción Otros) por los encuestados para expresar lo que les sugiere el concepto "balneario", se puede observar como en su mayoría se trata de aspectos positivos relativos todos ellos al confort corporal, a cuestiones de deseo permanente por el ser humano.

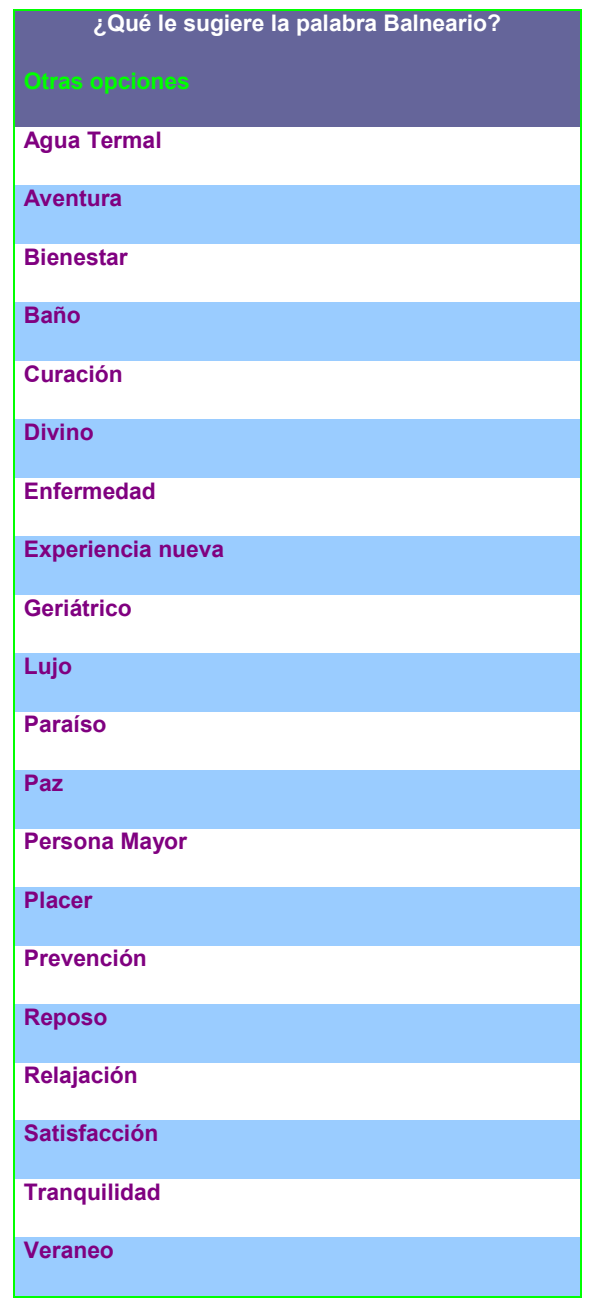


Si cruzamos la variable "sexo" con las distintas opciones obtenidas de forma agrupada, obtenemos la información que se presenta en este cuadro:

\begin{tabular}{|c|c|c|c|c|c|}
\hline Opciones & Según el sexo de los eI & $\begin{array}{l}\text { uestados la pal } \\
\text { Hombre }\end{array}$ & $\begin{array}{l}\text { labra balneario } \\
\text { Mujer }\end{array}$ & $\begin{array}{l}\text { le sugiere: } \\
\text { NS/NC }\end{array}$ & Total \\
\hline \multirow[t]{2}{*}{ Descanso } & Recuento & 61 & 83 & 14 & 158 \\
\hline & $\%$ de OPCION AGRUPADA & 38,6 & 52,5 & 8,9 & 100 \\
\hline \multirow[t]{2}{*}{ Salud } & Recuento & 69 & 111 & 18 & 198 \\
\hline & $\%$ de OPCION AGRUPADA & 34,8 & 56,1 & 9,1 & 100 \\
\hline \multirow[t]{2}{*}{ Turismo } & Recuento & 9 & 2 & 4 & 15 \\
\hline & $\%$ de OPCION AGRUPADA & 60 & 13,3 & 26,7 & 100 \\
\hline \multirow[t]{2}{*}{ Belleza corpo } & Recuento & 5 & 14 & 1 & 20 \\
\hline & $\%$ de OPCION AGRUPADA & 25 & 70 & 5 & 100 \\
\hline \multirow[t]{2}{*}{ Hospital } & Recuento & 0 & 1 & 0 & 1 \\
\hline & $\%$ de OPCION AGRUPADA & 0 & 100 & 0 & 100 \\
\hline \multirow[t]{2}{*}{ Tranquilidad } & Recuento & 33 & 56 & 3 & 92 \\
\hline & $\%$ de OPCION AGRUPADA & 35,9 & 60,9 & 3,3 & 100 \\
\hline \multirow[t]{2}{*}{ Curación } & Recuento & 14 & 11 & 3 & 28 \\
\hline & $\%$ de OPCION AGRUPADA & 50 & 39,3 & 10,7 & 100 \\
\hline \multirow[t]{2}{*}{ Placer } & Recuento & 9 & 19 & 4 & 32 \\
\hline & $\%$ de OPCION AGRUPADA & 28,1 & 59,4 & 12,5 & 100 \\
\hline \multirow[t]{2}{*}{ Ocio } & Recuento & 2 & 11 & 1 & 14 \\
\hline & $\%$ de OPCION AGRUPADA & 14,3 & 78,6 & 7,1 & 100 \\
\hline \multirow[t]{2}{*}{ Otras razones } & @ Recuento & 19 & 31 & 7 & 57 \\
\hline & $\%$ de OPCION AGRUPADA & 33,3 & 54,4 & 12,3 & 100 \\
\hline \multirow[t]{2}{*}{ Total } & Recuento & $221 \mid$ & 339 & 55 & 615 \\
\hline & $\%$ de OPCION AGRUPADA & $35,9 \|$ & 55,1 & 8,9 & 100 \\
\hline
\end{tabular}

Se observa, a tenor de los datos obtenidos, como el $78,6 \%$ de respuestas que relacionan la opción balneario con "ocio" pertenecen a mujeres, frente a un 14,3\% de respuestas provenientes de hombres; así mismo, es de destacar como el $60 \%$ de respuestas que relacionan la opción balneario con "turismo" pertenecen a hombres, frente a un $13,3 \%$ de respuestas que corresponden a mujeres. 


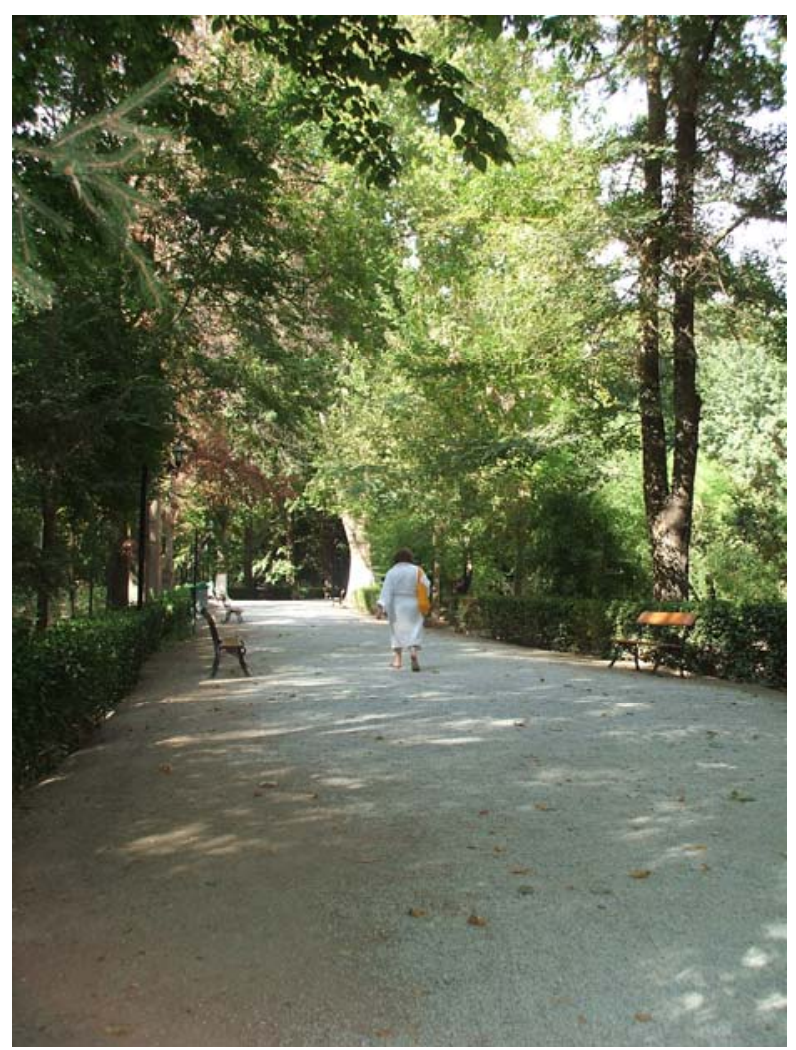

Una vez analizado la variable sexo y avanzando un poco más, si cruzamos la variable "edad" con las distintas opciones obtenidas de forma agrupada, obtenemos la información que se presenta en el cuadro de la siguiente página: 


\begin{tabular}{|c|c|c|c|c|c|c|c|c|c|}
\hline \multirow{2}{*}{ Edad } & & \multicolumn{8}{|c|}{ ¿Qué la sugiere la palabra balneario? } \\
\hline & & Descanso & Salud & Turismo & $\begin{array}{l}\text { Belleza } \\
\text { Corporal }\end{array}$ & Hospital & Tranquilidad & Curación & Placer \\
\hline \multirow[t]{2}{*}{ Menos de 30} & Recuento & 14 & 7 & 4 & 2 & 1 & 13 & 2 & 3 \\
\hline & $\%$ de OPCION AGRUPADA & 8,9 & 3,5 & 25 & 10 & 100 & 14,1 & 7,1 & 9,4 \\
\hline \multirow[t]{2}{*}{ De 30 a 39} & Recuento & 34 & 24 & 2 & 6 & 0 & 17 & 3 & 6 \\
\hline & $\%$ de OPCION AGRUPADA & 21,5 & 12,1 & 12,5 & 30 & 0 & 18,5 & 10,7 & 18,8 \\
\hline \multirow[t]{2}{*}{ De 40 a 49} & Recuento & 26 & 34 & 5 & 8 & 0 & 18 & 6 & 6 \\
\hline & $\%$ de OPCION AGRUPADA & 16,5 & 17,2 & 31,3 & 40 & 0 & 19,6 & 21,4 & 18,8 \\
\hline \multirow[t]{2}{*}{ De 50 a 59} & Recuento & 12 & 15 & 0 & 2 & 0 & 8 & 2 & 4 \\
\hline & $\%$ de OPCION AGRUPADA & 7,6 & 7,6 & 0 & 10 & 0 & 8,7 & 7,1 & 12,5 \\
\hline \multirow[t]{2}{*}{ De 60 a 64} & Recuento & 16 & 30 & 2 & 0 & 0 & 6 & 3 & 5 \\
\hline & $\%$ de OPCION AGRUPADA & 10,1 & 15,2 & 12,5 & 0 & 0 & 6,5 & 10,7 & 15,6 \\
\hline \multirow[t]{2}{*}{ Más de 64} & Recuento & 50 & 85 & 2 & 2 & 0 & 29 & 11 & 8 \\
\hline & $\%$ de OPCION AGRUPADA & 31,6 & 42,9 & 12,5 & 10 & 0 & 31,5 & 39,3 & 25 \\
\hline \multirow[t]{2}{*}{ NS/NC } & Recuento & 6 & 3 & 1 & 0 & 0 & 1 & 1 & 0 \\
\hline & $\%$ de OPCION AGRUPADA & 3,8 & 1,5 & 6,3 & 0 & 0 & 1,1 & 3,6 & 0 \\
\hline \multirow[t]{2}{*}{ Total } & Recuento & 158 & 198 & 16 & 20 & 1 & 92 & 28 & 32 \\
\hline & $\%$ de OPCION AGRUPADA & 100 & 100 & 100 & 100 & $100 \mid$ & 100 & 100 & 100 \\
\hline
\end{tabular}


El $40 \%$ de las personas a las que le sugiere la palabra "balneario"; "belleza corporal" tienen una edad entre 40 y 49 años; así mismo; es de destacar como el $42,9 \%$ de las personas a las que la palabra "balneario"; "salud" tienen más de 64 años.

A fin de poder conocer desde una perspectiva social las razones que impulsan a los encuestados a asistir a los balnearios, se les plantearon las opciones que se reflejan en el siguiente cuadro:

\begin{tabular}{|l|cr|}
\hline \multicolumn{2}{|c|}{ Razón por la que acude al balneario } \\
& Frecuencia & \\
\hline Se lo prescribió su médico & 66 & $13,60 \%$ \\
\hline Está de moda asistir a balnearios & 10 & $2,10 \%$ \\
\hline Por las características de sus aguas & 88 & $18,20 \%$ \\
\hline Decisión personal & 181 & $37,40 \%$ \\
\hline Lo encuentra una opción interesante para vacacionar & 33 & $6,80 \%$ \\
\hline Por conocer nuevas experiencias & 16 & $3,30 \%$ \\
\hline Se lo aconsejó un amigo & 75 & $15,50 \%$ \\
\hline Otra situación & 15 & $3,10 \%$ \\
\hline Total & & $100 \%$ \\
\hline
\end{tabular}




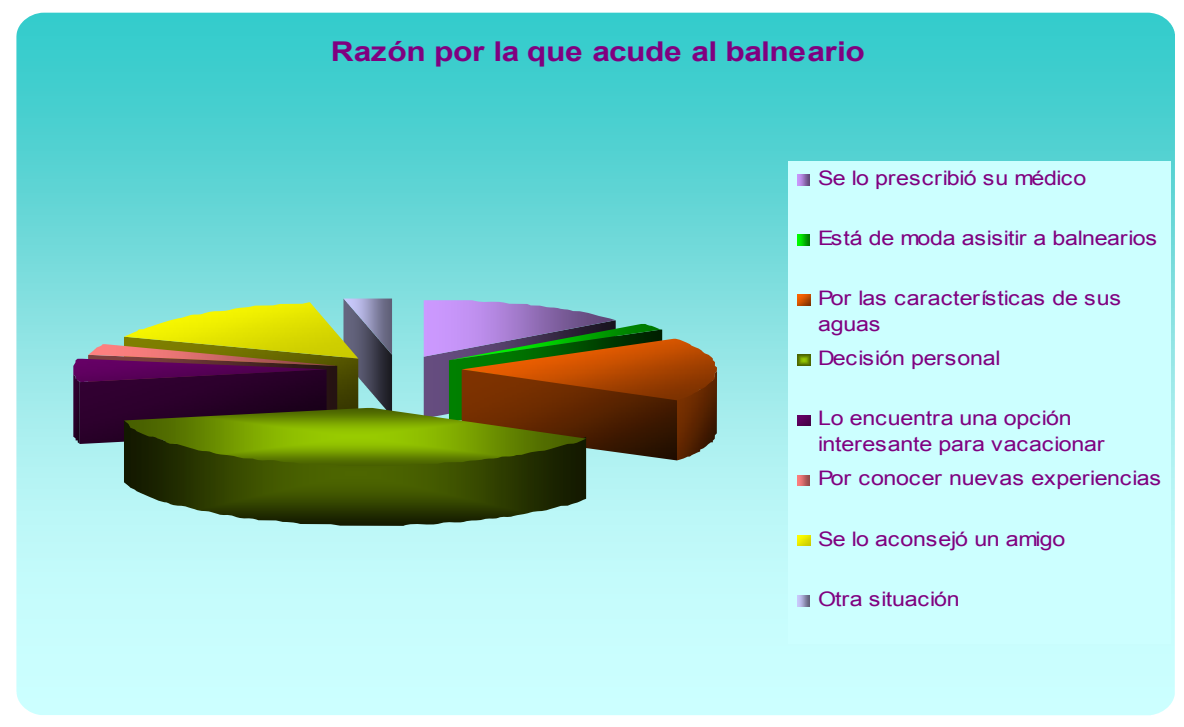

Conocer otro tipo de razones, no contempladas en el cuestionario que pudieran servirnos de información para este estudio, fue la intención de formular esta cuestión de forma abierta.

\begin{tabular}{|l|}
\hline \multicolumn{1}{|c|}{ Otras razones por las que se asiste a balnearios } \\
\hline Asignación del IMSERSO \\
\hline Conocía la bondad de las termas \\
\hline Cultural \\
\hline El barro \\
\hline Estrés \\
\hline La estancia en el balneario es un regalo \\
\hline La propia experiencia \\
\hline Por visitar la comarca en la que se sitúa el balneario (Turismo) \\
\hline Lo vio en Internet \\
\hline Lo vio en televisión \\
\hline Pertenece a Montepío \\
\hline Por acompañar a otra persona \\
\hline Por acompañar y se baña \\
\hline Por cercanía \\
\hline Por costumbre \\
\hline Por el trato \\
\hline Por invitación \\
\hline Por su entorno (Turismo) \\
\hline Por sus instalaciones \\
\hline Repite por que le gusta este balneario \\
\hline Se lo recomendó la Asociación de Parkinson \\
\hline Turismo \\
\hline Ya estuve y me encantó \\
\hline
\end{tabular}


El motivo por el que se encontraban en el balneario fue otra de las cuestiones por las que se preguntó a los encuestados, aparentemente la cuestión anterior y la expuesta en el cuadro que se presenta a continuación puede parece la misma, pero la intención de esta segunda pregunta es la de conocer los motivos personales, y no sociales que impulsaron al encuestado a su estancia en el balneario.

\begin{tabular}{|l|rr|}
\multicolumn{3}{|c|}{ Motivo por el que acude al balneario } \\
& Frecuencia & Porcentaje \\
\hline Salud & 255 & $55,10 \%$ \\
Ocio & 40 & $8,60 \%$ \\
Descanso & 162 & $35 \%$ \\
Otros Motivos & 6 & $1,30 \%$ \\
Total & 463 & 100 \\
\hline
\end{tabular}

Motivo por el que acude al balneario

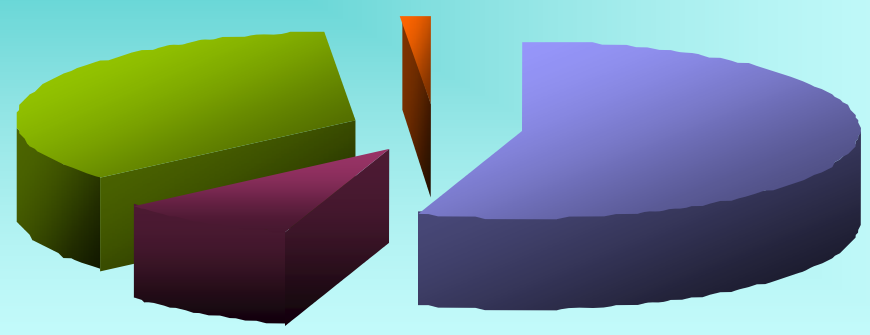

- Salud

- Ocio

- Descanso

- Otros Motivos 
Varias fueron las opciones elegidas a la hora de contestar a esta cuestión incluyéndose por parte de los encuestados nuevos motivos junto a los planteados.

En el cuadro que se exponen a continuación se refleja el porcentaje de incidencia en la respuesta.

"Salud" es la opción más contestada, seguida del "descanso", lo que viene a confirmar una de las afirmaciones mantenidas a lo largo de esta parte del capítulo dedicada al baño en aguas mineromedicinales.

Si agrupamos el motivo, según la variable sexo, podemos observar como el 55,7\% de respuestas cuyo motivo es "salud", y el $53,7 \%$ de respuestas cuyo motivo es "descanso" vendrían dadas por mujeres.

\begin{tabular}{|c|c|c|c|c|c|}
\hline \multirow[b]{2}{*}{ Motivo } & \multicolumn{5}{|c|}{ Motivo de asistencia a balneario según el sexo del encuestado } \\
\hline & & Hom bre & Mujer & NS/NC & Total \\
\hline \multirow[t]{2}{*}{ Salud } & Recuento & 92 & 142 & 21 & 255 \\
\hline & $\%$ de MOTIVO AGRUPADO & 36,1 & 55,7 & 8,2 & 100 \\
\hline \multirow[t]{2}{*}{ Ocio } & Recuento & 15 & 22 & 3 & 40 \\
\hline & $\%$ de MOTIVO AGRUPADO & 37,5 & 55 & 7,5 & 100 \\
\hline \multirow[t]{2}{*}{ Descanso } & Recuento & 59 & 87 & 16 & 162 \\
\hline & $\%$ de MOTIVO AGRUPADO & 36,4 & 53,7 & 9,9 & 100 \\
\hline \multirow[t]{2}{*}{ Otras razones } & Recuento & 1 & 4 & 1 & 6 \\
\hline & $\%$ de MOTIVO AGRUPADO & 16,7 & 66,7 & 16,7 & 100 \\
\hline \multirow[t]{2}{*}{ Total } & Recuento & 167 & 255 & 41 & 463 \\
\hline & $\%$ de MOTIVO AGRUPADO & 36,1 & 55,1 & 8,9 & 100 \\
\hline
\end{tabular}

Si cruzamos las variables, motivo y edad, observamos cómo el $52,5 \%$ de las personas que se dirigen al balneario por motivos de salud tienen más de 64 años. 


\begin{tabular}{|c|c|c|c|c|c|c|}
\hline & & Motivo agrupa & & & & \\
\hline Edad & & Salud & Ocio & Descanso & Otras razones & Total \\
\hline Menos de 30 & Recuento & 4 & 6 & 19 & 1 & 30 \\
\hline & $\%$ de MOTIVO AGRUPADC & 1,6 & 15 & 11,7 & 16,7 & 6,5 \\
\hline De 30 a 39 & Recuento & 20 & 12 & 39 & 0 & 71 \\
\hline & $\%$ de MOTIVO AGRUPADC & 7,8 & 30 & 24,1 & 0 & 15,3 \\
\hline De 40 a 49 & Recuento & 31 & 9 & 39 & 0 & 79 \\
\hline & $\%$ de MOTIVO AGRUPADC & 12,2 & 22,5 & 24,1 & 0 & 17,1 \\
\hline De 50 a 59 & Recuento & 19 & 2 & 16 & 0 & 37 \\
\hline & $\%$ de MOTIVO AGRUPADC & 7,5 & 5 & 9,9 & 0 & 8 \\
\hline De 60 a 64 & Recuento & 35 & 4 & 15 & 2 & 56 \\
\hline & $\%$ de MOTIVO AGRUPADC & 13,7 & 10 & 9,3 & 33,3 & 12,1 \\
\hline Más de 64 & Recuento & 134 & 7 & 33 & 3 & 177 \\
\hline & $\%$ de MOTIVO AGRUPADC & 52,5 & 17,5 & 20,4 & 50 & 38,2 \\
\hline NS/NC & Recuento & 12 & $\mathbf{0}$ & 1 & 0 & 13 \\
\hline & $\%$ de MOTIVO AGRUPADC & 4,7 & 0 & 0,6 & 0 & 2,8 \\
\hline & Recuento & 255 & 40 & 162 & 6 & 463 \\
\hline Total & $\%$ de MOTIVO AGRUPADO & 100 & 1020 & 100 & 100 & 100 \\
\hline
\end{tabular}

"Frecuencia con la que asiste al balneario", ésta fue otra de las cuestiones planteadas al objeto de conocer si su asistencia se trataba de una cuestión esporádica o continuada, sobre todo teniendo en cuenta que este tipo de baños es más efectivo si su aplicación es continuada:

\begin{tabular}{|c|c|c|}
\hline \multicolumn{3}{|c|}{ Frecuencia con la que asiste al balneario } \\
\hline & Frecuencia & Porcentaje \\
\hline Una vez al año & 272 & $69 \%$ \\
\hline Dos veces al año & 40 & $10,20 \%$ \\
\hline Tres o cuatro veces al año & 9 & $2,30 \%$ \\
\hline Otra situación & 73 & $18,50 \%$ \\
\hline Total & 394 & 100 \\
\hline
\end{tabular}


Frecuencia con la que as iste al balneario

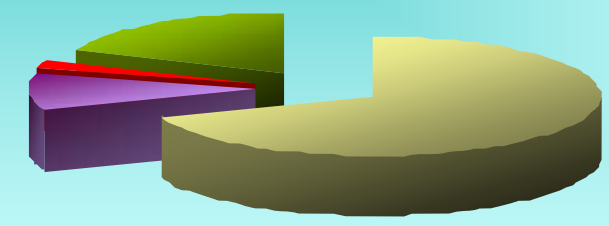

Una vez al año

nos veces al año

- Tres o cuatro veces al año

- Otra situación

En muchos de los casos se aludió al elevado coste de los tratamientos y de la estancia, como uno de los motivos por los cuales no se asiste con más regularidad a los centros balnearios.

En el cuadro siguiente se observa un alto porcentaje de encuestados que asisten a un centro balneario por primera vez:

\begin{tabular}{l|c|c|}
\hline \multicolumn{3}{|c|}{ Frecuencia con la que asiste al balneario } \\
\hline Otra situación & Frecuencia & Porcentaje \\
\hline De vez en cuando & 2 & $2,70 \%$ \\
\hline Es la primera vez & 63 & $86,30 \%$ \\
\hline Esporádicamente & 7 & $9,60 \%$ \\
\hline Una vez por semana & 1 & $1,40 \%$ \\
\hline Total & 73 & $100 \%$ \\
\hline
\end{tabular}




\subsubsection{Resultado de las entrevistas:}

Tras la información obtenida mediante encuestas aplicadas a una parte de nuestro público elegido aleatoriamente "el agüista", se hacía necesario la realización de entrevistas a "directores o responsables de balnearios"; ellos nos facilitaron una información interna sobre la situación real del sector y sobre la evolución de los distintos centros balnearios, analizados en este estudio.

A continuación se presenta un resumen de la información recogida en las entrevistas realizadas a los directores y responsables de los distintos centros balnearios que se ofrecieron a participar en esta investigación:

\section{Resumen de la información recogida:}

- fecha de las últimas reformas realizadas

- número de agüistas registrados el balneario en los últimos cinco años

- $\quad$ situación real, la evolución y el futuro del sector balneario

Con la intención de conocer la situación real de los centros balnearios en la actualidad, se preguntó por la fecha de las últimas reformas realizadas en los centros, esto nos permitirá conocer el estado de los distintos balnearios, su evolución en el tiempo y su adaptación a las necesidades del agüista de hoy.

Otra de las cuestiones a tratar en la entrevista, es el número de agüistas registrados el balneario en los últimos años, el objeto de esta cuestión es conocer si el número de asistentes a estos centros balnearios va en aumento, o si por el contrario, el sector se encuentra estacionario.

La opinión de los entrevistados con respecto a la situación real, la evolución y el futuro del sector balneario es el núcleo de las distintas entrevistas realizadas.

La opción de participar en esta parte de la investigación fue ofrecida a todos los responsables de los distintos centros balnearios, siendo rechazada en algún caso. 
La mayoría de los datos facilitados por los balnearios, corresponden al año $2005 / 2006$, se tomaron estos años como referencia, aunque la toma de datos para este estudio corresponde al año 2008/2009, por ser unos años en los que todos los balnearios estudiados disponían de una información actualizada.

El resultado de las entrevistas recogido en los distintos balnearios es la que se presenta a continuación, acompañada de una pequeña información sobre el lugar de ubicación geográfica del centro balneario participante en este estudio.

\section{Balneario de Ledesma:}

Análisis de situación: El balneario de Ledesma de origen romano, fundado en tiempos del emperador Marco Aurelio, se encuentra situado en la Comunidad Autónoma de Castilla y León, concretamente en la provincia de Salamanca a unos 25 $\mathrm{Km}$. de la capital, enclavado en plena naturaleza, junto al río Tormes. Una de sus peculiaridades es su pertenencia al Montepío de Mineros Asturianos, que se hace con la propiedad del balneario por las características de sus aguas y sus propiedades terapéuticas frente a la enfermedad de la silicosis; a este balneario puede asistir cualquier persona que lo solicite aunque no pertenezca al Montepío.

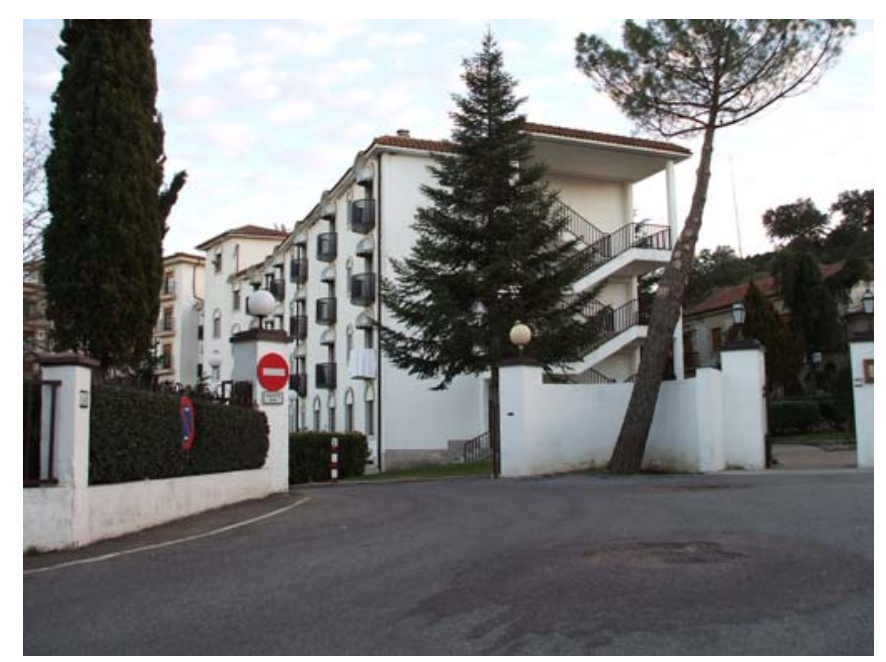




\section{Resultado de la entrevista}

Trascripción literal de la entrevista realizada a: D. Antonio Cirilo director del balneario de Ledesma

Reformas realizadas en los últimos años:

Año 1989, se realizan reformas tanto en el hotel (en cocina y habitaciones) como en el balneario, en el que se cambian las bañeras, los aparatos de inhalaciones que conllevan nuevos tratamientos.

Evolución en cuanto al número de usuarios:

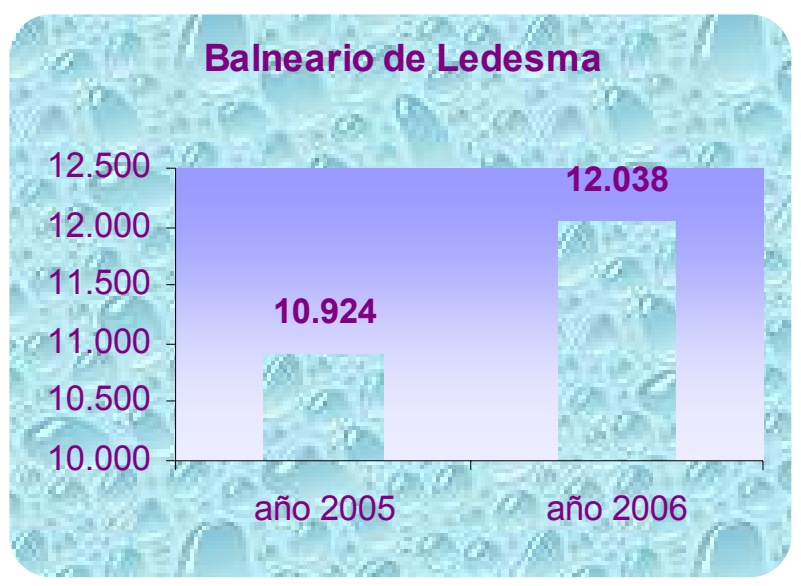

¿Considera que en la actualidad estamos asistiendo a una recuperación de los usos sociales y terapéuticos del agua?

Estamos asistiendo a una recuperación de los usos sociales y terapéuticos del agua, aunque el sector balneario en el futuro tiende a estabilizarse. 


\section{Balneario de Baños de Montemayor:}

Análisis de situación: El balneario Baños de Montemayor se encuentra situado al norte de la provincia de Cáceres y muy cerca del límite provincial de Salamanca, en plena naturaleza y entre montañas se encuentra este balneario cuyos manantiales datan del siglo II a. C. en la actualidad el balneario se encuentra al cien por cien de explotación en amplias instalaciones modernas, pero conservando las antigua instalaciones balnearias y su primitivo manantial, así como el museo de las termas, una verdadera joya en perfecto estado de conservación en el que se aprecia la importancia del baño en la época romana.

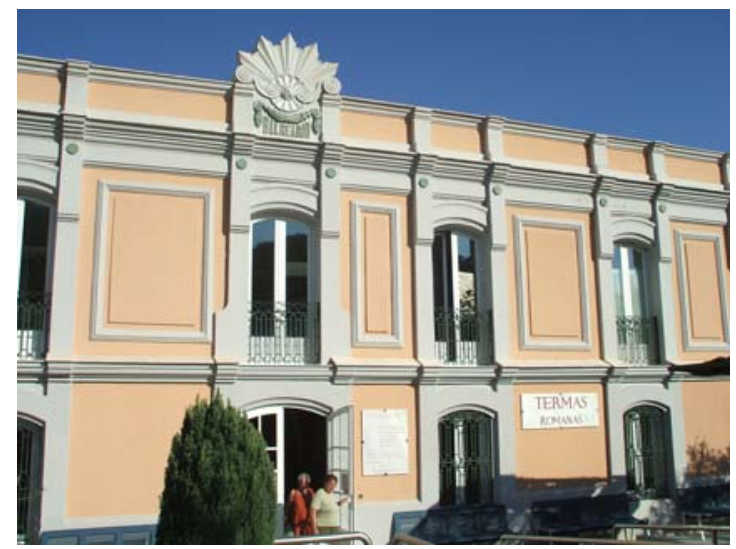

Ilustración 87 Fachada del Antiguo Balneario de Baños de Montemayor

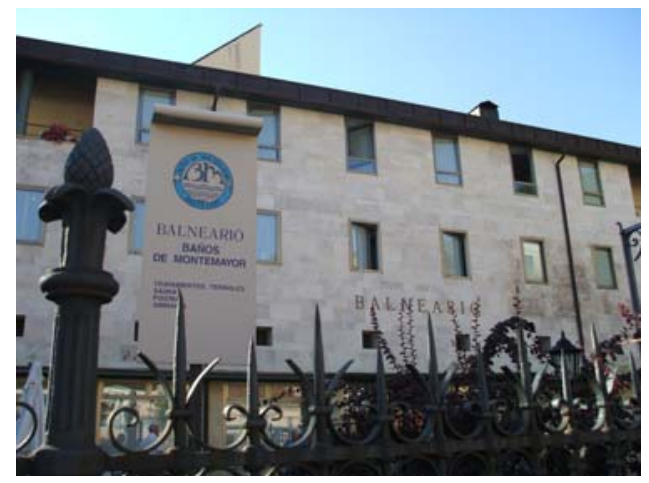

Ilustración 88 Fachada del nuevo Balneario de Baños de Montemayor 


\section{Resultado de la entrevista}

Trascripción de la entrevista realizada a: D. Gustavo. A Moreno Herrero

Reformas realizadas en los últimos años:

Año 1995, se pone en marcha el nuevo edificio anexo al balneario antiguo, este duplica la capacidad original de usuarios.

Año 2005, se realizan tres nuevos tipos de reformas:

- Cambio de suelos anti-deslizantes en varias instalaciones.

- Reforma de piscina con nuevos chorros de agua tipo SPA

- Nuevos vestuarios unisex

Año 2006, Nuevo circuito termal con bañeras de hidromasaje colectivas. Dos bañeras con capacidad para 6 personas cada una.

\section{Evolución en cuanto al número de usuarios:}

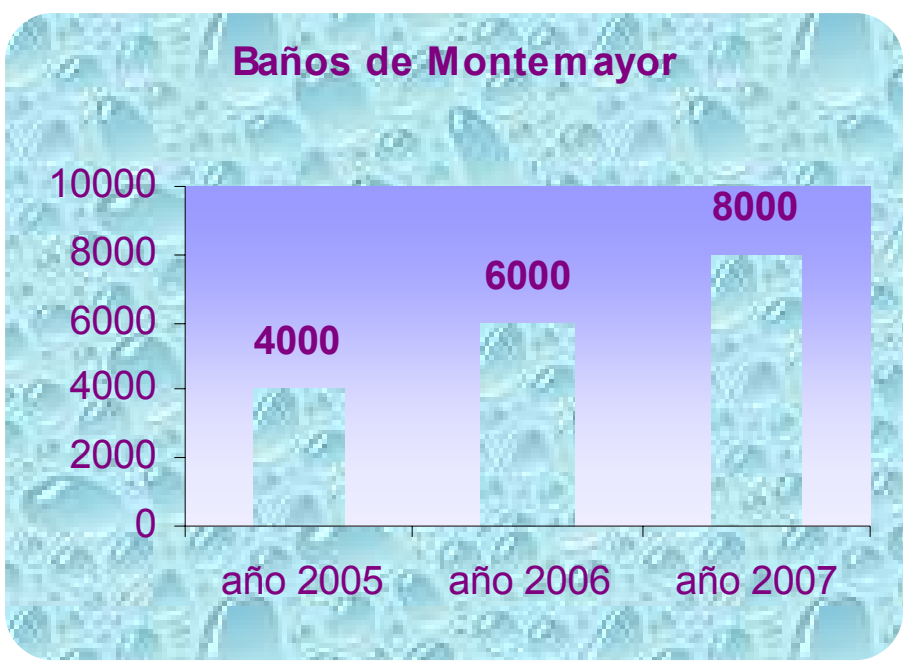


Motivos del crecimiento según se desprende de la entrevista: por un lado el aumento de las plazas ofrecidas por el INSERSO, y por otro lado, las ofrecidas por la administración local, en este caso la Junta de Extremadura.

\section{¿Existe una recuperación de los usos sociales y terapéuticos del agua?}

El uso terapéutico del agua, aunque existe mucho antes que las formas de turismo actual, ha resurgido de fusionar la vertiente curativa clásica con la vertiente lúdica de un turismo mucho más actual. Hoy en día las curas termales serían una actividad minoritaria y restringida a ciertas élites, si no existiera el apoyo decidido de las administraciones públicas, pero a su vez, éstas no la apoyarían si los usuarios no demandaran estos tratamientos cada vez más, debido a que entienden las curas termales, no sólo como un paliativo sino como unas vacaciones, un descanso que a diferencia de otros productos turísticos tienen unos efectos beneficiosos en su salud.

\section{¿Hacia dónde cree Vd. que se dirige el sector balneario en el futuro?}

Las acciones estratégicas que tomamos las empresas del sector vienen determinadas en gran medida por los cambios en los consumidores, en sus aspiraciones y exigencias. Las curas termales no escapan a la realidad del mercado y como cualquier otro producto de consumo la opinión y gustos de los consumidores son cruciales. Es aquí donde analizando al consumidor de nuestros establecimientos vemos un lento pero progresivo e inexorable cambio de tendencias que se acentuará en el futuro. Nuestro cliente ha evolucionado; desde el origen en el que existían dos tipos muy diferenciados de usuarios (uno de muy alto poder adquisitivo y otro de bajo poder adquisitivo subvencionado por el Estado) hasta la actualidad, donde estas diferencias se han estrechado, por una parte el cliente subvencionado tiene más renta y capacidad de elección y el cliente privado es menos elitista y busca buen servicio a un precio ajustado. Todo esto nos hace dirigirnos a un escenario en el que el cliente conoce el producto, prueba en muchos casos diferentes opciones y continuamente nos compara con el resto de ofertas turísticas que existen en el mercado, haciendo que los estándares de calidad que hace 10 años eran correctos hoy día no los toleren. Es por todo ello, que las inversiones en instalaciones y las mejoras en calidad 
son continuas y necesarias si queremos seguir creciendo en número de clientes y satisfacción percibida por estos.

\section{Balneario de Puente Viesgo:}

Análisis de situación: El Balneario de Puente Viesgo se encuentra situado en la Comunidad Autónoma de Cantabria a $30 \mathrm{Km}$ de Santander en el valle de Tornazo junto al río Pas. Se trata de un balneario que ha dejado ver a lo largo del tiempo su verdadera evolución con las sucesivas ampliaciones formadas por edificios anexos que constituyen en la actualidad un enorme complejo balneario dotado de modernas instalaciones hoteleras.

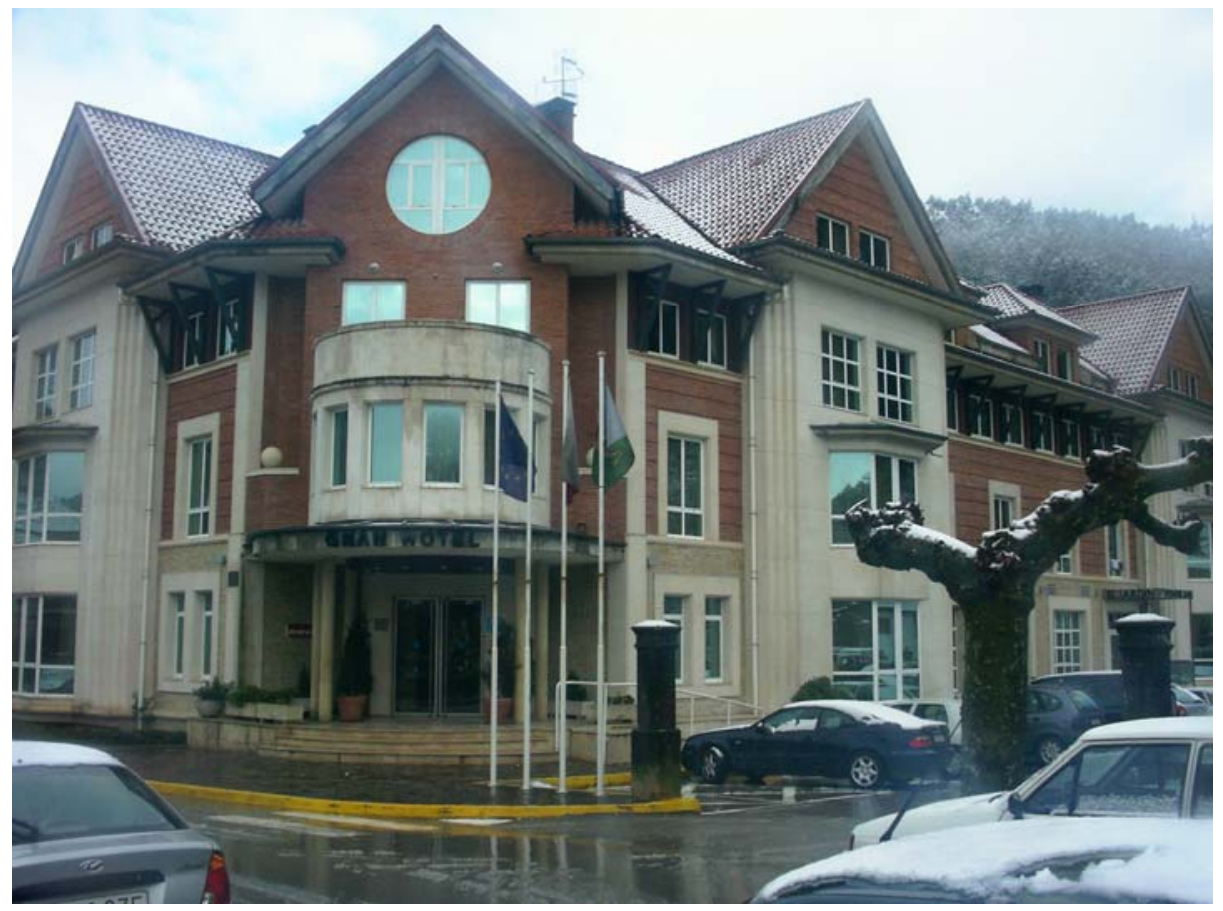

Ilustración 89 Instalaciones Hoteleras del Balneario de Puente Viesgo 


\section{Resultado de la entrevista}

Trascripción de la entrevista realizada: a Dña. Irene Hoyo Directora Médico del Balneario de Puente Viesgo.

Reformas realizadas en los últimos años:

Año 2006:

- En el mes de octubre abrimos 8 salas de masaje y estética.

- En el mes de diciembre hemos inaugurado el "Templo del Agua", espacio termo-lúdico de 1000 metros con piscina infantil, piscina dinámica (con chorros a distintos niveles, camas de burbujas, río contracorriente, cascada, jacuzzi, pozo frío, jacuzzi exterior, saunas a diferentes temperaturas y grados de humedad, duchas de contraste y sala de reposo.

Año 2007:

- En el mes de mayo, pusimos en marcha la piscina de flotación.

- En total una ampliación de 2000 metros cuadrados en este último año. 


\section{Evolución en cuanto al número de usuarios:}

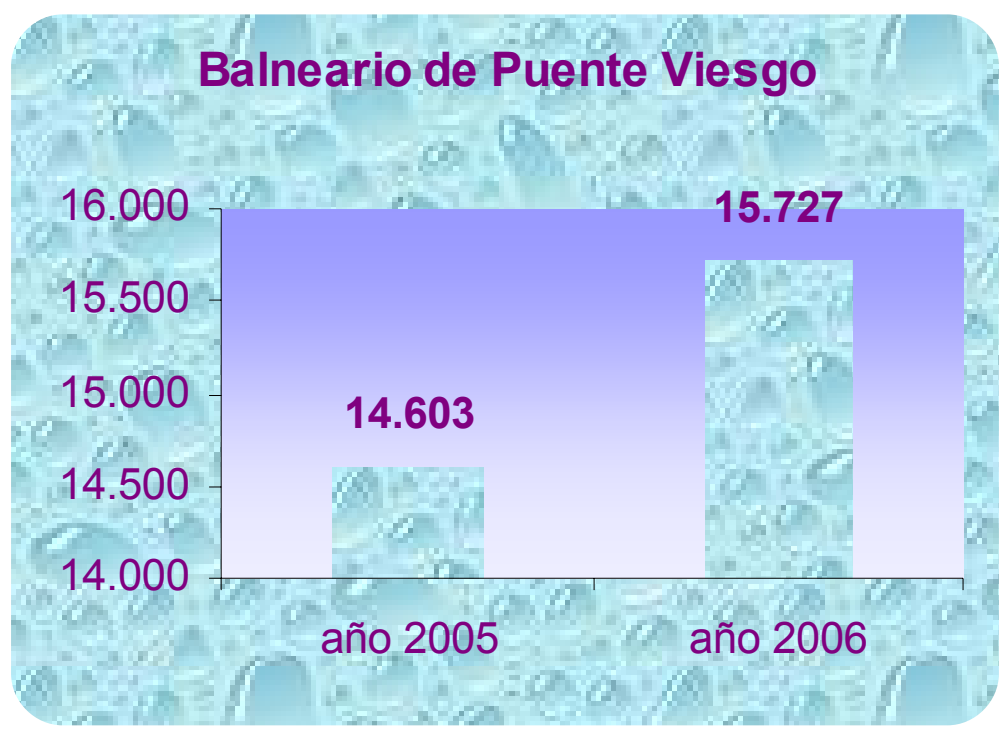

¿Considera que en la actualidad estamos asistiendo a una recuperación de los usos sociales y terapéuticos del agua?

Sin duda alguna, el gran impulso fue dado por la creación del programa de termalismo social, aunque en el caso de nuestro balneario, el porcentaje de usuarios perteneciente a este sector es mínimo, pero ha sido una forma importante de dar a conocer los beneficios de las aguas.

\section{¿Hacia dónde cree Vd. que se dirige el sector balneario en el futuro?}

Pienso que podemos diferenciar dos grupos de usurarios, uno que utiliza el balneario exclusivamente por su uso terapéutico y otro sector que no tiene ninguna patología y lo utiliza de forma preventiva, o simplemente para descansar (aunque ellos no vean éste uso como terapéutico, los médicos pensamos que es una forma de invertir en salud), o para hacerse tratamientos de belleza. 


\section{Otras cuestiones:}

Aquí durante los meses de julio, agosto y septiembre no trabajamos con termalismo social (grupos del IMSERSO), y los pacientes que tenemos en este momento tienen un nivel socioeconómico elevado, suelen ser empresarios, gerentes de grandes empresas, mujeres viudas con gran capital etc. Con lo cual por desgracia en esta temporada no podemos decir que el balneario esté al alcance de todos los bolsillos.

Sí que nos encontramos con un porcentaje de pacientes que no se alojan en el hotel y vienen exclusivamente al balneario a realizar tratamiento.

Por otra parte, el resto del año tenemos pacientes del programa de termalismo (10\% del número total de agüistas) y de convenios que hacemos con ayuntamientos, esto supone poder contar entre nuestros pacientes con personas de un nivel socioeconómico medio-bajo.

\section{Balneario de Alicún de las Torres:}

Análisis de situación: El balneario de Alicún de las Torres se encuentra a $8 \mathrm{~km}$ de la población de Villanueva de las Torres, a $30 \mathrm{Km}$ de Guadix y a $90 \mathrm{Km}$ de Granada, se encuentra en plena naturaleza y dispone de piscinas termales al aire libre.

\section{Resultado de la entrevista}

En el caso de Alicún de las Torres se da la coincidencia de que el director del centro D. José María Meialdea, es a su vez, Presidente de la Asociación de Balnearios de Andalucía, por lo que a continuación, sólo se presentan los datos facilitados pertenecientes a este balneario. La entrevista, dado su grado de interés por ser la opinión que corresponde a su cargo y no al de director del centro, tendrá un 
tratamiento aparte y se presentará al final del recorrido por todos los balnearios que han participado en esta investigación.

\section{Reformas realizadas en los últimos años:}

Desde 1997: Se vienen realizando reformas durante el periodo de cierre, obras generales que hacen que casi la totalidad del balneario esté reformado en la actualidad.

Año 2007: Las reformas consistieron en la incorporación de aire acondicionado en el $60 \%$ de las habitaciones del hotel.

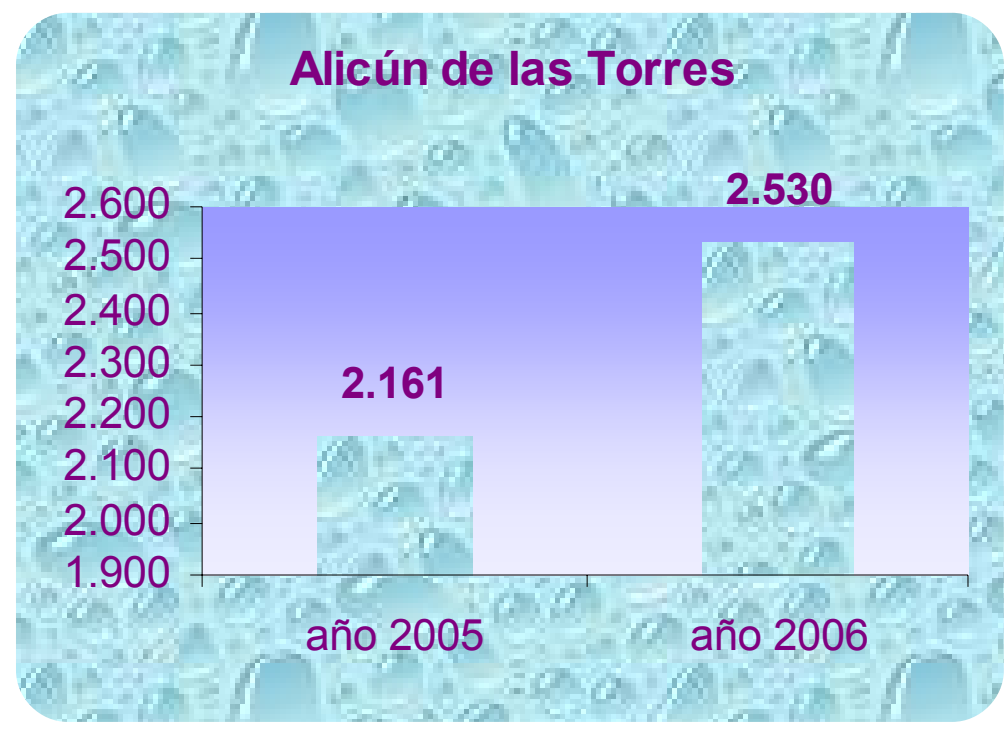

Evolución en cuanto al número de usuarios: el aumento de usuarios del año 2006 con respecto al 2005 , ha sido bastante notable. 


\title{
Balneario de Graena:
}

Análisis de situación: D. José Saavedra Sierra en su libro titulado "LOS BAÑOS DE GRAENA Un Manantial que Sana" comienza su libro describiendo de forma detallada la situación geográfica de este balneario situado en la población de su mismo nombre:

\begin{abstract}
"Los Baños de Graena es uno de los cuatro núcleos de población que forman el municipio de Cortes y Graena, en la provincia de Granada. Este municipio forma parte del río Alhama. Está nuestro pueblo situado en la cara norte de Sierra Nevada, a una distancia de 8 kilómetros de Guadix y 52 de la capital de la provincia. Su altitud es de 970 metros y está ubicado en una cañada entre el Cerro de las Narices y el Montual, este último con una altitud de 1.043 metros. ${ }^{, 247}$
\end{abstract}

\section{Resultado de la entrevista}

Trascripción literal de la entrevista realizada: a D. José Machado Director del centro

El balneario de Graena ha sido objeto de grandes obras de restauración y modernización de sus instalaciones

247 Saavedra Sierra J. (2007) Pág. 17 


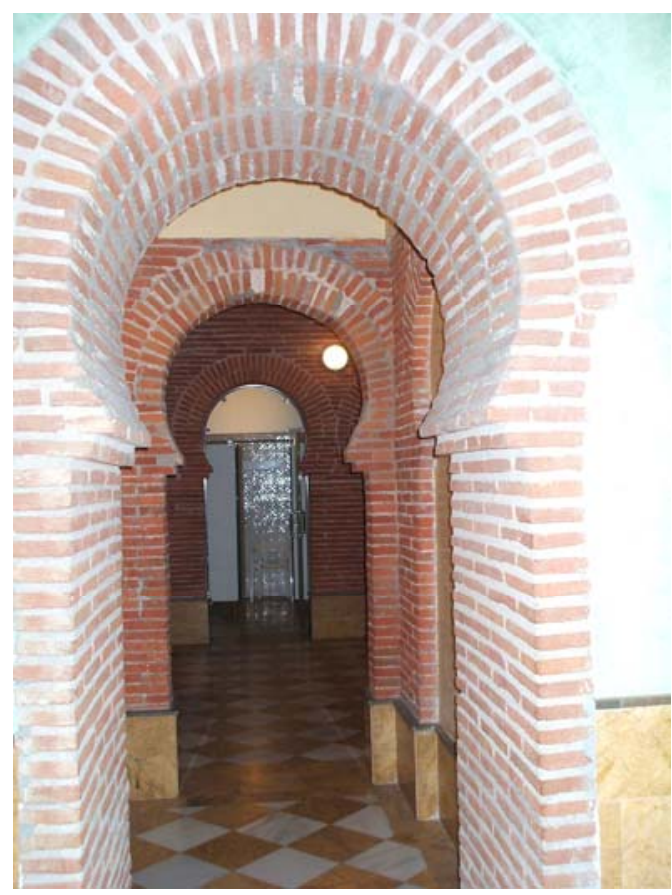

Ilustración 90 Interior del balneario de Graena

\section{Reformas realizadas en los últimos años:}

Años 2002/2004: Realización de una reforma integral de toda la instalación para dotar al balneario de nuevos tratamientos además de los que ya tenía.

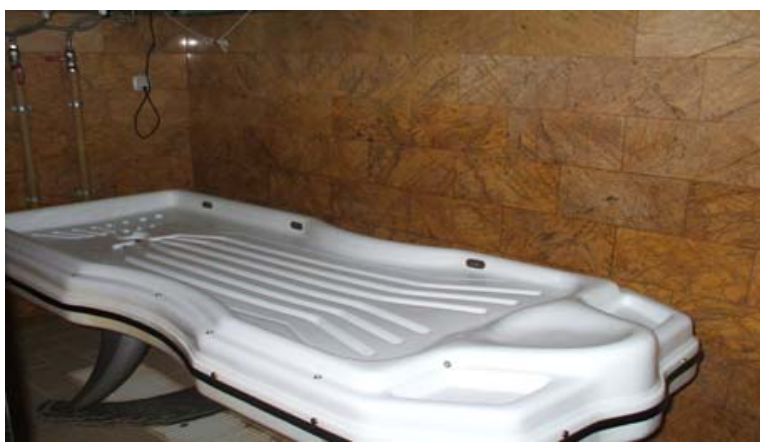

Ilustración 91 Sala de Terapia. Balneario de Graena en la Comarca de Guadix (Granada) 


\section{Evolución en cuanto al número de usuarios:}

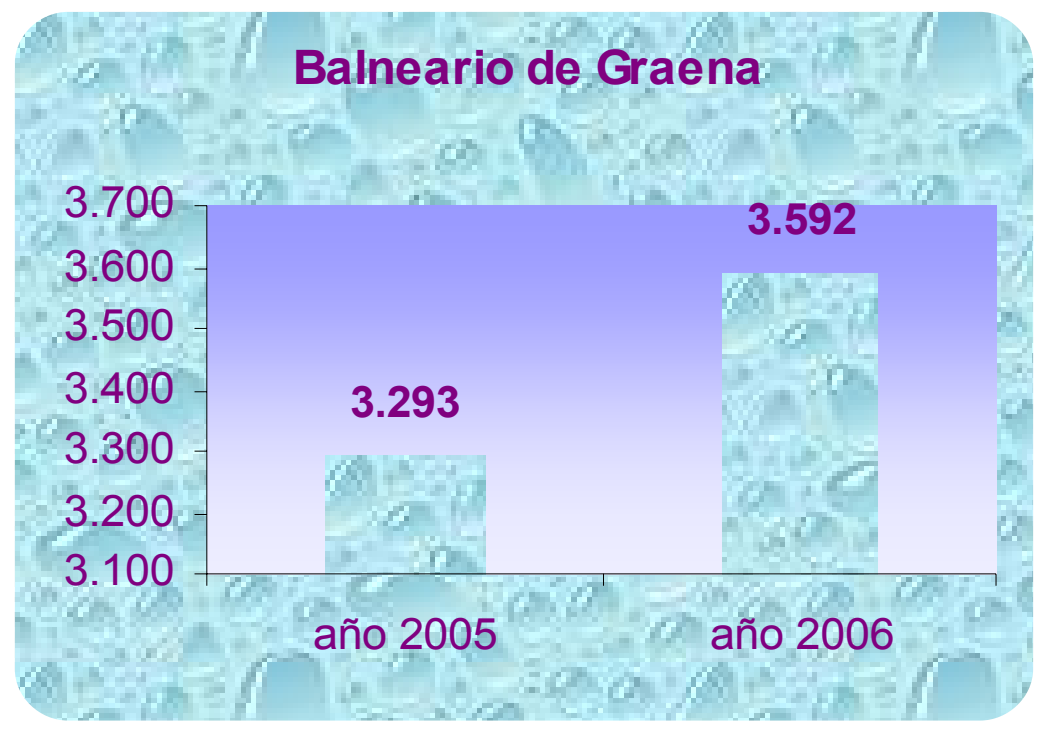

¿Considera que en la actualidad estamos asistiendo a una recuperación de los usos sociales y terapéuticos del agua?

Sí, estamos en un momento de crecimiento del sector

¿Hacia dónde cree Vd. que se dirige el sector balneario en el futuro?

Hacia la recuperación de la cultura del balneario como centro de salud y ampliando clientes que quieren hacer un tratamiento lúdico-terapéutico.

\section{Otras cuestiones:}

Tenemos un sector que nos compite (SPA) pero en mi opinión son centros que pasarán y quedará el balneario por sus probados efectos terapéuticos de las aguas. 


\section{Balneario de Alhama de Granada:}

Análisis de situación: En la Comunidad Autónoma de Andalucía en la provincia de Granada y perteneciente a la comarca de Loja se encuentra el balneario de Alhama de Granada. El balneario se encuentra en una alameda junto al río Merchán, un lugar donde reina la paz a muy pocos kilómetros del pueblo que lleva su nombre "Alhama de Granada"

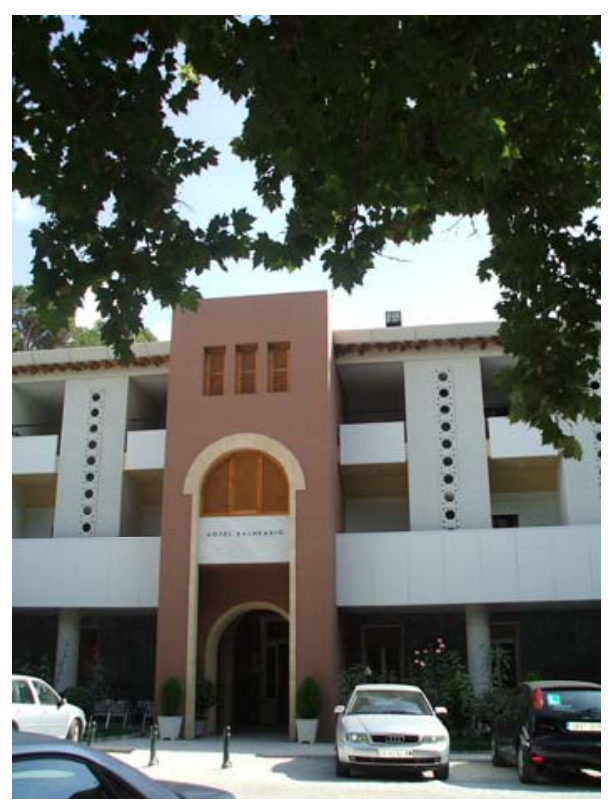

Ilustración 92 Puerta de entrada

Balneario de Alhama de Granada

\section{Resultado de la entrevista}

Trascripción de la entrevista realizada: D. Francisco Jiménez Director del balneario de Alhama de Granada 
Reformas realizadas en los últimos años:

Año 2006, Remodelación de unidades de alojamiento.

Evolución en cuanto al número de usuarios:

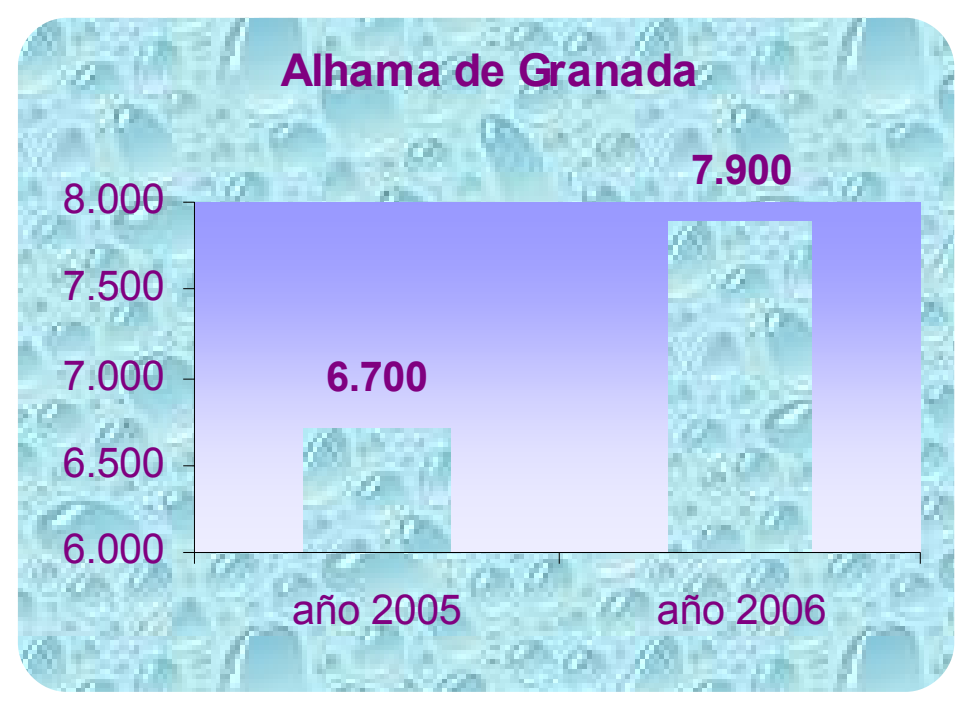

¿Considera que en la actualidad estamos asistiendo a una recuperación de los usos sociales y terapéuticos del agua?

Sí hay un importante resurgir de los balnearios.

¿Hacia dónde cree Vd. que se dirige el sector balneario en el futuro?

Salud, belleza y tratamientos anti estrés.

Otras cuestiones:

Cada vez tenemos más tiempo vacacional y nos preocupa la salud emocional. 


\section{Balneario de Archena:}

Análisis de situación: El balneario de Archena se encuentra situado en la Comunidad Autónoma de Murcia, a dos km de la población que lleva su nombre. Se encuentra entre montañas, a orillas del río Segura. Los romanos disfrutaron de sus aguas aunque antes fueron los íberos los que valoraron sus virtudes.

\section{Resultado de la entrevista}

Trascripción de la entrevista realizada: D. Juan Andrés Barroso director del Centro

Reformas realizadas en los últimos años: Acabamos de abrir al público un espacio con salas de masajes, cinco saunas (a diferente temperatura y humedad). Varias piscinas de relajación y una cámara de hielo.

Evolución en cuanto al número de usuarios: No se han facilitados datos al respecto

\section{¿Existe una recuperación de los usos sociales y terapéuticos del agua?}

- En lo tocante a lo social hay más demanda.

\section{¿Hacia dónde cree Vd. que se dirige el sector balneario en el futuro?}

- El "peligro" detectado, es que hay una dispersión del sector, nada clara, entre balnearios de aguas mineromedicinales y Spas hoteleros o balnearios "urbanos" que confunden bastante.

El sector tradicional, bajo mi punto de vista, se ha visto en parte superado por el gran aluvión de spas y balnearios urbanos, que al ser empresas jóvenes, dinámicas han copado buena parte del mercado "de turismo de salud". "organizan congresos donde no se conoce a los ponentes y se da prioridad al marketing o a la estética/belleza" sobre otros aspectos. 
Son empresas con menos costes de mantenimiento, ya que el agua suele ser "del grifo", poco erosiva, que se comporta normal al clorarla, a diferencia de la mineromedicinal, más erosiva y sometida muchos controles para mantener su idoneidad y sus propiedades.

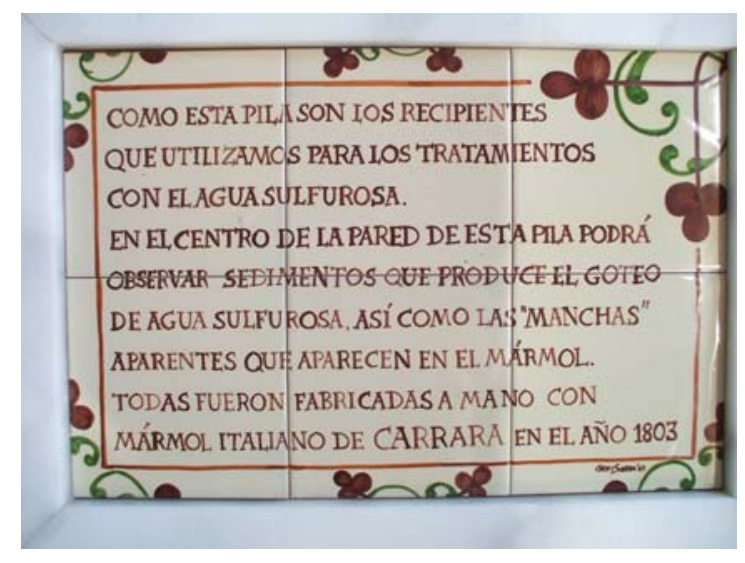

Ilustración 93 Azulejos situados en la pared del balneario situados sobre la bañera de la imagen posterior. En ellos se describen los efectos del agua sulfurosa

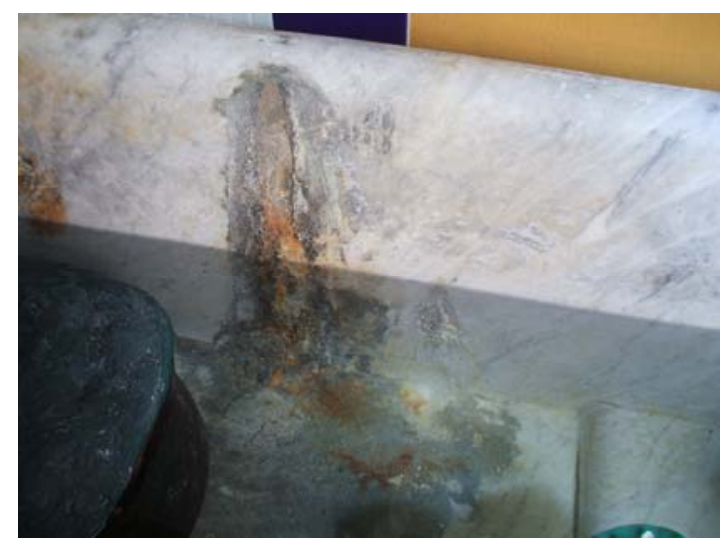

Ilustración 94 Imagen tomada en el Balneario de Fuente Amarga en Chiclana (Cádiz) 
Quizás el futuro aclare el panorama, pero el gran público que abarrota las instalaciones de todos estos establecimientos, por ahora no sabe en gran parte la diferencia.

\section{Balneario de Manzanera "El Paraíso":}

Análisis de situación: situado a $57 \mathrm{~km}$ de Teruel, el nombre de "El Paraíso" proviene de su ubicación cerca del llamado Paraíso Bajo uno de los barrios de la localidad de Manzanera, cuyos límites hacen frontera entre Aragón y Valencia, junto a los ríos Paraíso y Torrijas en la sierra de Javalambre, en las estribaciones de los Montes Universales.

\section{Resultado de la entrevista}

Trascripción de la entrevista realizada: a Dña. Ana Sanchís directora médico del balneario de Manzanera "El paraíso".

\section{Reformas realizadas en los últimos años:}

Año 2006. Concretamente reformas en cocina y centro termal, nueva sala de respiratorio. Además hemos implantado la "Q" de calidad lo que nos ha obligado a hacer reformas e inversiones importantes. Casi todos los años se hacen reformas.

\section{¿Existe una recuperación de los usos sociales y terapéuticos del agua?}

- Gracias a la apuesta del IMSERSO y otras del gobierno autonómico por el termalismo, estamos asistiendo a una recuperación de los usos sociales y terapéuticos del agua.

Este tipo de cliente sí valora el uso del agua medicinal como un tratamiento alternativo por sus dolencias, más aún cuando la medicina tradicional no ofrece 
curaciones definitivas. Así pues los tratamientos paliativos realizados en balnearios son muy valorados por este tipo de usuarios.

Para el usuario más joven y de fin de semana, el balneario es un lugar donde relajarse y realizar tratamientos pero no valora el uso o no, del agua medicinal.

\section{¿Hacia dónde cree Vd. que se dirige el sector balneario en el futuro?}

- Pienso que el futuro de los balnearios está en la línea de grupos subvencionados por gobierno central y autonómico.

El cliente particular, valora más el estado de las instalaciones y la oferta de tratamientos estéticos que el agua medicinal en sí, por lo que debemos ampliar, como de hecho se está haciendo, la oferta para estos grupos, así como los tratamientos personalizados aprovechando que los balnearios están en lugares privilegiados, pero sin dejar de promocionar los efectos beneficiosos de las aguas medicinales.

\section{Balneario Cervantes:}

Análisis de situación: El balneario Cervantes, se encuentra al sureste de la provincia de Ciudad Real, a sólo 1 km de Santa Cruz de Mudela. En el año 1929 fueron declarados de Utilidad Pública los dos manantiales que surten al balneario, el baños y el Villarosa también llamado de San Camilo, aunque ya en el siglo XVIII, la orden de los Camilos comenzaron a utilizar esta agua para curar enfermos.

\section{Resultado de la entrevista}

Trascripción de la entrevista realizada: Dña. Lola Llario Ciudad

Reformas realizadas en los últimos años: 
Año 2002, se realizaron reformas que consistieron en la apertura de: una piscina activa, sala de masajes, arcilla estética, chorros, duchas circulares, gimnasio, aseos y sala de descanso.

Evolución en cuanto al número de usuarios:

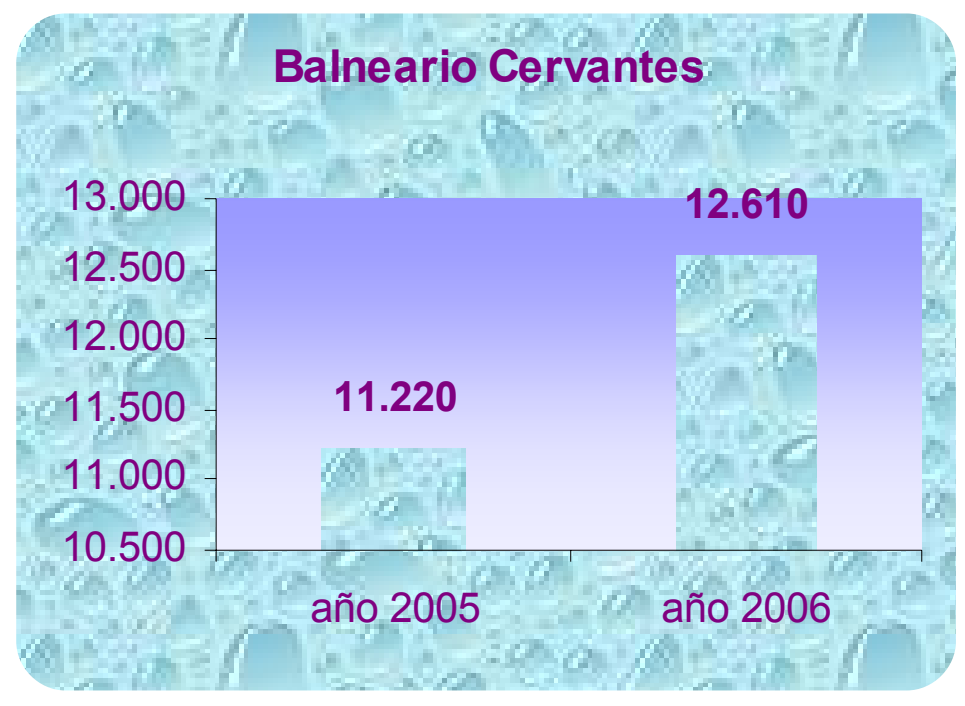

¿Considera que en la actualidad estamos asistiendo a una recuperación de los usos sociales y terapéuticos del agua?

Desde hace 10 años se ha notado un fuerte incremento en clientes mayores y jóvenes, sin embargo la aparición de SPAS y Talassos, desvía al público joven hacia ellos.

¿Hacia dónde cree Vd. que se dirige el sector balneario en el futuro?

Personas de edad madura.

Existen pocos balnearios y muchos establecimientos que hacen las mismas terapias con aguas no medicinales. 


\section{Balneario Sicilia, Estación Termal del Jaraba:}

Análisis de situación: El balneario se encuentra situado junto a otro balneario llamado "Balneario Serón", ambos se encuentran situados en el casco urbano de Jaraba en Zaragoza.

El nombre de "Jaraba" procede del árabe y significa "Agua abundante"

\section{Resultado de la entrevista}

Trascripción de la entrevista realizada: a Don Antonio García, director del centro

\section{Reformas realizadas en los últimos años:}

Año 2000, Reforma integral en la galería de baños, piscina termal activa, ampliación y reforma de habitaciones y dotar la galería de baños de nuevos aparatos para hacer más efectivos los tratamientos termales, así como nuevas cabinas de belleza.

\section{Evolución en cuanto al número de usuarios:}

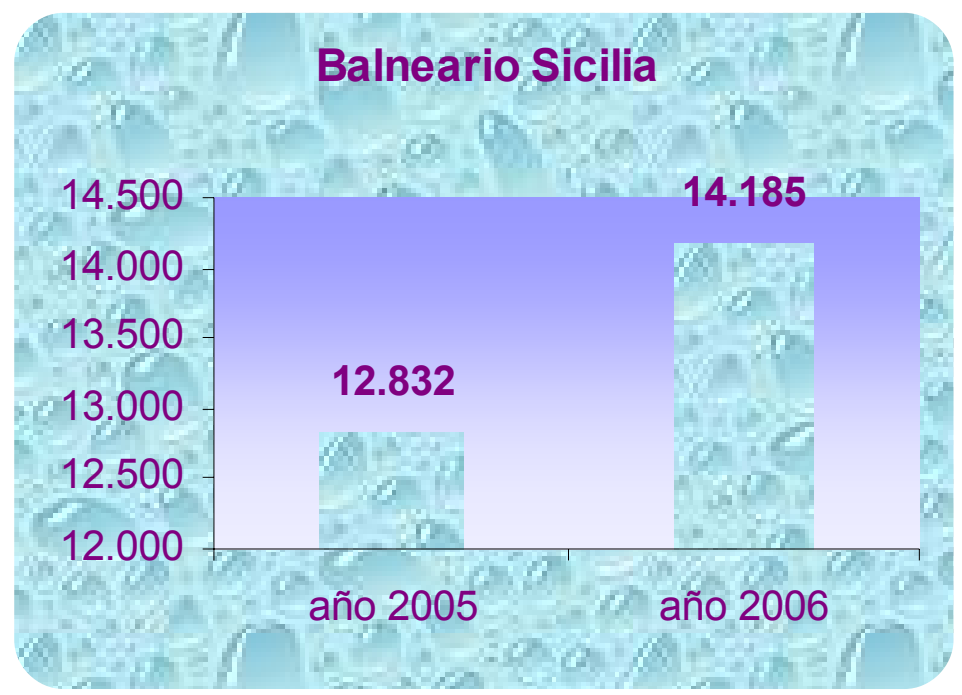




\section{¿Considera que en la actualidad estamos asistiendo a una recuperación de los usos sociales y terapéuticos del agua?}

Si hacemos aunque sea muy brevemente historia de la evolución que ha tenido el sector de balnearios en los últimos tiempos, yo diría que después de la guerra civil española, algunos balnearios quedaron con grandes desperfectos y en mano de particulares.

Hacia el año 1.960, poco quedó del esplendor de los Balnearios que tuvieron en los siglos XVIII y XIX, pero a partir de entonces, los efectos de la contaminación, el ruido y la aglomeración de las grandes ciudades, propiciaron un retorno de mucha gente a la naturaleza y a una modalidad de turismo más sosegado y desmasificado.

En el año 1.975, algunos balnearios en España empezaron a invertir en modernizar sus establecimientos y empezaron a abrir durante todo el año, durante los primeros años con grandes dificultades económicas.

Durante el año 1.989 surgió el Programa del Ministerio de Trabajo y Asuntos Sociales, gestionado a través del IMSERSO, destinado a personas mayores.

Este programa ha servido para dar a conocer a la sociedad española la existencia de los balnearios españoles. Al mismo tiempo se consiguió terminar con la estacionalidad.

Se hizo un estudio a nivel nacional, y se pudo comprobar que un $24 \%$ de la población entre 35 y 55 años de edad, que nunca había estado en un Balneario, se planteara dicha opción como una propuesta de relax.

A partir de este estudio una gran parte de los establecimientos balnearios empezaron a invertir grandes cantidades de dinero en reformar, ampliar instalaciones y servicios, tanto en la parte termal como hotelera, se cambió de estrategia y se diversificó el mercado, para que en un balneario pudieran estar los clientes cuya finalidad es hacer uso terapéutico de las aguas minero-medicinales, con otros nuevos públicos cuya finalidad es utilizar las aguas, instalaciones y servicios para pasar unos días tranquilos y relajantes. 
La realidad es que el sector de Balnearios en algunas comarcas, ha reactivado la economía y el mercado laboral, podemos decir sin miedo a equivocarnos, que balnearios se han convertido en motores económicos de algunas comarcas.

Hoy día los balnearios, ofrecen unas condiciones altamente sugerentes para poder disfrutar de unos días de descanso al más alto nivel de confort. Al mismo tiempo ofrecen la alternativa ideal al turismo ruidoso y masificado.

\section{¿Hacia dónde cree Vd. que se dirige el sector balneario en el futuro?}

Para que un establecimiento balneario tenga futuro, tiene que seguir diversificando el mercado, no tener dependencia de los Programas Sociales (estos programas deben servir para temporadas bajas), seguir invirtiendo en calidad de servicios, innovar en la galería de baños, satisfacer al cliente y sobre todo intentar fidelizar al cliente para que repita y sirva de mensaje para atraer a otras personas, esto pasa por prestar muy buenos servicios. Hay que hacer un gran esfuerzo de comunicación para mostrar a la sociedad, la nueva imagen de modernidad de los balnearios.

Por otra parte, el Turismo Termal o de Salud requiere una mayor formación y especialización del tur-operador y agentes de viaje, y sobre todo, hacer campañas de publicidad, dirigido a público urbano enmarcado entre los 35 y 55 años de edad y principalmente femenino.

Si se sigue una buena estrategia el futuro del sector de balnearios es irreversible.

\section{Balneario Arnoía Caldadaria:}

Análisis de situación: Se trata de un balneario joven ya que fue construido en el año 1995, se encuentra situado a cuatro kilómetros de la villa histórica de Ribadaxia en la provincia de Ourense y próximo a las principales ciudades gallegas. En plena naturaleza junto a los ríos Miño y Arnoia siendo de este último del que toma el nombre el establecimiento balneario. 


\section{Resultado de la entrevista}

Trascripción de la entrevista realizada: a Don Ramón Álvarez Adjunto de dirección

Reformas realizadas en los últimos años:

Año 2005, Las reformas consistieron en la reforma de recepción, el restaurante y la cafetería.

Evolución en cuanto al número de usuarios:

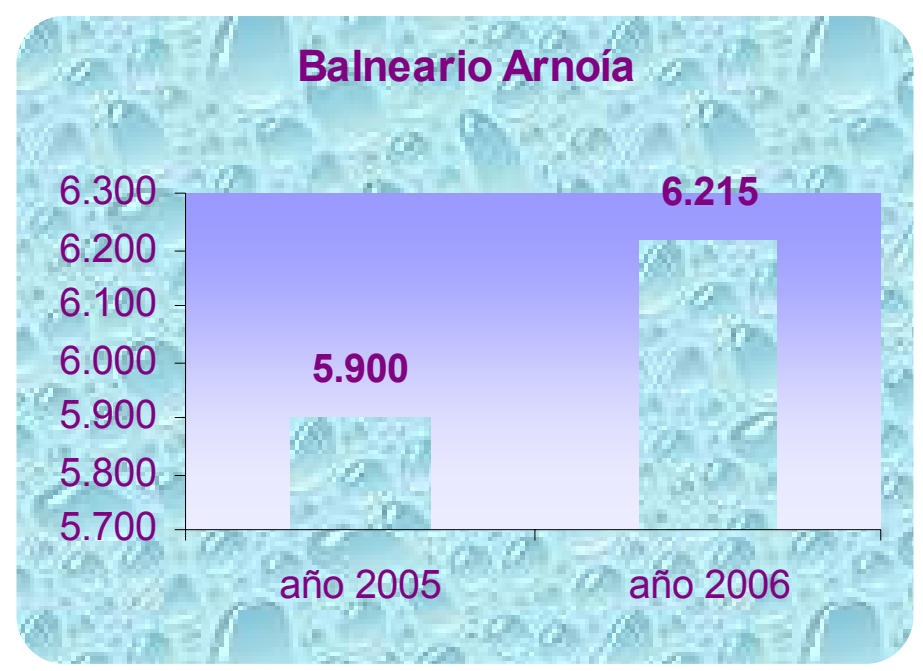

¿Considera que en la actualidad estamos asistiendo a una recuperación de los usos sociales y terapéuticos del agua?

Sí

¿Hacia dónde cree Vd. que se dirige el sector balneario en el futuro?

Hacía un turismo al alcance de todo el mundo. 
Termas de Laías:

Análisis de situación: Al igual que en el caso anterior, estamos ante un balneario de reciente creación, se encuentra enclavado en el valle del río Miño, en la provincia de Ourense a unos 15 minutos de la capital y a uno 45 minutos de Vigo.

\section{Resultado de la entrevista}

Trascripción de la entrevista realizada: D. Francisco Javier Ramos Pérez. Adjunto de dirección.

\section{Reformas realizadas en los últimos años:}

- Este balneario fue construido hace 6 años hasta el momento no se han hecho reformas.

\section{Evolución en cuanto al número de usuarios:}

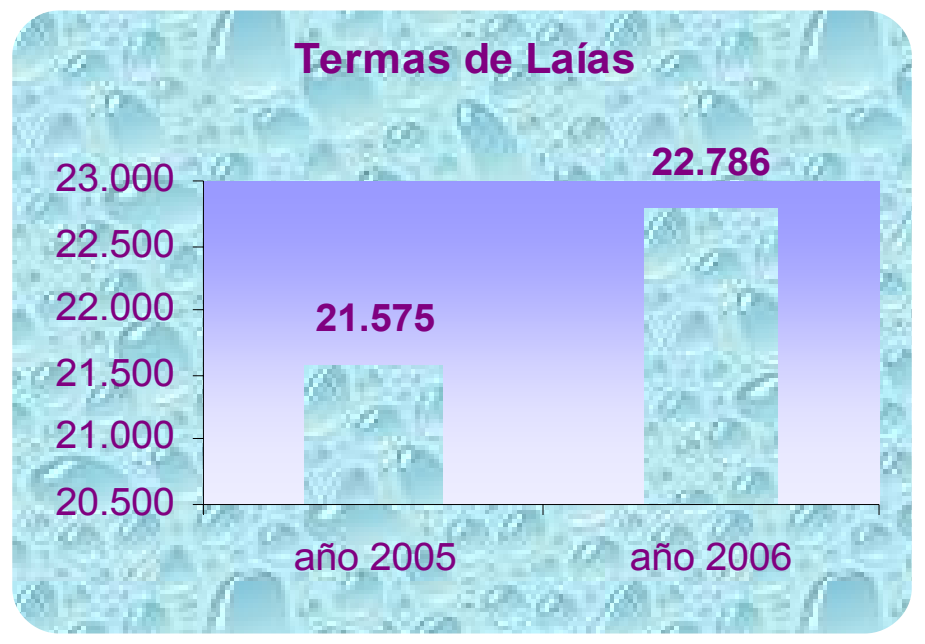


¿Hacia dónde cree Vd. que se dirige el sector balneario en el futuro?

- Grupos de Tercera Edad, gente joven que viene los fines de semana a descansar.

\section{Termas de Lobios:}

Análisis de situación: La villa termal de Lobios, se encuentra situada en el pueblo de Riocaldo a escasos kilómetros de una de las áreas naturales más importantes de Galicia por su valor ecológico: "El Parque natural Baixa Limia-Xurés". El balneario se encuentra a $70 \mathrm{Km}$ de la capital de Orense y a $6 \mathrm{Km}$ de Portugal a su paso por la frontera de Portela D'Home. Se encuentra cerca de la localidad portuguesa de Gerês, en el Parque Nacional Peneda Gerês, y las Villas Lusas de Ponte da Barca, Ponte da Limia y Arcos de Valdevez.

\section{Resultado de la entrevista}

Trascripción de la entrevista realizada: A D. Raquel González. Adjunta a dirección

Reformas realizadas en los últimos años:

No se han hecho reformas por ser un balneario de reciente construcción.

Evolución en cuanto al número de usuarios: No disponemos de datos

¿Considera que en la actualidad estamos asistiendo a una recuperación de los usos sociales y terapéuticos del agua?

Sí, además de los usos lúdicos.

¿Hacia dónde cree Vd. que se dirige el sector balneario en el futuro?

- Si se sabe dar la información apropiada, iremos hacia una mejora notable. 


\section{Balneario de Alange:}

Análisis de situación: El Balneario de Alange se encuentra en la provincia de Badajoz, en la parte central del Extremadura dentro del la población que lleva su mismo nombre; a unos dieciocho kilómetros de la ciudad de Mérida.

Alange se asienta sobre las estribaciones de la Sierra de Peñas Blancas, a sus pies un hermoso embalse alimentado por cinco ríos que ofrecen sus aguas al embalse (Matachel, Palomillas, Bonhabal, San Juan y Valdemedel), un privilegiado entorno para un balneario de aguas mineromedicinales.

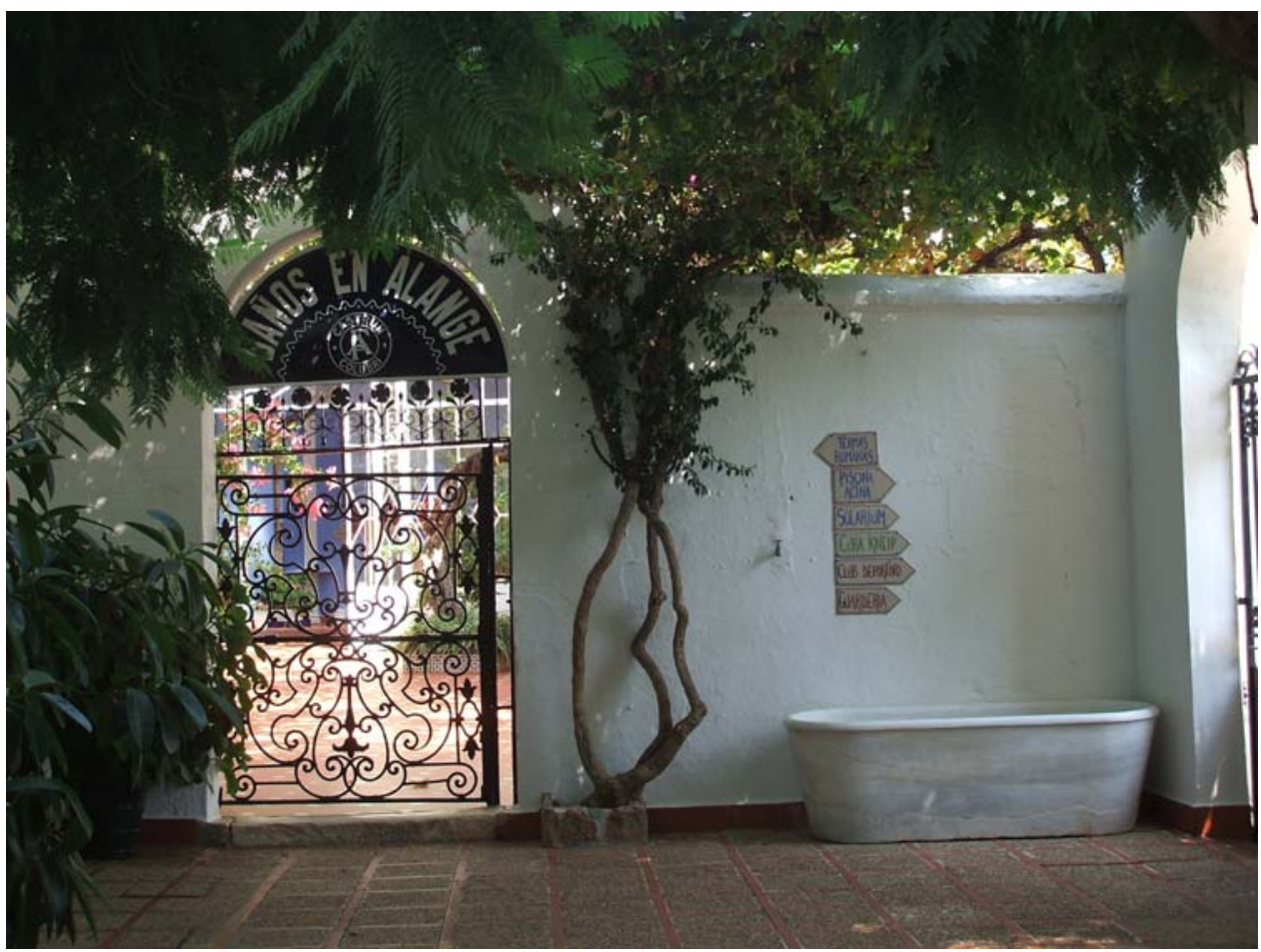

Ilustración 95 Balneario de Alange (Badajoz) 


\section{Resultado de la entrevista}

Trascripción de la entrevista realizada: D. Fernando Fernández-Chiralt Director Gerente del Balneario de Alange:

\section{¿Podría decirme el año en que se realizaron las últimas reformas del balneario y en que consistieron?}

En el año 2006 se construyó un hotel de 4 estrellas y 86 habitaciones. Aunque no es la misma empresa, el grupo es el mismo.

En el balneario llevamos haciendo reformas desde el año 89. La última fue reformar el centro del balneario construyendo una piscina climatizada, un baño turco y reformando el gabinete de duchas.

Sería importante para este estudio conocer el dato, de $\mathrm{n}^{\circ}$ de usuarios del balneario en los años 2005 2006:

Año 2005...2978 bañistas de más de 9 días y 1646 de menos de 9 días.

Año $2006 \ldots 3.800 \quad$ " " " " " $\quad$ " 1869 "

Los bañistas de un día no están contabilizados. EI IMSERSO supone el $45 \%$ de la facturación

1 - ¿Considera que en la actualidad estamos asistiendo a una recuperación de los usos sociales y terapéuticos del agua?

Sí, está claro que el uso del agua se está potenciando y todo lo que es cultura termal está apareciendo como de primera actualidad.

\section{2- ¿Hacia dónde cree que se dirige el sector balneario en el futuro?}

Creo que estamos en pleno desarrollo pero estamos perdiendo autenticidad. Nuestra labor ha sido siempre tratar algún tipo de enfermedad, y a la sombra de eso 
podemos trabajarnos el tema lúdico. La razón de ser de un balneario de agua mineromedicinal ha sido siempre tratar, aliviar o curar algún tipo de dolencia. Hoy día donde todo es maravilloso, todos estamos delgados y no hay nadie feo pues "como que queda muy mal " todo es chica mona y piscina fantástica. Curiosamente la mayoría de los SPA no están funcionando y los hoteles lo regalan como un servicio gratis del hotel.

Sin embargo, por poner un ejemplo, en nuestro balneario la gente lleva un riguroso orden en cuanto a tratamiento médico mandado por el médico que es el que manda en la instalación.

Las personas que vienen por lúdico, aunque no pasan por el médico, están sometidas al funcionamiento tradicional del balneario.

El problema es que estamos un poco solos pues la mayoría de los balnearios tradicionales se han apuntado al dinero fácil peligrando la credibilidad y el futuro del negocio.

Otro tema seria el cuidado del agua. De toda la vida a manantial grande, balneario grande y a manantial chico instalaciones chicas. Hoy día tenemos técnica suficiente para mantener un agua limpia durante toda la vida. Es más, sale más barato la manipulación de la instalación por medio de depuradora que mediante una persona que vacíe y limpie la piscina para volver a llenarla de agua del manantial.

El agua al manipularla excesivamente y añadirle productos químicos altera su composición natural que es la que la hace única.

Hoy día tenemos balnearios que su agua era roja por el hierro, pero hoy su agua es transparente, o sulfurosas que olían mal y hoy día no huelen.

Con todo esto lo que quiero dar a entender es que el sector se está " prostituyendo" con tal de ganar dinero rápido. 
Entrevista realizada al Presidente de la Asociación de Balnearios de Andalucía.

¿Considera que en la actualidad estamos asistiendo a una recuperación del los usos sociales y terapéuticos del agua?

No me cabe ninguna duda. De hecho, este fenómeno se viene produciendo desde finales de la década de los ochenta del pasado siglo, en gran parte debido a la promoción que supuso el Programa de Termalismo Social del IMSERSO.

\section{¿Hacia dónde creé que se dirige el sector balneario en el futuro?}

Hay dos tendencias. Una a cubrir la ludopatía y el culto al cuerpo que la floreciente sociedad del bienestar viene demandando. Hay otra, de la que me siento más participe, que trata de profundizar y mejorar en la terapéutica del agua como medicina alternativa.

La primera es modal y entra en competencia con los spa, etc. La segunda resulta menos popular pero ofrece prestigio y longevidad al sector.

¿Disponen los Balnearios de ayuda, de la administración central y/o autonómica, para la rehabilitación o para el mantenimiento de los centros balnearios?

No. las ayudas que anualmente ofrece la administración autonómica para reformas, y que supone "hasta" un $15 \%$ de la inversión, no merece la pena tramitarla.

La vía de los fondos europeos (planes Leader, Feder etc.) nunca supera el $20 \%$. No permite grandes inversiones privadas, pues suele tener un límite total. Tampoco merecen la pena. 
¿Me podría dar su opinión, sobre si existe una cierta confusión entre la opinión pública con respecto la consideración de "Spas o Balnearios Urbanos" y "Balnearios de aguas mineromedicinales"?

Existe, aunque desde la ANBAL (Asociación, Nacional de Balnearios) estamos haciendo un esfuerzo para evitarlo. No obstante, los usuarios de los balnearios, conocen muy bien la diferencia, siendo mayor el confusionismo entre la juventud.

\section{¿Considera que debería existir una legislación europea de balnearios?}

Sí. Ya se están dando los primeros pasos.

\section{¿Me podría decir cómo percibe Vd. a nivel general, las características socioeconómicas del usuario de los balnearios de Andalucía?}

La utilización del los balnearios de Andalucía en particular y los de España en general está muy vinculada al costumbrismo familiar. Acuden por tradición: Llevo muchos años asistiendo, ya Mis padres iban y les sentaba muy bien... También piensan que de no hacerlo, lo acusarán. Otros siguen al respecto, los consejos de familiares, amigos o vecinos.

Obviamente esta predisposición tiene mayor arraigo en niveles culturales medios y bajos, con independencia de la situación económica. Una persona de escasos recursos y habituada a un balneario, se privará incluso de sus necesidades primarias para poder asistir. Con la misma ilusión, aunque con menor esfuerzo, toman las aguas los potentados.

Los usuarios de nivel cultural alto, vienen a los balnearios con otra filosofía: Descanso, prevención, tranquilidad, vacaciones alternativas, bienestar, medicina alternativa, tratamientos de belleza etc.

¿Es Vd. partidario de que parte de las terapias sean incluidas en las prescripciones médicas y financiadas por la Seguridad Social?

Esto es un antiguo objetivo de nuestro sector. 
Hay una serie de actividades sanitarias que pueden realizarse perfectamente en un balneario e inclusive, mejor. La recuperación post traumática o post operatoria se hace mejor en un balneario que en un hospital por la mejor calidad de vida que se ofrece. Además, no es lo mismo realizar rehabilitación con agua mineromedicinal que con la del grifo como sucede en los hospitales. Del mismo modo, y teniendo en cuenta las listas de espera para la rehabilitación y las óptimas consecuencias del inicio inmediato de ella, se podría dar una mejor respuesta a la demanda social sanitaria actual. Todo ello con un importante ahorro para la administración: El coste medio diario de un enfermo en un hospital de España durante una rehabilitación o recuperación post operatoria, alcanza los 1300 Euros. Más del doble de los que cobraría un balneario. $Y$ con notable diferencia: No es lo mismo encontrarse en una habitación compartida con una o varias personas de la primera planta de un hospital, con horarios rígidos, visitas restringidas, sin animación.., que hacerlo en un balneario...

La solución es muy sencilla: que la administración exija unos determinados condicionantes para poder acoger a sus enfermos (médicos traumatólogos, Rayos $\mathrm{X}$, etc.). Una ver cumplidos, se formalizarían las correspondientes colaboraciones.

Esto, además de prestigio, consolidaría el sector por la importante fuente económica que supondría.

Ya existe algo parecido en otros países como Portugal.

De forma aproximada; ¿podría decirme cuantos puestos de trabajo directos genera un balneario? ¿Existe demanda de personal especializado?

Depende del tamaño del balneario y si tiene hotel o no. El de Alicún de las Torres que es pequeñito ( 100 plazas), da trabajo a 32 personas entre balneario y el hotel que los acoge.

Hasta hace escasos años, existía una fuerte demanda de personal especializado. Hoy en día, y merced a los numerosos cursos que desde los institutos de empleo y 
otros organismos organizan, ha disminuido considerablemente. Solo existe un fuerte déficit en médicos hidrólogos.

\section{口 Conclusiones de las entrevistas realizadas en los centros balnearios}

La recuperación de los usos sociales y terapéuticos es un hecho a tenor de los resultados obtenidos en esta investigación.

- Los agüistas apuestan por darse una tregua de descanso corporal en aras a su salud y a la búsqueda de belleza y placer, solos o en compañía, se premian con unas vacaciones termales en las que prima la naturaleza rural sobre las concurridas playas en época estival; la consideración de los balnearios como un lugar ideal para ir de vacaciones, comienza a ser una realidad actual y no un simple recuerdo decimonónico.

- El reparto geográfico de los balnearios permite contar con un centro cercano donde poder asistir sin necesidad de realizar largos y costosos viajes, el gasto dependerá de las terapias y del tiempo que se quieran prolongar las vacaciones balnearias, que aunque no se pueden tildar de económicas, sí se ha podido comprobar que están al alcance de la mayoría de los bolsillos que estén en situación de plantearse unas vacaciones fuera de su entorno familiar.

- El futuro del sector parece estar asegurado por su indiscutible valor mineromedicinal, la remodelación de instalaciones en los antiguos balnearios y las nuevas terapias adoptadas por los centros para dar servicio a un público cada vez más exigente hacen que se afiance ese gusto por el termalismo; la Administración Pública mediante los programas de termalismo del IMSERSO se convierten en el sostén de estos centros de agua mineromedicinal en la época ínter-vacacional. Por su parte, gran parte de los gerentes y responsables de estos centros apuestan por el marketing y la imagen de centros renovados capaces de convertir y transformar tensiones y estrés en placer y descanso en un entorno natural donde la salud es su mayor exponente. 


\subsubsection{Análisis observacional en el balneario de Ledesma}

En plena naturaleza, a orillas del río Tormes en la provincia de Salamanca, se encuentra el balneario de Ledesma al que Diego de Torres Villarroel (médico e hidrólogo) dedicó las páginas del libro titulado "Uso y Provechos de Los Baños de Ledesma"

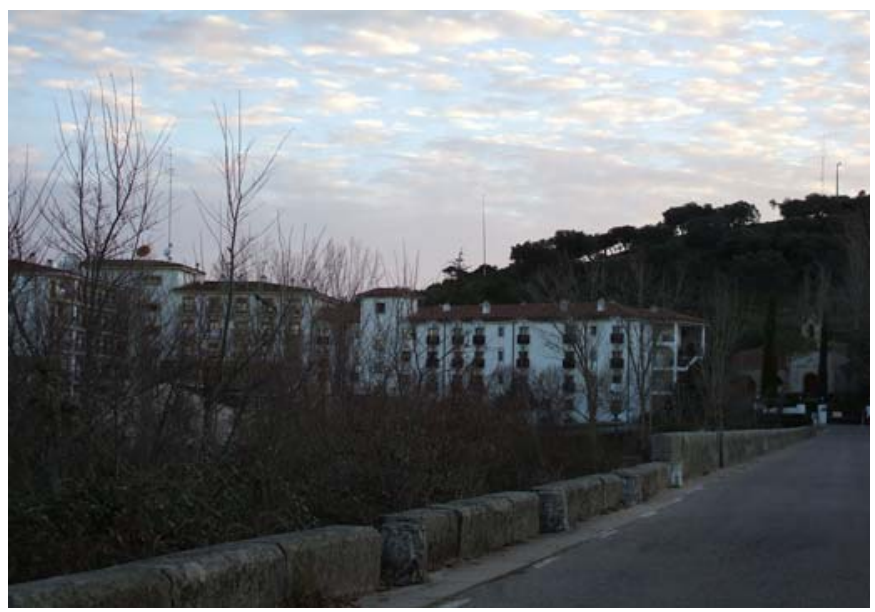

Al comienzo de la visita nos encontramos con el consultorio médico, (no hay que olvidar que estamos en un balneario de agua minero medicinal), la farmacia, y la iglesia, así como otra serie de servicios entre los que se encuentra la peluquería.

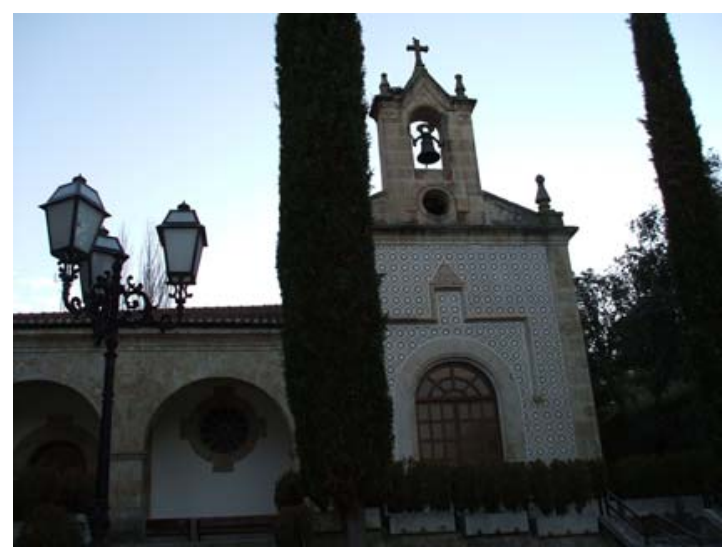


Las aguas de este balneario están especialmente indicadas para el tratamiento de:

"Debido al alto contenido en sulfuro y a su temperatura, estas aguas están indicadas en el tratamiento y prevención de enfermedades del aparato respiratorio, locomotor y también de afecciones neurológicas y dermatológicas como por ejemplo la psoriasis. ${ }^{248}$

Las indicaciones de las aguas, nos servirán de guía en nuestro recorrido por el interior de las instalaciones del balneario.
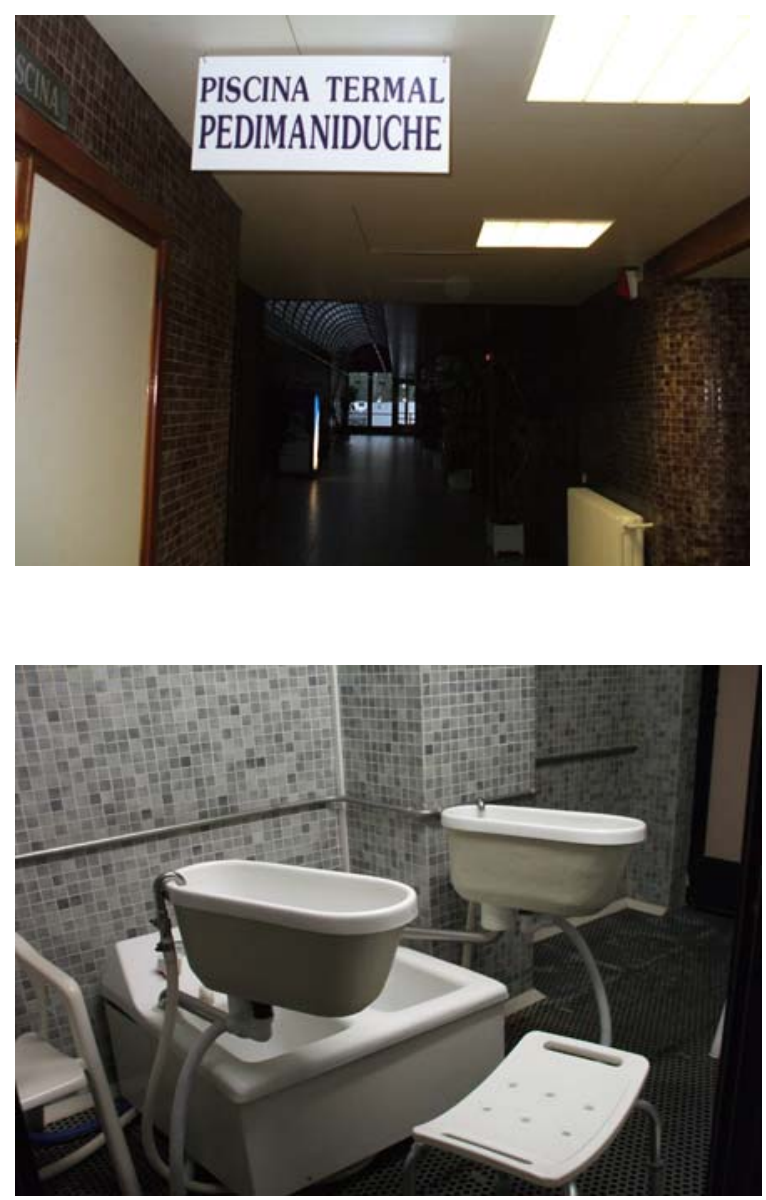

${ }^{248}$ http://www.mmma.es/contenido/1001/balneario-ledesma/presentacionserv_balneoterap/index.htm 
Piernas y manos se introducen para recibir el tratamiento adecuado. Tratamientos modernos que quedan lejos de antiguo baño en este mismo centro, descrito por Diego de Torres Villarroel en el ya citado libro de "Usos y Provechos de los Baños de Ledesma"
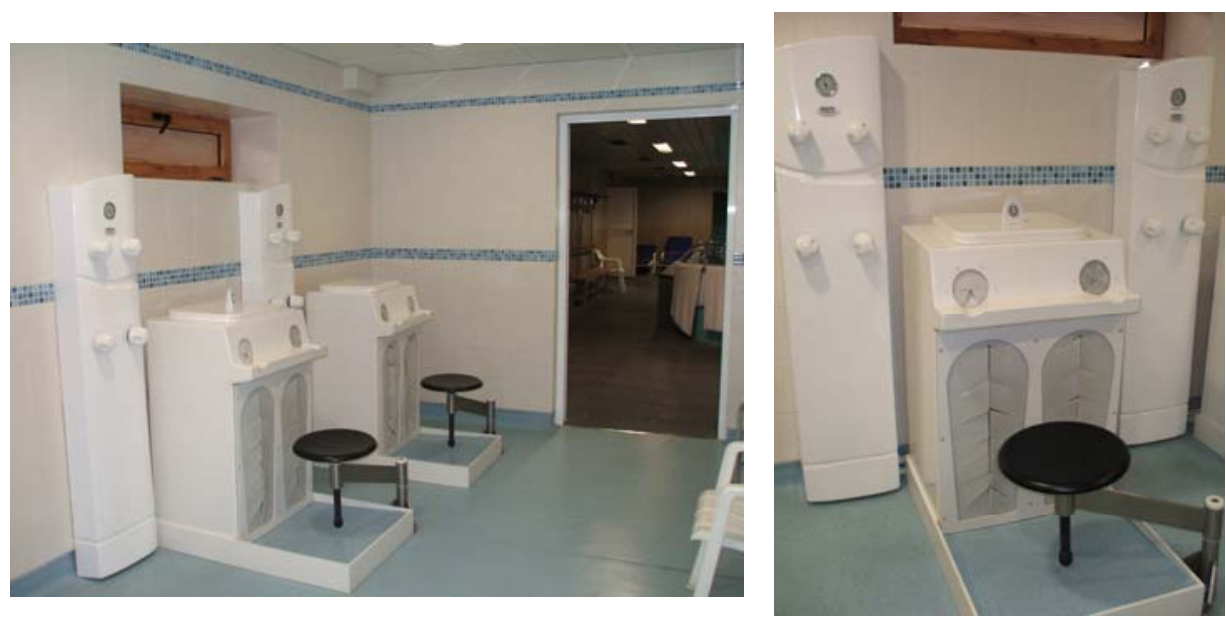

La piscina termal para el baño de inmersión dispone de una zona de descanso a utilizar tras el baño. Observemos su evolución comparando la cita tomada del libro "Usos y Provechos de los Baños de Ledesma" y las imágenes que se presentan:

"Otra grandeza no pequeña es la de los baños, que toman desta villa el nombre. Sus aguas son calientes, y valen contra enfermedades de frialdad. Por ser tan medicinales son visitadas de muchos, vienen encañadas al baño. Que es un gran pilón de poca hondura, que está cubierto por una bóveda de ladrillo, y en medio tiene una ventana por donde le entra la luz. Es un edificio antiguo. En una relación he leído, que los edificó un moro llamado Cepha." ${ }^{249}$

\footnotetext{
${ }^{249}$ Torres Villarroel, D. Edición preparada por: Blanco J. F. 1988 “Uso y Provechos de Los Baños de Ledesma” Ed. Europa Artes Gráficas. Salamanca. En: González de Ávila, G. "Historia de las antigüedades de la ciudad de Salamanca, vidas de sus obispos y cosas sucedidas en su tiempo”. Imp de Artus Taverniel. Salamanca, 1606, p. 259
} 

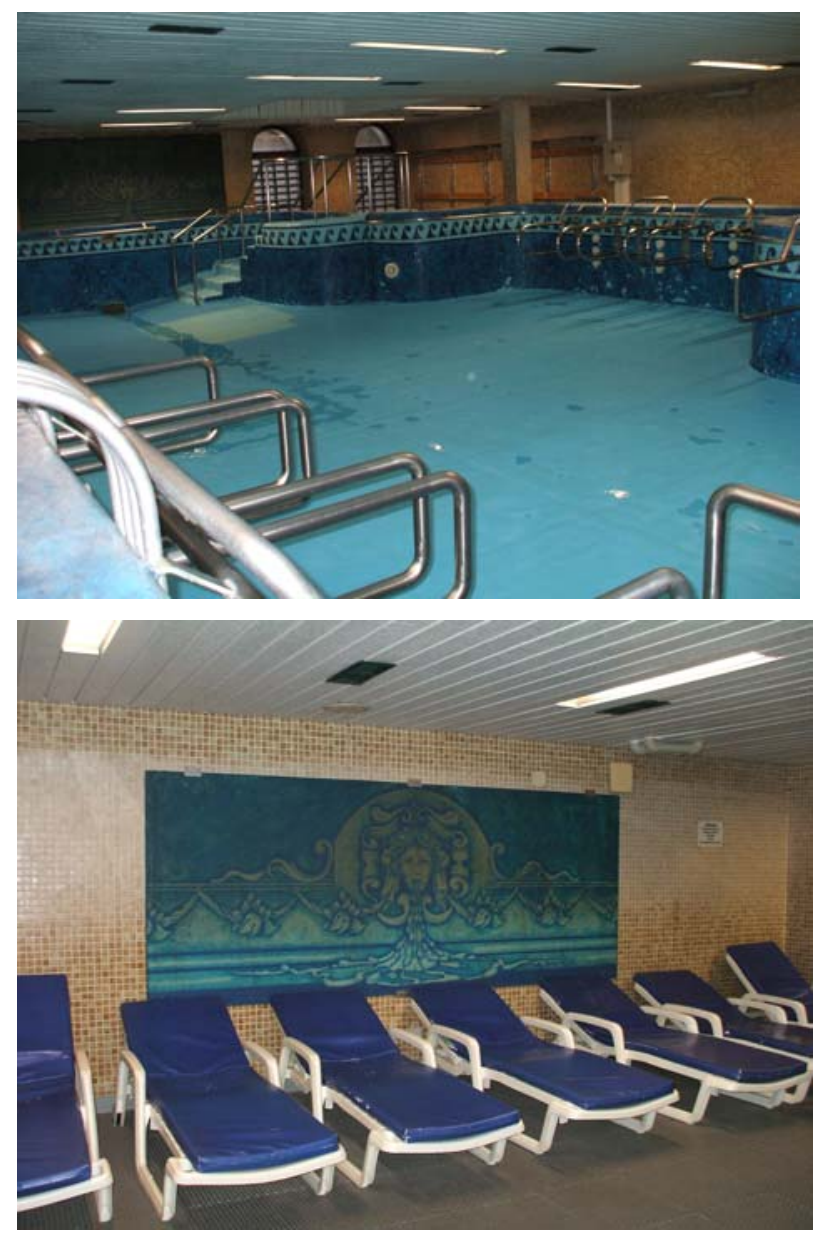
Los masajes y duchas circulares entran a formar parte de los tratamientos balnearios

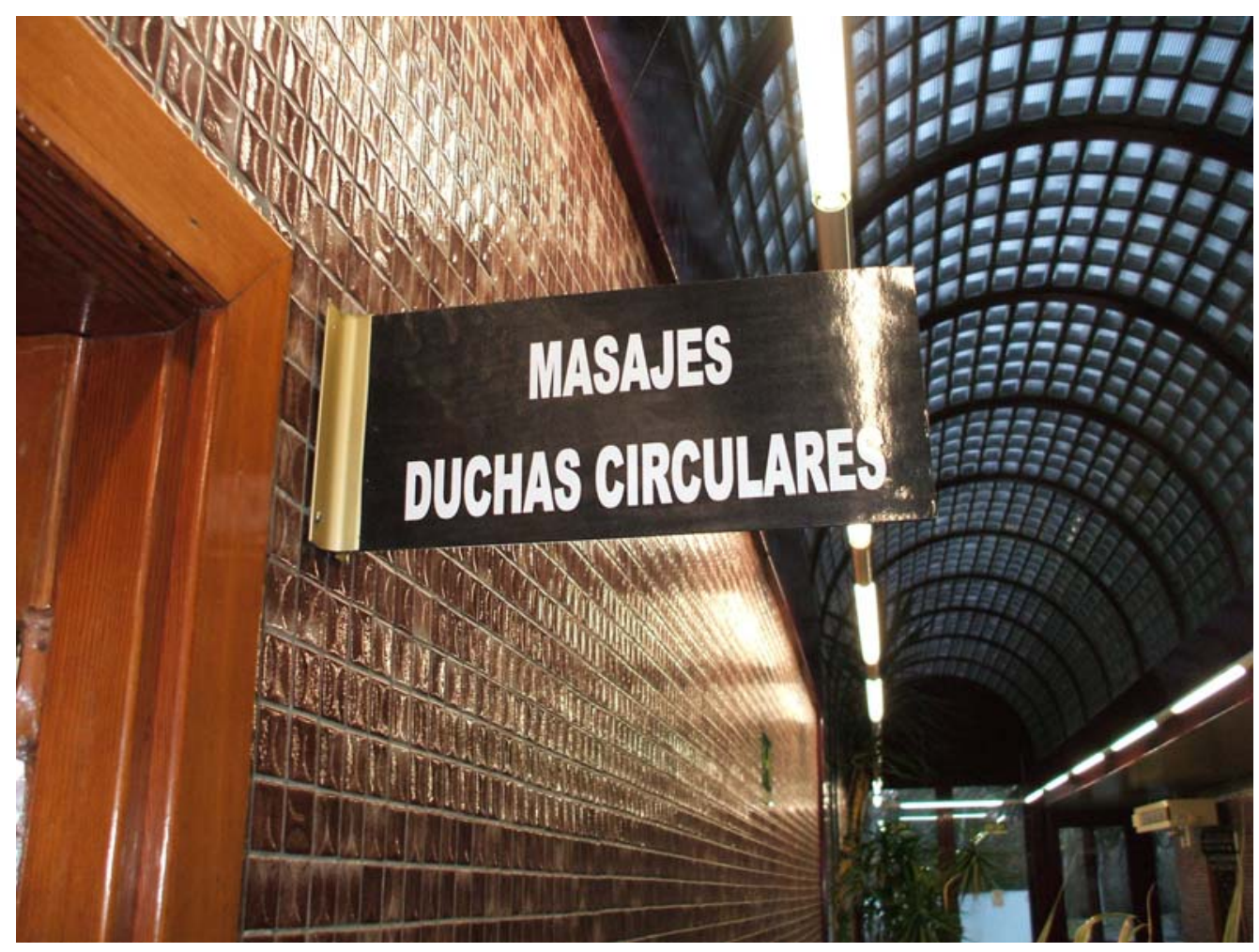

En las dos imágenes que se presentan a continuación podemos observar la sala de masajes y la ducha circular respectivamente, tal como muestra la imagen anterior. 

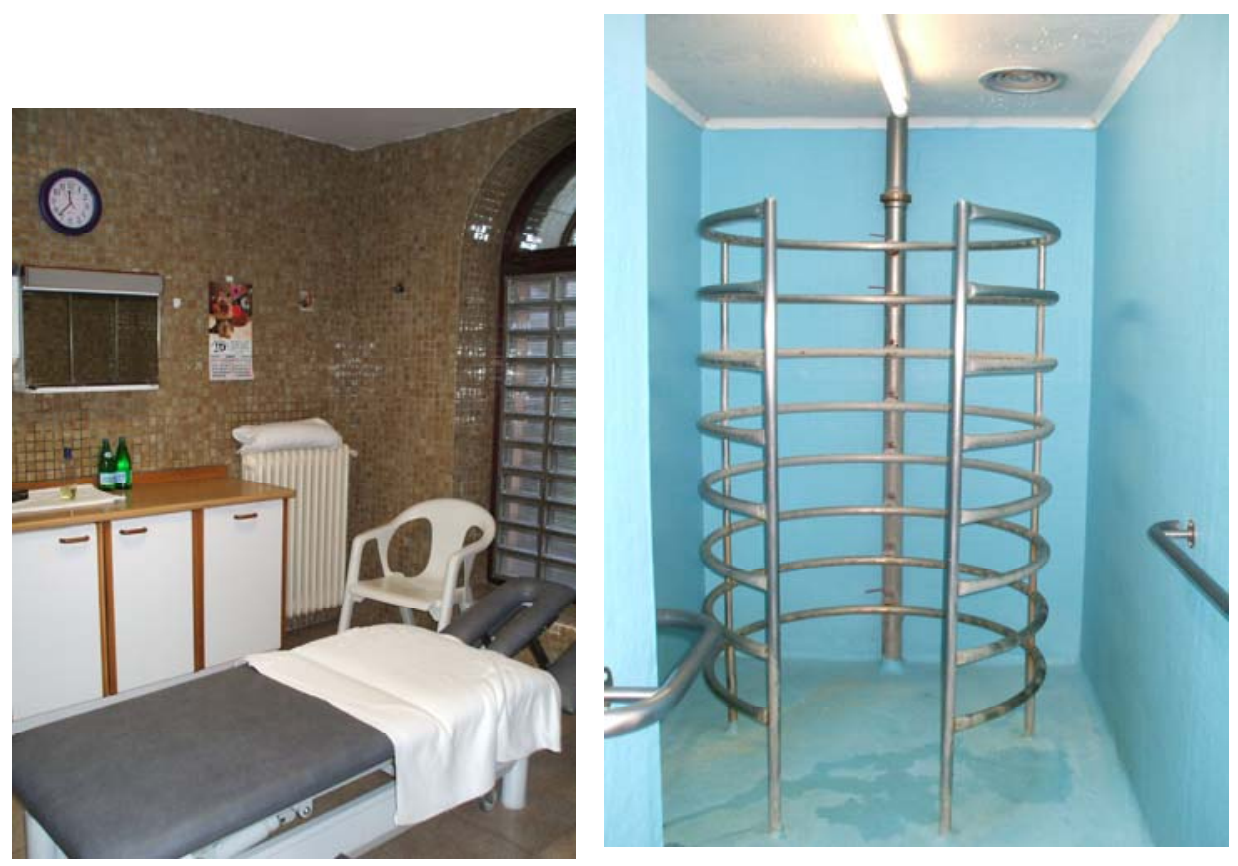

El balneario cuenta con un área dedicada al deporte, como complemento a las terapias hídricas

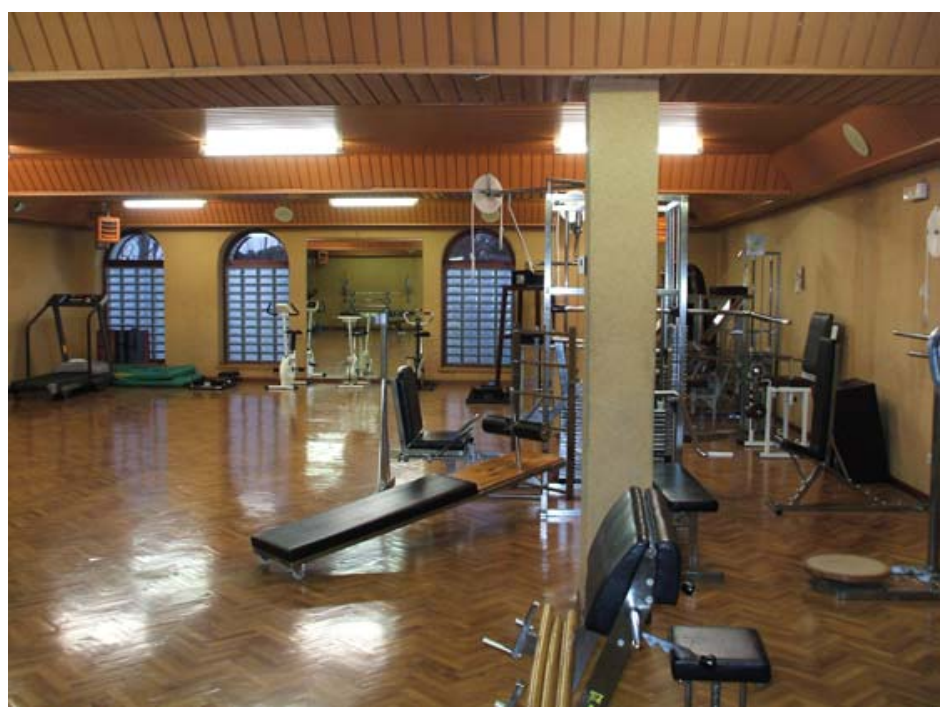


A parte de su uso para el baño, el agua es tomada por inhalación
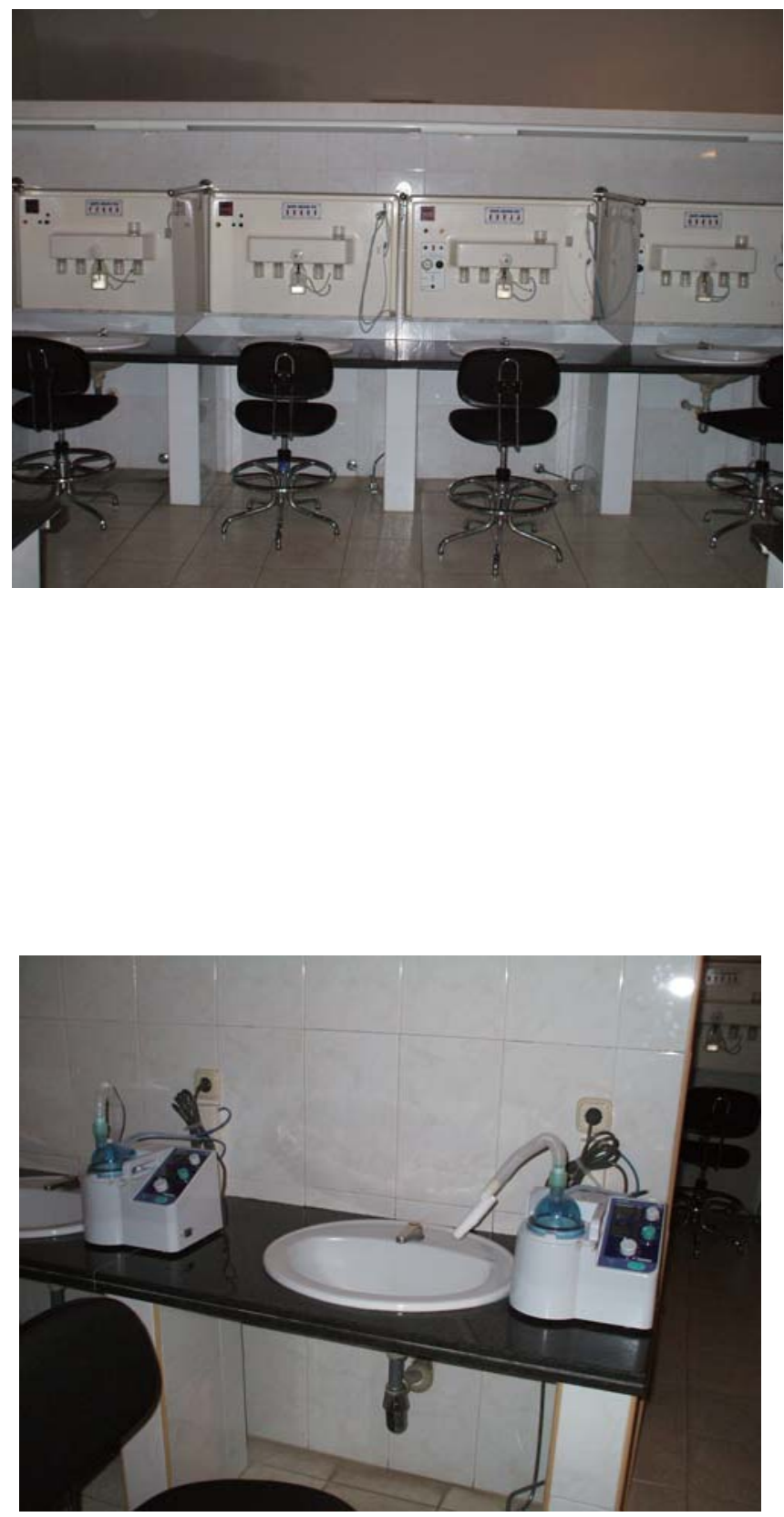
A continuación podemos observar en las imágenes la evolución de los aparatos utilizados para esta terapia, a la izquierda se encuentra un aparto moderno que sustituye a que se muestra en la foto de la derecha, este se conserva como parte de la memoria histórica del balneario. 

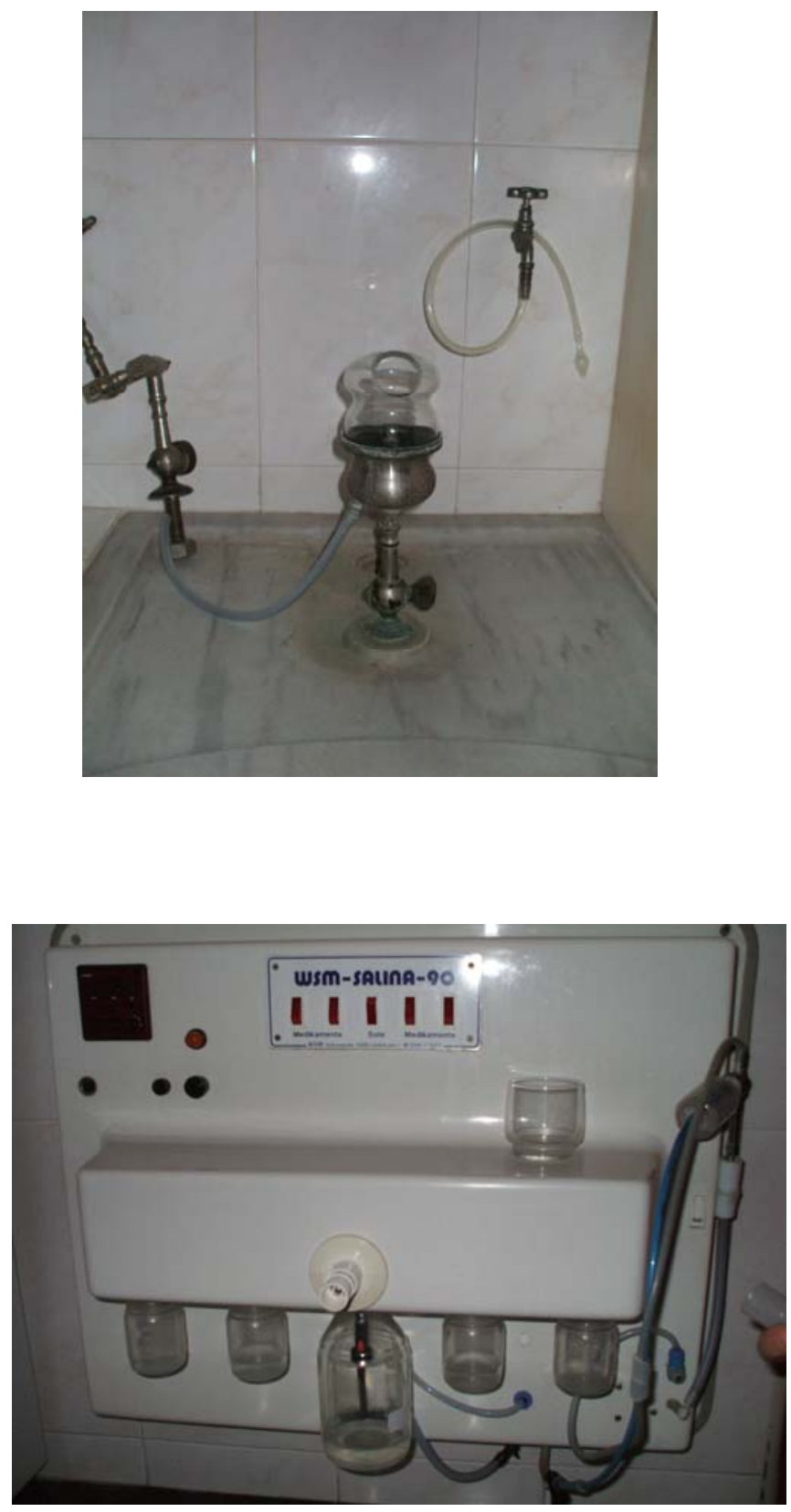
Estufas y parafangos: se trata de la aplicación corporal de la zona a tratar de arcillas y barros, estos tienen gran capacidad de absorción de toxinas y aportes minerales.
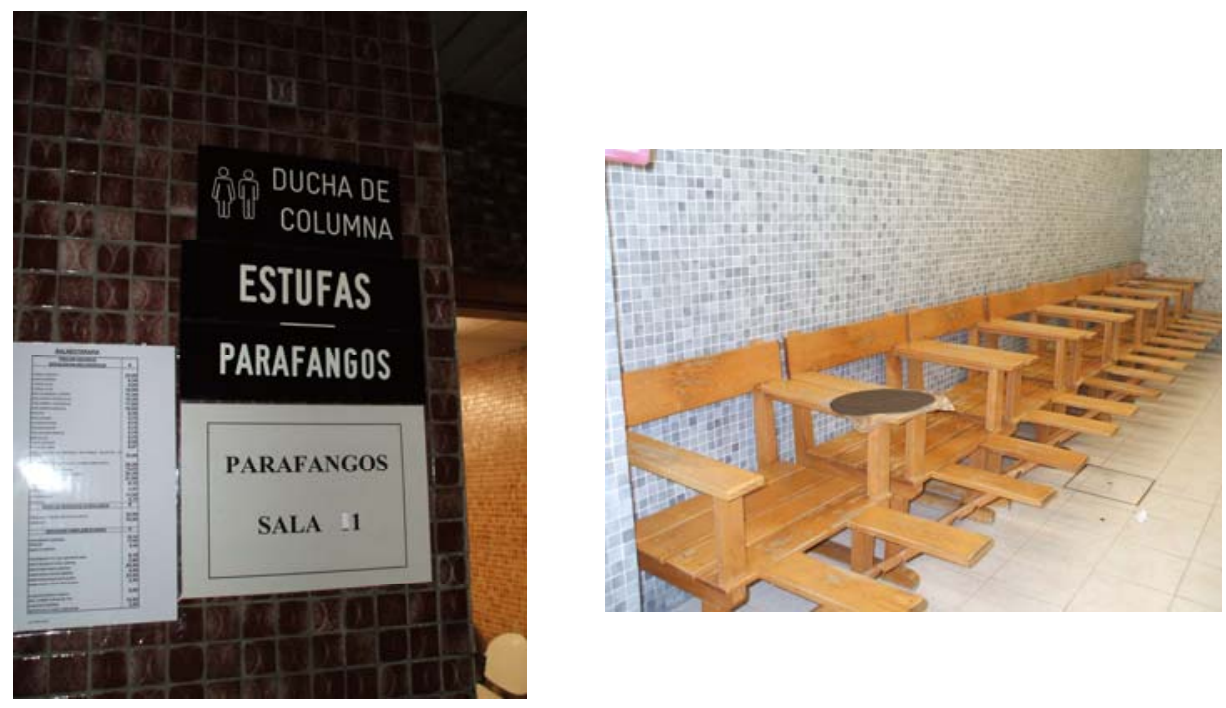

Tras la aplicación de los barros el agua vuelve a ser protagonista mediante la ducha o el baño.
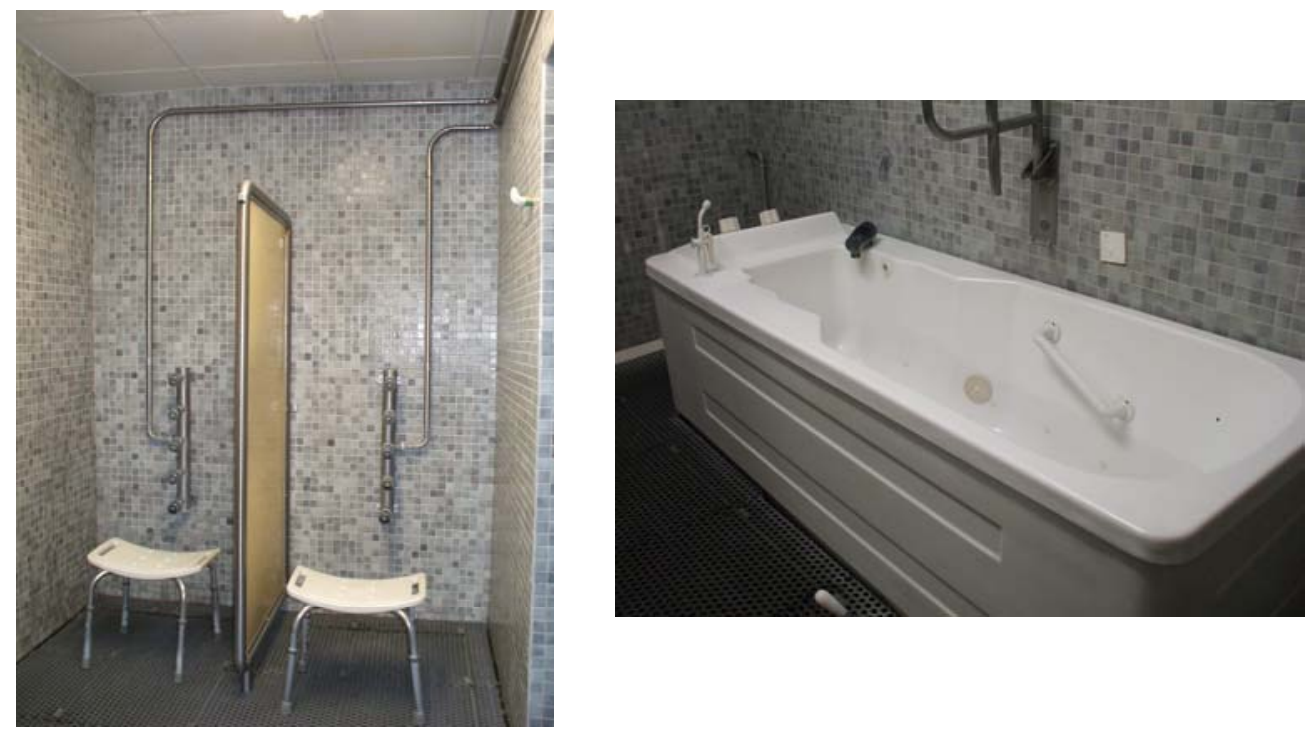


\subsubsection{Análisis observacional: balneario de Alange}

En el pueblo de Alange en la Comunidad Autónoma de Extremadura se encuentra este balneario de agua mineromedicinal cuyas características se presentan a continuación:

El agua de Alange procede de un manantial minero-medicinal con un caudal de 5 litros/segundo y a una temperatura de $28^{\circ}$. Se origina en capas muy profundas de la tierra, enriqueciéndose en su ascenso de energía alfa (radón 222 y 226) y minerales como el litio, carbonatos y bicarbonatos de sodio, magnesio y calcio, lo que la sitúa entre las pocas de Europa especialmente indicada para el sistema nervioso. Su particular composición permite que, siguiendo los tratamientos y prescripciones de los médicos especialistas, también se obtengan beneficios en afecciones del aparato locomotor y cardio-respiratorio, ginecopatías y alergias. ${ }^{250}$

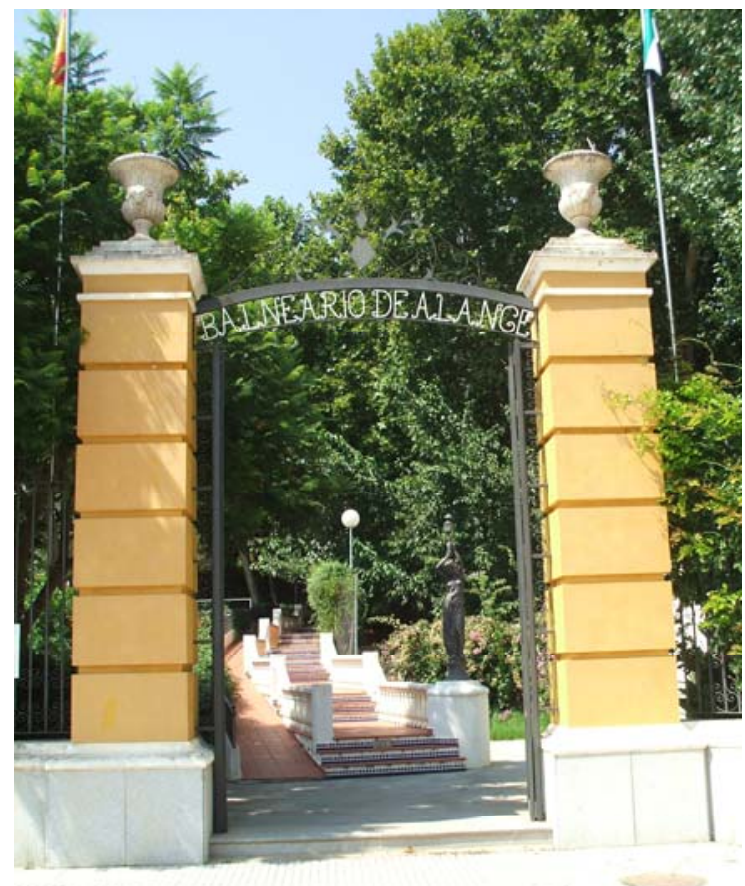

\footnotetext{
${ }^{250}$ http://www.balneariodealange.com/agua.htm
} 
Nos adentramos en las instalaciones del balneario, donde el ambiente se uniforma de albornoces que invitan al baño.
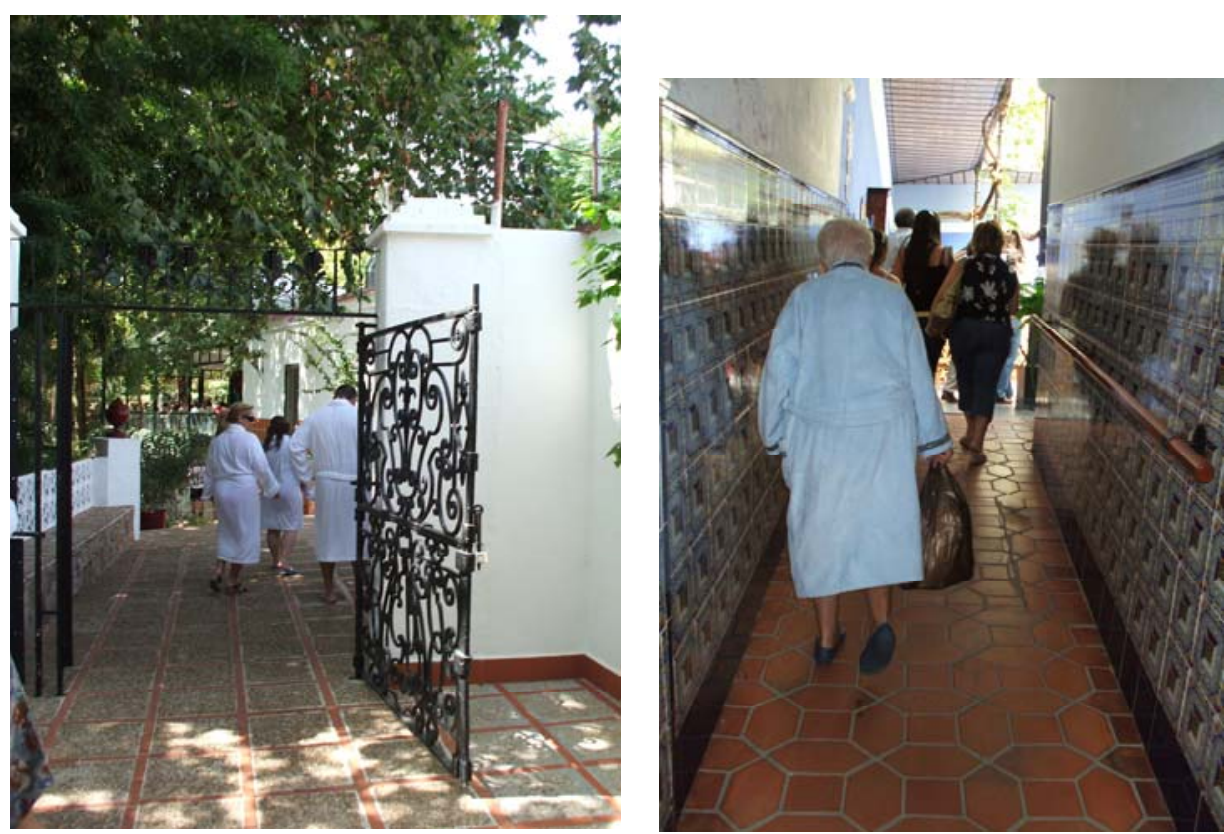

En sus instalaciones cuentan con los servicios de un médico de baño que será el encargado de reconocer al paciente antes y durante el periodo de baño.
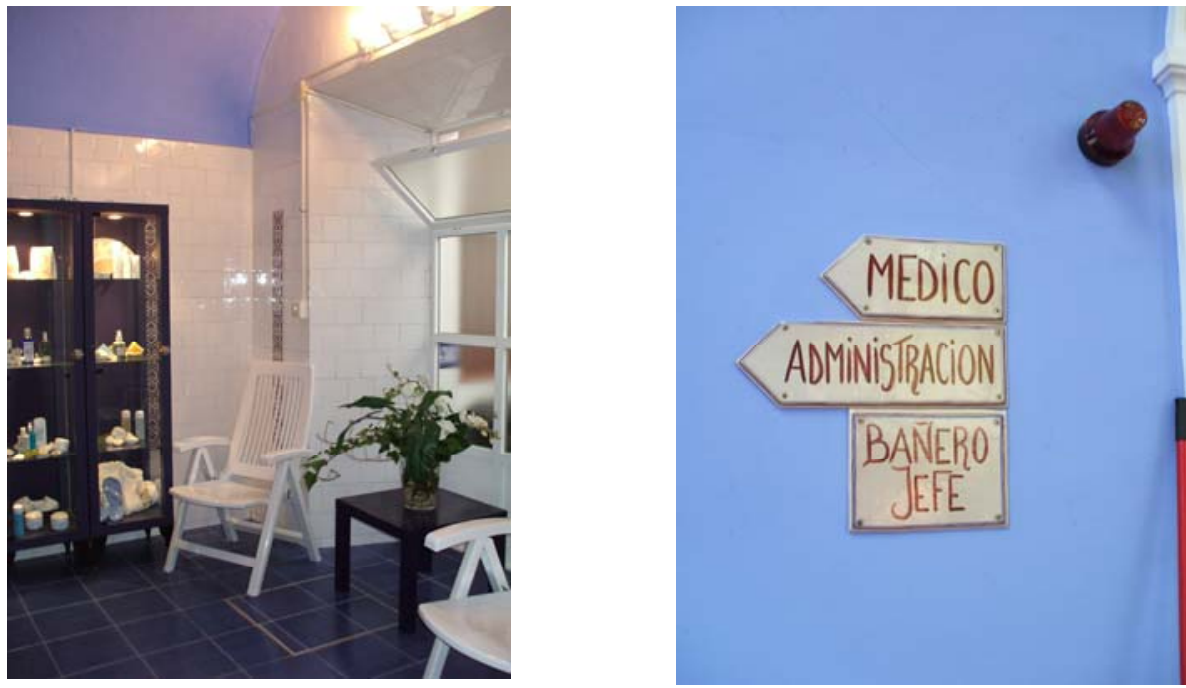
Tras el reconocimiento médico, un recorrido por las diversas terapias que ofrece el balneario.

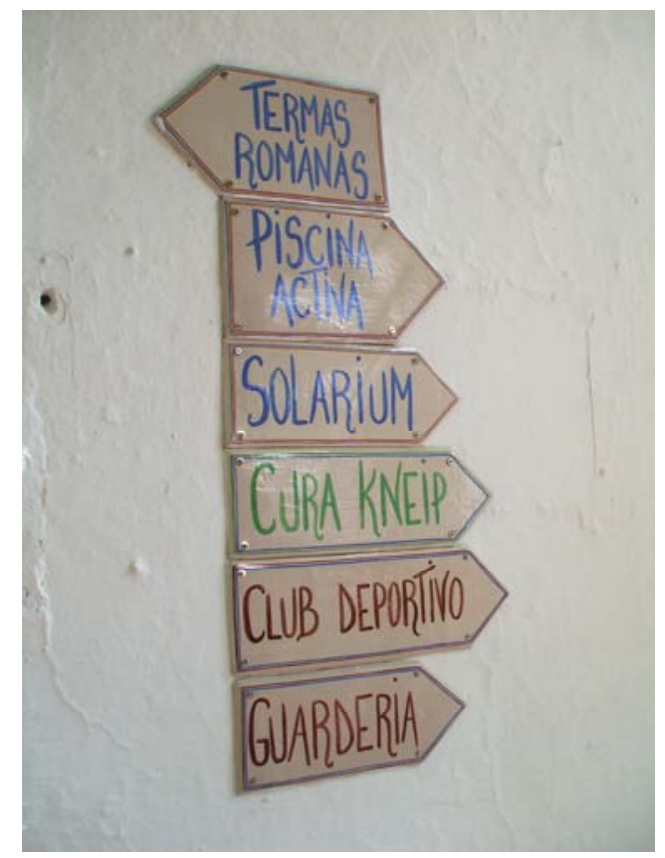

Dos tipos de zonas diferenciadas según el tratamiento, la zona húmeda para tratamientos hidrotermales y la zona seca para tratamientos corporales tras el baño.

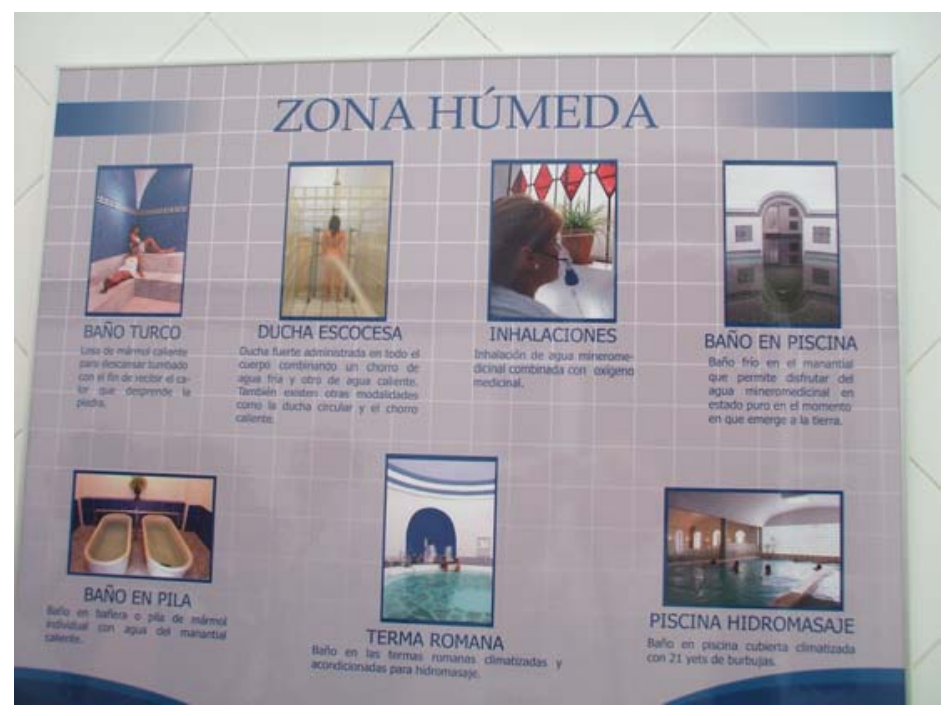


Baño en piscina o laguna del manantial. Se trata de un baño en agua fría, el agua se encuentra tal y como emerge del propio manantial, en estado puro. Indicada para el sistema nervioso, la mejora de la circulación, el aumento de las defensas etc..
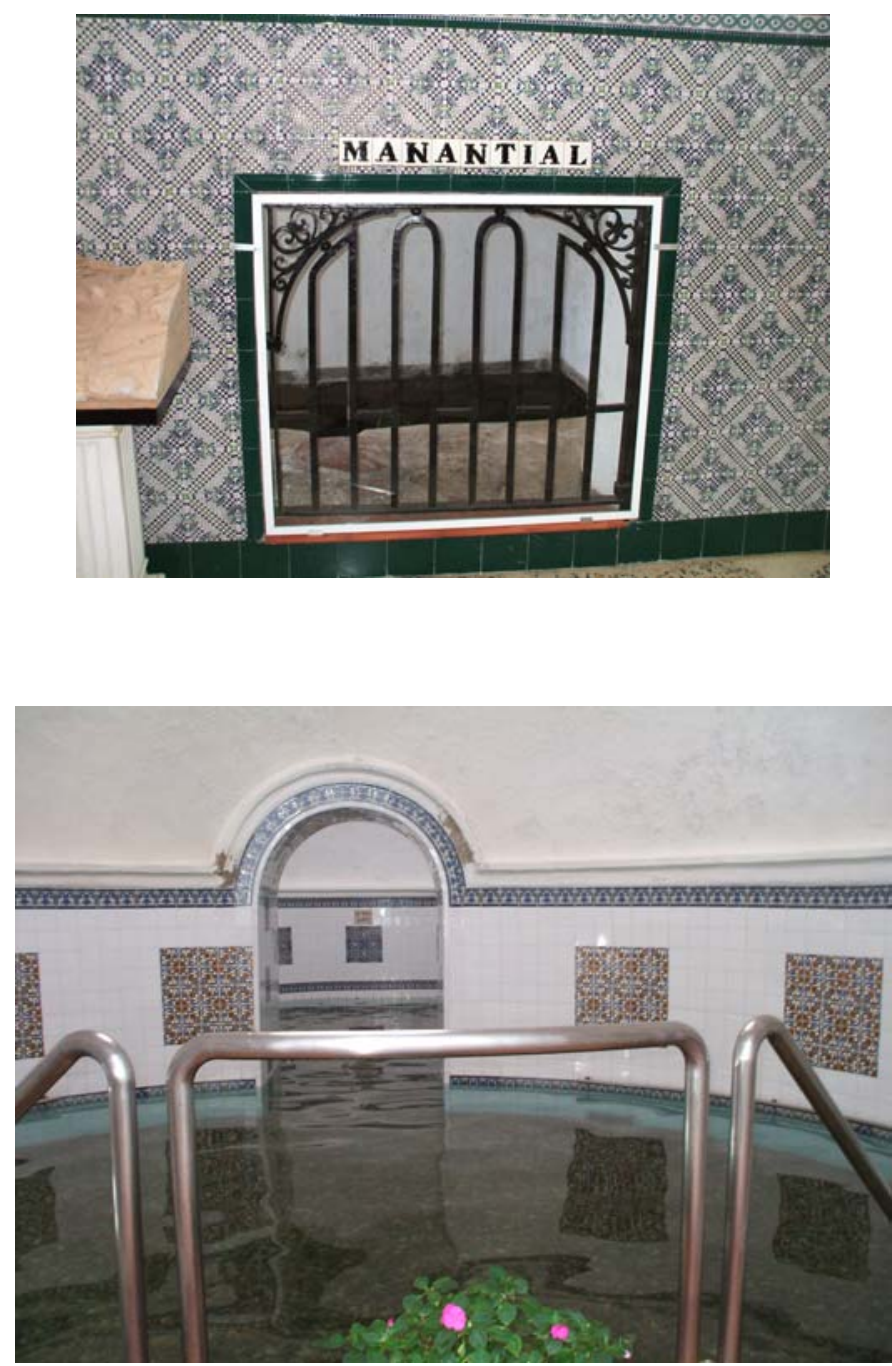
En la zona húmeda se hacen también tratamientos individuales, se trata de él "Baño en Pila", bañeras de mármol con agua de manantial caliente, que procuran un efecto antinflamatorio, relajante y sedante.

Varios tipos de ducha, "Escocesa", se trata de alternar mediante un fuerte chorro agua a distintas temperaturas, así mismo estaría otro tipo de ducha, la circular (que corresponde a la imagen que se presenta a continuación), esta activa la circulación y estimula el sistema nervioso y mejorando la respiración.

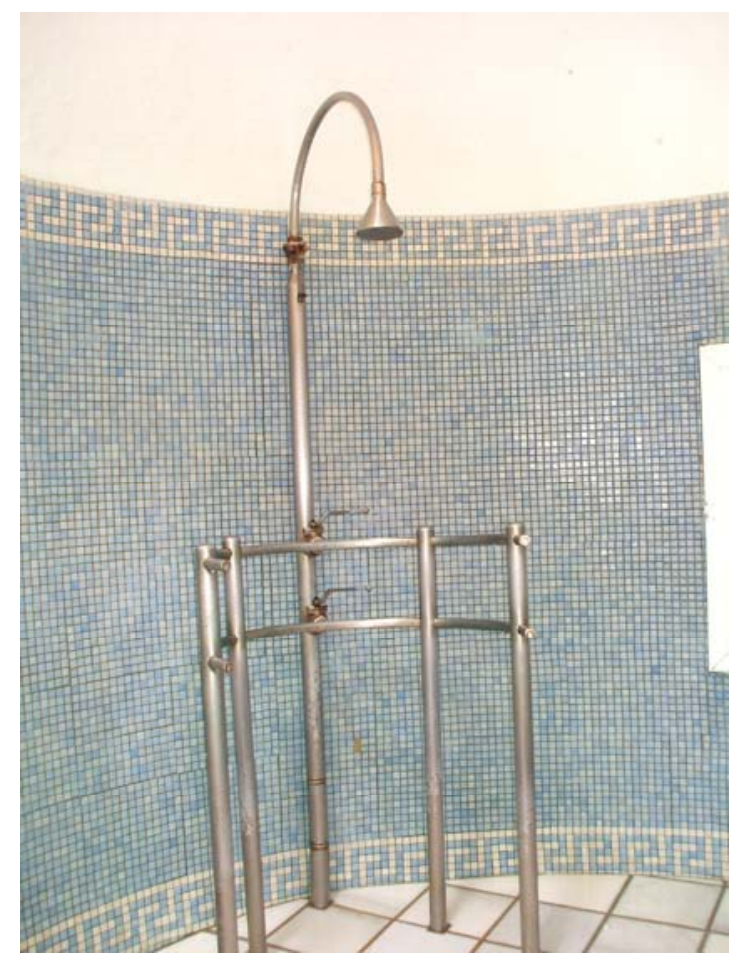

El baño en la "Terma Romana" relaja el sistema muscular, provoca efectos sedantes en el sistema nervioso y refuerza el ánimo. 

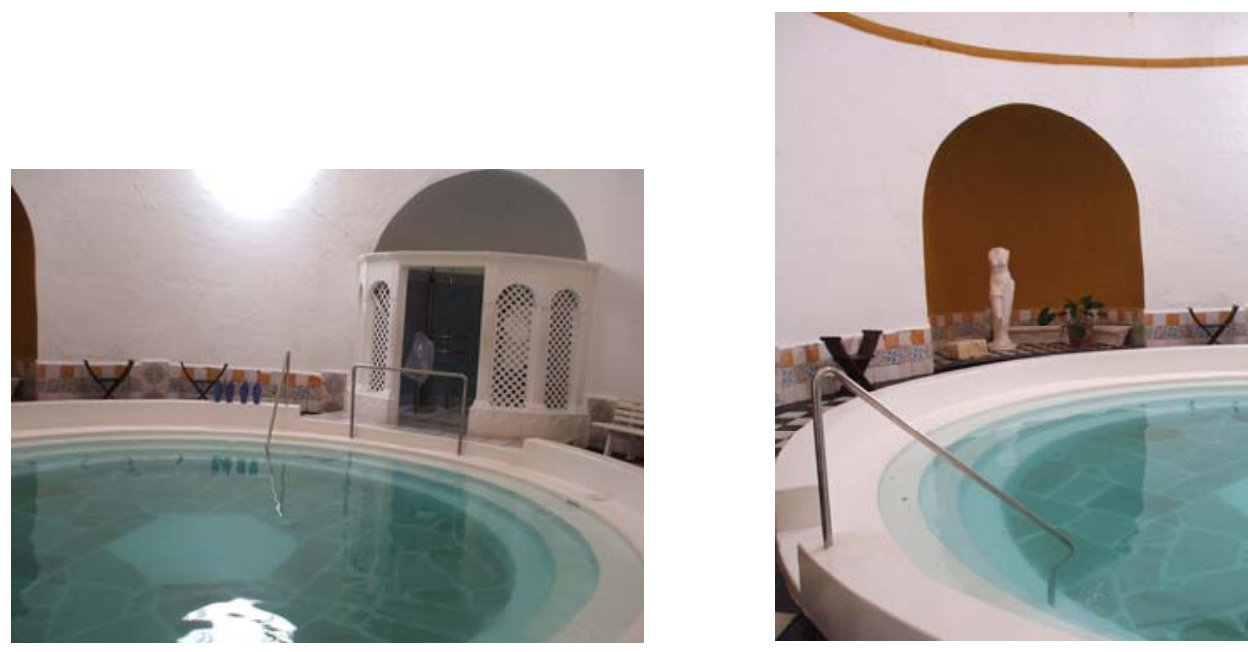

Inhalaciones se realizan con agua mineromedicinal mezclada con oxigeno medicinal, esto produce unos efectos en la disminución de la espasticidad bronquial, aumento de la circulación sanguínea y mejora del rendimiento intelectual.

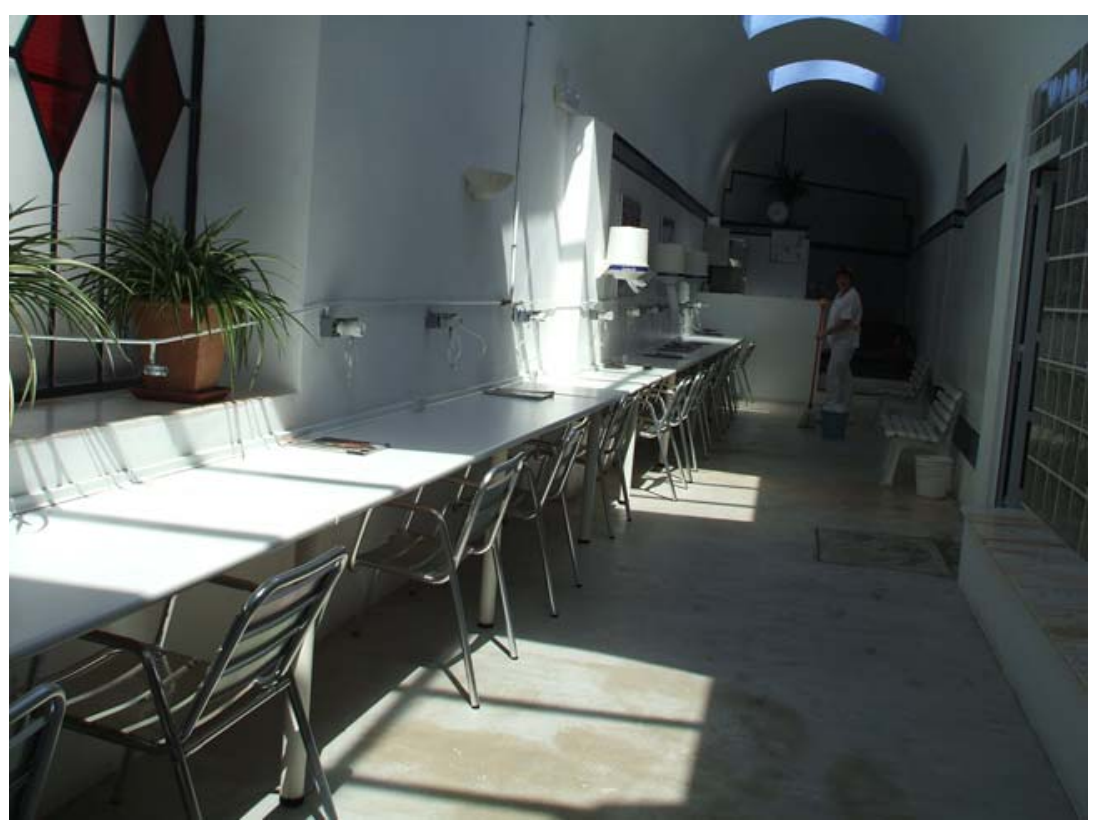


Estos son algunos ejemplos de tratamientos que se ofrecen en las instalaciones de este balneario para a zona húmeda.
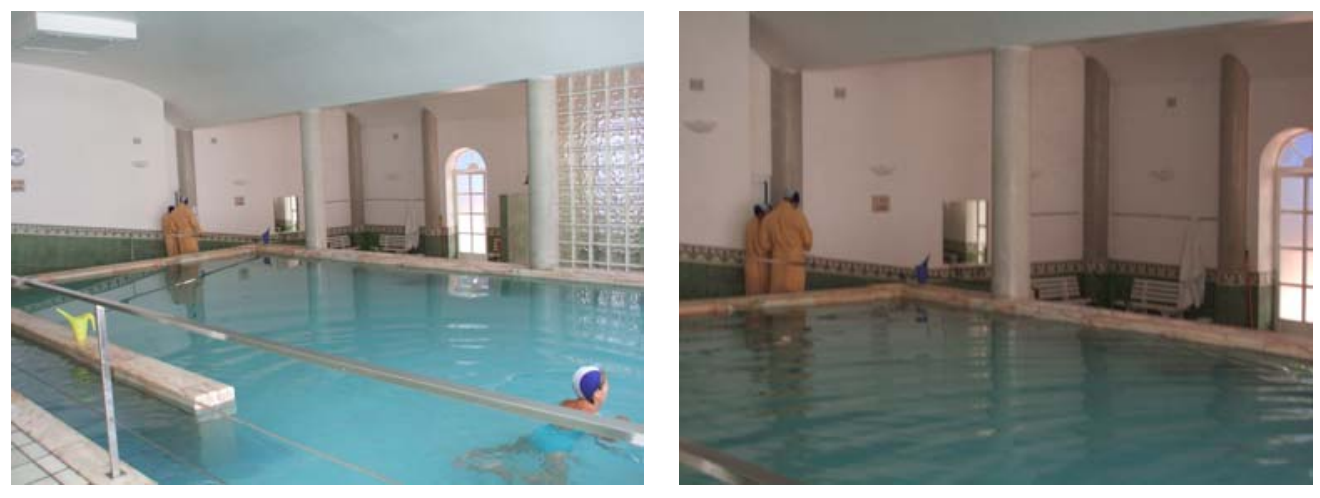

La zona seca está orientada a la aplicación de terapias y tratamientos corporales, masajes, aplicación de mascarillas, envolvimientos etc. La belleza corporal entra a formar parte de la terapia balnearia, los masajes son un complemento deleitoso que se suma al placer del baño. La zona seca no es visitable, la privacidad de los tratamientos hacen que no podamos mostrar imágenes de los mismos.

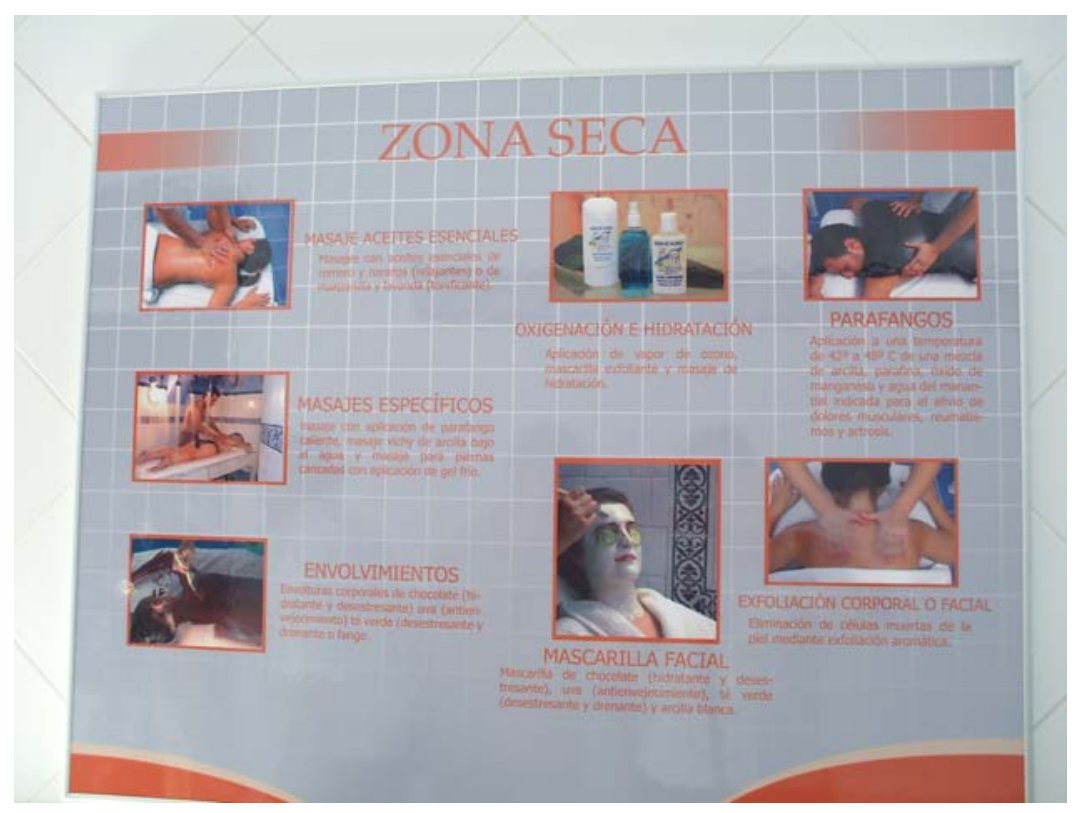


A continuación se muestra un pequeño plano que indica la ruta a seguir para realizar la cura Kneip, descrita anteriormente en este estudio.

"Es una terapia naturista, cuyo fin principal es potenciar la fuera curativa del organismo"251

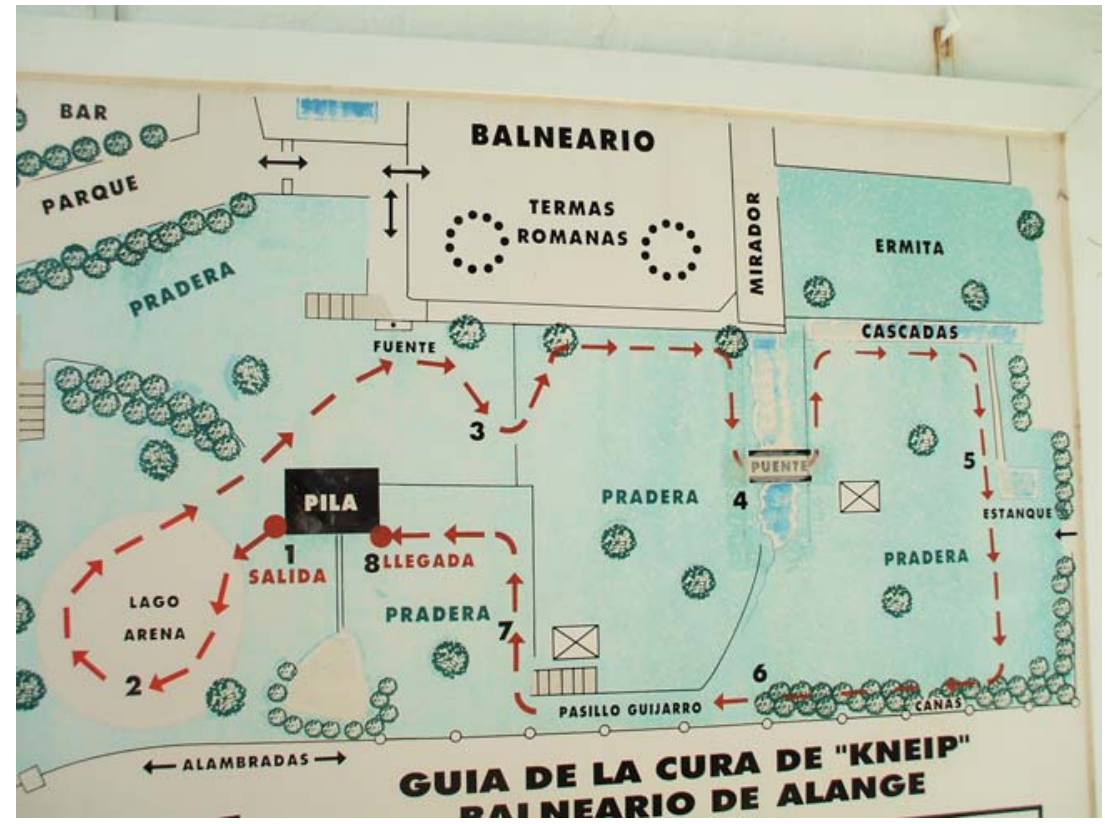

${ }^{251}$ Saz Peiro, P. “La Cura Kneip. En:

http://www.unizar.es/med_naturista/hidroterapia/La\%20cura\%20de\%20kneipp.pdf 
Aquí termina el recorrido por el balneario de Alange, un ejemplo de balneario de agua mineromedicinal, en el que las terapias se han modernizado al tiempo que lo han hecho las instalaciones.

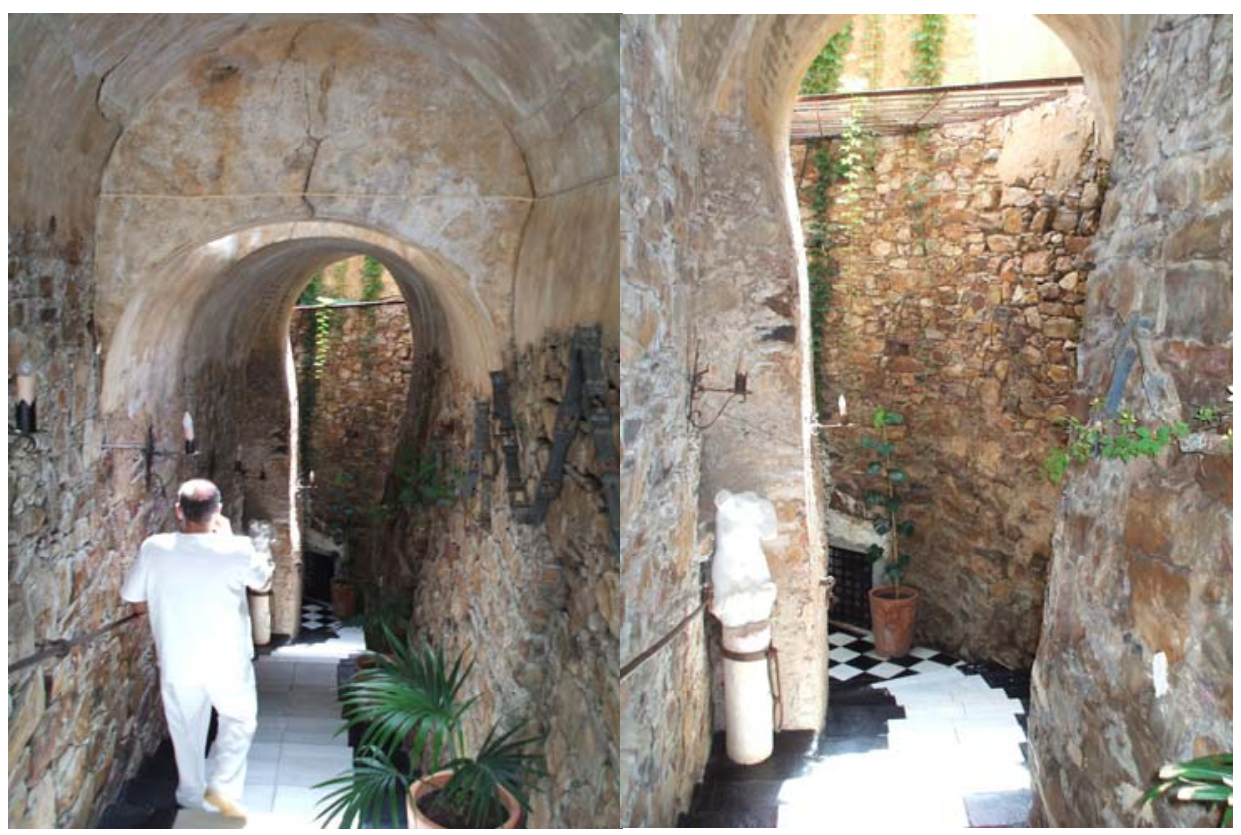




\section{El agua salada: El mar.y sus propiedades terapeúticas.}

$\mathrm{Si}$ al referiros al agua minero medicinal nos remitimos al balneario, al hablar de agua de mar tenemos que hacer referencia a los centros de Talasoterapia donde se practica una medicina alternativa valiéndose de las propiedades del agua marina; a lo largo de éste epígrafe se profundizará sobre la Talasoterapia y sus propiedades mediante el baño.

"El plasma marino y el plasma humano tienen la misma identidad física, química y fisiológica lo que hace que el agua del mar resulte inestimable para la prevención y tratamiento de las enfermedades"252

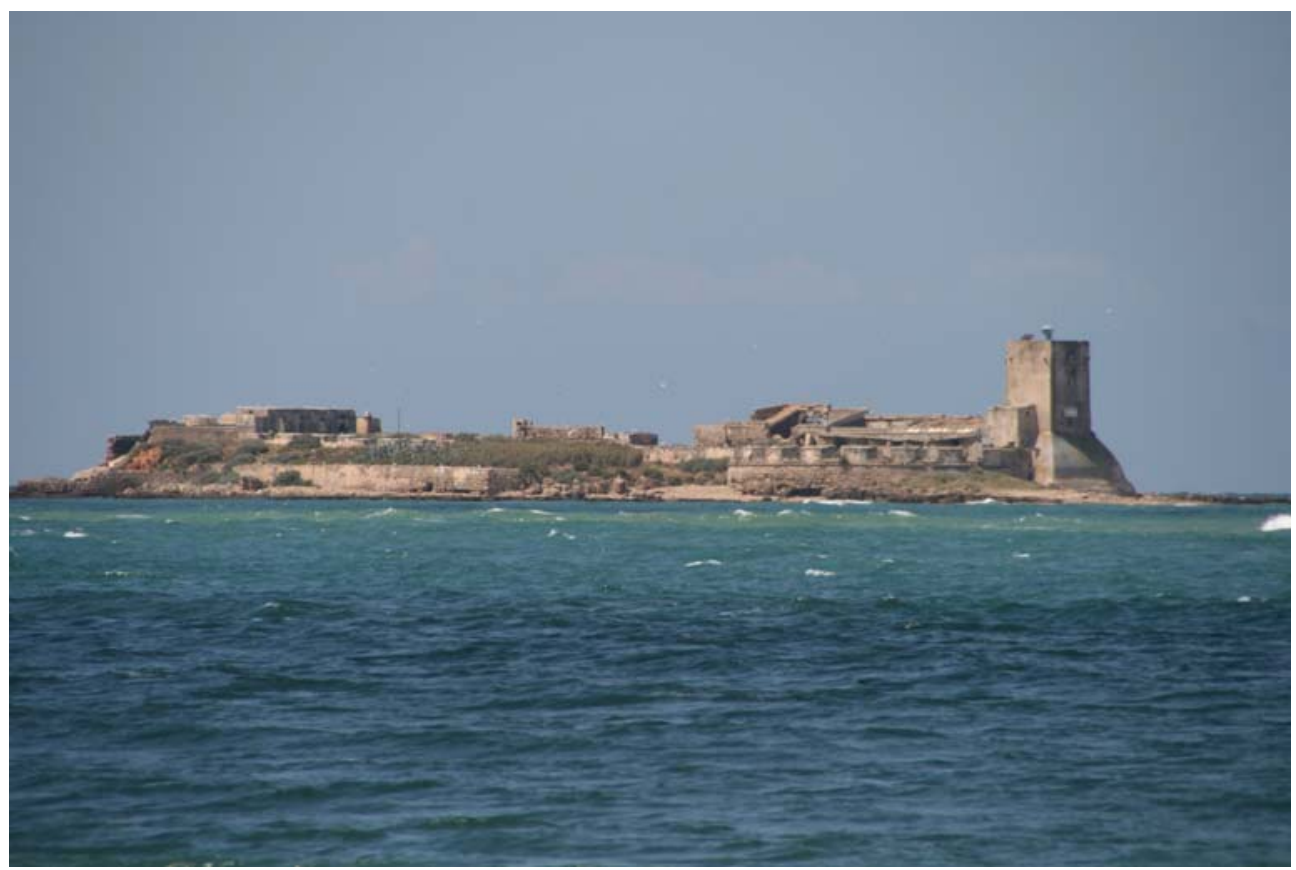

Ilustración 96 Castillo de Hércules. Cádiz

252 http://www.servisalud.com/elpensa/nutricion48.htm 


\section{¿Dónde se ocultan los beneficios del agua marina?}

Los primeros efectos se aprecian a nivel muscular, el ejercicio dentro del mar y la lucha del cuerpo contra el oleaje y el peso del agua al andar por la orilla, relaja y tonifica los músculos masajeando las piernas, lo que a su vez favorece en gran manera la circulación de la sangre mejorando las afecciones varicosas.

La gran masa de agua marina es un estupendo regulador de la temperatura corporal, lo que favorece a las dolencias reumáticas, esto es debido en su mayor parte a que los mares se calientan y enfrían de forma mucho más lenta que la superficie de la tierra o la atmósfera.

"El mar constituye un inmenso depósito de calor y, por ello, un agente de la regulación térmica, motivo por el cual la temperatura atmosférica es menos variable en las playas" ${ }^{253}$

La densidad del agua y su alto contenido en sal, permiten una flotación del cuerpo facilitando el ejercicio físico, lo que permite la recuperación de traumatismos facilitando la rehabilitación de los miembros afectados. La alta presión de la atmósfera a nivel del mar y la gran masa de oxígeno redundan en favorecer al organismo ante la realización de todas sus funciones vitales.

La composición del agua de mar es muy compleja, son numerosos los elementos que contiene, entre ellos podemos citar el sodio y el cloro, el magnesio, el azufre, el calcio, el yodo y el flúor; estos minerales son absorbidos por vía cutánea mediante el baño actuando posteriormente en el organismo.

El yodo es indispensable para el ser humano, se concentra en gran manera en el agua del mar, éste permite que la glándula tiroides produzca las hormonas tiroxina y

\footnotetext{
${ }^{253}$ Sintes Pros, J. (1980) “El Poder Curativo del Mar (Talasoterapia)”.Ed. Síntesis S.A Barcelona. Apto de Conclusiones.
} 
tryodotiroina, necesarias entre otras cosas para el crecimiento, el desarrollo cerebral y los tejidos entre otros;

"Los minerales son componentes inorgánicos que desempeñan un papel importante en el organismo, ya que son necesarios para los tejidos y para la síntesis de hormonas y vitaminas, así como en la mayor parte de las reacciones químicas en las que intervienen las encimas". 254

Fue el francés René Quinton (1867-1925) filosofo, fisiólogo y biólogo el que, a principios del siglo XX, descubrió la similitud entre el medio interno animal y el marino y como consecuencia las posibilidades del agua marina para el cuerpo humano.

Quinton escribió un libro en 1904 titulado << El agua del mar, medio orgánico〉>

"utilizando las virtudes del agua de mar, Quinton contribuyó grandemente a reducir la mortalidad infantil, salvando centenares de lactantes de la gastroenteritis o del cólera infantil,255

A este biólogo estudioso de las virtudes del agua marina, se debe el llamado "Plasma de Quinton" compuesto por agua de mar:

"René Quinton estableció la hipótesis de que la primera célula viva apareció en el medio marino, lo que explicaría la identidad constitutiva del agua del mar y del plasma sanguíneo,256

\footnotetext{
${ }^{254}$ Pérez Fernández, M ${ }^{a}$ R; (2005) “Principios de Hidroterapia y Balneoterapia” Ed. McGw- Hill. Interamericana; Pág. 203

${ }^{255}$ Sintes Pros, J. (1980). Pág. 13

${ }^{256}$ Sintes Pros ,J. (1980). Pág. 13
} 
Se trata de un regenerador del mecanismo celular. En Estados Unidos se está empleando para corregir problemas de Psoriasis, próstata, quemaduras, alopecia, artritis, osteoporosis, bronquitis, gingivitis, asma, problemas gastrointestinales o desequilibrios del sistema nervioso central entre otros tipos de patologías, así también, ha sido utilizado para el tratamiento en caso de alcoholismo y drogodependencia. El plasma de Quinton se recomienda a su vez para tratar problemas de piel, depresión del sistema inmune, infecciones, fatiga crónica o aguda, desórdenes de huesos en adultos, dolores de crecimiento en niños, embarazo, lactancia, abortos espontáneos repetidos, estrés y como normalizador en caso de deficiencia nutricional.

A pesar de sus propiedades altamente recomendadas, en la Unión Europea su uso sólo está reconocido y permitido como complemento dietético.

\subsection{El baño de mar}

El baño de mar se suele realizar en la temporada estival aprovechando las altas temperaturas que hacen del baño un placer tonificante, relajante y refrescante; otros viajan a zonas cálidas para disfrutar del baño en otras épocas del año, mientras que sólo unos pocos acostumbrados al baño diario se atreven a sumergirse en el mar en temporadas primaverales $u$ otoñales.

"El baño de mar en invierno es muy eficaz como tratamiento preventivo, pero para poder tomarlo hay que acostumbrarse desde joven y practicarlo todo el año. El baño será breve y se realizará ejercicio vigoroso antes y después del baño, secarse y comer algo.,257

\footnotetext{
${ }^{257}$ Pérez Fernández, Mª R. (2005). Pág. 211
} 
De forma general se puede decir que el baño de mar estimula, provoca el ejercicio físico voluntario e involuntario, y como consecuencia de ello, abre el apetito; por otro lado, favorece el metabolismo; de forma más concisa podemos precisar que el baño continuado durante 15 ó 20 días que es lo recomendable:

- tonifica los músculos: mediante los ejercicios realizados en el agua que al tener un alto contenido en sal facilita los movimientos y la flotación corporal.

- Estimula la circulación periférica: activando la circulación sanguínea.

- Estimula el crecimiento: mediante la absorción corporal del yodo.

- Mejora los problemas dermatológicos: ayuda a combatir los efectos del acné, cura las heridas y los hongos.

- Efecto antibiótico y bacteriostático: el agua salina impide el crecimiento de bacterias y virus

- Enfermedades ginecológicas: el ph del agua y la sal impiden el crecimiento de hongos

- Efecto depurativo y adelgazante: ayudan a eliminar toxinas, estimula el retorno venoso y linfático, ayuda a eliminar líquidos.

- Efecto anti-estrés: produce un efecto relajante y tranquilizador.

Un buen tratamiento de talasoterapia se puede realizar mediante el baño de sol y agua en cualquier playa, no es necesario ir a un centro de Talasoterapia para sentir los beneficios que brinda la naturaleza, sólo hay que ser constante y prudente con el tiempo de exposición a ambos tipos de baño; así, es recomendable por los expertos que los baños sean prolongados durante varias jornadas, aunque en la realidad el tiempo lo suelen marcar los días de vacaciones para disfrutar, en cuanto a la permanencia tanto al sol como dentro del agua, ha de ser prudencial. 
"Si el baño se prolonga aparece un segundo escalofrío, señal de fracaso de la termorregulación; este segundo escalofrío es perjudicial debe procurarse que no aparezca suspendiendo el baño antes." ${ }^{258}$

Al baño de mar se pueden sumar los tratamientos en un centro de Talasoterapia que cuentan con técnicas e instalaciones especialmente diseñadas para la práctica terapéutica, con agua de mar.

\title{
4.1.1. Virtudes saludables del baño en el medio marino.
}

Al igual que comentábamos en el capítulo dedicado al agua termal, muchas son las formas de aplicación del agua marina y de los elementos que el medio marino ofrece para curar las dolencias del hombre como es el caso de:

\author{
-Baños con algas \\ -Arenoterapia \\ -Pulverizaciones e inhalaciones \\ -Aplicación de lodos marinos \\ -Oligoterapía \\ -Ingesta de agua marina
}

Todos ellos forman parte del tratamiento talasoterapeútico y son por ello de especial interés para la salud, aunque en este estudio, nos centraremos como se ha hecho hasta ahora y cumpliendo con el objetivo planteado inicialmente, solamente en las aplicaciones mediante el baño como es el caso del baño de mar, duchas y chorros tanto de agua caliente como de agua fría etc.

\footnotetext{
${ }^{258}$ Pérez Fernández, Mª R. (2005); Pág. 203
} 
El agua de mar provoca saludables efectos sobre el organismo humano, motivo por el cual la práctica hídrica talasoterapica es recomendada.

Maria Reyes Pérez en su libro "Principios de la hidroterapia y balneoterapia", nos describe los efectos del agua de mar y su acción sobre el organismo:

"La acción e agua del mar es muy variada. Los efectos más importantes son el efecto vigorizante, el de fortalecimiento de los músculos y el estimulante de todas las funciones orgánicas, especialmente las metabólicas, endocrinas y nerviosas". ${ }^{259}$

\footnotetext{
${ }^{259}$ Pérez Fernández, M M R. (2005). Pág. 202.
} 


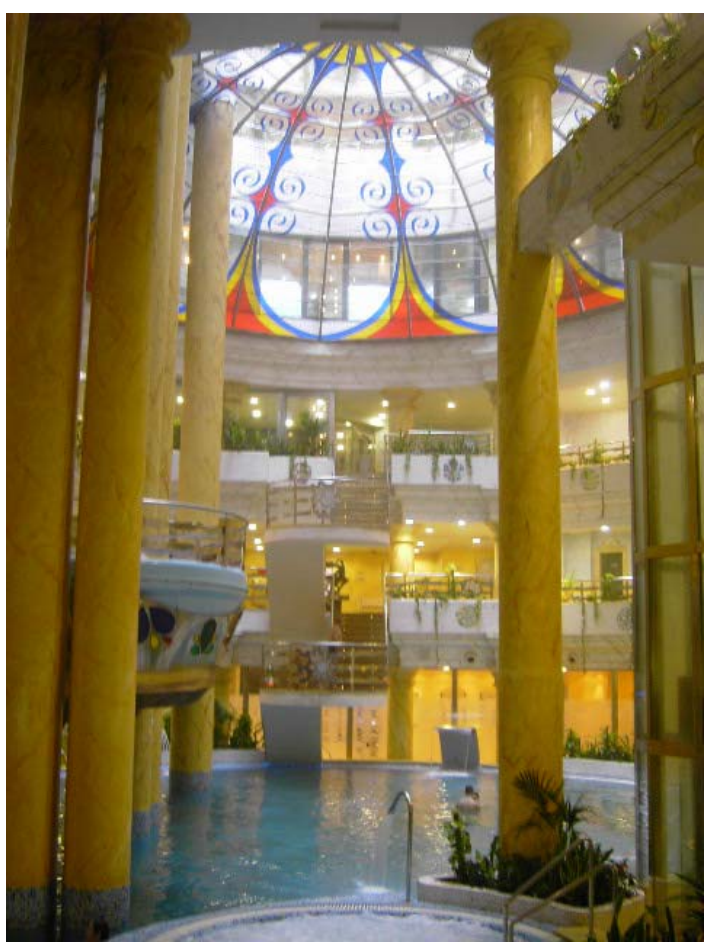

Ilustración 97 Balneario de agua marina. Marina D’Or En: Oropesa de Mar (Castellón)

\subsubsection{Contraindicaciones de los baños de mar:}

Como se puede observar a lo largo de este epígrafe dedicado al agua de mar y su influencia en el organismo mediante el baño y las terapias en centros talasso, son muchos los beneficios que puede aportar este líquido elemento para la prevención o curación de ciertas enfermedades, pero al igual que ocurría con el agua mineromedicinal al tratar el tema balneario, se observa que esa influencia puede ser negativa en algunos casos, de ahí que como diremos más adelante al hablar de los centros de Talasoterapía, éstos han de contar con un médico hidrólogo que dictamine su aplicación en cada caso. 
Jordi Sintes Pros en su libro titulado "El poder curativo del mar" advierte de que no a todos convienen los baños de mar, aludiendo a la comparación con la crenoterapia, según afirma Sintes, no se deben de tratar con este tipo de terapias, ninguna infección aguda, tuberculosis pulmonar, enfermedades infecciosas graves, los cánceres independientemente de su localización, grandes insuficiencias cardiacas, renales o hepáticas entre otras.

\subsubsection{Agua de mar: prevenir o curar}

La idea de prevención, hace de los centros de Talasoterapia un destino preferente para una parte de la sociedad preocupada por su salud, por sentirse bien, por conservar su naturaleza o por recuperarla en su caso.

Especialistas en Talasoterapia presentan en Túnez el decreto de 92-1297, de 13 de julio de 1992 en cuyo Art. Primero definen la Talasoterapia como:

"utilización simultánea, en un lugar marino privilegiado, bajo supervisión médica y con el fin preventivo y curativo, elementos del medio marino como el clima marino, el agua del mar, las algas, los barros marinos, la arena y otras substancias extraídas de este lugar................Una prestación a la vez terapéutica, preventiva y para la promoción de la salud, utilizando simultáneamente en un lugar marino privilegiado, bajo seguimiento médico con la participación de un staff cualificado, los elementos del medio marino que son el clima marino, el agua de mar, las algas, los barros marinos, la arena y todos las demás componentes extraídos de este medio “. 260

${ }^{260}$ http://www.webislam.com 
Existen por tanto dos propósitos, que al igual que en los centros balnearios, determinan la clientela de estos centros; el primero curar, por lo que seguidamente trataremos de las distintas dolencias que se pueden tratar con las distintas terapias en un centro talaso, el segundo, y de esto también trataremos en este epígrafe procurar descanso, placer y belleza, todo ello extraído de la misma fuente, el agua de mar.

\subsubsection{Talasoterapia:}

Se denomina con el nombre de talasoterapia a la aplicación del agua del mar como agente terapéutico; la palabra "talasoterapia" proviene del griego "Thalassos" que significa "mar".

La Talasoterapia es una medicina alternativa que se vale de todas las propiedades que brinda la naturaleza a través del medio marino, agua, aire, limos, lodos, arena, algas, piedras, para la práctica terapéutica.

"El plasma marino y el plasma humano tienen la misma identidad física, química y fisiológica lo que hace que el agua del mar resulte inestimable para la prevención y tratamiento de las enfermedades"261

\footnotetext{
${ }^{261}$ http://www.servisalud.com/elpensa/nutricion48.htm
} 


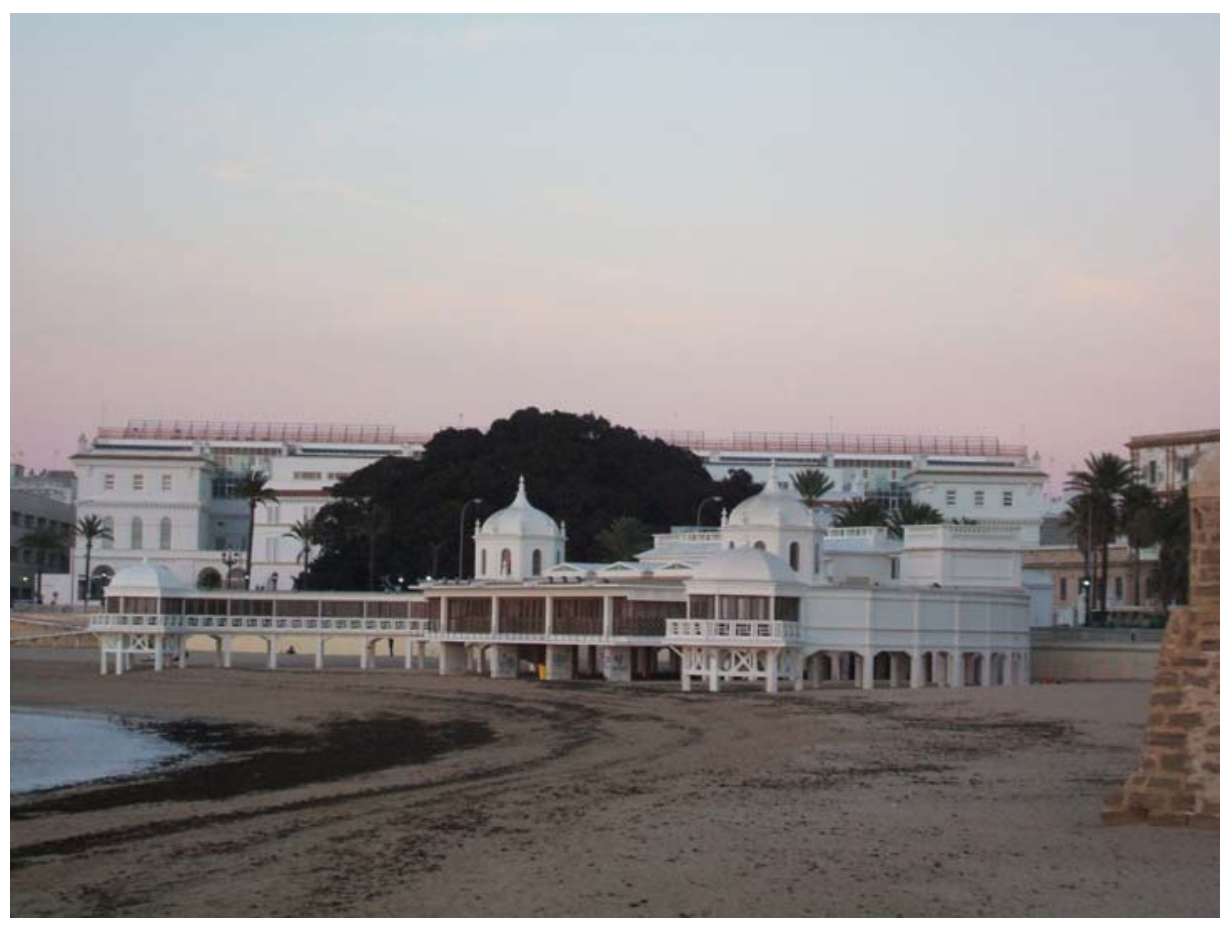

Ilustración 98 Nuestra Sra. de la Palma. Antiguo balneario situado en la playa de la Caleta en Cádiz

\subsubsection{Orígenes de la Talasoterapia}

Las virtudes terapéuticas del agua del mar tienen su reconocimiento desde tiempos remotos; parece que existen referencias encontradas en papiros egipcios en los que se alude al poder curativo del clima y los lodos del Nilo. 
"Se tienen registros del uso del agua de mar para curar enfermedades desde hace 4000 años. Nefertiti en el antiguo Egipto, curó una infección oftalmológica por clamydias usando limos de mar."262

Los Griegos practicaban las recomendaciones del uso de agua del mar tanto frías como calientes, algo que tomaron los Romanos y a lo que dieron auge al igual que al resto de prácticas hídricas como la anteriormente citada agua termal.

Eurípides, en la Antigua Grecia en el año 480 a. C., escribió:

"El mar cura las enfermedades del hombre"

Herodoto; 480 a.C decía:

"Las curas de sol y la cura de mar se imponen en la mayor parte de las enfermedades y sobre todo en las afecciones de la mujer"

Aristóteles, 428 a -347 se reafirma en la misma tesis de Eurípides diciendo:

"El agua del mar cura todos los males"263

A estas afirmaciones se sumarían las de Avicena, Galeno y las del padre de la medicina, Hipócrates 350 a.C defendiendo el agua marina como medio curativo y preventivo con su aplicación tanto externa como interna.

En la primera mitad de la Edad Media aún se practicaban los baños marinos, aunque esta práctica caería en desuso de forma coyuntural ya que a partir del siglo XII, la iglesia se opone a este tipo de prácticas hídricas.

En Inglaterra en 1697, dos ingleses Floyer y Russell, investigan sobre los baños en agua de mar y su aplicación en el cuerpo humano a diferentes temperaturas. Años más tarde, el doctor John Lathan funda el que se considera primer hospital marino.

El primer tratado sobre los beneficios del agua del mar para la salud, fue escrito en el siglo XVIII por el Dr. Charles Russel.

\footnotetext{
262 http://termasworld.com/content/view/51/35/

${ }^{263}$ Cronología del método marino de Rene Quinton. En:

http://www.elalmanaque.com/temasdehoy/balnearios/metodo1.htm
} 


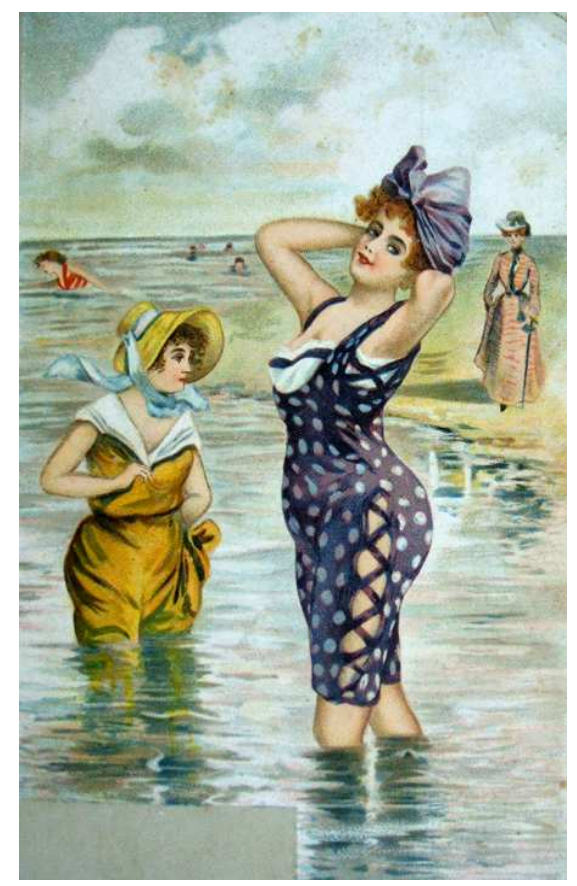

www.almirante23.net/.../banistas/banistas.htm

En Alemania a principios del siglo XIX se fundan los primeros centros de Talasoterapia.

En la playa del Lido en Venecia (Italia), también a principios del siglo XX, el Dr. Ceresole fundó el instituto dedicado al estudio de los efectos del mar sobre el hombre sano y enfermo.

En España, fue Tolosa Latour uno de los pioneros de la Talasoterapia en Pediatría. Fue a finales del siglo XIX cuando el doctor Latour eligió la playa de Regla en Chipiona por la calidad de sus aguas, su alto contenido en yodo y por su orientación lo que provoca que el aire del atlántico sople propicio para la curación de enfermedades, como la tuberculosis, fueron toda esta conjunción de elementos físicos y climáticos los que indujeron al doctor a fundar el Sanatorio de San Carlos, al que acudieron multitud de niños afectados por la tuberculosis, problemas de piel o enfermedades de los huesos. 
En Francia la talasoterapia se institucionaliza:

"En 1778, se inaugura en Dieppe e primer instituto francés.......Fue en Francia, el 18 de junio de 1997, cuando la Talasoterapia pasa a tener existencia oficial. Surge la Federación Internacional de Talasoterapia Mer et Santè junto con la certificación de calidad Qualicert, las premisas fundamentales para definir una institución como centro de Talasoterapia"264

\subsubsection{El Sector de la Talasoterapia.}

El sector de la Talasoterapia es un sector que está dirigido a una clientela escogida, fundamentalmente clases medias altas o clases altas, que disponen de una posición acomodada o un alto poder adquisitivo. Los centros de Talasoterapia se encuentran ubicados en su mayor parte en hoteles dirigidos a ofrecer al cliente calidad y lujo, centros que ofrecen todo lo necesario para permanecer en ellos una pequeña estancia sin echar de menos el exterior. Son verdaderos centros vacacionales dedicados a la búsqueda del bienestar, la salud y el placer de quienes acuden a estos lugares donde el agua de mar es la base de su propia esencia.

El sector de la Talasoterapia se encuentra amparado por el sector turístico, por su ubicación en zonas costeras, lugares promocionados para el turismo y cuidados por su condición de litoral, en su mayor parte protegido.

Es un sector competitivo, se enfrenta a una competencia fuerte compartiendo posibles clientes entre balnearios y SPA, todos ellos con un máximo común, el recurso hídrico, con un elemento diferenciador, el propio agua, aunque suene paradójico nos referimos a las distintas clases de agua desde el punto de vista de su composición; así, comparten con el sector balneario, agua, turismo y salud. Es esta

${ }^{264}$ http://termasworld.com/content/view/51/35/ 
competitividad la que obliga al sector a buscar nuevas oportunidades de negocio ampliando los servicios de terapia y diversificando, por un lado, en el campo de la belleza, mediante la aplicación de masajes, depilaciones y en algunos casos operaciones de estética; y por otro, con la fabricación de líneas de cosmética, cremas, jabones etc. que en algunos caso representan una marca propia; todo ello atrae a una clientela joven que busca en estos centros de talasoterapia disfrutar de unos días de descanso, estancias que suelen ser breves, fines de semana, pequeñas vacaciones etc. con el objetivo de conseguir desconectar del trabajo diario, descansar, disfrutar del placer del baño e incluso conseguir un aspecto físico mejor.

\subsubsection{La técnica de la Talasoterapia}

El agua, se extrae a unos 1000 metros de la orilla del mar para posteriormente ser depurada y esterilizada mediante la utilización de rayos ultravioleta, estando en perfectas condiciones para su aplicación terapéutica, es decir, libre de agentes patógenos. El agua se aplica a una temperatura corporal, es decir, a unos $36^{\circ} \mathrm{C}$ aproximadamente, lo que según los expertos, mantiene a los microorganismos marinos vivos, así mismo, a esta temperatura permite el paso de los iones dentro del cuero a través de la piel facilitan la absorción de las sales minerales y yodo contenidas en el agua beneficiosas para el cuerpo humano, esto es posible por una similitud química existente entre la sangre y el agua del mar.

En Talasoterapia al igual que en la aplicación de agua termal, los tratamientos son prescritos por un médico hidrólogo, que dictamina las distintas terapias o tratamientos necesarios en cada caso.

Calude Bernard 1865) defendía que el agua marina permanece en el interior del cuerpo humano "aquel en el que se bañan las células sin comunicación con el exterior” el (L.E.C.) así explicaba el sabor salado de las lágrimas, del sudor o de las secreciones nasales. Según esta teoría las células no están en contacto unas con 
otras, el agua es el soporte de todas las células y es la encargada de recoger cualquier información tanto metabólica como inmunológica o nerviosa.

\subsubsection{Centros de Talasoterapia}

Al igual que los centros balnearios, los centros de Talasoterapia tienen que cumplir unos requisitos o condiciones; así el centro debe estar situado cerca del mar, un lugar de clima marino, no hay que olvidar que para la práctica terapéutica son necesarias muchas sustancias extraídas del mar entre otras, el agua, las algas, los lodos, las arenas y a su vez se complementa con el sol y el aire, por lo que estas terapias se sirven tanto del medio como del clima marino.

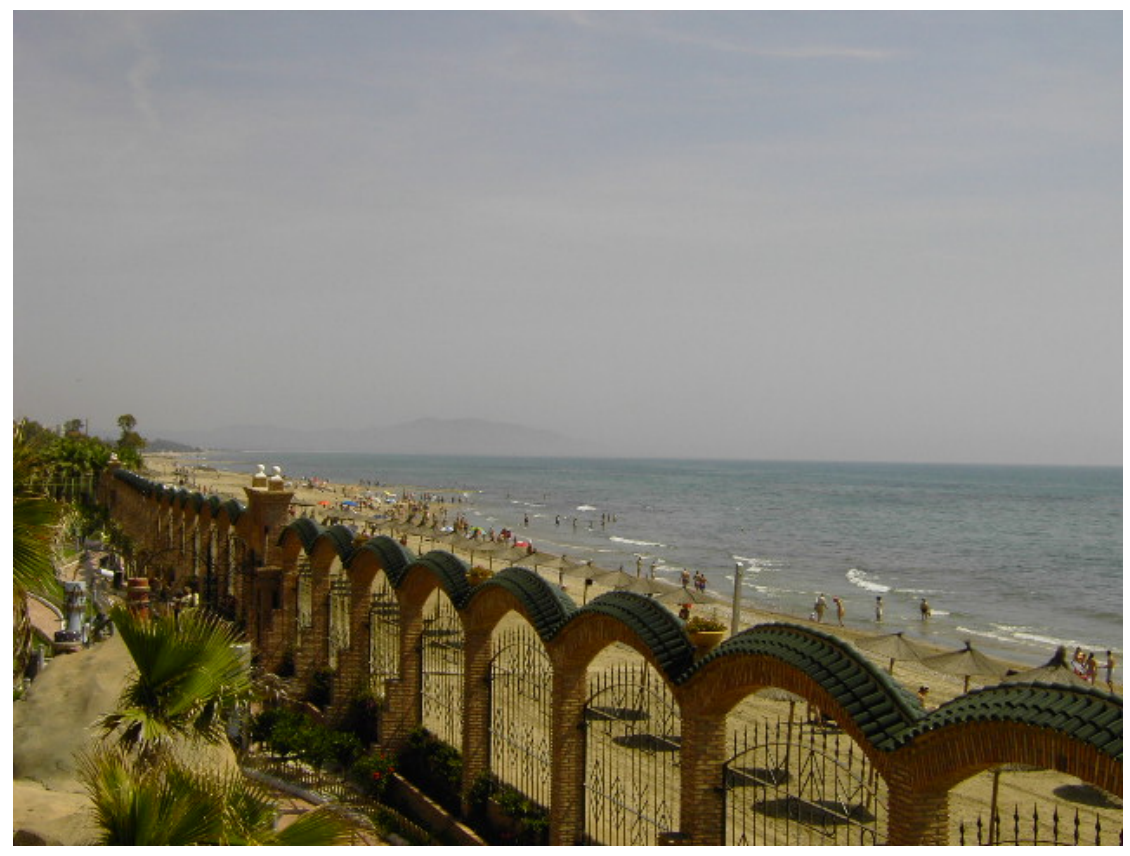

Ilustración 99 Marina D’Or Balneario de agua marina situado En: Oropesa de Mar (Castellón) 
El agua utilizada para la práctica terapéutica ha de ser agua de mar viva, y al igual que en el sector balneario es necesario contar con la supervisión de médicos y profesionales hidrólogos terapeutas y fisioterapeutas.

Los centros de Talasoterapia han de estar dotados de estructura y equipamiento adecuados para la práctica terapéutica.

Dependiendo de la filosofía del centro o del grado de modernización del mismo, los centros de talasoterapia se dotan de instalaciones novedosas, que los hacen cada vez más competitivos entre sí; lo importante es ofrecer al agüista las últimas tendencias en aparatología y servicios que hagan de la estancia en el Talasos, no sólo unos días de recuperación terapéutica sino también unos días de placer.

En un centro de talasoterapia podemos encontrarnos:

- Piscinas de agua de mar fría.

- Piscinas de agua de mar caliente $\left(37-40^{\circ}\right)$.

- Piscinas con chorros submarinos para realizar masajes localizados.

- Bañeras con duchas submarinas.

- Jacucci

- Baños de vapor marino

- Baños de lodo marino o fangoterapia.

- Baños de vapor de agua con agua de mar.

Cuando se habla de duchas submarinas, nos referimos a una ducha local en el interior de la bañera para la proyección de agua a presión; se trata de una ducha que dura 20 minutos y que tiene una acción antiálgica y descontractante.

"Un tipo concreto de ducha subacuática es la denominada $<<J e t$ submarino>>, que se realiza dentro de una piscina y consiste en la 
aplicación de un chorro de alta presión que efectúa un agradable e intenso masaje sobre los músculos y las articulaciones. ${ }^{265}$

Toda una terapia en la que la salud y el placer se mezclan en la ducha.

El baño de mar caliente hay que disfrutarlo en un centro Talaso, ya que es el lugar idóneo por la disponibilidad de medios técnicos para calentar el agua mediante calentadores, o vapor y de bañeras o piscinas preparadas al efecto.

${ }^{265}$ Núñez, M y Navarro, C. (2001) “Como Cura el Mar” Ed. RBA libros S.A Barcelona. Pág. 39 


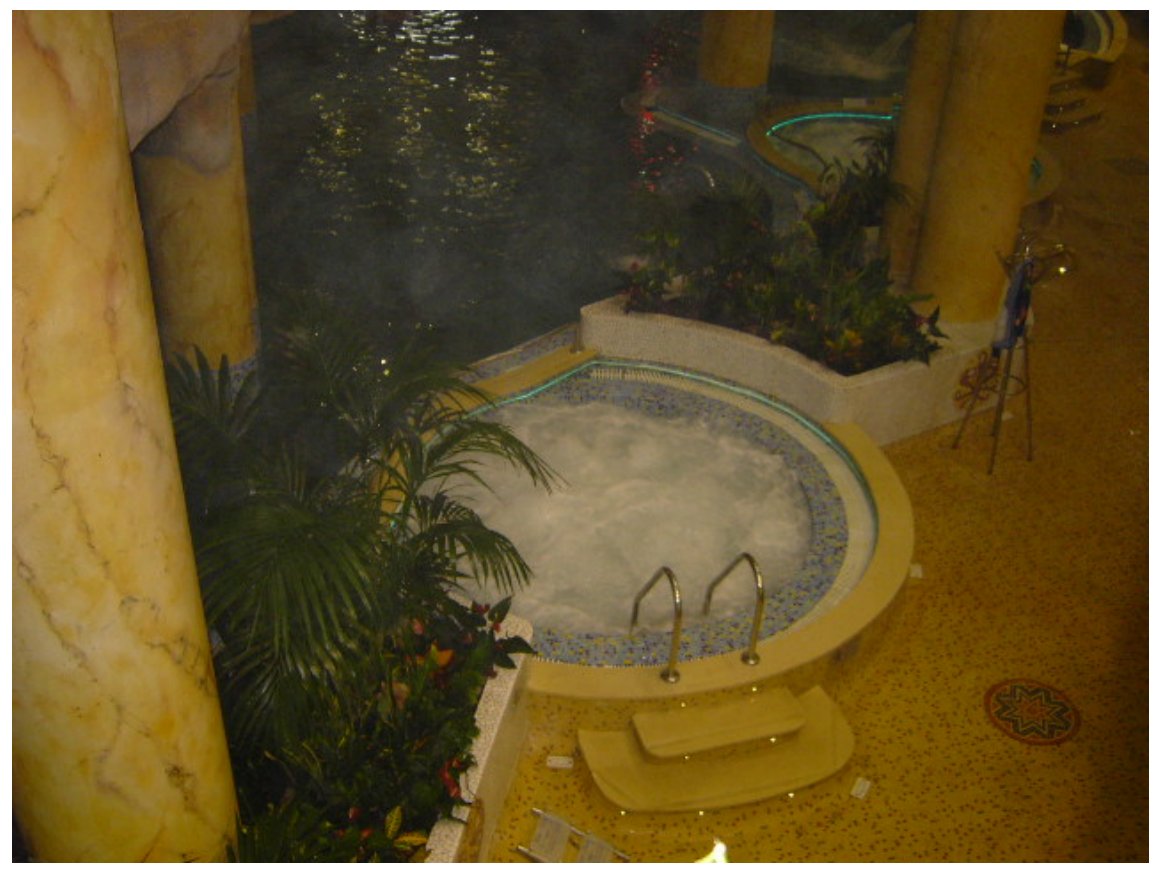

Ilustración 100 Marina D’Or Balneario de agua marina situado en Oropesa de Mar (Castellón)

Con la intención de potenciar los efectos terapéuticos del agua del mar, en los centros de Talasoterapia se enriquece cuando así se estima oportuno, el agua extraída del mar, así podemos hablar del agua de mar enriquecida con sal, con gas carbónico, oxigeno u ozono como se indica en la cita que se expone a continuación

"Para potenciar el efecto del agua de mar a veces se le añade sal marina cruda o aguas madres salinas para enriquecer su contenido en sales magnésicas y bromuros.................Agua enriquecida con gas carbónico... se utiliza el agua del mar calentada a $36^{\circ}$ y saturada con ácido carbónico para tratar los problemas vasculares...Baños de agua oxigenados y ozonizados: El agua del mar a la que se ha añadido 
oxígeno $u$ ozono ejerce un masaje sobre la piel con efectos favorables.." ${ }^{266}$

En los centros de Talasoterapia además de enriquecer el agua para favorecer las terapias, también se incluyen nuevas técnicas y tecnologías, que ayudan a su aplicación y mejoran sus resultados así podemos citar el Cavisotonic y el Vaporarium.

"Cavisotonic: Es una bañera de agua de mar que incorpora ultrasonidos de baja frecuencia. La sucesión de ondas provoca rápida difusión de los componentes del agua salada y por tanto aumenta su absorción a través de la piel.

Vaporarum: Es un baño de vapor marino que se consigue calentando el agua de mar hasta unos $50^{\circ}$....limpia e hidrata gracias a la sudoración que provoca. ${ }^{267}$

\subsection{Requisitos a cumplir por un centro de talasoterapia:}

10- Proximidad al mar: el centro ha de estar ubicado a una distancia máxima de 1000 metros.

$2^{\circ}$ - Utilización de agua de mar natural: el agua de mar ha de tomarse a una distancia determinada, 700 metros y 9 metros respectivamente.

$3^{\circ}$ - Han de realizarse controles periódicos de la calidad de las aguas.

$4^{\circ}$ - Las instalaciones han de conservarse en perfecto estado, primando la funcionalidad, adecuación e higiene.

\footnotetext{
${ }^{266}$ Núñez M y Navarro, C. (2001). Pág. 40

${ }^{267}$ Núñez M y Navarro, C. (2001). Pág. 43
} 
5- Supervisión y seguimiento médico de los curistas, los tratamientos y terapias aplicadas.

$6^{\circ}$ - Ha de contar con un personal cualificado, profesionales titulados (fisioterapeutas, hidroterapeutas, etc...)

\subsection{Dolencias a tratar en un centro de Talasoterapia}

Son muchas las dolencias que se pueden llegar a tratar en un centro de Talasoterapia, fundamentalmente se trata de aliviar numerosas patologías ayudando a la recuperación o a la prevención en su caso.

La talasoterapia se hace ideal para el tratamiento de enfermedades de tipo crónico como son los reumas, problemas circulatorios, musculares o de piel entre otros.

"El efecto del mar puede ser más estimulante o sedante, dependiendo de las condiciones climáticas. En general se puede decir que las enfermedades también se pueden dividir entre las que precisan estimulación o relajación, aunque ambos efectos están presentes siempre en toda cura marina.,268

Según Sintes Pros en su libro "El poder curativo del Mar" entre los tipos de dolencias para los que se recomiendan las terapias marinas podemos citar las siguientes:

- Los reumatismos crónicos (artritis, artrosis, neuritis)

- La Celulitis

- Afecciones del aparato respiratorio (Asma Bronquial)

- Enfermedades alérgicas (Asma del heno, eczema, acné, urticaria)

${ }^{268}$ Núñez, M y Navarro, C. (2001). Pág. 55 
- Tuberculosis osteo-articulares, ganglionares.

- Enfermedades ginecológicas (metritis, salpingitis, vaginitis)

- Fatigas, secuelas de fracturas etc.

\subsection{Belleza y placer en centros Talaso}

La belleza y el placer es otro de los objetivos a conseguir en un centro de talasoterapia, estos, procuran terapias orientadas a conseguir relajación mediante tratamientos anti-estrés, como son, el shiatsu, la sofrología o la reflexología plantar; belleza corporal mediante ejercicios y métodos de adelgazamiento que permitan la recuperación de las formas corporales socialmente aceptadas, de las que se trataron al inicio de este estudio; los centros de Talasoterapia intentan dar respuesta a problemas personales de aquéllos que se sienten descontentos con su físico y de aquellos que se sienten presionados por su trabajo diario en el entorno urbano.

En los Talaso ayudan a encontrar las claves del bienestar mediante la búsqueda del placer para aumentar las cotas de salud física y psíquica.

\subsubsection{Túnez, un país referente en Talasoterapia.}

No es posible tratar el tema de la Talasoterapia sin detenerse en un país referente en este tipo de prácticas; dispone de un gran prestigio y reconocimiento en este sector tanto por las sociedades científicas internacionales, como por la sociedad en general que acude a este país en busca de una talasoterapia de calidad, Túnez es el segundo destino después de Francia.

La talasoterapia nace en Túnez por el año 1994, año en el que se inaugura el primer centro de Talasoterapia "Abou Nawas Boujâafar", en Sousse. Se trata de un país que cuenta con una situación estratégica privilegiada ya que se encuentra bañado por el mar Mediterráneo y cuenta con una gran pureza en las aguas marinas, bien preservada gracias a la buena orientación de sus corrientes y a una política de protección del medio ambiente. Túnez cuenta hoy con 35 Centros de Talasoterapia distribuidos por: Hammamet, Sousse, Tabarka, Costas de Cartago, Port El Kantaoui, 
Mahdia, Monastir , Djerba y Zarzis; todos ellos con un objetivo común, la aplicación del agua del mar con fines curativos; así, sus terapias están orientadas al anti-estrés, antí- tabaco, el reuma, la artrosis, aparato respiratorio y circulatorio, así mismo, muchos de sus tratamientos giran en torno a la búsqueda de la belleza, el adelgazamiento, mediante la eliminación de celulitis, la recuperación posparto etc. y todo ello, en el marco incomparable que prestan lujosos hoteles y de la mano de los especialistas más cualificados en este tipo de prácticas y terapias.

La Talasoterapia en Túnez está regulada por Ley, esto como se ha citado con anterioridad, está ausente en el talasoterapia europea. A lo largo de cinco capítulos se recoge toda la normativa entorno al sector, desde la definición del término "Talasoterapia" a la calidad del agua de mar a utilizar y las condiciones de uso de la misma, recoge también, los tratamientos y prestaciones, así como el equipamiento de los centros, las normas de explotación de los mismos y, la formación del personal.

Túnez está representado en la Internacional Society of Medical Hydrology and Climatology, como reconocimiento de la importancia adquirida por el Turismo de salud.

En el año 2000 se presenta en Hamamet con gran éxito el XXI Congreso Internacional de Talasoterapia, en el que estaban representados doce países, entre ellos España.

En Túnez la gestión y explotación de los centros de talasoterapia, se lleva a cabo por parte de dos ministerios, el de salud y el de turismo.

En Túnez se encuentra la ciudad de "Hamamet" que significa los baños, se encuentra situada en un golfo de agua transparente y arena muy fina, se trata de una de las ciudades balnearias más importantes de Túnez. A unos cincuenta kilómetros hacia el interior se encuentra "Zaghouan": donde los romanos encontraron el agua, se trata de un pueblecito morisco en cuyo interior se encuentra el templo de las aguas o templo de las Ninfas, en el que se construye un acueducto cuya misión era la de llevar el agua hasta Cartago. 


\subsubsection{España y Francia: dos ejemplos de talasoterapia en Europa}

Para hablar de la talasoterapia en Europa traeremos a estudio dos países, España y Francia, el primero por su gran cantidad de kilómetros de playas y Francia por su gran oferta en los grandes centros de lujo dedicados a este tipo de prácticas hídricas.

\section{$>$ España:}

La costa de España tiene más de 7.900 Kilómetros y más de 2000 playas; los inmensos recursos de sol y playa con los que cuenta son los que hacen que este país se convierta en el lugar perfecto para la práctica de la Talasoterapia.

\section{$>$ Francia:}

Al acercarnos a la Talasoterapia en Europa, hemos de hacer un alto en la costa de la Bretaña francesa, "la Balue" lugar escogido por las capas altas de la sociedad francesa para disfrutar de la terapias marinas en lujosos Talasos como "Thalgo la Balue", que aún conserva la esencia de la época dorada del baño en el siglo XIX en el que fue construido y que hoy mezcla la magia y las bellas reminiscencias del pasado conjugándola con la frescura de los mejores centros dedicados al baño en la actualidad. 


\section{Aguas dulces simples; salud y/oplacer}

Aguas dulces simples o agua de grifo, dicho de una forma más vulgar, es el elemento utilizado en centros dedicados al baño que nada tienen que ver con los Talaso y balnearios, que como hemos podido ver a lo largo de este capítulo tienen ubicados sus centros dedicados al baño junto a fuentes de agua termal con propiedades mineromedicinales, como es el caso de los balnearios, o cerca del mar, como es el caso de los Talaso; por el contrario, los llamados "Balnearios Urbanos" o "Spas", basan sus terapias en las propiedades térmicas del masaje con agua dulce o simple, procedente de la red de aguas urbana, por lo que se encuentran situados principalmente en el centro de las ciudades.

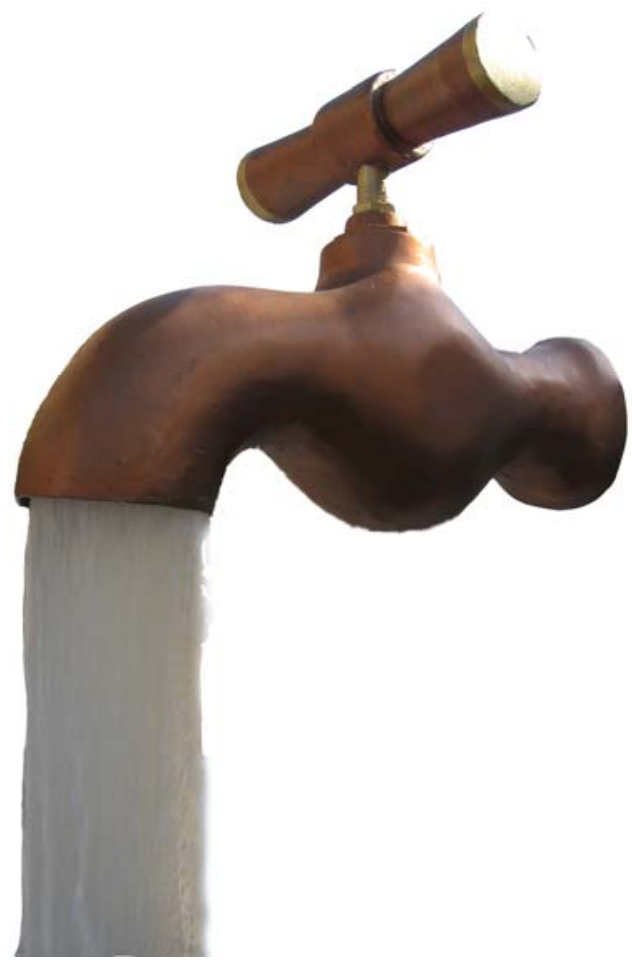

Ilustración 101 Imagen tomada en Zaragoza (Exposición Universal del Agua 2008) 
¿Se puede hablar de salud utilizando en las terapias agua dulce simple, es decir, agua de grifo? Si nos atenemos a las propiedades curativas del agua no, el agua de grifo no cura, se puede decir que aplicada de diferente forma estimula; puede que ese estimulo pueda causar efectos beneficiosos para la salud, así, el hecho de alternar piscinas a diferentes temperaturas tonifica el cuerpo pudiendo llegar en algún caso a mejorar el sistema circulatorio; por otro lado, parece cierto que el uso de la sauna contribuye a eliminar toxinas; que el baño de vapor limpia las vías respiratorias y que el masaje subacuático ayuda a combatir la celulitis mejorando el retorno venoso, también parece ser que enfermedades como el estrés, que afecta a una gran parte de la sociedad y que en gran manera está provocada por la propia sociedad misma a causa del ritmo de vida que en la actualidad lleva el ser humano, es en gran manera paliada e incluso curada mediante terapias hídricas, mediante la práctica continuada de un buen baño relajado en un lugar tranquilo, que aísle a la persona del mundanal ruido como dijo en su día San Juan de la Cruz; dicho esto, cabría formularse nuevamente la pregunta ¿Se puede hablar de salud utilizando en la terapias agua dulce simple, es decir, agua de grifo? Es posible que en vez de hablar de curación se pueda hablar de efectos secundarios beneficiosos para la salud. Estos efectos secundarios son quizá el mejor argumento utilizado por empresarios del sector del ocio y el turismo, que tiene su máximo exponente en el recurso hídrico y que basándose en la búsqueda de la naturaleza como una alternativa vacacional provocan a una clientela deseosa de un cambio, tanto corporal como interior, consumiendo un producto sin duda deleitoso y relajante aunque no curativo en sí mismo.

El concepto de balneario urbano no es novedoso, se trata de una recuperación de idea de negocio que fue muy demandada en la época romana, ya entonces existían baños públicos en el interior de las ciudades, que compartían la misma filosofía del agua que comparten estos centros en la actualidad. 
"Usaron los antiguos del los Baños con gran exceso como tenemos notado en otras partes ya para hacer con más comodidad, dispusieron fabricas, haciendo en ellas estancias y divisiones para diferentes usos, todos en orden a tomar los baños con mejor disposición, según la mejor opinión más conforme a razón"269

\subsection{De las facultades de aguas simples}

Con este título se iniciaba el capítulo I del libro de Limón Montero escrito en el año 1697 "Espejo Cristalino de las Aguas". En este capítulo primero describe de forma muy concisa y pormenorizada, "Cuáles se llaman aguas simples"; a su vez hace una distinción entre baños de aguas simples y frías y el baño cálido de aguas simples.

"Aguas dulces o simples llamamos aquellas que no tienen mezcla de algún metálico, o universal fino que según su naturaleza elemental se considera experimentan sin mezcla de cosa extraña: Estas se llaman simples porque no están mixtas, y dulces, no por que tengan dulzura positiva; sino porque se representan al gusto suaves, y deleitosas por su sutileza, frialdad y humedad con que templan la sed, $y$ ardor $y$ recrean $y$ así las percibe el gusto como dulces." 270

Este tipo de aguas aplicadas al baño, tiene según Montero, enfriar, humedecer y alisar la piel, así mismo los efectos dependerán también de la duración del baño y de la predisposición del agüista a tomar el baño.

\footnotetext{
${ }^{269}$ Limón Montero, A. año (1697). Pág.348

${ }^{270}$ Limón Montero, A. año (1697). Pág. 347
} 
Baños de aguas simples frías: (Para definir este tipo de baños, el doctor Limón Montero se remite a Savonarola en su libro I de Baños cap. I en la letra B)

"El baño de agua fría dulce, es un cuerpo líquido frío (debese añadir al húmedo) el cual ocurre al cuerpo cerrándole alrededor y actualmente le altera. Las operaciones o efectos de este baño unos son tales por sus propias facultades como efectos que de ella diaman, y nace sin el concurso de otras causas, y otras que dependen de ellos por el concurso de otras causas. ${ }^{271}$

Uno de los efectos es la extinción del calor natural, otro procurar higiene;

"Lavar el cuerpo de la fordicie e inmundicia que tiene en el cuero y las partes externas" calienta los miembros externos y sanan en ellos las enfermedades frías que dependen de humores fríos y de flatos lo cual hace revocando el calor natural"

Baño cálido de aguas simples: (Para definir este tipo de baños, el doctor Limón Montero se remite a Galeno en el séptimo, del Método en el capítulo VI).

Aconseja que el calor del agua del baño no sea intenso a fin de no cerrar los poros, el aboga por las aguas templadas:

"Porque así el cuerpo se recrea y se deleita y el cuerpo se laxa y sus porosidades, y entra el agua y por ella las partes interiores, y así

${ }^{271}$ Limón Montero, A. año (1697); Pág. 347 
humedece y resuelve y despega los humores.... el agua caliente es más acomodada que la fría para lavar y limpiar la fordicie"272

\subsection{Del Agua Simple: SPA y Baños Urbanos}

La ventaja del SPA y Baños Urbanos, reside fundamentalmente en la posibilidad de acercar el placer del baño al lugar de residencia, ya que se trata de negocios que por sus características pueden formar parte de un hotel urbano, o simplemente de un centro dedicado al baño situado en el corazón de la ciudad misma.

La idea de balneario urbano, no es nueva, los baños públicos existían en la época de los romanos, eran centros sociales, lugares donde asistir en busca de placer. Esto en cierto modo está cambiando, ya que así como se resaltaba la condición social de los centros balnearios, los Centros SPA se alejan de este concepto; son lugares a los que se asiste en grupos reducidos como pueden ser varios amigos, en pareja o personas solas.

La palabra SPA, significa salud por el agua, lo que resulta paradójico si se tiene en cuenta que el agua utilizada para la realización de baños y terapias es agua del grifo, carente de propiedades mineromedicinales y termales; que consiguen su aproximación termal mediante el calentamiento del agua, por medio de calentadores convencionales. En lo que se refiere a las propiedades minerales, en algunas ocasiones es enriquecida con sales que se añaden al agua para mejorar sus propiedades e incluso para perfumarla, pero hay una parte, la medicinal, de la que el agua procedente de la red urbana de agua está exenta.

La palabra "Balneario Urbano" también ha generado bastante controversia dentro del sector dedicado a la hidrología, por la confusión social provocada por el propio término, ya que a la palabra "Balneario" se asocia la condición de agua mineromedicinal, algo de lo que no dispone, ya que al igual que en los centros SPA

${ }^{272}$ Limón Montero, A. año (1697); Pág. 348 
se sirve de la red urbana de aguas para el llenado de piscinas y jacuzzis. Esta controversia se alimenta mediante los conceptos que denominan las distintas terapias, así, la terapia denominada "Circuito Termal" alude a Termalismo, pero aunque pueda ser termal por la temperatura del agua utilizada durante el circuito, no hay que confundirla con el agua Termal de manantial mineromedicinal.

Se trata de un sector que intenta por un lado, terminar con la estacionalidad de las vacaciones, cualquier momento es bueno para acudir a un centro SPA, y por otro lado, convertirse en destino final. Los SPA buscan los espacios de ocio para instalarse, así los centros comerciales comienzan a ser objetivo de este tipo de industria.

A favor de este tipo de centros hay que aludir a las modernas instalaciones que ofrecen a sus clientes, son lugares estudiados tanto a nivel arquitectónico como decorativo, suelen evocar la esencia de otras culturas relacionadas directamente con el agua, así en algunos casos la decoración es oriental, con motivos hindúes, en otros, se acerca a la decoración de antiguos baños árabes; todo en ellos está estudiado, hasta las luces, que pasan a ser una de las grandes protagonistas convirtiendo estos centros en lugares sugestivos, exquisitos, que se convierten en irresistibles.

\subsection{Público objetivo de los centros SPA y balnearios urbanos}

Como decíamos anteriormente, el concepto de centro social y de ocio tiene otra lectura en estos establecimientos, ya que el ocio no es algo alternativo o a conjugar entre baño y baño como ocurría en los centros balnearios de agua termal, aquí el ocio es el circuito "Termal" en sí mismo. El tiempo de disfrute suele rondar los 50 minutos, no se trata de un tratamiento continuado durante varios días, por el contrario, uno decide el momento de disfrutar de una hora de placer hídrico en un centro SPA. 
A continuación se presenta una cita que muestra el perfil del público objetivo de estos centros SPA, son datos de un estudio realizado por la consultora Magma Turismo:

“- La gran mayoría de los clientes de un hotel con SPA tienen entre 30 y 60 años (76\%), de los que la mayoría provienen del extranjero.

- La clientela del balneario es mayoritariamente nacional (con porcentajes superiores al 95\%).

-Casi la mitad de los clientes (48\%) viaja a un SPA con su pareja.

-El 52\% de los clientes del SPA son mujeres, aunque está aumentando considerablemente la afluencia de los hombres a estos centros.

-La clientela de SPA lo ha conocido por el boca-oreja (24\%) o a través de Internet

-El nivel de educación es alto, están más informados y tienen gran capacidad de compra,273

Pese al significado de la Palabra SPA (salus per aquam) estos lugares, están pensados para gente sana, e incluso se podría decir que para gente joven que busca belleza y placer, descanso y relajación en un lugar ideado única y exclusivamente para hacerle sentir bien.

El gusto que uno dé a su cuerpo en un SPA o Balneario Urbano, dependerá de la cantidad de dinero que esté dispuesto a pagar, ya que puede disfrutar de un Circuito Termal o recorrido por todos los servicios que ofrece el centro, solicitar la aplicación de masajes de chocolate, cerezas o incluso disfrutar de un baño de cava; por otro lado, la aplicación corporal de oxígeno mediante las más novedosas tecnologías contribuirá a rejuvenecerse y sentirse bien.

\footnotetext{
273 “La Industria Termal en España” (Conferencia Intereconomía Spas y Balnearios. En: http://www.balneariosurbanos.com
} 


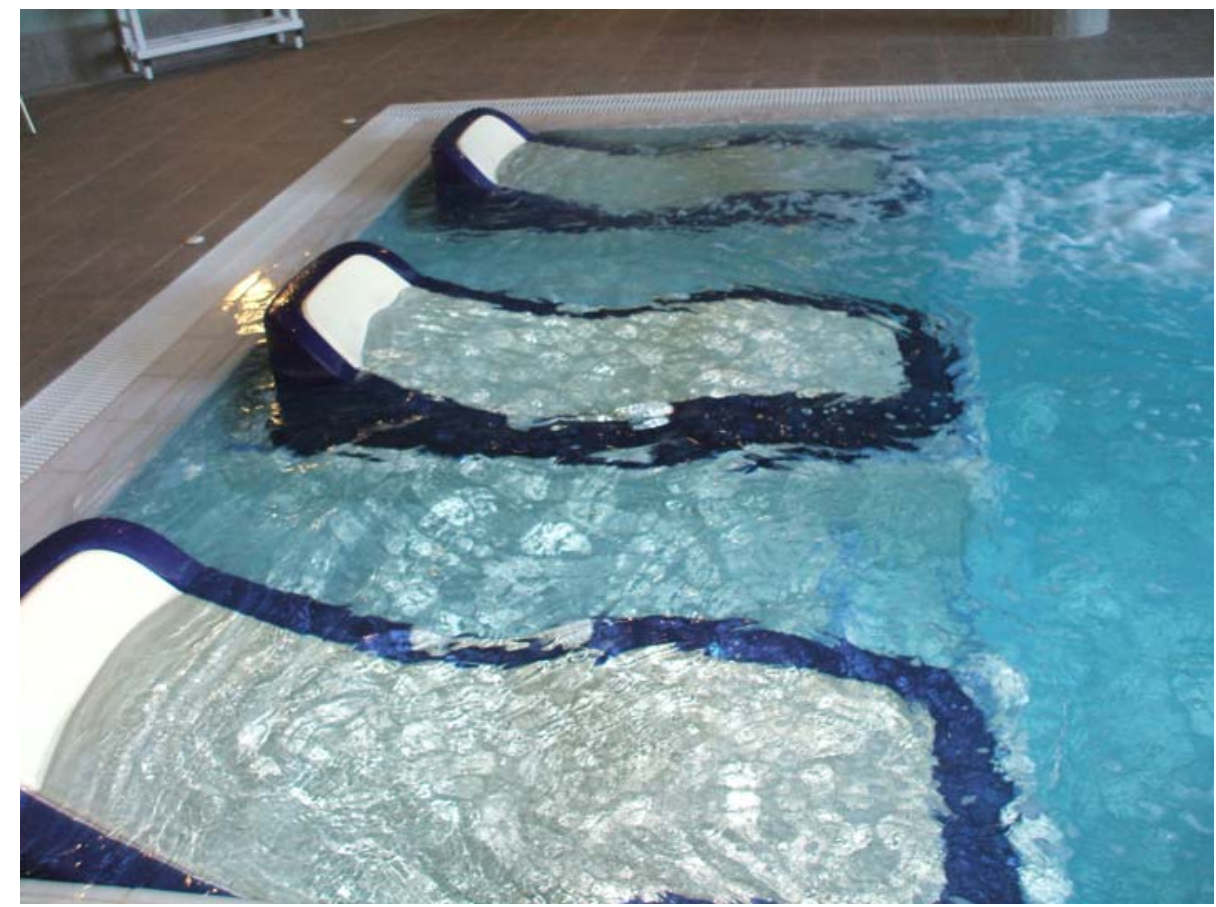

\subsection{Concepto social de SPA:}

El agüista, en su mayor parte joven (entre 25 y 55 años), acude a estos centros acompañado de algún grupo muy reducido de amigos, en pareja e incluso solo. Se trata de lugares que buscan ofrecer intimidad al cliente, así, cuentan con un número relativamente pequeño para cada turno de disfrute hídrico, llegando incluso si el cliente lo desea, y lo contrata previamente, a disponer de las instalaciones de forma totalmente privada por un tiempo determinado, los valores individualistas toman forma en estos centros concebidos y diseñados por expertos arquitectos, sociólogos y estudiosos del marketing, que conocen de la nueva sociedad posmoderna y de las tendencias actuales consiguiendo de forma certera una oferta de instalaciones y servicios a la medida de usuario del baño . 
Son lugares ideados para personas cuyo poder adquisitivo sea medio alto, personas cuyas necesidades principales están cubiertas por lo que su objetivo prioritario empieza a ser el cuidado de sí mismo y de su bienestar personal.

Si realizamos un análisis de ubicación podemos observar cómo este tipo de negocios se sitúan en zonas de la ciudad, en la que los residentes poseen un nivel económico alto.

\subsection{Espacios hídricos, lugares pensados para el placer del baño.}

SPA, Balnearios Urbanos y otros centros de nueva construcción dedicados al placer del baño, mezclan gresite con madera y acero inoxidable, buscando en cada caso crear un ambiente holístico, enigmático, e incluso místico, así, podemos encontrar varios tipos de SPA:

De aventura: con actividades realizadas al aire libre.

Holísticos: su filosofía de SPA se centra en el desarrollo mental y físico. Muy apreciados por aquéllos que buscan en el agua una alternativa para orientar su vida mediante un programa de bienestar integral.

A continuación se presenta una fotografía que corresponde a un SPA holístico., se trata de un centro de moderna creación. Su imagen externa recuerda a la arquitectura árabe. 


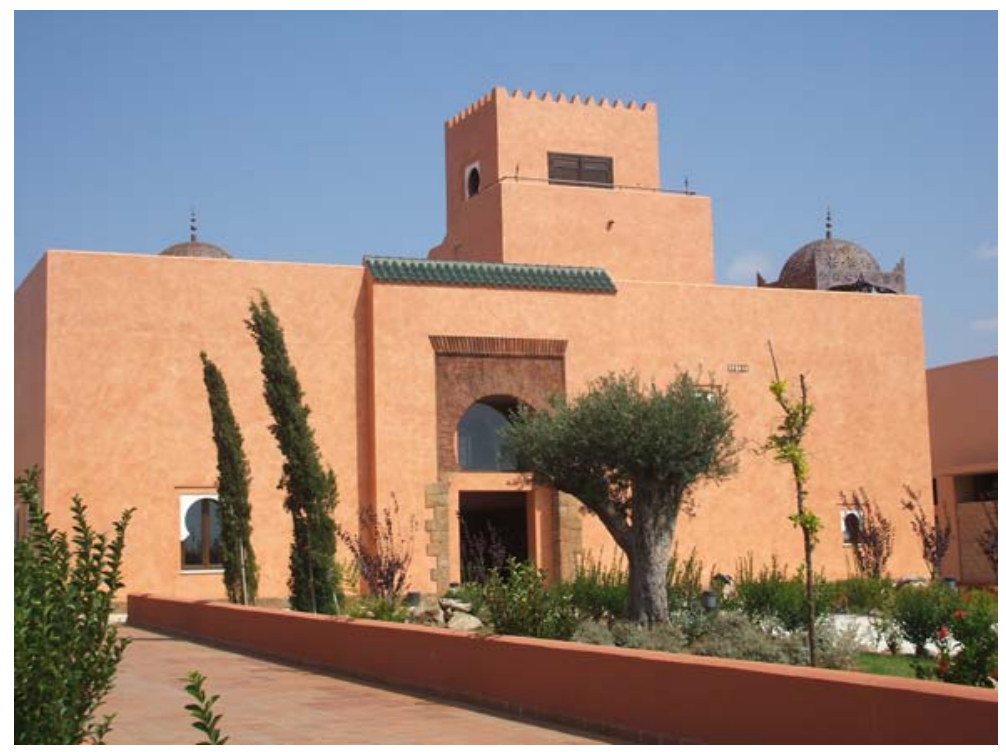

Ilustración 102 Nature Center Sancti Petri . Spa holístico (Chiclana de la Frontera Cádiz)

Se trata de centros con una filosofía propia basados en un concepto holístico, como se puede observar en la siguiente cita que forma parte de la publicidad del centro SPA correspondiente a la fotografía anterior.

"Nature center es un Spa con una filosofía integral que contempla al ser humano en su totalidad, en los aspectos físico, mental y emocional. Es un centro integral unisex donde salud, belleza, relajación y bienestar están unidos. ${ }^{274}$

\footnotetext{
${ }^{274}$ http://cadizjerez.com/ocio-cadiz/spa-nature-center-sancti-petri-chiclana.htm
} 
Lugares donde las terapias tienen como objetivo provocar sensaciones, en todas ellas se contempla el baño, a continuación se presentan algunas de ellas:

-BELLEZA Y RELAJACION DESDE ISRAEL EXÓTICO - RELAJANTE - ESTÉTICO

- DULCE TENTACIÓN DE CHOCOLATE SENSORIAL - ESTÉTICO - EXÓTICO

- MIMOS DE CANELA ESTÉTICO - RELAJANTE - SEDANTE

- heRBAL RELAX RELAJANTE

- REENCUENTRO CON LA LUZ SENSORIAL - EMOCIONAL

> Médicos: incorporan en sus instalaciones alta tecnología, ofreciendo tratamientos de cirugía plástica y estética.

$>$ De destino: estos forman parte de paquetes turísticos.

En los nuevos centros de baño se mezclan las tecnologías más vanguardistas, en lo que se refiere a aparatología, con los materiales más innovadores, todo ello, creando espacios que forman parte de un paisaje, en el que el protagonista es el bañista y el motivo es el agua, camas de hidromasaje, cascadas de agua, chorros, jacucci, piscinas contracorriente, pediluvio duchas de sensaciones, distintas estancias en las que juegan un papel principal los contrastes de temperatura, y la presión del agua; se trata de dejarse llevar durante cincuenta minutos por los relajantes cambios térmicos. 


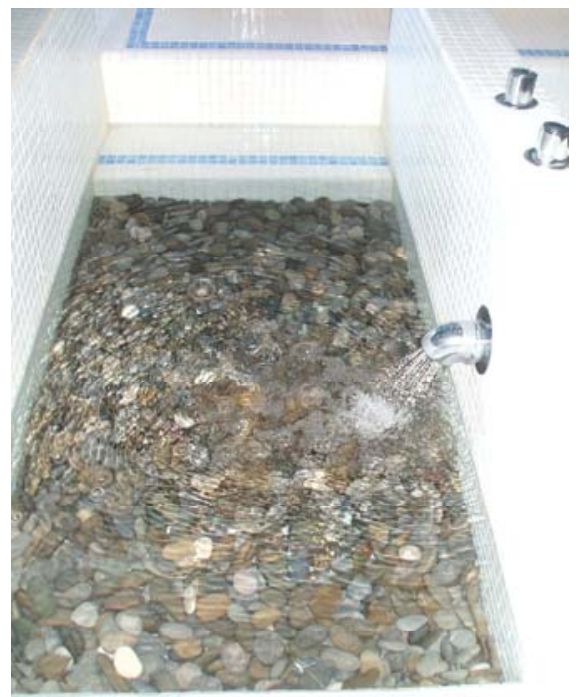

Ilustración 103 Piscina de cantos rodados (Hotel SPA El Rompido en Huelva).

Son lugares en los que se cuidan todos los detalles, desde la decoración del propio local, hasta los complementos necesarios para la toma del baño como toallas, albornoces, zapatillas etc. forman parte de un coordinado decorativo que hace que el bañista pase a formar parte de ese paisaje del todo inexcusable.

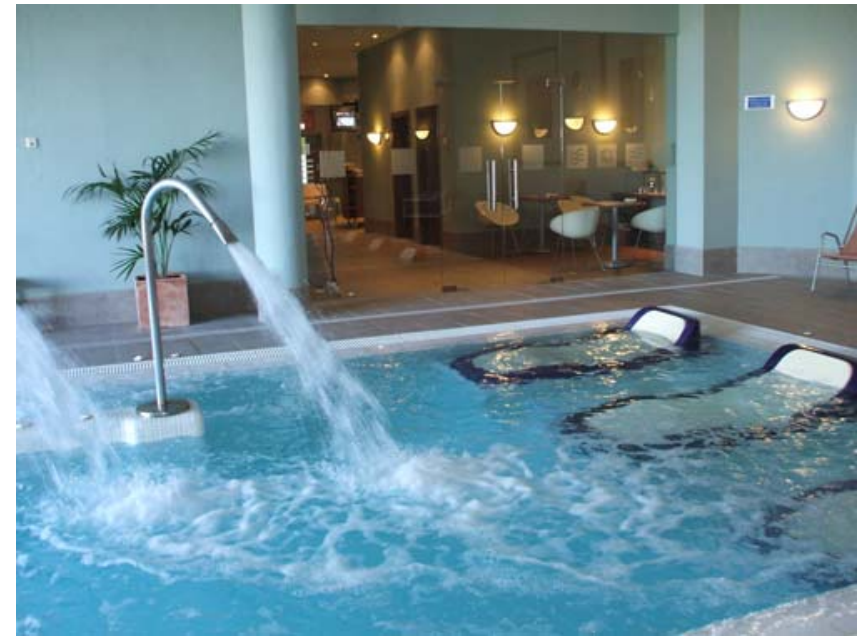

Ilustración 104 Piscina con chorros y camas relajantes.

Imagen tomada en el Hotel Spa el Rompido (Huelva) 
Una vez finalizado el baño, es necesario recuperar los líquidos perdidos durante el tiempo expuesto a las altas temperaturas de la sauna, para ello hay espacios habilitados en los que durante un pequeño tiempo de reposo se ofrece un refrigerio a base de té, Café o zumos de diversos gustos, cuyo fin es el de recuperar los líquidos perdidos durante la estancia en la sauna.

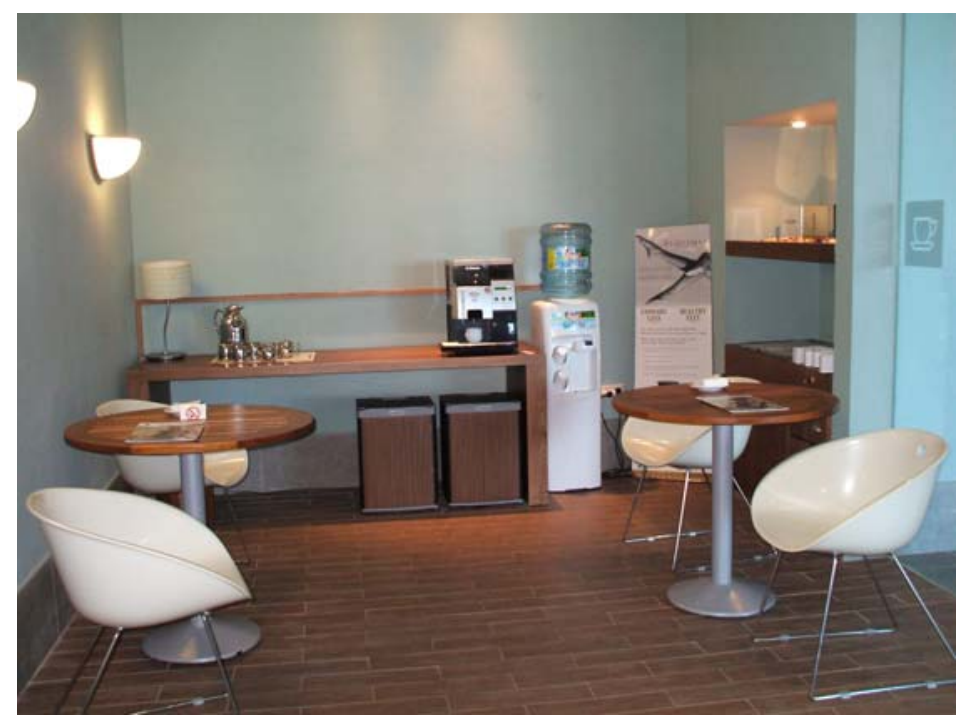

Ilustración 105 Imagen tomada en el Spa del hotel el Rompido en Huelva. (Zona dedicada al refrigerio tras el baño)

Todo está pensado y para encontrarse bien, tanto por dentro como por fuera, la mayor parte de estos centros llevan aparejados, otras estancias que prestan servicios complementarios como es el caso de depilaciones, peluquerías y todo lo necesario para salir del centro con una imagen renovada. 


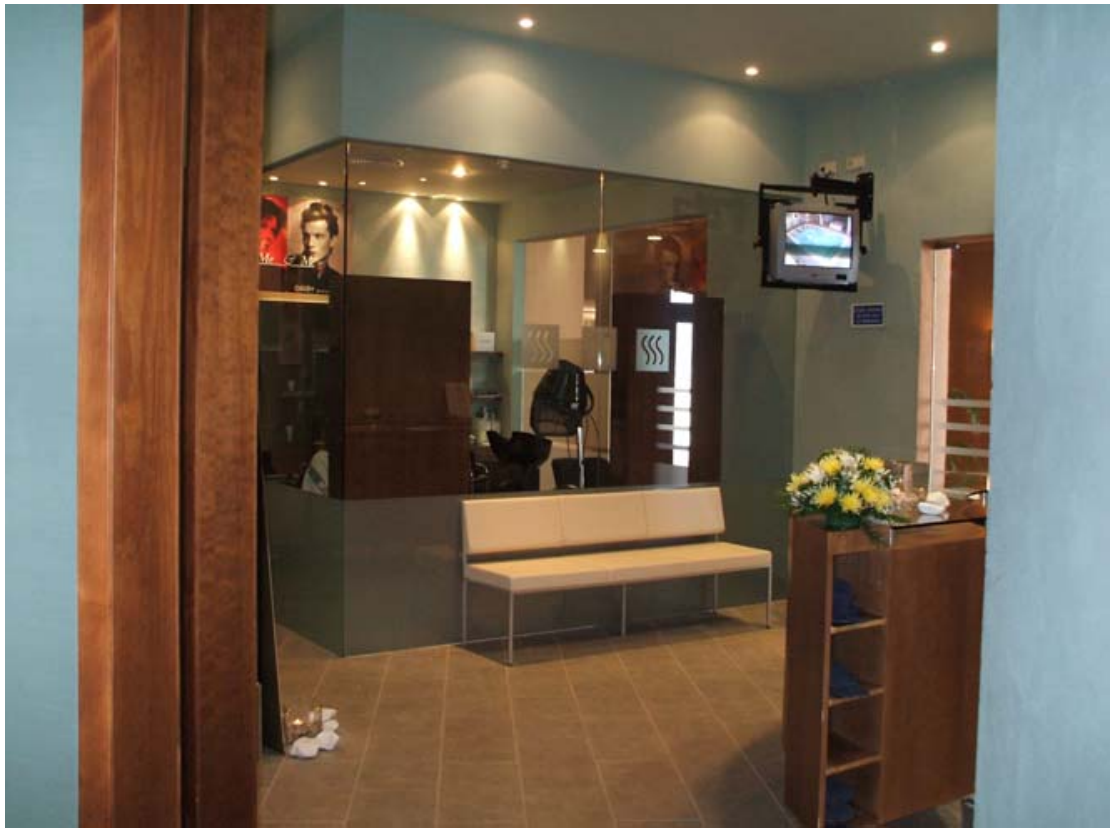

Ilustración 106 Imagen tomada en el Spa del hotel el Rompido en Huelva. (Zona dedicada al servicio de peluquería)

Todo está ideado para que el cliente tenga la sensación de que existe un antes y un después de su paso por estos centros de descanso placer y belleza. Conquistar al cliente es la clave, conseguir su fidelidad es el objetivo preferente.

Los SPA han sido los grandes adoptados por los centros hoteleros, que han visto en este tipo de espacios un atractivo negocio para atraer a una clientela que consideraba al hotel, como un lugar para residir durante su permanencia en una ciudad concreta y no como un lugar donde disfrutar de sus propias instalaciones. Contar con un SPA supone para el cliente un valor añadido a la hora de decantarse por un hotel $u$ otro, esto es tenido en cuenta por las grandes cadenas hoteleras que apuestan por reservar parte de su zona más selecta para la inclusión de este tipo de negocio que, por otro lado, atrae a otro tipo de clientela que sin registrarse en el hotel como usuario, si lo son del SPA, lo que hace del mismo una nueva línea de negocio con clientela propia. 


\section{CONCLUSIONESGENERALES}

Durante los nueve capítulos que forman este trabajo hemos podido observar cómo el uso del agua mediante el baño recobra protagonismo en la sociedad actual como fuente de salud y placer; los balnearios rescatan su valor más preciado para ponerlo al servicio del usuario en unas instalaciones renovadas acordes con las exigencias de la demanda. Las antiguas casas de baños reaparecen como negocio en forma de balnearios urbanos acercando al público parte de la naturaleza a su entorno más cercano. La salud por el agua deja de ser cuestionable y la prevención de enfermedades por medios naturales comienza a tener un papel preferencial.

La juventud se acerca a la naturaleza a través del uso del agua; pertenecientes una población de riesgo ante el estrés, enfermedad social fruto de la presión por objetivos, redescubren los antiguos balnearios y se convierten en una nueva clientela exigente a la hora de recibir servicios hídricos. Las administraciones públicas comienzan a fomentar el uso del turismo de salud, sobre todo para la tercera edad, los mayores en España son los principales usuarios mantenedores del sector balneario, ya que gozan de tiempo libre que a su vez se ve favorecido por ese colchón económico gubernamental orientado al disfrute; las políticas públicas a este respecto se gestionan a través del Imserso como servicios sociales complementarios de las prestaciones del sistema de Seguridad Social, pero el agua mineromedicinal como agente curativo y preventivo, aún no tiene cabida en el sistema español de Seguridad Social, un objetivo a largo plazo que una vez cumplido cambiaría el panorama del sector balneario. Por otro lado, las administraciones públicas han visto en el turismo de salud una vía para la reactivación económica de aquellas zonas rurales deprimidas que cuentan con la gracia natural de fuentes de aguas mineromedicinales. 
El fenómeno del veraneo se mantiene, pero toma especial preeminencia el tiempo de ocio en fin de semana, escapadas de pocos días pero de forma frecuente; esto se ha visto favorecido por la mejora en el transporte y las comunicaciones, que permiten viajar de forma rápida y cómoda, brindando la posibilidad de acercarse a conocer y disfrutar de la oferta hídrica existente tanto en nuestro país como en el resto de Europa en un periodo de tiempo relativamente pequeño. Ocio y descanso van unidos al concepto de baño, vivir intensamente cada momento sin esperar a mañana se ha convertido en uno de los objetivos fundamentales; la vida es como una aventura constante de fin de semana, período en el que disfrutar al máximo del tiempo dedicado a nosotros mismos.

Ha quedado patente en este estudio el negocio generado en torno al baño, la cara materialista y pragmática del amable uso del agua que se convierte en abuso cuando pasa a formar parte de un mercado en el que prima el beneficio sobre la conciencia ecológica.

Hemos podido observar como la importancia del baño de placer, actualmente, es comparable a la relevancia que tuvo tiempos de Roma, pero en la sociedad actual algo ha cambiado con respecto al uso del baño; si en Roma el baño era considerado un centro de reunión, de encuentro, un lugar donde compartir algo más que el gusto por el agua, en la actualidad el concepto cambia, el baño es un lugar de evasión, de intimidad, de búsqueda del propio ser, un lugar eminentemente social donde cada individuo, pareja o grupo, busca su espacio dentro de la esfera pública que conforma el baño. Son tiempos de apogeo para los centros balnearios, como lo fueron en el siglo XIX, el baño se convierte en una moda pero las modas cambian y se mezclan con nuevos intereses y nuevas formas de ver la naturaleza, el baño de salud comienza a formar parte del turismo de salud. 
La figura de "narciso" aparece en la escena social, el hombre gusta de sí mismo, de su imagen, cuidándose tanto interna como externamente y para ello el elemento ideal es el agua, fluido natural que limpia, embellece y relaja. Estamos asistiendo a un retorno a la naturaleza, y por consiguiente, ante una nueva valoración del agua como componente de unión entre el ser y su origen, el hombre regresa al elemento que le acompaña cuando nace y en el que se mantiene envuelto durante su gestación para tomar de él aquello que con el paso de los años va perdiendo externamente, frescura, juventud, lozanía, e internamente, paz, descanso y relajación, todo cuanto el agua procura en el seno materno.

El agua recurso escaso, es a su vez un recurso inagotable de virtudes, paradoja hídrica que envuelve al baño. Bajo la mirada Heracles, el agua se convierte en fuente salud y placer. 


\section{Referencias Bibliográficas}

Abad Varela, (1992) "Espacio, Tiempo y Forma", Serie II, Ha Antigua, T. V Ed. Un UNED. Madrid

Armijo Valenzuela, M. San Martin Bacaicoa J. (2000) "Curas Balnearias y Climáticas Talasoterapia y Helioterapia"Ed. Un. Complutense.

Baeza Rodríguez-Caro, J. y Fernández Sánchez J. A “Aspectos Legales y Técnicos en la Protección de Las Aguas Minerales". En: "Panorama Actual de las Aguas Minerales y Minero-Medicinales en España" Ed. Instituto Tecnológico Geo-Minero de España. Madrid.

Bel Ortega, C. y Martínez González, D. (1995) "Balnearios de Andalucía"Ed: Centro Andaluz del Libro, SA. Sevilla.

Beth janssen, M. (2003) "Belleza Radiante" Guía de salud y cosmética natural para el bienestar de todo el cuerpo." Ed: Océano. Barcelona.

Bravo, A. (1996) "Femenino Singular. La Belleza a través de la Historia" Alianza Ed. Madrid.

Cadenas y Vicent, V. (1984) "Jornadas de Fernando VII y de Amalia de Sajonia en los Reales Baños de Solán de Cabras en busca del deseado Sucesor". Ed. Hidalguía. Madrid.

Cano, R. (1895) "Las Leyes de la Belleza"Imp. Calatrava. Salamanca.

Cencerrado Alcañiz, F. (1981) "Antropología del simbolismo religioso" Ed. Ingrasa Cádiz.

De la Rosa, Ma C y Mosso, Ma A; (2004) "Historia de las aguas mineromedicinales en España" Ed. Observatorio Medioambiental. Madrid

Del Moral Crespo, J (2000) "Panorama actual de las Aguas Minerales y Mineromedicinales en España". En: "Contribución Socioeconómica de la Aguas Minerales en la Comunidad Autónoma de Galicia".

Del Val Valdivieso, Ma I. (2002) "Usos Sociales del Agua en las Ciudades Hispánicas de la Edad Media"Ed. Un de Valladolid. 
Diez de Velasco, F.. (1997) "Termalismo y Religión: Consideraciones Generales en el apartado dedicado al Culto al Manantial: Rito y Objetos". En: "Termalismo Antiguo" (/ Congreso Peninsular, Actas) Ed. Un. UNED. Madrid.

Dufourq, C.E. (1994). "La vida Cotidiana de los Árabes en la Europa Medieval". Ed. Temas de Hoy (Colección bolsiTemas 22) Madrid

Esteva de Sagrera, J.(2007) En: Historia de la Farmacia. "La Farmacia del siglo XVIII una terapéutica barroca" Vol. 26. Ed. Un Complutense de Madrid.

Fernández Ochoa, C. Morillo Cerdán A. Zarzalejos Prieto M. García Entero V. (1997) "Las Termas Romanas de Hispania: Balance Historiográfico y Perspectivas de Investigación". En: (I Congreso Peninsular .Actas) Ed. Un UNED. Madrid.

García López, A. (2003) "Historia del Real Sitio de la Isabela" Ed. Bornova. Guadalajara.

Giddens, A. (1991) "Modernidad e Identidad del Yo, El Yo y la Sociedad en la Época Contemporánea". Ed. Península. Barcelona.

Girlanda, A. 1990, "Agua". En: Nuevo Diccionario de Teología Bíblica. Ed. Paulinas. Madrid.

Godoy Fernández, C. (1997) "Algunas Aportaciones al Simbolismo del Agua en el Sacramento de la Iniciación Cristiana". En: "Termalismo Antiguo" (I Congreso Peninsular, Actas) Ed. Un UNED. Madrid.

González Alcantud, J. A y Malpica Cuello, A. (1992). "El Agua. Mitos. Ritos y Realidades", Ed. Diputación de Granada.

Guillen, J. (1977) "URBS ROMA Vida y costumbres de los romanos" Ed. Sígueme. Salamanca.

Gutiérrez de los Ríos, M. (1753)."Juicio sobre la méthodo controvertida de curar los morbos con el uso del agua y limitación en los purgantes". Imp. De Música. Madrid. En: León Sanz P- y Barettino Coloma D. "La Polémica del Agua" En: http://www.navarra.es/

Hesse, H. (1993) "En el Balneario"Ed. Diario de Burgos, S.A. Burgos.

Imam An-Nawawl (Traducido por: Zakaría Maza Vielva) (1999) "Los Jardines de los Justos: Del beneficio de la ablución". Ed.: Junta Islámica centro de documentación y publicaciones. Almodóvar del Río. Córdoba. 
Inglehart, R. (2001) “Modernización y Posmodernización". Ed. CIS Madrid.

Jiménez Espinosa, R. (2002) "Indicaciones y Técnicas Crenoterápicas de las aguas Minero-Medicinales" Ponencia presentada en las Jornadas de Aguas Mineromedicinales en España titulado: "Presente y Futuro del las Aguas Subterráneas en la Provincia de Jaén" ( IGME. MADRID 2002. ISBN. 84-7840-4724

Jiménez Pérez, P.R. (1993) "Historia del Balneario de Gravalos". Ed. Logi Organización S L. Zaragoza.

Joseph Ferré, (1998) "Arquitectura balnearia:¿un patrimonio amenazado". En: "Los Balnearios Españoles". Ed. Un de Salamanca.

Juan Pablo II, (2000). "Creo en la Vida Eterna: Catequesis sobre el Credo (VI)". Ed. Palabra. Madrid.

Laín Entralgo, (1963) "Historia de la Medicina Moderna y Contemporánea". Ed. Científico-Médica. 2a a Ed. En: León Sanz P- y Barettino Coloma D. "La Polémica del Agua.". En: http://www. navarra.es/

Laín P. (1970) "La Medicina Hipocrática". Ed. Espasa Calpe. Madrid.

Lara García Mạ, P. (1997) "La Cultura del Agua: Los Baños Públicos en Málaga" Ed. Sarriá. Málaga

Lévi Provençal: V, 278-279. En: Dufourcq C.E. (1994) "La Vida Cotidiana de los Árabes en la Europa Medieval" Ed. Temas de Hoy (colección bolsiTEMAS 22) Madrid.

Limón Montero, A. (1697) "Espejo cristalino de las aguas de España". Imp. F García Fernádez. Alcalá.

Lipovetsky, G. (2004) "El Imperio de lo Efímero"Ed. Anagrama. Barcelona.

Lipovestky, G. (1994) "El Crepúsculo del Deber. La ética indolora de los nuevos tiempos democráticos" Ed. Anagrama. Barcelona.

Lipovetsky, G. (2008) "La Era del Vacío (ensayos sobre el individualismo contemporáneo)"Ed. Anagrama. Barcelona.

López de Azcona, J. M. Bellot Rodríguez M. A. Carrasco de Salazar y Fuentes Catells A. 1980 "Estudios sobre el balneario de Solán de Cabras"Anales de la Real Academia de Farmacia № 4 Madrid 
López Monteagudo, G. (1997), "Termas y Tecnología de las Aguas. Testimonios Musivos". En: "Termalismo Antiguo" (I Congreso Peninsular .Actas), M.J. Peréx. Ed. Un. UNED. Madrid.

López Morales, M. (2004) "Los balnearios como centros de salud". Incex Enfem, vol.13. no 47.

López Pérez, J, A. (2000) "Tratados Hipocráticos". Ed. Gredos. Madrid.

Madoz, P. (1846-1850) "Diccionario geográfico-estadístico-histórico de España y sus posesiones de ultramar" Ed. Establecimiento tipográfico de P. Madoz y L. Sagasti. Madrid.

Mann, T. (2006) "La Montaña Mágica". Ed. Pocket Edhasa. Barcelona.

Manzaneque, M., en Peréx Argorreta (1997) "Termalismo Antiguo" Ed. UNED Madrid.

Maraver Eyzaguirre, F. (2006) "Establecimientos balnearios: historia literatura y medicina" Ed. Un Complutense de Madrid

Martín Gaite, C. (1993) "El Balneario" Alianza Ed. S.A. Madrid.

Maseru, E. Jürgen, F (2006) "El poder Curativo del agua". Ed. Obelisco. Barcelona

Ministerio de Asuntos Sociales (1992) "Evaluación de la Calidad de los Servicios de Programa de Termalismo Social". Ed. Instituto Nacional e Servicios Sociales. Madrid

Mircea Eliade. (1999) "Imágenes y Símbolos": En: Cáp. V "Historia y Simbolismo (Bautismo, Diluvio y Simbolismo Acuático"Ed. Taurus. Madrid.

Molina Villar, J.J. (1997) "Termalismo Antiguo en los Balnearios del Siglo XIX". En: Termalismo Antiguo (I Congreso Peninsular, Actas). Ed. UNED. Madrid.

Núñez, M y Navarro, C. (2001) "Como Cura el Mar". Ed. RBA libros S.A Barcelona.

Ortiz Palomar, M.P. y Paz Peralta J.A. (1997) "El Vidrio en los Baños Romanos". En: (I Congreso Peninsular .Actas) Ed. UNED. Madrid.

Pereira González, A.E. (2004) "Hipócrates: Aires Aguas y Lugares". Ed. Gredos. Madrid.

Pérez Fernández, Mạ R. (2005) "Principios de Hidroterapia y Balneoterapia". Ed. McGraw- Hill. Interamericana. Madrid. 
Pérez Menzel, N. año (2000) "Presente y Futuro del Termalismo Español y Europeo". En: "Panorama de las Aguas Minerales y Minero-Medicinales en España." Ed. Instituto Tecnológico Geominero de España. Madrid.

Pérez Morillo, M. (1997) "Pervivencia de los conocimientos Termales de la Antigüedad en los escritores Neolatinos de los siglos XVI al XVIII" Ed. UNED. Madrid

Pérez, V. (1752) "El promotor de la salud de los hombres, sin dispendio el menor de sus caudales: Admirable método de curar todo mal con brevedad, seguridad y a placer" Imp. Toledo

Plinio el Antiguo, XXXVIII, 55. En: Carcopino J. (1942) "La Vida Cotidiana en Roma en el Apogeo del Imperio"Ed. Librería Hachete S.A. Buenos Aires.

Polanco Martínez, F. Renal Araque I. (Redactores) (2002) Diccionario Anaya de la Lengua Ed. Anaya Madrid

Saavedra Sierra, J. (2007) "Los Baños de Graena un Manantial que Sana". Imp. Proyecto Sur Industrias Gráficas, S. L. Granada.

San Martín Bacaicoa, J. (2000) "Técnicas actuales de tratamiento balneario. Balneocinesiterapia". En: "Panorama actual de las aguas Minerales $y$ Mineromedicinales en España". Ed. Ministerio de Medio ambiente. ITGE Madrid.

San Nicolás Pedraz M. P. (1997), "Termas y Tecnología de las Aguas. Testimonios Musivos". En: Termalismo Antiguo (I Congreso Peninsular .Actas), M.J. Peréx. Ed. UNED Madrid.

San Pedro Martínez, Mạ A. (1993) "El Balneario de Puente Viesgo 1793-1936". Ed. Un Cantabria

Sánchez Ferré, J. (1998) "Arquitectura Balnearia: ¿Un Patrimonio Amenazado?". En: "Los Balnearios Españoles"II Reunión de Estudios Históricos sobre Balnearios, Agua y Terapéutica. Ed. Un Salamanca.

Serra Ráfols, J de C. (1944) "La Vida en España en la Época Romana". Ed. Alberto Martín. Barcelona.

Sintes Pros, J. (1980) "El Poder Curativo del Mar (Talasoterapia)". Ed. Síntesis. Barcelona.

Taschen, A. Arieff, A. Burkhart, B. (2008) "SPA" Edited by Allison Arieff San Francisco.

Torres Villarroel, D. edición preparada por: Blanco J. F. (1988) "Uso y Provechos 
de Los Baños de Ledesma". Ed. Europa Artes Gráficas. Salamanca.

Urkia Etxabe, J. Ma (1998) "Los Balnearios Vascos: su Esplendor en los Balnearios Españoles"..I En: "Los Balnearios Españoles" II Reunión de Estudios Históricos sobre Balnearios, Agua y Terapéutica. Ed. Un Salamanca.

Vázquez Montalbán, M. (1986) "El Balneario"Ed. Planeta Booket. Barcelona.

Vázquez-Illa, J (1997) "Estudio Producto Termal". Anet-Futures. En: "Panorama Actual de las Aguas Minerales y Minero-Medicinales En: España"; Ed. Instituto Tecnológico Geo-Minero de España. Madrid.

Viejo, T. (2009) "La Memoria del Agua" Ed. Martínez Roca. Barcelona.

Vílchez Vílchez, C. (2004) "Baños Árabes" Ed. Diputación de Granada (Guías de Historia y Arte) Granada

Yuste Grijalva, F. (1971) "Hacia una sociología de la Medicina" Ed. Aula. Barcelona.

Zaragoza Rubira, J R. (1971) "Medicina y Sociedad en la España Romana" Ed. Pulso. Barcelona. 


\section{Páginas Web}

http://www. balneario.com/ cofrentes/

http://www.cfnavarra.es/Salud/docencia.investigacion/textos/temas_medicina/6_ferrer/polemica_agua.pdf

http://www.cespte. gob. mx/Hist-agua.htm

http://www.castillalamanca.es/cImsalud/contenidos/vida_sana/baños.

Pérez Fernández M.R. y Novoa Castro B. 2006 Pág. 10 http://www.doyma.es

http://www . abalnearios.com/ historia/ edadmedi a/

http//www . aytojaen.es

http://ddd.uab.cat/pub/ dynamis/02119536v5-6p417.pdf.

http:/ /www.elmundo.es/1998/11/22/madrid/22N0077.htm

http://www. elguaitador.com/ medicina/watsu.htm

http://elrincondelabruja.mforos.com

http://cosmetic anatural.jaimaalkauzar.es

http://www. wateryear2003.org (Página dedicada al año 2003 como Año Internacional del Agua Dulce

http:// www.thewaterpage.com/ religion.htm

www. mu sulmanesperuanos.com/ghusl.htm

http://www. nurelislam.gal eon.com/purificacion.htm

http://www.granada-in.com/hammam_granada-in/informacion_banos_arabes.html

http://jinuj. net/articulos_ver.php? $\mathrm{id}=60$

J unqué Tort E. (Tomado de la Revista Ave María) http://www. lamparaencendida.net

www. Nortedecastilla.es

http://revista.consumer.es/ página 10

http://www. mu ndoferial.com/ turismo- de-salud/termatalia-2009-refuerza-el-negocio-internacional-del-turismode-salud-y-de-la-industria-termal/

http://www.cosmobelleza.com/es/wellness/informacion/tecnicos

www.turismocastillayleon.com

http://www. balneario.com/ cofrentes

Gubert A. F. (Miembro Titular de la Cámara Argentina de Termalismo

y Turismo de Salud - Delegado para la región N.E.A.) Fuente: www.termasalud.com

http://www. castillalamancha. es/turismo/sp/ contenidos/turismo $\% 20$ saludable/ enlac es/PonenciaAgu as. pdf

http://www. villastermales. com/ legislacion.htm

Dra Suárez Santos M. http://www.termasworld.com

http://www.termasworld.com/ 


\section{Artículos de Revistas:}

Mailin Falkenmark 2006 "Agua El desafío del siglo XXI" Vanguardia Dossier no 21

Tales de Mileto 1936 "Los Grandes Pensadores", Tomo I. Revista de Occidente.

De Pablo O. Noviembre de 2003 "Mimar el cuerpo y el alma entre mosaicos y celosías", número 25 Suplemento del diario El Mundo.

De Miguel J.M. y Ponce de León O. 1998 "Para una Sociología de la Fotografía" Reis Pág. 86

Basteiro M. I 2006 "El Baño en las Diferentes Culturas" Revista Thermaespa, № 14

Rev. Cubana Salud Pública vol. 33 no. 4 Ciudad de La Habana Oct.-Dec. 2007

Vidal Corella V 5/8/ 1994 "La Valencia de otros tiempos: Antiguas Temporadas de Baño (Los baños Moros)" art. Periodístico; El Dominical (Provincias) Valencia

Revista Thermaespa; ํㅜ13

Guía de la Tercera Edad 20.Diciembre, Enero y Febrero, 2006/2007 Muface 


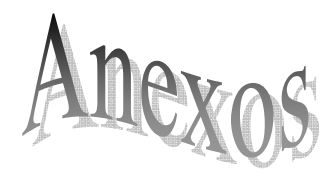


BALNEARIO:

(Recogida de Información para Tesis Doctoral)

¿De dónde procede? (Municipio o Provincia)

Sexo ? Hombre ? Mujer

1. ¿A cuál de estos grupos de edad pertenece?:
O Menos de 30 (máximo 29)
De 40 a 49
O De 60 a 64
O De 30 a 39
O De 50 a 59
○ Más de 64

2. ¿Indique de las siguientes opciones aquella que le sugiera la palabra Balneario?
Descanso
O Salud
Turismo
O hospital
Tranquilidad
Curación
Belleza corporal
Ocio
Otra razón (Cuá).
Placer

3. ¿Por favor, indique el motivo por el que está Usted en este balneario?
O salud
O Ocio
Descanso
Otras razones
Por favor indique ¿Cuál?

4. ¿Asiste a este Balneario Porque: ? (en caso de existir más de una opción iiipor favorii enumérelas 1,2,3...)
Se lo prescribió su médico
Está de moda asistir a balnearios
Decisión personal
Lo encuentra una opción interesante para vacaciona
Por la características de sus aguas
Se lo aconsejó un amigo
O Otra situación (cuál)

5. UD asiste a centros balne ari os
Una vez al año
Tres o cuatro veces a l año
O Dos veces al año
Otras; indique cuantas.

6. En el Balneario ¿esta Ud?:
○ Sólo
Con la familia (esposo/a; e hijos)
○ con un acompañante
Otra situación (cuál)

7. ¿Podría decirnos, a cual de estos grupos se ap roximan los ingresos mensuales que entran en su casa?
Hasta $600 €$
De 601 a $1.200 €$
De 2.101 a $3000 €$
De 1.201 a $2.100 €$
De 3001 a $4.500 €$
De 4.501 a $6000 €$
O Más de $6000 €$

8. ¿En cuál de los siguientes grupos laborales se encuentra Vd. actualmente?
Trabaja (por favor indique actividad)
Ama de casa
Jubilado Pensionista
Estudiante
Desempleado
Otras (por favor indique cual)

MODELO DE ENTREVI STA

Realizada al Presidente de la Asociación de Balnearios de Andalucía 
Sr. Director del Balneario de Alicún de las Torres y Presidente de la Asociación de Balnearios de Andalucía:

Es de gran importancia para mí conocer su opinión a cerca del sector balneario.

En la respuesta a estas preguntas va la información que necesitaría sin menosprecio de todas aquellas cuestiones que deseé mencionar, que sin duda, serán una aportación de gran valor documental para mi Tesis.

¡Gracias por todo¡

¿Podría decirme el año en el que se realizaron las últimas reformas del balneario de Alicún de las Torres, y en que consistieron?

Año

Consistieron en:

Sería importante para este estudio conocer el dato, si Vd. me lo puede facilitar, del $n$ o de usuarios del balneario de Alicún de las Torres en los años 2005 y 2006.

Año 2005

Año 2006

ME GUSTARÍA QUE ME DIESE SU OPINIÓN SOBRE LAS SIGUIENTES CUESTIONES. COMO PRESIDENTE DE LA ASOCIACIÓN DE BALNEARIOS DE ANDALUCÍA

ii PUEDE AÑADIR TODO AQUELLO QUE CONSIDERE OPORTUNO $\mathrm{ii}$

$1{ }^{0}$ ¿Considera que en la actualidad estamos asistiendo a una recuperación de los usos sociales y terapéuticos del agua?

$2^{\circ}$ ¿Hacia donde creé que se dirige el sector balneario en el futuro?

3 a ¿Disponen los Balnearios de ayudas de la administración (central y/o autonómica) para la rehabilitación o para el mantenimiento de los centros balnearios?

40 ¿Me podría dar su opinión, sobre si existe una cierta confusión entre la opinión pública con respecto a la consideración de "Spa o Balnearios Urbanos" y "balnearios de aguas mineromedicinales", creada por el mercado de forma consciente para abrir nuevas vías de 
negocio'. (Me refiero a la utilización del término Balneario para calificar a centros que por no disponer de agua mineromedicinal no deberían de llevar este calificativo).

50 ¿Considera que debería existir una legislación europea de balnearios?

6a ¿Me podría decir como percibe VD. a nivel general, las características socioeconómicas del usuario de los balnearios de Andalucía?

7a ¿Es Vd. partidario de que parte de las terapias sean incluidas en las prescripciones y financiadas por la Seguridad Social?

8 ¿De forma aproximada; podría decirme cuantos puestos de trabajo directos genera un balneario?

¿Existe demanda de personal especializado?

\section{Gracias por su colaboración}

\section{MODELO DE ENTREVISTA}

\section{Realizada a los directores o Responsables de los establecimientos balneario}

Sr. Director:

Es de gran importancia para mí conocer su opinión a cerca del sector balneario.

En la respuesta a estas preguntas va la información que necesitaría sin menosprecio de todas aquellas cuestiones que deseé mencionar y, que sin duda, serán una aportación de gran valor documental para mi Tesis.

¡Gracias por todo;

¿Podría decirme el año en el que se realizaron las últimas reformas del balneario, y en que consistieron?

Sería importante para este estudio conocer el dato, si Vd. me lo puede facilitar, del $n$ o de usuarios del balneario en los años 2005 y 2006.

Año 2005:

Año 2006: 
¿Considera que en la actualidad estamos asistiendo a una recuperación de los usos sociales y terapéuticos del agua?

¿Hacia donde creé que se dirige el sector balneario en el futuro?

Otras cuestiones a las que $\mathrm{Vd}$. deseé hacer referencia. 